UNIVERSIDADE DE SÃO PAULO

FACULDADE DE MEDICINA DE RIBEIRÃO PRETO

NtCDKG;2, uma proteína multifuncional, relacionada aos processos de transcrição, processamento de RNA e organização do fuso acromático no ciclo celular de Nicotiana tabacum

GREICE LUBINI

Ribeirão Preto, SP 
Universidade de São Paulo

Faculdade de Medicina de Ribeirão Preto

Departamento de Genética

NtCDKG;2, uma proteína multifuncional, relacionada aos processos de transcrição, processamento de RNA e organização do fuso acromático no ciclo celular de Nicotiana tabacum

Tese apresentada à Faculdade de Medicina de Ribeirão Preto da Universidade de São Paulo para obtenção do título de DOUTORA em CIÊNCIAS - Área de concentração: GENÉTICA

Aluna Greice Lubini

Orientadora Profa. Dra. Maria Helena de Souza Goldman

Ribeirão Preto 
AUTORIZO A DIVULGAÇÃO TOTAL OU PARCIAL DESTE TRABALHO, POR QUALQUER MEIO CONVENCIONAL OU ELETRÔNICO, PARA FINS DE ESTUDO E PESQUISA, DESDE QUE CITADA A FONTE.

\section{Lubini, Greice}

NtCDKG;2, uma proteína multifuncional, relacionada aos processos de transcrição, processamento de RNA e organização do fuso acromático no ciclo celular de Nicotiana tabacum. / Greice Lubini; orientadora Maria Helena de Souza Goldman — - Ribeirão Preto - 2016.

232 p.: 34 il.

Tese de Doutorado, apresentada à Faculdade de Medicina de Ribeirão Preto/USP - Área de concentração: Genética.

1. SCI1. 2. CDK. 3. ciclo celular. 4. localização subcelular. 5. fuso acromático. 6. BiFC. 7. Y2H. 
PARECER DA BANCA EXAMINADORA

Prof. Dr.

Instituição:

Parecer:

Assinatura:

Prof. Dr.

Instituição:

Parecer:

Assinatura:

Prof. Dr.

Instituição:

Parecer:

Assinatura:

Prof. Dr.

Instituição:

Parecer:

Assinatura:

Prof. Dr.

Instituição:

Parecer:

Assinatura:

Ribeirão Preto, de de 2016. 
'"'Once we accept our own limits, we can go beyond them. "'I' (Albert Einstein) 
Ao meu avô, Egon Leopoldo Boufleur.

Obrigada por sempre mostrar que a educação leva ao melhor caminho.

Dedico... 


\section{Agradecimentos}

Meus agradecimentos mais sinceros...

À Prof. Dra. Maria Helena de Souza Goldman, por sua excelência e ética profissional. Tu és um exemplo para todos nós! Agradeço também por ser uma orientadora de verdade, por todo apoio, carinho, incentivo. Agradeço também todos bolos e guloseimas que tu trazes para alegrar nossos dias. Ahhh, os bolos... muito, muito obrigada!

Ao Departamento de Genética da Faculdade de Medicina de Ribeirão Preto, pela valiosa oportunidade e suporte oferecido durante a realização do mestrado e do doutorado. Em especial, agradeço ao Prof. Dr. Ademilson Espencer Egea Soares e à secretária Susie Adriana Penha Nalon pelo incansável apoio, motivação e amizade.

À Faculdade de Filosofia, Ciências e Letras de Ribeirão Preto, pela utilização de sua estrutura.

À CAPES, pelas bolsas concedidas às quais possibilitaram a realização do doutorado no Brasil (PROEX) e no exterior (Processo: BEX 7686/13-7- CAPES/NUFFIC).

A CAPES, ao CNPq e a FAPESP por todo o suporte financeiro oferecido para o desenvolvimento da pesquisa em nosso laboratório.

À FAEPA, pelo suporte financeiro concedido para a participação de eventos científicos.

Aos professores Prof. Dr. Luis Lamberti Pinto da Silva, Silvana Aparecida Creste Dias de Souza e Adriana Pinheiro Martinelli, pelas valiosas sugestões como membros da minha banca de qualificação e também em todos os outros momentos que nos auxiliaram durante as nossas pesquisas.

Ao Prof. Dr. Gustavo Henrique Goldman, pela constante disponibilização da estrutura de seu laboratório e pelos auxílios científicos sempre que precisamos.

À Prof. Dra. Zilá Luz Paulino Simões, por disponibilizar o acesso à estrutura de seu laboratório e também pelo carinho pelos membros do nosso laboratório.

Ao Prof. Dr. John Campbell McNamara, por disponibilizar a sala de estudos onde consegui escrever esta tese. 
À Dr. Andréa C. Quiapim, por ser o braço direito de todos nós no laboratório e por mantermos uma bela amizade. Obrigada pelas inúmeras ajudas, risadas, brigadeiros, massagens e tudo mais.

Ao Dr. Edward, o “Tio Ed”, por todos seus ensinamentos e auxílios durante o andamento desta pesquisa.

Ao Dr. Juca, por toda "luz" que tu tens trazido às nossas pesquisas, em especial, por nos auxiliar nas interpretações dos dados e mostrar o quanto eles são valiosos!

A todos membros do LBMP, meus mais profundos agradecimentos! Ao Pedrito, agradeço por me acompanhar e me deixar te acompanhar nos nossos experimentos overnight. Agradeço por ser tão querido com todos, tão solícito e por ser tão sincero e honesto em tuas amizades. À Fran, agradeço por me ajudar tanto na finalização da minha tese, nas coletas e formatações finais. Agradeço à amizade valiosa que sei que temos e ao carinho e preocupação. Tu és muito especial, nunca esqueça. À Pat, agradeço por ter entrado na minha vida de uma maneira tão intensa, enérgica. Obrigada por trazer vida a todos nós, pelo carinho e amizade sincera. Agradeço também por dividir tua mãezinha querida conosco. Dona There, tenho tanto a te agradecer... Ao Vitor, obrigada por todas ideias e ajudas durante a elaboração de hipóteses para nossos resultados. À Jo, agradeço pela amizade que já sinto que cultivamos. Faz pouco tempo que chegou no Lab, mas "já é de casa”. Obrigada pelo carinho e companhia na fase final deste trabalho. Ao Bruno, por ter permitido que fosse sua "coorientadora" e, agora, amiga. Foi pouco tempo de Lab, mas fico muito feliz que tu tenhas "te encontrado" ainda dentro da Biologia, não como pesquisador, mas como um excelente Professor!!! O Brasil precisa de mais pessoas como tu! À Vanessa, por ser tão querida e especial. Tu ainda vais longe, guria. Força aí! Ao Rafa, pela amizade e auxílios. MUITO obrigada!!! Cada um de vocês sabe toda importância que tem para mim. Obrigada por todas as ajudas que vocês me deram!!!

Ao Mikito, Lígia, Hebréia, Niltão, Ana, Marcella, Cris “Protein”, Henrique, Luisinho, Luiz Roberto, Samantha, Vivi, Ian, Tamiris...membros mais antigos do laboratório, mas que continuam perto da gente, nos auxiliando sempre e com os quais sei que posso contar até hoje. Eu também agradeço imensamente pela amizade que cultivamos. À Ferzita, em especial, por sua imensa amizade, apoio e carinho em todos momentos. Obrigada por ajudar a cultivar esta amizade maravilhosa que já tem alguns anos, né, Comadre?!

Ao Paulão, pela ajuda e por continuar sendo só alegria.

Aos companheiros e agora amigos que compartilharam comigo a sala 01-C, Mari, Auristela, Rafa e Argos. Obrigada pelo silêncio (na maioria do tempo). Esse silêncio foi essencial! Obrigada também pelos momentos de descontração. 
Aos membros do Laboratório do Prof. Dr. Gustavo Henrique Goldman (FCFRP-USP), principalmente à Patrícia e à Marcela, agradeço por toda ajuda.

À minha maravilhosa Mãe, tenho tanto a agradecer que nem sei por onde começar. Obrigada pelo amor incondicional! Obrigada por ser meu maior exemplo! E muito obrigada por ter passado um pouco dessa tua garra e confiança para mim nos momentos que mais precisei. Tu me trouxeste segurança e confiança quando tive medo, presença de coração quando eu tive saudades, paciência quando estava (muito) ansiosa. Obrigada por vivermos juntas mesmo tão longes. Junto a mãe, agradeço também ao Luís, meu "paidrasto" que nos momentos de angústias e dificuldades, teve sempre uma palavra de incentivo, agradeço ternamente.

Ao meu Paizão que, mesmo sem entender direito o que faço me apoia, auxilia e vibra com todas minhas conquistas. Obrigada, pai, pelo amor, carinho e por entender que, mesmo longe, estamos sempre juntos. Obrigada por ser este homem honesto e íntegro que todos gostam. Eu sei que nem sempre acertou, mas, mesmo os teus erros sempre foram tentando acertar. Obrigada pelo abraço forte e por me socorrer sempre que mais precisei. Agradeço também à Janda, por todo carinho que tem por mim, minha "mãedrasta”, pelas comidinhas gostosas e pipocas com Sazon (inesquecíveis! Nunca mais! Hahaha). Agradeço à Cris, minha maninha mais nova, por tornar minha vida mais doce e leve a cada sorriso e abraço.

À Jóice, minha irmã mais que irmã, que diz que sou sua "irmãe". Obrigada por confiar em mim, nos meus cuidados e por dizer que sou um exemplo para ti. Obrigada, mana, pela paciência, pelo carinho, incentivo e por estar sempre comigo, não importa a distância. Contigo não tem tempo ruim, mana! Ao fim da vida, seremos nós, uma pela outra. Conte comigo sempre! Queria que estivéssemos mais perto...

A todos meus Familiares que sabem do valor dessa luta e do amor incondicional que tenho pela família. Agradeço pelo afeto, solidariedade e compreensão de todos parentes, principalmente por entenderem minha distância. Ao Vô Egon (in memorian), ao qual esta tese é dedicada, e à Vó Cadi que também foram super pais para mim. Ao vô Egon, faço um agradecimento especial, pois muito incentivou meus estudos, sempre ficando orgulhoso com cada conquista minha. Queria tanto que estivesse aqui para participar de mais esta alegria!!!

Ao Shin, meu querido companheiro e melhor amigo... não tenho nem palavras para agradecer. Tu sempre foste paciente, compreensivo, solícito e incentivador. Tu és um exemplo de integridade, honestidade, honra. Obrigada por me encher de amor, carinhos e por me fazer dormir sorrindo. 
Obrigada por estar comigo sempre, mesmo quando a saudade já apertava!!! Obrigada também à família Miranda Yokoyama, por me deixar fazer parte de suas vidas e por todo carinho recebido. Aos meus queridos amigos/irmãos do Sul e desse Brasilzão, por fazerem com que a distância não diminua o valor de nossa amizade. Sou muito feliz por cultivar tantas amizades maravilhosas. Não irei nominá-los, mas tenho certeza que todos sabem do valor que sua amizade representa.

Ao Dr. Ruud de Maagd, meu co-orientador durante o período em que desenvolvi parte do doutorado na Holanda. Por ter me aceitado em seu laboratório e me ensinado tanto. Agradeço também a todos psquisadores do PDS group que me receberam com muito carinho e me auxiliaram em todos momentos. Eu não estava esperando fazer tantas amizades e tão especiais. Obrigada pela linda amizade que continuamos cultivando, mesmo à distância. Um dia, eu voltarei...

A todos amigos que fiz em Wageningen. Aoooow, Wageningen!!! Vocês foram essenciais. Sem vocês, não teria sido tão bom!!! Em especial, agradeço à querida Vanja, que me acolheu em sua casa com tanto amor.

Aos gaúchos de RP, obrigada por matarmos um pouco da saudade do pago a cada chimarrão. Obrigada por compreenderem minhas ausências. O incentivo de vocês foi muito importante!

Às maravilhosas amizades que cultivei aqui em Ribeirão. Obrigada, meus queridos, pelo carinho, receptividade, incentivo e por todos momentos felizes.

Sou muito agradecida a todos que contribuíram para a realização deste trabalho. Sem o apoio de inumeráveis pessoas, a execução desse trabalho teria sido impossível.

Gratidão!!! 


\section{Sumário}

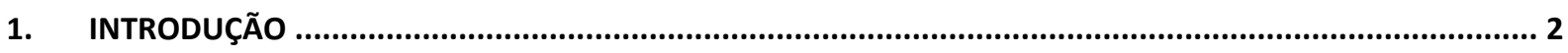

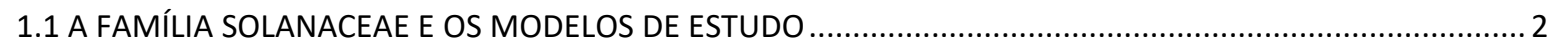

1.2 O DESENVOLVIMENTO PÓS-EMBRIONÁRIO DAS PLANTAS E A FORMAÇÃO DAS FLORES ..........................4

1.3 NtSCI1 E A REGULAÇÃO DO CICLO CELULAR NO PISTILO DE N. tabacum ............................................. 7

1.4 CDKS PRESENTES EM PLANTAS E SEU ENVOLVIMENTO NO CICLO CELULAR .......................................8

1.5 NtCDKG;2 E SUAS HOMÓLOGAS DE A. thaliana E de Homo sapiens........................................................ 11

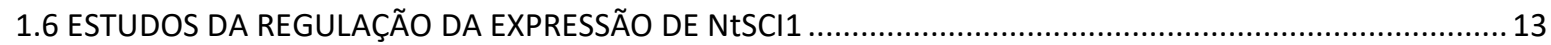

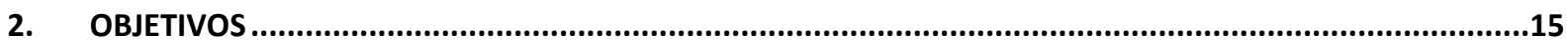

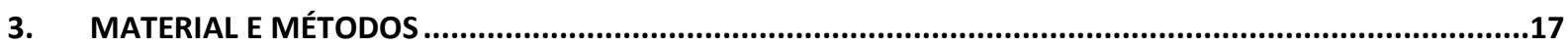

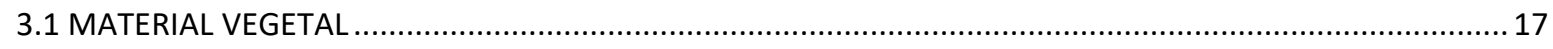

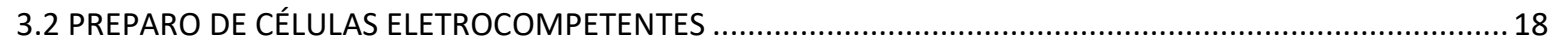

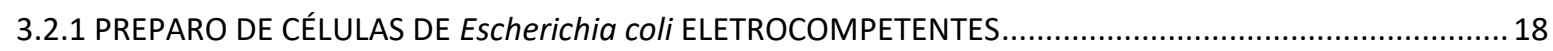

3.3.2 PREPARO DE CÉLULAS DE Agrobacterium tumefaciens ELETROCOMPETENTES .....................................19

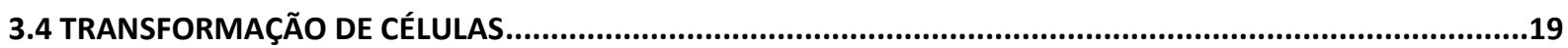

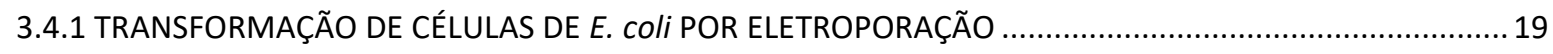

3.4.2 TRANSFORMAÇÃO DE CÉLULAS DE A. tumefaciens POR ELETROPORAÇÃO............................................20

3.4.3 TRANSFORMAÇÃO DE CÉLULAS DE Saccharomyces cerevisiae POR CHOQUE TÉRMICO ........................20

3.5 PREPARAÇÃO DE DNA PLASMIDIAL EM PEQUENA ESCALA (MINI-PREP) ...........................................21

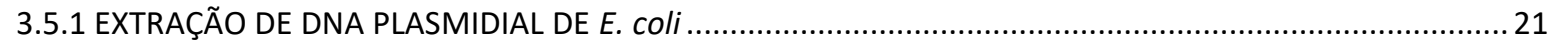

3.5.1.1 Método de extração de DNA plasmidial utilizando a lisozima ......................................................2 21

3.5.1.2 Método de extração de DNA plasmidial com alto grau de pureza ................................................22

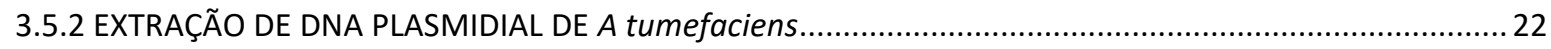

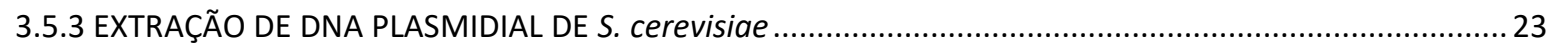

3.6 PURIFICAÇÃO DE DNA PELO MÉTOdO dO FENOL-CLOROFÓRMIO ........................................................23

3.7 DIGESTÃO DO DNA UTILIZANDO ENZIMAS DE RESTRIÇÃO ........................................................24

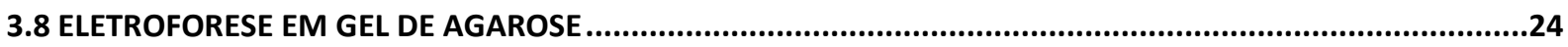

3.9 PURIFICAÇÃO DE FRAGMENTOS DE DNA A PARTIR DE GEL DE AGAROSE ...........................................25

3.10 IDENTIFICAÇÃO E AMPLIFICAÇÃO DAS PUTATIVAS REGIÕES PROMOTORAS DE NtSCI1 DAS CÓPIAS DE N.

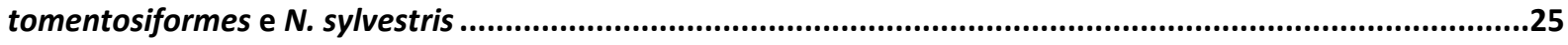

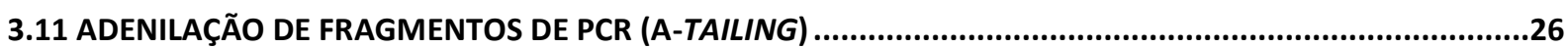




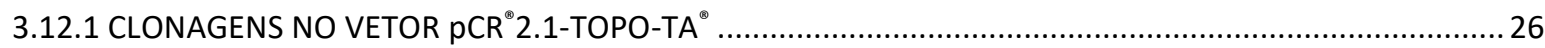

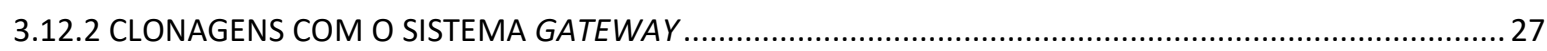

3.12.2.2 Inserção dos sítios attBs para recombinação de fragmentos pelo Sistema Gateway .................. 28

3.12.2.3 Recombinação BP: reação entre região codificadora do gene e o vetor de entrada do Sistema

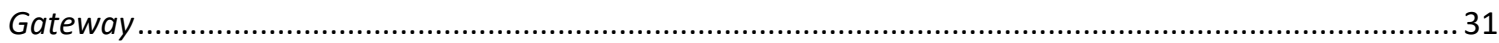

3.12.2.4 Recombinação LR: reação entre o vetor de entrada e o vetor de destino do Sistema Gateway .. 31

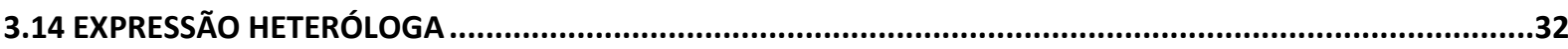

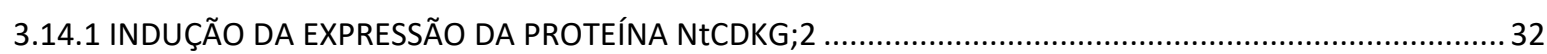

3.14.2 LISE BACTERIANA PARA SOLUBILIZAÇÃO DOS CORPOS DE INCLUSÃO …............................................33

3.15 SDS-PAGE .33

3.16 TRANSFERÊNCIA PARA MEMBRANA E WESTERN BLOTTING .34

3.17 REVELAÇÃO DO WESTERN BLOTTING POR ECL (ENHANCED CHEMILUMINESCENT) .35

3.18 PURIFICAÇÃO COM RENATURAÇÃO DA PROTEÍNA. .35

3.19 LISE DAS CÉLULAS VEGETAIS .36

3.20 EXPERIMENTOS DE LOCALIZAÇÃO, CO-LOCALIZAÇÃO E BiFC EM CÉLULAS VEGETAIS ..............................36

3.20.1 EXPRESSÃO ESTÁVEL DE NtCDKG;2 EM CULTURA DE CÉLULAS BY-2 ….......................................36

3.20.2 EXPRESSÃO TRANSIENTE DE NtCDKG;2 EM FOLHAS DE NICOTIANA BENTHAMIANA ..........................37

3.20.3 CO-TRANSFORMAÇÃO DE NTCDKG;2 COM PROTEÍNAS MARCADORAS PARA ENSAIOS DE COLOCALIZAÇÃO 38

3.21 Marcação das células vegetais com corantes .................................................................................39

3.21.1 MARCAÇÃO DE CÉLULAS DE FOLHAS DE N. benthamiana COM O CORANTE DAPI..............................39

3.21.2 MARCAÇÃO DE CÉLULAS BY-2 COM O CORANTE HOECHST ........................................................40

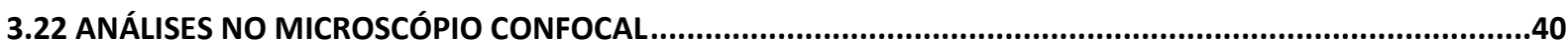

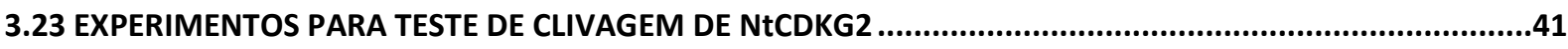

3.24 EXPERIMENTOS IN VIVO PARA TESTE DE INTERAÇÕES ENTRE PROTEÍNAS ...........................................41

3.24.1 ENSAIOS DE INTERAÇÃO ENTRE NtCDKG;2-hGFP e NtSCI1-tGFP EM CÉLULAS VEGETAIS ...................42

3.24.2 ENSAIOS DE DUPLO-HÍBRIDO EM LEVEDURAS S. cerevisiae ..........................................................42 
3.24.2.1 Screening da biblioteca do sistema do duplo-híbrido, utilizando BD-NtCDKG;2 como proteína alvo

3.24.2.2 Análise do fenótipo dos transformantes para os genes repórteres ........................................45

3.24.2.3 Identificação das proteínas candidatas à interação...............................................................45

3.24.2.4 Ensaios par-a-par para confirmação da interação entre proteínas candidatas ...........................46

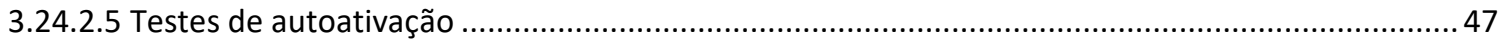

3.25 EXPERIMENTOS IN VIVO PARA TESTE DE INTERAÇÕES ENTRE DNA-PROTEÍNA: ENSAIO DE YEAST ONE-

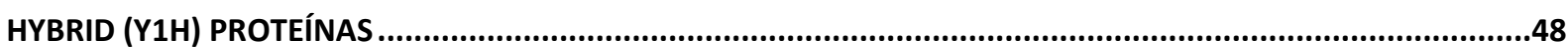

3.25.1 DIGESTÃO DO PLASMÍDEO CONTENDO DNA DE INTERESSE …...................................................49

3.25.2 TRANSFORMAÇÃO PARA INTEGRAÇÃO DO FRAGMENTO LINEARIZADO NO GENOMA DA LEVEDURA 50

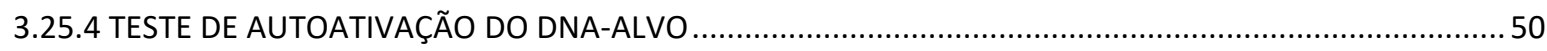

3.25.5 TRANSFORMAÇÃO DE CÉLULAS DE LEVEDURA COM A BIBLIOTECA DE cDNAS para Y1H ....................50

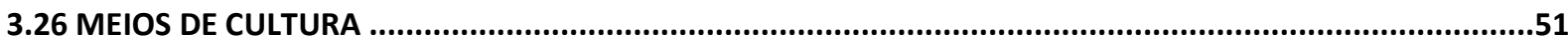

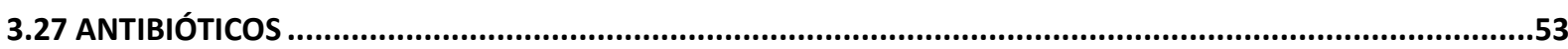

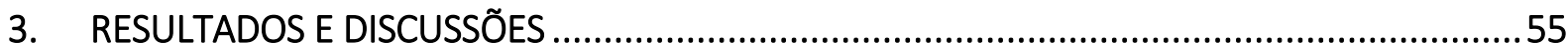

3.1 A PROTEÍNA GFP-NTCDKG;2 ESTÁ PRESENTE NO NUCLEOPLASMA E EM SPECKLES NUCLEARES NAS CÉLULAS DE N. benthamiana

3.2 NtCDKG;2 PODE ESTAR INTRINSECAMENTE RELACIONADA À REGIÃO ORGANIZADORA DA FORMAÇÃO DO

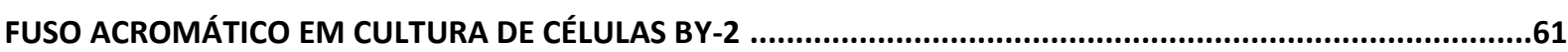

3.3 OBTENÇÃO DA PROTEÍNA RECOMBINANTE HIS-NTCDKG;2 EM E. coli E PRODUÇÃO DE ANTICORPO

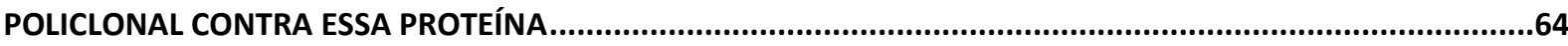

3.4 A PROTEÍNA NTCDKG;2 PODE APRESENTAR DIFERENTES ISOFORMAS ASSIM COMO SUA HOMÓLOGA CDK11 DE HUMANOS.

3.4.1 IDENTIFICAÇÃO DE UM PUTATIVO SÍTIO IRES PARA TRADUÇÃO CAP-INDEPENDENTE EM NtCDKG;2 ...66 3.4.2 A PROTEÍNA NTCDKG;2 PODE APRESENTAR ISOFORMAS MENORES EM FOLHAS DE N. tabacum ..........68

3.4.3 A PROTEÍNA HIS-NtCDKG;2 PRODUZIDA EM E. coli PODE SER CLIVADA APÓS INCUBAÇÃO COM EXTRATO DE FOLHAS DE N. tabacum

\subsection{ANÁLISES IN SILICO DA PROTEÍNA NTCDKG;2 APONTAM DIVERSOS MOTIVOS PARA INTERAÇÃO COM}

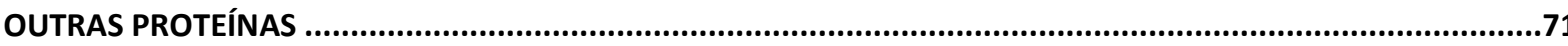

3.6 ENSAIO DE DUPLO-HÍBRIDO REVELA INTERAÇÃO DE NtCDKG;2 COM IMPORTANTES PARCEIROS.............75 
3.4.2 TRANSFORMAÇÃO DE CÉLULAS DE E. coli COM OS DNAs EXTRAÍDOS DOS CLONES POSITIVOS E

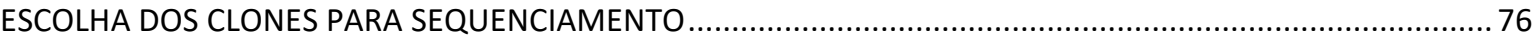

3.6.3 IDENTIFICAÇÃO DE PUTATIVAS PROTEÍNAS PARCEIRAS DE INTERAÇÃO DE NtCDKG;2 …........................ 77

3.6.4 NtCDKG;2 INTERAGE COM NtCDKF;1, UMA REGULADORA DA TRASCRIÇÃO E SPLICING ....................... 81

3.6.5 NtCDKG;2 INTERAGE COM O REGULADOR INICIAL DE TRANSCRIÇÃO NtCBP1 ..................................... 83

3.6.6 NtCDKG;2 INTERAGE COM A PROTEÍNA RanBP1 DE N. tabacum ....................................................... 84

3.7 A INTERAÇÃO ENTRE NtSCI1 E NtCDKG;2 OCORRE NO NUCLÉOLO DAS CÉLULAS DE N. tabacum ...............86

3.8 NtCDKG;2 INTERAGE COM A 14-3-3D DE $N$. tabacum, UMA PARCEIRA DE INTERAÇÃO DE NtSCl1 .............88

3.9 NtSCI1 INTERAGE COM A SUBUNIDADE NRPB11 DA RNA POLIMERASE II, PARCEIRA DE INTERAÇÃO DE

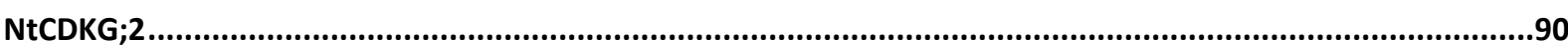

3.10 IDENTIFICAÇÃO DE PUTATIVAS SEQUÊNCIAS CIS REGULATÓRIAS DO PROMOTOR E DA SEQUÊNCIA

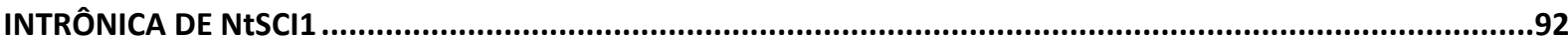

3.11 IDENTIFICAÇÃO DE FATORES DE TRANSCRIÇÃO QUE POSSAM SE LIGAR AOS DOMÍNIOS CIS REGULATÓRIOS DE NtSCI1 .96

3.12 OBTENÇÃO DAS SEQUÊNCIAS UPSTREAM E DOWNSTREAM AO ATG INICIAL DE NTSCI1 .99

3.12.1 AMPLIFICAÇÃO DOS PUTATIVOS PROMOTORES DE NtSCI1 DAS CÓPIAS DE N. tomentosiformis E $N$. sylvestris 99

3.12.2 AMPLIFICAÇÃO DA REGIÃO DOWNSTREAM AO ATG INICIAL DE NtSCI1 CÓPIA DE N. tomentosiformis 101

3.13 ENSAIO DE INTERAÇÃO DNA-PROTEÍNA EM BUSCA DE FATORES DE TRANSCRIÇÃO QUE POSSAM

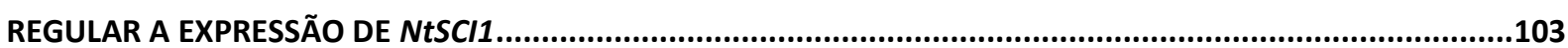

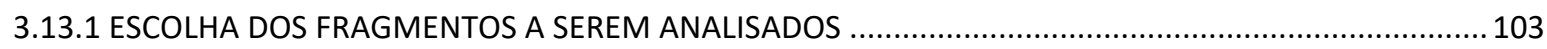

3.13.2 CONSTRUÇÃO DOS VETORES PARA ENSAIOS DE INTERAÇÃO DNA-PROTEÍNA EM LEVEDURA ............ 104

3.13.3 TRANSFORMAÇÃO E INTEGRAÇÃO DOS DNAs-ALVO NO GENOMA DE LEVEDURAS E TESTE DE AUTOATIVAÇÃO. 105

3.13.4 SCREENING EM BUSCA DE PUTATIVOS FATORES DE TRANSCRIÇÃO QUE INTERAGEM COM OS DNASALVO DO PROMOTOR E DA SEQUÊNCIA INTRÔNICA DE NTSCI1 106

4. CONCLUSÕES. .110

5. REFERÊNCIAS BIBLIOGRÁFICAS .113

Apêndice A - ARTIGO PARA SUBMISSÃO EM REVISTA CIENTÍFICA DA ÁREA .137

APÊNDICE B - CLONES IDENTIFICADOS NO SCREENING DE DUPLO HÍBRIDO COM NTCDKG;2 .170 
APÊNDICE C - ALINHAMENTO DAS SEQUÊNCIAS GENÔMICAS DE SCI1 DE $N$. tabacum, $\boldsymbol{N}$. tomentosiformis E $N$. sylvestris .185

APÊNDICE D - ELEMENTOS CIS REGULATÓRIOS IDENTIFICADOS NO PROMOTOR DE NTSCI1 CÓPIA DE $N$. tomentosiformis .193

APÊNDICE E - ELEMENTOS CIS REGULATÓRIOS IDENTIFICADOS NO PROMOTOR DE NTSCI1 CÓPIA DE $N$. sylvestris .198 APÊNDICE F - RESULTADOS OBTIDOS DURANTE O PERÍODO DE DOUTORADO REALIZADO NA UNIVERSIDADE DE WAGNENINGEN, REINO DOS PAÍSES BAIXOS 202 -

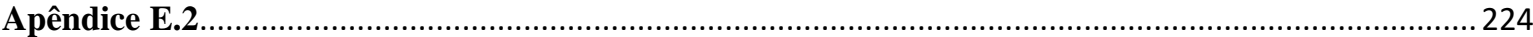

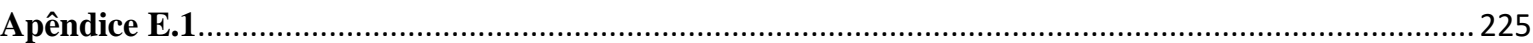

ANEXO A - PLASMÍDEOS UTILIZADOS PARA AS CLONAGENS .230 


\section{Lista de Abreviaturas e Siglas}

3-AT - 3-amino-1,2,4-trizole (3-amino-1,2,4-triazol)

AD - Activation Domain - domínio de ativação do fator de transcrição GAL4

Ade - adenina

BD - DNA Binding Domain - domínio de ligação ao DNA

BiFC - Bimolecular Fluorescence Complementation

BY-2 - cultivar Bright Yellow - 2

cDNA - DNA complementar

CDS - Coding sequence - sequência codificadora

CTD - Carboxi-terminal domain - Domínio carboxi-terminal

DAPI - 4',6-diamidino-2-phenylindole

$\mathrm{dH}_{2} \mathrm{O}$ - água deionizada

DMSO - Dimetilsulfóxido

dATP - Deoxyadenosine triphosphate

dNTP - Deoxyribonucleotide 5'-triphosphate

EDTA - Etbylenediamine tetraacetic acid

$\mathrm{g}$ - força gravitaconal

GFP - Green Fluorescent Protein - Proteína Verde Fluorescente

hGFP - head-Green Fluorescent Protein - porcão amino-terminal da GFP

tGFP - tail- Green Fluorescent Protein - porção carboxi-terminal da GFP

GST - Glutathione S-transferase

HEPES - 4-(2-hydroxyethyl)-1-piperazineethanesulfonic acid

His - histidina 
IgG - Imunoglobulina $G$

IPTG - Isopropyl $\beta$-D-1-thiogalactopyranoside

Leu - leucina

LiAc - acetato de lítio

MES - 2-N-morpholino ethanesulfonic acid

$\mathrm{NaOH}$ - Hidróxido de sódio

NtCBP1 - Nicotiana tabacum SBP1

NtCDKG;2 - Nicotiana tabacumCDKG;2

NtSCI1 - Nicotiana tabacumSCI1

NtRanBP1 - Nicotiana tabacuM RanBP1

Nt14-3-3D - Nicotiana tabacuM 14-3-3D

$\mathrm{OD}_{600}$ - Optical Density - Densidade Optica a $600 \eta \mathrm{m}$

ORF - Open Reading Frame

$35 \mathrm{~S}_{\text {prom }}$ - promotor $35 \mathrm{~S}$ do vírus do mosaico da couve-flor

$\mathrm{pb}$ - pares de bases

PCR - Polymerase Chain Reaction - Reação em cadeia da polimerase

PEG3350 - Polyethylene Glycol 3350

$\mathrm{rpm}$ - rotações por minuto

SDS - Sodium Dodecyl Sulphate

SDS-PAGE - Sodium Dodecyl Sulphate - Polyacrylamide gel electrophoresis

Ser - serina

T.A. - temperatura ambiente

Thr - treonina

Trp - triptofano

UV - ultravioleta 
$\mathrm{w} / \mathrm{v}$ - massa/volume

Y2H - Yeast Two-Hybrid - Duplo-híbrido em leveduras

Y1H - Yeast One-Hybrid-Mono-híbrido em leveduras 


\section{Resumo}

LUBINI, G. NtCDKG;2, uma proteína multifuncional, relacionada aos processos de transcrição, processamento de RNA e organização do fuso acromático no ciclo celular de Nicotiana tabacum. [Tese de Doutorado]. Ribeirão Preto: Universidade de São Paulo, Faculdade de Medicina de Ribeirão Preto, 2016. 232 p.

Os estudos em reprodução e desenvolvimento das plantas, especialmente voltados ao pistilo, são de grande interesse agronômico, econômico e científico. Em nosso laboratório,

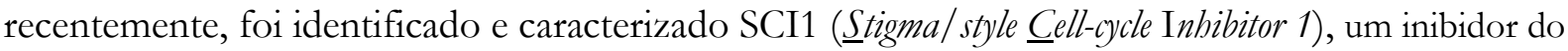
ciclo celular que atua de forma tecido específica no pistilo de Nicotiana tabacum L. e Arabidopsis thaliana (L.) Heynh. (DEPAOLI et al., 2011; DEPAOLI; DORNELAS; GOLDMAN, 2014). Foi identificada a proteína NtCDKG;2 (․․ tabacum Cyclin- $\underline{\text { dependent }}$ Kinase 2) como parceira de interação de NtSCI1 (N. tabacum SCI1), em um ensaio de pull-down (STRINI, 2014). A literatura aponta que os inibidores de ciclo celular regulam o ciclo através da inibição de CDK, o que sugere que NtSCI1 possa regular o ciclo celular através da inibição de NtCDKG;2. O presente estudo mostra análises detalhadas da localização de GFP-NtCDKG;2 em células epiteliais de $N$. benthamiana. Verificou-se que a proteína NtCDKG;2 está presente no nucleoplasma e também co-localiza em speckles nucleares. Em cultura de células BY2 expressando GFP-NtCDKG;2 de forma estável, foi observado que, durante a metáfase e anáfase, a proteína NtCDKG;2 está junto ao fuso acromático. Adicionalmente, ensaios de BiFC (Bi-molecular Fluorescence Complementation) realizados neste trabalho mostram que a interação entre as proteínas NtCDKG;2 e NtSCI1 ocorre em uma região localizada na periferia nucleolar, durante a interfase. Também foram identificadas possíveis isoformas de NtCDKG;2. A possibilidade da ocorrência de isoformas sugere que, de maneira análoga à sua homóloga em humanos, as isoformas resultantes de NtCDKG;2 possam atuar em diferentes processos. Em busca de parceiros de interação de NtCDKG;2, para identificar em que vias esta proteína atua, foi realizado um screening de uma biblioteca de cDNAs de estigmas e estiletes de $N$. tabacum, no sistema de duplo-híbrido em leveduras (Y2H). Através desse ensaio, foram identificados diversos parceiros envolvidos com transcrição e processamento de RNA. Dentre as proteínas identificadas, cuja interação foi confirmada neste trabalho, destaca-se a proteína NtCDKF;1, uma proteína que fosforila o CTD da RNA Polimerase II e, dessa forma, auxilia a transcrição e o splicing cotranscricional (HAJHEIDARI et al., 2012). O presente trabalho mostra também a interação entre NtCDKG;2 e a proteína NtCBP1, uma proteína que possui um papel importante na regulação inicial da transcrição de proteínas mediadoras do crescimento do tubo polínico (LI et al., 2015). 
Adicionalmente, o screening de $\mathrm{Y} 2 \mathrm{H}$ possibilitou a identificação da interação entre NtCDKG;2 e NtRanBP1, uma proteína chave na formação do fuso acromático que, em humanos, interage com uma isoforma homóloga a NtCDKG;2, a CDK11 ${ }^{\mathrm{p} 46}$ (MIKOLAJCZYK et al., 2003; YOKOYAMA et al., 2008; ZHANG; DAWE, 2011). Análises in silico realizadas com a sequência de aminoácidos de NtCDKG;2 apontaram motivos de interação com proteína do tipo F-Box, ciclina, CDK, fosfatase, 14-3-3, BRCA1 e indicaram o local provável de interação do complexo CDK-Ciclina com o respectivo inibidor. Foi testada e comprovada a interação entre NtCDKG;2 e a 14-3-3D, por $\mathrm{Y} 2 \mathrm{H}$, uma parceira de NtSCI1. Outra lacuna que precisava ser preenchida é referente à regulação da expressão de NtSCI1. Com este intuito, foram realizadas análises in silico para identificar elementos cis-regulatórios na sequência genômica de NtSCI1. Essas análises indicaram a presença de importantes elementos cis-regulatórios relacionados à identidade meristemática (como WUSCHEL e AINTEGUMENTA), identidade do carpelo (AGAMOUS, BELL) e progressão do ciclo celular (E2F e CDC5). Algumas considerações podem ser feitas associando os resultados obtidos a estudos feitos paralelamente em nosso laboratório: 1) Compilando a localização de NtCDKG;2 em splicing speckles e sua interação com os diferentes parceiros de interação relacionados à transcrição e splicing, sugere-se que NtCDKG;2 também atue nos processos transcricionais e de splicing. 2) Considerando a localização subcelular de NtCDKG;2 durante as diferentes fases do ciclo celular, às análises in silico dessa proteína que identificaram sua possível interação com BRCA1, além da interação confirmada com a proteína NtRanBP1, é possível sugerir que NtCDKG;2 atue, direta ou indiretamente, na organização do fuso acromático de plantas. 3) Propõem-se que NtSCI1 regule a proliferação celular no pistilo através da interação com NtCDKG;2 que se dá no nucléolo das células. Dessa forma, NtSCI1 prenderia NtCDKG;2 no nucléolo e inibiria sua atuação, como na organização do fuso acromático, o que acarretaria inibição da divisão celular. 4) Devido aos motivos cis-regulatórios encontrados na sequência genômica de NtSCI1 e o efeito que a proteína possui desde as fases iniciais do desenvolvimento do pistilo, sugere-se que a expressão desse gene seja regulada por elementos diretamente envolvidos no controle do término do meristema floral e nas vias de desenvolvimento de órgãos florais.

Palavras-chave: SCI1, CDK, ciclo celular, localização subcelular, fuso acromático, BiFC, Y2H. 


\begin{abstract}
LUBINI, G. NtCDKG;2, a multifunctional protein, related to RNA transcription, RNA processing and achromatic spindle organization in Nicotiana tabacum cell cycle. [Tese de Doutorado]. Ribeirão Preto: Universidade de São Paulo, Faculdade de Medicina de Ribeirão Preto, 2016. 232 p.
\end{abstract}

Studies on plant reproduction and development, specifically those related to the pistil, are of great agronomic, economic and scientific interest. In our laboratory, we recently identified and characterized SCI1 ( tigma/style Cell-cycle Inbibitor 1), an inhibitor of the cell cycle which acts tissuespecifically in the pistil of Nicotiana tabacum L. and Arabidopsis thaliana (L.) Heynh. (DEPAOLI et al., 2011; DEPAOLI; DORNELAS; GOLDMAN, 2014). The NtCDKG;2 (N. tabacum Cyclin-dependent $\underline{\text { Kinase }}$ G; 2) protein was identified as an interaction partner of NtSCI1 (N. tabacum SCI1) in a pulldown assay (STRINI, 2014). The literature suggests that cell cycle inhibitors control the cycle through the inhibition of CDKs, indicating that NtSCI1 might control cell cycle by inhibiting $\mathrm{NtCDKG;2.} \mathrm{This} \mathrm{study} \mathrm{shows} \mathrm{detailed} \mathrm{analysis} \mathrm{of} \mathrm{GFP-NtCDKG;2} \mathrm{localization} \mathrm{in} \mathrm{leaf} \mathrm{cells} \mathrm{of} N$. benthamiana. The analysis shows that NtCDKG;2 is present in the nucleoplasm and also co-localizes with nuclear speckles. In BY2 cell culture stably expressing GFP-NtCDKG;2, it was observed that $\mathrm{NtCDKG;2}$ is at the achromatic spindle during metaphase and anaphase. Additionally, BiFC (Bimolecular Fluorescence Complementation) assays performed in this study have shown that the interaction of $\mathrm{NtCDKG} ; 2$ and $\mathrm{NtSCI} 1$ occurs in the nucleolar periphery during interphase. Putative isoforms of NtCDKG;2 were also identified. The possible occurrence of these isoforms suggests that, in a similar way to its human homologue, $\mathrm{NtCDKG} ; 2$ putative isoforms could act in different processes. To identify in which processes this protein could act, a search for NtCDKG;2 interaction partners was performed through the screening of a N. tabacum stigma and style cDNA library in the yeast two-hybrid $(\mathrm{Y} 2 \mathrm{H})$ system. Several partners identified through this assay have roles in RNA transcription and processing. Among the identified partners with interaction confirmed during this work, stands out the NtCDKF;1 protein, a CDK that phosphorylates the RNA polymerase II CTD, and thus, supports transcription and co-transcriptional splicing (HAJHEIDARI et al., 2012). This study also shows the interaction of NtCDKG;2 with NtCBP1, a protein which has an important role in the transcriptional regulation of genes encoding proteins mediating pollen tube growth (LI et al., 2015). Furthermore, the Y2H screening allowed the identification of the interaction of NtCDKG;2 with NtRanBP1, a key protein in the formation of the achromatic spindle which, in humans, interacts with the CDK11 ${ }^{\mathrm{p} 46}$ isoform (MIKOLAJCZYK 
et al., 2003; YOKOYAMA et al., 2008; ZHANG; DAWE, 2011), a homologue of NtCDKG;2. In silico analysis of the amino acid sequence of $\mathrm{NtCDKG} ; 2$ revealed motifs of predicted interaction with F-box proteins, cyclins, CDKs, phosphatases, 14-3-3s, BRCA1, and also pointed the region where the CDK-cyclin complex might interact with its respective inhibitor. The interaction of $\mathrm{NtCDKG}$;2 with 14-3-3D, a known partner of NtSCI1, was tested and confirmed by $\mathrm{Y} 2 \mathrm{H}$. Another gap that needed to be filled is related to the regulation of NtSCI1 expression. To address this issue, in silico analysis to identify cis-regulatory elements was performed in NtSCI1 genomic region. These analyses revealed the presence of important cis-regulatory elements related to meristem identity (such as WUSCHEL and AINTEGUMENTA), carpel identity (AGAMOUS, BELL), and cell cycle progression (E2F and CDC5). Taken together results from this study and parallel studies performed in our laboratory, a few remarks can be made: 1) Taken the localization of NtCDKG;2 in splicing speckles, and its interaction with different proteins involved in transcription and splicing, it is suggested that $\mathrm{NtCDKG;2}$ also has roles on these processes; 2) Considering the subcellular localization of NtCDKG;2 during the different cell cycle phases, the in silico analysis of this protein that predicts its interaction with BRCA1, and the confirmed interaction with $\mathrm{NtRanBP1}$ protein, it is possible to suggest that NtCDKG;2 has a direct or indirect role in the organization of the achromatic spindle in plants; 3) It is proposed that NtSCI1 regulates cell proliferation in the pistil through its interaction with $\mathrm{NtCDKG;2,} \mathrm{which} \mathrm{occurs} \mathrm{in} \mathrm{the} \mathrm{nucleolus.}$ Thus, NtSCI1 could hold NtCDKG;2 in the nucleolus, inhibiting its actions, such as in the organization of the achromatic spindle, resulting in cell division arrest. 4) Due to the cis-regulatory elements found in the genomic sequence of NtSCI1, and the effect of this protein since the initial stages of pistil development, it is suggested that its expression is regulated by elements directly involved in the control of the floral meristem termination and pathways of floral organ development.

Keywords: SCI1, CDK, cell cycle, subcellular localization, achromatic spindle, BiFC, Y2H. 

Lubini, G. 2016

Introdução 


\section{INTRODUÇÃO}

A maioria dos alimentos consumidos pelos animais, dentre eles, o homem, é composta de frutos e sementes, partes reprodutivas das plantas. Devido a isso, os estudos em reprodução e desenvolvimento das plantas da família Solanaceae, especialmente voltados ao pistilo e ao fruto, são de grande interesse agronômico, econômico e científico. O Laboratório de Biologia Molecular de Plantas possui como foco o estudo do desenvolvimento do pistilo e utiliza como planta modelo a espécie Nicotiana tabacum, pertencente à família Solanaceae. O presente trabalho pretende auxiliar nas hipóteses em relação aos mecanismos através dos quais o desenvolvimento do pistilo é influenciado pelo inibidor de proliferação celular tecido específico NtSCI1 (N. tabacum $\underline{\text { tigma/S }}$ tyle Cell Cycle Inbibitor 1 ) e sua parceira de interação, a proteína NtCDKG;2.

\subsection{A FAMÍLIA SOLANACEAE E OS MODELOS DE ESTUDO}

Dentro da família Solanaceae, encontram-se diversas espécies com importância agronômica, medicinal e ornamental. Os indivíduos da família são cultivados no mundo todo (exceto Antártida), nos mais diferenciados climas, porém, a maior diversidade de representantes é encontrada na América do Sul e Central (KNAPP, 2002). Dentre as quase 3000 espécies contidas na família (KNAPP, 2002), destacam-se espécies de importância econômica, como o tomateiro e a batata (pertencentes a Solanum, o maior gênero da família), a planta do tabaco ou fumo (N. tabacum), algumas pimentas e pimentões (espécies do gênero Capsisicum) e a petúnia (espécies do gênero Petunia).

É relatado que, dentre as espécies do gênero Nicotiana, 40\% são poliploides naturais (LEITCH et al., 2008). Dentre elas, a espécie $N$. tabacum é uma alotetraplóide $(2 \mathrm{n}=4 \mathrm{x}=48)$, originada da hibridação interespecífica de duas espécies diplóides, N. sylvestris e N. tomentosiformis (GOODSPEED, 1954; GRAY et al., 1974). Acredita-se que o genoma materno de N. tabacum originou-se da espécie ancestral de N. sylvestris (BLAND; MATZINGER; LEVINGS, 1985; KENTON et al., 1993; MURAD et al., 2002; VOLKOV et al., 1999; YUKAWA; TSUDZUKI; SUGIURA, 2006). Estudos de evolução dos genomas poliploides mostram que, em poucos casos, há manutenção ou aumento do tamanho do genoma nas espécies poliploides. Normalmente, o que se espera após um processo de poliploidização são eventos de perda dos genes duplicados, subfuncionalização e, até mesmo, neofuncionalização gênica (LEITCH; BENNETT, 2004). 
Entretanto, as mudanças no genoma poliploide são relatadas em espécies cuja ploidia se deu há milhões de anos. Por exemplo, Oryza sativa foi originada há, aproximadamente, 70 milhões de anos e Zea mays entre 3-11 milhões de anos. Nessas espécies, é relatado que 30-65\% e 50\% dos genes duplicados foram perdidos, respectivamente (MESSING et al., 2004; WANG et al., 2005). Entretanto, é sugerido que o processo de hibridação interespecífica que originou N. tabacum tenha ocorrido há 200.000 anos (DOYLE et al., 2008), o que ainda é considerado recente quando se refere a tempo de evolução. Recentemente, os genomas de três variedades de N. tabacum e os genomas e transcriptomas de seus parentais foram sequenciados e suas análises demostraram que o genoma de N. tabacum ainda é muito similar aos genomas parentais (SIERRO et al., 2013, 2014). Portanto, acredita-se que os genes homeólogos presentes no genoma de N. tabacum ainda sejam expressos, apresentem funções redundantes, sendo regulados e transcritos de formas similares.

Apesar de possuir um genoma poliploide, N. tabacum foi a primeira espécie vegetal a ser geneticamente transformada com sucesso (HERRERA-ESTRELLA et al., 1983) e, desde então, vem sendo utilizada como um grande modelo experimental em investigações científicas nas áreas de engenharia genética, farmácia, biologia reprodutiva, biologia celular e molecular. A espécie também serve como modelo em estudos que envolvam órgãos florais já que, nessa planta, as flores são numerosas e os elementos florais são grandes e de fácil manipulação e, após fertilização, há geração de muitas sementes, garantindo a facilidade em sua propagação. Além disso, o ciclo de vida de $N$. tabacum é relativamente curto (aproximadamente 6 meses) e a planta é bem adaptada a climas quentes, como o de Ribeirão Preto, SP. Por essas razões, o nosso grupo de pesquisa utiliza N. tabacum como modelo experimental nos estudos de desenvolvimento do pistilo.

Devido a muitas espécies de Solanaceae terem grande importância econômica, foi estabelecido um consórcio internacional (International Solanaceae Genomics Project - SOL Genomics Network) a fim de sequenciar o genoma de diferentes espécies da família. Os estudos objetivaram compreender como, em uma mesma família, espécies com carga genética semelhantes podem ser tão diversas a nível morfológico e tão diferentemente adaptadas a nível ecológico. O projeto definiu como primeiro plano o sequenciamento dos 12 cromossomos do tomateiro, o qual foi dividido entre centros de diferentes países. Após o sequenciamento do tomateiro, seu genoma foi utilizado como base de comparação e organizações filogenéticas para outros organismos da família (The Tomato Genome Consortium, 2012). 


\subsection{O DESENVOLVIMENTO PÓS-EMBRIONÁRIO DAS PLANTAS E A FORMAÇÃO DAS FLORES}

As plantas são organismos sésseis e, como tais, precisam enfrentar diversos estresses rotineiramente, como variações climáticas e predação por herbívoros e tiveram que se adaptar para enfrentar as condições adversas. As Angiospermas são o maior grupo vegetal. Acredita-se que tamanha plasticidade adaptativa desse grupo se deva ao surgimento de estruturas exclusivas: as flores e os frutos (RAVEN, 2007). Em decorrência da incessante necessidade de adaptação, as plantas adultas ainda possuem células embrionárias em constante atividade que estão localizadas em tecidos denominados meristemas. Em resposta a sinais endógenos e às condições ambientais favoráveis à reprodução, uma rede gênica finamente orquestrada leva ao desenvolvimento de flores (IRISH, 2010).

Uma flor hermafrodita é composta por folhas modificadas, as quais são organizadas em dois verticilos externos e dois verticilos internos. Os dois verticilos externos são estéreis e constituídos pelo conjunto de sépalas (cálice) e pétalas (corola). $\mathrm{O}$ androceu e o gineceu constituem os dois verticilos florais internos e são órgãos férteis (RIECHMANN; WELLMER, 2014). O androceu corresponde à parte masculina da flor e é formado pelos estames. A produção dos gametófitos masculinos (grãos de pólen) ocorre na porção apical dos estames, denominada antera. O gineceu, parte feminina da flor, é composto pelo conjunto de pistilos que, geralmente, se diferenciam em estigma (na porção distal), estilete e ovário (na porção basal), sendo esse último o local onde são produzidos óvulos que contêm as células germinativas femininas, também denominadas de sacos embrionários (ESAU, 1977). A Figura 1 esquematiza a constituição de uma flor completa. 


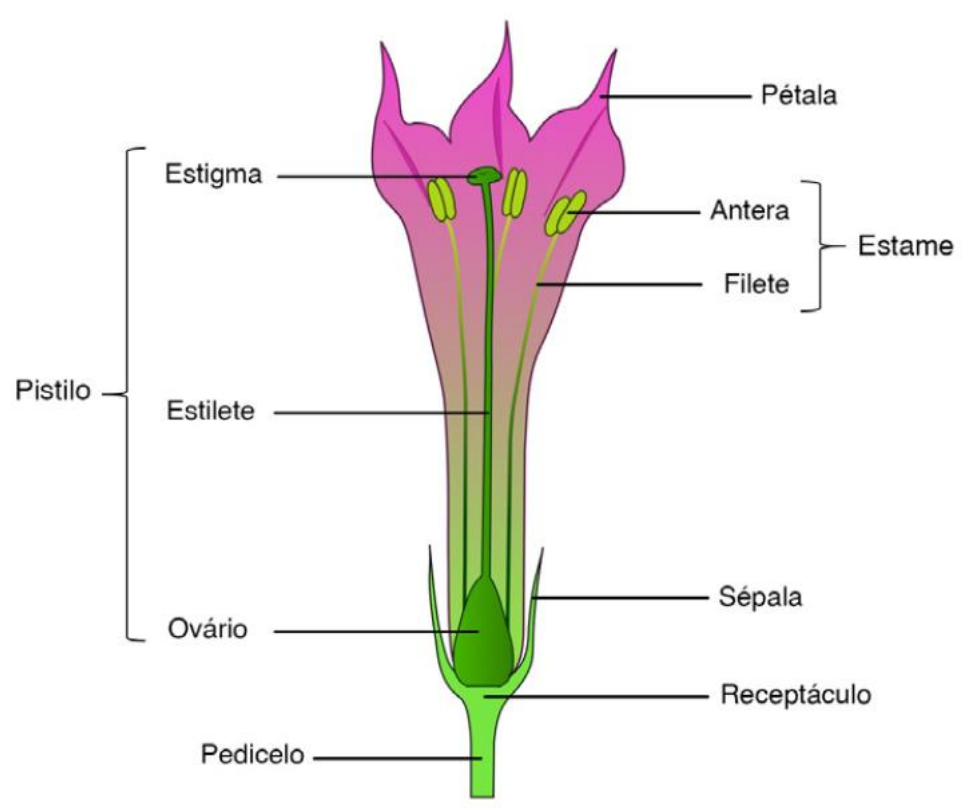

Figura 1. Desenho esquemático de uma flor de N. tabacum (extraído de Ferreira, 2013).

A manutenção das células indiferenciadas e do crescimento indeterminado do

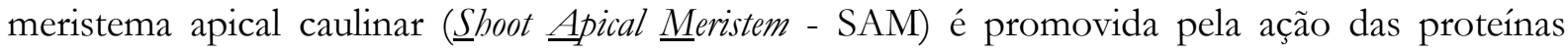
WUSCHEL (WUS) e $\underline{S} H O O \underline{\underline{M}} \underline{M} E R I S T E M L E S S$ (STM) (LAUX et al., 1996; SINHA; WILLIAMS; HAKE, 1993). Ambas proteínas são requeridas durante a embriogênese e também para manutenção de células meristemáticas nos meristemas. Durante a fase reprodutiva, algumas das células indiferenciadas do SAM originam as células do meristema de inflorescência (Inflorescence

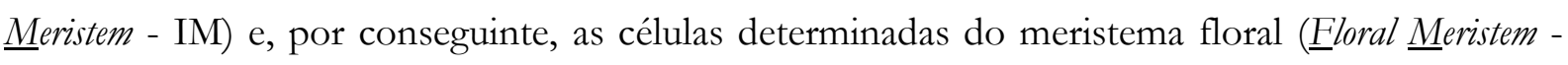
FM), as quais, por sua vez, originarão os verticilos florais (RIECHMANN; WELLMER, 2014). No SAM, os genes de florescimento são reprimidos pelas proteínas $\underline{S} H O R T \underline{V E G E T A T I V E} \underline{\mathrm{P} H A S E}$ (SVP) e $\underline{F L O W E R I N G ~ L O C U S ~} \underline{\mathrm{C}}$ (FLC). Essas proteínas bloqueiam o florescimento ao reprimirem a transcrição de genes promotores do florescimento (MICHAELS; AMASINO, 1999). A repressão/ativação do FLC depende de modificações na cromatina do próprio locus FLC. A proteína FRIGIDA (FRI) ativa a transcrição de FLC antes da vernalização (CHOI et al., 2011; JOHANSON et al., 2000), enquanto a proteína LERNALIZATION INSENSITIVE $\underline{3}$ (VIN3) reduz a transcrição de FLC durante a vernalização (SUNG; AMASINO, 2004). Assim, durante a vernalização, no FM, os genes SVP e FLC são reprimidos e, em decorrência ocorre o estímulo da transcrição de genes promotores do florescimento, dentre eles, os genes FLOWERING LOCUS T (FT), LEAFY (LFY), APETALA1 (AP1), CAULIFOWER (CAL) e SUPRESSOR OF OVVEREXPRESSION OF COO1 (SOC1) (HELLIWELL et al., 2006; SEARLE et al., 2006; IRISH, 2010; SHELDON et al., 2000). Evidências sugerem que, em resposta a dias longos, ocorre a 
transcrição e tradução da proteína FT nas folhas, a qual é transportada ao ápice caulinar (CORBESIER et al., 2007; HUANG et al., 2005). Nessa região, o fator de transcrição FT ativa dos genes LFY, AP1 e CAL nos primórdios florais (HUANG et al., 2005; RUIZ-GARCÍA et al., 1997). No SAM, a expressão desses genes é inibida pelo fator de transcrição TERMINAL FLOWER (TF), garantindo a indeterminação das células desse meristema (KARDAILSKY et al., 1999). Após expresso, LFY atua na identidade e determinação floral, principalmente por ativar AP1 (WEIGEL et al., 1992), que, juntamente com CAL, são responsáveis pela transição do IM para FM (SABLOWSKI, 2007). A Figura 2 apresenta um modelo de regulação dos genes no SAM e no FM em resposta à vernalização.
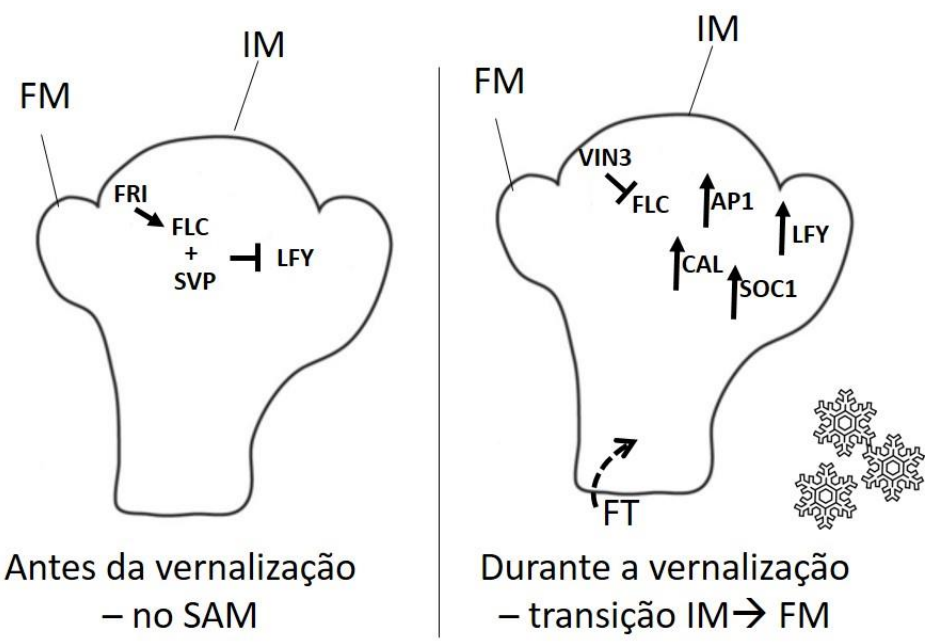

Figura 2: Regulação do florescimento através do ajuste da expressão de $\boldsymbol{F} \boldsymbol{L} \boldsymbol{C}$. Antes da vernalização, a proteína FRI ativa a transcrição do locus FLC. No SAM, as proteínas FLC e SVP reprimem os genes promotores do florescimento. WUS e STM promovem a manutenção das células indiferenciadas e do crescimento indeterminado do SAM. O processo de vernalização desencadeia uma série de sinais celulares que levam ao florescimento. Esse processo inicia com com a repressão do SVP e com a proteína VIN3 reduzindo a transcrição de FLC. Com isso, os genes LFY, AP1, CAL e SOC1 são transcritos O gene FT é transcrito em folhas e sua proteína é transportada até o ápice caulinar, onde também ativa LFY, AP1 e CAL nos primórdios foliares. LFY também ativa $\mathrm{AP1}$ e, juntamente à proteína CAL, são responsáveis pela transição do IM para FM. Dessa forma, algumas células do SAM originam o IM, o qual originará o FM e, por fim, os verticilos florais. No SAM, a expressão de TF garante a indeterminação dessas células.

Após ser iniciado, o FM produz os quatro verticilos florais (VADDEPALLI; SCHOLZ; SCHNEITZ, 2015). A identidade dos verticilos é dada, principalmente, por proteínas das classes MADS-box (JONES et al., 2013). AGAMOUS (AG) é um fator de transcrição chave para o término do meristema floral, mas também desencadeia o desenvolvimento dos verticilos reprodutores, de acordo com seu parceiro de interação. Quando AG interage com as proteínas AP3 e PI, promove o desenvolvimento de estames. Quando não interage com essas proteínas, 
promove tanto o desenvolvimento do carpelo, quanto determina o término do FM. A região da base do carpelo corresponde ao centro do FM e ainda contém as células meristemáticas. A emergência do primórdio carpelar ocorre quando o gene WUS - promotor de indiferenciação celular - é reprimido indiretamente pelo fator de transcrição AG. Alguns dados demonstram que KNUCKLES (KNU) é o intermediário entre AG e WUS (SUN et al., 2009). De acordo com os autores, AG é necessário para a expressão de KNU. Por sua vez, a proteína KNU é suficiente para reprimir a expressão de WUS e, por consequência, reprimir a manutenção de células meristemáticas na flor. Essa repressão resulta na determinação floral e bloqueia o desenvolvimento de órgãos florais no lugar de óvulos. O conjunto de dados mostra a importância de AG no desenvolvimento do carpelo e no término do FM, em um programa de desenvolvimento finamente regulado. A Figura abaixo (3) ilustra o início e o término do desenvolvimento floral.

\section{Desenvolvimento Floral}

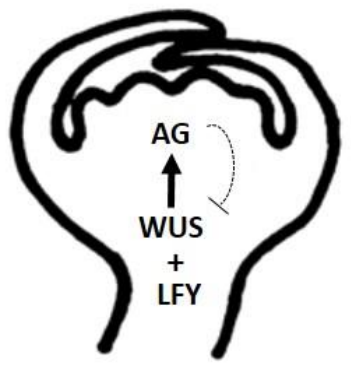

Estádios iniciais

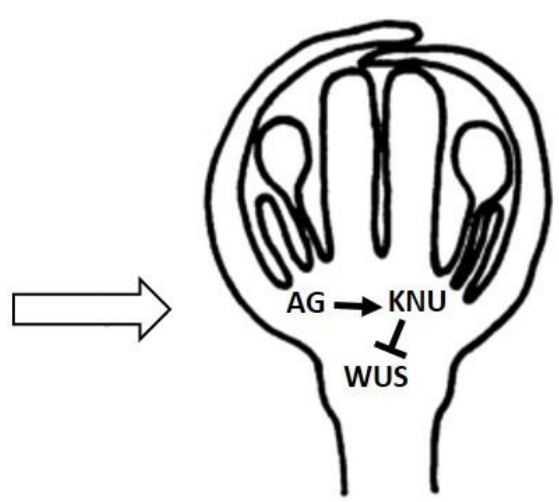

Estádios finais

Figura 3: Regulação de AG e WUS durante o desenvolvimento do carpelo e o término do meristema floral (modificado de LENHARD et al., 2001). Em estádios iniciais de desenvolvimento da flor, WUS e LFY promovem a expressão de AG no centro do FM. Em estádios finais, AG ativa a expressão da proteína KNU, a qual, reprime WUS e, assim, termina a manutenção das células meristemáticas nessa região e permite a diferenciação do gineceu.

\subsection{NtSCI1 E A REGULAÇÃO DO CICLO CELULAR NO PISTILO DE N. tabacum}

Visando identificar genes preferencialmente e/ou especificamente expressos nos estigmas/estiletes de N. tabacum, DePaoli (2006) realizou a construção de uma biblioteca subtrativa de cDNAs desses tecidos. Dentre os vários clones identificados, o gene correspondente ao clone HS1-002E06 foi escolhido para análise e caracterização (DePAOLI, 2010). Foi verificado que, além de preferencialmente expresso em estigmas/estiletes, esse gene possui maior expressão nos 
estigmas/estiletes pertencentes aos estádios iniciais do desenvolvimento floral (DEPAOLI et al., 2011). Além disso, as plantas transgênicas com superexpressão e silenciamento desse gene apresentaram fenótipos muito evidentes em relação ao tamanho do pistilo quando comparadas com plantas selvagens. Análises histológicas elucidaram que as plantas de silenciamento possuíam um aumento do tamanho dos estiletes e das áreas estigmáticas devido ao aumento do número de células do tecido transmissor do estilete (ST'T) e da zona secretória do estigma (SSZ). Apesar de menos evidentes, fenótipos opostos foram observados nas plantas de superexpressão, as quais possuíam estigmas menores que as plantas selvagens, consequência de um menor número de células. Assim, por acreditar que o produto gênico seja um inibidor do ciclo celular, capaz de regular a proliferação celular na zona secretória do estigma e no tecido transmissor do estilete, esse gene

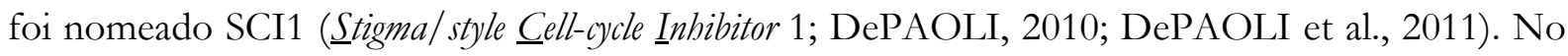
presente trabalho, o gene SCI1 de N. tabacum será denominado NtSCI1.

Apesar de estar bem demonstrado que NtSCI1 causa efeitos na proliferação celular, a forma e o momento em que a proteína NtSCI1 inibe o ciclo celular são perguntas ainda não respondidas. Um modo de estudar a função de uma proteína é estudar as proteínas com as quais ela interage. Para isso, Strini (2014) realizou um ensaio de pull-down no qual a proteína recombinante NtSCI1 foi presa por uma cauda de GST (Glutathione S-transferase) em uma coluna de afinidade. Por esta coluna foi passado um extrato proteico enriquecido com proteínas nucleares de estigmas/estiletes de $N$. tabacum. As proteínas que interagiram (direta ou indiretamente) com GST-NtSCI1 foram eluídas da coluna, separadas por SDS-PAGE e seus peptídeos foram analisados por espectrometria de massa e identificados pelo software Mascot. Uma das proteínas identificadas por esse experimento de

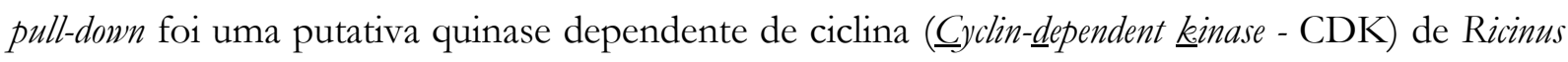
comunis (CDK10/11). A proteína identificada correspondeu à CDKG;2 de Arabidopsis thaliana (At1g67580) e será melhor apresentada a seguir.

\subsection{CDKS PRESENTES EM PLANTAS E SEU ENVOLVIMENTO NO CICLO CELULAR}

Posto que uma das proteínas identificadas como parceira de interação de NtSCI1 corresponde a uma proteína da classe das CDKs (STRINI, 2014), é possível que, assim como outros inibidores de ciclo celular, NtSCI1 exerça seu papel de regulação da proliferação celular em estigmas/estiletes através da inibição dessa CDK. Os diferentes complexos CDK/ciclina fosforilam uma série de proteínas ao longo das diferentes fases do ciclo celular, promovendo a 
divisão celular (INZÉ; DE VEYLDER, 2006; MENGES et al., 2005). As CDKs exercem atividades chaves na regulação do desenvolvimento vegetal, através do controle da proliferação e diferenciação celular (DE VEYLDER; BEECKMAN; INZÉ, 2007). Para estarem ativas, as CDKs precisam passar por eventos de fosforilação e desfosforilação de alguns resíduos de aminoácidos. Portanto, elas necessitam da atuação de uma fosfatase, a qual desfosforila dois resíduos Treonina e Tirosina dos sítios inibitórios, e de uma quinase, a qual fosforila o resíduo treonina da região Tloop (STALS; INZÉ, 2001). Como o próprio nome sugere, as CDKs precisam se ligar a uma ciclina através de um motivo conservado (JEFFREY et al., 1995). As ciclinas são proteínas que possuem ciclos de síntese e degradação durante o ciclo celular, por isso, seu nome. A Figura 4, sintetiza os mecanismos envolvidos na regulação da atividade do complexo CDK/ciclina.

A

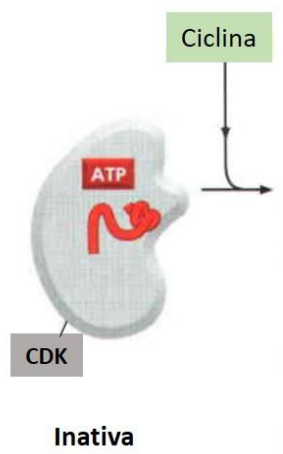

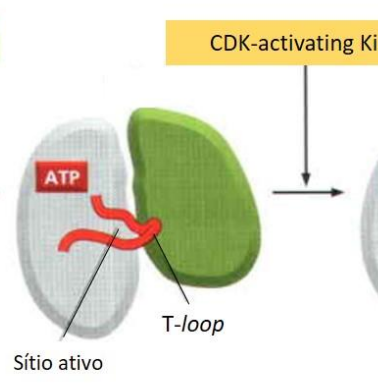

Parcialmente ativa

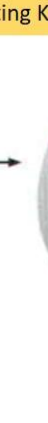

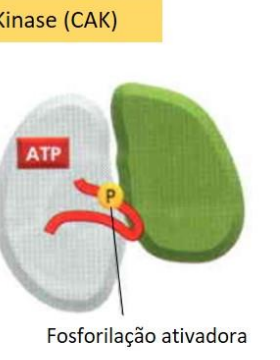

Completamente ativa
B

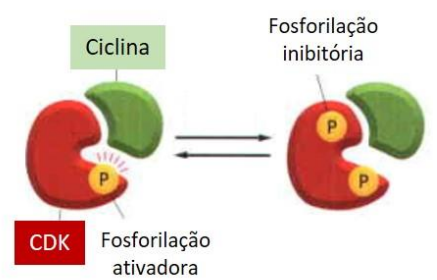

Ativa

Inativa

Figura 4: Base estrutural da regulação das CDKs (modificado de Alberts et al., 2008). A Figura (A) mostra os estados de atividade da CDK. No estado inativo, a CDK não está ligada à ciclina e o seu sítio ativo é bloqueado pelo T-loop. A ligação com a ciclina modifica a conformação da CDK, o que remove o Tloop e libera o sítio ativo. Por fim, a atuação de uma CAK na fosforilação da CDK em um sítio treonina do T-loop modifica a conformação do T-loop, o que permite a ligação da CDK com seus substratos. A Figura (B) mostra que o complexo CDK/ciclina é desligado quando uma quinase fosforila dois resíduos que se localizam próximos ao sítio ativo da enzima. A remoção das fosforilações inibitórias é realizada por uma fosfatase.

Com base nas análises dos domínios de ligação à ciclina existentes nas CDKs, as mesmas são classificadas em oito classes (CDKA a CDKG e CDK-Like, CKL) (DE VEYLDER; BEECKMAN; INZÉ, 2007; MENGES et al., 2005; TANK; THAKER, 2011; VANDEPOELE et al., 2002). A classe CDKA constitui o maior grupo de CDKs de plantas. Os genes dessa classe são ortólogos aos genes cdc28 de levedura e CDK1/CDK2 de H. sapiens. As proteínas dessa classe são reguladores-chave do controle da transição entre o gap 1 e a síntese de DNA (G1/S) e entre o gap 2 e mitose (G2/M) do ciclo celular (HIRT et al., 1993; TANK; THAKER, 2011a). As CDKAs são quinases indispensáveis para a divisão celular durante a gametogênese do pólen (HARASHIMA; SHINMYO; SEKINE, 2007). Para ser ativada, além da interação com uma ciclina, 
a proteína CDKA precisa ser fosforilada por uma CDK do tipo CAK (CDK Activating Kinase)(DISSMEYER et al., 2007).

A segunda maior classe, $\mathrm{CDKB}$, compõe uma classe de CDKs específica de plantas (DE VEYLDER; BEECKMAN; INZÉ, 2007). Em Oryza sativa (arroz), essa classe está relacionada com o controle da progressão do ciclo celular (LEE et al., 2003). Em A. thaliana, essa quinase é fundamental para o desenvolvimento dos estômatos e manutenção da identidade do meristema apical caulinar (ANDERSEN et al., 2008; BOUDOLF et al., 2004).

Membros da classe CDKC atuam juntamente à ciclina T na extensão da transcrição e no splicing. Isso ocorre através da fosforilação do domínio C-terminal (CTD) da RNA Polimerase II (FÜLÖP et al., 2005). Por sua vez, os membros da classe CDKE interagem com a ciclina C e possuem um efeito negativo na transcrição através da fosforilação do domínio CTD da RNA polimerase II (LI et al., 2014). A classe CDKE também é necessária para a especificação de estames e carpelos e término do meristema floral (WANG; CHEN, 2004).

Conforme mencionado anteriormente, para serem funcionais, as CDKs também necessitam estar fosforiladas adequadamente. Essa fosforilação no resíduo treonina do T-loop (Thr160 ou resíduo equivalente) é realizada por CDKs e induz mudanças conformacionais, além de tornar possível para a CDK o reconhecimento de seus substratos (INZÉ, 2007). As classes de CDKs que fosforilam outras CDKs são ditas CAKs (quinase ativadora de CDK - CDK Activating Kinase). O genoma de $A$. thaliana codifica 4 CAKs: três constituem a classe CDKD e a outra constitui a classe CDKF. Se as condições forem favoráveis, a CDKF fosforila as CDKDs, ativandoas e desencadeando outros processos de fosforilações e a divisão celular (SHIMOTOHNO et al., 2004). Portanto, a CDKF;1, particularmente, é uma CAKAK (quinase ativadora de quinase ativadora de $\mathrm{CDK}$ ) e somente é encontrada em plantas (UMEDA; SHIMOTOHNO; YAMAGUCHI, 2005). Assim como CDKC e CDKE, ambas CDKD e CDKF;1 também são responsáveis pela regulação da atividade da RNA Polimerase II através de fosforilações no domínio CTD (HAJHEIDARI et al., 2012).

Finalmente, a classe CDKG foi descrita em $A$. thaliana como uma nova classe por possuir um motivo para ligação à ciclina que ainda não havia sido identificado, o motivo PLTSLRE (MENGES et al., 2005). Em A. thaliana, a classe G compreende duas proteínas: AtCDKG;1 e AtCDKG;2 (TANK; THAKER, 2011a). A proteína AtCDKG;1 atua na regulação do splicing do pré-mRNA do gene CALLOSE SYNTHASE (CalS5) durante a formação da parede celular do grão-de-pólen (HUANG et al., 2013). Recentemente, foi sugerida sua participação nos processos de sinapse cromossômica e recombinação durante a gametogênese masculina. Nesses processos, a AtCDKG;1 atuaria em complexo com a proteína Ciclina L1 (Cyclin L1 - CycL1) (ZHENG et al., 
2014). A CycL1 é uma proteína do tipo SR-Like (DICKINSON et al., 2002) e sua importância foi demonstrada ao afetar o splicing constitutivo em células de animais (LOYER et al., 2008). Devido a sua importância no presente trabalho, as proteínas CDKG;2 de plantas serão abordadas no tópico a seguir (1.5), juntamente com suas homólogas de H. sapiens.

\subsection{NtCDKG;2 E SUAS HOMÓLOGAS DE $A$. thaliana E DE Homo sapiens}

A proteína NtCDKG;2 recentemente identificada em N. tabacum como parceira de interação de NtSCI1 (STRINI, 2014) é homóloga à AtCDKG;2 de A. thaliana e à CDK11 de $H$. sapiens (FERREIRA, 2016). Inicialmente, uma análise de expressão global mostrou que, em $A$. thaliana, a AtCDKG;2 é expressa em calos celulares e em plântulas (MENGES et al., 2005). Visando determinar em que momento a proteína AtCDKG;2 é requerida durante os eventos de organogênese e proliferação celular, foram analisados os processos de indução de calos e regeneração de plantas in vitro, utilizando calos de uma linhagem de $A$. thaliana com o gene AtCDKG;2 inativo (ŻABICKI et al., 2013). Os autores do trabalho demonstraram que os mutantes AtCDKG;2 apresentaram atraso e defeitos na organogênese. Devido a deformidades na formação dos órgãos reprodutivos, os mutantes não formaram sementes em suas inflorescências, além disso, houve malformação do caule. Conforme sugerido pelos autores, esses fenótipos indicam que a função de AtCDKG;2 não é restrita ao controle do ciclo celular, podendo a proteína estar envolvida durante estádios de desenvolvimento iniciais da planta e na formação dos órgãos.

As análises filogenéticas indicavam um possível envolvimento da AtCDKG;2 no processamento do mRNA e no acoplamento da progressão do ciclo celular com o splicing (DOONAN; KITSIOS, 2009; VAN LEENE et al., 2010a). Interações entre AtCDKG;2 e demais

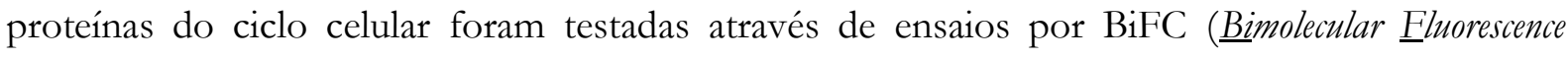

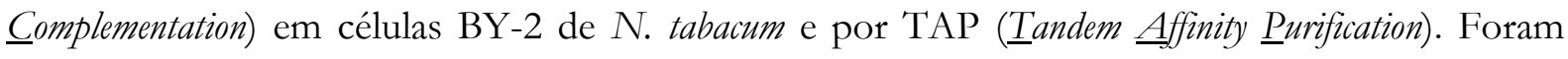
comprovadas as interações entre AtCDKG;2 e seis ciclinas (CycA3;4/CycD4;1/CycD4;2/CycF1/CycH1/CycL1), duas CDKs (CDKB;1/CDKF;1) e um inibidor de CDK (KRP4)(BORUC et al., 2010b; VAN LEENE et al., 2007, 2010a). Além disso, foi sugerido que a AtCDKG;2 pudesse estar envolvida nos processos de diferenciação celular (TANK; THAKER, 2011a)

A importância da $\mathrm{CDKG} ; 2$ de $A$. thaliana foi demonstrada na regulação do florescimento (MA et al., 2015). O trabalho de Ma et al. (2015) relatou uma antecipação do florescimento em plantas mutantes $c d k g ; 2$ quando comparadas às plantas selvagens. A fim de determinar as possíveis 
causas desse fenótipo, foram realizadas análise de expressão de genes relacionados ao florescimento. Como resultado, observaram o decréscimo da expressão do gene FLC e aumento da expressão dos genes SOC1, AP1 e LFY, promotores de florescimento (MA et al., 2015). Entretanto, os autores não souberam explicar quais vias estão sendo alteradas para que esses genes tenham sua expressão alterada.

Em nosso laboratório foi clonada a NtCDKG;2. O gene $N t C D K G ; 2$ possui expressão ubíqua nos diferentes órgãos e sua proteína se localizada no núcleo celular (FERREIRA, 2016; LUBINI, 2012). Não foram evidenciadas alterações fenotípicas morfológicas nas plantas transgênicas de superexpressão ou silenciamento geradas, quando comparadas às plantas selvagens de N. tabacum (LUBINI, 2012). No entanto, acredita-se que sua proteína possui considerável importância no desenvolvimento dos estigmas/estiletes, especialmente nos estádios mais tardios de desenvolvimento floral de $N$. tabacum já que ela possui maior expressão nesses estádios (LUBINI, 2012). Paralelamente, Ferreira (2016) também analisou a interação de NtCDKG;2 com proteínas provenientes de um screening que visava a identificação de possíveis parceiros de interação de NtCDKG;2 (esta tese).

Em H. sapiens, a CDK11 possui diferentes isoformas. As CDK11 ${ }^{\mathrm{p} 110}, \mathrm{CDK} 11^{\mathrm{p} 58}, \mathrm{CDK} 11^{\mathrm{p} 46}$ e CDK11 ${ }^{\mathrm{p} 60}$ são nomeadas com base no peso molecular das proteínas $(110 \mathrm{kDa}, 58 \mathrm{kDa}$, $46 \mathrm{kDa}$ e $60 \mathrm{kDa}$ respectivamente). A isoforma $\mathrm{CDK} 11^{\mathrm{p} 110}$ é originada pela tradução cap-dependente do mRNA e sua função foi atrelada aos eventos de regulação da transcrição e splicing (TREMBLEY et al., 2004). Já a isoforma $\mathrm{CDK} 11^{\mathrm{p} 58}$ tem sua origem devido a uma tradução com entrada do ribossomo em um sítio interno do mRNA, denominado IRES (Internal R $\underline{\text { ibosome }}$ Entry $\underline{\text { Site) }}$. Essa tradução, mediada por IRES, não requer o cap na extremidade 5', sendo, portanto, denominada capindependente. Estudos indicam que a isoforma CDK11 ${ }^{\mathrm{p} 58}$ é requerida durante a mitose para maturação do centrossomo e formação correta do fuso mitótico (CORNELIS et al, 2000; PETRET'TI et al., 2006; TREMBLEY et al., 2002, 2004). As isoformas CDK11 ${ }^{\mathrm{p} 46}$ provém de uma clivagem das isoformas maiores, $\mathrm{CDK} 11^{\mathrm{p} 110}$ e CDK11 ${ }^{\mathrm{p} 58}$, e contém apenas o domínio catalítico (carboxi-terminal) da proteína. Quando a CDK11 ${ }^{\mathrm{p} 110}$ é clivada, a porção amino-terminal gera a CDK11 ${ }^{\mathrm{p} 60}$. Essa clivagem é realizada por uma proteína do tipo Caspase. A isoforma CDK11 ${ }^{\mathrm{p} 46}$ é gerada em resposta aos eventos apoptóticos (MIKOLAJCZYK; NELSON, 2004; TREMBLEY et al., 2004). 


\subsection{ESTUDOS DA REGULAÇÃO DA EXPRESSÃO DE NtSCI1}

Complementarmente, como um passo inicial no estudo da regulação da expressão do gene SCI1, Strini (2010) realizou buscas no banco de dados SOL, na tentativa de identificar a sequência genômica de NtSCI1. Como o sequenciamento do genoma de N. tabacum ainda não estava disponível, foi possível identificar apenas sequências parciais, que foram montadas e analisadas com o auxílio de ferramentas de bioinformática, gerando a putativa sequência genômica de NtSCI1. A análise mostrou que esse gene é composto por 4 éxons e 3 íntrons. Strini (2010) realizou ainda uma busca por elementos cis-regulatórios na sequência genômica disponível. Contudo, ainda que alguns elementos cis-regulatórios tenham sido encontrados em análises in silico, a putativa região promotora ainda não havia sido identificada. Assim, ainda há necessidade de realizar estudos a fim de indicar quais fatores de transcrição possam estar envolvidos na transcrição de NtSCI1. Com base nesses fatores pode-se finalmente, sugerir em que momentos esse gene é transcrito e trazer luz às vias em que a proteína NtSCI1 atua para controlar a proliferação celular. 


\section{OBJETIVOS}

Este trabalho visa contribuir para a elucidação dos mecanismos que envolvem NtSCI1 e sua parceira de interação NtCDKG;2, na regulação da proliferação celular no pistilo de N. tabacum. Para tal, este estudo pretende responder, especificamente, as seguintes questões:

1. Qual a localização subnuclear de NtCDKG;2?

2. Como NtCDKG;2 se comporta durante as diferentes fases do ciclo celular?

3. A proteína NtCDKG;2 possui outras isoformas assim como sua homóloga de H. sapiens?

4. Quais são os motivos presentes na proteína NtCDKG;2 para reconhecimento e interação com outras proteínas?

5. Quais são os possíveis parceiros de interação da proteína NtCDKG;2?

6. Qual a localização subnuclear da interação entre as proteínas NtCDKG;2 e NtSCI1?

7. Qual a sequência genômica de NtSCI1? Ela difere entre as cópias de NtSCI1 vindas dos genomas de $N$. tomentosiformis e N. sylvestris?

8. Quais os elementos regulatórios que podem modular a expressão de NtSCI1? 


\section{MATERIAL E MÉTODOS}

\subsection{MATERIAL VEGETAL}

As sementes de N. tabacum selvagem (cultivar Petit Havana SR1) foram cedidas pelo Jardim Botânico da University of Nijmegen (Holanda). Inicialmente, as sementes foram dispostas em composto vegetal de fabricação comercial (Bioplant Prata) e foram irrigadas com água acrescida de macronutrientes diluídos [Nitrogênio, Fósforo e Potássio (NPK 30-10-10). Após semeadura, as plantas foram mantidas em câmara de com ambiente controlado, à temperatura de $22^{\circ} \mathrm{C}$, umidade média de 55\% e fotoperíodo 12h:12h (luz:escuro). Ao germinarem e atingirem, aproximadamente, $2 \mathrm{~cm}$, as plântulas foram transferidas para sacos com substrato. As plântulas foram irrigadas semanalmente com água acrescida de macronutrientes (NPK 30-10-10). Quando as mudas atingiram entre $10 \mathrm{~cm}$ e $15 \mathrm{~cm}$ de altura, foram transferidas para vasos contendo uma mistura de terra e substrato. As plantas foram mantidas em casa de vegetação situada no campus da

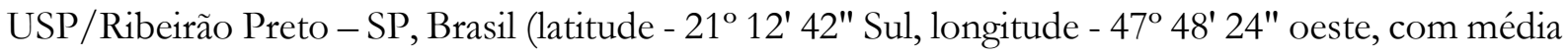
de temperatura mínima de $20^{\circ} \mathrm{C}$ e máxima de $25^{\circ} \mathrm{C}$ ). A irrigação foi controlada para 30 minutos, duas vezes ao dia. As folhas utilizadas para extração de proteínas foram coletadas, imediatamente congeladas em nitrogênio líquido e armazenados em freezer $-70^{\circ} \mathrm{C}$ para o uso em experimentos subsequentes.

Planta da espécie N. benthamiana foram utilizadas para os experimentos de localização de proteínas, co-localização e BiFC (Bimolecular Fluorescence Complementation). As sementes dessa espécie foram germinadas e acondicionadas da mesma forma que a espécie N. tabacum SR1. Para os experimentos mencionados, foram utilizados indivíduos com 70-90 dias após a germinação. Até sua utilização, as plantas foram mantidas em câmara de com ambiente controlado, à temperatura de $22^{\circ} \mathrm{C}$, umidade média de $55 \%$ e fotoperíodo $12 \mathrm{~h}: 12 \mathrm{~h}$ (luz:escuro).

Para cultivo de plantas transgênicas de N. tabacum, as sementes foram germinadas em condições estéreis, utilizando meio MS para plantas (item 3.26) suplementado com o antibiótico necessário para seleção dos transgênicos. Após crescimento dos transgênicos em cultura in vitro, as plântulas foram dispostas em substrato comercial e o protocolo a seguir foi o mesmo utilizado para crescimento de SR1. As sementes transgênicas foram originadas do trabalho de LUBINI (2012). 


\subsection{PREPARO DE CÉLULAS ELETROCOMPETENTES}

Todos os procedimentos para a preparação de células competentes foram realizados em condições estéreis, em um fluxo laminar.

\subsubsection{PREPARO DE CÉLULAS DE Escherichia coli ELETROCOMPETENTES}

Este método foi utilizado para o preparo de células competentes de E. coli das cepas DH10B e BL21-CodonPlus (DE3)-RP. Inicialmente, uma pequena alíquota bacteriana foi estriada com auxílio de uma alça de platina, em uma placa contendo meio LB sólido. A placa foi incubada durante 16 horas, a $37^{\circ} \mathrm{C}$. A seguir, uma colônia foi transferida para $5 \mathrm{ml}$ de meio LB líquido e incubada durante 16 horas, a $37^{\circ} \mathrm{C}$, sob agitação de $220 \mathrm{rpm}$. Em seguida, foram transferidos $2 \mathrm{ml}$ da suspensão bacteriana para $200 \mathrm{ml}$ de meio LB, e mantidos a $37^{\circ} \mathrm{C}$, sob agitação de $220 \mathrm{rpm}$ até a leitura da absorbância atingir a $\mathrm{OD}_{600 \text { ng }}$ igual a 0,3 . A cultura foi mantida no gelo durante 30 minutos e em seguida, foi acondicionada em 4 tubos de $50 \mathrm{ml}$ e centrifugada. Todas as centrifugações foram feitas a $1100 \mathrm{x} g$, por 10 minutos, a $4^{\circ} \mathrm{C}$. O sobrenadante foi removido e as células foram ressuspendidas, delicadamente, em $200 \mathrm{ml}$ (50 ml/tubo) de água estéril e gelada. A suspensão de células foi novamente centrifugada. As células precipitadas foram ressuspendidas, delicadamente, em $100 \mathrm{ml}$ ( $25 \mathrm{ml} /$ tubo) de água estéril e gelada. O conteúdo de quatro tubos foi reunido em dois tubos, contendo $50 \mathrm{ml} \mathrm{em} \mathrm{cada} \mathrm{um.} \mathrm{Assim,} \mathrm{foi} \mathrm{realizada} \mathrm{uma} \mathrm{nova} \mathrm{etapa} \mathrm{de}$ centrifugação. O sobrenadante foi descartado e, desta vez, as células foram ressuspendidas, delicadamente, em $10 \mathrm{ml}$ de glicerol 10\% (5 ml/tubo) a $4^{\circ} \mathrm{C}$. O conteúdo dos dois tubos foi reunido em um tubo apenas e centrifugado. Nessa última etapa, as células foram ressuspendidas, delicadamente, em um volume final de $400 \mu \mathrm{l}$ de glicerol 10\% gelado. O volume final foi dividido em alíquotas de uso de $40 \mu$, posteriormente mantidas sob $-70^{\circ} \mathrm{C}$ até o momento do uso. 


\subsubsection{PREPARO DE CÉLULAS DE Agrobacterium tumefaciens ELETROCOMPETENTES}

Células em estoque da cepa C58C1RifR (pGV2260) foram estriadas em uma placa contendo meio LB sólido e incubadas a $28^{\circ} \mathrm{C}$ por 48 horas ou em T. A. por 72 horas. Uma colônia isolada foi inoculada em meio LB líquido e incubada a $28^{\circ} \mathrm{C}, 150 \mathrm{rpm}$ por 16 horas. A seguir, a cultura foi centrifugada $\left(9900 \mathrm{x} g\right.$, por 1 minuto, a $\left.4^{\circ} \mathrm{C}\right)$ e o sobrenadante foi descartado. O precipitado celular foi ressuspendido com $500 \mu \mathrm{l}$ de $1 \mathrm{mM}$ HEPES [4-(2-bydroxyethyl)-1piperazineethanesulfonic acid] e centrifugado novamente $\left(9900 \mathrm{x} g\right.$, por 1 minuto, a $\left.4^{\circ} \mathrm{C}\right)$. Esse processo foi repetido duas vezes. Após descartar o sobrenadante, as células foram ressuspendidas em $200 \mu \mathrm{l}$ de glicerol $10 \%$, e o volume final foi dividido em alíquotas de uso de $40 \mu \mathrm{l}$, sendo mantidas a $-70^{\circ} \mathrm{C}$ até o momento de uso.

\subsection{TRANSFORMAÇÃO DE CÉLULAS}

\subsubsection{TRANSFORMAÇÃO DE CÉLULAS DE E. coli POR ELETROPORAÇÃO}

Uma alíquota de $1,8 \mu \mathrm{l}$ do DNA de interesse foi adicionada em $40 \mu \mathrm{l}$ de células DH10B eletrocompetentes, previamente preparadas. Essa mistura foi colocada em uma cubeta de eletroporação previamente resfriada por 10 minutos no gelo. O conjunto foi submetido a um pulso de $1,8 \mathrm{kV} / 25 \mu \mathrm{F}$ (eletroporador Gene Pulse, BioRad) por 5 segundos, aproximadamente. Imediatamente após o pulso elétrico, as células foram ressuspendidas, delicadamente, em $1 \mathrm{ml}$ de meio LB líquido. A seguir, a suspensão de células transformadas foi transferida para um tubo de ensaio, o qual foi incubado durante 1 hora a $37^{\circ} \mathrm{C}$ sob agitação de $200 \mathrm{rpm}$. Passado o período de incubação, a cultura foi distribuída uniformemente, com o auxílio de uma alça de Drigalski, em placas de Petri contendo meio LB sólido suplementado com antibiótico apropriado. As placas foram, então, incubadas a $37^{\circ} \mathrm{C}$ durante $16-20$ horas. 


\subsubsection{TRANSFORMAÇÃO DE CÉLULAS DE $A$. tumefaciens POR ELETROPORAÇÃO}

A transformação de $A$. tumefaciens é similar à de E. coli, porém existem algumas diferenças. Após o pulso elétrico, as células foram incubadas a $28^{\circ} \mathrm{C}$ sob agitação de $150 \mathrm{rpm}$ durante 4 horas. A seguir, foram plaqueados 50-100 $\mu$ l dessa cultura em placa de LB suplementado com antibiótico para seleção do plasmídeo transformado. Finalmente, as bactérias ficaram incubadas a $28^{\circ} \mathrm{C}$ por 48 horas ou em T. A. por 72 horas.

\subsubsection{TRANSFORMAÇÃO DE CÉLULAS DE Saccharomyces cerevisiae POR CHOQUE TÉRMICO}

A cepa de Saccharomyces cerevisiae PJ69-4a (trp1-901; leu2-3,112; ura3-52; his3-200; gal4A; gal80A; GAL2-ADE2; lys2::GAL1-HIS3; met2::GAL7-lacZ), que apresenta os genes repórteres HIS3 (biossíntese de histidina), ADE2 (biossíntese de adenina) e lac $Z$, foi recuperada do estoque em glicerol, estriando-se em uma placa contendo meio SD sólido suplementado com solução dropout completa. A placa foi incubada por 3 dias, a $30^{\circ} \mathrm{C}$. Uma colônia isolada foi isolada da placa com o auxílio de um palito dental autoclavado e colocada em meio SD líquido suplementado com solução dropout completa. O tubo de ensaio foi mantido sob agitação $\left(200 \mathrm{rpm}, 30{ }^{\circ} \mathrm{C}\right)$. No dia seguinte, a suspensão celular foi transferida para um Erlenmeyer contendo $50 \mathrm{ml}$ de meio SD líquido completo a uma $\mathrm{OD}_{600 n_{\mathrm{m}}}$ entre 0,1 e 0,2 . O frasco foi colocado em incubadora a $30^{\circ} \mathrm{C}$, sob agitação, até que $\mathrm{OD}_{600 n_{\mathrm{m}}}$ atingisse $\mathrm{o}$ valor ente 0,4 e 0,6. A seguir, para cada transformação foram precipitados $2 \mathrm{ml}$ de cultura (10 segundos, $16000 \mathrm{x}$ ). O sobrenadante foi descartado, o precipitado de células foi, gentilmente, ressuspendido em $1 \mathrm{ml} 100 \mathrm{mM}$ LiAc e incubado por 1 minuto à T. A. Os tubos foram novamente centrifugados nas mesmas condições. O precipitado de células foi ressuspendido em $240 \mu \mathrm{l}$ de 50\% w/v PEG-3350 (polyethylene glycol) e foram adicionados $\sim 500 \eta \mathrm{g}$ de cada pDNA de interesse acrescido de $\mathrm{dH}_{2} \mathrm{O}$ em q.s.p. $70 \mu$ l. Posteriormente, foram adicionados $36 \mu \mathrm{l} 1 \mathrm{M}$ LiAc e $50 \mu \mathrm{g}$ de carreador de DNA previamente fervido $\left(5\right.$ minutos a $95^{\circ} \mathrm{C}$; Ambion AM9680). O tubo foi agitado em vórtex por 1 minuto. Nesse passo, para aumentar a eficiência da transformação de células para screening da biblioteca de cDNA (DNA complementar), foram adicionados $36 \mu$ de DMSO (Dimetilsulfóxido) estéril. O tubo foi incubado, em banho-maria, a $42^{\circ} \mathrm{C}$ por $45-60$ minutos. Em seguida, ele foi centrifugado a 16000 x $g$ por 10 segundos. O 
sobrenadante foi removido e o precipitado de células foi ressuspendido em $300 \mu l$ de água deionizada e centrifugado nas mesmas condições. Por fim, foram acrescentados $50 \mu \mathrm{lde} \mathrm{dH}_{2} \mathrm{O}$ às células transformadas foram plaqueadas no meio de cultura SD suplementado com a solução dropout adequada.

\subsection{PREPARAÇÃO DE DNA PLASMIDIAL EM PEQUENA ESCALA (MINI-PREP)}

A extração do DNA plasmidial de bactérias e leveduras foi feita em pequena escala e utilizando diferentes protocolos, conforme descrito a seguir.

\subsubsection{EXTRAÇÃO DE DNA PLASMIDIAL DE E. coli}

A extração de DNA plasmidial de E. coli foi realizada por dois métodos, os quais dependiam da aplicação subsequente. Em ambos os métodos, a etapa inicial consistiu no crescimento da colônia de interesse em meio LB líquido suplementado com antibióticos de seleção adequados, incubada a $37^{\circ} \mathrm{C}$ por $16-20$ horas e $220 \mathrm{rpm}$, precedendo a extração. Essa colônia foi obtida a partir de uma placa resultante de transformação por eletroporação ou de células estriadas a partir de estoques em glicerol. No primeiro caso, um estoque semipermanente em glicerol $25 \%$ foi feito antes da extração (SAMBROOK; FRITSCH; MANIATIS, 1989). Os estoques foram armazenados a $-70^{\circ} \mathrm{C}$.

\subsubsection{Método de extração de DNA plasmidial utilizando a lisozima}

Para a checagem de insertos nos diferentes vetores com enzimas de restrição, foi utilizado DNA plasmidial obtido pelo método da lisozima. Inicialmente, as células foram precipitadas (16000 $\mathrm{x} g$ por 2 minutos a T. A.). O precipitado celular foi ressuspendido em $175 \mu$ le tampão TES [10 $\mathrm{mM}$ Tris- $\mathrm{HCl} \mathrm{pH}$ 8,0; 1 mM EDTA (Ethylenediamine tetraacetic acid) $\mathrm{pH}$ 8.0; 15\% Sacarose]. Foram adicionados $20 \mu \mathrm{l}$ de lisozima $(10 \mathrm{mg} / \mathrm{ml})$, agitando-se a mistura gentilmente com a mesma ponteira. A amostra foi incubada a temperatura ambiente por 10 minutos e, em seguida, colocada em banhomaria a $73^{\circ} \mathrm{C}$ por 15 minutos. O tubo foi centrifugado a 16000 x $g$ por 15 minutos, para precipitação 
dos restos celulares juntamente ao DNA cromossômico. O sobrenadante foi recuperado e transferido para novo tubo ao qual foi adicionado 1/10 do volume total da amostra de acetato de sódio $3 \mathrm{M}$ e 2 volumes de etanol absoluto gelado, para precipitação do DNA plasmidial. O tubo foi colocado a $-20^{\circ} \mathrm{C}$ por, no mínimo, 1 hora ou a $-70^{\circ} \mathrm{C}$ por 15 minutos. Centrifugou-se a 16000 $\mathrm{x} g$ por 15 minutos. O sobrenadante foi descartado e o precipitado foi lavado uma vez com $400 \mu \mathrm{l}$ de etanol 70\% gelado. O tubo foi novamente centrifugado a $16000 \mathrm{x} g$ por 1 minuto. O sobrenadante foi descartado e o tubo foi mantido aberto e invertido para completa evaporação do etanol. O DNA foi ressuspendido em $50 \mu \mathrm{l}$ de $\mathrm{dH}_{2} \mathrm{O}$ e armazenado a $-20^{\circ} \mathrm{C}$.

\subsubsection{Método de extração de DNA plasmidial com alto grau de pureza}

Para obter DNA plasmidial com alto grau de pureza necessário para as reações de sequenciamento e transformações de levedura, optou-se pela utilização de um kit comercial GeneJET TM Plasmid Miniprep Kit (Thermo Fisher Scientific). A extração do DNA plasmidial com o kité por meio de lise alcalina e foi realizada seguindo as instruções do fabricante.

\subsubsection{EXTRAÇÃO DE DNA PLASMIDIAL DE $\boldsymbol{A}$ tumefaciens}

A lise alcalina foi utilizada como método de extração de DNA plasmidial de $A$. tumefaciens, adaptado em protocolo de Brasileiro e Carneiro (1998). Diferentemente do método de extração e purificação de DNA plasmidial por lisozima, o método por lise alcalina, como o próprio nome sugere, baseia-se na diferença de desnaturação, em condições alcalinas, que são apresentadas entre o DNA plasmidial e o DNA cromossomal.

Previamente à extração, a colônia de interesse foi inoculada em meio LB suplementado com antibióticos de seleção e incubada por 24 horas a $28^{\circ} \mathrm{C}$ e $150 \mathrm{rpm}$. Caso o inóculo tenha sido feito de uma placa de colônias recém transformadas, foi feito também o estoque semipermanente em glicerol como descrito no item anterior (3.5.1.1). A seguir, $1.5 \mathrm{ml}$ de cultura foram transferidos a um tubo Eppendorf e submetidos à centrifugação por 2 minutos. Todas as centrifugações foram feitas a $13400 \mathrm{x} g$ e T.A. O sobrenadante foi descartado e o precipitado ressuspendido em $1 \mathrm{ml}$ de Tampão I [ $\mathrm{NaCl}$ 0,2 M em Tris-EDTA]. O conteúdo foi centrifugado por 2 minutos. O 
sobrenadante foi descartado e o precipitado foi ressuspendido, novamente, em $1 \mathrm{ml}$ de Tampão I e centrifugado nas mesmas condições. Após as lavagens, o sobrenadante foi descartado e o precipitado foi ressuspendido em $200 \mu \mathrm{l}$ de Tampão I e foram acrescentados $200 \mu \mathrm{l}$ de Solução I $[\mathrm{NaOH}$ 0,2 N; SDS 1\%]. O conteúdo foi homogeneizado por leves inversões (de 4 a 6 vezes) e mantido no gelo por 15 minutos. O detergente tem por finalidade lisar membranas e desnaturar proteínas celulares. Enquanto isso, o hidróxido de sódio eleva o potencial hidrogeniônico a valores muito alcalinos. Dessa forma, o DNA bacteriano é desnaturado e o DNA plasmidial permanece inalterado. A seguir, foram adicionados $150 \mu \mathrm{l}$ de acetato de potássio $3 \mathrm{M}(\mathrm{pH}$ 5.2) refrigerado, o tubo foi invertido manualmente 4 vezes e mantido no gelo por 30 minutos. O conteúdo foi centrifugado por 5 minutos, precipitando o DNA cromossomal juntamente aos restos celulares. $\mathrm{O}$ sobrenadante foi, cuidadosamente, transferido a um tubo limpo e a ele foram adicionados 2 volumes de etanol absoluto, deixando a $-20^{\circ} \mathrm{C}$ por 1 hora, no mínimo. Após, o conteúdo foi centrifugado por 30 minutos e o precipitado, DNA plasmidial, foi lavado com $400 \mu \mathrm{l}$ de etanol $70 \%$, centrifugado por 2 minutos. O sobrenadante foi descartado e o tubo contendo o precipitado foi mantido aberto a T.A. até completa evaporação do álcool. O DNA plasmidial foi ressuspendido em $20 \mu \mathrm{l}$ de $\mathrm{dH}_{2} \mathrm{O}$ e armazenado a $-20^{\circ} \mathrm{C}$ até sua utilização.

\subsubsection{EXTRAÇÃO DE DNA PLASMIDIAL DE $S$. cerevisiae}

Previamente à extração, uma colônia isolada foi inoculada em meio SD líquido com solução dropout adequada e incubada a $30^{\circ} \mathrm{C}$ e $250 \mathrm{rpm}$ por 24 horas. Depois desse período, $1,5 \mathrm{ml}$ da cultura foi centrifugado a 16000 x $g$ por $30 \mathrm{~s}$ a T.A. Após o descarte do sobrenadante, os precipitados celulares foram mantidos a $-20^{\circ} \mathrm{C}$ para extração posterior. Durante os screenings de $\mathrm{Y} 2 \mathrm{H}$ e $\mathrm{Y} 1 \mathrm{H}$, as colônias positivas foram inoculadas em placas de 96 poços, permitindo a extração gradual das colônias. As extrações foram realizadas com o kit Zymoprepp ${ }^{\mathrm{TM}}$ Yeast Plasmid Miniprep I (Zymo Research), de acordo com as instruções do fabricante.

\subsection{PURIFICAÇÃO DE DNA PELO MÉTODO DO FENOL-CLOROFÓRMIO}

A purificação do DNA plasmidial foi feita para material extraído pelo método da lisozima, o qual pode conter contaminação com proteínas e outras macromoléculas. Para a purificação, o 
volume inicial da solução de DNA plasmidial foi completado com $\mathrm{dH}_{2} \mathrm{O}$ estéril q.s.p. $200 \mu \mathrm{l}$. À essa solução foram adicionados $4 \mu \mathrm{l}$ de solução de RNAse $(10 \mu \mathrm{g} / \mu \mathrm{l})$, e a mistura foi mantida em banho-maria a $37^{\circ} \mathrm{C}$ por 30 minutos. A seguir, foram adicionados $200 \mu \mathrm{l}$ de fenol tamponado em $\mathrm{pH} 8,0$, e a mistura foi agitada em vórtex por 1 minuto e centrifugada a $16000 \mathrm{x} g$ por 3 minutos e T.A. A fase superior da mistura foi removida e transferida para um novo tubo, ao qual foi adicionado 1 volume de clorofórmio:álcool isoamílico na proporção 24:1. Esse tubo foi agitado em vórtex e centrifugado nas mesmas condições anteriores. A fase superior da mistura foi removida e transferida para um novo tubo, ao qual foi adicionado acetato de sódio $3 \mathrm{M}$ (1/10 de volume) e etanol absoluto gelado (2 volumes). Essa mistura foi mantida a $-70^{\circ} \mathrm{C}$ por 15 minutos para ocorrer a precipitação do DNA plasmidial. Em seguida, o tubo foi centrifugado a 16000 x g por 15 minutos e T.A. O sobrenadante foi descartado e o precipitado foi lavado com $400 \mu \mathrm{l}$ de etanol 70\%, passando por uma nova centrifugação por 3 minutos nas mesmas condições da anterior. $O$ sobrenadante foi descartado e o tubo ficou aberto a T.A. até a evaporação do etanol residual. O precipitado foi ressuspendido em $50 \mu$ de água deionizada estéril.

\subsection{DIGESTÃO DO DNA UTILIZANDO ENZIMAS DE RESTRIÇÃO}

Após a transformação de células de E. coli, um número determinado de transformantes foi analisado. As digestões foram planejadas utilizando a ferramenta NEBCutter V2.0 (http://tools.neb.com/NEBcutter2/, New England BioLabs), a qual indica sítios de restrição de diversas enzimas para a sequência de interesse. Para cada reação foram escolhidas enzimas com sítios de restrição na sequência de interesse e também na sequência do vetor, para confirmar a inserção. Caso a sequência de interesse não estivesse sequenciada, foram escolhidas enzimas que excisavam o fragmento inserido, para extrapolar a inserção através da comparação do tamanho do fragmento resultante com o tamanho esperado do inserto. As digestões foram feitas de acordo com as instruções do fabricante das enzimas utilizadas. O produto da reação foi submetido a uma corrida de eletroforese em gel de agarose.

\subsection{ELETROFORESE EM GEL DE AGAROSE}

Esse tipo de análise foi feito para checagem dos fragmentos de DNA em duas situações: 1) fragmentos de DNA resultante da digestão enzimática com nucleases de restrição e 2) produtos de reações de PCR para posterior excisão e purificação desse material. Os DNAs digeridos e produtos 
de PCR foram submetidos a eletroforese em gel de agarose 1\% $(w / v)$, preparado com tampão TBE 0,5X [50 mM Tris-base; 50 mM Ácido Bórico; 2 mM EDTA; pH 8], adicionando-se 0,5 $\mu \mathrm{g} / \mathrm{ml}$ de brometo de etídeo (SAMBROOK; FRITSCH; MANIATIS, 1989), um agente intercalante de DNA que permite a visualização das bandas de DNA quando o gel é exposto a luz ultravioleta. Durante as corridas eletroforéticas, os géis estavam imersos em TBE 0,5X. As amostras foram preparadas adicionando $1 \mu \mathrm{l}$ de tampão de carregamento [0,25\% azul de bromofenol, 0,25\% xileno cianol e $15 \%$ ficol tipo 400-DL] para cada $5 \mu \mathrm{l}$ de amostra. A voltagem utilizada (geralmente ao redor de 100 volts) e o tempo das corridas variaram de acordo com o tamanho do gel preparado (em comprimento), tamanho da cuba e tamanho do fragmento esperado. Os tamanhos dos fragmentos de DNA foram inferidos por comparação com a migração dos fragmentos do Marcador de Peso Molecular $1 \mathrm{~Kb}$ Plus DNA Ladder (Invitrogen).

Após a eletroforese, o gel foi retirado da cuba e transferido ao sistema Kodak Gel Logic 100 Imaging System (Kodak), o qual possui um sistema de emissão de luz UV acoplado a uma câmera e a um computador. As imagens foram capturadas através do software que acompanha o sistema, e as condições de exposição e iluminação foram otimizadas para melhor visualização.

\subsection{PURIFICAÇÃO DE FRAGMENTOS DE DNA A PARTIR DE GEL DE AGAROSE}

A porção do gel onde se encontrava o fragmento de DNA de interesse foi excisada com o auxílio de um bisturi e, a seguir, foi purificada com o auxílio do kit GeneJET ${ }^{\mathbf{T M}}$ Gel Extraction (Fermentas Lifesciences), de acordo com instruções do fabricante.

\subsection{IDENTIFICAÇÃO E AMPLIFICAÇÃO DAS PUTATIVAS REGIÕES PROMOTORAS DE NtSCI1 DAS CÓPIAS DE N. tomentosiformes E N. sylvestris}

A identificação das putativas regiões promotoras de ambas cópias homeólogas de NtSCI1 foi realizada no banco de dados GeneBank utilizando os algoritmos de BLAST com a sequência já descrita de ambas cópias de NtSCI1 (STRINI, 2010). Foram consideradas região promotoras as regiões à montante do primeiro éxon de ambas cópias e que não incluíam nenhuma sequência codificadora de outro gene. Para as amplificações, foram utilizados primers específicos das sequências alvo (vide tabela 1). As reações de PCR para clonagens foram feitas com a enzima Phusion ${ }^{\circledR}$ High-Fidelity DNA Polymerase (New England Biolabs). Para a PCR1, o DNA molde 
(concentração final de $10^{-3}$ a $1 \mathrm{ng} / \mu \mathrm{L}$ ) foi acrescido de 10 pmoles/ $\mu \mathrm{l}$ do primer forward , 10 pmoles/ $\mu \mathrm{l}$ de primer reverse (10 pmoles/ $\mu \mathrm{l}), 10 \mathrm{mM}$ de dNTPs (Deoxyribonucleotide 5'-triphosphate), 0,5

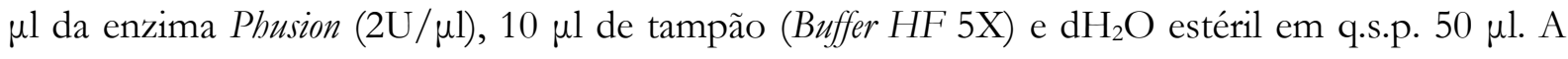
desnaturação inicial foi feita a $98^{\circ} \mathrm{C}$ por 30 segundos. Em seguida, as PCRs foram submetidas a 39 ciclos com 3 fases: 1) $98^{\circ} \mathrm{C}$ por 30 segundos; 2) $\mathrm{T}$ de anelamento por 30 segundos; 3) $72^{\circ} \mathrm{C}$ por 30 segundos/Kb. A extensão final ocorreu em $72^{\circ} \mathrm{C}$ por 10 minutos. Para cada par de primers utilizado, foi definida uma temperatura de anelamento entre 2 e 5 graus a menos da temperatura de melting (Tm) do primer com menor Tm. A duração da extensão nos ciclos dependeu do tamanho do DNA molde, tendo sido utilizados, no mínimo 30 segundos para cada $1000 \mathrm{pb}$. As reações ficaram a $10^{\circ} \mathrm{C}$ até serem retiradas do termociclador. Após as PCRs terem os tamanhos esperados confirmados em gel de agarose, os fragmentos foram excisados e purificados. A seguir, as sequências foram adeniladas e clonadas no vetor $\mathrm{pCR}^{\circledR} 2.1-\mathrm{TOPO}-\mathrm{TA}^{\circledR}$.

\subsection{ADENILAÇÃO DE FRAGMENTOS DE PCR (A-TAILING)}

A adição do nucleotídeo adenosina à extremidade 3' foi realizada em produtos de PCR com extremidades abruptas e que necessitavam ser clonados no vetor $\mathrm{PCR}^{\circledR}$ 2.1-TOPO-TA ${ }^{\circledR}$. Para tanto, o produto de PCR foi, primeiramente, excisado do gel e purificado. A seguir, a 25 ng de DNA molde purificado foram acrescentados de $10 \mathrm{mM}$ dATP (Deoxyadenosine triphosphate), $1 \mathrm{U}$ de enzima KAPA TAq DNA Polymerase, tampão para condições ótimas da enzima e $\mathrm{dH}_{2} \mathrm{O}$ estéril em q.s.p. 50 $\mu$ l. A reação foi mantida por 20 minutos à $72^{\circ} \mathrm{C}$.

\subsection{CLONAGENS E SUBCLONAGENS}

\subsubsection{CLONAGENS NO VETOR PCR ${ }^{\circledR}$ 2.1-TOPO-TA ${ }^{\circledR}$}

Após os fragmentos de PCR serem adenilados, eles foram clonados no vetor $\mathrm{pCR}^{\circledR} 2.1$ TOPO-TA $^{\circledR}$ (Invitrogen; para mais detalhes do vetor, veja o Anexo A). A reação de clonagem foi feita com $4 \mu \mathrm{l}$ do produto da PCR adenilado, $1 \mu \mathrm{l}$ da diluição 1:4 da solução salina $[1,2 \mathrm{M}$ de $\mathrm{NaCl}$; $60 \mathrm{mM}$ de $\mathrm{MgCl}_{2}$ ) e $1 \mu \mathrm{l}$ do vetor. As ligações foram mantidas por 16-20 horas à temperatura ambiente. No outro dia, as ligações foram transformadas em células de E. coli DH10B eletrocompetentes e plaqueadas em meio LB suplementado com X-gal, IPTG (Isopropyl $\beta$-D-1thiogalactopyranoside) e canamicina. As placas permaneceram por $16-20$ horas a $37^{\circ} \mathrm{C}$. Das placas 
geradas, foram selecionadas colônias, colocadas em meio LB líquido com canamicina e deixadas de 16 a 20 horas a $37^{\circ} \mathrm{C}$ sob agitação de $220 \mathrm{rpm}$. Após esse período, foram feitos estoques em glicerol e mini-preparações de DNA por lisozima, as quais foram digeridas com a enzima EcoRI. As amostras foram aplicadas em um gel de agarose e submetidas a uma corrida eletroforética. O DNA relativo à mini-preparação escolhida foi tratado com RNase, limpo pelo método fenol/clorofórmio e o clone foi sequenciado.

\subsubsection{CLONAGENS COM O SISTEMA GATEWAY}

Todas as reações de recombinação utilizadas para clonagens e subclonagens deste trabalho foram desenvolvidas utilizando o sistema Sistema Gateway ${ }^{\circledR}\left(\right.$ Gateway ${ }^{\circledR}$ Technology, Life Technologies). Uma característica importante desse sistema é que, enquanto transfere sequências de DNA entre os vetores, ele é capaz de manter a orientação correta dessas sequências. Esse sistema baseia-se na propriedade de recombinação sítio-específica do bacteriófago $\lambda$ (HARTLEY; TEMPLE; BRASCH, 2000). Os sítios, denominados att, estão contidos no fragmento de DNA interesse e nos vetores plasmidiais de clonagem e de expressão. Existem quatro tipos de sítios att. Os attB são adicionados através de PCR às extremidades de uma DNA de interesse. Os sítios attP estão presentes nos vetores doadores (pDONR) do Sistema Gateway. Os sítios attL flanqueiam a sequência de interesse dentro do plasmídeo de clonagem para entrada no Gateway (pENTRY) e são originados após uma reação BP. Finalmente, os sítios attR estão presentes nos vetores de destino vazios e, após recombinados com um pENTRY, geram um clone de expressão (pEXP) com um sítio attB. A Figura 5 resume o sistema Gateway de clonagem. Todos os plasmídeos citados a partir daqui encontram-se descritos no Anexo A 


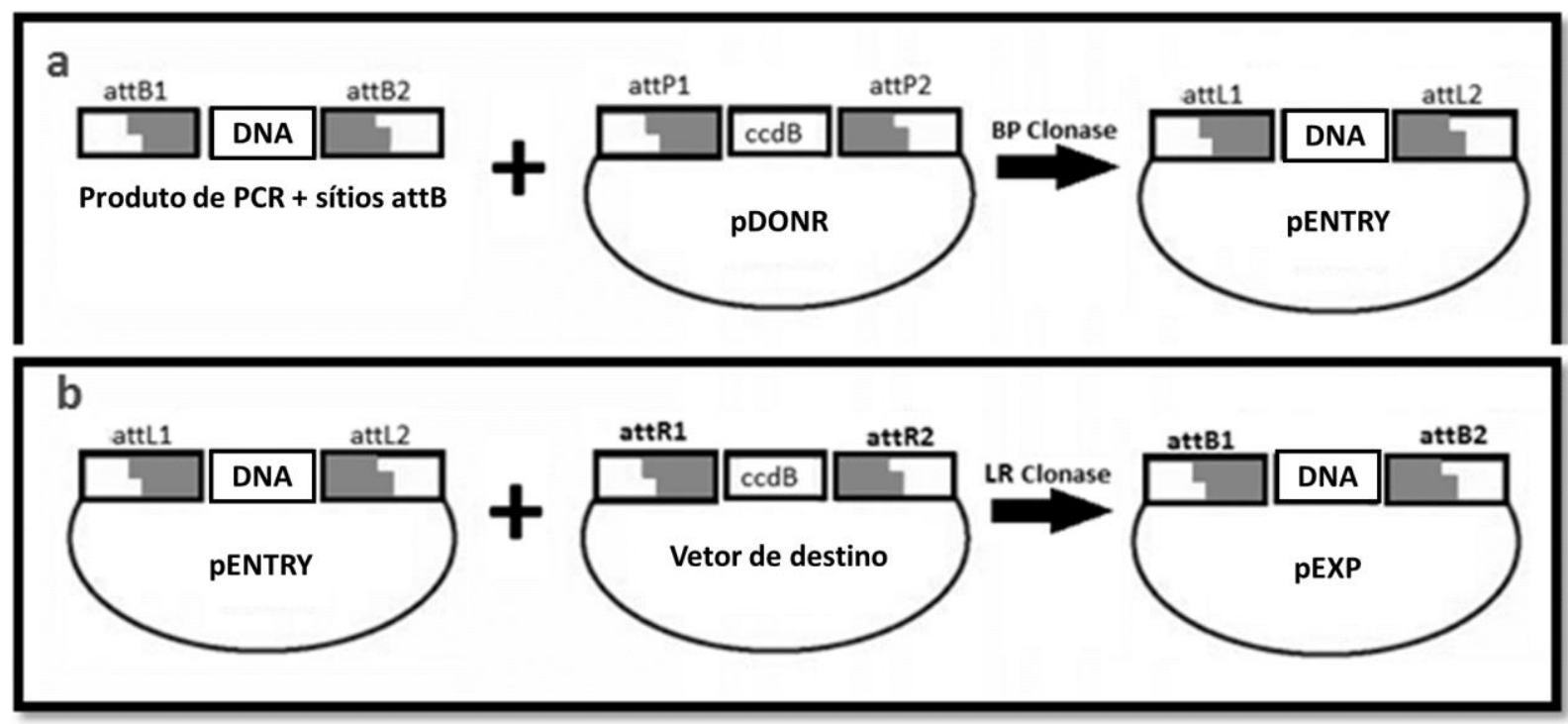

Figura 5: Esquema ilustrativo das reações Gateway BP e LR . (a) e (b) ilustram as reações BP e LR, respectivamente. Os subprodutos gerados nessas reações e não utilizados, não foram demonstrados.

\subsubsection{Inserção dos sítios attBs para recombinação de fragmentos pelo Sistema Gateway}

A estratégia para inserção das sequências de DNA de interesse nos vetores de entrada do sistema Gateway foi a mesma. Conforme representado na Figura 5, antes e depois dos nucleotídeos que anelarão à sequência de interesse, foram incluídos nucleotídeos que compõem os sítios attB1 e attB2 do sistema Gateway. É imprescindível que, pelo menos, 35\% das bases componentes desse tipo de primer apresentem complementariedade com a sequência alvo para que a amplificação possa ocorrer com sucesso. Foram feitas duas reações de PCR (denominadas PCR1 e PCR2) para introduzir a sequência completa de ambos os sítios attB no fragmento de DNA de interesse. $\mathrm{Na}$ primeira amplificação (PCR1), os primers utilizados foram desenhados de forma a conter uma parte das sequências correspondentes aos sítios attB1 e attB2. Em seguida, foi feita a segunda amplificação (PCR2), utilizando os primers específicos dos sítios de recombinação, BP-1 e BP-2, os quais complementam a sequência dos sítios attB1 e attB2, respectivamente. A Figura 6 esquematiza as reações de PCR. 


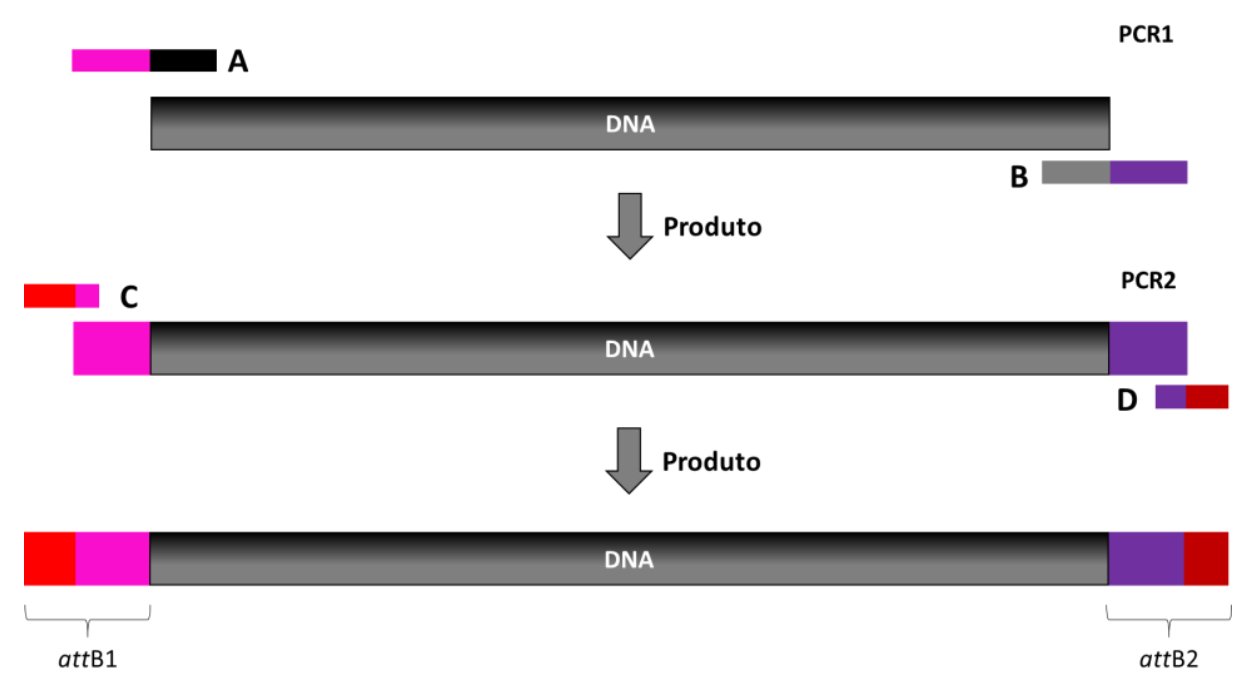

Figura 6: Esquema generalista representando a elaboração de primers específicos para a amplificação das sequências de interesse de forma a permitir sua inserção no sistema Gateway. A, B C e D são gravuras de primers que foram desenhados. A: Primer forward utilizado na primeira reação de PCR (PCR1). Esse primer possui complementariedade à sequência que será amplificada (fragmento grafite da dupla fita de DNA) e parte do sítio attB1 (fragmento rosa). B: Primer reverse utilizado na primeira reação de PCR (PCR1). Esse primer possui complementariedade à sequência que será amplificada (fragmento preto da dupla fita de DNA) e parte do sítio attB2 (fragmento roxo). C: Primer forward BP-1 utilizado na segunda reação de PCR (PCR2). Esse primer possui complementariedade à sequência que será amplificada (fragmento rosa) e o complemento para o sítio attB1 (fragmento vermelho). D: Primer reverse BP-2 utilizado na segunda reação de PCR (PCR2). Esse primer possui complementariedade à sequência que será amplificada (fragmento roxo) e parte do sítio attB2 (fragmento bordô).

As reações de PCR para clonagens foram feitas com a enzima Phusion ${ }^{\circledR}$ High-Fidelity DNA Polymerase (New England Biolabs) de acordo com o descrito no item 3.10. As reações foram submetidas à análise por eletroforese em gel de agarose para analisar os produtos da PCR1. Esses foram então excisados, extraídos dos géis e utilizados para a segunda reação de PCR (PCR2) e complementação dos sítios attB.

$\mathrm{Na}$ PCR2, os sítios de recombinação attB1 e attB2 que flanqueiam o fragmento gerado na PCR1 são complementados, utilizando o produto da PCR1 como molde. A PCR2 foi feita nos moldes da PCR1, mas utilizou o par de primers BP-1 e BP-2. Os produtos das reações de PCR2 foram analisados por eletroforese em gel de agarose, extraídos do gel e armazenado a $-20^{\circ} \mathrm{C}$ até o momento do uso. Todos os primers utilizados nas clonagens e sub-clonagens estão listados na Tabela 1. 
Tabela 1: Primers utilizados para amplificações e sequenciamentos. F3 e F4: par de primers Forward e Reverse utilizados nas reações de PCR1 para clonagem da região downstream do gene NtSCI1 e inserção de parte dos sítios attB1 e attB2, respectivamente; F205 e F206: par de primers Forward e Reverse utilizados na clonagem do putativo promotor do gene NtSCI1 cópia de N. tomentosiformis; F207 e F208: par de primers Forward e Reverse utilizados na clonagem do putativo promotor do gene NtSCI1 cópia de N. sylvestris; F215 e F216: par de primers Forward e Reverse utilizados nas reações de PCR1 para clonagem do Fragmento 1 do putativo promotor do gene NtSCI1 com inserção de parte dos sítios attB1 e attB2, respectivamente; F217 e F218: par de primers Forward e Reverse utilizados nas reações de PCR1 para clonagem do Fragmento 2 do putativo promotor do gene NtSCI1 com inserção de parte dos sítios attB1 e attB2, respectivamente; F219 e F220: par de primers Forward e Reverse utilizados nas reações de PCR1 para clonagem do Fragmento 3 do putativo promotor do gene NtSCI1 com inserção de parte dos sítios attB1 e attB2, respectivamente; F221 e F222: par de primers Forvard e Reverse utilizados nas reações de PCR1 para clonagem do Fragmento 4 do terceiro íntron do gene NtSCI1 com inserção de parte dos sítios attB1 e attB2, respectivamente. J7 e J8: par de primers Forward e Reverse utilizados nas reações de PCR2 para complementação dos sítios attB1 e attB2, respectivamente; J16: primer utilizado para sequenciamento dos clones contidos no vetor pDEST22; J21 e J22: primers utilizados para sequenciamentos dos clones nos vetores do tipo TOPO_TA e pDONR; J15 e J37: primers utilizados para sequenciamentos dos clones nos vetores do tipo TOPO_TA.

\begin{tabular}{|l|l|l|}
\hline ID & Nome do primer & Sequência (5'--> 3') \\
\hline F3 & Ct11attB1FW & GCAGGCTTCACCATGGGGAGCGATAAGAAGAC \\
\hline F4 & Ct11attB2RV & AAGCTGGGTCTTACTTTTTGATATTCCAAGCGTG \\
\hline F205 & promNtomSCI1-Fw & GCCATAAGCTATAAGTTGGTCACCCCCAAC \\
\hline F206 & promNtomSCI1Rv & GACATTTGGATTTATGGGATTTGTGCTTCTCC \\
\hline F207 & promNsylvSCI1-Fw & CCCTCATCTGGTCACGGAGCACCTTGTTT'TTGTTTTCC \\
\hline F208 & promNsylvSCI1-Rv & CTTGGTTTTGTGCTTTTCCCCTGACTTCTTC \\
\hline F215 & SCI1p-N.to-Frag1-Fw & GCAGGCTTCGTAGCATACGATGCGGTTTC \\
\hline F216 & SC11p-N.to-Frag1-Rv & AAGCTGGGTCCTAGTTATGATAGCCGCAGCAC \\
\hline F217 & SC11p-N.to-Frag2-Fw & GCAGGCTTCCCTTCTGGAGGAAACTAATC \\
\hline F218 & SCI1p-N.to-Frag2-Rv & AAGCTGGGTCCCTCACTGTAAGTACGATG \\
\hline F219 & SC11p-N.to-Frag3-Fw & GCAGGCTTCCTACCAAACATATCAGGTGC \\
\hline F220 & SC11p-N.to-Frag3-Fw & AAGCTGGGTCGATTAGTTTCCTCCAGAAGG \\
\hline F221 & SC11-3rdIntron-N.to-Fw & GCAGGCTTCCGCGTAGTTATTATCCTTCGCAC \\
\hline F222 & SCI1-3rdIntron-N.to-Rv & AAGCTGGGTCCTGCTACTGCTACAGTCTAAC \\
\hline J7 & BP-1 & GGGGACAAGTTTGTACAAAAAAGCAGGCTTC \\
\hline J8 & BP-2 & GGCGACCACTTTGTACAAGAAAGCTGGGTC \\
\hline J16 & DEST22-AD502-Fw & TATAACGCGTTTGGAATCACT \\
\hline J21 & M13-Fw & GTAAAACGACGGCCAGT \\
\hline J22 & M13-Rv & CAGGAAACAGCTATGAC \\
\hline J15 & T7-Fw & TAATACGACTCACTATAGGG \\
\hline J37 & T7-Rv & CTAGTTATTGCTCAGCGGTG \\
\hline
\end{tabular}




\subsubsection{Recombinação BP: reação entre região codificadora do gene e o vetor de entrada do Sistema Gateway}

Um conjunto de enzimas catalisa as reações de recombinação. Elas se ligam aos sítios att, os reúnem, clivam e os ligam covalentemente, substituindo o gene tóxico $c c d B$ pelo fragmento de DNA de interesse. Existe um conjunto de enzimas para cada tipo de reação. Para recombinar os sítios attB com os sítios attP, são necessárias as enzimas Integrase (Int) e Integration Host Factor (IHF) (Life Technologies, 2012). Esse tipo de recombinação gera dois subprodutos. O primeiro, contém o fragmento de DNA de interesse que foi integrado ao vetor de clonagem, permanecendo flanqueado por sítio at $\mathrm{L}$. O segundo subproduto é constituído do gene $c c d B$ flanqueado por sítios attR. O kit BP clonase II (Invitrogen) contém as enzimas Int e IHF que catalisam a via lisogênica e foi utilizado para as devidas reações de recombinação. As reações foram feitas seguindo orientações do fabricante, com algumas modificações. Nessa reação foram misturados $\sim 200 \eta \mathrm{g}$ do produto de PCR2, $150 \eta \mathrm{g}$ do vetor de entrada, $2 \mu \mathrm{l}$ do tampão BP (5X), $1 \mu \mathrm{l}$ da mistura da enzima BP clonase, em $\mathrm{dH}_{2} \mathrm{O}$ estéril em q.s.p. $10 \mu \mathrm{l}$. A reação foi incubada overnight a T.A. A seguir, foram adicionados $2 \mu \mathrm{g}$ de proteinase $\mathrm{K}$ e a reação foi incubada a $37^{\circ} \mathrm{C}$, durante 10 minutos, para que ocorresse a degradação de proteínas presentes na reação. As ligações foram eletroporadas em células da linhagem $D H 10 B$ de E. colie plaqueadas em meio LB com seleção pelos antibióticos estreptomicina e espectinomicina. A seguir foram feitos inóculos, estoques em glicerol e mini-preparações de DNA.

\subsubsection{Recombinação LR: reação entre o vetor de entrada e o vetor de destino do Sistema Gateway}

Para recombinar os sítios attL e attR, além das enzimas Int e IHF, também é necessária a enzima Exciosionase (Xis). Esse tipo de recombinação, denominada LR, também gera dois subprodutos. Desta vez, o primeiro subproduto contém o fragmento de DNA de interesse integrado ao vetor de expressão com a reconstituição do sítio attB. O segundo subproduto, por sua vez, contém o gene $c c d B$ flanqueado por sítios attP no vetor de clonagem. O kit LR clonasse II (Invitrogen) contém as 3 enzimas, Int, IHF e Xis, as quais catalisam a via lítica (Life Technologies, 2012). Para as reações LR, foram homogeneizados 150 ng da construção no vetor de clonagem, $300 \eta \mathrm{g}$ do respectivo vetor de expressão, $2 \mu \mathrm{l}$ do tampão $5 \mathrm{X}$ LR Clonase ${ }^{\mathrm{TM}}$ (Invitrogen), $1 \mu \mathrm{l}$ do mix de enzima LR Clonase ${ }^{\mathrm{TM}}$ (Invitrogen) em $\mathrm{dH}_{2} \mathrm{O}$ estéril em q.s.p. $10 \mu \mathrm{l}$. A reação foi incubada overnight a T.A. A seguir, foram adicionados $2 \mu \mathrm{g}$ de proteinase $\mathrm{K}$ e a reação foi incubada a $37^{\circ} \mathrm{C}$, durante 
10 minutos, para que ocorresse a degradação de proteínas presentes na reação. As ligações foram eletroporadas em células da linhagem $D H 10 B$ de E. coli e plaqueadas em meio LB com seleção pelos antibióticos estreptomicina e espectinomicina. A seguir foram feitos inóculos, estoques em glicerol e mini-preparações de DNA.

Os plasmídeos foram confirmados através de digestões com enzimas de restrição e por sequenciamento. As mini-preparações de DNA selecionadas para transformação em $A$. tumefaciens foram tratadas com RNase, limpas com fenol/clorofórmio e quantificadas.

\subsection{SEQUENCIAMENTO}

As reações de sequenciamento foram preparadas pela técnica do Laboratório Dra. Andréa Carla Quiapim e sequenciadas com o equipamento ABI 3100 (Applied Biosystems), o qual faz sequenciamentos pelo método de síntese interrompida de DNA.

\subsection{EXPRESSÃO HETERÓLOGA}

A expressão da proteína recombinante HIS-NtCDKG;2 foi realizada em sistema heterólogo de E. coli da cepa BL21-CodonPlus (DE3)-RP. Para isso, foi utilizada a construção pEXP17_HIS-NtCDKG;2 (plasmídeo de Expressão de NtCDKG;2 com cauda N-terminal de histidina) desenvolvida por LUBINI (2012).

\subsubsection{INDUÇÃO DA EXPRESSÃO DA PROTEÍNA NtCDKG;2}

A cepa E. coli BL21-CodonPlus (DE3)-RP foi transformada por eletroporação com a construção pEXP17_HIS-NtCDKG;2. Após serem transformadas, as células foram submetidas à indução de expressão das proteínas recombinantes, conforme descrito a seguir. Da placa contendo células de E. coli transformadas com os plasmídeos de expressão, uma colônia isolada foi recuperada, e um inóculo foi preparado com $5 \mathrm{ml}$ de meio LB suplementado com os antibióticos adequados, nas concentrações apropriadas. Após crescimento (16-20 horas), a $37^{\circ} \mathrm{C}$, sob agitação (200 rpm), em um Erlenmeyer, contendo $300 \mathrm{ml}$ de meio LB suplementado com os antibióticos apropriados, foi adicionado $1 \mathrm{ml}$ de cultura. A seguir, o inóculo resultante foi incubado (até o 
momento da indução) a $37^{\circ} \mathrm{C}$, sob agitação $(200 \mathrm{rpm})$. Após a culturas atingirem $\mathrm{OD}_{600 n \mathrm{~m}}$ entre 0,4 e 0,6, foi retirada uma alíquota de $1 \mathrm{ml}$, a qual foi submetida a centrifugação (6000 x $g$ por 10 minutos), o precipitado celular foi suspendido em $200 \mu \mathrm{lde} \mathrm{dH}_{2} \mathrm{O}$ e denominado "tempo zero" (pré-indução). Ao inóculo, foi adicionado $0,5 \mathrm{mM}$ IPTG dando início à indução da expressão. A cultura foi deixada a $28^{\circ} \mathrm{C}$ sob agitação de $180 \mathrm{rpm}$, por 4 horas. Ao término das induções, as culturas foram centrifugadas a $4^{\circ} \mathrm{C}$, por 10 minutos, a $6000 \mathrm{x} g$, para a obtenção dos precipitados celulares. Ao final das centrifugações, o sobrenadante foi descartado, e as células precipitadas foram estocadas em freezer $-20^{\circ} \mathrm{C}$, para posterior lise celular.

\subsubsection{LISE BACTERIANA PARA SOLUBILIZAÇÃO DOS CORPOS DE INCLUSÃO}

Esse protocolo de lise bacteriana com liberação das proteínas contidas em corpos de inclusão foi gentilmente cedido pelo Prof. Dr. Arthur Henrique Cavalcante de Oliveira (Faculdade de Filosofia, Ciência e Letras de Ribeirão Preto - FFCLRP/USP). Após a cultura ter sido induzida e peletizada, cada precipitado bacteriano (resultante de $50 \mathrm{ml}$ de cultura) foi ressuspenso em $2,5 \mathrm{ml}$ de tampão de lise [2 M de Uréia; 20 mM de Tris-HCL pH 8; 20 mM Imidazol; 0,5 M NaCl; 0.05\% Inibidor de protease - Sigma; $\mathrm{dH}_{2} \mathrm{O}$ estéril (em q.s.p. 2,50 ml)]. Após ressuspender o precipitado em soluções de lise, o homogeneizado foi incubado no gelo por 30 minutos. A seguir, foi feito o processo de sonicação para a lise celular e solubilização de corpos de inclusão. As amostras foram sonicadas empregando-se 6 pulsos de 30 segundos a $25 \%$ de potência $(100 \%=400 \mathrm{~W})$ e intervalos de 1 minuto entre cada pulso (Branson Sonifier ${ }^{\mathrm{TM}}$ S 450 Digital Ultrasonic Cell Dismptor/Homogenizer, Fisher Scientific). Ao final, a suspensão celular resultante foi centrifugada por 10 minutos, a 22000 x $g$ e $4^{\circ} \mathrm{C}$ e o sobrenadante foi transferido para um novo tubo e armazenado. O precipitado foi ressuspenso com 2,5 ml do tampão de lise e o protocolo de lise por sonicação/centrifugação/ressuspensão do precipitado foi repetido por mais 5 vezes, armazenando todas as frações solúveis geradas. Após o preparo, as frações sobrenadantes dos extratos proteicos foram submetidas à eletroforese em gel de poliacrilamida (SDS-PAGE) e análises por western blotting.

\subsection{SDS-PAGE}

Para as análises por SDS-PAGE e transferência das proteínas foram utilizados géis de bisacrilamida a uma concentração de $12,5 \%$ peso/volume $(w / v)$ fornecidos pela empresa BIO-RAD 
(Mini-PROTE $A N^{\circledR} T G X^{T M}$ Precast Gels -456-1043). O cassete foi montado e colocado na cuba de eletroforese contendo o tampão de corrida [Tris-base $25 \mathrm{mM}$; SDS 0,05\%; glicina 0,2 M]. As amostras foram preparadas misturando $21 \mu \mathrm{l}$ do extrato de proteínas obtido com a lise celular a 7 $\mu \mathrm{l}$ de tampão de amostra 4X [Tris-HCl 125 mM, pH 6,8; SDS 4\%; glicerol 10\%; azul de bromofenol $0,2 \% ; \beta$-mercaptoetanol $4 \%$. A mistura foi fervida a $100^{\circ} \mathrm{C}$, por 5 minutos, precedendo a aplicação no gel. As amostras foram então aplicadas com o auxílio de uma microseringa e, quando necessário, os poços sem amostras foram preenchidos com tampão de amostra $1 \mathrm{X}$ e $\mathrm{dH}_{2} \mathrm{O}$ em q.s.p. $28 \mu \mathrm{l}$. O marcador utilizado foi o Precision Plus Protein ${ }^{\mathrm{TM}}$ Kaleidoscope $^{\mathrm{TM}}$ (BIO-RAD).

\subsection{TRANSFERÊNCIA PARA MEMBRANA E WESTERN BLOTTING}

Depois de submetidas à eletroforese em gel de acrilamida, as amostras foram transferidas a uma membrana de PVDF (Amersham Hybond PVDF 0.45). A membrana e o gel foram dispostos lado-a-lado e submetidos a uma corrente de forma que as proteínas foram transferidas do gel para a membrana e, posteriormente, reconhecidas pelos anticorpos específicos (western blotting). Inicialmente, o material a ser utilizado para transferência foi deixado por 30 minutos em equilíbrio no tampão de transferência. A seguir, o aparato de transferência foi preparado na seguinte ordem: fibra, 2 papéis-filtro, membrana, gel a ser transferido, 2 papéis-filtro e fibra. O material foi colocado em um cassete, dentro da cuba com tampão de transferência e gelo. O aparato foi submetido a uma corrente de $100 \mathrm{~V}$ por 1 hora e 15 minutos. Após a corrida, a membrana foi corada com solução de Ponceau por 3 minutos, agitando manualmente. Os poços e o marcador foram delineados. A seguir, a membrana foi submersa em uma solução bloqueadora contendo $5 \%$ de leite em pó desnatado $\left(\right.$ Molico $^{\circledR}$ - Nestlé) diluído em tampão TBS [Tris-HCl 20mM, pH 7,5; NaCl 150mM; Tween $0,05 \%$ ]. A membrana permaneceu na solução bloqueadora por 1 hora a T.A. Após esse período, a membrana foi lavada 3 vezes (10 minutos cada lavagem) com o tampão TBS. Posteriormente, a membrana foi incubada em $15 \mathrm{ml}$ da solução de bloqueio, contendo o anticorpo primário, permanecendo incubada nessa solução overnight a $4^{\circ} \mathrm{C} . \mathrm{F}$ Após esta incubação, foram efetuadas três lavagens de 10 minutos cada, com o tampão TBS e, a seguir, a membrana foi incubada por 1 hora em $15 \mathrm{ml}$ da solução de bloqueio, contendo o anticorpo secundário conjugado com peroxidase. Após esta incubação, a membrana passou por três lavagens de 10 minutos cada em tampão TBS. Após a lavagem final, a membrana é lavada com PBS [137 mM NaCl; 2,7 mM $\mathrm{KCl}$; 10 mM Na2HPO4; 2 mM KH2PO4; pH 7,2] para retirar o Tween e não comprometer a detecção. Foram utilizados os anticorpos primários Anti-HIS (produzido em rato - Sigma/H1029; 
diluição 1:2500) e Anti-NtCDKG;2 (produzido em coelho - Proteimax; diluição 1:1700). Para reconhecimento do anticorpo primário Anti-His, foi utilizado o anticorpo secundário Anti- IgG de rato conjugado à peroxidase (produzido em cabra - Sigma/A4416; diluição 1:2000). Já para reconhecimento dos anticorpos primários Anti-NtCDKG;2 e Anti-GFP, foi utilizado o Anti IgG de coelho (produzido em cabra - Sigma/A0545; diluição 1:2500).

\subsection{REVELAÇÃO DO WESTERN BLOTTING POR ECL (ENHANCED CHEMILUMINESCENT)}

Este protocolo de revelação foi gentilmente cedido pelo Prof. Dr. Luis Lamberti Pinto da Silva (Faculdade de Medicina de Ribeirão Preto - FMRP/USP). Em sala escura, foram misturadas as soluções 1 e 2 [Solução 1: $1 \mathrm{ml}$ TRIS/HCl 1 M pH 8.5, $100 \mu \mathrm{l}$ Luminol 250 mM, 44 l p-coumaric

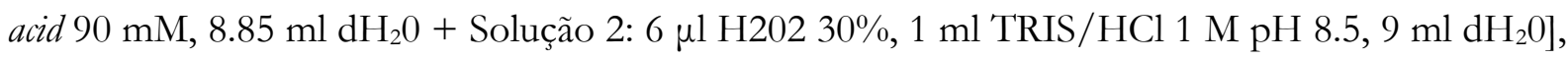
deixando-as em contato com a membrana a ser marcada por 2 minutos. A membrana foi colocada dentro de um plástico, em um cassete de autorradiografia. O filme foi colocado em contato com a membrana. A incubação inicial foi feita de acordo com a intensidade da luminescência. $O$ filme foi deixado pelo tempo necessário para observação das bandas esperadas, podendo variar de 3 segundos a 20 minutos. Posteriormente, o filme foi revelado e fixado utilizando soluções comerciais (Solução reveladora: 8610248; Solução fixadora: 1562826; KODAK Dental).

\subsection{PURIFICAÇÃO COM RENATURAÇÃO DA PROTEÍNA}

Após a confirmação por western blotting da produção heteróloga da proteína HISNtCDKG;2 nas frações solúveis, a mesma necessitou ser purificada. Devido a ureia utilizada no protocolo de solubilização das proteínas contidas nos corpos de inclusão desnaturar as proteínas, acoplado ao processo de purificação, foi realizado um processo de renaturação da NtCDKG;2. A purificação foi realizada por cromatografia de afinidade, utilizando uma resina de níquel (Ni Sepharose 6 Fast Flow; GE Healthcare) à qual a tag His possui afinidade. A resina foi lavada com 5 volumes de água deionizada e centrifugada $\left(4^{\circ} \mathrm{C}, 2000 \mathrm{x} g\right.$, por 3 minutos). Posteriormente, ela foi equilibrada com 5 volumes do tampão de lise e centrifugada nas mesmas condições. A seguir, a coluna foi empacotada a um fluxo constante de $0,5 \mathrm{ml} /$ minuto em coluna de vidro. Os sobrenadantes contendo a proteína recombinante HIS-NtCDKG;2 foram passados através da coluna e a proteína recombinante ficou imobilizada na coluna graças à tag His. A seguir, foram 
passados pela coluna 5 volumes de coluna do tampão de lise, ainda contendo $2 \mathrm{M}$ de ureia. As frações solúveis que não ficaram imobilizadas na coluna juntamente com o líquido que passou pela coluna com a lavagem foram armazenadas em um tubo e denominadas Flowthrough. Logo após, a proteína HIS-NtCDKG;2 que estava presa à coluna foi passada pelo processo de purificação e renaturação (refolding). Durante esse processo, a coluna foi lavada com subsequentes aplicações de 5 volumes de coluna de tampão de lise contendo $1 \mathrm{M}$ de ureia e, após, com 5 volumes de coluna de tampão de lise sem ureia. As lavagens também foram armazenadas, separadamente, caso fosse necessária sua aplicação em gel. A seguir, a proteína foi eluída da coluna com 5 volumes de coluna de tampão sem ureia e com $300 \mathrm{mM}$ de imidazol. O fluxo foi mantido constante durante todo o processo (0,5 ml/min). Para confirmar a purificação da proteína recombinante HIS-NtCDKG;2, as frações eluídas foram submetidas ao western blotting com detecção da proteína utilizando os anticorpos primários Anti-HIS e Anti-NtCDKG;2.

\subsection{LISE DAS CÉLULAS VEGETAIS}

Para obtenção de extratos de proteínas vegetais, as folhas de N. tabacum foram maceradas em nitrogênio líquido até obtenção de um pó. Para cada $7 \mathrm{~g}$ de tecido macerado, foram utilizados $15 \mathrm{ml}$ do seguinte tampão de extração: $50 \mathrm{mM}$ Tris- $\mathrm{HCl}$ pH 7,5; 1\% Triton X-100; 75 mM NaCl; 5\% glicerol; 2 mM EDTA; 5 mM Ortovanadato de sódio; 5 mM NaF; 20 mM b-Glicerolfosfato; +20 mM imidazol; 1 pastilha de inibidor de protease da Sigma (Roche-11836170001). A mistura foi agitada em vórtex por 1 minuto e deixada sob agitação no gelo por 30 minutos. A seguir, o extrato foi sonicado a 35\% de intensidade, 6 pulsos de 30 segundos com intervalos de 1 minuto no gelo. Em sequência, o tubo foi centrifugado $4^{\circ} \mathrm{C}, 30^{\prime}, 22000 \mathrm{x} g$ e o sobrenadante foi filtrado.

\subsection{EXPERIMENTOS DE LOCALIZAÇÃO, CO-LOCALIZAÇÃO E BIFC EM CÉLULAS VEGETAIS}

\subsubsection{EXPRESSÃO ESTÁVEL DE NtCDKG;2 EM CULTURA DE CÉLULAS BY-2}

O cultivo, manipulação e transformação das células BY-2 (cultivar Bright Yellow - 2)foram realizados de acordo com o descrito em (NAGATA T, NEMOTO Y, 1992; NOCAROVA; 
FISCHER, 2009). Células BY-2 foram cultivadas em meio MS modificado para este tipo de células (item 3.26). Suspensões de células foram preparadas, ressuspendendo aproximadamente $1 \mathrm{ml}$ de calo fresco de células em $50 \mathrm{ml}$ de meio líquido. As células em suspensão foram subcultivadas a cada sete dias ( $1 \mathrm{ml}$ de células em $50 \mathrm{ml}$ de meio líquido), no escuro, a $28^{\circ} \mathrm{C}$ e rotação de $150 \mathrm{rpm}$. Para obter culturas de células em fase de crescimento exponencial, a suspensão de células foi subcultivada por, ao menos, 4 semanas. Estoques de calos de células BY-2 foram mantidos em meio sólido com $0,7 \%(w / v)$ de ágar, $28^{\circ} \mathrm{C}$, no escuro, e subcultivados mensalmente.

Para transformação de células BY-2, uma alíquota de $2 \mathrm{ml}$ de uma cultura de células com 3 dias (subcultivada após atingir a fase de crescimento exponencial) foi cultivada com $100 \mu \mathrm{M}$ acetoseringona e $200 \mu \mathrm{l}$ de uma cultura de A. tumefaciens transformado com a construção prom35S::GFP-NtCDKG;2 (FERREIRA, 2013). A cultura foi mantida no escuro, a T.A, sem agitação, por dois dias. Após este período, as células foram lavadas com $50 \mathrm{ml}$ de sucrose $3 \%$ estéril e $20 \mathrm{ml}$ de meio líquido contendo $100 \mu \mathrm{g} / \mathrm{ml}$ de cefotaxima utilizando filtros de $45 \mu \mathrm{m}$ (Millipore) estéreis. Em seguida, as células foram plaqueadas em meio MS sólido contendo $50 \mu \mathrm{g} / \mathrm{ml}$ de canamicina e $100 \mu \mathrm{g} / \mathrm{ml}$ de cefotaxima. As células foram mantidas no escuro, a T.A. até o aparecimento de calos (cerca de 4 semanas). Estes calos foram delicadamente transferidos para novas placas contendo meio MS suplementado com os antibióticos descritos anteriormente. Neste momento, foi evitada a contaminação com células não transformadas. As células foram mantidas nas mesmas condições por cerca de 1 mês até que os calos se desenvolvessem. Após esse período, culturas de linhagens estáveis de BY-2 prom35S::GFP-NtCDKG;2 foram obtidas ressuspendendo, aproximadamente, $1 \mathrm{ml}$ de calo fresco de células em $50 \mathrm{ml}$ de meio líquido acrescido do antibiótico adequado. As células eram repicadas a cada 7 dias.

\subsubsection{EXPRESSÃO TRANSIENTE DE NtCDKG;2 EM FOLHAS DE NICOTIANA BENTHAMIANA}

Este procolo foi elaborado de acordo com sugestões do professor Daniel Scherer de Moura (Laboratório de Bioquímica de Proteínas, Escola Superior de Agricultura "Luiz de Queiroz" -

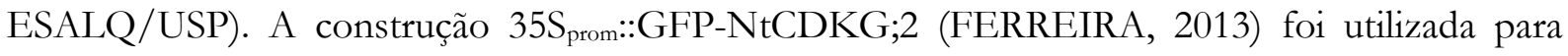
ensaios de localização através de sua expressão transiente em células de $N$. benthamiana. Adicionalmente, foi ainda utilizado o plasmídeo pCB301-p19, o qual contém a proteína de supressão do silenciamento gênico p19, do vírus do nanismo arbustivo do tomate (TBSV - Tomato 
Bushy Stunt Virus). A utilização desse plasmídeo aumenta os níveis de expressão transiente em plantas (LOMBARDI et al., 2009; ZHENG et al., 2009). Uma colônia de A. tumefaciens contendo essa construção foi inoculada em $5 \mathrm{ml}$ de meio LB líquido com os antibióticos adequados, deixando-se o inóculo a $28^{\circ} \mathrm{C}$ com agitação de $200 \mathrm{rpm}$. Após 24 horas de cultivo, a cultura foi centrifugada em um tubo de $1,5 \mathrm{ml}$, a $2500 \mathrm{x} g$ por 5 minutos. O precipitado de células foi ressuspendido em $1 \mathrm{ml}$ de meio de ativação [10 mM MÊS - 2-N-morpholino ethanesulfonic acid; $10 \mathrm{mM}$ $\mathrm{MgCl}_{2} ; 200 \mu \mathrm{M}$ de acetoseringona]. Essa mistura ficou no escuro entre 2 e 4 horas. A seguir, a O.D. de cada suspensão foi determinada por leitura da absorbância a 600 ñm. A OD de cada cultura de A. tumefaciens foi ajustada para o valor 0,3 , acrescentando-se mais meio de infiltração. Posteriormente, com o auxílio de uma seringa de $1 \mathrm{ml}$, a suspensão de células foi infiltrada na região abaxial de folhas de N. benthamiana. O processo de infiltração foi realizado da seguinte maneira: foram produzidos pequenos orifícios na região abaxial da folha, com o auxílio de uma ponteira para $10 \mu \mathrm{l}$. A seguir, a abertura da seringa foi posicionada nesses orifícios. Com o dedo apoiado na parte de adaxial da folha, o conteúdo da seringa foi aplicado delicadamente enquanto não houvesse resistência por parte do tecido foliar e a suspensão de células se espalhasse pelo tecido. Este procedimento foi repetido até que toda a área foliar fosse infiltrada. Foram utilizadas plantas jovens de N. benthamiana, com cerca de 2 a 3 meses de idade, visto que apresentaram melhores resultados. Após infiltração, as plantas foram mantidas a temperatura ambiente por 2-6 dias até análise em microscópio confocal.

\subsubsection{CO-TRANSFORMAÇÃO DE NtCDKG;2 COM PROTEÍNAS MARCADORAS PARA ENSAIOS DE CO-LOCALIZAÇÃO}

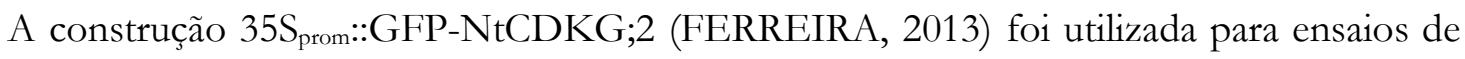
co-localização com marcadores de corpúsculos nucleares através de sua expressão transiente em células de $N$. benthamiana. Os marcadores utilizados são proteínas de $A$. thaliana cuja localização nuclear já fora descrita. Foram utilizados os marcadores AtFIB1 (Fibrillarin 1), AtCypRS64 (RS domain-containing cyclophilin) e o fator de splicing AtSRp34a (Serine/Arginine-Rich Protein Splicing Factor 34a). Os marcadores de corpos nucleares descritos por KOROLEVA et al. (2009) foram gentilmente cedidos pelo Dr. Peter J. Shaw, do Departamento de Biologia Celular do Centro John Innes, Reino Unido. Para realizar os ensaios de co-localização, foram inoculadas uma colônia de

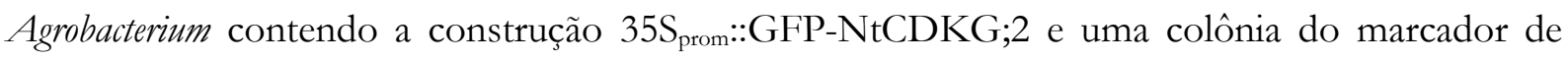
corpúsculos nucleares a ser co-transformado para análise. Também foram inoculadas células de $A$. 
tumefaciens contendo o plasmídeo pCB301-p19 para expressão da proteína supressora de silenciamento gênico. O protocolo de crescimento das culturas, ativação das agrobactérias com o tampão e infiltração nas folhas de N. benthamiana foi descrito no item anterior (3.20.2). Foi utilizada uma O.D de 0,3 para cada uma das culturas a serem infiltradas o que correspondeu a uma O.D. final de 0,9 .

\subsection{MARCAÇÃO DAS CÉLULAS VEGETAIS COM CORANTES}

Para facilitar a identificação dos núcleos, as células vegetais transformadas foram marcadas com dois diferentes corantes, dependendo do tipo celular. Ambos corantes utilizados, Hoechst 33342 e DAPI (4',6-diamidino-2-phenylindole), possuem a propriedade de se intercalar no sulco menos da dupla fita de DNA (PORTUGAL; WARING, 1988). A propriedade intercalante confere aos corantes a capacidade de marcar heterocromatina em azul/ciano. Regiões ricas em eucromatina se caracterizam por áreas de pouca ou nenhuma marcação pelos corantes.

\subsubsection{MARCAÇÃO DE CÉLULAS DE FOLHAS DE N. benthamiana COM O CORANTE DAPI}

O marcador DAPI foi utilizado para marcar as folhas de N. benthamiana que haviam sido infiltradas. Inicialmente, as folhas foram seccionadas com o auxílio de um bisturi em pequenas porções de $0,5 \mathrm{~cm}^{2}$, em média. A seguir, os segmentos foliares foram colocados em tampão PBS contendo o corante DAPI na concentração de $1,25 \mu \mathrm{g} / \mathrm{ml}$. Os cortes foliares foram mantidos nesta solução, em vácuo de 10-15 polegadas de $\mathrm{Hg}$, por 15 minutos. Esse passo permite a penetração do DAPI nas células e a formação do complexo com a molécula de DNA. Após a aplicação do vácuo, as placas foram mantidas cobertas por 30 minutos a T.A e posteriormente lavadas com PBS. Após a lavagem, os cortes foram mantidos em PBS até o momento da visualização em microscópio confocal. 


\subsubsection{MARCAÇÃO DE CÉLULAS BY-2 COM O CORANTE HOECHST}

Hoechst 33342 é conhecido como supravital, ou seja, permite que as células sobrevivam durante o tratamento (ZHANG et al., 2011). Por possuir conferir essa sobrevida às células, ele foi utilizado para facilitar a identificação dos núcleos de células BY-2 nas diferentes fases do ciclo celular. Para o procedimento de marcação, uma alíquota de $2 \mathrm{ml}$ de uma cultura estável de células BY-2 prom35S::GFP-NtCDKG;2 de 3 dias, foi transferida para um tubo de $50 \mathrm{ml}$. A estas células foi adicionado o corante Hoechst $(5 \mu \mathrm{g} / \mathrm{ml})$ e a cultura foi mantida a $28^{\circ} \mathrm{C}, 150 \mathrm{rpm}$, overnight. Para captura das imagens, uma alíquota de células foi depositada sobre uma lâmina juntamente com uma gota de meio MS líquido. Após cobrir as células com uma lamínula, procedeu-se com a análise das mesmas em um microscópio confocal.

\subsection{ANÁLISES NO MICROSCÓPIO CONFOCAL}

Após marcação com os corantes, os cortes foliares e as células BY-2 foram analisados no microscópio confocal Leica TCS SP5 (Leica Microsystems) do Laboratório Multiusuário de Microscopia Confocal (LMMC - FMRP/USP). A captura das imagens foi realizada de acordo com (KOROLEVA et al., 2009). Para a visualização do DNA marcado com DAPI, a amostra foi excitada com luz ultravioleta, no comprimento de onda de $405 \mathrm{~nm}$, e a captura das imagens (detecção da fluorescência) foi feita no intervalo de 420-480 ทm. Para a captura da marcação com Hoechst, a amostra também foi excitada com luz ultravioleta no comprimento de onda de $405 \eta \mathrm{m}$ mas a emissão foi capturada entre 440-470 $\eta \mathrm{m}$. Para a GFP, a excitação foi feita com laser de argônio, no comprimento de onda de $488 \eta \mathrm{m}$, e a captura foi feita no intervalo entre 500-530 $\eta \mathrm{m}$. Para os marcadores de corpúsculos nucleares fusionados a proteína mRFP, a excitação foi realizada

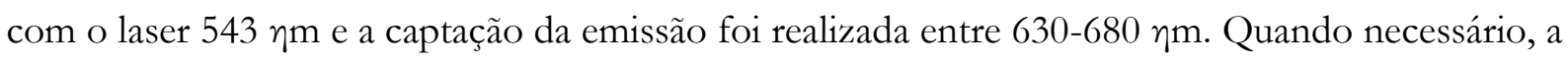
presença de cloroplastos foi analisada através de excitação com o laser Hélio-Neônio (HeNe) no comprimento de onda de $543 \eta \mathrm{m}$ e a captação da emissão foi realizada entre 650-720 $\eta \mathrm{m}$. As aquisições de imagens foram feitas no modo sequencial, ou seja, cada laser foi ligado separadamente para impedir crosstalking (interferências causadas pela excitação não-intencional de fluoróforos de excitação similar). As capturas, as análises e montagem de imagens e suas escalas foram feitas com o software Leica LAS AF v.2.x, que acompanha o microscópio. 


\subsection{EXPERIMENTOS PARA TESTE DE CLIVAGEM DE NtCDKG2}

Inicialmente, a proteína recombinante HIS-NtCDKG;2 foi produzida em E. coli utilizando o método de solubilização de corpos de inclusão e purificada por cromatográfica de afinidade em resina de Níquel (itens 3.14-3.18). Em seguida, a proteína purificada foi incubada juntamente com um extrato proteico de folhas de N. tabacum SR1. Foram feitos dois experimentos de incubação em paralelo: um experimento foi realizado à T.A. e o outro a $4^{\circ} \mathrm{C}$. A incubação em ambos experimentos durou 18 horas. Foram retiradas alíquotas dos experimentos após 1,5 horas, 5,5 horas e 18 horas de incubação. As alíquotas foram mantidas em freezer $-20^{\circ} \mathrm{C}$ até sua análise em gel SDS-PAGE (Sodium Dodecyl Sulphate - Polyacrylamide gel electrophoresis) e posterior western blotting para detecção da proteína recombinante. Foram feitos dois controles negativos. Para fazer os controles negativos, uma alíquota da proteína recombinante foi incubada somente com o tampão utilizado para extrair as proteínas de folhas. Os controles negativos foram mantidos por 18 horas nas temperaturas de $4^{\circ} \mathrm{C}$ e T.A.

\subsection{EXPERIMENTOS IN VIVO PARA TESTE DE INTERAÇÕES ENTRE PROTEÍNAS}

A interação entre as proteínas NtCDKG;2 e NtSCI1 foi identificada em experimento de pull-down e confirmada por ensaio de BiFC (Bimolecular fluorescence Complementation) por STRINI (2014). Nesse caso, o experimento de BiFC havia sido realizado em células de N. tabacum uma única vez, gerando poucas fotomicrografias. As imagens indicavam que a localização da interação era nuclear, mas sem muitos detalhes. Para analisar melhor essa interação, foram feitos ensaios de BiFC em folhas de N. benthamiana, dando atenção para a fase do ciclo celular em que a interação ocorre e em que local exatamente.

Também foram realizados ensaios para identificação de interações entre proteínas candidatas utilizando leveduras $S$. cerevisiae. Foram feitos ensaios para identificar proteínas que possam interagir com NtCDKG;2. Esses ensaios consistiram de um screening em busca de parceiros de interação de NtCDKG;2. Algumas das proteínas parceiras identificadas no screening com $\mathrm{NtCDKG;2} \mathrm{também} \mathrm{tiveram} \mathrm{sua} \mathrm{interação} \mathrm{testada} \mathrm{com} \mathrm{a} \mathrm{proteína} \mathrm{NtSCI1.} \mathrm{Adicionalmente,} \mathrm{a}$ proteína NtCDKG;2 teve sua interação testada com uma proteína do tipo 14-3-3, a qual possui interação descrita com NtSCI1. 


\subsubsection{ENSAIOS DE INTERAÇÃO ENTRE NtCDKG;2-hGFP E NtSCI1-tGFP EM CÉLULAS VEGETAIS}

Os ensaios de BiFC foram realizados de acordo com BRACHA-DRORI et al. (2004). Uma colônia de $A$. tumefasciens cepa GV2260/pGV2260, portadora da construção Pro35S::NtCDKG;2hGFP (sequência codificadora da proteína NtCDKG;2 fusionada à extremidade N-terminal da proteína hGFP - aminoácidos 1 a 149 da proteína GFP, sob o controle do promotor CaMV 35S) foi inoculada em $5 \mathrm{ml}$ de meio LB suplementado com os antibióticos adequados e mantida overnight, a $28^{\circ} \mathrm{C}$, com agitação de $200 \mathrm{rpm}$. O mesmo foi realizado com uma colônia de $A$. tumefasciens contendo a construção Pro35S::NtSCI1-tGFP (sequência codificadora da proteína NtSCI1 fusionada à extremidade N-terminal da proteína tGFP - aminoácidos 150 a 238 da proteína GFP, sob o controle do promotor CaMV 35S). Também foram inoculadas células de A. tumefaciens contendo o plasmídeo pCB301-p19 para expressão da proteína supressora de silenciamento gênico. O protocolo de crescimento das culturas, ativação das agrobactérias com o tampão e infiltração nas folhas de N. benthamiana foi descrito no item 3.20.2. Foi utilizada uma O.D de 0,3 para cada uma das culturas a serem infiltradas o que correspondeu a uma O.D. final de 0,9. A restauração da fluorescência da proteína GFP, resultante da interação NtCDKG;2-hGFP e NtSCI1-tGFP foi analisada no microscópio confocal (conforme item 3.22) entre 2 e 6 dias após a infiltração.

\subsubsection{ENSAIOS DE DUPLO-HÍBRIDO EM LEVEDURAS $S$. cerevisiae}

Em 1989, Fields e Song desenvolveram um método ainda muito utilizado para avaliação de interação proteína-proteína. Certas proteínas possuem múltiplos domínios que agem independentemente e que, quando aproximados por meio de ligações não covalentes, reconstituem a atividade da proteína intacta. Baseados nessa característica de algumas proteínas, o sistema de duplo-híbrido em leveduras ( $\underline{\text { Yeast two }}$-hybrid - Y2H) (FIELDS; SONG, 1989) é um método in vivo para detecção de interações entre proteínas. Essa técnica utiliza os domínios do fator de transcrição GAL4: Domínio de Ligação ao DNA (DNA B Binding Domain, BD) e Domínio de Ativação da transcrição (Áctivation Domain, AD). Cada um dos domínios é expresso em forma de proteínas de fusão com uma das proteínas candidatas à interação. Somente se as proteínas candidatas interagirem ocorre reaproximação dos domínios e expressão de genes repórteres que promoverão 
auxotrofia a aminoácidos. Para a detecção das interações, são utilizadas linhagens de leveduras que possuem genes repórteres, como o HIS3, ADE2 e lacZ, cujas cópias ativas foram introduzidas no genoma das leveduras e sua regulação está sob controle de um promotor GAL4-indutível. Em nosso laboratório, foi construída uma biblioteca de cDNAs para uso no sistema ProQuest TwoHybrid com a tecnologia Gateway (STRINI, 2014). Nessa biblioteca, o RNA de estigmas/estiletes foi convertido em cDNAs que foram clonados, através do sistema Gateway de recombinação, em vetores contendo o domínio $\mathrm{AD}$, constituindo proteínas candidatas utilizadas no estudo. A Figura 7 mostra, esquematicamente, os processos compreendidos no ensaios de $\mathrm{Y} 2 \mathrm{H}$.

Transformação S. cerevisiae com isca (BD-NtCDKG;2)<smiles>C=CC=C</smiles>

Transformação S. cerevisiae com BD-NtCDKG;2 com biblioteca cDNA (30 placas)<smiles>[C]1=CC=C1</smiles>

Resgate das colônias em placas de 96 poços<smiles>C1=CC=C1</smiles>

Crescimento em -Leu-Trp-His e em -Leu-Trp-Ade<smiles>[CH]=C</smiles>

Extração do pDNA das leveduras<smiles>C1=CCCC1</smiles>

Transformação do pDNA das leveduras em E. coli<smiles>[C]1=CC=C1</smiles>

Extração do pDNA de 6 colônias de E. coli<smiles>C1=CC=C1</smiles>

Digestão dos pDNAs extraídos $(\mathrm{BsrGI}) \rightarrow$ gel de agarose<smiles>C1=CC=C1</smiles>

Seleção dos clones e sequenciamento

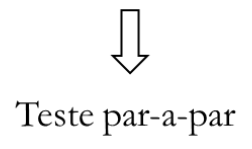

Figura 7: Representação esquemática dos processos percorridos no screening de duplo-híbrido em leveduras para levantar possíveis candidatos à interação com NtCDKG;2. 


\subsubsection{Screening da biblioteca do sistema do duplo-híbrido, utilizando BD-NtCDKG;2 como proteína alvo}

Para realizar o screening da biblioteca de cDNAs, os experimentos de duplo-híbrido foram realizados com o kit ProQuestTM Two-Hybrid System (Invitrogen), baseado no sistema Gateway de recombinação. Os controles positivos e negativo, utilizados para os experimentos foram: controle positivo de interação forte (Krev1-RalGDSwt); controle positivo de interação fraca (Krev1RalGDS-m1), e controle de interação negativa (Krev1-RalGDS-m2), todos presentes no kit. Para realizar o screening, a proteína de fusão BD-NtCDKG;2 (pDEST32) foi utilizada como proteínaalvo. A biblioteca de cDNAs de estigmas/estiletes de nosso laboratório (STRINI, 2014), construída em vetor de expressão (pDEST22) adequado ao sistema de duplo-híbrido, foi utilizada como fonte de proteínas candidatas à interação. Para seleção das colônias de interesse, o meio SD foi acrescido os suplementos nutritivos de acordo com a seleção desejada. Para saber detalhes dos plasmídeos, veja o Anexo A.

Para o screening da biblioteca de cDNAs, construída para uso no sistema de duplo-híbrido, foram utilizadas células de levedura competentes contendo a construção BD-NtCDKG;2 previamente transformada (item 3.4.3). A seguir, as células já transformadas foram utilizadas para novas transformações. Dessa vez, foi transformada a biblioteca de cDNAs de estigma/estilete de N. tabacum. Essa biblioteca foi feita em plasmídeos pDEST22. Foram realizadas 30 transformações, quantidade necessária para obtenção de $10^{6}$ transformantes (a eficiência de transformação foi previamente determinada em nosso laboratório), sendo, de acordo com o protocolo, a quantidade ideal de transformantes para a realização do screening. Para cada uma das transformações, foram utilizados: uma alíquota da levedura competente contendo a construção BD-NtCDKG;2; $1 \mu \mathrm{g}$ de DNA da biblioteca; $5 \mu \mathrm{l}$ de esperma de salmão fervido (50 $\mu \mathrm{g})$ e $300 \mu \mathrm{l}$ de 40\% PEG-3350 / 1X LiAc /1X TE estéril. Os 30 tubos foram cuidadosamente homogeneizados e incubados a $30^{\circ} \mathrm{C}$ por 30 minutos. Em seguida, a cada tubo foram adicionados $36 \mu$ l de DMSO (Dimetilsulfóxido) estéril (Sigma) e a preparação foi agitada cuidadosamente. As transformações por choque térmico foram feitas de acordo com o descrito em 3.4.3. Cada suspensão de células foi plaqueada em uma placa de Petri de $15 \mathrm{~cm}$ contendo meio SC-Leu-Trp-His, sendo o gene HIS3 utilizado como gene repórter neste momento. As 30 placas foram incubadas a $30^{\circ} \mathrm{C}$ por 48 horas e, em seguida, mais 48 horas a temperatura ambiente.

Após este período, as colônias que cresceram neste meio seletivo foram inoculadas em 1,5 $\mathrm{ml}$ de meio líquido SC-Leu-Trp em placas de cultura de 96 poços (Greiner) e mantidas a $30^{\circ} \mathrm{C}, 250$ 
rpm por 48 horas. Após crescimento, $300 \mu \mathrm{l}$ de cada cultura foram utilizados para a obtenção de estoque em glicerol $20 \%$ e armazenados a $-80^{\circ} \mathrm{C}$. Uma alíquota de $200 \mu \mathrm{l}$ de cada cultura foi transferida para placas de 96 poços (Corning). O restante da cultura, presente na placa de cultura, foi centrifugado a 1250 x g por 5 minutos (centrifuga Eppendorf 5810 R). O precipitado de células foi armazenado a $-20^{\circ} \mathrm{C}$ até o momento de extração do DNA plasmidial das leveduras.

\subsubsection{Análise do fenótipo dos transformantes para os genes repórteres}

A placa de 96 poços (Corning) contendo os $200 \mu$ de cada cultura foi utilizada como molde para replicar as culturas em placas de Petri de $15 \mathrm{~cm}$, contendo os meios seletivos dos genes repórter HIS3 (SC-Leu-Trp-His) e ADE2 (SC-Leu-Trp-Ade). Também foi feita uma primeira réplica em meio seletivo SC-Leu-Trp, servindo de controle do crescimento das células para os testes com os genes repórteres. Para tanto, um replicador de 96 pocos (Boekel), estéril, foi inserido nos 96 poços da placa. O replicador foi levantado e colocado em contado com os meios para seleção do gene repórter, preparados em placas de Petri de $15 \mathrm{~cm}$. As células foram obtidas em formato de spots. As réplicas foram incubadas a $30^{\circ} \mathrm{C}$ por 72 horas. Após esse período, foram analisadas as colônias que cresceram nos diferentes meios seletivos. Os clones que apresentaram ativação dos genes repórteres HIS3 foram selecionados e procedeu-se com a extração de DNA plasmidial dos pellets de células de leveduras correspondentes, que estavam armazenados a $-20^{\circ} \mathrm{C}$.

\subsubsection{Identificação das proteínas candidatas à interação}

Durante a transformação das células de leveduras no procedimento de screening da biblioteca, uma mesma célula de levedura pode ser transformada com mais de umplasmídeo e gerar um único transformante com várias proteínas candidatas. Neste caso, em uma mesma célula serão encontradas a construção BD-NtCDKG;2 e algumas construções candidatas diferentes (ADcDNA da biblioteca). Em cada clone positivo, por probabilidade, apenas uma das construções ADcDNA codifica uma proteína que interage com NtCDKG;2 e, portanto, está efetivamente ativando o sistema. Com o objetivo de resolver este problema, procedeu-se com o isolamento dos cDNAs das candidatas através da extração do DNA dos clones de levedura positivos (item 3.5.3).

Para identificação dos possíveis parceiros de interação de NtCDKG;2, $1 \mu$ do DNA plasmidial extraído de levedura de cada clone foi transformado em células de E. coli DH10B. 
Posteriormente, todo o conteúdo da transformação foi plaqueado em meio LB suplementado com ampicilina para seleção das células que incorporaram apenas o plasmídeo com a candidata, o pDEST22. Após crescimento, seis colônias isoladas foras selecionadas e inoculadas no mesmo meio de cultura, contendo o mesmo antibiótico. Após 16-20 horas, o DNA plasmidial de todas as colônias foi extraído pelo método da lisozima e, posteriormente, digerido com a enzima de restrição BsrGI (New England Biolabs) e submetidos à eletroforese em gel de agarose 1\%. Os DNAs de todos os clones que apresentaram perfis distintos de digestão enzimática foram selecionados e sequenciados, utilizando o primer J16 (Tabela 1). Após obtenção das sequências, estas foram analisadas nos bancos de dados GenBank e TAIR (The Arabidopsis Information Resource), pela ferramenta tblastx, comparando-se com as sequências já existentes nestes bancos.

\subsubsection{Ensaios par-a-par para confirmação da interação entre proteínas candidatas}

Os DNAs sequenciados e que foram considerados relevantes para nosso estudo foram cotransformados em leveduras competentes juntamente a construção BD-NtCDKG;2. Após transformadas, as células foram plaqueadas em meio SC-Leu-Trp e mantidas a $30^{\circ} \mathrm{C}$ por 48 horas até a obtenção dos transformantes. Em seguida, uma colônia foi inoculada em meio SC -Leu-Trp líquido e incubada a $30^{\circ} \mathrm{C}, 220 \mathrm{rpm}$, por 48 horas. Após este período, as células foram diluídas em meio SC líquido para a $\mathrm{OD}_{600 n_{\mathrm{m}}}$ 0,2 e plaqueadas nos seguintes meios sólidos: SC-Leu-Trp-His, SCLeu-Trp-Ade e SC completo com uma membrana de nylon Hybond -N+ (Amersham Biosciences). Esses meios foram utilizados para testar a interação mediante a ativação dos genes reporteres HIS3, $A D E 2$ e lacZ. Neste caso, o crescimento dos transformantes nos meios indica que a interação entre $\mathrm{NtCDKG;2} \mathrm{e} \mathrm{a} \mathrm{proteína} \mathrm{candidata} \mathrm{correspondente} \mathrm{é} \mathrm{positiva.} \mathrm{Estes} \mathrm{ensaios} \mathrm{foram} \mathrm{sempre}$ conduzidos utilizando controles para os níveis de interação, autoativação da NtCDKG;2 e autoativação da proteína candidata (de acordo com o próximo item, 3.24.2.5).

Após este procedimento, o fenótipo das células correspondentes a cada teste de interação e para cada gene repórter pode ser comparado aos controles de nível de interação e autoativação. A interação entre NtCDKG;2 e uma candidata foi considerada positiva para o gene repórter HIS3, quando as células correspondentes ao teste de interação eram capazes de crescer em meio SC-LeuTrp-His, enquanto que os controles de autoativação da NtCDKG;2 e da proteína candidata não eram capazes. Da mesma forma, para o teste com $A D E 2$, foi considerada positiva a interação entre as proteínas de fusão contidas nas leveduras que cresceram em meio SC-Leu-Trp-Ade. Para o gene 
repórter lacZ, o teste de interação foi considerado positivo quando a coloração azulada nos spots de células submetidas ao teste com X-gal e correspondentes ao teste de interação eram mais evidentes do que os spots correspondentes aos testes de autoativação.

Os ensaios par-a-par também foram utilizados para testar a interação entre NtSCI1 e algumas proteínas identificadas no screening que utilizou NtCDKG;2 como proteína-alvo. Além disso, o teste par-a-par foi utilizado para verificar a interação entre NtCDKG;2 e uma 14-3-3 identificada como forte parceira de interação de NtSCI1.

\subsubsection{Testes de autoativação}

A cada novo experimento para teste de interação, eram feitos os testes de autoativação da proteína-alvo e das proteínas candidatas à interação.

Da proteína-alvo: Células de levedura competentes contendo o plasmídeo com DNA da proteína-alvo foram transformadas com 500 ng do vetor pDEST22 vazio, para testar se a proteína híbrida BD-alvo, expressa juntamente com o domínio AD, e ser capaz de autoativar o sistema. $\mathrm{O}$ produto da transformação foi distribuído em placa contendo meio de cultura SC sem Leucina e sem Triptofano (SC-Leu-Trp), para seleção dos transformantes, incubada a $30^{\circ} \mathrm{C}$ por 48 horas. Uma colônia isolada obtida foi inoculada em meio líquido SC-Leu-Trp e incubada a $30^{\circ} \mathrm{C}, 220 \mathrm{rpm}$ por 48 horas. Após este período, a concentração de células foi estimada medindo-se a $\mathrm{DO}_{600}$ da cultura. Esta foi diluída para a concentração $\mathrm{DO}_{600}=0,2$, a qual foi novamente submetida a diluições seriadas 1:5. Todas estas diluições foram aplicadas em placas contendo SC-Leu-Trp-His, incubadas a $30^{\circ} \mathrm{C}$ por 48 horas. Se houver crescimento de colônias, a proteína-alvo, sozinha, autoativa o sistema. Neste caso é necessário a titulação de 3-AT (3-amino-1,2,4-triazol) necessária para inibir a autoativação. Se não houver crescimento, a proteína-alvo não autoativa o sistema, podendo ser utilizada para o screening na biblioteca de duplo-híbrido.

Das proteínas candidatas: $O$ teste de autoativação para as proteínas candidatas foi feito da mesma forma que para a proteína-alvo. Porém, foi feita co-transformação em células de levedura sem nenhuma construção, com o vetor pDEST22 contendo a proteína candidata de teste e o vetor pDEST32 vazio. A co-transformação foi plaqueada em meio SC-Leu-Trp para seleção dos transformantes para ambos os vetores. Após crescimento em meio líquido, a transformação foi plaqueada em meio SC-Leu-Trp-His, como descrito para o teste com a proteína-alvo. 


\subsection{EXPERIMENTOS IN VIVO PARA TESTE DE INTERAÇÕES ENTRE DNA- PROTEÍNA: ENSAIO DE YEAST ONE-HYBRID (Y1H) PROTEÍNAS}

Os ensaios de interação DNA-proteínas foram realizados por meio da técnica de Yeast onebybrid $(\mathrm{Y} 1 \mathrm{H})$. O sistema de $\mathrm{Y} 1 \mathrm{H}$ é amplamente utilizado para testar a interação de proteínas (normalmente fatores de transcrição) e um fragmento de DNA de interesse (REECE-HOYES; MARIAN WALHOUT, 2012). Fatores de transcrição podem ativar ou reprimir um gene através de sua ligação com elementos cis regulatórios. Esses elementos podem estar presentes na região promotora do gene alvo, dentro de íntrons, éxons ou mesmo a distâncias maiores. Portanto, foi necessário desenvolver um método que possa ser utilizado para detecção dessas interações. No sistema de $\mathrm{Y} 1 \mathrm{H}$, uma única proteína é fusionada ao domínio de ativação AD do GAL4 e ela mesma serve como ligante ao DNA (BD). Assim, se a proteína se ligar ao DNA alvo, a transcrição do gene repórter é ativada. Finalmente, a interação é testada através do crescimento das leveduras em antibiótico.

Primeiramente, as sequências de DNA de interesse foram amplificadas e clonadas em um plasmídeo de entrada para utilização do sistema Gateway de recombinação. O vetor original pAbAi (Clontech) foi modificado e contém os sítios attR1 e attR2 do Gateway no MCS (sítio de clonagem múltipla). Esse vetor modificado, agora denominado pAbAi-GW, foi confeccionado e gentilmente cedido pela técnica Froukje van der Wal (grupo Plant Developmental Systems - PDS, unidade de pesquisa Biosciences da empresa Plant Research International - PRI, Wageningen University e Research Center, Reino dos Países Baixos). Assim, os vetores de entrada do Sistema Gateway puderam ser utilizados para recombinação homóloga LR com o vetor pAbAi-GW. Para detalhes do plasmídeo, veja o Anexo A. A Figura 8 mostra o passo-a-passo para a realização do screening de Y1H. 
Lineariazação do vetor pAbAi-GW contendo o DNA de interesse

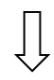

Integração do vetor linearizado no genoma de S. cerevisiae PJ69-4alfa

$\sqrt{ }$

Teste de autoativação em AbA

$\sqrt{ }$

Transformação S. cerevisiae +DNA integrado no genoma com biblioteca cDNA (30 placas)<smiles>[CH]=C</smiles>

Resgate das colônias em placas de 96 poços

$\sqrt{ }$

Crescimento em -Leu-Trp-Ura +AbA

$\sqrt{ }$

Extração do pDNA das leveduras

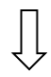

Transformação do pDNA das leveduras em E. coli

$\sqrt{2}$

Extração do pDNA de 6 colônias de E. coli<smiles>[CH]1C=C1</smiles>

Digestão dos pDNAs extraídos $(\mathrm{BsrGI}) \rightarrow$ gel de agarose

$\sqrt{2}$

Seleção dos clones e sequenciamento

$\sqrt{1}$

Teste par-a-par

Figura 8: Representação esquemática dos processos percorridos no screening de Y1H para levantar possíveis candidatos à interação com NtSCI1.

\subsubsection{DIGESTÃO DO PLASMÍDEO CONTENDO DNA DE INTERESSE}

Após clonada a região promotora/DNA de interesse no vetor pAbAi-GW, o plasmídeo foi linearizado através de digestão com a enzima BstBI seguindo o seguinte protocolo: Foram adicionados aos $30 \mu \mathrm{l}$ de DNA plasmidial $5 \mu \mathrm{l}$ NEB2 buffer 10X, $3 \mu \mathrm{l}$ da enzima BstBI e $12 \mu \mathrm{l}$ de água deionizada. A reação foi colocada a $37^{\circ} \mathrm{C}$ por $16-20$ horas, tempo suficiente para o fragmento ser completamente digerido e linearizado. 


\subsubsection{TRANSFORMAÇÃO PARA INTEGRAÇÃO DO FRAGMENTO LINEARIZADO NO GENOMA DA LEVEDURA}

O vetor pAbAi-GW não pode ser propagado de forma epissomal nas células de levedura. Assim, para fazer os ensaios de $\mathrm{Y} 1 \mathrm{H}$ foi necessário colocar o fragmento linearizado dentro do genoma das células de levedura PJ69-4 $\alpha$. Essa integração foi feita mediante recombinação homóloga. A enzima BstBI cliva dentro do gene para biossíntese da Uracila (vide Anexo A). Os fragmentos do gene URA3 irão recombinar com locus ura3-52 presente no genoma da levedura. URA3 também é um marcador nutricional que também pode ser utilizado para seleção das leveduras recombinantes. Os DNAs-alvo linearizados foram transformados em células de levedura S. cerevisiae PJ69-4 $\alpha$ conforme descrito no item 3.4.3.

\subsubsection{TESTE DE AUTOATIVAÇÃO DO DNA-ALVO}

Foi utilizada a resistência ao antibiótico Aureobasidina A (AbA) conferida pelo gene repórter $A U R$ 1-C para os ensaios de autoativação do sistema. Primeiramente, houve seleção de 10 colônias transformadas cujo DNA-alvo estava integrado no genoma das células de levedura. As leveduras foram testadas para resistência ao antibiótico AbA a uma concentração entre 0 e 500 $\eta \mathrm{g} / \mathrm{ml}$ de meio. Cada uma das 10 colônias selecionadas foi dissolvida em $200 \mu \mathrm{l}$ de água e $5 \mu \mathrm{l}$ foram gotejados com a pipeta em placas contendo SD-Ura + Aurobasidina nas seguintes concentrações: 0, 50, 100, 150, 200, 250, 300, 400 e 500 ng/ml. Foram escolhidas as colônias que cresciam muito bem em meio sem antibiótico e que apresentavam os índices mais baixos de autoativação do sistema.

\subsubsection{TRANSFORMAÇÃO DE CÉLULAS DE LEVEDURA COM A BIBLIOTECA DE cDNAS PARA Y1H}

As células de levedura contendo o plasmídeo linearizado pAbAi-GW com o fragmento de interesse foram transformadas com a mesma biblioteca de cDNAs de estigmas/estiletes de $N$. tabacum utilizada para o screening de duplo-híbrido (STRINI, 2014). Inicialmente, foi feita uma cultura overnight de células PJ69-4 $\alpha$ em $10 \mathrm{ml}$ de meio SD com dropout completo em um tubo de 50 
$\mathrm{ml}$. A cultura foi deixada por $16-20$ horas a $30^{\circ} \mathrm{C}$, sob agitação de $250 \mathrm{rpm}$. Na manhã seguinte, a cultura foi diluída até atingir $\mathrm{DO}_{600}$ 0,1-0,2 em SD completo, em volume de $50 \mathrm{ml}$ (Erlenmeyer previamente autoclavado). A cultura cresceu $\left(30^{\circ} \mathrm{C}, 250 \mathrm{rpm}\right)$ até atingir uma $\mathrm{OD}_{600 \eta \mathrm{m}}$ entre $0,4 \mathrm{e}$ 0,6. O conteúdo do Erlenmeyer foi colocado em um tubo de $50 \mathrm{ml}$ e precipitado (5 minutos, 4000 x g. A seguir, o precipitado celular foi, gentilmente, ressuspendido em $25 \mathrm{ml} 100 \mathrm{mM} \mathrm{LiAc}$ e centrifugado nas mesmas condições. O sobrenadante foi removido, cuidadosamente, com pipeta e o precipitado foi ressuspendido com 2,4 $\mathrm{ml}$ de 50\% $w / v$ PEG. Foram adicionados $360 \mu \mathrm{l} 1 \mathrm{M}$ LiAc, $50 \mu \mathrm{l}$ DNA de esperma de salmão (10mg/ml), $680 \mu \mathrm{l}$ de água deionizada e $20 \mu \mathrm{g}$ da biblioteca de cDNAs. O conteúdo foi agitado em vórtex por 1 minuto e, a seguir, incubado por 1 hora a $42^{\circ} \mathrm{C}$. Após esse período, o tubo foi centrifugado ( 5 minutos, $4000 \mathrm{x} \mathrm{g}$ ) e o precipitado com as células transformadas foi lavado em $500 \mu \mathrm{l}$ de água deionizada, centrifugado novamente e, por fim, ressuspendido em $300 \mu \mathrm{l}$ de água deionizada e plaqueado em meio seletivo apropriado. As células foram plaqueadas em placas de $15 \mathrm{~cm}$. O meio seletivo foi utilizado de acordo com os resultados dos testes de autoativação para cada fragmento integrado no genoma das leveduras. A seguir, as placas foram incubadas a $30^{\circ} \mathrm{C}$ por 3 dias.

\subsection{MEIOS DE CULTURA}

Os meios de cultura utilizados foram preparados dissolvendo-se os respectivos componentes em água destilada, ajustando-se o pH quando necessário. Todos os meios foram autoclavados para esterilização.

\section{Meio LB (Luria-Bertanı) para bactérias}

Para 1 litro de meio LB foram adicionados $10 \mathrm{~g}$ de triptona, $5 \mathrm{~g}$ de extrato de levedura e $10 \mathrm{~g}$ de $\mathrm{NaCl}$. Para o meio LB sólido, foi adicionado 1,5\% de ágar bacteriológico.

\section{Meio MS para plantas (MURASHIGE; SKOOG, 1962)}

Foram adicionados 4,4g de sais MS, 30g de sacarose, 0,5 g de MES em q.s.p. 1 litro de água destilada. O pH do meio foi ajustado para 5,8 com KOH 4N. Para obtenção do meio sólido foram acrescentados 1,75 g de ágar (DIFCO) para cada $250 \mathrm{ml}$ de meio líquido. 


\section{Meio MS para cultivo de células BY-2 (modificado de LINSMAIER; SKOOG, 1965)}

Para fazer 1 litro de meio, foram adicionados 4,3 $\mathrm{g}$ de sais basais para meio MS (Sigma) sem as vitaminas; $30 \mathrm{~g}$ de sacarose; 0,5 g de MES, $10 \mathrm{ml}$ de $\mathrm{KH}_{2} \mathrm{PO}_{4}$ (solução estoque - $440 \mathrm{mM}$ ), $10 \mathrm{ml}$ de B1-inositol [solução estoque - Tiamina $\mathrm{HCl}(0,3 \mathrm{mM})$ myo-inositol (55,5 mM)], $1 \mathrm{ml}$ de 2,4D (10 mM). O pH do meio foi ajustado para 5,8 com KOH 4N. Para obtenção do meio sólido foram acrescentados $6 \mathrm{~g}$ de ágar (DIFCO) para cada litro de meio líquido.

\section{Meio SD para leveduras}

Para fazer 1 litro, foram adicionados 6,7 g Yeast Nitrogen Base without aminoacids (YNB), $20 \mathrm{~g}$ de dextrose (D+glucose) e água destilada em q.s.p. 900 ml. Para meio SD sólido, adicionou-se $20 \mathrm{~g} / 1$ de ágar. A seguir, meio foi autoclavado. Antes de ser utilizado, foram adicionados $10 \%$ da solução dropout 10X de acordo com a seleção necessária.

\section{Solução Dropout}

Para uma solução dropout 10X completa, foram adicionados todos os componentes da Tabela 2 (a seguir), dissolvidos em 1 litro de água destilada e a solução foi autoclavada. Para fazer um meio seletivo, os componentes apropriados foram deixados de fora.

Tabela 2: Listagem dos componentes utilizados para fazer solução dropout $10 \mathrm{X}$ e sua respectiva quantidade.

\begin{tabular}{|ll|}
\hline Componente & Quantidade $(\mathrm{mg} / \mathrm{l})$ \\
\hline & \\
\hline Isoleucine & 300 \\
\hline L-Valine & 1500 \\
\hline L-Adenine hemisulfate salt & 200 \\
\hline L-Arginine HCl & 200 \\
\hline L-Histidine HCl Monohydrate & 200 \\
L-Leucine & 1000 \\
\hline L-Lysine HCl & 300 \\
\hline L-Methionine & 200 \\
\hline L-Phenylalanine & 500 \\
\hline L-Threonine & 2000 \\
\hline L-Tryptophan & 200 \\
\hline L-Tyrosine & 300 \\
\hline L-Uracil & 200 \\
\hline
\end{tabular}




\subsection{ANTIBIÓTICOS}

Quantidades apropriadas de cada antibiótico foram pesadas e dissolvidas em água deionizada. Em seguida, a solução foi esterilizada em filtro de $0,22 \mu \mathrm{m}$. Foram feitas alíquotas que permaneceram estocadas a $-20^{\circ} \mathrm{C}$. A concentração final dos antibióticos em meios de cultura está descrita na Tabela 3 para E. coli e A. tumefaciens.

Tabela 3: Concentração final dos antibióticos utilizados nos meios de cultura, para seleção de bactérias.

\begin{tabular}{|c|c|c|c|c|}
\hline Plasmídeo & Construção & Antibiótico & \multicolumn{2}{|c|}{ Concentração final } \\
\hline & & & E. coli & A. tumefaciens \\
\hline $\begin{array}{l}\text { PCR2.1 } \\
\text { TOPO-TA }\end{array}$ & Clonagem & canamicina & $50 \mu \mathrm{g} / \mathrm{ml}$ & - \\
\hline pDONR201 & Entrada no sistema Gateway & canamicina & $50 \mu \mathrm{g} / \mathrm{ml}$ & - \\
\hline pDONR 207 & Entrada no sistema Gateway & gentamicina & $25 \mu \mathrm{g} / \mathrm{ml}$ & - \\
\hline pDONR221 & Entrada no sistema Gateway & canamicina & $50 \mu \mathrm{g} / \mathrm{ml}$ & - \\
\hline pDEST17 & $\begin{array}{l}\text { Expressão em E. coli- tag de } \\
\text { His }\end{array}$ & ampicilina & $100 \mu \mathrm{g} / \mathrm{ml}$ & - \\
\hline pK7FWG2 & $\begin{array}{l}\text { Expressão em planta - tag de } \\
\text { GFP }\end{array}$ & $\begin{array}{l}\text { estreptomicina } \\
\text { espectinomicina }\end{array}$ & $\begin{array}{l}12,5 \mu \mathrm{g} / \mathrm{ml} \\
50 \mu \mathrm{g} / \mathrm{ml}\end{array}$ & $\begin{array}{l}300 \mu \mathrm{g} / \mathrm{ml} \\
100 \mu \mathrm{g} / \mathrm{ml}\end{array}$ \\
\hline pDEST22 & $\begin{array}{l}\text { Expressão em levedura - } \\
\text { domínio AD do GAL4 para } \\
\text { Y2H }\end{array}$ & ampicilina & $100 \mu \mathrm{g} / \mathrm{ml}$ & - \\
\hline pDEST32 & $\begin{array}{l}\text { Expressão em levedura - } \\
\text { domínio BD do GAL4 para } \\
\text { Y2H }\end{array}$ & gentamicina & $25 \mu \mathrm{g} / \mathrm{ml}$ & - \\
\hline pTFT1 & $\begin{array}{l}\text { Expressão em levedura - para } \\
\text { Y3H }\end{array}$ & ampicilina & $100 \mu \mathrm{g} / \mathrm{ml}$ & - \\
\hline pAbAi-GW & $\begin{array}{lll}\text { Inserção no genoma } & \text { de } \\
\text { leveduras } & (\mathrm{PJ} 69-4 \square)\end{array}$ & ampicilina & $100 \mu \mathrm{g} / \mathrm{ml}$ & - \\
\hline
\end{tabular}

A descrição completa dos vetores encontra-se no Anexo A. 
Resultados e Discussão 


\section{RESULTADOS E DISCUSSÕES}

\subsection{A PROTEÍNA GFP-NTCDKG;2 ESTÁ PRESENTE NO NUCLEOPLASMA E EM SPECKLES NUCLEARES NAS CÉLULAS DE N. BENTHAMIANA}

A localização subcelular de uma proteína é importante para elucidar e compreender a sua função na célula. A fim de realizar essas observações, as células foliares de N. benthamiana foram

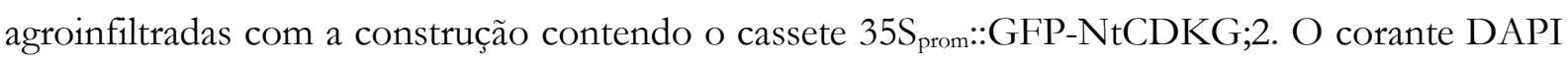
foi utilizado para observações dos núcleos. As imagens a-f (Figura 9), mostram células com um padrão de cromatina característico da intérfase. Nessas células, pode-se observar que a proteína NtCDKG;2 possui localização nucleoplasmática e em pontos que se assemelham a speckles nucleares (seta vermelha da imagem d). Das 100 células analisadas, 90 estavam com a cromatina pouco condensada (característico da intérfase). Em 95\% das células interfásicas, a proteína NtCDKG;2 apresentava-se concentrada em speckles. Além disso, em algumas células (como mostrado nas setas brancas das Figuras 9a e 9g), verificam-se pequenas concentrações da proteína em pontos situados na porção interna do nucléolo. Entretanto, cabe ressaltar que a proteína $\mathrm{NtCDKG;2} \mathrm{não} \mathrm{está} \mathrm{presente} \mathrm{no} \mathrm{nucléolo} \mathrm{de} \mathrm{forma} \mathrm{abundante.} \mathrm{Em} \mathrm{células} \mathrm{com} \mathrm{a} \mathrm{cromatina} \mathrm{mais}$ condensada (imagens g-1 da Figura 9), a localização da NtCDKG;2 deixa de ser difusa ou em estruturas que se assemelham a speckles. Interessantemente, nessas células, o sinal de GFP está ausente na região da cromatina quando a mesma está mais condensada, indicando que a célula possa estar em um estádio inicial de divisão celular. 


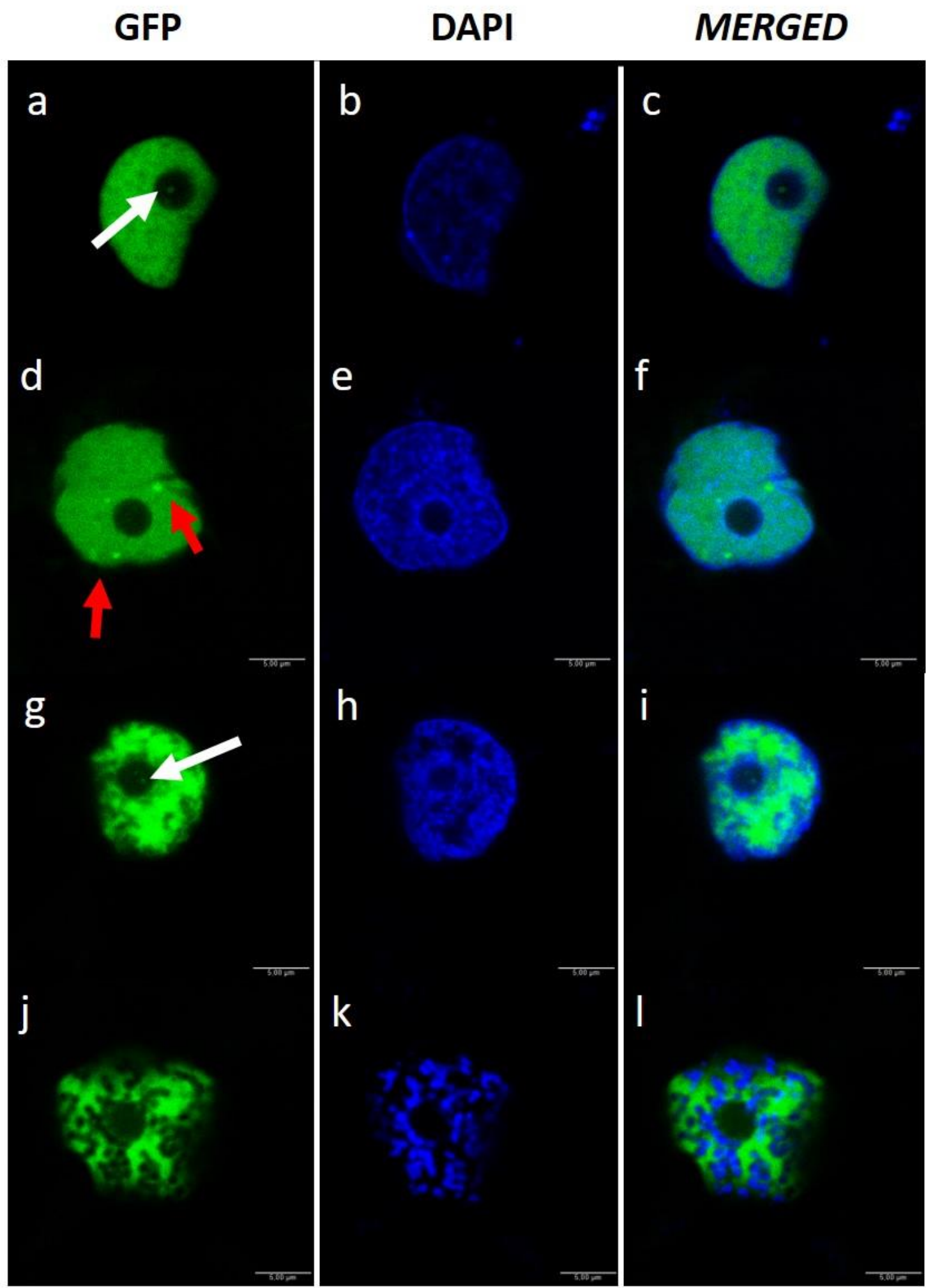

Figura 9: Fotomicrografias de núcleos de células de $N$. benthamiana transformadas de forma

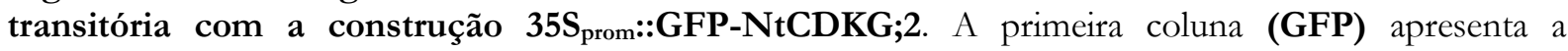
fluorescência emitida por GFP-NtCDKG;2. A segunda coluna (DAPI) mostra os núcleos corados por DAPI. A terceira coluna $(\boldsymbol{M E R} \boldsymbol{G E D})$ corresponde à sobreposição das colunas anteriores, mostrando que há localização da proteína NtCDKG;2 no núcleo celular. Seta vermelha: concentração de proteína em pontos semelhantes à splicing speckles. Setas brancas: concentração de proteína GFP-NtCDKG;2 em pontos nucleolares. Barra $=5 \mu \mathrm{m}$. As imagens foram obtidas utilizando-se o aparelho Leica TCS SP5 (Leica Microsystems - FMRP/USP). 
A localização da proteína NtCDKG;2 foi verificada no núcleo e em estruturas semelhantes a speckles em células de N. benthamiana (Ferreira, 2016). Porém, nesse estudo, haviam sido analisadas poucas células e, dentre elas, todas as células registradas estavam em intérfase ou com a cromatina pouco condensada. Visto que a localização das proteínas pode ser alterada durante o ciclo celular, eram necessárias mais observações da proteína GFP-NtCDKG;2 considerando os estádios de condensação da cromatina. Dessa forma, o presente estudo mostra que, durante a intérfase, a proteína NtCDKG;2 concentra-se em estruturas nucleolares pontuadas semelhantes à splicing speckles. Além disso, este estudo mostra, originalmente, que NtCDKG;2 não está concentrada na região da cromatina quando as células estão em início de prófase.

Com o objetivo de tentar identificar os speckles nucleares que contêm NtCDKG;2, as células foliares de N. benthamiana foram co-transformadas com a construção GFP-NtCDKG;2 e com proteínas marcadoras de speckles nucleares de $A$. thaliana. Como marcadoras, foram utilizadas as proteínas AtCypRS64 (RS domain-containing gyclophilin) e o fator de splicing AtSRp34a (Serine/Arginine$\boldsymbol{R}$ ich Protein Splicing Factor 34a). Todas as proteínas marcadoras estavam fusionadas em sua porção carboxi-terminal à proteína fluorescente RFP. Nas Figuras 10 e 11, a proteína GFP-NtCDKG;2 co-localiza com ambas as proteínas em speckles. 


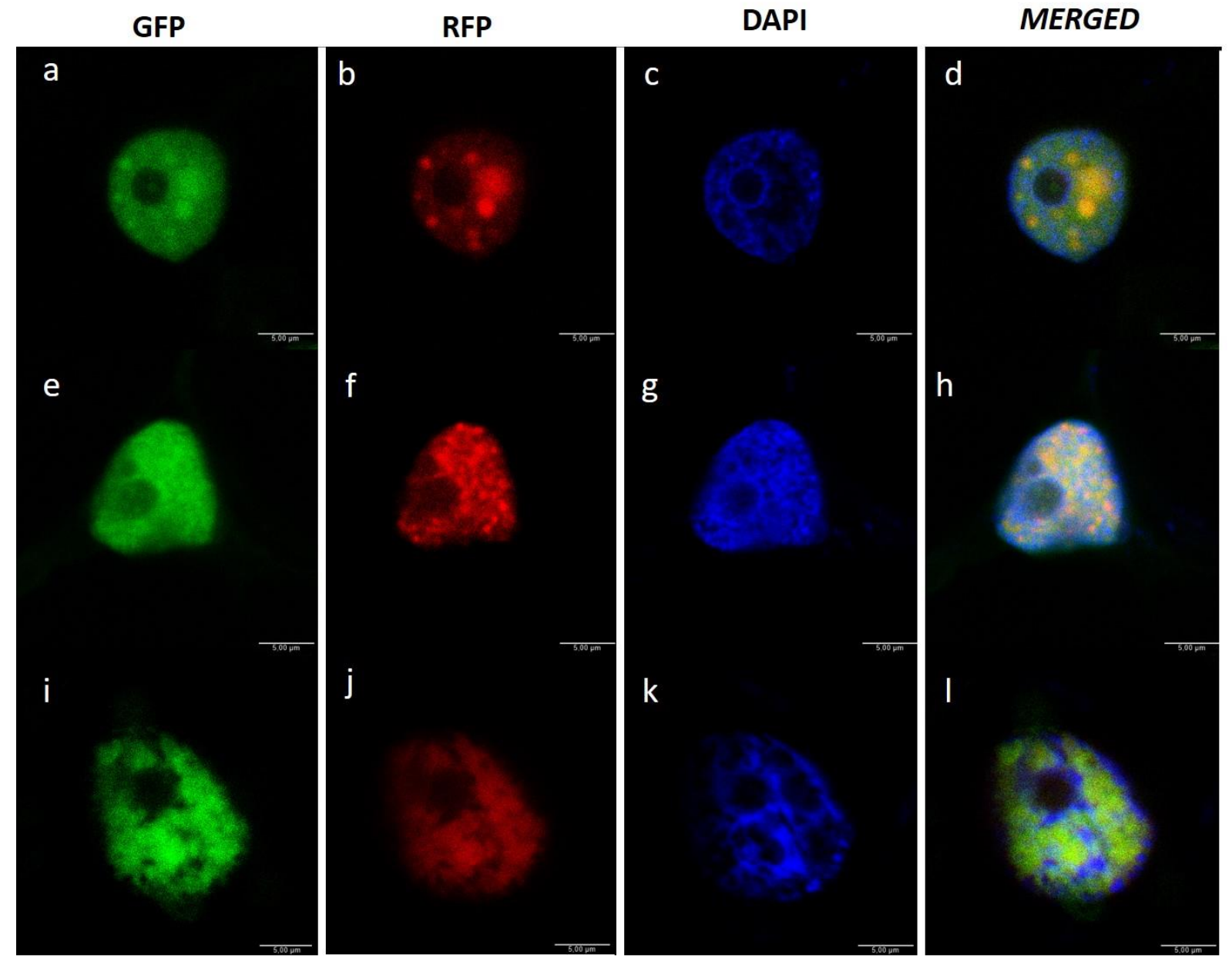

Figura 10: Fotomicrografias da co-expressão das proteínas NtCDKG;2 e AtCypRS64 em núcleos de células de $\boldsymbol{N}$. benthamiana. A primeira coluna (GFP) apresenta a fluorescência verde emitida por GFP$\mathrm{NtCDKG;2.} \mathrm{A} \mathrm{segunda} \mathrm{coluna} \mathrm{(RFP)} \mathrm{apresenta} \mathrm{a} \mathrm{fluorescência} \mathrm{vermelha} \mathrm{emitida} \mathrm{por} \mathrm{AtCypRS64-RFP.} \mathrm{A}$ terceira coluna (DAPI) mostra os núcleos corados por DAPI (azul) e, finalmente, a quarta coluna (MERGED) corresponde à sobreposição das colunas anteriores, mostrando que há co-localização das proteínas GFP-NtCDKG;2 e AtCypRS64-RFP no núcleo, indicando que a proteína NtCDKG;2 ocupa o mesmo local de speckles nucleares que contêm ciclofilina. Barra $=5 \mu \mathrm{m}$. As imagens foram obtidas utilizandose o aparelho Leica TCS SP5 (Leica Microsystems - FMRP/USP). 
GFP

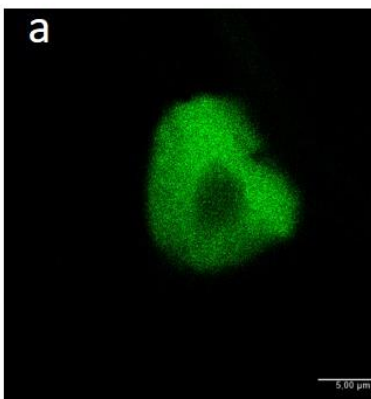

e

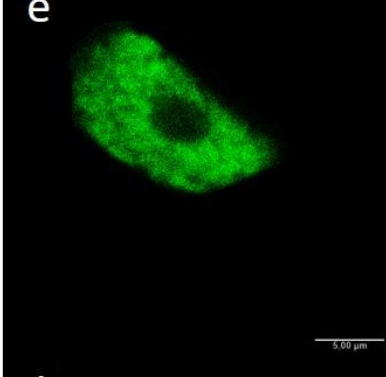

i

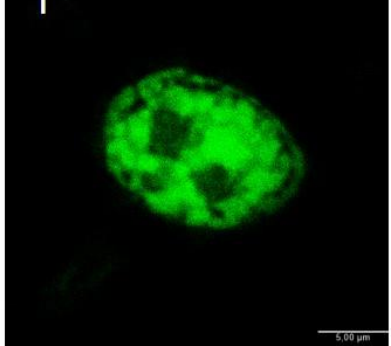

RFP

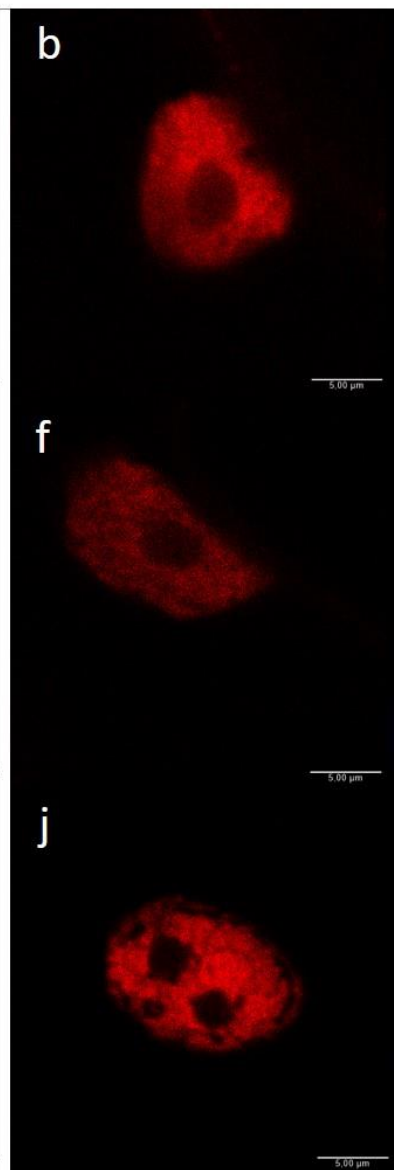

DAPI

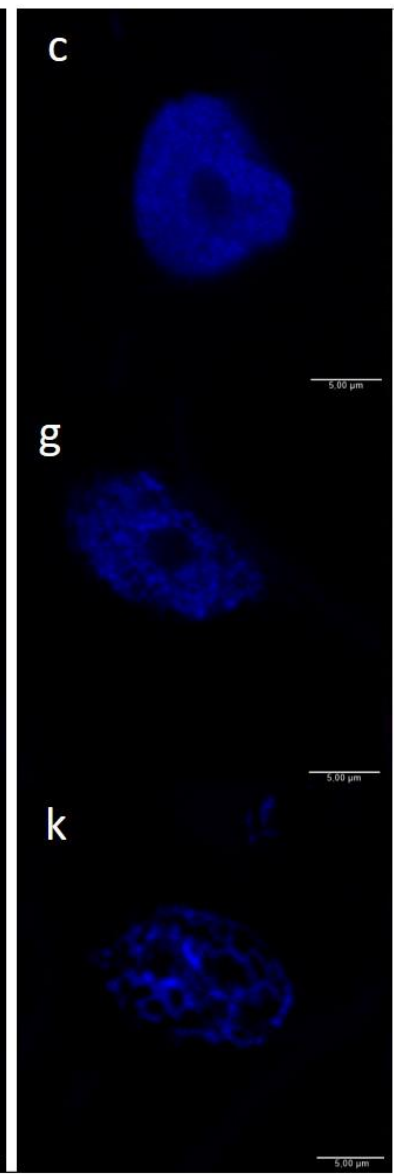

MERGED

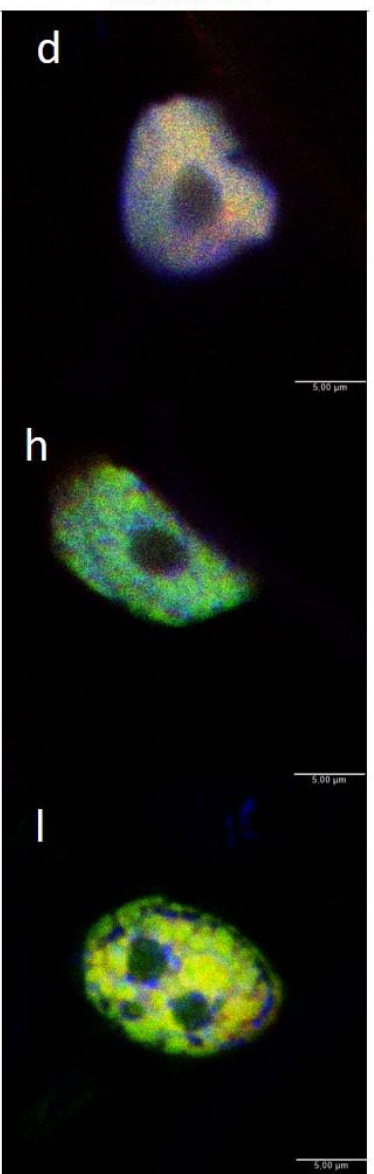

Figura 11: Fotomicrografias da co-expressão das proteínas NtCDKG;2 e AtSRp34 em núcleos de células de $\boldsymbol{N}$. benthamiana. A primeira coluna (GFP) apresenta a fluorescência verde emitida por GFPNtCDKG;2. A segunda coluna (RFP) apresenta a fluorescência vermelha emitida por AtSRp34-RFP. A terceira coluna (DAPI) mostra os núcleos corados por DAPI (azul) e, finalmente, a quarta coluna (MERGED) corresponde à sobreposição das colunas anteriores, mostrando que há co-localização das proteínas GFP-NtCDKG;2 e AtSRp34-RFP no núcleo, indicando que a proteína NtCDKG;2 ocupa o mesmo local de splicing speckles. Barra $=5 \mu \mathrm{m}$. As imagens foram obtidas utilizando-se o aparelho Leica TCS SP5 (Leica Microsystems - FMRP/USP).

Conforme mencionado anteriormente, a proteína GFP-NtCDKG;2 não está presente de forma proeminente no nucléolo. Para confirmar que NtCDKG;2 não se localiza nessa estrutura, foram feitos ensaios de co-localização utilizando a proteína marcadora de nucléolo Fibrilarina 1, de Arabidopsis, fusionada à RFP (AtFIB1-RFP). Analisando as imagens (Figura 12), verificou-se que a proteína NtCDKG;2 está presente no nucléolo somente na forma de pequenos sinais com fluorescência mais intensa (Setas brancas). Na literatura, não foram encontrados relatos sobre o que seriam estes locais no nucléolo. A CDK-like da ameba Physarum polycephalum é a única CDK reportada na literatura com localização nucleolar (LI; XING; HU, 2004). 


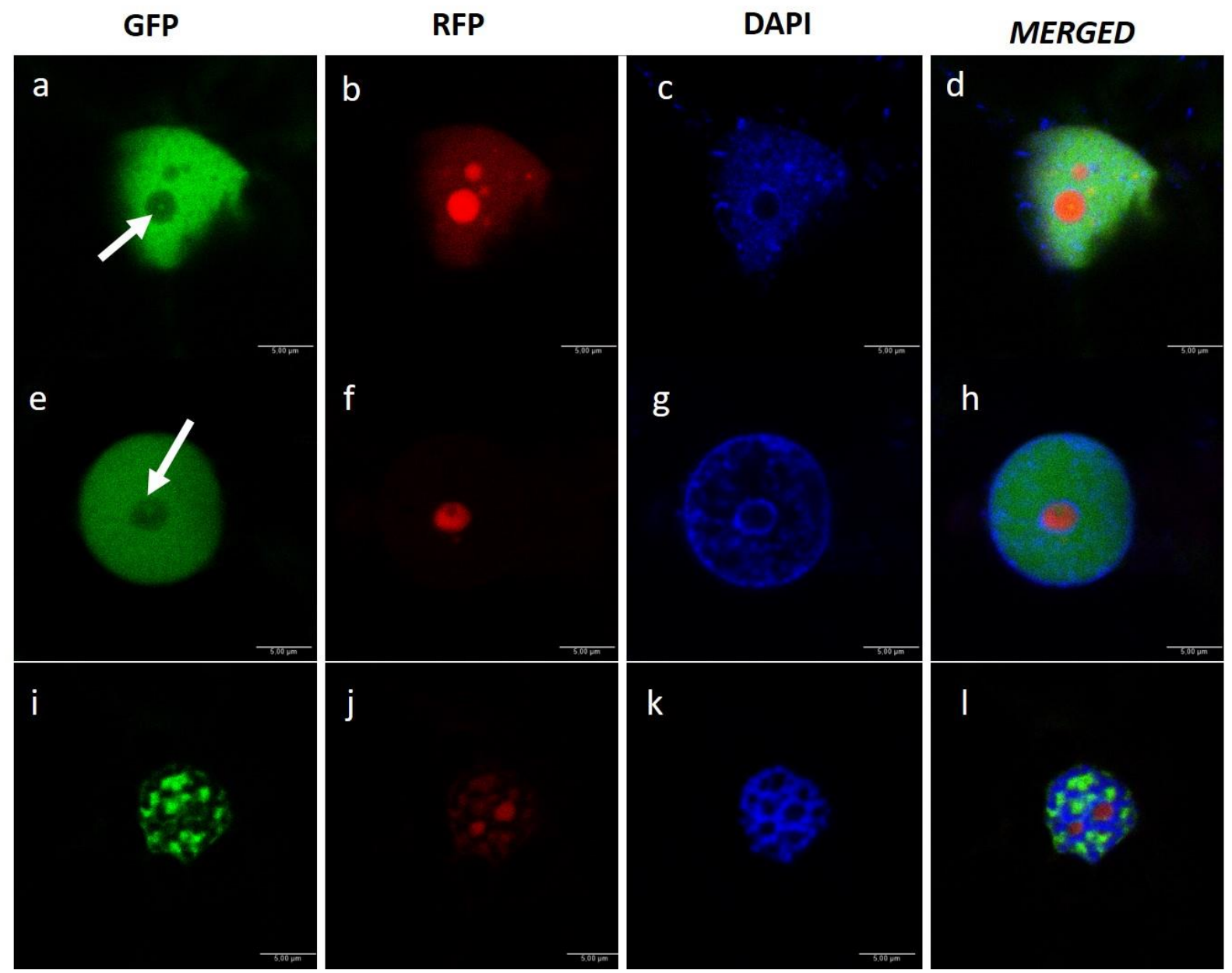

Figura 12: Fotomicrografias mostrando a co-expressão das proteínas NtCDKG;2 e AtFIB1 em núcleos de células de $\boldsymbol{N}$. benthamiana. A primeira coluna (GFP) apresenta a fluorescência verde emitida por GFP-NtCDKG;2. A segunda coluna (RFP) apresenta a fluorescência vermelha emitida por AtFIB1RFP. A terceira coluna (DAPI) mostra os núcleos corados por DAPI (azul) e, finalmente, a quarta coluna (MERGED) corresponde à sobreposição das colunas anteriores, mostrando que não há co-localização das proteínas GFP-NtCDKG;2 e AtFIB1-RFP no nucléolo. Setas brancas: concentração de proteína GFP$\mathrm{NtCDKG} ; 2$ em pontos nucleolares. Barra $=5 \mu \mathrm{m}$. As imagens foram obtidas utilizando-se o aparelho Leica TCS SP5 (Leica Microsystems - FMRP/USP).

Cabe aqui reportar que, em geral, as CDKs possuem localização nuclear e, em alguns casos, a localização, além de nuclear, é citoplasmática. (DOONAN e KITSIOS, 2009; KITSIOS et al., 2008; TANK e THAKER, 2011). Em humanos, a isoforma CDK11 ${ }^{\text {p110 }}$, homóloga de NtCDKG;2, se localiza no nucleoplasma em speckles nucleares, principalmente, quando está associada às suas parceiras CycL $\alpha$ e CycL $\beta$ (HU et al., 2003; LOYER et al., 1998, 2008; TREMBLEY et al., 2002). Em Arabidopsis, a proteína AtCDKG;1 se localiza em speckles nucleares.

De acordo com Lorkovic et al. (2004), a proteína CypRS64 é localizada de forma difusa no nucleoplasma ou em speckles nucleares. Entretanto, a proteína se muda sua localização quando coexpressa com parceiros de interação. Por exemplo, quando CypRS64 é co-expressa com seu parceiro SRp34a, a sua localização é em speckles nucleares (LORKOVIĆ et al., 2004). Além disso, 
o estado de fosforilação de proteínas SR pode alterar sua habilidade de interação proteína-proteína ou proteína-RNA com o complexo de splicing, sendo, portanto, uma importante forma de regulação dessas proteínas (LOPATO et al., 1999; MISTELI, 1999; XIAO e MANLEY, 1997). Convém salientar aqui que as proteínas AtCDKG;2 e AtSRp34a possuem interação predita em $A$. thaliana (VAN LEENE et al., 2010a). Além disso, a proteína NtSCI1, importante parceira de interação de NtCDKG;2, co-localiza com a proteína SRp34a em alguns momentos do ciclo celular (STRINI, 2014). Assim, considerando que o estado de fosforilação e a presença de parceiros de interação são fatores determinantes para a localização de proteínas RS, é plausível que a proteína NtCDKG;2 co-localize com as proteínas CypRS64 e SRp34a em speckles nucleares.

\subsection{NtCDKG;2 PODE ESTAR INTRINSECAMENTE RELACIONADA À REGIÃO ORGANIZADORA DA FORMAÇÃO DO FUSO ACROMÁTICO EM CULTURA DE CÉLULAS BY-2}

De acordo com os resultados apresentados, em N. benthamiana a proteína NtCDKG;2 se apresenta difusa no nucleoplasma, no nucleólo e também concentrada em speckles durante o período que antecede a mitose. Entretanto, em estádios iniciais de divisão celular, a proteína NtCDKG;2 não é observada em regiões de maior condensação da cromatina. A fim de elucidar a localização subcelular durante as fases do ciclo celular, células BY-2 de tabaco foram estavelmente transformadas para expressar a proteína NtCDKG;2 com fusão amino-terminal à GFP (GFPNtCDKG;2). As células transformadas foram coradas com Hoechst 33342 e analisadas em microscopia confocal. Foi possível observar todas as fases da divisão celular (Figura 13). 


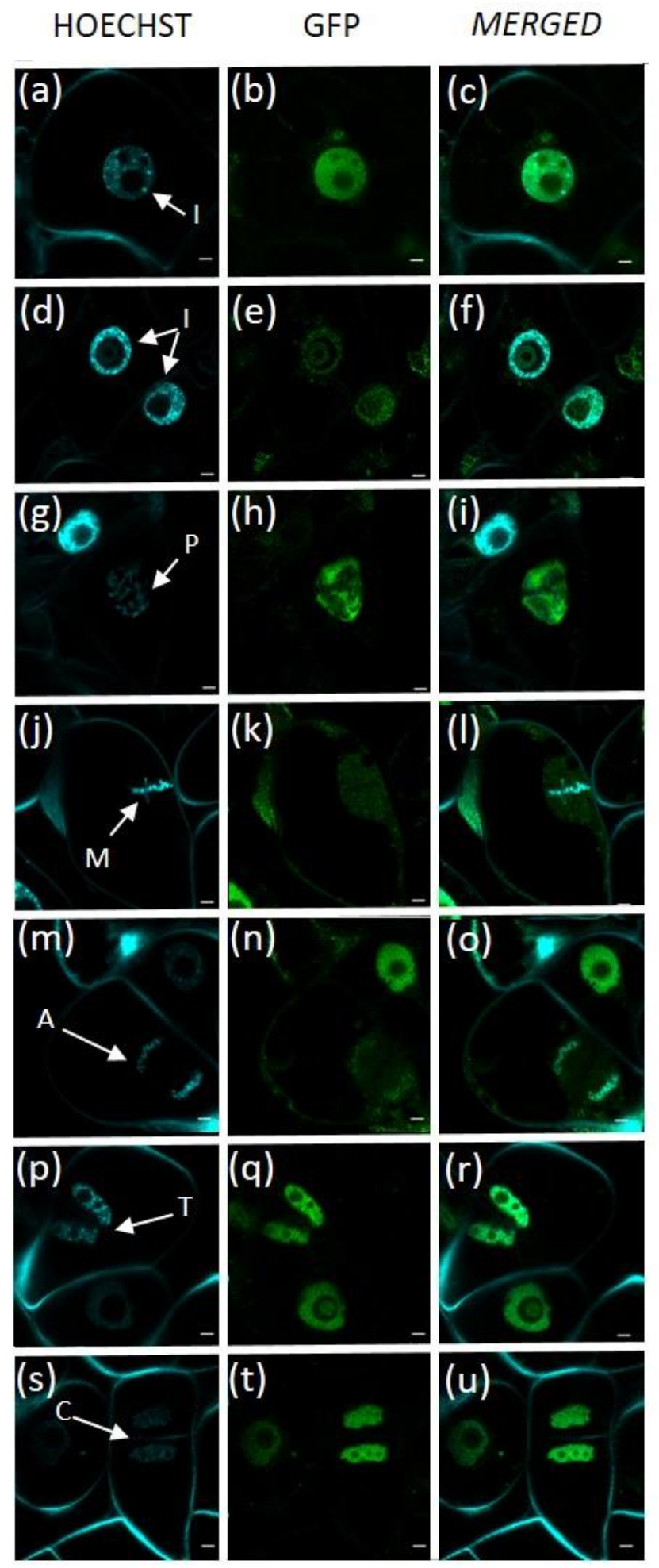

Figura 13: Fotomicrografia de células BY-2 de $N$. tabacum, transformadas de forma estável com a

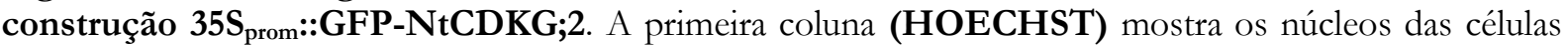
em diferentes fases do ciclo celular corados com Hoechst33342. A segunda coluna (GFP) apresenta a localização subcelular da proteína GFP-NtCDKG;2. A terceira coluna (MERGED) representa a sobreposição das duas primeiras colunas. As setas indicam os núcleos em intérfase $(\mathbf{I})$, Prometáfase $(\mathbf{P})$, Metáfase $(\mathbf{M})$, Anáfase $(\mathbf{A})$, Telófase $(\mathbf{T})$ e Citocinese $(\mathbf{C})$. Barra $=5 \mu \mathrm{m}$. As imagens foram obtidas utilizando-se o aparelho Leica TCS SP5 (Leica Microsystems - FMRP/USP). 
Durante a intérfase, a NtCDKG;2 se localiza no núcleo, mas também está no citoplasma, embora em menor quantidade (Figuras 13b e 13e). Em prometáfase e metáfase, a NtCDKG;2 é detectada na região adjacente aos cromossomos (Figuras 13h e 13k). Em especial, durante a metáfase, a proteína está difusa e é observada no citoplasma junto ao fuso acromático (Figura 13k). Ainda se observa que, nessa fase, a proteína alvo está completamente ausente no plano equatorial. Interessantemente, durante a anáfase, é evidente a associação da NtCDKG;2 junto aos conjuntos cromossômicos segregados (Figura 13n). Ao final da mitose (durante a telófase e a citocinese), a NtCDKG;2 é novamente encontrada juntamente à cromatina (Figuras 13q e 13t), devido à reorganização do núcleo.

Loyer et al. (1998) mostraram que, durante a intérfase e o início da prófase, a isoforma CDK11 ${ }^{\mathrm{p} 110}$ é encontrada no nucleoplasma e em speckles de células HeLa. Porém, utilizando um anticorpo que reconheça ambas as isoformas $\mathrm{CDK} 11^{\mathrm{p} 110}$ e $\mathrm{CDK} 11^{\mathrm{p} 58}$, foi possível detectar as proteínas na região centrossômica, com sinal de fluorescência aumentado em prometáfase e metáfase e diminuído ao final da divisão celular (PETRETTI et al., 2006). Em ensaios posteriores, os autores provaram, por meio de reconstituição fenotípica do mutante CDK11, que a isoforma p58 se associa ao centrossomo e está diretamente envolvida na formação do fuso mitótico. Também foi mostrado que as cromátides irmãs são mantidas unidas graças a CDK11 ${ }^{\mathrm{p} 58}$ (HU et al., 2007). Cabe ressaltar que, caso existam diferentes isoformas de NtCDKG;2, a construção GFP$\mathrm{NtCDKG;2} \mathrm{utilizada} \mathrm{em} \mathrm{nossos} \mathrm{estudos} \mathrm{apenas} \mathrm{permitiria} \mathrm{a} \mathrm{análise} \mathrm{da} \mathrm{localização} \mathrm{da} \mathrm{isoforma}$ maior.

Em células de vertebrados, a organização do fuso acromático depende de dois mecanismos: (i) cromossomos e (ii) centrossomos. Quando o envelope nuclear desorganiza, a compartimentalização nuclear é perdida. Nesse momento, há formação de um gradiente de RanGTP nas proximidades dos cromossomos e RanGDP próximo a face interna do plasmalema. Dessa forma a RanGTP atua como sinalizadora para organização do fuso mitótico adjacente aos cromossomos (CAUDRON, 2005; KALÁB et al., 2006). Uma das proteínas regulada pelo acúmulo de RanGTP é a proteína TPX2 (Targeting Protein for Xklp2). Durante a intérfase, a TPX2 é localizada no núcleo e é liberada pela RanGTP ativa durante a desorganização do envelope nuclear (KARSENTI, 2001). Ao ser liberada, TPX2 induz a nucleação de microtúbulos no cinetócoros na região centromérica dos cromossomos (TULU et al., 2006). Além disso, TPX2 localiza e ativa a Aurora A, uma quinase, que por sua vez fosforila a TPX2 (KUFER et al., 2002). As proteínas do tipo Aurora também ativam a nucleação dos microtubulos em centrossomos, participam da 
segregação cromossômica e da citocinese (BISCHOFF; PLOWMAN, 1999; DUCAT; ZHENG, 2004).

Em células de plantas vasculares, a formação do fuso acromático difere de outros eucariotos, devido ao fato das células vegetais não possuírem centríolos. Pouco se sabe sobre a formação do fuso mitótico nos vegetais superiores, no entanto, há evidências de que os microtúbulos se organizam em uma região próxima ao envoltório nuclear anterior à sua desorganização, um mecanismo que difere do que ocorre em células animais (VOS et al., 2008). Em Arabidopsis, foram identificadas proteínas homólogas à TPX2, designadas como TPX2-related (EVRARD et al., 2009; VOS et al., 2008). Nessa espécie, também foram identificadas 3 proteínas do tipo Aurora, denominadas AtAurora1, AtAurora2 e AtAurora3 (DEMIDOV et al., 2005; VAN DAMME et al., 2004). Foi demonstrado também que AtAurora1 fosforila uma proteína TPX2related que, por sua vez, ativa a AtAurora1 (TOMAŠTíKOVÁ et al., 2015).

Em plantas, as proteínas associadas à formação do fuso acromático estão dentro do núcleo. Quando ocorre a desorganização do envoltório nuclear, as proteínas responsáveis pela organização do fuso já estão posicionadas adjacentes aos cromossomos. Apesar de identificadas, em vegetais, algumas proteínas homólogas às proteínas de animais, a elucidação de como os eventos formadores do fuso acromático e quais as proteínas envolvidas em plantas ainda é um caminho em emergência. Devido ao padrão distinto de localização subcelular de NtCDKG;2 durante as diferentes fases do ciclo celular, o presente trabalho sugere que esta proteína possa estar intrinsecamente relacionada à região organizadora da formação do fuso acromático em vegetais superiores.

\subsection{OBTENÇÃO DA PROTEÍNA RECOMBINANTE HIS-NtCDKG;2 EM E. coli E PRODUÇÃO DE ANTICORPO POLICLONAL CONTRA ESSA PROTEÍNA}

Até o início deste trabalho, a proteína NtCDKG;2 tinha sido expressa utilizando caudas de HIS e GST em diferentes cepas de expressão de E. coli (Lubini, 2012). No entanto, todas as tentativas falharam em produzir a proteína de forma solúvel. Em todas as ocasiões, a proteína recombinante se agregava de forma insolúvel em corpos de inclusão. Para a solubilização dos corpos de inclusão, com manutenção da integridade proteica, a literatura recomenda utilizar uma molaridade de ureia entre 1 e 4M (PALMER; WINGFIELD, 2004; SINGH et al., 2015). 
A proteína NtCDKG;2 foi expressa em células BL21-CodonPlus (DE3)-RP de E. coli em fuso com uma cauda amino-terminal de Histidina (HIS-NtCDKG;2). A seguir, as células foram lisadas em um tampão contendo $2 \mathrm{M}$ de ureia. Após a lise, obtiveram-se as frações precipitada e solúvel (Figura 14A e 14B). A fração precipitada contém os corpos de inclusão. A seguir, a fração precipitada foi sonicada, com manutenção da baixa molaridade de ureia, por 6 ciclos de sonicação e centrifugação, gerando 6 frações solúveis. Estas amostras foram analisadas por eletroforese em gel de poliacrilamida, transferidas para a membrana (western blotting) e detectadas com o anticorpo contra a cauda de HIS. A Figura 14C apresenta marcação da proteína HIS-NtCDKG;2 nos sobrenadantes 5 e 6 . Essas frações foram purificadas por cromatografia de afinidade, utilizando uma resina carregada com Níquel, à qual a cauda de Histidina possui afinidade. A seguir, as frações eluídas foram analisadas por eletroforese em gel de poliacrilamida, transferidas para membrana e detectadas com anticorpo contra a cauda de HIS (Figura 14D).
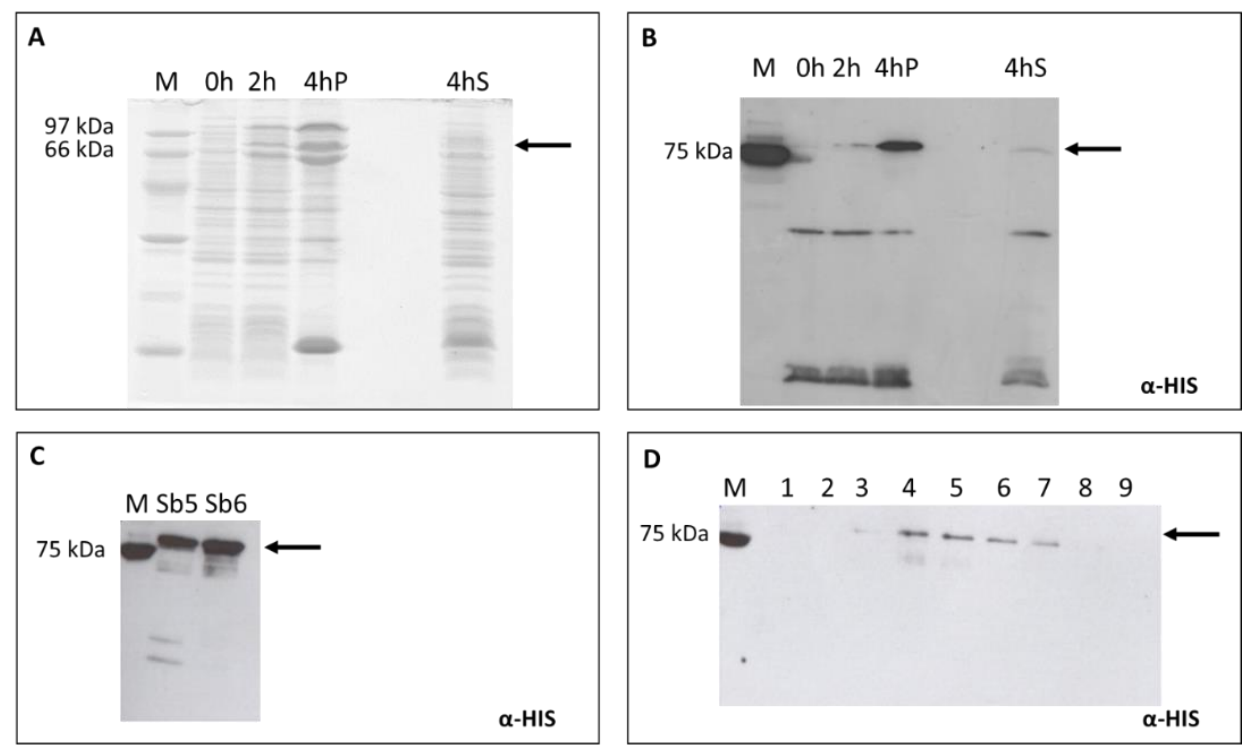

Figura 14: Expressão da proteína recombinante HIS-NtCDKG;2 em células de $E$. coli BL21(DE3) CodonPlus RP, seguida de solubilização de corpos de inclusão e isolamento por cromatografia de afinidade. Figura 14A: Fotografia do gel de poliacrilamida dos extratos proteicos da expressão heteróloga de HIS-NtCDKG;2 em E. coli à $28^{\circ} \mathrm{C}$ submetidos à SDS-PAGE. Figura 14B: Filme revelado após western blotting com reconhecimento pelo anticorpo $\alpha$-HIS para detecção da proteína recombinante HIS$\mathrm{NtCDKG;2} \mathrm{(} \mathrm{79} \mathrm{kDa;} \mathrm{seta} \mathrm{preta).} \mathrm{Figura} \mathrm{14C:} \mathrm{Filme} \mathrm{revelado} \mathrm{após} \mathrm{western} \mathrm{blotting} \mathrm{das} \mathrm{frações} \mathrm{solúveis}$ obtidas após repetições de sonicações seguidas por centrifugação. Figura 14D: Filme revelado após western blotting das amostras obtidas após cromatografia por afinidade. M: Marcador de peso molecular Precision Plus Protein ${ }^{\mathrm{TM}}$ Dual Color Standards (BIO-RAD); 0h: Suspensão celular adquirida imediatamente antes da indução; 2h: Lisado celular adquirido 2 horas após a indução com IPTG; 4hP: Fração insolúvel (precipitada) do lisado celular, adquirida 4 horas após a indução com IPTG; 4hS: Fração solúvel (sobrenadante) do lisado celular adquirida 4 horas após a indução com IPTG. Sb5: Fração solúvel obtida após 5 sonicações seguidas de centrifugação; Sb6: Fração solúvel obtida após 6 sonicações seguidas de centrifugação; 1 a 9: amostras das frações 1 a 9, respectivamente, eluídas após cromatografia. A proteína recombinante foi isolada com sucesso nas frações 4 a 7 . 
Após padronização do protocolo de expressão e recuperação de HIS-NtCDKG;2 em células de E. coli, amostras da proteína, extraídas do gel, foram enviadas para a empresa Proteimax (www.proteimaxnet.com.br), onde foram utilizadas para produção de um anticorpo policlonal em coelho. A obtenção do anticorpo capaz de reconhecer NtCDKG;2 constitui uma importante ferramenta para uma melhor caracterização dessa proteína, podendo auxiliar na elucidação dos mecanismos pelos quais ela atua em N. tabacum.

\subsection{A PROTEÍNA NtCDKG;2 PODE APRESENTAR DIFERENTES ISOFORMAS ASSIM COMO SUA HOMÓLOGA CDK11 DE HUMANOS \\ 3.4.1 IDENTIFICAÇÃO DE UM PUTATIVO SÍTIO IRES PARA TRADUÇÃO $C A P$ - INDEPENDENTE EM NtCDKG;2}

A produção de proteínas pode ser regulada de várias formas de acordo com as necessidades celulares. Uma das formas de regulação é através de modificações na maquinaria de tradução, o que inclui o reconhecimento de sítios de tradução independentes de cap (5'-terminal $7 \mathrm{mG}$ cap). Foram feitas análises na sequência de mRNA de NtCDKG;2 em busca de um putativo sítio interno

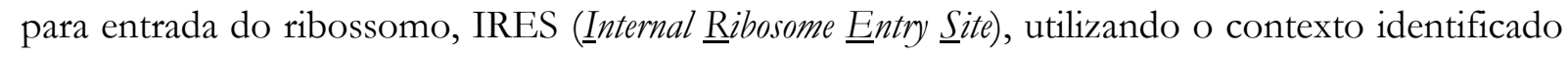
por Cornelis (2000). A Tabela 4 apresenta os resultados dessa análise. 
Tabela 4: Contexto de nucleotídeos dos 20 códons Met (AUG) em fase de leitura de NtCDKG;2.

\begin{tabular}{cccc}
\hline & Posição (AUG) $^{\mathbf{a}}$ & Contexto (CC [A/G]CCAUGG) $^{\mathbf{b}}$ & Id. Consenso $^{\mathbf{c}}$ \\
\hline 1 & 1 & - & \\
2 & 147 & ga c ga AUG a & 0.0 \\
3 & 168 & ga $G$ ag AUG a & 16.7 \\
4 & 171 & ag $A$ ug AUG a & 16.7 \\
5 & 348 & au $A$ ga AUG u & 16.7 \\
6 & 402 & au u Cu AUG a & 16.7 \\
7 & 813 & a $C$ u $C$ AUG $G$ & 66.7 \\
8 & 939 & ua $A$ a $C$ AUG c & 33.3 \\
9 & 1068 & uu $A$ aa AUG $G$ & 33.3 \\
10 & 1197 & uu u $C$ AUG $G$ & 33.3 \\
11 & 1203 & ug $G$ ug AUG $G$ & 33.3 \\
12 & 1212 & aa u aC AUG $G$ & 33.3 \\
13 & 1236 & $C g$ u ua AUG $G$ & 33.3 \\
14 & 1245 & ag $A$ Ca AUG a & 33.3 \\
15 & 1284 & gC c uu AUG c & 16.7 \\
16 & 1518 & uu $G C$ AUG u & 33.3 \\
17 & 1539 & gu $A C$ AUG $G$ & 50.0 \\
18 & 1734 & $C C$ u uC AUG $G$ & 66.7 \\
19 & 1875 & aa u uC AUG c & 16.7 \\
& & & \\
\hline
\end{tabular}

a: Posição da Adenina do códon na sequência codificadora;

b : 5 nucleotídeos upstream e 1 nucleotídeo downstream ao códon AUG na sequência, em itálico estão os nucleotídeos idênticos à sequência consenso de IRES;

c: Porcentagem equivalente à identidade da sequência envolvendo os códons AUG em relação à sequência consenso de IRES. Em cinza, estão assinaladas as sequências com maior porcentagem de consenso com o contexto. Baseado em Cornelis et al., 2000.

A análise da Tabela 4 permite observar que o mRNA de $N t C D K G ; 2$ possui 19 códons AUG em fase de leitura com o códon inicial de tradução. Foram identificados 2 sítios passíveis de IRES com 66,7 \% de similaridade entre as sequências de mRNA de NtCDKG;2 e CDK11. Dentre esses sítios, caso o sítio ACUCCAUGG fosse utilizado como IRES, geraria uma proteína de, aproximadamente, 45,9 kDa. O sítio IRES identificado por Cornelis (2000) é responsável pela tradução cap-independente da isoforma CDK11 ${ }^{\mathrm{p} 58}$. Esse sítio compreende uma sequência AUG que está na mesma fase de leitura que a AUG inicial utilizada para tradução da isoforma CDK11 ${ }^{\text {p110 }}$.

Complementarmente à análise com base no sítio IRES da CDK11, fez-se uma análise em um banco de dados de elementos IRES disponibilizado por Mokrejs e colaboradores (2009). Esse banco de dados considera a sequência contexto do elemento, a estrutura do mRNA, sua posição em relação às sequências adjacentes, além de outros aspectos relevantes para o reconhecimento desse sítio pela maquinaria de tradução. A análise nesse banco de dados também identificou um elemento IRES na mesma região do elemento identificado utilizando o contexto de Cornelis (2000) $[($ Score $=26$ bits, E-value $=7.2$; Identidade $=14 / 14(100 \%)]$ o que corrobora os resultados apresentados neste trabalho. 
Tem sido proposto que a tradução cap-independente mediada por IRES sirva para fornecer à célula um elevado controle espacial e temporal, necessário para adequar uma resposta ao estresse (GRABER; HOLCIK, 2007). Além disso, os elementos IRES são fundamentais para dirigir a tradução em determinados estádios do ciclo celular em que algumas proteínas ainda são necessárias e a tradução cap-dependente está comprometida. É o caso da tradução mediada por IRES da isoforma $\mathrm{CDK} 11^{\mathrm{p} 58}$, a qual é necessária durante a mitose, período em que não ocorre tradução da isoforma $\mathrm{CDK}^{\mathrm{p} 110}$ (CORNELIS, 2000; FITZGERALD; SEMLER, 2009).

\subsubsection{A PROTEÍNA NtCDKG;2 PODE APRESENTAR ISOFORMAS MENORES EM FOLHAS DE N. tabacum}

Para detecção da proteína NtCDKG;2, foram analisados extratos proteicos de folhas de $\mathrm{N}$. tabacum com superexpressão de NtCDKG;2 e folhas selvagens (SR1), utilizando o anticorpo $\alpha$ NtCDKG;2. Observou-se que a proteína identificada pelo anticorpo não possuía o tamanho esperado da proteína completa $(\sim 76 \mathrm{kDa})$. No entanto, podem ser vistas duas bandas de, aproximadamente, 33 e 45,9 kDa (Figura 15, setas pontilhadas). Uma amostra de extrato da proteína recombinante HIS-NtCDKG;2 produzida em E. coli foi utilizada como controle positivo de detecção do anticorpo. Nessa amostra, foi detectada a banda na altura esperada para HISNtCDKG;2 ( 79 kDa; Figura 15, seta contínua), além de outras bandas maiores. Devido ao anticorpo ter sido produzido contra uma proteína recombinante que foi expressa no sistema heterólogo de E. coli., acredita-se que as bandas maiores identificadas nesse extrato, sejam proteínas que foram purificadas juntamente com HIS-NtCDKG;2 durante o preparo da amostra contra a qual foi feito o anticorpo.

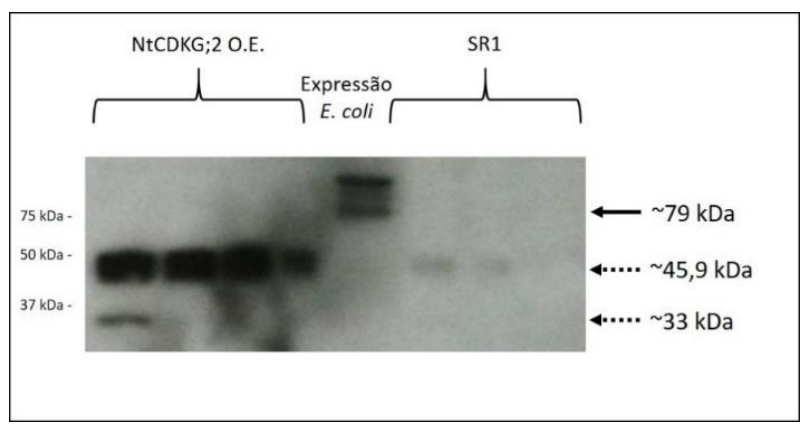

Figura 15: Revelação de Western Blotting para detecção da proteína NtCDKG;2 com anticorpo $\alpha$ NtCDKG;2. Foram utilizados extratos totais de folhas de planta de superexpressão (NtCDKG;2 O.E.) e de plantas selvagens (SR1). Além disso, foi aplicada uma amostra da proteína recombinante HIS$\mathrm{NtCDKG;2}$ produzida em E. coli e purificada por cromatografia de afinidade. O tamanho esperado das proteínas HIS-NtCDKG;2 e NtCDKG;2 é, aproximadamente, $79 \mathrm{kDa}$ e $76 \mathrm{kDa}$, respectivamente. No extrato de E. coli, é possível verificar a HIS-NtCDKG;2 com o tamanho esperado (seta contínua). Já nos extratos de folha, observam-se duas bandas com tamanho menor do que o esperado (setas pontilhadas). 
Devido ao reconhecimento de duas bandas de tamanho menor do que o esperado para a proteína NtCDKG;2, há indicação de que as proteínas identificadas em folhas possam corresponder à isoformas de menor peso molecular. Entretanto, esses resultados não permitem dizer de que maneira essas isoformas menores são produzidas. As isoformas podem ser produzidas devido à tradução cap-independente utilizando o sítio IRES identificado no mRNA de NtCDKG;2 ou mesmo por clivagens pós-traducionais.

\subsubsection{A PROTEÍNA HIS-NtCDKG;2 PRODUZIDA EM E. coli PODE SER CLIVADA APÓS INCUBAÇÃO COM EXTRATO DE FOLHAS DE N. tabacum}

Para averiguar se uma ou ambas proteínas de menor peso molecular identificadas no experimento anterior poderiam corresponder à NtCDKG;2 originada por clivagem da proteína, a proteína HIS-NtCDKG;2 ( 79 kDa) produzida em E. coli foi incubada com extrato de folhas selvagens (SR1) de N. tabacum (Figura 16). Foram feitas incubações com diferentes tempos: 1,5 h; 5,5 h; 24 h. Como um controle negativo para a clivagem, a proteína recombinante também foi incubada somente com o tampão utilizado para a extração das proteínas foliares por $24 \mathrm{~h}$.
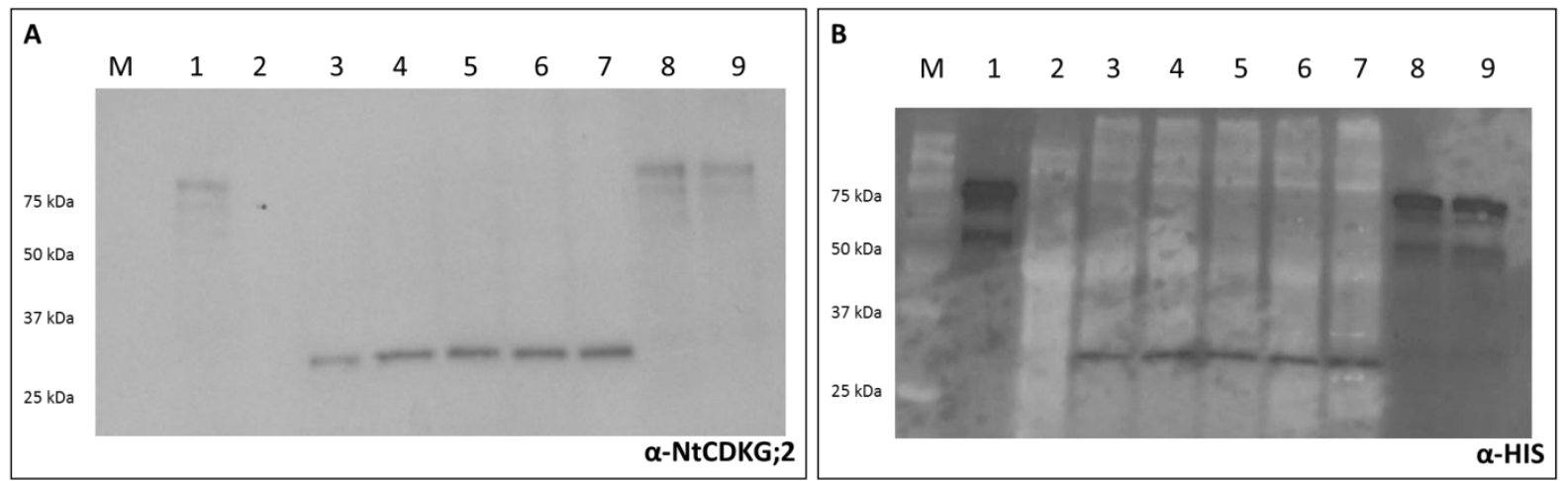

Figura 16: Teste para verificar clivagem de HIS-NtCDKG;2 através de incubação da proteína produzida em $E$. coli com extrato de folhas de $N$. tabacum. Figura 16A: Identificação de HISNtCDKG;2 por Western Blotting com anticorpo $\alpha$-NtCDKG;2; Figura 16B: Identificação de HIS$\mathrm{NtCDKG;2}$ por Western Blotting com anticorpo $\alpha$-HIS. M: Marcador de peso molecular Precision Plus Protein $^{\mathrm{TM}}$ Dual Color Standards (BIO-RAD); 1: HIS-NtCDKG;2 produzida em E. coli e purificada por cromatografia de afinidade; 2: Extrato de folhas de N. tabacum; 3: 1,5 horas após a incubação de HISNtCDKG;2 com extrato de folhas à T. A.; 4: 5,5 horas após incubação de HIS-NtCDKG;2 com extrato de folhas à $4{ }^{\circ} \mathrm{C} ; 5: 5,5$ horas após incubação de HIS-NtCDKG;2 com extrato de folhas à T.A.; 6: 24 horas após incubação de HIS-NtCDKG;2 com extrato de folhas à $4{ }^{\circ} \mathrm{C} ; 7: 24$ horas após incubação de HISNtCDKG;2 com extrato de folhas à T.A.; 8: 24 horas após incubação de HIS-NtCDKG;2 com tampão de extração à $4{ }^{\circ} \mathrm{C}$ (controle negativo à $4{ }^{\circ} \mathrm{C}$ ); 9: 24 horas após incubação de HIS-NtCDKG;2 com tampão de extração à T.A. (controle negativo à T.A.). O tamanho esperado da proteína HIS-NtCDKG;2 é, aproximadamente, $79 \mathrm{kDa}$. No extrato de E. coli, é possível verificar a HIS-NtCDKG;2 com o tamanho esperado. Já no extrato de E. coli que foi incubado com folhas de SR1, por diferentes tempos, observa-se uma banda com tamanho menor do que o esperado. 
Utilizando ambos anticorpos $\alpha$-NtCDKG;2 e $\alpha$-HIS houve detecção de uma banda $\sim 79$ $\mathrm{kDa}$ nas frações de HIS-NtCDKG;2 incubadas somente com o tampão de extração (controle negativo de clivagem). Essa banda corresponde à proteína HIS-NtCDKG;2. No entanto, é preciso destacar que uma banda de menor peso molecular $(\sim 33 \mathrm{kDa})$ é gerada somente nas amostras incubadas com extrato de folhas. Além disso, é preciso salientar que a proteína de menor tamanho detectada está fusionada à cauda de Histidina, já que também é reconhecida utilizando o anticorpo $\alpha$-HIS. Assim, a fração detectada em ambas imagens da Figura 16 corresponde ao fragmento amino-terminal de NtCDKG;2.

Assim, os resultados aqui apresentados sugerem que a banda de menor peso molecular $(\sim 33 \mathrm{kDa})$ corresponde a uma isoforma dessa proteína gerada em eventos de clivagem proteolítica de NtCDKG;2. Além disso, acredita-se que a banda de $\sim 45,9 \mathrm{kDa}$ previamente identificada em extrato de folhas (Figura 15) possa ser outra isoforma de NtCDKG;2 que é gerada em processos pré-traducionais. É importante salientar que, até o momento, não há estudos indicando que as proteínas homólogas à NtCDKG;2 sejam clivadas em planta. A existência de uma putativa isoforma de NtCDKG;2, gerada por clivagem da proteína, aponta para papéis ainda não estabelecidos do envolvimento das CDKs de plantas, especialmente as CDKs do grupo G.

A proteína com maior correspondência à NtCDKG;2 em bumanos é a CDK11 (FERREIRA, 2016), para a qual foram identificadas 4 isoformas. São elas: CDK11 ${ }^{\mathrm{p} 110}$, CDK11 ${ }^{\mathrm{P} 58}$, $\mathrm{CDK}^{\mathrm{p} 60}$ e CDK11 ${ }^{\mathrm{p} 46}$ (TREMBLEY et al., 2002). A isoforma CDK11 ${ }^{\mathrm{p} 110}$ contém a sequência completa da proteína e possui importância descrita na regulação da transcrição e splicing (TREMBLEY et al., 2004). A isoforma CDK11 ${ }^{\mathrm{p} 58}$ é produzida por tradução sem dependência de cap (cap-independente) através de um elemento IRES do mRNA do gene CDK11. Esse elemento possibilita a tradução da isoforma $C D K 11^{\mathrm{p} 58}$ durante $\mathrm{G} 2 / \mathrm{M}$, com importância na maturação do centrossomo e formação correta do fuso mitótico (CORNELIS et al, 2000; PETRETTI et al., 2006; TREMBLEY et al., 2002, 2004).

Estudos mostram que os processos traducionais das células diminuem significativamente quando a célula entra em apoptose (JEFFREY et al., 2002; MORLEY; MCKENDRICK; BUSHELL, 1998). A fosforilação da isoforma CDK11 ${ }^{\mathrm{p} 110}$ durante a apoptose promove o aumento do processamento dessa CDK por clivagem proteolítica mediada por caspases, o que gera as isoformas CDK11 ${ }^{\mathrm{p} 46}$ e CDK11 ${ }^{\mathrm{p} 60}$ (TANG; GURURAJAN; KIDD, 1998; ARIZA et al., 1999; BEYAERT et al., 1997; LAHTI et al., 1995). A isoforma CDK11 ${ }^{\mathrm{p} 46}$ corresponde ao domínio quinase livre (carboxi-terminal) da CDK11 (MIKOLAJCZYK; NELSON, 2004; TREMBLEY et al., 2004). Durante a apoptose, também é relatado que a isoforma CDK11 ${ }^{\mathrm{p} 46}$ fosforila o fator de 
tradução eIF3f, aumentando a sua associação com outras subunidades do complexo eIF3 e desencadeando o processo de apoptose (SHI et al., 2003; SHI; HERSHEY; NELSON, 2009). É relatado que a isoforma complementar $\mathrm{CDK}^{\mathrm{p} 60}$ seja realocada para a mitocôndria mediante um processo que acarreta a liberação do citocromo $c$, uma pequena proteína da membrana mitocondrial (FENG et al., 2005a). Indiretamente, essa liberação do citocromo $c$ também promove a atividade da caspase-3, o que retroalimenta a cascata apoptótica (FENG et al., 2005a).

Analisando estudos prévios e os resultados aqui apresentados, é preciso destacar três fatos: Em primeiro lugar, a proteína NtCDKG;2 identificada por ensaios de pull-down como parceira de interação de NtSCI1 possui $\sim 80$ kDa (STRINI, 2014), o que corresponderia, portanto, à putativa isoforma maior. Em segundo lugar, devido a NtSCI1 possuir expressão preferencial em estigmas e estiletes (DEPAOLI et al., 2011), no referido ensaio de pull-down, foram utilizados extratos de proteínas de estigmas e estiletes. Em terceiro lugar, convém lembrar que a isoforma homóloga em humanos, CDK11 $\mathrm{p}^{110}$, necessita estar fosforilada para que ocorra a clivagem (TANG; GURURAJAN; KIDD, 1998). Assim, sugere-se que NtCDKG;2 possui três isoformas: uma isoforma completa $(\sim 76 \mathrm{kDa})$, uma isoforma originada após fosforilação e clivagem da isoforma completa $(\sim 33 \mathrm{kDa})$ e uma isoforma originada em eventos pós-transcricionais $(\sim 45,9 \mathrm{kDa})$. Propõem-se que a proteína NtCDKG;2 seja fosforilada e clivada em folhas. Adicionalmente, sugere-se que a isoforma gerada após clivagem atue em processos regulatórios independentes da atuação de NtSCI1. Por final, acredita-se que NtSCI1 interaja com a isoforma completa de $\mathrm{NtCDKG;2.}$

\subsection{ANÁLISES IN SILICO DA PROTEÍNA NtCDKG;2 APONTAM DIVERSOS MOTIVOS PARA INTERAÇÃO COM OUTRAS PROTEÍNAS}

A função de uma proteína nas células depende, basicamente, de suas redes de interação. Por sua vez, as possíveis interações dependem da estrutura terciária das proteínas envolvidas. A proteína NtCDKG;2 é composta por 669 aminoácidos distribuídos em uma porção amino-terminal com 5 motivos RS, um domínio catalítico presente em quinases do tipo serina/treonina (STK_c) e uma curta porção carboxi-terminal. Em busca de sítios putativos para interação com outras proteínas, foram feitas análises in silico da sequência proteica de NtCDKG;2 utilizado o servidor ELM (E ukaryotic Linear Motif; DINKEL et al., 2016; PUNTERVOLL et al., 2003). Para identificar sinais de localização nuclear, utilizou-se WoLF PSORT II (http://www.genscript.com/wolf- 
psort.html). Dentre os elementos que foram identificados no presente estudo e considerados mais interessantes para o nosso trabalho encontram-se: elementos para ligação com ciclinas, inibidores de CDK/ciclina, F-Box, 14-3-3, BRCA1, além de motivos para fosforilação por CDKs e desfosforilação por fosfatases (Tabela 5).

Tabela 5: Elementos identificados na sequência proteica de NtCDKG;2.

\begin{tabular}{|llll|}
\hline Elemento & Sequência de ligação & Posição & Score \\
\hline \hline DEG_SCF_FBW7 $^{a}$ & (I)LGTPNET & 539546 & $7.138 \mathrm{e} 04$ \\
& (IS)LTPPVE & $164-171$ & $3.882 \mathrm{e} 04$ \\
DOC_CKS1_1 $^{b}$ & LGTPNE & $540-545$ & $1.991 \mathrm{e} 03$ \\
DOC_CYCLIN_1 $^{c}$ & KSLTP & $230-234$ & $5.324 \mathrm{e} 03$ \\
& KALM & $410-413$ & \\
& KCLML & $426-430$ & \\
& KLLTY & $593-597$ & \\
DOC_PP1_RVXF_1 $^{d}$ & GVKVNFV & 556562 & $8.301 \mathrm{e} 04$ \\
LIG_14-3-3_CanoR_1 $^{e}$ & RWVTDVDDSP & $195-204$ & $4.477 \mathrm{e} 03$ \\
& (R)RKSLT & $228-233$ & \\
& RAQSSESDDHI & $243-253$ & \\
& RSSSRDSY & $254-261$ & \\
& RFTQSEVKCLM & $419-429$ & \\
& RITAEAAL & $602-609$ & \\
LIG_BRCT_BRCA1_1 $^{f}$ & KSKEF & $621-625$ & $1.912 \mathrm{e} 03$ \\
MOD_CDK_1 $^{g}$ & QYGSPLK & $472-478$ & $1.929 \mathrm{e} 03$ \\
\hline
\end{tabular}

${ }^{a}$ Elemento para interação com a F-Box FBW7 F (F-box and WD repeat domain-containing 7) do complexo SCF (Skp1_Cullin-Fbox). A ubiquitinação resultante é dependente de fosforilação.

${ }^{b}$ Elemento dependente de fosforilação para ligação com a proteína Cks1 (Cyclin-dependent kinases regulatory subunit 1). Essa ligação medeia o encaixe de CDK-ciclina a substratos e reguladores.

c Elemento para interação com ciclina e com inibidores do complexo CDK/ciclina.

${ }^{d}$ Elemento para interação com PP1c (Protein phosphatase 1 catalytic subunit) para desfosforilação.

• Elemento para interação com proteínas 14-3-3.

$f$ Elemento para ligação ao domínio carboxi-terminal da proteína BRCA1 (Breast Cancer 1).

$g$ Elemento (substrato) para fosforilação por outra CDK.

Conforme a tabela anterior, a proteína NtCDKG;2 possui dois putativos domínios para ligação com proteínas do tipo F-Box e um domínio para ligação com Cks1(CDK subunit 1). Muitas proteínas F-Box até então caracterizadas estão envolvidas em processos de degradação proteica através da via ubiquitina-proteassoma (KIPREOS; PAGANO, 2000). Por vezes, as proteínas Fbox necessitam que seu alvo esteja fosforilado para então serem capazes de reconhece-lo (DESHAIES, 1999). Por exemplo, em H. sapiens, o inibidor de CDK p27Kip1 necessita ser fosforilado pelo complexo CDK2/Ciclina E para, então, ser reconhecido e levado à degradação pela F-Box SKP2 (CARRANO et al., 1999; MÜLLER et al., 1997; SHEAFF; GROUDINE; ROBERTS, 1997). O reconhecimento da fosforilação do inibidor de CDK p27Kip1 pela F-box SKP2 é mediado pela proteína acessória Cks1 (SPRUCK et al., 2001). Assim como SKP2 e outras 
proteínas F-Box, a proteína FBW7, cujo elemento foi encontrado em NtCDKG;2, também depende da fosforilação de seus substratos para conseguir se ligar a eles e, por sua vez, promover sua degradação. Dentre os alvos dessa F-Box, encontram-se vários proto-oncogenes como MYC e ciclina E. A FBW7 é considerada um supressor tumoral, pois sua perda de função ocasiona tumorigênese e instabilidade cromossômica (WELCKER; CLURMAN, 2008).

Além disso, alguma F-Box precisam ser fosforiladas para estarem ativas. Por exemplo, em H. sapiens, foi identificado que a fosforilação da F-box FBXO28 pela CDK1/2 causa sua ativação. A fosforilação de FBXO28, por sua vez, permite marcar o fator de transcrição e oncoproteína MYC para ubiquitinação não proteolítica. De tal modo, a fosforilação de F-box, dependente de CDK1/2, acarreta aumento dos processos transcricionais, proliferação celular e tumorigênese dirigidos pela oncoproteína (CEPEDA et al., 2013).

Com base nas análises apresentadas, sugere-se que a interação da NtCDKG;2 com uma FBox ocorra devido a três possibilidades: (i) a F-Box pode poli-ubiquitinar a proteína NtCDKG;2, ocasionando sua degradação; (ii) a proteína NtCDKG;2 fosforila a F-Box; e finalmente (iii) $\mathrm{NtCDKG;2} \mathrm{pode} \mathrm{atuar} \mathrm{em} \mathrm{um} \mathrm{complexo} \mathrm{que} \mathrm{envolve} \mathrm{as} \mathrm{proteínas} \mathrm{F-Box} \mathrm{e} \mathrm{Cks1.} \mathrm{Na} \mathrm{última}$ hipótese, NtCDKG;2 fosforila o alvo a ser degradado. Dessa maneira, a proteína F-Box seria capaz de reconhecer o alvo através do auxílio da proteína Cks1, para a qual também foi encontrado elemento de interação em NtCDKG;2.

Adicionalmente, foi encontrado um elemento para ligação à proteína BRCA1 (마east $\underline{\text { Cancer }}$ 1). Em humanos, a proteína BRCA1 é um importante supressor tumoral, necessário para reparo de quebra em dupla-fita de DNA (ALLI; FORD, 2015; SILVER; LIVINGSTON, 2012; ZHANG; POWELL, 2005). Estudos mostram que as plantas possuem um homólogo para o gene de humano. Em $A$. thaliana, o gene $A t B R C A 1$ é expresso em todos tecidos da planta, mas seus níveis mais altos são encontrados em botões florais e em culturas de células em fase de crescimento exponencial (LAFARGE; MONTANÉ, 2003). A proteína BRCA1 de humanos é localizada próxima aos centrossomos (SANKARAN et al., 2007). Recentemente, foi identificado o envolvimento dessa proteína na regulação de nucleação dos microtúbulos, através da ubiquitinação de tubulina $\gamma$ (YU et al., 2008). Essa proteína é regulada pós-traducionalmente através da fosforilação pela Aurora A (SANKARAN et al., 2007). Como foi encontrado um sítio para ligação com BRCA1 na proteína NtCDKG;2, sugere-se que essa CDK cause a fosforilação de BRCA1. Novamente, a hipótese do envolvimento de NtCDKG;2 com a organização do fuso acromático é reforçada.

Adicionalmente, a Tabela 5 também aponta a identificação de um sítio para fosforilação da $\mathrm{NtCDKG;2}$ por outra CDK e de quatro sítios para interação com proteínas do tipo ciclina e 
inibidores do complexo CDK/ciclina. As interações de NtCDKG;2 com uma CDK, no caso, a NtCDKF;1, e com o inibidor NtSCI1 serão mostradas mais adiante neste trabalho (itens 3.7 e 3.8, respectivamente). A interação com uma ciclina (Ciclina L1) também já foi identificada e apresentada por Ferreira (2016). Adicionalmente, foram identificados seis sítios para interação com proteínas do tipo 14-3-3 e um sítio para interação com fosfatase. As interações com proteínas 14-3-3 e fosfatase foram identificadas neste trabalho e serão abordadas mais adiante (itens 3.6.3 e 3.8). Todas essas interações confirmadas fortalecem as análises in silico. A Figura 17 é uma representação esquemática da proteína NtCDKG;2. Para sua confecção, foram utilizadas as análises para identificação de sítio IRES e as análises in silico para identificação de domínios, sinal de localização subcelular e elementos de ligação a proteínas. Além disso, foram levadas em consideração as análises da NtCDKG;2 previamente publicadas (FERREIRA, 2013; LUBINI, 2012).

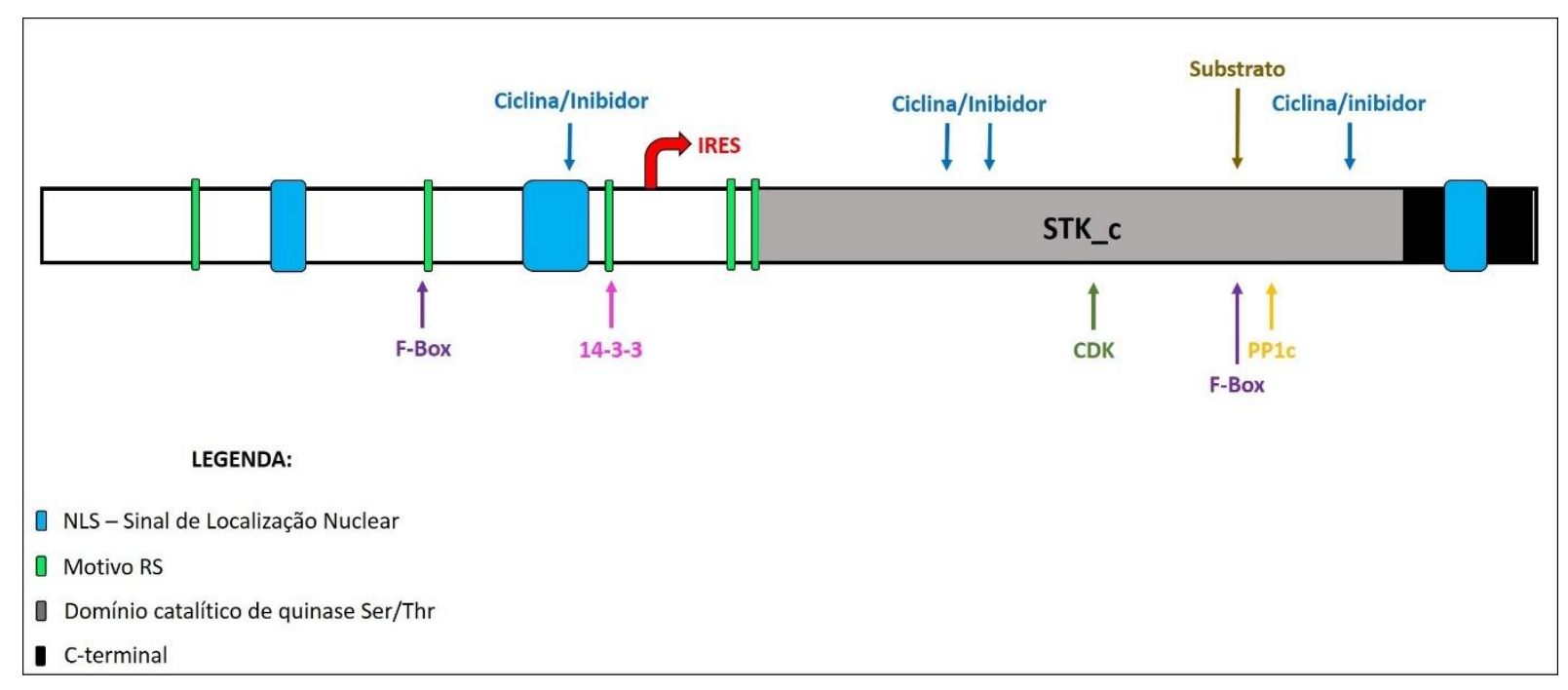

Figura 17: Esquema da proteína NtCDKG;2. A NtCDKG;2 possui uma região N-terminal estendida, rica em motivos RS (blocos verdes) que podem estar envolvidos na ligação com fatores de splicing. A sequência possui múltiplos Sítios de Localização Nuclear (NLS - blocos azuis). Adicionalmente, estão destacados os sítios para interação com ciclinas e com inibidores do complexo CDK/ciclina (setas azuis), com substrato (seta marrom), com proteínas F-Box (setas roxas), com proteínas 14-3-3 (setas rosas), além de sítios para fosforilação por CDKs (seta verde) e desfosforilação por fosfatase. O domínio catalítico (STK_c) está destacado em cinza e o putativo sítio para entrada de ribossomo e tradução cap-independente (IRES) está indicado com a flecha vermelha. 


\subsection{ENSAIO DE DUPLO-HÍBRIDO REVELA INTERAÇÃO DE NTCDKG;2 COM IMPORTANTES PARCEIROS}

O screening de uma biblioteca de duplo-híbrido em levedura $(\mathrm{Y} 2 \mathrm{H})$ tem se tornado uma ferramenta molecular capaz de revelar os parceiros de interação de uma proteína específica quando os mesmos ainda são desconhecidos. Em busca de parceiros de interação de NtCDKG;2, foi realizado o screening de uma biblioteca de cDNAs de transcritos de estigmas/estiletes de N. tabacum. À porção-amino terminal das proteínas produzidas estava fusionado o domínio de ativação da transcrição do fator de transcrição GAL4 (Activation Domain -AD). A proteína NtCDKG;2 foi produzida com fusão amino-terminal ao domínio de ligação ao DNA do fator de transcrição GAL4 (DNA Binding Domain - BD). Para realizar o screening da biblioteca de cDNAs, foi utilizado o kit ProQuest Two-Hybrid System with Gateway Technology (Invitrogen, EUA) seguindo o protocolo fornecido pelo fabricante com algumas modificações (item 3.24.2). Caso haja interação entre NtCDKG;2 e uma proteína da biblioteca, a atividade transcricional do fator de transcrição GAL4 se reconstitui, ativando a transcrição dos genes repórteres que estão sob controle do promotor que é ativado pelo GAL4. Nesse screening foi testada a ativação do gene repórter HIS3.

\subsubsection{SCREENING DA BIBLIOTECA DE DUPLO-HÍBRIDO COM A ISCA BD- NtCDKG;2}

Inicialmente, o screening da biblioteca com BD-NtCDKG;2 resultou em 227 clones positivos para o gene repórter HIS3, sendo, portanto capazes de crescer em meio SC não suplementado com histidina. Os 227 clones do screening foram dispostos em 3 placas de 96 poços (placas 1, 2 e 3) e nomeados de acordo com o posicionamento nas placas. A primeira letra, $G$, serve para identificar o screening com a proteína NtCDKG $; 2$. O primeiro número serve para identificar a placa da qual o clone foi retirado (1, 2 ou 3). Por último, a combinação letra + número identifica a posição na placa de 96 poços. Os números de 1 a 12 na horizontal e as letras A a H, dispostas na vertical. Assim, o clone G1A5, por exemplo, corresponde ao poço onde se encontram a primeira linha (A) com a quinta coluna (5) da placa 1 (vide Figura 18). Posteriormente, os 227 clones foram re-analisados para verificação do seu crescimento nos genes repórteres HIS3 e ADE2. Ao final, 205 clones cresceram em meio seletivo não suplementado com Histidina, dos quais, 7 também cresceram em meio não suplementado com Adenina. Especificamente, o crescimento de colônias nos testes para $A D E 2$ representa um indicativo de que as putativas interações tenham um caráter forte. Os controles de interação forte e fraca utilizados confirmam a capacidade de crescimento celular nas condições utilizadas. Entretanto, nenhuma inferência pode ser realizada com relação à força de 
interação dos clones obtidos, devido a não padronização da quantidade de células plaqueadas em cada spot.

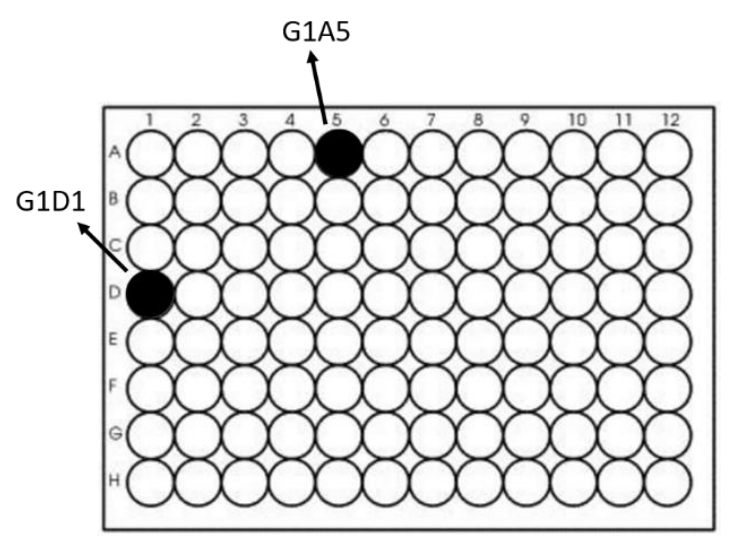

Figura 18: Desenho esquemático da placa 1 do screening de Y2H com NtCDKG;2. Na placa, destacam-se em preto os poços correspondentes aos clones G1D1 e G1A5, apenas para título de exemplificação da nomenclatura utilizada.

\subsubsection{TRANSFORMAÇÃO DE CÉLULAS DE E. COLI COM OS DNAs EXTRAÍdOS DOS CLONES POSITIVOS E ESCOLHA DOS CLONES PARA SEQUENCIAMENTO}

Frequentemente, as células de levedura podem receber mais de um plasmídeo em um mesmo evento de transformação. Dessa maneira, haverá a tradução de mais de uma proteína candidata à interação com NtCDKG;2, portanto é necessário saber qual das proteínas presentes em cada levedura interagiu com a proteína alvo NtCDKG;2 e promoveu o crescimento da levedura em meio seletivo. Para isso, o DNA plasmidial das leveduras foi extraído e transformado em células competentes de E. coli, já que estas só recebem um plasmídeo por transformação. As células de E. coli foram plaqueadas em meio seletivo para crescimento das células transformadas com o plasmídeo pDEST22, o qual contém cDNAs de proteínas candidatas à interação com NtCDKG;2. Em seguida, os DNAs plasmidiais oriundos de 6 colônias de E. coli foram digeridos com a enzima BsrGI. Essa enzima cliva o vetor pDEST22, já recombinado com um cDNA, em duas regiões, gerando uma banda de $1090 \mathrm{pb}$, outra de $6007 \mathrm{pb}$ e as demais bandas obtidas equivalem ao inserto de cDNA recombinado ao vetor. A Figura 19 apresenta a imagem de uma das eletroforeses do produto da digestão dos DNAs extraídos de 12 colônias de E. coli com a enzima BsrGI, as quais haviam sido transformadas com os DNAs dos clones de levedura G1E3 e G1F3. 


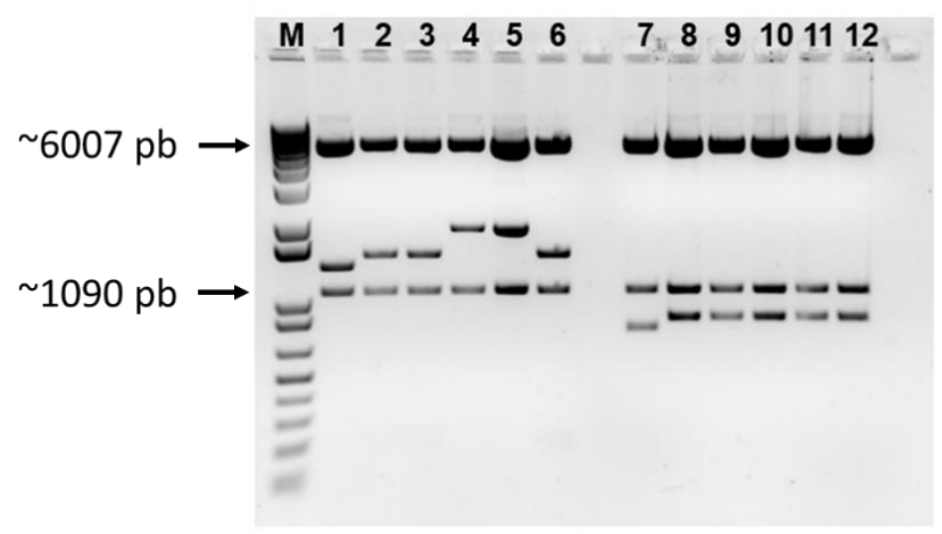

Figura 19: Eletroforese em gel de agarose 1\% das amostras de DNA plasmidial digerido com a enzima BsrGI. As amostras 1 a 6 e 7 a 12 correspondem ao DNA plasmidial de bactérias E. coli transformadas com os DNAs dos clones de levedura G1E3 e G1F3, respectivamente. A análise dos padrões de bandas geradas mostra que o clone G1E3 produziu 3 padrões de bandas (1; 2, 3 e 6; 4 e 5). Já o clone G1F3 produziu 2 padrões de bandas (o peso molecular das bandas da canaleta 7 é diferente das canaletas 8 a 12).

No presente trabalho, foram extraídos DNAs de 64 colônias de levedura e, ao final, foram analisados os padrões de digestão de 318 clones de E. coli. Os perfis distintos de digestão, referentes a um mesmo clone de levedura, confirmam a presença de cDNAs distintos dentro destes clones de levedura. O DNA de um representante de cada um dos clones de bactérias, que apresentou perfil distinto de digestão foi selecionado para sequenciamento. O mesmo procedimento foi realizado para todos os clones de levedura que foram transformados em bactéria.

\subsubsection{IDENTIFICAÇÃO DE PUTATIVAS PROTEÍNAS PARCEIRAS DE INTERAÇÃO DE NtCDKG;2}

Após o sequenciamento dos DNAs selecionados, as sequências codificadoras dos clones foram analisadas nos bancos de dados NCBI e TAIR, através de análises de similaridade utilizando algoritmos BLAST. Esse procedimento resultou na identificação de diversas proteínas consideradas interessantes para o presente trabalho. A Tabela 6 apresenta os resultados encontrados para os diferentes clones de E. coli obtidos. 
Tabela 6: Identificação de putativos candidatos a interação com NtCDKG;2, através de ensaio de Y2H. Os clones grifados em rosa correspondem a clones que foram testados em interação par-a-par com NtCDKG;2, tiveram resultado positivo e serão apresentados a seguir, no presente trabalho. Os clones grifados em cinza correspondem a clones que foram testados em interação par-a-par com NtCDKG;2 que tiveram resultado positivo (Ferreira, 2016).

\begin{tabular}{|c|c|c|c|c|}
\hline E. coli & NCBI blastn & E-value & TAIR blastx & E-value \\
\hline \multicolumn{5}{|c|}{ Outras quinases } \\
\hline G1E1.1 & $\begin{array}{l}\text { Nta cyclin-dependent kinase F- } \\
\text { 1-like }\end{array}$ & $\begin{array}{l}4,00 \mathrm{E}- \\
154\end{array}$ & $\begin{array}{l}\text { AT4G28980.2 - CDKF;1, CAK1AT, } \\
\text { CDK-activating kinase 1AT }\end{array}$ & $1,00 \mathrm{E}-29$ \\
\hline G1B1.4 & $\begin{array}{l}\text { Vitis vinifera serine/threonine- } \\
\text { protein kinase OXI1-like }\end{array}$ & & $\begin{array}{l}\text { AT1G51170.1 - Protein kinase superfamily } \\
\text { protein }\end{array}$ & \\
\hline G1D4.1 & $\begin{array}{l}\text { Nsy calcium-dependent protein } \\
\text { kinase } 8 \text {-like }\end{array}$ & 0 & $\begin{array}{l}\text { AT2G41860.2 - CPK14, calcium- } \\
\text { dependent protein kinase } 14\end{array}$ & 0,00002 \\
\hline G1A7.2 & Nta TA20 gene & 0 & AT3G46280.1 - Protein kinase-related & \\
\hline \multicolumn{5}{|c|}{ Fatores de transcrição e ligantes de DNA } \\
\hline G1B4.2 & Nsy uncharacterized & 0 & $\begin{array}{l}\text { AT2G15890.1 - CBP1, CCG-BINDING } \\
\text { PROTEIN 1, MATERNAL EFFECT } \\
\text { EMBRYO ARREST 14, MEE14 }\end{array}$ & $9 \mathrm{E}-32$ \\
\hline G1C1.2 & $\begin{array}{l}\text { Nsy PH domain-containing } \\
\text { protein DDB_G0287875-like }\end{array}$ & & $\begin{array}{l}\text { AT3G58630.1 - sequence-specific DNA } \\
\text { binding transcription factors }\end{array}$ & \\
\hline G1A3.1 & $\begin{array}{l}\text { Nto zinc finger A20 and AN1 } \\
\text { domain-containing stress- } \\
\text { associated protein 5-like }\end{array}$ & 0 & $\begin{array}{l}\text { AT3G12630.1 - A20/AN1-like zinc finger } \\
\text { family protein }\end{array}$ & $3 \mathrm{E}-44$ \\
\hline G1C4.1 & $\begin{array}{l}\text { Nsy probable WRKY } \\
\text { transcription factor } 32\end{array}$ & 0 & $\begin{array}{l}\text { AT4G30935.1 - WRKY32, ATWRKY32, } \\
\text { WRKY DNA-binding protein } 32\end{array}$ & $2 \mathrm{E}-44$ \\
\hline G1F4.1 & Nta histone H2B1 & & $\begin{array}{l}\text { AT5G59910.1 - HTB4, Histone } \\
\text { superfamily protein }\end{array}$ & \\
\hline \multicolumn{5}{|c|}{ Tráfego de proteínas e estabilização do fuso mitótico } \\
\hline G1D2.6 & $\begin{array}{l}\text { Nto ran-binding protein } 1 \\
\text { homolog c-like }\end{array}$ & 0 & $\begin{array}{l}\text { AT5G58590.1 - RANBP1, RAN binding } \\
\text { protein } 1\end{array}$ & $2 \mathrm{E}-84$ \\
\hline \multicolumn{5}{|c|}{ Fosfatases } \\
\hline G1C4.2 & $\begin{array}{l}\text { Nto serine/threonine-protein } \\
\text { phosphatase PP2A catalytic } \\
\text { subunit }\end{array}$ & 0 & $\begin{array}{l}\text { AT3G58500.1 - PP2A-4, protein } \\
\text { phosphatase } 2 \text { A-4 }\end{array}$ & $6 \mathrm{E}-90$ \\
\hline G1E3.1 & $\begin{array}{l}\text { Nto thiosulfate/3- } \\
\text { mercaptopyruvate } \\
\text { sulfurtransferase } 1\end{array}$ & 0 & $\begin{array}{l}\text { AT1G79230.1 - ST1, ATMST1, MST1, } \\
\text { ATRDH1, STR1, mercaptopyruvate } \\
\text { sulfurtransferase } 1\end{array}$ & $1 \mathrm{E}-88$ \\
\hline \multicolumn{5}{|c|}{ Metabolismo de RNAs } \\
\hline G1A2.5 & Nto la-related protein $6 \mathrm{~A}$ & 0 & AT5G46250.1 - RNA-binding protein & 0,00000005 \\
\hline G1G3.1 & $\begin{array}{l}\text { Nsy DNA-directed RNA } \\
\text { polymerase II subunit RPB7 }\end{array}$ & 0 & $\begin{array}{l}\text { AT5G59180.1 - NRPB7, DNA-directed } \\
\text { RNA polymerase II }\end{array}$ & $6 \mathrm{E}-72$ \\
\hline \multicolumn{5}{|c|}{ Regulação do florescimento } \\
\hline G1H1.1 & Nsy FRIGIDA-like protein 3 & 0 & AT5G48385.1 - FRIGIDA-like protein & $7 \mathrm{E}-43$ \\
\hline \multicolumn{5}{|c|}{ Função desconhecida } \\
\hline G1A3.2 & Nsy uncharacterized & 0 & $\begin{array}{l}\text { AT3G52050.4 - 5'-3' exonuclease family } \\
\text { protein }\end{array}$ & $4 \mathrm{E}-78$ \\
\hline G1B6.3 & $\begin{array}{l}\text { Nto switch-associated protein } \\
70\end{array}$ & 0 & $\begin{array}{l}\text { AT2G30880.2 - Pleckstrin homology }(\mathrm{PH}) \\
\text { domain-containing protein }\end{array}$ & $1 \mathrm{E}-70$ \\
\hline G1E2.1 & $\begin{array}{l}\text { Nsy PH domain-containing } \\
\text { protein DDB_G0287875-like }\end{array}$ & 0 & $\begin{array}{l}\text { AT3G58630.1 - sequence-specific DNA } \\
\text { binding transcription factors }\end{array}$ & $8 \mathrm{E}-35$ \\
\hline G1F3.2 & Nsy uncharacterized & 0 & AT3G03150.1 - unknown protein & $\begin{array}{l}8 \mathrm{E}-26 \\
(\text { Continua })\end{array}$ \\
\hline
\end{tabular}


Tabela 6 (Continuação):

\begin{tabular}{|c|c|c|c|c|}
\hline E. coli & NCBI blastn & E-value & TAIR blastx & E-value \\
\hline \multicolumn{5}{|c|}{ F-Box } \\
\hline G1F7.1 & $\begin{array}{l}\text { Nsy F-box/LRR-repeat protein } \\
\text { 17-like }\end{array}$ & 0 & $\begin{array}{l}\text { AT3G54650.1 - FBL17, RNI-like } \\
\text { superfamily protein }\end{array}$ & 9E-42 \\
\hline \multicolumn{5}{|c|}{ Reparo de DNA } \\
\hline G1H6.3 & $\begin{array}{l}\text { Nsy MMS19 nucleotide excision } \\
\text { repair protein homolog }\end{array}$ & 0 & $\begin{array}{l}\text { AT5G48120.1 - ARM repeat superfamily } \\
\text { protein }\end{array}$ & $3 \mathrm{E}-47$ \\
\hline \multicolumn{5}{|c|}{ Falsos positivos } \\
\hline \multicolumn{5}{|c|}{ Proteínas ribossomais } \\
\hline G1A4.1 & Nto 40S ribosomal protein AS & 0 & $\begin{array}{l}\text { AT3G04770.2 - RPSAb, 40s ribosomal } \\
\text { protein SA B }\end{array}$ & $5 \mathrm{E}-90$ \\
\hline G1A7.5 & Nto 40S ribosomal protein AS & 0 & $\begin{array}{l}\text { AT3G04770.2 - RPSAb, 40s ribosomal } \\
\text { protein SA B }\end{array}$ & $5 \mathrm{E}-89$ \\
\hline G1B1.2 & Solanum lycopersicum cDNA & & $\begin{array}{l}\text { AT1G72370.1 - P40, AP40, RP40, RPSAA, } \\
\text { 40s ribosomal protein SA }\end{array}$ & \\
\hline G1D4.3 & Nto 40S ribosomal protein AS & 0 & $\begin{array}{l}\text { AT3G04770.2 - RPSAb, 40s ribosomal } \\
\text { protein SA B }\end{array}$ & 4E-101 \\
\hline G1E6.6 & Nto 40S ribosomal protein AS & 0 & $\begin{array}{l}\text { AT3G04770.2 - RPSAb, 40s ribosomal } \\
\text { protein SA B }\end{array}$ & 9E-129 \\
\hline G1H4.1 & $\begin{array}{l}\text { Nta } 40 \text { S ribosomal protein SA- } \\
\text { like }\end{array}$ & & $\begin{array}{l}\text { AT3G04770.2 - RPSAb, 40s ribosomal } \\
\text { protein SA B }\end{array}$ & \\
\hline G1H6.1 & $\begin{array}{l}\text { Nsy 60S ribosomal protein L21- } \\
\text { 1-like }\end{array}$ & 0 & $\begin{array}{l}\text { AT1G57860.1 - Translation protein SH3- } \\
\text { like family protein }\end{array}$ & $7 \mathrm{E}-83$ \\
\hline \multicolumn{5}{|c|}{ Outras proteínas } \\
\hline G1A2.1 & $\begin{array}{l}\text { Nsy low-temperature-induced } \\
\text { cysteine proteinase-like }\end{array}$ & 0 & $\begin{array}{l}\text { AT5G43060.1 - Granulin repeat cysteine } \\
\text { protease family protein }\end{array}$ & $8 \mathrm{E}-45$ \\
\hline G1A7.1 & $\begin{array}{l}\text { Nsy glucan endo-1,3-beta- } \\
\text { glucosidase }\end{array}$ & 0 & $\begin{array}{l}\text { AT4G16260.1 - Glycosyl hydrolase } \\
\text { superfamily protein }\end{array}$ & $6 \mathrm{E}-57$ \\
\hline G1B2.1 & $\begin{array}{l}\text { Nsy serine carboxypeptidase } 24- \\
\text { like }\end{array}$ & 0 & $\begin{array}{l}\text { AT4G30610.1 - BRS1, SCPL24, } \\
\text { alpha/beta-Hydrolases superfamily protein }\end{array}$ & 1E-104 \\
\hline G1B4.1 & $\begin{array}{l}\text { Nsy pyruvate kinase, cytosolic } \\
\text { isozyme-like }\end{array}$ & 0 & $\begin{array}{l}\text { AT3G52990.1 - Pyruvate kinase family } \\
\text { protein }\end{array}$ & $2 \mathrm{E}-63$ \\
\hline G1B6.1 & $\begin{array}{l}\text { Nsy glucan endo-1,3-beta- } \\
\text { glucosidase }\end{array}$ & 0 & $\begin{array}{l}\text { AT4G16260.1 - Glycosyl hydrolase } \\
\text { superfamily protein }\end{array}$ & $6 \mathrm{E}-57$ \\
\hline G1B7.3 & $\begin{array}{l}\text { Nsy UDP-glucuronate 4- } \\
\text { epimerase } 3\end{array}$ & 0 & $\begin{array}{l}\text { AT4G00110.1 - GAE3, UDP-D- } \\
\text { glucuronate 4-epimerase } 3\end{array}$ & $2 \mathrm{E}-71$ \\
\hline G1B7.5 & $\begin{array}{l}\text { Nsy glucose-1-phosphate } \\
\text { adenylyltransferase small } \\
\text { subunit, } \\
\text { chloroplastic/amyloplastic }\end{array}$ & 0 & $\begin{array}{l}\text { AT5G48300.1 - ADG1, APS1, ADP } \\
\text { glucose pyrophosphorylase } 1\end{array}$ & $4 \mathrm{E}-72$ \\
\hline G1C4.3 & $\begin{array}{l}\text { Nto UDP-glucuronate } 4- \\
\text { epimerase } 3\end{array}$ & 0 & $\begin{array}{l}\text { AT1G02000.1 - GAE2, UDP-D- } \\
\text { glucuronate 4-epimerase } 2\end{array}$ & $6 \mathrm{E}-70$ \\
\hline G1C6.1 & $\begin{array}{l}\text { Nsy glucan endo-1,3-beta- } \\
\text { glucosidase }\end{array}$ & 0 & $\begin{array}{l}\text { AT4G16260.1 - Glycosyl hydrolase } \\
\text { superfamily protein }\end{array}$ & $6 \mathrm{E}-57$ \\
\hline G1C7.4 & $\begin{array}{l}\text { Nsy glucan endo-1,3-beta- } \\
\text { glucosidase }\end{array}$ & 0 & $\begin{array}{l}\text { AT4G16260.1 - Glycosyl hydrolase } \\
\text { superfamily protein }\end{array}$ & $6 \mathrm{E}-57$ \\
\hline G1D2.1 & $\begin{array}{l}\text { Nsy protein transport protein } \\
\text { Sec61 subunit beta-like }\end{array}$ & 0 & $\begin{array}{l}\text { AT3G60540.2 - Preprotein translocase Sec, } \\
\text { Sec61-beta subunit protein }\end{array}$ & $1 \mathrm{E}-14$ \\
\hline G1D6.1 & Nto $21 \mathrm{kDa}$ protein-like & 0 & $\begin{array}{l}\text { AT5G20740.1 - Plant invertase/pectin } \\
\text { methylesterase inhibitor superfamily } \\
\text { protein }\end{array}$ & $2 \mathrm{E}-54$ \\
\hline G1D6.2 & $\begin{array}{l}\text { Nsy glucan endo-1,3-beta- } \\
\text { glucosidase }\end{array}$ & 0 & $\begin{array}{l}\text { AT4G16260.1 - Glycosyl hydrolase } \\
\text { superfamily protein }\end{array}$ & $6 \mathrm{E}-57$ \\
\hline G1D7.3 & $\begin{array}{l}\text { Nsy probable polyamine oxidase } \\
2\end{array}$ & 0 & $\begin{array}{l}\text { AT2G43020.1 - ATPAO2, PAO2, } \\
\text { polyamine oxidase } 2\end{array}$ & $2 \mathrm{E}-114$ \\
\hline
\end{tabular}


Tabela 6 (Continuação):

\begin{tabular}{|c|c|c|c|c|}
\hline E. coli & NCBI blastn & E-value & TAIR blastx & E-value \\
\hline G1D7.4 & $\begin{array}{l}\text { Nsy glucan endo-1,3-beta- } \\
\text { glucosidase }\end{array}$ & 0 & $\begin{array}{l}\text { AT4G16260.1 - Glycosyl hydrolase } \\
\text { superfamily protein }\end{array}$ & 6E-57 \\
\hline G1E3.2 & $\begin{array}{l}\text { Nto S-adenosylmethionine } \\
\text { synthase 2-like }\end{array}$ & 0 & $\begin{array}{l}\text { AT3G17390.1 - MTO3, SAMS3, MAT4, } \\
\text { S-adenosylmethionine synthetase family } \\
\text { protein }\end{array}$ & 4E-85 \\
\hline G1E3.4 & Nto pectinesterase-like & 0 & $\begin{array}{l}\text { AT3G14310.1 - ATPME3, PME3, pectin } \\
\text { methylesterase } 3\end{array}$ & 0,0000004 \\
\hline G1E4.1 & $\begin{array}{l}\text { Nsy glucan endo-1,3-beta- } \\
\text { glucosidase }\end{array}$ & 0 & $\begin{array}{l}\text { AT4G16260.1 - Glycosyl hydrolase } \\
\text { superfamily protein }\end{array}$ & 9E-57 \\
\hline G1E5.4 & $\begin{array}{l}\text { Nta mRNA for cytosolic } \\
\text { ascorbate peroxidase }\end{array}$ & & $\begin{array}{l}\text { AT1G07890.8 - APX1, MEE6, CS1, } \\
\text { ATAPX1, ATAPX01, ascorbate peroxidase } \\
1\end{array}$ & \\
\hline G1E6.1 & $\begin{array}{l}\text { Nsy glucan endo-1,3-beta- } \\
\text { glucosidase }\end{array}$ & 0 & $\begin{array}{l}\text { AT4G16260.1 - Glycosyl hydrolase } \\
\text { superfamily protein }\end{array}$ & 6E-57 \\
\hline G1F6.2 & $\begin{array}{l}\text { Nsy glucan endo-1,3-beta- } \\
\text { glucosidase }\end{array}$ & 0 & $\begin{array}{l}\text { AT4G16260.1 - Glycosyl hydrolase } \\
\text { superfamily protein }\end{array}$ & $6 \mathrm{E}-57$ \\
\hline G1F7.2 & & 0 & $\begin{array}{l}\text { AT4G16260.1 - Glycosyl hydrolase } \\
\text { superfamily protein }\end{array}$ & 6E-57 \\
\hline G1G1.1 & $\begin{array}{l}\text { Nsy glyceraldehyde-3-phosphate } \\
\text { dehydrogenase }\end{array}$ & 0 & $\begin{array}{l}\text { AT1G13440.1 - GAPC-2, GAPC2, } \\
\text { glyceraldehyde-3-phosphate dehydrogenase } \\
\text { C2 }\end{array}$ & 7E-110 \\
\hline G1G6.6 & $\begin{array}{l}\text { Nsy pyruvate dehydrogenase E1 } \\
\text { component subunit beta-3 }\end{array}$ & 0 & $\begin{array}{l}\text { AT2G34590.1 - Transketolase family } \\
\text { protein }\end{array}$ & 1E-63 \\
\hline G1G7.4 & $\begin{array}{l}\text { Nsy glucan endo-1,3-beta- } \\
\text { glucosidase }\end{array}$ & 0 & $\begin{array}{l}\text { AT4G16260.1 - Glycosyl hydrolase } \\
\text { superfamily protein }\end{array}$ & $7 \mathrm{E}-57$ \\
\hline G1H6.2 & $\begin{array}{l}\text { Nsy glucan endo-1,3-beta- } \\
\text { glucosidase }\end{array}$ & 0 & $\begin{array}{l}\text { AT4G16260.1 - Glycosyl hydrolase } \\
\text { superfamily protein }\end{array}$ & $7 \mathrm{E}-57$ \\
\hline G1H7.2 & Nto apyrase-like & 0 & $\begin{array}{l}\text { AT5G18280.1 - ATAPY2, APY2, apyrase } \\
2\end{array}$ & $5 \mathrm{E}-40$ \\
\hline G1H7.3 & $\begin{array}{l}\text { Nsy glucan endo-1,3-beta- } \\
\text { glucosidase }\end{array}$ & 0 & $\begin{array}{l}\text { AT4G16260.1 - Glycosyl hydrolase } \\
\text { superfamily protein }\end{array}$ & $5 \mathrm{E}-57$ \\
\hline G1B3.1 & $\begin{array}{l}\text { Nsy pistil-specific extensin-like } \\
\text { protein }\end{array}$ & 0 & $\begin{array}{l}\text { AT2G34700.1 - Pollen Ole e } 1 \text { allergen and } \\
\text { extensin family protein }\end{array}$ & 7E-31 \\
\hline G1E6.4 & $\begin{array}{l}\text { Nsy pistil-specific extensin-like } \\
\text { protein }\end{array}$ & 0 & $\begin{array}{l}\text { AT2G34700.1 - Pollen Ole e } 1 \text { allergen and } \\
\text { extensin family protein }\end{array}$ & $5 \mathrm{E}-31$ \\
\hline G1F3.1 & $\begin{array}{l}\text { Nsy pistil-specific extensin-like } \\
\text { protein }\end{array}$ & 0 & $\begin{array}{l}\text { AT2G34700.1 - Pollen Ole e } 1 \text { allergen and } \\
\text { extensin family protein }\end{array}$ & $4 \mathrm{E}-27$ \\
\hline G1F6.1 & $\begin{array}{l}\text { Nsy pistil-specific extensin-like } \\
\text { protein }\end{array}$ & 0 & $\begin{array}{l}\text { AT2G34700.1 - Pollen Ole e } 1 \text { allergen and } \\
\text { extensin family protein }\end{array}$ & $2 \mathrm{E}-27$ \\
\hline G1G6.5 & $\begin{array}{l}\text { Nsy pistil-specific extensin-like } \\
\text { protein }\end{array}$ & 0 & $\begin{array}{l}\text { AT2G34700.1 - Pollen Ole e } 1 \text { allergen and } \\
\text { extensin family protein }\end{array}$ & $4 \mathrm{E}-31$ \\
\hline G1H3.1 & $\begin{array}{l}\text { Nsy pistil-specific extensin-like } \\
\text { protein }\end{array}$ & 0 & $\begin{array}{l}\text { AT2G34700.1 - Pollen Ole e } 1 \text { allergen and } \\
\text { extensin family protein }\end{array}$ & $3 \mathrm{E}-30$ \\
\hline G1C5.1 & $\begin{array}{l}\text { Nta stem-specific protein } \\
\text { TSJT1-like }\end{array}$ & & $\begin{array}{l}\text { AT4G27450.1 - Aluminium induced } \\
\text { protein with YGL and LRDR motifs }\end{array}$ & \\
\hline G1D1.2 & Nsy defensin-like protein & 0 & $\begin{array}{l}\text { AT1G61070.1 - LCR66, PDF2.4, low- } \\
\text { molecular-weight cysteine-rich } 66\end{array}$ & 1E-12 \\
\hline G1D7.1 & $\begin{array}{l}\text { Tabacco Cab21 mRNA for } \\
\text { major chlorophyll a/b binding } \\
\text { protein }\end{array}$ & 0 & $\begin{array}{l}\text { AT1G29930.1 - CAB1, AB140, CAB140, } \\
\text { LHCB1.3, chlorophyll A/B binding } \\
\text { protein } 1\end{array}$ & 2E-114 \\
\hline G1E5.1 & $\begin{array}{l}\text { Nta mitochondrial adenine } \\
\text { nucleotide transporter ADNT1- } \\
\text { like }\end{array}$ & & $\begin{array}{l}\text { AT4G01100.2 - ADNT1, adenine } \\
\text { nucleotide transporter } 1\end{array}$ & \\
\hline
\end{tabular}

(Continua) 
Tabela 6 (Conclusão):

\begin{tabular}{|c|c|c|c|c|}
\hline E. coli & NCBI blastn & E-value & TAIR blastx & $\overline{\text { E-value }}$ \\
\hline G1E5.2 & $\begin{array}{l}\text { Nta metallothionein-like protein } \\
\text { type } 2\end{array}$ & & $\begin{array}{l}\text { AT5G02380.1 - Symbols: MT2B, } \\
\text { metallothionein 2B }\end{array}$ & \\
\hline G1E5.3 & $\begin{array}{l}\text { Nta NtLTP1 gene for lipid } \\
\text { transfer protein }\end{array}$ & & $\begin{array}{l}\text { AT5G59320.1 - LTP3, lipid transfer } \\
\text { protein } 3\end{array}$ & \\
\hline G1E7.4 & $\begin{array}{l}\text { Nto phytanoyl-CoA } \\
\text { dioxygenase }\end{array}$ & 0 & $\begin{array}{l}\text { AT2G01490.1 - phytanoyl-CoA } \\
\text { dioxygenase }(\mathrm{PhyH}) \text { family protein }\end{array}$ & $1 \mathrm{E}-71$ \\
\hline G1F5.6 & $\begin{array}{l}\text { Nta NtLTP1 gene for lipid } \\
\text { transfer protein }\end{array}$ & & $\begin{array}{l}\text { AT5G59320.1 - LTP3, lipid transfer } \\
\text { protein } 3\end{array}$ & \\
\hline G1G7.5 & $\begin{array}{l}\text { Nsy V-type proton ATPase } 16 \\
\text { kDa proteolipid subunit }\end{array}$ & 0 & $\begin{array}{l}\text { AT1G19910.1 - AVA-P2, AVA-2PE, } \\
\text { ATVHA-C2, ATPase, F0/V0 complex, } \\
\text { subunit C protein }\end{array}$ & $2 \mathrm{E}-73$ \\
\hline G1C3.1 & $\begin{array}{l}\text { Yeast two-hybrid vector pNtrp } \\
\text { DNA }\end{array}$ & 0 & & \\
\hline G1G2.1 & $\begin{array}{l}\text { Saccharomyces cerevisiae strain } \\
\text { ySR127 chromosome XV }\end{array}$ & 0 & & \\
\hline
\end{tabular}

Dentre as proteínas identificadas, três delas foram selecionadas para ensaios de Y2H para-par. São elas: CDKF;1, CBP1 e RanBP1. Suas interações com NtCDKG;2 foram confirmadas e serão apresentadas a seguir. Além disso, muitos clones foram considerados falsos-positivos, o que é frequente em screenings de Y2H (CAUFIELD; SAKHAWALKAR; UETZ, 2012; CHINI, 2014). Foram considerados falsos positivos as proteínas que também foram identificadas em grandes quantidades em screenings paralelos realizados por Ferreira (2016) e Strini (2014), os quais utilizaram a mesma biblioteca de cDNAs para os sreenings.

\subsubsection{NtCDKG;2 INTERAGE COM NtCDKF;1, UMA REGULADORA DA TRASCRIÇÃO E SPLICING}

De acordo com análises de similaridade no TAIR, o DNA sequenciado do clone G1E1.1 (primeira colônia do respectivo clone de levedura) corresponde a uma putativa CDKF;1. Portanto, o DNA do clone correspondente à CDKF;1 de N. tabacum foi utilizado para co-transformar leveduras de identificar se essa presa estava interagindo com a isca (re-teste). Para tanto, as transformações foram plaqueadas em meio SC-Leu-Trp-His, SC-Leu-Trp-Ade e SC completo com membrana de nylon, obtendo-se colônias isoladas contendo isca (BD-NtCDKG;2) e presa (AD$\mathrm{NtCDKF}$;1). É preciso salientar que, os testes de autoativação para as ambas proteínas foram realizados juntamente aos ensaios de interação. $\mathrm{O}$ ensaio foi positivo para o teste de ativação dos genes repórteres HIS3, ADE2 e lacZ e as proteínas testadas não auto-ativaram o sistema (Figura 
20), confirmando, portanto, a interação entre as proteínas NtCDKG;2 e NtCDKF;1 através do ensaio de duplo-híbrido.
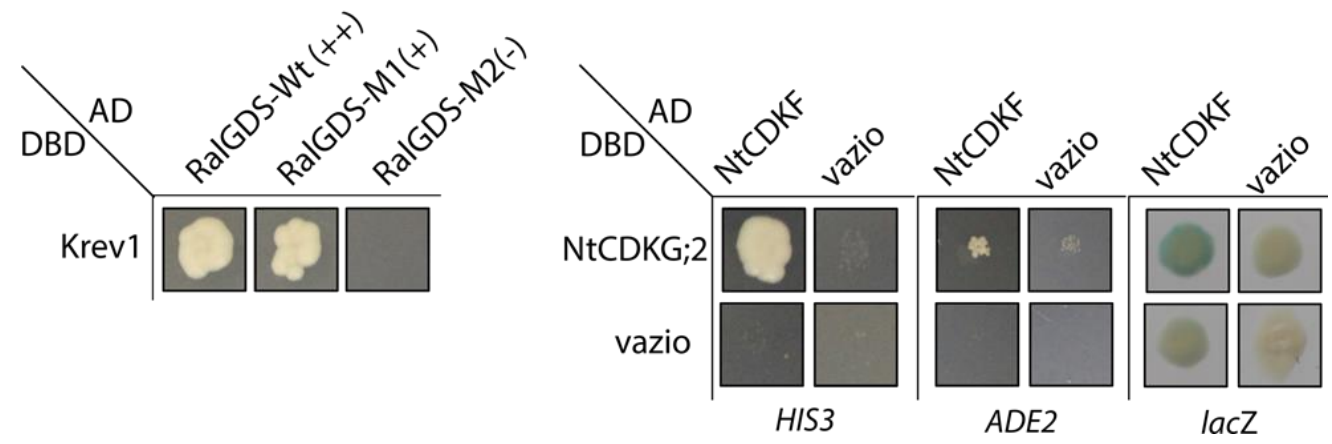

Figura 20: Ensaio de duplo-híbrido (teste de confirmação) mostrando interação positiva entre NtCDKG;2 e NtCDKF;1. Os genes repórteres HIS3, ADE2 e lacZ foram utilizados para confirmação da interação.

O ensaio em meios seletivos sem histidina e sem adenina mostra o crescimento apenas das colônias cujas proteínas de fusão interagem entre si, promovendo a autotrofia para histidina e adenina, respectivamente. $O$ teste para o gene repórter lac $Z$ também foi positivo, mostrando colônias azuladas (pois houve degradação do substrato X-GAL) nos ensaios de interação entre BD-NtCDKG;2 e AD-NtCDKF;1. Portanto, os ensaios de duplo-híbrido para os três genes repórteres confirmam a interação das proteínas de fusão NtCDKG;2 e NtCDKF;1 e indicam que essa interação seja forte, devido ao crescimento de colônias no ensaio lac $Z$ e no teste para o gene ADE2.

A interação da CDKF;1 com NtCDKG;2 foi testada e confirmada por ensaio de BiFC e co-localização (FERREIRA, 2016). Esses experimentos mostram que, apesar de isoladamente aparecerem espalhadas no nucleoplasma (em experimentos de co-localização), quando estão interagindo, as proteínas se concentram especialmente na região do nucléolo das células interfásicas. A CDKF;1 em $A$. thaliana atua como uma CAK (quinase ativadora de CDK) e também age como uma CAKAK (quinase ativadora de quinase ativadora de $\mathrm{CDK}$ ), devido à fosforilação dos resíduos Ser/Thr das CDKDs. Assim, com base no papel da AtCDKF;1 descrito na literatura, somado à identificação do sítio de fosforilação por ligação à $\mathrm{CDK}$ na sequência proteica de NtCDKG;2 e à identificação e confirmação da interação entre NtCDKF;1 e NtCDKG;2, sugerese que a NtCDKF;1 fosforile a proteína NtCDKG;2. 


\subsubsection{NtCDKG;2 INTERAGE COM O REGULADOR INICIAL DE TRANSCRIÇÃO NtCBP1}

O cDNA presente no clone G1B4.2 foi sequenciado e possui similaridade com mRNA codificador proteína CBP1 ( $\underline{C} C G \underline{B}$ inding $\underline{\text { Protein } 1) . ~ A s s i m, ~ o ~ D N A ~ d o ~ c l o n e ~ c o r r e s p o n d e n t e ~ a ̀ ~}$ CBP1 de N. tabacum (NtCBP1) foi utilizado em ensaio par-a-par de Y2H com NtCDKG;2. Os testes de autoativação também foram realizados para ambas proteínas do ensaio. De acordo com o ensaio, a interação entre NtCDKG;2 e NtCBP1 foi positiva, mostrando que as células são capazes de crescer em meio não suplementado com histidina (Figura 21).
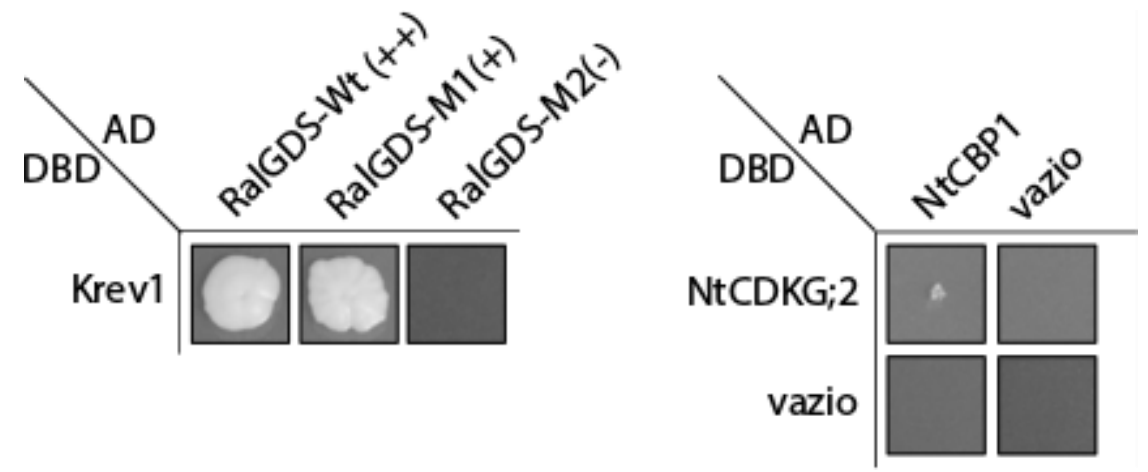

FIGURA 21: Ensaio de duplo-híbrido (teste de confirmação) mostrando interação positiva entre NtCDKG;2 e a proteína NtCBP1. O gene repórter HIS3 foi utilizado para confirmação da interação. As colônias que cresceram produzem a proteína HIS3 da biossíntese de histidina.

Conforme mostrado na Figura 21, a colônia resultante da interação entre NtCDKG;2 e NtCBP1 possui tamanho muito inferior ao apresentado pelos controles positivos de interação. Isso ocorre devido ao caráter da interação envolvida. Quando uma interação é muito forte, ou seja, as proteínas interagem por um período de tempo maior, as colônias crescem mais rapidamente e possuem tamanho maior. Porém, quando a interação é rápida, não há tempo suficiente para a colônia se desenvolver apropriadamente, resultando em menor tamanho.

A proteína CBP1 foi recentemente identificada, é conservada apenas em plantas e não possui homologia com outras proteínas de animais ou fungos. Em Arabidopsis, a CBP1 foi encontrada no núcleo da célula central do gametófito feminino e tem função na regulação inicial da transcrição de proteínas mediadoras de atração do tubo polínico (LI et al., 2015). Acredita-se que esta função seja exercida graças a sua capacidade de ligação com a proteína CCG (ㅌentral $\underline{\text { Cell }}$ Guidance), essencial para atração do tubo polínico. 
Análises de perfis de expressão de óvulos de plantas ccg/CCG mostraram que $34 \%$ dos genes downregulados codificam proteínas secretadas, das quais, 78 \% são CRPs (Cysteine-rich peptides). Os pequenos peptídeos sinal pertencente ao grupo CRP são abundantes no gametófito feminino das plantas e desempenham funções essenciais na atração do tubo polínico, fertilização e embriogênese (COSTA et al., 2014; JONES-RHOADES; BOREVITZ; PREUSS, 2007; SPRUNCK et al., 2012; TAKEUCHI; HIGASHIYAMA, 2011, 2012).

Li e colaboradores (2015) demostraram que ambas proteínas CBP1 e CCG interagem com o domínio carboxi-terminal da RNA Polimerase II. Além disso, CBP1 interage com as subunidades MED7 e MED9 do complexo Mediator. O complexo Mediator funciona como uma ponte entre a RNA Pol II e proteínas ativadoras da transcrição. CBP1 também interage com 8 fatores de transcrição AGAMOUS-Like. Assim, foi proposto que CBP1 e CCG recrutam o complexo Mediator e a maquinaria de transcrição, como os fatores de transcrição AGAMOUS-Like e, juntos, modulam a expressão dos peptídeos sinal CRPs.

Convém relatar que duas subunidades da RNA polimerase II (NRPB7 e NRPB11) foram identificadas no screening de $\mathrm{Y} 2 \mathrm{H}$ e confirmadas como sendo parceiros de interação de NtCDKG;2 (FERREIRA, 2016). Analisando todos esses fatos, é possível que a NtCDKG;2 interaja com NtCBP1 através de duas formas: (i) Fosforilando a proteína NtCBP1 e, consequentemente, ativando ou inativando ela; (ii) atuando juntamente à proteína NtCBP1 e CCG como mediadores da transcrição.

\subsubsection{NtCDKG;2 INTERAGE COM A PROTEÍNA RanBP1 DE $N$. tabacum}

Análises do sequenciamento do clone G1D2.6 mostram que a proteína codificada pelo cDNA desse clone apresenta alta similaridade com a proteína RanBP1 de Arabidopsis. De modo similar ao realizado para confirmação das interações de NtCDKG;2 com NtCDKF;1 e NtCBP1, também foi feita a análise par-a-par da interação entre NtCDKG;2 com NtRanBP1. O ensaio foi positivo (Figura 22), confirmando mais uma interação descoberta através do screening de Y2H. 

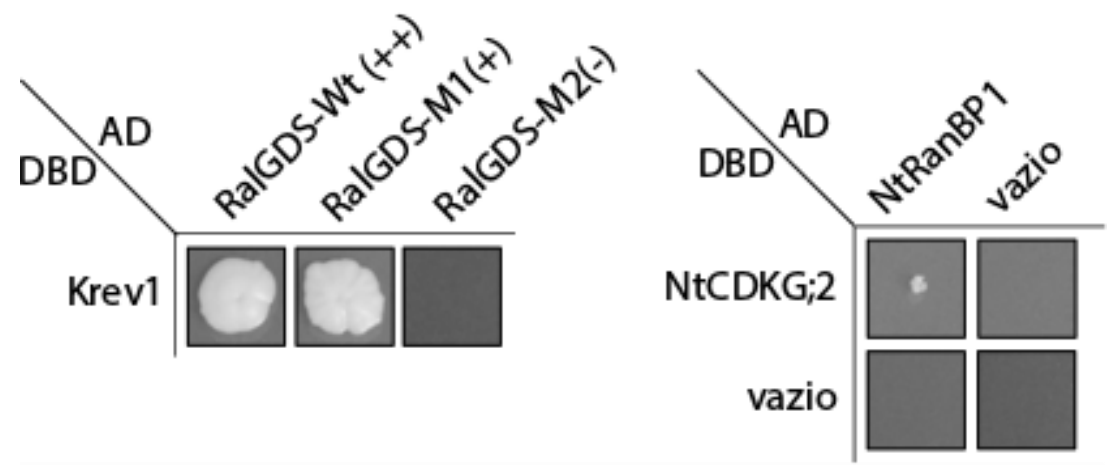

Figura 22: Ensaio de duplo-híbrido (teste de confirmação) mostrando interação positiva entre NtCDKG;2 e a proteína NtRanBP1. O gene repórter HIS3 foi utilizado para confirmação da interação. As colônias que cresceram produzem a proteína HIS3 da biossíntese de histidina.

A proteína RanBP1 se liga ao GTP e, essa ligação, promove o tráfego de proteínas para dentro e fora do núcleo de células de Arabidopsis. A RanBP1 foi a primeira Ran caracterizada em plantas (HAIZEL et al., 1997). RanBP1 pertence à superfamília gênica que codifica Small GTPbinding proteins e à subfamília Ran (소s- related nuclear protein) (TAKAI; SASAKI; MATOZAKI, 2001). A proteína Ran de mamíferos interage com RCC1 (BISCHOFF; PONSTINGL, 1991), uma proteína que se associa à cromatina e cuja carência é capaz de gerar células com micronúcleos e defeitos na conclusão da mitose (NISHITANI et al., 1991). Mais tarde, identificou-se que esses estudos prévios estavam sendo feitos com uma proteína Ran truncada e, à proteína completa deuse o nome de RanBPM (NISHITANI et al., 2001). MIKOLAJCZYK e colaboradores (2003) fizeram diversos ensaios de interação envolvendo as proteínas RanBPM e a isoforma CDK11 ${ }^{\mathrm{p} 46}$. A interação entre CDK11 $11^{\mathrm{p} 46}$ e RanBPM foi identificada em ensaio de Y2H e confirmada por pulldown. A seguir, os ensaios de imunolocalização detectaram que a interação entre ambas proteínas ocorre no núcleo. Adicionalmente, os autores mostraram que a CDK11 ${ }^{\mathrm{p} 46}$ é capaz de se auto-ativar por fosforilação e, em sequência, fosforilar a RanBPM. Interessantemente, foi verificado que RanBP é uma proteína-chave na dissociação de RanGTP através do poro nuclear (SEEWALD et al., 2003). Além disso, foi demonstrado no anfíbio Xenopus laevis que a sua CDK11 é responsável pela estabilização dos microtúbulos dependente de RanGTP, o que é essencial para formação e funcionamento corretos do fuso mitótico (MIKOLAJCZYK et al., 2003; YOKOYAMA et al., 2008). Em suma, podemos sugerir que a NtCDKG;2 também seja responsável pela fosforilação da NtRanBP1. Novamente, esses dados reforçam a hipótese de que NtCDKG;2 esteja envolvida com a organização do fuso acromático em células de N. tabacum. 
Adicionalmente, outros clones identificados pelo presente trabalho foram testados em ensaios par-a-par de Y2H com NtCDKG;2 por Ferreira (2016). O autor testou e confirmou a interação de NtCDKG;2 com proteínas envolvidas em diversos processos como transcrição e processamento de RNAs, controle de ciclo celular e florescimento. Dentre as proteínas identificadas neste trabalho e tiveram sua interação confirmada com NtCDKG;2, encontram-se dois putativos fatores de transcrição que contêm o domínio PH (Pleckstrin homology), o fator de transcrição WRKY32, as proteínas envolvidas na regulação do florescimento BOI-related E3 e FRIGIDA-like, a subunidade catalítica da fosfatase PP2A (PP2A-4), a proteína de ligação a RNA LARP-6a, a subunidade NRPB7 da RNA polimerase II, a F-Box FBL17. Além dessas proteínas, Ferreira (2016) confirmou a interação com a proteína ainda não caracterizadas ATMST1. Essa proteína possui similaridade baixa, porém significativa, com a proteína CDC25 (cell division cycle 25) de Schizosaccharomyces pombe (e-value 2e-08 por DELTA-BLAST no NCBI), uma importante proteína-chave da regulação do ciclo celular. Além disso, concomitantemente ao presente trabalho, Ferreira deu continuidade ao screening, identificou novas candidatas e testou sua interação com NtCDKG;2. Dentre elas, o autor confirmou a interação de NtCDKG;2 com os fatores de transcrição Homeobox 22, TCP7, com a subunidade regulatória da fosfatase PP2A-A2, com o fator de splicing U2A' e outra subunidade da RNA Polimerase II, a NRPB11. O Apêndice B contém uma lista com todos os clones identificados no screening até o momento, incluindo clones publicados por Ferreira (2016).

\subsection{A INTERAÇÃO ENTRE NtSCI1 E NtCDKG;2 OCORRE NO NUCLÉOLO DAS CÉLULAS DE N. tabacum}

Os ensaios de BiFC (Bi-molecular Fluorescence Complementation) foram realizados com o objetivo de determinar a distribuição subcelular in vivo da interação entre NtCDKG;2 e NtSCI1. Para isso, as folhas de N. benthamiana foram infiltradas com agrobactérias contendo a região codificante de NtSCI1 fusionada à porção N-terminal de GFP (NtSCI1-hGFP) e a região codificante de NtCDKG;2 fusionada à porção C-terminal de GFP (NtCDKG;2-tGFP). Caso haja interação entre as proteínas, a GFP é restaurada e a fluorescência detectada, assim determinando o local onde as proteínas interagem. A fluorescência foi observada através de microscópio confocal e a coloração com DAPI foi utilizada para observar a localização dos núcleos e o estado da cromatina. A Figura 23 mostra a interação entre NtCDKG;2 e NtSCI1 em quatro células durante ensaios de BiFC. 


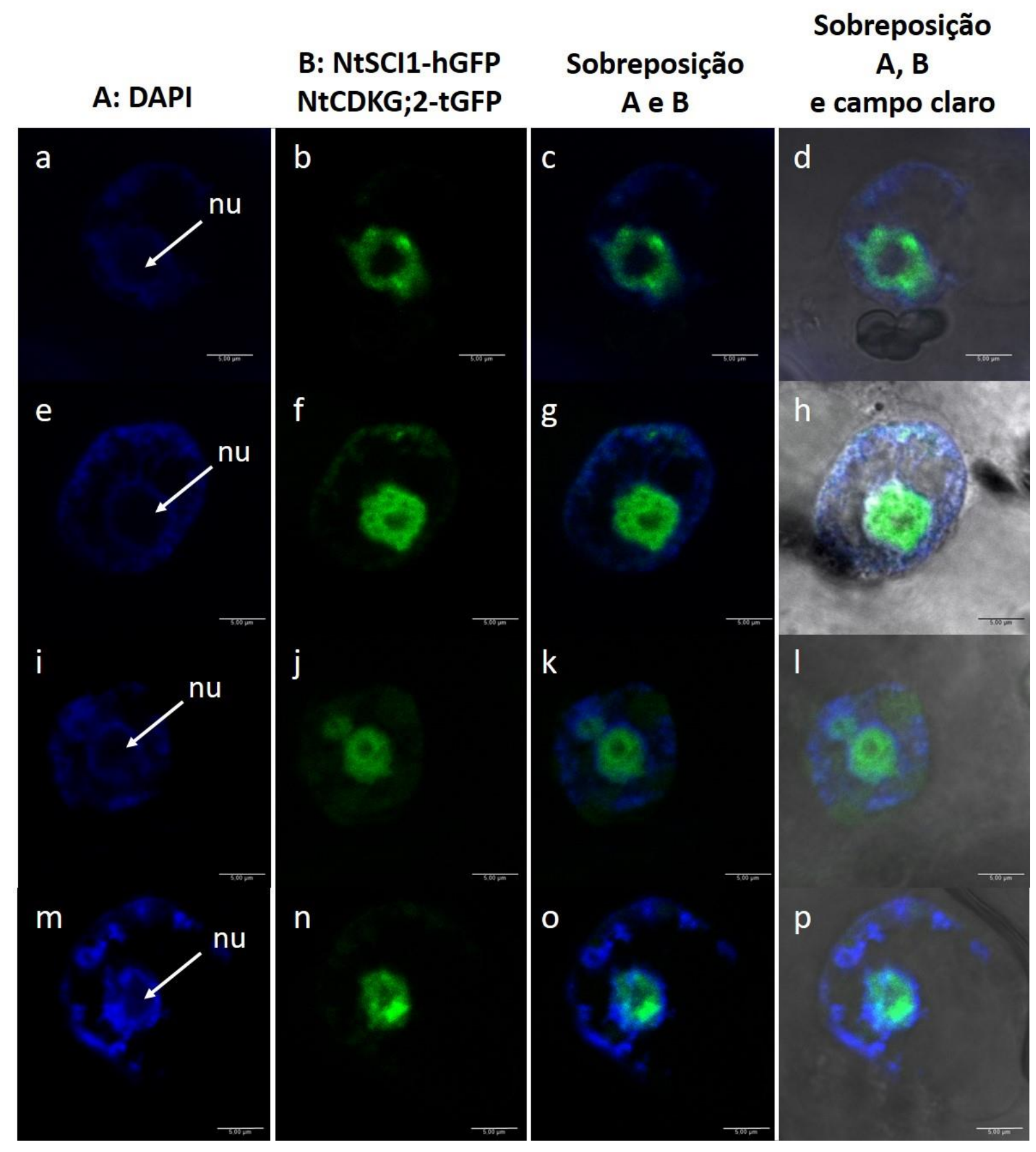

FIGURA 23: Fotomicrografia que apresenta a interação entre as proteínas NtCDKG;2 e NtSCI1 em folhas de $\boldsymbol{N}$. benthamiana por meio do ensaio de BiFC. As imagens de microscopia confocal mostram células epidérmicas, que foram transformadas com a combinação das construções que codificam as proteínas híbridas NtCDKG;2-tGFP e NtSCI1-hGFP. A primeira coluna (A) mostra os núcleos corados por DAPI. A segunda coluna (B) apresenta a fluorescência emitida graças à reconstituição da proteína GFP devido à interação de NtCDKG;2 e NtSCI1. A terceira coluna (C) corresponde à sobreposição das colunas anteriores, mostrando que a interação das proteínas ocorre no nucléolo adjacente a regiões ricas em heterocromatina. Setas brancas (nu): Indicação do nucléolo celular. hGFP e tGFP são os fragmentos contendo os resíduos de aminoácidos 1-149 e 150-238 da proteína eGFP, respectivamente. Barra $=5 \mu \mathrm{m}$. As imagens foram obtidas utilizando-se o aparelho Leica TCS SP5 (Leica Microsystems - FMRP/USP). 
A análise da figura 23 permite observar que a reconstituição da GFP promovida pela interação entre NtCDKG;2-tGFP e NtSCI1-hGFP ocorre no núcleo das células, corroborando os resultados obtidos por Strini (2014). Adicionalmente, o presente trabalho mostra que o sinal com maior intensidade de GFP pode ser observado em uma região peculiar, localizada na periferia dos nucléolos (setas brancas da Figura 23). Destaca-se que durante os ensaios de BiFC, a proteína $\mathrm{NtCDKG;2} \mathrm{é} \mathrm{produzida} \mathrm{com} \mathrm{fusão} \mathrm{à} \mathrm{tGFP} \mathrm{em} \mathrm{sua} \mathrm{porção} \mathrm{carboxi-terminal.} \mathrm{Isso} \mathrm{sugere} \mathrm{que,} \mathrm{caso}$ a proteína seja clivada como foi sugerido na discussão do item 3.4.3, essa localização no BiFC corresponde à interação de NtSCI1 com a porção quinase (carboxi-terminal) de NtCDKG;2. É preciso salientar também que foram encontradas poucas células com fluorescência durante os experimentos de BiFC, mas todas elas apresentavam o padrão de cromatina observado na Figura 23. Esses fatos sugerem que a interação entre essas proteínas ocorra em um curto momento do ciclo celular. Adicionalmente, foram realizadas tentativas de identificação da interação entre NtCDKG;2 e NtSCI1 por ensaios de pull-down, co-imunoprecipitação e Y3H. Este último ensaio foi feito utilizando as proteínas DEAD-BOX35, CycL1 e CDKF;1 como candidatas a proteínas mediadoras da interação entre NtCDKG;2 e NtSCI1. No entanto, nenhum desses ensaios foi conclusivo.

Convém ressaltar que o padrão de fluorescência originado pela interação entre NtCDKG;2 e NtSCI1 é muito peculiar. A proteína NtCDKG;2 não apresenta esse mesmo padrão de fluorescência quando interage com outro parceiro. Adicionalmente, em experimentos de BiFC, Strini (2014) observou que a localização da interação de NtSCI1 com NtCycL1 também ocorre na mesma região perinuclear, e possui o mesmo padrão de fluorescência da interação de NtCDKG;2 e NtSCI1. Ferreira (2016) aponta que a interação entre NtCDKG;2 e NtCycL1 ocorre no nucleoplasma. Tomando em conjunto todos os dados, sugere-se que NtCDKG;2 se encontre nessa região perinuclear apenas enquanto interage com NtSCI1.

\subsection{NtCDKG;2 INTERAGE COM A 14-3-3D DE N. tabacum, UMA PARCEIRA DE INTERAÇÃO DE NtSCI1}

Para averiguar em que vias as proteínas NtCDKG;2 e NtSCI1 possam atuar em conjunto, foram feitos alguns ensaios buscando interações com proteínas em comum. Recentemente, Ferreira (2016) descreveu a interação entre NtCDKG;2 com a RNA-helicase NtDEAD-BOX35 e a ciclina NtCycL1, encontrados por Strini (2014) como parceiros de NtSCI1. A interação dessas proteínas 
com NtCDKG;2 serviu para sustentar a hipótese de que NtCDKG;2 também possa estar envolvida em processos de splicing.

Na busca de parceiros de interação de NtSCI1, Strini (2014) realizou um screening de Y2H e, dentre esses parceiros, descreveu a interação com a proteína Nt14-3-3D por Y2H, BiFC e coimunoprecipitação. Para saber se ela também poderia se um parceiro de interação comum entre NtSCI1 e NtCDKG;2, foram feitos ensaios de Y2H utilizando as proteínas BD-NtCDKG;2 e ADNt14-3-3D. O ensaio contou com replicatas biológicas e testes de autoativação de isca e presa. O ensaio foi positivo para o gene repórter HIS3, mostrando que NtCDKG;2 interage com Nt14-33D de maneira direta (Figura 24).

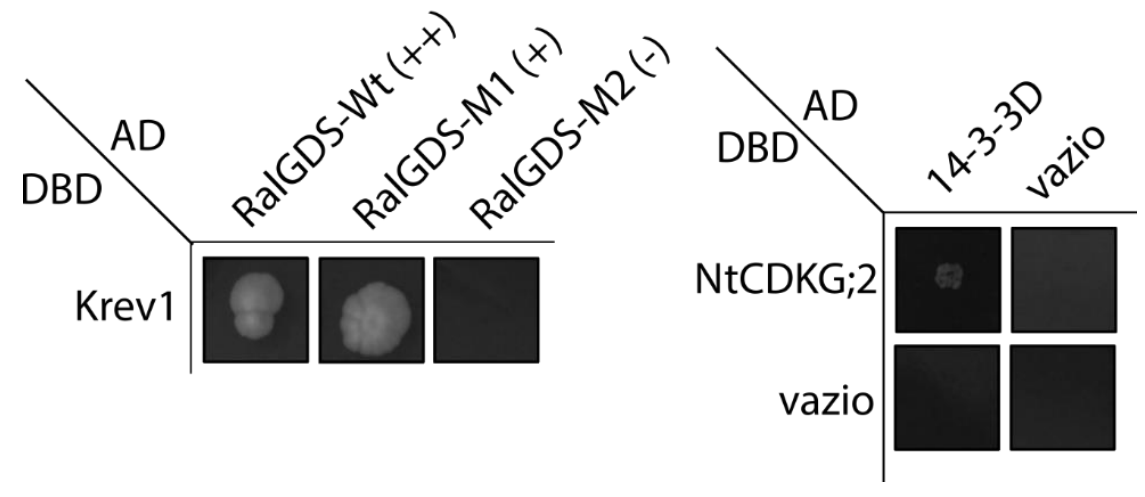

Figura 24: Ensaio de duplo-híbrido mostrando a interação positiva entre as proteínas NtCDKG;2 e 14-3-3D. As fotografias foram capturadas após 9 dias do início do ensaio. As imagens foram obtidas de placas com meio SD seletivo sem leucina, triptofano e histidina e acrescido de $1 \mathrm{mM}$ de 3 -aminotriazol (SD $-\mathrm{LWH}+3-\mathrm{AT} 1 \mathrm{mM})$.

Esse resultado é fortalecido por análises in silico que apontaram sítios de interação com proteínas 14-3-3 na sequência proteica de NtCDKG;2 (item 3.5) e por análises da proteína AtCDKG;2 no repositório Gene Mania (http://genemania.org), as quais mostram que a homóloga de Arabidopsis possui interação predita com proteínas do tipo 14-3-3, lá denominadas de GRFs. Além disso, em continuidade ao screening de Y2H com NtCDKG;2, Ferreira (2016) verificou que o clone G1H9.2 corresponde à proteína 14-3-3-like protein 16R, a qual possui homologia com a 143-3 $\Omega$ de Arabidopsis.

Foi demonstrado que a proteína 14-3-3 $\sigma$ de H. sapiens possui um papel fundamental durante a citocinese ao promover a tradução cap-independente em detrimento da tradução canônica, capdependente. Em condições normais, a proteína 14-3-3 $\sigma$ deve se ligar ao fator de início da tradução eIF4B, o que irá impedi-lo de promover a tradução cap-dependente durante a mitose, garantindo, 
assim, a tradução cap-independente da isofoma CDK11 ${ }^{\mathrm{p} 58}$ (WILKER et al., 2007). Além disso, a

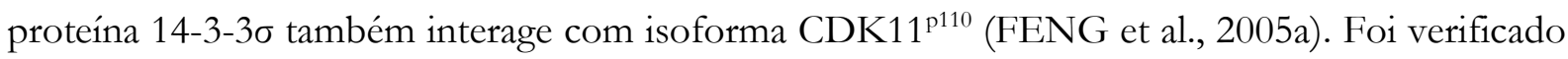

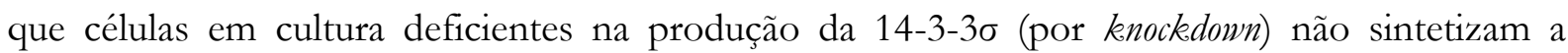
isoforma CDK11 ${ }^{\mathrm{p} 58}$, necessária para a mitose (WILKER et al., 2007). Assim, na ausência da 14-3$3 \sigma$, o eIF4B fica livre, e a isoforma p58 não é traduzida. O que foi especulado por Feng e

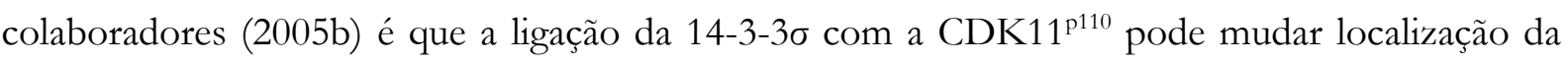
$\mathrm{CDK}^{\mathrm{p} 110}$, deixando livre a isoforma $\mathrm{CDK} 11^{\mathrm{p} 58}$ durante a mitose.

Analisando os dados em conjunto, nós propomos que a interação com Nt14-3-3D possa acarretar mudança da localização da isoforma maior da proteína NtCDKG;2. Essa hipótese deverá ser verificada por ensaios de co-localização e de interação por BiFC entre NtCDKG;2 e Nt14-33D. Caso a proteína Nt14-3-3D promova a mudança de localização de NtCDKG;2, poderão ser feitos ensaios de isolamento de proteína para saber se está ocorrendo tradução mediada por IRES, o que produzirá uma isoforma de NtCDKG;2 com menor tamanho.

\subsection{NtSCI1 INTERAGE COM A SUBUNIDADE NRPB11 DA RNA POLIMERASE II, PARCEIRA DE INTERAÇÃO DE NtCDKG;2}

Conforme apresentado, durante o screening em busca de parceiros de interação de $\mathrm{NtCDKG;2} \mathrm{foram} \mathrm{identificadas} \mathrm{proteínas} \mathrm{cujos} \mathrm{homólogos} \mathrm{estão} \mathrm{envolvidos} \mathrm{nos} \mathrm{processos} \mathrm{de}$ transcrição e processamento de RNAs, controle de ciclo celular e florescimento. Esses parceiros identificados tiveram suas interações confirmadas por Ferreira (2016). Para identificar outros parceiros em comum entre NtCDKG;2 e NtSCI1, foram feitos estudos de interação (Y2H) entre $\mathrm{NtSCI} 1$ e os parceiros identificados no screening da NtCDKG;2. As proteínas que tiveram sua interação testada com NtSCI1 e o respectivo resultado do teste são apresentados na tabela a seguir (Tabela 7).

Tabela 7: Proteínas que interagem com NtCDKG;2 e foram utilizadas para testes de interação por Y2H com NtSCI1. A coluna da direita mostra o resultado obtido no referido teste.

\begin{tabular}{||l|l|l||}
\hline Proteína & Processos no qual sua homóloga participa & Resultado \\
\hline \hline NRPB11 & $\begin{array}{l}\text { Subunidade 11 da RNA polimerase II. Envolvida em transcrição e } \\
\text { processamento de RNAs. }\end{array}$ & Positivo \\
\hline NRPB7 & $\begin{array}{l}\text { Subunidade 07 da RNA polimerase II. Envolvida em transcrição e } \\
\text { processamento de RNAs. }\end{array}$ & Negativo \\
\hline
\end{tabular}

(Continua) 
Tabela 7(Conclusão)

\begin{tabular}{|c|c|c|}
\hline Proteína & Processos no qual sua homóloga participa & Resultado \\
\hline $\mathrm{NtCDKF} ; 1$ & Regulação de proteínas por fosforilação & Negativo \\
\hline Cdc25-Like & $\begin{array}{l}\text { Possui similaridade com a CDC25 (cell division cycle 25) de } \\
\text { Schizosaccharomyces pombe. Retira fosforilações inibitórias de CDKs } \\
\text { envolvidas no ciclo celular }\end{array}$ & Negativo \\
\hline PP2A-4 & $\begin{array}{l}\text { Subunidade catalítica da fosfatase PP2. Envolvida na regulação do } \\
\text { ciclo celular por desfosforilação de proteínas }\end{array}$ & Negativo \\
\hline PP2A-2 & $\begin{array}{l}\text { Subunidade regulatória da fosfatase PP2. Envolvida na regulação } \\
\text { do ciclo celular por desfosforilação de proteínas }\end{array}$ & Negativo \\
\hline FBL17 & F-Box envolvida na degradação de inbidores de CDKs & Negativo \\
\hline TCP7 & Fator de transcrição envolvido na regulação de ciclo celular & Negativo \\
\hline WRKY32 & Fator de transcrição não caracterizado. & Negativo \\
\hline LARP6a & La-Related Protein 6 a. Envolvida no metabolismo de RNA & Negativo \\
\hline $\begin{array}{l}\text { FRIGIDA- } \\
\text { Like }\end{array}$ & Regulação do florescimento & Negativo \\
\hline $\begin{array}{l}5^{\prime}-3^{\prime}- \\
\text { Exonuclease }\end{array}$ & $\begin{array}{l}\text { Proteína desconhecida que possui o domínio exonuclease H3TH } \\
\text { (belix-3-turn-belix). Esse domínio também corresponde a domínio } \\
\text { encontrado nas DNAs polimerase para ligação ao DNA. }\end{array}$ & Negativo \\
\hline $\begin{array}{l}\text { Pleckstin- } \\
\text { domain }\end{array}$ & Putativo fator de transcrição ainda não caracterizado. & Negativo \\
\hline
\end{tabular}

A seguir, a Figura 25 mostra o resultado positivo para o teste da interação entre NtSCI1 e a subunidade NRPB11 da RNA Polimerase II.
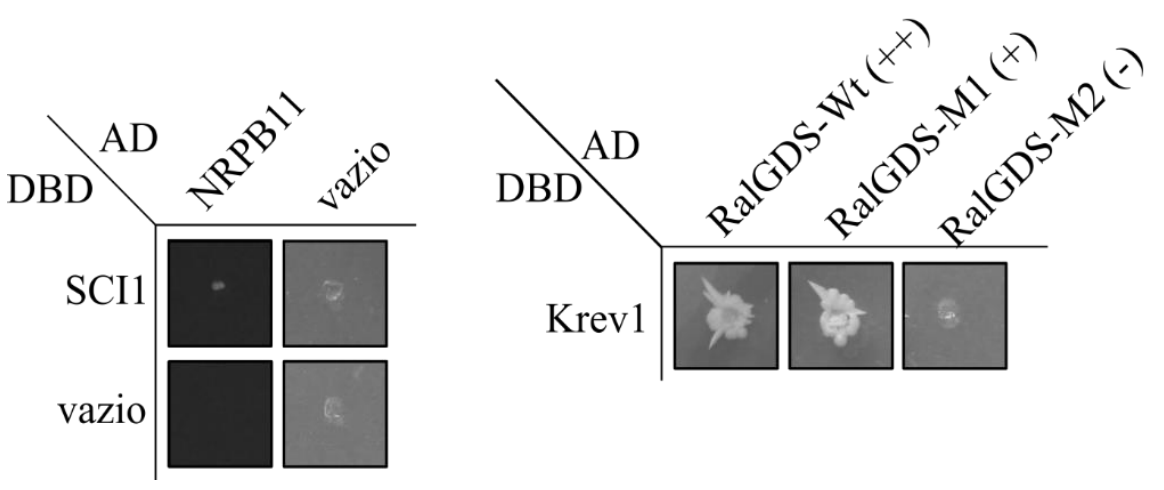

Figura 25: Interação testada por Y2H entre a subunidade NRPB11 da RNA Polimerase II e a proteína NtSCI1. A proteína NtSCI1 está em fusão com o DNA binding domain - DBD do fator de transcrição GAL4, enquanto a proteína NRPB11 está em fusão com o activation domain - AD do fator de transcrição GAL4. Os ensaios de interação controles do experimento e o ensaio de autoativação da isca DBD-NtSCI1 são mostrados na imagem à direita. Através destes ensaios, vemos que a proteína NtSCI1 interage, porém, fracamente, com a subunidade NRPB11 da RNA polimerase II.

Esses resultados sugerem que a proteína NtCDKG;2 está envolvida em processos mais gerais de ciclo celular que não envolvem, necessariamente, a proteína NtSCI1. Entretanto, é 
importante ressaltar que um resultado negativo em experimento de $\mathrm{Y} 2 \mathrm{H}$ não indica que as proteínas testadas não interagem, apenas mostra que essa interação não é direta. Assim, não foi descartada a hipótese de que NtSCI1 interaja de maneira indireta com essas proteínas testadas. Para isso, deverão ser realizados testes de interação por BiFC e/ou outras técnicas.

\subsection{IDENTIFICAÇÃO DE PUTATIVAS SEQUÊNCIAS CIS REGULATÓRIAS DO PROMOTOR E DA SEQUÊNCIA INTRÔNICA DE NtSCI1}

O produto da expressão do gene NtSCI1 é um inibidor de proliferação celular tecidoespecifico. Entretanto, ainda são desconhecidos os fatores genéticos que regulam a sua expressão, em que momento ou em resposta a que fatores ambientais essa regulação ocorre. Uma análise extensiva em busca de domínios cis regulatórios nas regiões intrônicas de NtSCI1 foi apresentada por Strini (2014). Dentre eles, o autor identificou elementos de regulação em resposta a auxina e um elemento para interação com a proteína WUSCHEL. No entanto, a putativa região promotora de NtSCI1 ainda não havia sido identificada.

O genoma parcial de N. tabacum foi recentemente publicado (Sierro et al., 2014) tornando possível também a identificação e análise das putativas regiões promotoras. Para identificar as putativas regiões promotoras de NtSCI1, foram feitas análises de similaridade utilizando o banco de dados NCBI. Ao final, a região compreendida entre a última ORF encontrada upstream e o ATG inicial de NtSCI1 foi considerada como putativa região promotora. Essa consideração foi feita em ambas cópias de N. tomentosiformis e N. sylvestris. Ao final, em N. tomentosiformis e N. sylvestris a putativa região promotora de NtSCI1 se estende a 1937 pb e 1455 pb upstream ao ATG inicial, respectivamente.

As sequências das putativas regiões promotoras de ambas as cópias de NtSCI1 foram submetidas à análise para identificação de elementos cis regulatórios nos bancos de dados PLACE (Plant Cis-acting Regulatory DNA Elements) e PlantCARE (Cis-acting Regulatory Elements). Em alguns casos, foram encontradas múltiplas cópias de um mesmo elemento. As listas contendo todos os possíveis elementos cis regulatórios que foram identificados em ambas as cópias de NtSCI1 estão nos Apêndices D e E. A presença de dois genes homeólogos codificadores de NtSCI1 resulta do processo de hibridação entre N. tomentosiformis e N. sylvestris, o qual ocorreu há 200.000 (DOYLE et al., 2008). Visto que esse é um processo recente na história da evolução, acredita-se que os homeólogos tenham funções redundantes, sendo, portanto, regulados da mesma forma. Portanto, foram considerados relevantes para a regulação de NtSCI1 os elementos cis regulatórios que 
encontrados em ambas cópias dos putativos promotores. A Figura 26 aponta a localização de alguns elementos cis regulatórios presentes na região promotora de ambas cópias de NtSCI1. Dentre todos elementos identificado, a Tabela 8 apresenta alguns dos elementos cis regulatórios comuns às duas cópias de NtSCI1 e os elementos considerados mais interessantes ao trabalho. Além disso, a tabela informa quais as suas sequências e quantas cópias estão presentes em cada genoma e quais fatores de transcrição se ligam a essas sequências. 


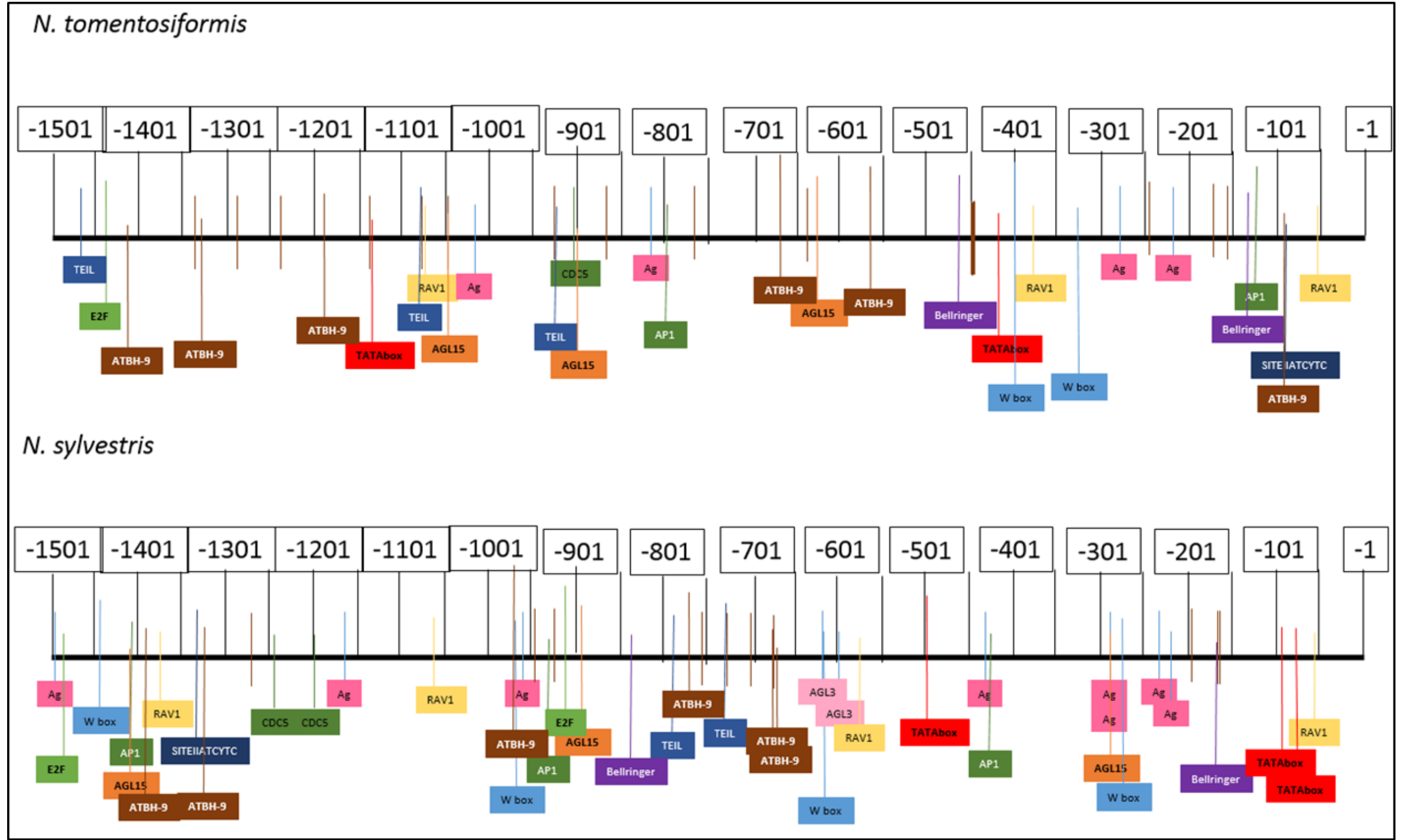

Figura 26: Desenho esquemático de $1500 \mathrm{pb}$ da sequência promotora do gene $\mathbf{N t S C I 1}$ das cópias de $\mathbf{N}$. tomentosiformis (desenho de acima) e $\mathbf{N}$. sylvestris (desenho de baixo). Os blocos coloridos indicam a localização dos elementos cis regulatórios correspondentes. 
Tabela 8: Lista contendo os principais elementos cis regulatórios identificados e sua sequência nos putativos promotores de $\mathbf{N t S C I 1}$ das cópias referentes a $\mathbf{N}$. tomentosiformis e $\mathrm{N}$. sylvestris. ${ }^{a}{ }^{k}$ : os fatores de transcrição que se ligam a cada um dos elementos estão listados ao final da tabela.

\begin{tabular}{|c|c|c|}
\hline Elemento & $\begin{array}{l}\text { Sequências dos elementos em NtSCI1 } \\
-N \text {. tomentosiformis }\end{array}$ & $\begin{array}{c}\text { Sequências dos elementos em } \\
N t S C I 1-N \text {. sylvestris }\end{array}$ \\
\hline \multirow[t]{3}{*}{ CarG-box a } & CATATATATG & CAAATAATTG \\
\hline & CATTAATATG & CATTTTTTTAG \\
\hline & CAAAATAATG & CCAAATTTGG \\
\hline \multirow[t]{6}{*}{$\mathrm{AG}^{\mathrm{b}}$} & taaаCCAAAaaagaaaaa & ggtagtaacTT'TGGggcg \\
\hline & tttatacca'T'TGGagat & ggcatagtgTT'TGGtgtc \\
\hline & tttagaccaTTTGGGattg & ggcgCCAAAttgtttgag \\
\hline & CCATTTGGAGA & ttccCCAAAaatcctaaa \\
\hline & CСATT'T'TAAGT & gttaCCAAAtttggacct \\
\hline & & gagtCCAAAagaaccaca \\
\hline \multirow[t]{3}{*}{ AP1 c } & CTAAAAA & CCAAAAA \\
\hline & CCAAAAA & CTAAAAA \\
\hline & & TTTTTAG \\
\hline \multirow[t]{2}{*}{ BELLRINGER ${ }^{\mathrm{d}}$} & AAATTAGT & AAATTAAT \\
\hline & TCTAATTT & AAATTAGA \\
\hline \multirow[t]{6}{*}{ ATHB-9 e } & agacttaATCATtgagcta & ctagcgcATCATtacctgc \\
\hline & attaagaATCATaatttga & ggttgttATGATatctgct \\
\hline & gaaactaATCATcaataag & tttttttATGATctagaaa \\
\hline & tgtttgaATGATtagctta & atgtgctATGATtgataat \\
\hline & tcgctcgATCATtttcatt & tcacctaATGATtatatga \\
\hline & tgcggctATCATaactagt & \\
\hline \multirow[t]{2}{*}{$\mathrm{CDC}^{\mathrm{f}}$} & tgtTCAGCtaa & ttgTCAGCcac \\
\hline & & tctTCAGCtgt \\
\hline \multirow[t]{5}{*}{ W BOX ${ }^{g}$} & TGACT & GTCAA \\
\hline & TGACT & AGTCA \\
\hline & & TGACT \\
\hline & & GGTCA \\
\hline & & GGTCA \\
\hline \multirow{2}{*}{$\begin{array}{l}\text { E2F } \\
\text { CONSENSUS h }\end{array}$} & CGGCGAAT & GGGCGAAT \\
\hline & & GCGCCAAA \\
\hline ANT $^{\mathrm{i}}$ & ttTCGGGtatcgct & \\
\hline
\end{tabular}

${ }^{a}$ : diversas MADS-Box - (HEPWORTH et al., 2002; SMACZNIAK et al., 2012)

${ }^{b}$ : AG (AGAMOUS) - TANG; PERRY, 2003

c: AP1 (APETALA1) - TILLY; ALLEN; JACK, 1998

$\mathrm{d}$ :BELL1 (BELL HOMEOBOX PROTEIN 1) - BAO et al., 2004

e: ATHB-9 (HOMEOBOX-LEUCINE ZIPPER PROTEIN ATHB-9) - WILLIAMS et al., 2005

f: Cdc 5 (CELL DIVISION CONTROL PROTEIN 5) - HIRAYAMA; SHINOZAKI, 1996 (Continua) 
g: diversos WRKY (WRKY DNA-BINDING PROTEIN) - YU; CHEN; CHEN, 2001

h: E2F (ELONGATION FACTOR E2F) - VANDEPOELE et al., 2005

i: ANT (AINTEGUMENTA) - KRIZEK, 2003

\subsection{IDENTIFICAÇÃO DE FATORES DE TRANSCRIÇÃO QUE POSSAM SE LIGAR AOS DOMÍNIOS CIS REGULATÓRIOS DE NtSCI1}

Conforme indicado na Tabela anterior (8), foram identificados alguns fatores de transcrição que possam se ligar aos respectivos domínios cis regulatórios da região promotora de NtSCI1 pertencente às cópias de N. tomentosiformis e N. sylvestris. Dentre os fatores de transcrição, alguns possuem funções bem estabelecidas na regulação do desenvolvimento de órgãos florais, proliferação celular, embriogênese, resposta a estresses e hormônios. A seguir, são abordadas algumas características dos fatores de transcrição identificados como possíveis reguladores da transcrição de NtSCI1.

As análises in silico mostram que os putativos promotores de cada uma das cópias de NtSCI1 possuem 3 elementos gerais (CarG-Box) para ligação de fatores de transcrição do tipo MADS-Box. Em plantas, os fatores de transcrição MADS-Box são conhecidos pelo controle da identidade dos órgãos florais, sobretudo por serem reguladores-chave no que se refere à transição da fase vegetativa para reprodutiva (SMACZNIAK et al., 2012). A ampla maioria dos genes relacionados à determinação da identidade dos meristemas e dos órgãos florais pertence à família MADS-box (RIJPKEMA et al., 2010). Estudos também apontam para funções desses fatores de transcrição no desenvolvimento do fruto (BUSI et al., 2003).

Também foram identificados 5 elementos de ligação ao fator de transcrição AGAMOUS 1 (AG1) no putativo promotor de $N$. tomentosiformis e 6 elementos no putativo promotor de $N$. sylvestris. A proteína AG1 é um membro da família MADS-Box e está envolvida na especificação da identidade dos estames e do carpelo, na identidade do meristema floral e na regulação do desenvolvimento dos óvulos (MODRUSAN et al., 1994).

Adicionalmente, foram identificados 2 elementos de ligação ao fator de transcrição APETALA 1 (AP1) no putativo promotor de N. tomentosiformis e 3 elementos no putativo promotor de N. sylvestris. A proteína AP1 também é membro da família de fatores de transcrição MADS-Box e participa da determinação do meristema floral ao suprimir a formação de novas flores (BOWMAN et al., 1993; HAN; JIAO, 2015; IRISH; SUSSEX, 1990).

De acordo com as análises in silico, as putativas sequências promotoras de $N$. tomentosiformis e N. sylvestris apresentam elementos para ligação aos fatores de transcrição BELL HOMEOBOX 
PROTEIN 1 (BELL1) e HOMEOBOX-LEUCINE ZIPPER PROTEIN ATHB-9 (ATHB-9). As proteínas da família homeobox são necessárias para a regulação do desenvolvimento em vertebrados, invertebrados, fungos e plantas. Elas são categorizadas de acordo com seus domínios de associação (MUKHERJEE; BROCCHIERI; BÜRGLIN, 2009). O fator de transcrição BELL1 pertence a uma das 11 classes de proteínas homeobox encontradas em plantas (BÜRGLIN; AFFOLTER, 2015). Ele possui papel no desenvolvimento de óvulos através da supressão do gene AGAMOUS (MODRUSAN et al., 1994; RAY et al., 1994; TAMARA L. WESTERN; GEORGE W. HAUGHN, 1999). O fator de transcrição ATHB-9 pertence a outra classe de proteínas homeobox específica de plantas, a classe HD-Zip. Fatores de transcrição dessa classe estão envolvidos em diversos processos, dentre eles, regulação meristemática (MCCONNELL et al., 2001; OTSUGA et al., 2001; WILLIAMS et al., 2005). É proposto que os fatores de transcrição PHABULOSA, PHAVOLUTA e CORONA, pertencentes à classe HD-Zip, restrinjam a atividade de SAM através da regulação da transcrição do gene WUS (WILLIAMS et al., 2005).

Também foram identificados elementos para ligação ao fator de transcrição Myb-related Cdc5. Em Arabidopsis, esse fator de transcrição é expresso em tecidos com altas taxas de proliferação celular e sua ausência em processos embrionários é letal. Ele é essencial para a correta transição de G2/M, um importante momento de checagem durante o ciclo celular. Em decorrência disso, sua ausência compromete o funcionamento do meristema apical caulinar (Shoot Apical Meristem -SAM) e suprime as vias de sinalização dos genes Wuschel-Clavata (WUS-CLV) e Shoot Meristemless (STM). Entretanto, ainda não ficou estabelecido se Cdc5 se liga diretamente aos promotores dos genes WUS, CLV e STM ou se a sua participação na regulação desses genes é indireta (HIRAYAMA; SHINOZAKI, 1996; LIN et al., 2007).

Adicionalmente, foram identificados elementos de ligação a fatores de transcrição do tipo WRKY em ambas cópias de NtSCI1. A família de fatores de transcrição WRKY está envolvida em muitos processos de desenvolvimento das plantas, em todos os órgãos. Estudos apontam que os fatores de transcrição WRKY participam da resistência a drogas e sinalização de ABA (LUO et al., 2013a; TRIPATHI; RABARA; RUSHTON, 2014), desenvolvimento e germinação dos grãos de pólen, desenvolvimento da semente, embriogênese, crescimento da raiz, além de atuarem na transição da fase vegetativa para reprodutiva (EULGEM et al., 2000; GRUNEWALD et al., 2011; GUAN et al., 2014; LUO et al., 2013b). Em Arabidopsis, WRKY2 ativa a transcrição do gene WOX (WUSCHEL RELATED HOMEOBOX) e direciona as divisões assimétricas do zigoto (UEDA; ZHANG; LAUX, 2011). Recentemente, foi constatado que o fator de transcrição WRKY71 promove a aceleração do florescimento através de sua ligação ativadora aos promotores dos genes FLOWERING LOCUS T (FT) e LEAFY (LFY) (YU et al., 2016). 
Por sua vez, nas duas cópias de NtSCI1 foram identificados elementos regulatórios para ligação de fatores de transcrição pertencentes à família E2F. Os membros dessa família podem funcionar como ativadores ou repressores transcricionais. Em geral, eles são responsáveis por decidir se a célula irá ou não se dividir, através da regulação de genes-alvos necessários para diferenciação, progressão do ciclo celular, apoptose, reparo e replicação de DNA (DEGREGORI, 2002; DEGREGORI; KOWALIK; NEVINS, 1995; HUI-ZI CHEN; LEONE, 2009; ZHAN et al., 2014, 2016). Além disso, a transcrição de genes necessários para as transições de fase G1-S e G2-M também é regulada por fatores E2F (MATSUNAGA et al., 2013).

A Tabela 8 mostra que o putativo promotor de NtSCI1 pertencente à cópia de $N$. tomentosiformis contém um elemento regulatório que se liga ao fator de transcrição AINTEGUMENTA (ANT). Esse fator de transcrição pertence à superfamília de fatores de transcrição específicos de planta AP2/ERF (APETALA 2/Etbylene Response Factor). É proposto que o fator de transcrição ANT atue como promotor da proliferação celular e da identidade meristemática (HORSTMAN et al., 2014, 2015), além de regular número e crescimento de células durante a organogênese (MIZUKAMI; FISCHER, 2000). A proteína ANT é expressa tanto em tecidos vegetativos quanto florais e os fenótipos dos mutantes indicam que ANT desempenha função no crescimento do tegumento e desenvolvimento dos óvulos, além de manter o crescimento de primórdios florais e vegetativos (BAKER et al., 1997; ELLIOTT et al., 1996; KEVIN M. KLUCHER, HELEN CHOW, LEONORE REISER, 1996). Os defeitos em iniciação e crescimento de órgãos florais dos mutantes ant sugerem, ainda, que a sua proteína possa estar envolvida na regulação da divisão celular em flores (KRIZEK, 1999, 2009). Também é proposto que ANT atue de forma redundante à proteína AP2 ao reprimir AG em células da segunda camada do meristema floral e que esteja envolvido na promoção da identidade das pétalas (KRIZEK; PROST; MACIAS, 2000).

Sabe-se que NtSCI1 afeta o desenvolvimento do pistilo e isso acontece devido a alterações na proliferação celular nesse órgão. Adicionalmente, é preciso ressaltar que os maiores níveis de expressão de NtSCI1 concentram-se em estádios iniciais de desenvolvimento do pistilo (DEPAOLI et al., 2011). Portanto, é coerente que os elementos cis-regulatórios identificados estejam envolvidos com identidade meristemática e do carpelo e também com progressão celular. Também foram identificados elementos aos quais se ligam fatores de transcrição responsivos a hormônios (vide Apêndices D e E), o que é suportado pela já proposta hipótese de que NtSCI1 seja controlado em resposta a auxina (DEPAOLI; DORNELAS; GOLDMAN, 2014). 


\subsection{OBTENÇÃO DAS SEQUÊNCIAS UPSTREAM E DOWNSTREAM AO ATG INICIAL DE NtSCI1}

\subsubsection{AMPLIFICAÇÃO DOS PUTATIVOS PROMOTORES DE NtSCI1 DAS CÓPIAS} DE N. tomentosiformis E N. sylvestris

Considerando as análises in silico do putativo promotor NtSCI1 da cópia de N. tomentosiformis, optou-se por amplificar um fragmento de 2202 pb, o qual inclui 1937 bases anteriores ao ATG inicial e mais 265 bases correspondentes ao primeiro éxon, o primeiro íntron e parte do segundo éxon de NtSCI1. Em relação à cópia de NtSCI1 de N. sylvestris, optou-se por amplificar uma sequência de aproximadamente 3000 pb, sendo 1455 pb anteriores ao ATG inicial até parte do terceiro éxon. Foram definidos primers de orientação reversa diferentes para manter a especificidade das reações. Na Figura 27, a banda de, aproximadamente, 2,2 kb corresponde ao fragmento amplificado de NtSCI1 cópia de $N$. tomentosiformis e a banda de aproximadamente $3 \mathrm{~kb}$ corresponde ao fragmento de NtSCI1 cópia N. sylvestris.

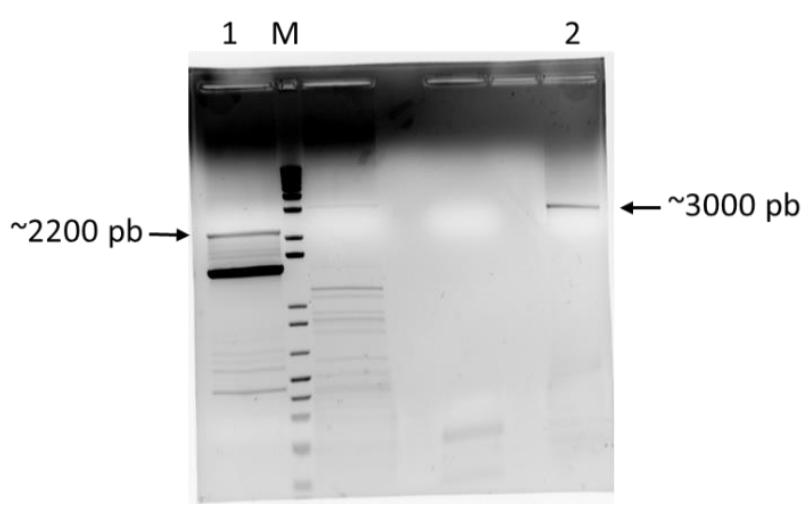

Figura 27: Amostras de PCR analisadas por eletroforese em gel de agarose 1\%. As bandas indicadas pelas flechas correspondem aos fragmentos esperados para NtSCI1 cópia de N. tomentosiformis $(\sim 2200 \mathrm{pb}$, à esquerda) e cópia de N. sylvestris ( 3000 pb, à direita).

A seguir, as bandas correspondentes aos fragmentos desejados foram excisadas do gel, purificadas pelo método de limpeza com fenol/clorofórmio e adeniladas. O produto adenilado foi clonado no plasmídeo PCR2.1 TOPO-TA, transformado em células eletrocompetentes DH10B e, logo após, foram feitas minipreparações de DNA plasmidial. Ao total, foram selecionadas 24 colônias que deveriam corresponder ao promotor de NtSCI1 cópia de N. tomentosiformis e 19 colônias que deveriam corresponder ao promotor de NtSCI1 cópia de N. sylvestris. Os DNAs foram 
digeridos com a enzima de restrição EcoRI e analisados por eletroforese em gel de agarose (Figura 28). Os tamanhos esperados dos fragmentos após digestão eram de $\sim 2200$ pb e $\sim 4000$ pb para a cópia de $N$. tomentosiformis e $\sim 3000$ pb e $\sim 4000$ pb para a cópia de N. sylvestris. Após corrida eletroforética, por apresentarem os padrões desejados, as amostras 2, 12, 19 e 23 de NtSCI1 cópia de $N$. tomentosiformis e as amostras 2, 11, 15, 18 e 19 de NtSCI1 cópia de N. sylvestris foram sequenciadas. O sequenciamento confirmou a amplificação e clonagem das cópias de $N$. tomentosiformis e sylvestris no vetor PCR2.1 TOPO-TA. O DNA correspondente à amostra 23 do promotor de NtSCI1 cópia de N. tomentosiformis foi escolhido para ser levado adiante nos experimentos.

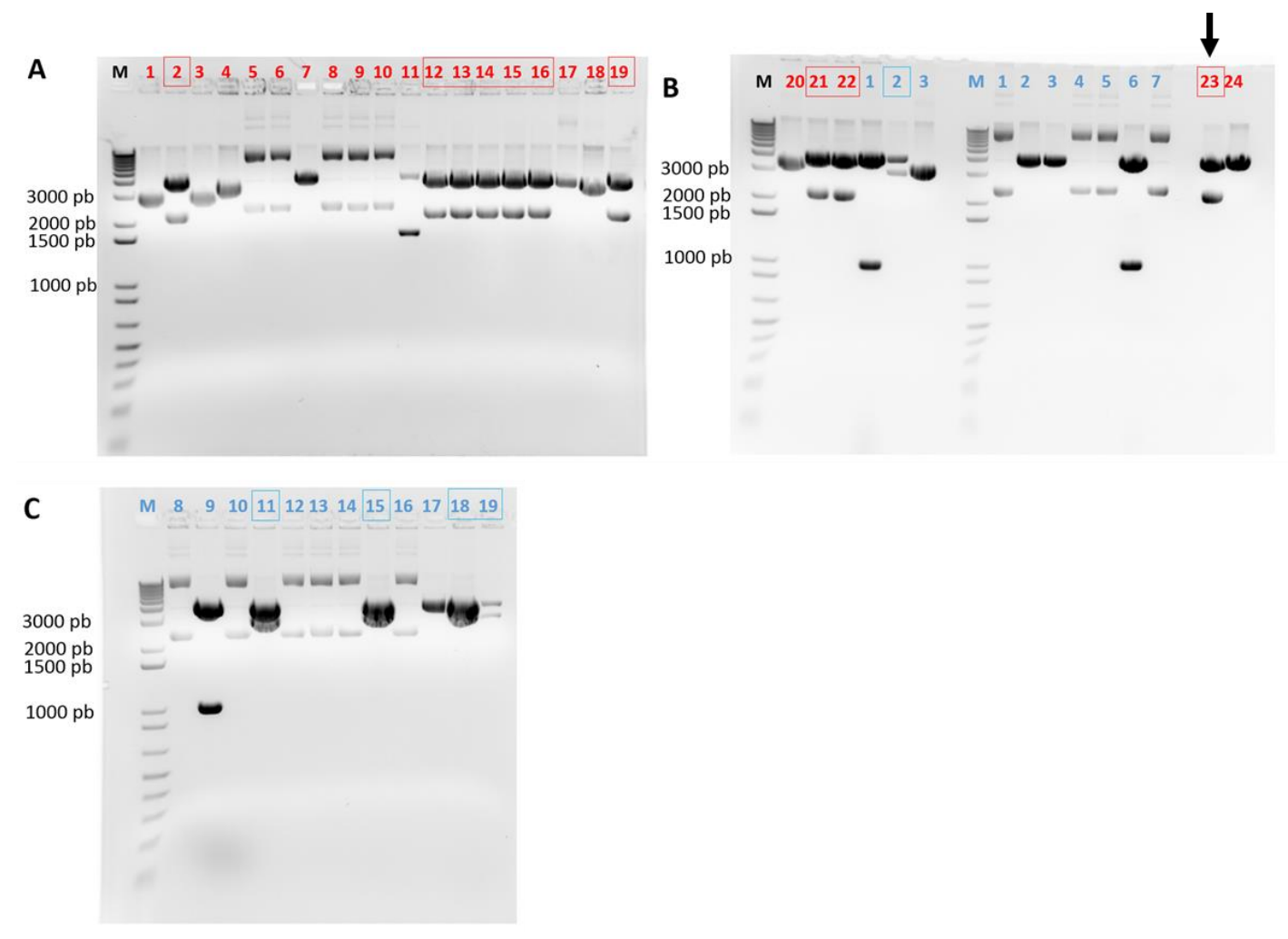

Figura 28: A, B e C: Géis de agarose 1\% após eletroforese. M: Marcador de Peso Molecular 1 kb Plus DNA Ladder (Invitrogen); Em vermelho: amostras 1 a 24 das minipreparações de DNA plasmidial de colônias resultantes da ligação do promotor de NtSCI1 cópia de N. tomentosiformis, no plasmídeo PCR2.1 TOPO-TA, após digestão com EcoRI; Em azul: amostras 1 a 19 das minipreparações de DNA plasmidial de colônias resultantes da ligação do promotor de NtSCI1 cópia de N. sylvestris, no plasmídeo PCR2.1 TOPO-TA, após digestão com EcoRI. As amostras selecionadas 2, 12, 13, 14, 15, 16, 19, 21, 22 e 23 de NtSCI1 cópia de N. tomentosiformis e 2, 11, 15, 18 e 19 de NtSCI1 cópia de N. sylvestris apresentam os padrões de bandas esperados. 


\subsubsection{AMPLIFICAÇÃO DA REGIÃO DOWNSTREAM AO ATG INICIAL DE NtSCI1} CÓPIA DE $N$. tomentosiformis

De acordo com análises in silico, o fragmento genômico downstream ao ATG inicial até o stop codon de NtSCI1 da cópia vinda de N. tomentosiformis deveria ter, aproximadamente, 2521 pb. Para amplificar o DNA genômico de N. tabacum, foram utilizados oligonucleotídeos que pareiam desde o ATG inicial ao stop codon. O fragmento de, aproximadamente, $2.5 \mathrm{~kb}$ foi obtido com sucesso (Figura 29).

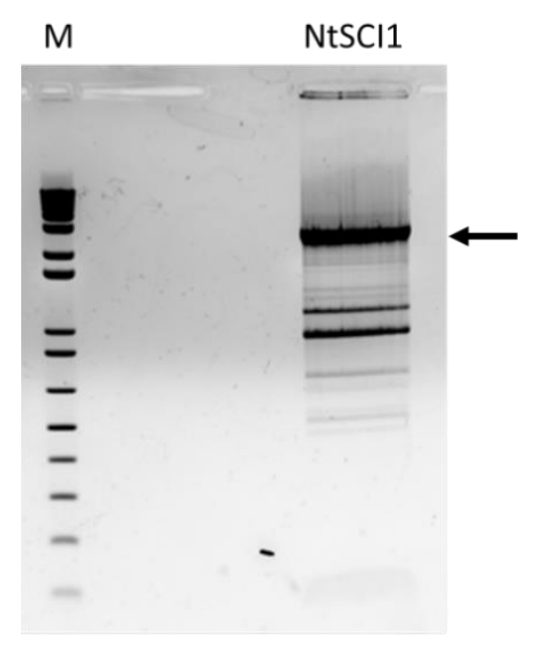

Figura 29: Eletroforese em gel de agarose 1\%. M: Marcador de Peso Molecular 1 kb Plus DNA Ladder (Invitrogen); A banda indicada pela flecha corresponde ao tamanho esperado para amplificação da região transcrita de NtSCI1 referente à cópia de N. tomentosiformis ( 2521 pb).

O fragmento de DNA selecionado foi excisado do gel, purificado e clonado no vetor PCR2.1 TOPO-TA. O produto da clonagem foi transformado em bactérias competentes da cepa DH10B por eletroporação e, a seguir, foram feitas minipreparações de DNA plasmidial de 16 colônias. A Figura 30 apresenta os fragmentos das 16 minipreparações de DNA plasmidial após digestão com a enzima EcoRI. 


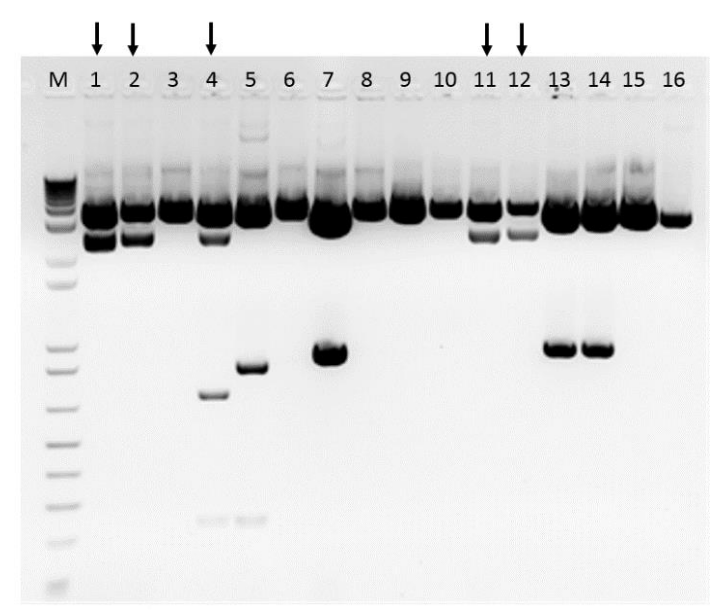

Figura 30: Gel de agarose 1\% após eletroforese. M: Marcador de Peso Molecular 1 kb Plus DNA Ladder (Invitrogen); Amostras 1 a 16 das minipreparações de DNA plasmidial de colônias, resultantes da clonagem da região transcrita de NtSCI1 no plasmídeo PCR2.1 TOPO-TA, após digestão com a enzima EcoRI; As amostras indicadas pelas flechas superiores apresentam os padrões de bandas esperados $(\sim 2,5 \mathrm{~kb} \mathrm{e} \sim 4 \mathrm{~kb})$. A amostra 4 apresentou as duas bandas esperadas além de outras duas bandas ( $\sim 700 \mathrm{pb}$ e $\sim 280 \mathrm{pb}$ ), as quais podem ser fruto de contaminação.

O DNA plasmidial dos clones selecionados (1, 2, 4, 11 e 12) foi digerido com as enzimas de restrição HindIII e SacI (Figura 31). A seguir, o DNA do clone 1 foi sequenciado e verificou-se que corresponde à NtSCI1 cópia de N. tomentosiformis. Esse DNA foi utilizado para dar prosseguimento ao trabalho.

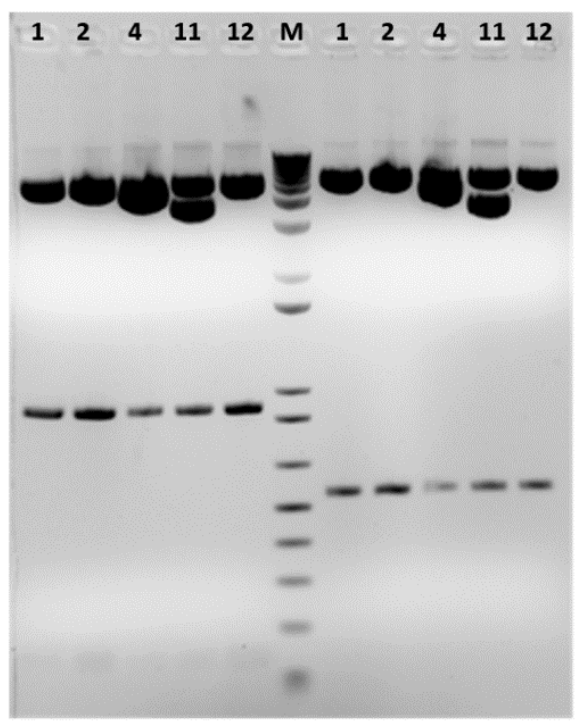

Figura 31: Gel de agarose 1\% após eletroforese. M: Marcador de Peso Molecular 1 kb Plus DNA Ladder (Invitrogen); Amostras 1, 2, 4, 11 e 12 das minipreparações de DNA plasmidial de colônias, resultantes da clonagem da região transcrita de NtSCI1 no plasmídeo PCR2.1 TOPO-TA, após digestão com as enzimas de restrição HindIII (amostras à esquerda do marcador) e SacI (amostras dispostas à direita do marcador). As amostras 1, 2 e 12 apresentam os padrões de bandas esperados. 


\subsection{ENSAIO DE INTERAÇÃO DNA-PROTEÍNA EM BUSCA DE FATORES DE TRANSCRIÇÃO QUE POSSAM REGULAR A EXPRESSÃO DE NtSCI1}

O Yeast one-hybrid é uma variação da técnica de $\mathrm{Y} 2 \mathrm{H}$ e consiste em um método muito utilizado para o estudo de interações de fatores de transcrição que se ligam a um determinado fragmento de DNA de interesse (REECE-HOYES; MARIAN WALHOUT, 2012). Esse ensaio é realizado in vivo em células de levedura. Para os testes de interação, o DNA-alvo ao qual as proteínas se ligam é inserido no genoma da levedura em uma região upstream ao gene repórter que confere resistência à Aurebasidina. As proteínas candidatas, por sua vez, são produzidas em fusão com o domínio AD do GAL4. Caso uma proteína candidata interaja com o fragmento de DNA, ocorre a transcrição do gene repórter e as células serão capazes de crescer em meio seletivo com Aureobasidina.

\subsubsection{ESCOLHA DOS FRAGMENTOS A SEREM ANALISADOS}

De acordo com resultados preliminares de RNA-Seq, obtidos em nosso laboratório (Ferreira, dados não publicados), a cópia de NtSCI1 N. tomentosiformis é, aparentemente, duas vezes mais expressa que a cópia vinda de N. sylvestris. Além disso, análises detalhadas em busca por elementos cis regulatórios, contidos nos íntrons de NtSCI1 cópia N. tomentosiformis, mostram um possível sítio de regulação pela proteína WUSCHEL localizado no terceiro íntron (STRINI, 2010). A proteína WUSCHEL é conhecida por atuar na determinação do meristema floral de $A$. thaliana (Sablowski, 2007). Devido a essas razões, a cópia NtSCI1 de N. tomentosiformis foi escolhida para realizar os ensaios de Yeast One-Hybrid e identificar possíveis fatores de transcrição que regulam esse gene. Assim, com base em análises in silico, foram selecionados quatro fragmentos de interesse do gene NtSCI1 que apresentavam putativos elementos cis regulatórios mais relevantes ao estudo do desenvolvimento do pistilo. Desses fragmentos, três pertencem ao putativo promotor e o quarto fragmento abrange parte do terceiro íntron de NtSCI1. Os quatro fragmentos selecionados para os estudos possuem, aproximadamente, 500 pb e estão apresentados na Figura 32. 


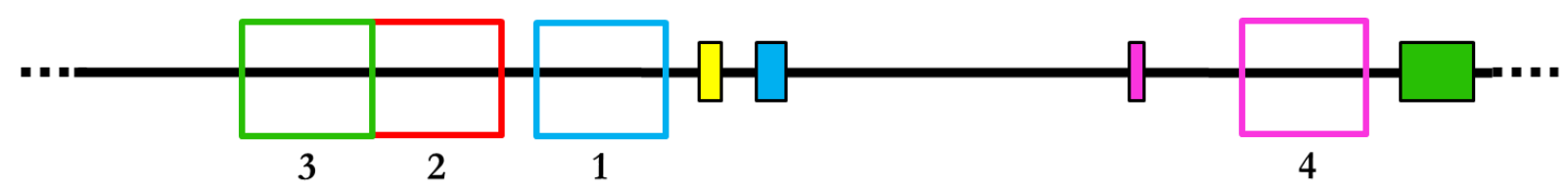

Figura 32: Fragmentos genômicos de NtSCI1 pertencente à cópia de $\mathbf{N}$. tomentosiformis, que foram escolhidos para os experimentos de Yeast One-Hybrid $(\mathrm{Y} 1 \mathrm{H})$. Os blocos preenchidos em amarelo, azul, rosa e verde correspondem ao primeiro, segundo, terceiro e quarto éxons, respectivamente. Os fragmentos 1 (azul), 2 (vermelho) e 3 (verde), representados em blocos coloridos não preenchidos, fazem parte da putativa sequência promotora do gene NtSCI1. E, por fim, o Fragmento 4 está localizado no terceiro íntron de NtSCI1.

\subsubsection{CONSTRUÇÃO DOS VETORES PARA ENSAIOS DE INTERAÇÃO DNA- PROTEÍNA EM LEVEDURA}

Para a realização dos ensaios, os fragmentos 1, 2 e 3 do promotor e o fragmento 4, contendo o terceiro íntron de NtSCI1 cópia de N. tomentosiformis foram amplificados e, em suas extremidades, foram colocados os sítios attB1 e attB2. Os produtos das amplificações foram purificados e clonados no vetor de entrada pDONR221. As células de E. coli foram transformadas com cada uma das recombinações e o DNA plasmidial das colônias obtidas para cada transformação foi extraído e analisado por digestões enzimáticas. A seguir, as amostras foram recombinadas com o vetor pAbAi-GW e transformadas em E. coli. Ao final, o DNA plasmidial de cada uma das amostras foi sequenciado e os plasmídeo de integração com cada um dos fragmentos foi nomeado conforme tabela que segue (Tabela 9).

Tabela 9: Amostras selecionadas após clonagens no plasmídeo de integração (pINT) pAbAi-GW.

\begin{tabular}{|l|l|}
\hline Nome do clone & $\mathbf{N}^{\mathbf{o}}$ do Fragmento \\
\hline pINT-Frag1_promNtSCI1 & $1-$ promotor \\
\hline pINT-Frag2_promNtSCI1 & $2-$ promotor \\
\hline pINT-Frag3_promNtSCI1 & 3 - promotor \\
\hline pINT-Frag4_3'Íntron NtSCI1 & $4-$ terceiro íntron \\
\hline
\end{tabular}




\subsubsection{TRANSFORMAÇÃO E INTEGRAÇÃO DOS DNAS-ALVO NO GENOMA DE LEVEDURAS E TESTE DE AUTOATIVAÇÃO}

Após identificação dos fragmentos 1, 2, 3 e 4 e clonagem dos mesmos em plasmídeos de integração, os DNAs plasmidiais foram linearizados com a enzima BstBI e, a seguir, integrados no genoma de leveduras da cepa PJ69-4 $\alpha$. Após a integração, foram selecionadas 10 colônias para que fosse realizado o ensaio de autoativação do sistema com o antibiótico aureobasidina (AbA). O gene repórter $A U R$ 1-C está contido no genoma da levedura utilizada e confere resistência ao antibiótico AbA. Quando ocorre interação entre as proteínas presas e o fragmento de DNA inserido na levedura, há transcrição de $A U R 1-C$ e, por consequência, a célula se torna resistente à $\mathrm{AbA}$. O teste de autoativação do sistema foi feito utilizando concentrações entre 0 e $500 \mathrm{ng} / \mathrm{ml}$ de AbA. A seguir, foi selecionada 1 colônia contendo cada um dos fragmentos de interesse para fazer o screening (Figura 33).

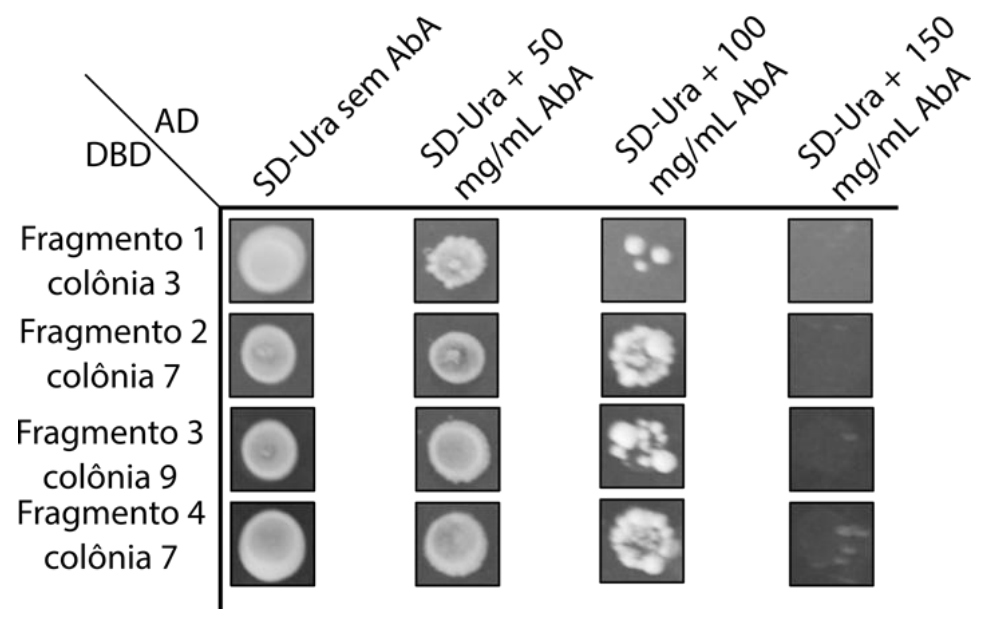

Figura 33: Teste de autoativação para ensaio de Y1H. As colônias analisadas possuem os fragmentos 1,2 e 3 do promotor e de parte do terceiro íntron (fragmento 4) de NtSCI1 correspondente à cópia de $\boldsymbol{N}$. tomentosiformis. Ao total, foram analisadas 10 colônias com cada um dos fragmentos. Nesta Figura, são mostradas as colônias que foram selecionadas. Todas elas cresceram na placa SD-Ura com $100 \mathrm{~m} / \mathrm{mL}$ do antibiótico Aureobasidina (AbA), porém, não cresceram quando a concentração do referido antibiótico aumentou para $150 \mathrm{mg} / \mathrm{mL}$. 


\subsubsection{SCREENING EM BUSCA DE PUTATIVOS FATORES DE TRANSCRIÇÃO QUE INTERAGEM COM OS DNAS-ALVO DO PROMOTOR E DA SEQUÊNCIA INTRÔNICA DE NtSCI1}

Para fazer um screening em busca de proteínas que possam regular a expressão de NtSCI1, foi utilizada a biblioteca de cDNAs construída por Strini (2014), a qual contém cDNAs de estigmas e estiletes de N. tabacum. Colônias contendo cada um dos 4 fragmentos foram transformadas com cDNAs da biblioteca de presas. Ao total, foram realizados 4 screenings em busca de proteínas regulatórias para os fragmentos (DNAs-alvo) integrados no genoma de levedura. Com base nos ensaios de autoativação, foram utilizadas concentrações específicas de AbA (indicadas na metodologia, item 3.25.4). Ao total, cresceram 367 colônias, correspondentes aos 4 ensaios de Y1H, sendo que 128, 154, 57 e 28 colônias são derivadas dos ensaios com os fragmentos 1, 2, 3 e 4, respectivamente. A Figura abaixo (34) esquematiza o número de colônias produzidas e a posição dos fragmentos em relação à sequência de DNA de NtSCI1.

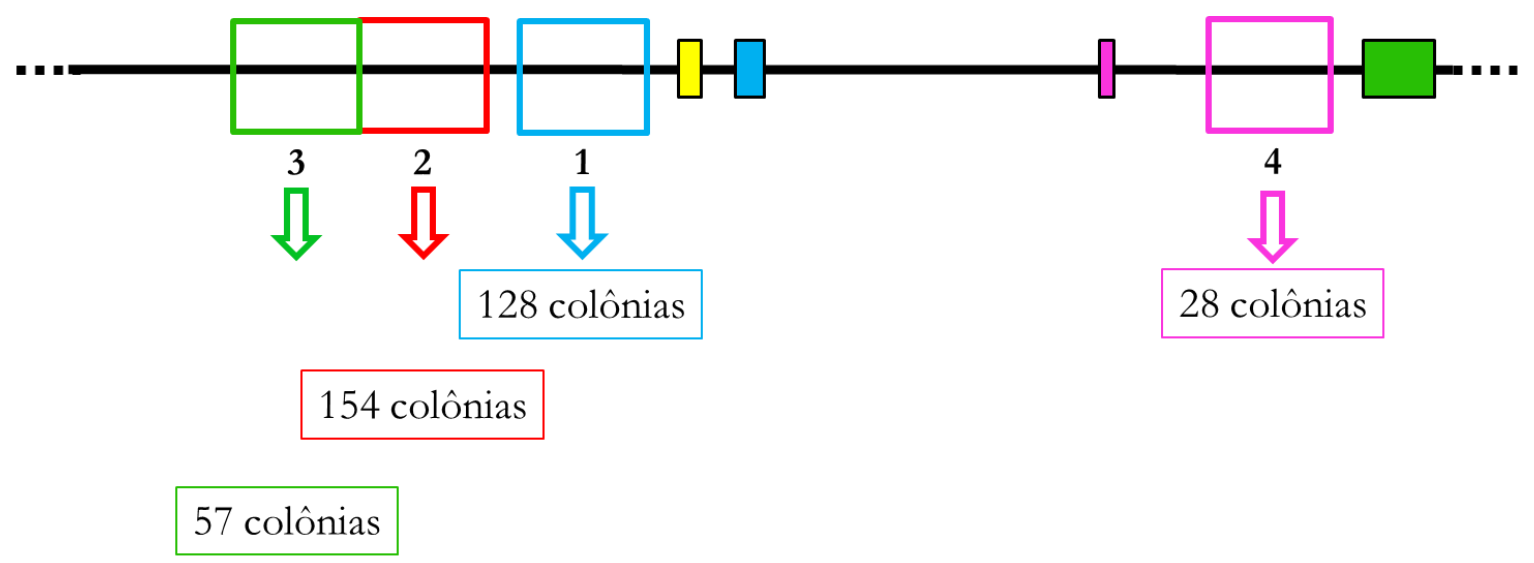

Figura 34: Representação esquemática apontando a posição dos fragmentos 1, 2 e 3 na região promotora e do fragmento 4 na região intrônica de $\mathbf{N} \boldsymbol{t} \boldsymbol{S C I 1}$. O total de colônias geradas em cada um dos ensaios de $\mathrm{Y} 1 \mathrm{H}$ está destacado para cada um dos fragmentos.

O screening Y1H ainda está em andamento e servirá como uma importante ferramenta para a descoberta de fatores de transcrição que possam regular a expressão de NtSCI1. Além disso, os resultados obtidos nesse ensaio auxiliarão a compreensão das vias em que NtSCI1 atua para regular a proliferação celular em pistilos de N. tabacum. 


\section{MODELOS PROPOSTOS}

\section{Regulação da expressão de NtSCI1}

Foi demonstrado que NtSCI1 possui um efeito evidente no tamanho do pistilo das plantas (DEPAOLI et al., 2011; 2014). Em suma, as plantas de silenciamento possuíam estiletes alongados e aumento da área estigmática. Análises histológicas mostraram que isso se deve ao aumento do número de células. Além disso, os pistilos das plantas transgênicas com NtSCI1 silenciado se desenvolviam temporalmente mais cedo que os pistilos de plantas selvagens. Esse fenótipo é evidenciado pelo início precoce das divisões celulares na região de fusão dos carpelos, as quais culminam na formação do estigma (DEPAOLI et al., 2011). No nosso entendimento, esse momento representa o término do meristema floral. Sabe-se que a terminação do meristema é iniciada por AG e reprimida por WUS, que por sua vez é reprimido por AG. Portanto, devido aos motivos putativos de ligação de WUS e AG encontrados na sequência genômica de NtSCI1, sugerese que a expressão desse gene no pistilo seja regulada por elementos que estejam diretamente envolvidos no controle do término do meristema floral e nas vias de desenvolvimento de órgãos florais.

\section{Inibição da proliferação celular através da interação de NtSCI1 com a proteína NtCDKG;2}

As células das plantas vasculares diferem das células animais por não possuírem centríolos. Por isso, quais proteínas estão associadas e como ocorre a organização do fuso acromático ainda são questões que não foram elucidadas completamente nessas células vegetais. Foi mostrado que a isoforma CDK11 ${ }^{\mathrm{p} 46}$, homóloga de NtCDKG;2 em humanos, é capaz de se autofosforilar e, sequencialmente, interage com a proteína RanBPM, fosforilando-a (MIKOLAJCZYK et al., 2003). Mais tarde, foi demonstrado que a CDK11 é um fator de estabilização dos microtúbulos dependente de RanGTP (YOKOYAMA et al., 2008). Os ensaios de localização subcelular deste trabalho, mostram que NtCDKG;2 se localiza em uma região que se assemelha à região ocupada pelas fibras do fuso acromático de plantas durante as diferentes fases do ciclo celular. Além disso, o screening de $\mathrm{Y} 2 \mathrm{H}$ possibilitou a identificação da interação entre NtCDKG;2 com uma RanBP1de N. tabacum, uma proteína-chave na dissociação de RanGTP através do poro nuclear (SEEWALD et al., 2003). Somando-se a isso, as análises in silico da proteína NtCDKG;2 permitiram a identificação de um sítio de interação que seria reconhecido por uma proteína BRCA1. Em 
humanos, recentemente foi demonstrado que essa proteína é fosforilada pela Aurora A (BRODIE; HENDERSON, 2012). Também foi mostrado o papel dessa quinase na regulação da inibição que BRCA1 exerce sobre a nucleação de microtúbulos dependente de centrossomos (SANKARAN et al., 2007). Adicionalmente, este trabalho mostra que a interação entre NtSCI1 e NtCDKG;2 ocorre no nucléolo durante a intérfase. A literatura aponta que, devido às particularidades já mencionadas, em células vegetais o processo de nucleação dos microtúbulos inicia na intérfase e é sugerido que os sítios candidatos à nucleação se localizam no citoplasma e na superfície nuclear (MURATA; HASEBE, 2010). Em conjunto, todos esses dados sugerem que NtSCI1 mantenha NtCDKG;2 no nucléolo, impedindo a proteína de interagir com seus parceiros para organização do fuso acromático e, por consequência, impedindo a progressão do ciclo celular no pistilo.

\section{Envolvimento de NtCDKG;2 nos processos de transcrição e splicing}

A localização subcelular de NtCDKG;2 mostra que essa proteína também é encontrada em speckles nucleares. Para reforçar a ideia de que NtCDKG;2 se localiza em speckles, foram realizados ensaios através dos quais foi demonstrado que a proteína NtCDKG;2 co-localiza com os marcadores nucleares de speckles AtSRp34 e AtCypRS64. Através de ensaios de Y2H com um screening de uma biclioteca de cDNAs de estigmas/estiletes de N. tabacum, o presente trabalho e o trabalho de Ferreira (2016), paralelamente realizado em nosso laboratório, identificou e confirmou diversos parceiros de interação com NtCDKG;2. Muitas das proteínas identificadas possuem homólogos em outras espécies envolvidos com transcrição, como as subunidades NRPB7 e NRPB11 da RNA polimerase II, cinco putativos fatores de transcrição (TCP14, Homeobox 22, WRKY32 e dois fatores que contêm o domínio Pleckstrin Homology). Além disso, os trabalhos verificaram a interação entre NtCDKG;2 e proteínas relacionadas ao processamento de RNA, como a proteína de ligação a RNA LARP-6a e o fator de splicing U2A'. Além dessas, foi identificada a interação com a proteína NtCDKF;1. Essa proteína fosforila o CTD da RNA Polimerase II e, dessa forma, auxilia a transcrição e o splicing co-transcricional (HAJHEIDARI et al., 2012). É importante salientar que Ferreira (2016) também identificou a interação de NtCDKG;2 com o CTD da RNA Polimerase II, por Y2H. Somando os resultados obtidos da localização de $\mathrm{NtCDKG;2} \mathrm{em} \mathrm{splicing} \mathrm{speckles} \mathrm{e} \mathrm{sua} \mathrm{interação} \mathrm{com} \mathrm{os} \mathrm{parceiros} \mathrm{identificados} \mathrm{nos} \mathrm{ensaios} \mathrm{de} \mathrm{Y} 2 \mathrm{H}$, propõem-se que NtCDKG;2 também exerça papel nos processos de transcrição e de splicing. 
Conclusões 


\section{CONCLUSÕES}

A presente tese atendeu a todos os questionamentos propostos e, assim, contribuiu para a elucidação dos mecanismos que envolvem NtSCI1 e sua parceira NtCDKG;2 na regulação da proliferação celular no pistilo de N. tabacum. Os resultados apresentados neste trabalho permitem as seguintes conclusões:

1. A proteína NtCDKG;2 está presente no nucleoplasma e também se localiza em speckles nucleares, conforme os dados referentes à co-localização com os marcadores de speckles nucleares AtCypRS64-RFP e AtSRp34-RFP.

2. A localização subcelular da proteína NtCDKG;2 durante o ciclo celular sugere que essa proteína possa atuar na organização do fuso mitótico, um evento ainda não esclarecido em plantas. 3. Foi identificado um putativo sítio para tradução cap-independente (IRES) na sequência de RNA de NtCDKG;2. A presença desse sítio e a identificação de uma putativa isoforma de tamanho semelhante ao esperado, sugere fortemente que NtCDKG;2 possua uma isoforma produzida pela tradução mediada por IRES em folhas de N. tabacum.

4. Em folhas de N. tabacum, foi identificada uma putativa isoforma de NtCDKG;2 que pode ser gerada por clivagem.

5. Análises in silico realizadas na proteína $\mathrm{NtCDKG;2} \mathrm{apontaram} \mathrm{motivos} \mathrm{de} \mathrm{interação} \mathrm{com}$ proteína do tipo F-Box, ciclina, CDK, fosfatase e 14-3-3. Além disso, indicaram o local onde possa ocorrer a interação do complexo CDK-ciclina com o respectivo inibidor.

6. O screening de duplo-híbrido foi altamente eficiente para desvendar diversas proteínas parceiras de interação de NtCDKG;2, as quais foram confirmadas por ensaios de Y2H.

7. Dentre as proteínas identificadas pelo screening de Y2H, destaca-se a proteína NtCDKF;1, uma importante CDK ativadora de outras CDKs e reguladora do CTD da RNA polimerase II. 
8. Adicionalmente, foi identificada a interação entre NtCDKG;2 e a proteína NtCBP1, a qual possui papel importante na regulação inicial da transcrição de proteínas mediadoras do crescimento do tubo polínico.

9. $\mathrm{O}$ screening de $\mathrm{Y} 2 \mathrm{H}$ também possibilitou a identificação da interação entre NtCDKG;2 e NtRanBP1, uma proteína chave na formação do fuso mitótico. Essa interação reforça a hipótese do envolvimento de NtCDKG;2 durante a organização do fuso mitótico de plantas.

10. A interação entre as proteínas NtCDKG;2 e NtSCI1 ocorre em uma região localizada na periferia nucleolar. Sugere-se que a proteína NtCDKG;2 somente seja encontrada nessa região enquanto está interagindo com NtSCI1.

11. As proteínas NtCDKG;2 e Nt14-3-3D interagem diretamente, como verificado por $\mathrm{Y} 2 \mathrm{H}$. Essa interação provavelmente ocorre através dos sítios identificados nas análises in silico.

12. NtSCI1 interage com a subunidade NRPB11 da RNA Polimerase II, por Y2H, uma das parceiras de interação de NtCDKG;2. Essa interação sugere que NtSCI1 possa ter uma participação durante o processo de transcrição.

13. Análises in silico da sequência genômica de NtSCI1 indicaram a presença de putativos elementos cis-regulatórios, que seriam importantes na regulação da sua transcrição. Muitos desses elementos identificados estão relacionados a eventos como manutenção do meristema, da formação do carpelo e progressão do ciclo celular. 
Referências Bibliográficas 


\section{REFERÊNCIAS BIBLIOGRÁFICAS}

ALBERTS B. Molecular Biology of The Cell. 5th ed. New York, NY: Garland Science. 2008.

ALLI, E.; FORD, J. M. BRCA1 : Beyond double-strand break repair. DNA Repair, v. 32, p. 165$171,2015$.

AMMERER, G. Identification, purification, and cloning of a polypeptide (PRTF/GRM) that binds to mating-specific promoter elements in yeast. Genes \& Development, v. 4, p. 299-312, 1990.

ANDERSEN, S. U. et al. Requirement of B2-type cyclin-dependent kinases for meristem integrity in Arabidopsis thaliana. The Plant cell, v. 20, n. 1, p. 88-100, 2008.

ARIZA, M. E. et al. Fas-induced apoptosis in human malignant melanoma cell lines is associated with the activation of the p34(cdc2)-related PITSLRE protein kinases. J Biol CheM, v. 274, n. 40, p. 28505-28513, 1999.

BAKER, S. C. et al. Interactions among genes regulating ovule development in Arabidopsis thaliana. Genetics, v. 145, n. 4, p. 1109-1124, 1997.

$\mathrm{BAO}, \mathrm{X}$. et al. Repression of AGAMOUS by BELLRINGER in floral and inflorescence meristems. The Plant cell, v. 16, n. 6, p. 1478-1489, 2004.

BECKER, F. et al. A three-hybrid approach to scanning the proteome for targets of small molecule kinase inhibitors. Canadian Field-Naturalist, v. 11, n. 2, p. 211-223, 2004.

BEMER, M. et al. The tomato FRUITFULL homologs TDR4/FUL1 and MBP7/FUL2 regulate ethylene-independent aspects of fruit ripening. The Plant cell, v. 24, n. 11, p. 4437-4451, 2012.

BERGERVOET, J. H. W. et al. High amounts of nuclear DNA in tomato (Lycopersicon esculentum Mill.) pericarp. Plant Science, v. 116, p. 141-145, 1996.

BEYAERT, R. et al. Cleavage of PITSLRE Kinases by ICE/CASP-1 and CPP32/CASP-3 during Apoptosis Induced by Tumor Necrosis Factor. Journal Of Biological Chemistry, v. 272, n. 18, p. 11694, 1997.

BISCHOFF, F. R.; PONSTINGL, H. Mitotic regulator protein RCC1 is complexed with a nuclear ras-related polypeptide. Proceedings of the National Academy of Sciences of the United States of America, v. 88, n. 23, p. 10830-4, 1991.

BISCHOFF, J. R.; PLOWMAN, G. D. The Aurora/Ipl1p kinase family: Regulators of chromosome segregation and cytokinesis. Trends in Cell Biology, v. 9, n. 11, p. 454-459, 1999. 
BLAND, M. M.; MATZINGER, D. F.; LEVINGS, C. S. Comparison of the mitochondrial genome of Nicotiana tabacum with its progenitor species. Theoretical and Applied Genetics, v. 69, n. 5-6, p. 535-541, 1985.

BOISVERT, F.-M. et al. The multifunctional nucleolus. Nat Rev Mol Cell Biol, v. 8, n. 7, p. 574 $85,2007$.

BORUC, J. et al. Functional modules in the Arabidopsis core cell cycle binary protein-protein interaction network. The Plant cell, v. 22, n. 4, p. 1264-1280, 2010a.

BORUC, J. et al. Systematic localization of the Arabidopsis core cell cycle proteins reveals novel cell division complexes. Plant physiology, v. 152, n. 2, p. 553-65, fev. 2010 b.

BOUDOLF, V. et al. B1-Type Cyclin-Dependent Kinases Are Essential for the Formation of Stomatal Complexes in Arabidopsis thaliana. Society, v. 16, p. 945-955, 2004.

BOWMAN, J. L. et al. Control of flower development in Arabidopsis thaliana by APETALA1 and interacting genes. Development, v. 119, p. 721-743, 1993.

BOWMAN, J. L.; SMYTH, D. R.; MEYEROWITZ, E. M. Genes directing flower development in Arabidopsis. The Plant cell, v. 1, n. 1, p. 37-52, 1989.

BOWMAN, J. L.; SMYTH, D. R.; MEYEROWITZ, E. M. Genetic interactions among floral homeotic genes of Arabidopsis. Development (Cambridge, England), v. 112, p. 1-20, 1991.

BRACHA-DRORI, K. et al. Detection of protein-protein interactions in plants using bimolecular fluorescence complementation. Plant Journal, v. 40, n. 3, p. 419-427, 2004.

BRODIE, K. M.; HENDERSON, B. R. Characterization of BRCA1 protein targeting, dynamics, and function at the centrosome: A role for the nuclear export signal, CRM1, and aurora a kinase. Journal of Biological Chemistry, v. 287, n. 10, p. 7701-7716, 2012.

BÜRGLIN, T. R.; AFFOLTER, M. Homeodomain proteins: an update. Chromosoma, p. 497$521,2015$.

BUSI, M. V. et al. MADS-box genes expressed during tomato seed and fruit development. Plant molecular biology, v. 52, p. 801-15, 2003.

CARRANO, A C. et al. SKP2 is required for ubiquitin-mediated degradation of the CDK inhibitor p27. Nature cell biology, v. 1, n. 4, p. 193-199, 1999.

CAUDRON, M. Spatial Coordination of Spindle Assembly by Chromosome-Mediated Signaling 
Gradients. Science, v. 309, n. 5739, p. 1373-1376, 2005.

CAUFIELD, J. H.; SAKHAWALKAR, N.; UETZ, P. A comparison and optimization of yeast two-hybrid systems. Methods, v. 58, n. 4, p. 317-324, 2012.

CEPEDA, D. et al. CDK-mediated activation of the SCFFBXO28 ubiquitin ligase promotes MYCdriven transcription and tumourigenesis and predicts poor survival in breast cancer. EMBO Molecular Medicine, v. 5, n. 7, p. 999-1018, 2013.

CHEVALIER, C. Cell cycle control and fruit development. In: INZÉ, D. (Ed.). . Annual Plant Reviews. Oxford: Blackwell Publishing Ltd, 2007. v. 32p. 269-293.

CHINI, A. Application of Yeast-Two Hybrid Assay to Chemical Genomic Screens: A HighThroughput System to Identify Novel Molecules Modulating Plant Hormone Receptor Complexes. In: HICKS, G. R.; ROBERT, S. (Eds.). . Y2H Chemical Genomic Screen Applied to Phytohormone Receptors. [s.1.] Methods Mol Biol, 2014. v. 1056p. 35-43.

CHOI, K. et al. The FRIGIDA Complex Activates Transcription of FLC , a Strong Flowering Repressor in Arabidopsis, by Recruiting Chromatin Modification Factors. v. 23, n. January, p. 289303, 2011.

CHUNG, M. Y. et al. A tomato (Solanum lycopersicum) APETALA2/ERF gene, SlAP2a, is a negative regulator of fruit ripening. Plant Journal, v. 64, n. 6, p. 936-947, 2010.

CHURCHMAN, M. L. et al. SIAMESE, a plant-specific cell cycle regulator, controls endoreplication onset in Arabidopsis thaliana. Plant Cell, v. 18, n. 11, p. 3145-3157, 2006.

CIANNAMEA, S. et al. Protein interactions of MADS box transcription factors involved in flowering in Lolium perenne. Journal of experimental botany, v. 57, n. 13, p. 3419-3431, 2006.

CORBESIER, L. et al. FT protein movement contributes to long-distance signaling in floral induction of Arabidopsis. Science (New York, N.Y.), v. 316, n. 5827, p. 1030-1033, 2007.

CORNELIS, S. et al. Identification and characterization of a novel cell cycle-regulated internal ribosome entry site. Molecular Cell, v. 5, n. 4, p. 597-605, 2000.

COSTA, L. M. et al. Central Cell-Derived Peptides Regulate Early Embryo Patterning in Flowering Plants. Science, v. 344, n. 6180, p. 168-172, 2014.

DE FOLTER, S.; IMMINK, R. G. H. Yeast protein-protein interaction assays and screens. In: Methods in Molecular Biology. [s.l: s.n.]. v. 754p. 145-165. 
DE LA FUENTE VAN BENTEM, S. et al. Phosphoproteomics reveals extensive in vivo phosphorylation of Arabidopsis proteins involved in RNA metabolism. Nucleic Acids Research, v. 34, n. 11, p. 3267-3278, 2006.

DE VEYLDER, L. et al. Functional analysis of cyclin-dependent kinase inhibitors of Arabidopsis. Plant Cell, v. 13, n. 7, p. 1653-1667., 2001.

DE VEYLDER, L.; BEECKMAN, T.; INZÉ, D. The ins and outs of the plant cell cycle. Nature reviews. Molecular cell biology, v. 8, n. 8, p. 655-65, ago. 2007.

DEGREGORI, J. The genetics of the E2F family of transcription factors: Shared functions and unique roles. Biochimica et Biophysica Acta - Reviews on Cancer, v. 1602, n. 2, p. 131-150, 2002.

DEGREGORI, J.; KOWALIK, T.; NEVINS, J. R. Cellular Targets for Activation by the E2F1 Transcription Factor Include DNA Synthesis- and G 1 / S-Regulatory Genes. v. 15, n. 8, p. 42154224, 1995.

DEMIDOV, D. et al. Identification and dynamics of two classes of aurora-like kinases in Arabidopsis and other plants. Plant Cell, v. 17, n. 3, p. 836-848, 2005.

DEPAOLI, H. C. et al. Stigma/style cell cycle inhibitor 1 (SCI1), a tissue-specific cell cycle regulator that controls upper pistil development. New Phytologist, v. 190, n. 4, p. 882-95, 2011.

DEPAOLI, H. C.; DORNELAS, M. C.; GOLDMAN, M. H. S. SCI1 is a component of the auxindependent control of cell proliferation in Arabidopsis upper pistil. Plant Science, v. 229, p. 122 130, 2014.

DEPAOLI, H.; GOLDMAN, G.; GOLDMAN, M.-H. SCI1, the first member of the tissuespecific inhibitors of CDK (TIC) class, is probably connected to the auxin signaling pathway. Plant Signaling \& Behavior, v. 7, n. 1, p. 1-6, 2012.

DESHAIES, R. J. SCF AND CULLIN/RING H2-BASED UBIQUITIN LIGASES. n. 15, p. 435-467, 1999.

DICKINSON, L. A. et al. Cyclin L is an RS domain protein involved in pre-mRNA splicing. Journal of Biological Chemistry, v. 277, n. 28, p. 25465-25473, 2002.

DINKEL, H. et al. ELM 2016-data update and new functionality of the eukaryotic linear motif resource. Nucleic acids research, v. 44, p. D294-300, 2016. 
DISSMEYER, N. et al. T-loop phosphorylation of Arabidopsis CDKA;1 is required for its function and can be partially substituted by an aspartate residue. The Plant cell, v. 19, n. 3, p. 972$85,2007$.

DONG, T. et al. A tomato MADS-box transcription factor, SIMADS1, acts as a negative regulator of fruit ripening. Plant physiology, v. 163, n. 2, p. 1026-36, 2013.

DOONAN, J. H.; KITSIOS, G. Functional evolution of cyclin-dependent kinases. Molecular biotechnology, v. 42, n. 1, p. 14-29, 2009.

DOYLE, J. J. et al. Evolutionary genetics of genome merger and doubling in plants. Annual review of genetics, v. 42, n. 1, p. 443-461, 2008.

DUCAT, D.; ZHENG, Y. Aurora kinases in spindle assembly and chromosome segregation. Experimental Cell Research, v. 301, n. 1, p. 60-67, 2004.

DUDERSTADT, K. E. et al. Replication-Fork Dynamics. Cold Spring Harb Perspect Biol, p. $1-17,2014$.

EGEA-CORTINES, M.; SAEDLER, H.; SOMMER, H. Ternary complex formation between the MADS-box proteins SQUAMOSA, DEFICIENS and GLOBOSA is involved in the control of floral architecture in Antirrhinum majus. EMBO Journal, v. 18, n. 19, p. 5370-5379, 1999.

ELLIOTT, R. C. et al. AINTEGUMENTA, an APETALA2-like Gene of Arabidopsis with Pleiotropic Roles in Ovule Development and Floral Organ Growth. v. 8, n. February, p. 155-168, 1996.

ESCOBAR, C. et al. Isolation of active DNA-binding nuclear proteins from tomato galls induced by root-knot nematodes. Plant Molecular Biology Reporter, v. 19, n. 4, p. 375a-375h, 2001.

EULGEM, T. et al. The WRKY superfamily of plant transcription factors. Trends in Plant Science, v. 5, n. 5, p. 199-206, 2000.

EVRARD, J.-L. et al. Plant TPX2 and related proteins. Plant signaling \& behavior, v. 4, n. 1, p. 69-72, 2009.

FENG, Y. et al. Death-signal-induced relocalization of cyclin-dependent kinase 11 to mitochondria. The Biochemical journal, v. 392, n. Pt 1, p. 65-73, 2005a.

FENG, Y. et al. The cyclin-dependent kinase 11 interacts with 14-3-3 proteins. Biochemical and biophysical research communications, v. 331, n. 4, p. 1503-9, 17 jun. 2005 b. 
FERRÁNDIZ, C. et al. Redundant regulation of meristem identity and plant architecture by FRUITFULL, APETALA1 and CAULIFLOWER. Development (Cambridge, England), v. 127 , n. 4, p. 725-734, 2000.

FERREIRA, P. B. Estudos de localização e interações proteína-proteína de uma putativa proteína quinase, NtCDKG;2, de Nicotiana tabacum. [s.l.] FACULDADE DE MEDICINA DE RIBEIRÃO PRETO - UNIVERSIDADE DE SÃO PAULO, 2013.

FERREIRA, P. B. A identificação de parceiros de interação de NtCDKG;2 revela suas possíveis funções biológicas em Nicotiana tabacum. [s.l.] FACULDADE DE MEDICINA DE RIBEIRÃO PRETO - UNIVERSIDADE DE SÃO PAULO, 2016.

FIELDS, S.; SONG, O. A novel genetic system to detect protein-protein interactions. Nature, v. 340, n. 6230, p. 245-246, 1989.

FITZGERALD, K. D.; SEMLER, B. L. Bridging IRES elements in mRNAs to the eukaryotic translation apparatus. Biochim Biophys Acta, v. 1789, n. 9-10, p. 518-528, jan. 2009.

FORMENT, J. et al. Expression of Arabidopsis SR-like splicing proteins confers salt tolerance to yeast and transgenic plants. The Plant journal, v. 30, n. 5, p. 511-519, jun. 2002.

FÜLÖP, K. et al. The Medicago CDKC;1-CYCLINT;1 kinase complex phosphorylates the carboxy-terminal domain of RNA polymerase II and promotes transcription. Plant Journal, v. 42, n. 6 , p. $810-820,2005$.

GILLASPY, G.; BEN-DAVID, H.; GRUISSEM, W. Fruits: A Developmental Perspective. The Plant cell, v. 5, n. 10, p. 1439-1451, 1993.

GIOVANNONI, J. Genetic regulation of fruit development and ripening. The Plant Cell Online, v. 16, p. 170-181, 2004.

GIOVANNONI, J. J. Fruit ripening mutants yield insights into ripening control. Current Opinion in Plant Biology, v. 10, n. 3, p. 283-289, 2007.

GOTO, K.; KYOZUKA, J.; BOWMAN, J. L. Turning floral organs into leaves, leaves into floral organs. Current Opinion in Genetics and Development, v. 11, n. 4, p. 449-456, 2001.

GRABER, T. E.; HOLCIK, M. Cap-independent regulation of gene expression in apoptosis. Molecular BioSystems, v. 3, n. 12, p. 825-834, 2007.

GRAIFER, D.; KARPOVA, G. Roles of ribosomal proteins in the functioning of translational 
machinery of eukaryotes. Biochimie, v. 109, p. 1-17, 2015.

GRAY, J. C. et al. Origin of Nicotiana tabacum L. detected by polypeptide composition of fraction I protein. v. 252, p. 226-227, 1974.

GRUNEWALD, W. et al. Transcription factor WRKY23 assists auxin distribution patterns during Arabidopsis root development through local control on fl avonol biosynthesis. Proceedings of the National Academy of Sciences of the United States of America, v. 109, n. 5, p. 1554 1559, 2011.

GU, Q. et al. The FRUITFULL MADS-box gene mediates cell differentiation during Arabidopsis fruit development.Development (Cambridge, England), 1998.

GUAN, Y. et al. Phosphorylation of a WRKY Transcription Factor by MAPKs Is Required for Pollen Development and Function in Arabidopsis. PloS one, v. 10, n. 5, 2014.

HAIZEL, T. et al. Characterization of proteins that interact with the GTP-bound form of the regulatory GTPase Ran in Arabidopsis. Plant Journal, v. 11, n. 1, p. 93-103, 1997.

HAJHEIDARI, M. et al. CDKF;1 and CDKD Protein Kinases Regulate Phosphorylation of Serine Residues in the C-Terminal Domain of Arabidopsis RNA Polymerase II. The Plant Cell, v. 24, n. 4, p. 1626-1642, 2012.

HAN, Y.; JIAO, Y. APETALA1 establishes determinate floral meristem through regulating cytokinins homeostasis in Arabidopsis. Plant Signaling \& Behavior, v. 10, n. 11, p. e989039, 2015.

HARASHIMA, H.; SHINMYO, A.; SEKINE, M. Phosphorylation of threonine 161 in plant cyclin-dependent kinase a is required for cell division by activation of its associated kinase. Plant Journal, v. 52, n. 3, p. 435-448, 2007.

HARTLEY, J. L.; TEMPLE, G. F.; BRASCH, M. A. DNA Cloning Using In Vitro Site-Specific Recombination. Genome Research, v. 10, n. 11, p. 1788-1795, 2000.

HEIJMANS, K.; MOREL, P.; VANDENBUSSCHE, M. MADS-box genes and floral development: the dark side. Journal of Experimental Botany, v. 63, n. 15, p. 5397-5404, 2012.

HELLIWELL, C. A. et al. The Arabidopsis FLC protein interacts directly in vivo with SOC1 and FT chromatin and is part of a high-molecular-weight protein complex. Plant Journal, v. 46, n. 2, p. 183-192, 2006.

HEPWORTH, S. R. et al. Antagonistic regulation of flowering-time gene SOC1 by CONSTANS 
and FLC via separate promoter motifs. EMBO Journal, v. 21, n. 16, p. 4327-4337, 2002.

HERNANDEZ-VERDUN, D. et al. The nucleolus: Structure/function relationship in RNA metabolism. Wiley Interdisciplinary Reviews: RNA, v. 1, n. 3, p. 415-431, 2010.

HERRERA-ESTRELLA, L. et al. Expression of chimaeric genes transferred into plant cells using a Ti-plasmid-derived vector. Nature, v. 303, p. 209-213, 1983.

HILEMAN, L. C. et al. Molecular and phylogenetic analyses of the MADS-box gene family in tomato. Molecular Biology and Evolution, v. 23, n. 11, p. 2245-2258, 2006.

HIRAYAMA, T.; SHINOZAKI, K. A cdc5+ homolog of a higher plant, Arabidopsis thaliana. Proceedings of the National Academy of Sciences, v. 93, n. 23, p. 13371-13376, 1996.

HIRT, H. et al. cdc2MsB, a cognate cdc2 gene from alfalfa, complements the G1/S but not the G2/M transition of budding yeast cdc28 mutants. Plant Journal, v. 4, n. 1, p. 61-69, 1993.

HO, L. C.; HEWITT, J. D. Fruit development. In: ATHERTON, J.; RUDICH, J. (EDS. . (Eds.). . The Tomato Crop: A scientific basis for improvement. [s.l: s.n.]. p. 201-239.

HORSTMAN, A. et al. AINTEGUMENTA-LIKE proteins : hubs in a plethora of networks. Trends in Plant Science, v. 19, n. 3, p. 146-157, 2014.

HORSTMAN, A. et al. STEM CELLS AND REGENERATION AIL and HDG proteins act antagonistically to control cell proliferation. p. 454-464, 2015.

HU, D. et al. CDK11 complexes promote pre-mRNA splicing. Journal of Biological Chemistry, v. 278, n. 10, p. 8623-8629, 2003.

HU, D. et al. CDK11(p58) is required for the maintenance of sister chromatid cohesion. Journal of cell science, v. 120, n. Pt 14, p. 2424-2434, 2007.

HUANG, T. et al. The mRNA of the Arabidopsis Gene FT Moves from Leaf to Shoot Apex and Induces Flowering. v. 309, p. 1694-1696, 2005.

HUANG, X.-Y. et al. CYCLIN-DEPENDENT KINASE G1 is associated with the spliceosome to regulate CALLOSE SYNTHASE5 splicing and pollen wall formation in Arabidopsis. The Plant cell, v. 25, n. 2, p. 637-648, 2013.

HUI-ZI CHEN, S.-Y. T.; LEONE, G. Emerging roles of E2Fs in cancer: an exit from cell cycle control. v. 9, n. 11, p. 785-797, 2009.

IMMINK, R. G. H. et al. SEPALLATA3: the "glue" for MADS box transcription factor complex 
formation. Genome biology, v. 10, n. 2, p. R24, 2009.

INAGAKI, S.; UMEDA, M. Cell-Cycle Control and Plant Development. 1. ed. [s.l.] Elsevier Inc., 2011. v. 291

INZÉ, D.; DE VEYLDER, L. Cell cycle regulation in plant development. Annual Review of Genetics, v. 40, p. 77-105, jan. 2006.

IRISH, V. F. The flowering of Arabidopsis flower development. Plant Journal, v. 61, n. 6, p. 1014-1028, 2010.

IRISH, V. F.; SUSSEX, I. M. Function of the apetala-1 gene during Arabidopsis floral development. The Plant cell, v. 2, n. 8, p. 741-753, 1990.

ITKIN, M. et al. TOMATO AGAMOUS-LIKE 1 is a component of the fruit ripening regulatory network. Plant Journal, v. 60, n. 6, p. 1081-1095, 2009.

JEFFREY, I. W. et al. Inhibition of protein synthesis in apoptosis: Differential requirements by the tumor necrosis factor ?? family and a DNA-damaging agent for caspases and the doublestranded RNA-dependent protein kinase. Cancer Research, v. 62, n. 8, p. 2272-2280, 2002.

JEFFREY, P. D. et al. Mechanism of CDK activation revealed by the structure of a cyclinA-CDK2 complex. Nature, v. 376, n. 6538, p. 313-320, 1995.

JOHANSON, U. et al. Molecular Analysis of FRÍGIDA, a Major Determinant of Natural Variation in Arabidopsis Flowering Time. Science, v. 290, n. October, p. 344-348, 2000.

JONES, D. T.; TAYLOR, W. R.; THORNTON, J. M. The rapid generation of mutation data matrices from protein sequences. Computer Applications in the Biosciences, v. 8, n. 3, p. 275282, 1992.

JONES, R. et al. The molecular life of plants. 1st. ed. [s.l: s.n.].

JONES-RHOADES, M. W.; BOREVITZ, J. O.; PREUSS, D. Genome-wide expression profiling of the Arabidopsis female gametophyte identifies families of small, secreted proteins. PLoS Genetics, v. 3, n. 10, p. 1848-1861, 2007.

JOUBÈS, J. et al. CDK-related protein kinases in plants. Plant molecular biology, v. 43, n. 5-6, p. $607-620,2000$.

KALÁB, P. et al. Analysis of a RanGTP-regulated gradient in mitotic somatic cells. Nature, v. 440, n. 7084 , p. 697-701, 2006. 
KARDAILSKY, I. et al. Activation tagging of the floral inducer FT. Science, v. 286, n. 5446, p. 1962-1965, 1999.

KARIMI, M.; INZÉ, D.; DEPICKER, A. GATEWAY ${ }^{\mathrm{TM}}$ vectors for Agrobacterium-mediated plant transformation. Trends in Plant Science, v. 7, n. 5, p. 193-195, 2002.

KARLOVA, R. et al. Transcriptome and metabolite profiling show that APETALA2a is a major regulator of tomato fruit ripening. The Plant cell, 2011.

KARLOVA, R. et al. Identification of microRNA targets in tomato fruit development using highthroughput sequencing and degradome analysis. Journal of Experimental Botany, v. 64, n. 7, p. 1863-1878, 2013.

KARLOVA, R. et al. Transcriptional control of fleshy fruit development and ripening. Journal of Experimental Botany, v. 65, n. 16, p. 4527-4541, 2014.

KARSENTI, E. The Mitotic Spindle: A Self-Made Machine. Science, v. 294, n. 5542, p. 543-547, 2001.

KAUFMANN, K.; MELZER, R.; THEISSE, G. MIKC-type MADS-domain proteins: Structural modularity, protein interactions and network evolution in land plants. Gene, v. 347, p. 183-198, 2005.

KENTON, A. et al. Characterization of the Nicotiana tabacum L. genome by molecular cytogenetics. MGG Molecular \& General Genetics, v. 240, n. 2, p. 159-169, 1993.

KEVIN M. KLUCHER, HELEN CHOW, LEONORE REISER, AND R. L. F. The AINTEGUMENTA Gene of Arabidopsis Required for Ovule and Female Gametophyte Development 1 s Related to the Floral Homeotic Gene APETALA2. v. 8, n. February, p. 137-153, 1996.

KIPREOS, E. T.; PAGANO, M. The F-box protein family. Gen Biol, v. 1, n. 5, p. 1-7, 2000.

KITSIOS, G. et al. A cyclin-dependent protein kinase, CDKC2, colocalizes with and modulates the distribution of spliceosomal components in Arabidopsis. The Plant journal : for cell and molecular biology, v. 54, n. 2, p. 220-35, abr. 2008.

KLEE, H. J.; GIOVANNONI, J. J. Genetics and Control of Tomato Fruit Ripening and Quality Attributes. Annual Review of Genetics, v. 45, n. 1, p. 41-59, 2011.

KNAPP, S. Floral diversity and evolution in the Solanaceae. In: Developmental genetics and 
plant evolution. [s.l: s.n.]. p. 267-297.

KOLTUNOW, A. M. et al. Different Temporal and Spatial Gene Expression Patterns Occur during Anther Development. The Plant cell, v. 2, n. 12, p. 1201-1224, 1990.

KOROLEVA, O. A et al. Dynamic behavior of Arabidopsis eIF4A-III, putative core protein of exon junction complex: fast relocation to nucleolus and splicing speckles under hypoxia. The Plant cell, v. 21, n. 5, p. 1592-606, 2009.

KRIZEK, B. A. Ectopic expression of AINTEGUMENTA in Arabidopsis plants results in increased growth of floral organs. Developmental genetics, v. 25, n. 3, p. 224-236, 1999.

KRIZEK, B. A. AINTEGUMENTA utilizes a mode of DNA recognition distinct from that used by proteins containing a single AP2 domain. Nucleic Acids Research, v. 31, n. 7, p. 1859-1868, 2003.

KRIZEK, B. A. AINTEGUMENTA and AINTEGUMENTA-LIKE6 Act Redundantly to Regulate Arabidopsis Floral Growth. v. 150, n. August, p. 1916-1929, 2009.

KRIZEK, B. A.; PROST, V.; MACIAS, A. AINTEGUMENTA Promotes Petal Identity and Acts as a Negative Regulator of AGAMOUS. v. 12, n. August, p. 1357-1366, 2000.

KRIZEK, B. A; MEYEROWITZ, E. M. Mapping the protein regions responsible for the functional specificities of the Arabidopsis MADS domain organ-identity proteins. Proceedings of the National Academy of Sciences of the United States of America, v. 93, n. 9, p. 4063-4070, 1996.

KUFER, T. A. et al. Human TPX2 is required for targeting Aurora-A kinase to the spindle. Journal of Cell Biology, v. 158, n. 4, p. 617-623, 2002.

LAFARGE, S.; MONTANÉ, M. H. Characterization of Arabidopsis thaliana ortholog of the human breast cancer susceptibility gene 1: AtBRCA1, strongly induced by gamma rays. Nucleic Acids Research, v. 31, n. 4, p. 1148-1155, 2003.

LAHTI, J. M. et al. PITSLRE protein kinase activity is associated with apoptosis. Mol Cell Biol, v. 15, n. 1, p. 1-11, 1995.

LAM, Y. W.; TRINKLE-MULCAHY, L. New insights into nucleolar structure and function. F1000Prime Reports, v. 7, n. April, p. 48, 2015.

LAUX, T. et al. The WUSCHEL gene is required for shoot and floral meristem integrity in 
Arabidopsis. Development (Cambridge, England), v. 122, p. 87-96, 1996.

LEE, J. et al. Cell cycle function of a rice B2-type cyclin interacting with a B-type cyclin-dependent kinase. The Plant journal : for cell and molecular biology, v. 34, n. 4, p. 417-25, maio 2003.

LEITCH, I. J. et al. The ups and downs of genome size evolution in polyploid species of Nicotiana (Solanaceae). Annals of Botany, v. 101, n. 6, p. 805-814, 2008.

LEITCH, I. J.; BENNETT, M. D. Genome downsizing in polyploid plants. Biological Journal of the Linnean Society, v. 82, n. 4, p. 651-663, 2004.

LENHARD, M. et al. Termination of stem cell maintenance in Arabidopsis floral meristems by interactions between Wuschel and Agamous. Cell, v. 105, n. 6, p. 805-814, 2001.

LESEBERG, C. H. et al. Interaction study of MADS-domain proteins in tomato. Journal of Experimental Botany, v. 59, n. 8, p. 2253-2265, 2008.

LI, F. et al. Modulation of RNA polymerase II phosphorylation downstream of pathogen perception orchestrates plant immunity. Cell Host and Microbe, v. 16, n. 6, p. 748-758, 2014.

LI, G. Y.; XING, M.; HU, B. A PSTAIRE CDK-like protein localizes in nuclei and cytoplasm of Physarum polycephalum and functions in the mitosis. Cell research, v. 14, n. 2, p. 169-175, 2004.

LI, H. J. et al. Arabidopsis CBP1 Is a Novel Regulator of Transcription Initiation in Central CellMediated Pollen Tube Guidance. Plant Cell, v. 27, n. 10, p. 2880-2893, 2015.

LILJEGREN, S. J. S. et al. SHATTERPROOF MADS-box genes control seed dispersal in Arabidopsis. Nature, v. 404, n. April, p. 0-4, 2000.

LIM, S.; KALDIS, P. Cdks, cyclins and CKIs: roles beyond cell cycle regulation. Development, v. 140, n. 15, p. 3079-3093, 2013.

LIN, Z. et al. AtCDC5 regulates the G2 to M transition of the cell cycle and is critical for the function of Arabidopsis shoot apical meristem. Cell research, v. 17, n. 9, p. 815-828, 2007.

LINSMAIER, E. M.; SKOOG, F. Organic growth factor requirements of tobacco tissue cultures. Physiologia Plantarum, v. 18, n. 1, p. 100-127, 1965.

LOMBARDI, R. et al. High-level HIV-1 Nef transient expression in Nicotiana benthamiana using the P19 gene silencing suppressor protein of Artichoke Mottled Crinckle Virus. BMC biotechnology, v. 9, p. 96, 2009.

LOPATO, S. et al. atSRp30, one of two SF2/ASF-like proteins from Arabidopsis thaliana, 
regulates splicing of specific plant genes. Genes and Development, v. 13, n. 8, p. 987-1001, 1999. LORKOVIĆ, Z. J. et al. Interactions of Arabidopsis RS domain containing cyclophilins with SR proteins and U1 and U11 small nuclear ribonucleoprotein-specific proteins suggest their involvement in pre-mRNA splicing. Journal of Biological Chemistry, v. 279, n. 32, p. 33890 33898, 2004.

LORKOVIĆ, Z. J.; JULIA, H.; BARTA, A. Use of fluorescent protein tags to study nuclear organization of the spliceosomal machinery in transiently transformed living plant cells. Molecular biology of the cell, v. 15, n. 7, p. 3233-3243, 2004.

LOYER, P. et al. The RNP protein, RNPS1, associates with specific isoforms of the p34cdc2related PITSLRE protein kinase in vivo. Journal of cell science, v. 111, p. 1495-506, 1998.

LOYER, P. et al. Characterization of cyclin L1 and L2 interactions with CDK11 and splicing factors: Influence of cyclin 1 isoforms on splice site selection. Journal of Biological Chemistry, v. 283, n. 12, p. 7721-7732, 2008.

LUBINI, G. Caracterização do gene NtCDKG ; 2 expresso no pistilo de Nicotiana tabacum L. [s.l.] FACULDADE DE MEDICINA DE RIBEIRÃO PRETO - UNIVERSIDADE DE SÃO PAULO, 2012.

LUNN, D. et al. Cell wall composition of tomato fruit changes during development and inhibition of vesicle trafficking is associated with reduced pectin levels and reduced softening. Plant Physiology and Biochemistry, v. 66, p. 91-97, 2013.

LUO, X. et al. Expression of wild soybean WRKY20 in Arabidopsis enhances drought toleranc. Journal of Experimental Botany, v. 64, n. 8, p. 2155-2169, 2013a.

LUO, X. et al. Ectopic Expression of a WRKY Homolog from Glycine soja Alters Flowering Time in Arabidopsis. PLoS ONE, v. 8, n. 8, p. 1-13, 2013 b.

MA, X. et al. CYCLIN-DEPENDENT KINASE G2 regulates salinity stress response and salt mediated flowering in Arabidopsis thaliana. Plant Molecular Biology, v. 88, n. 3, p. 287-299, 2015.

MASIERO, S. et al. Ternary complex formation between MADS-box transcription factors and the histone fold protein NF-YB. Journal of Biological Chemistry, v. 277, n. 29, p. 26429-26435, 2002.

MATSUNAGA, S. et al. New insights into the dynamics of plant cell nuclei and 
chromosomes. 1. ed. [s.l.] Elsevier Inc., 2013. v. 305

MCCONNELL, J. R. et al. Role of PHABULOSA and PHAVOLUTA in determining radial patterning in shoots. Nature, v. 411, n. June, p. 709-713, 2001.

MENGES, M. et al. Global analysis of the core cell cycle regulators of Arabidopsis identifies novel genes, reveals multiple and highly specific profiles of expression and provides a coherent model for plant cell cycle control. The Plant Journal, v. 41, n. 4, p. 546-66, 2005.

MESSING, J. et al. Sequence composition and genome organization of maize. PNAS, v. 101, n. 40, p. 14349-14354, 2004.

MICHAELS, S. D.; AMASINO, R. M. FLOWERING LOCUS C encodes a novel MADS domain protein that acts as a repressor of flowering. The Plant cell, v. 11, n. 5, p. 949-56, 1999.

MIKOLAJCZYK, M. et al. The cyclin-dependent kinase 11p46 isoform interacts with RanBPM. Biochemical and Biophysical Research Communications, v. 310, n. 1, p. 14-18, out. 2003.

MIKOLAJCZYK, M.; NELSON, M. A. Regulation of stability of cyclin-dependent kinase CDK11 p110 and a caspase-processed form, CDK11 p46, by Hsp90. v. 467, p. 461-467, 2004.

MISTELI, T. RNA splicing: What has phosphorylation got to do with it? Current Biology, v. 9, n. 6, p. 198-200, 1999.

MIZUKAMI, Y.; FISCHER, R. L. Plant organ size control : AINTEGUMENTA regulates growth and cell numbers during organogenesis. v. 97, n. 2, 2000.

MODRUSAN, Z. et al. Homeotic Transformation of Ovules into Carpel-like Structures in Arabidopsis. The Plant cell, v. 6, n. 3, p. 333-349, 1994.

MOKREJŠ, M. et al. IRESite - tool for the examination of viral and cellular internal ribosome entry sites. Nucleic Acids Research, v. 38, p. 1-6, 2009.

MORGAN, D. O. The cell cycle - Principles of control. London: New Science Press Ltd, 2007. MORLEY, S. J.; MCKENDRICK, L.; BUSHELL, M. Cleavage of translation initiation factor 4G (eIF4G) during anti-Fas IgM-induced $\backslash$ rapoptosis does not require signalling through the p38 mitogen-activated protein $\backslash$ r(MAP) kinase. FEBS Letters, v. 438, p. 41-48, 1998.

MUKHERJEE, K.; BROCCHIERI, L.; BÜRGLIN, T. R. A comprehensive classification and evolutionary analysis of plant homeobox genes. Molecular Biology and Evolution, v. 26, n. 12, p. 2775-2794, 2009. 
MÜLLER, D. et al. Cdk2-dependent phosphorylation of p27 facilitates its Myc-induced release from cyclin E/cdk2 complexes. Oncogene, v. 15, n. 21, p. 2561-76, 1997.

MURAD, L. et al. The origin of tobacco's T genome is traced to a particular lineage within Nicotiana tomentosiformis (Solanaceae). American Journal of Botany, v. 89, n. 6, p. 921-928, 2002.

MURASHIGE, T.; SKOOG, F. A Revised Medium for Rapid Growth and Bio Assays with Tobacco Tissue Cultures. Physiologia Plantarum, v. 15, p. 473-497, 1962.

MURATA, T.; HASEBE, M. Microtubule Nucleation and Organization in Plant Cells. In: The Plant Cytoskeleton. [s.l: s.n.]. p. 81-94.

NAGATA T, NEMOTO Y, H. S. Tobacco BY-2 cell line as the "HeLa" cells in the cell biology of higher plants. In: International Review of Cytology-a Survey of Cell Biology. [s.l: s.n.]. p. $1-30$.

NG, M.; YANOFSKY, M. F. Function and evolution of the plant MADS-box gene family. Nat Rev Genet, v. 2, p. 186-195, 2001.

NISHITANI, H. et al. Loss of RCC1, a nuclear DNA-binding protein, uncouples the completion of DNA replication from the activation of $\mathrm{cdc} 2$ protein kinase and mitosis. The EMBO journal, v. 10, n. 6, p. 1555-64, 1991.

NISHITANI, H. et al. Full-sized RanBPM cDNA encodes a protein possessing a long stretch of proline and glutamine within the $\mathrm{N}$-terminal region, comprising a large protein complex. Gene, v. 272, n. 1-2, p. 25-33, 2001.

NOCAROVA, E.; FISCHER, L. Cloning of transgenic tobacco BY-2 cells; an efficient method to analyse and reduce high natural heterogeneity of transgene expression. BMC plant biology, v. 9, p. $44,2009$.

NORMAN, C. et al. Isolation and properties of cDNA clones encoding SRF, a transcription factor that binds to the c-fos serum response element. Cell, v. 55, n. 6, p. 989-1003, 1988.

OTSUGA, D. et al. REVOLUTA regulates meristem initiation at lateral positions. Plant Journal, v. 25, n. 2, p. 223-236, 2001.

PALMER, I.; WINGFIELD, P. T. Preparation and Extraction of Insoluble (Inclusion-Body) Proteins from Escherichia coli. Curr Protoc Protein Sci, p. 1-25, 2004. 
PESARESI, P. et al. Genetic regulation and structural changes during tomato fruit development and ripening. Frontiers in plant science, v. 5, n. April, p. 124, 2014.

PETRETTI, C. et al. The PITSLRE/CDK11 p58 protein kinase promotes centrosome maturation and bipolar spindle formation. EMBO reports, v. 7, n. 4, p. 418-424, 2006.

PINYOPICH, A. et al. Assessing the redundancy of MADS-box genes during carpel and ovule development.Nature, 2003.

PORTUGAL, J.; WARING, M. J. Assignment of DNA binding sites for 4???,6-diamidine-2phenylindole and bisbenzimide (Hoechst 33258). A comparative footprinting study. BBA - Gene Structure and Expression, v. 949, n. 2, p. 158-168, 1988.

PUNTERVOLL, P. et al. ELM server: A new resource for investigating short functional sites in modular eukaryotic proteins. Nucleic Acids Research, v. 31, n. 13, p. 3625-3630, 2003.

RAY, A et al. Arabidopsis floral homeotic gene BELL (BEL1) controls ovule development through negative regulation of AGAMOUS gene (AG). PNAS, v. 91, n. 13, p. 5761-5765, 1994.

REDDY, A. S. N. Plant serine/arginine-rich proteins and their role in pre-mRNA splicing. Trends in Plant Science, v. 9, n. 11, p. 541-547, 2004.

REECE-HOYES, J. S.; MARIAN WALHOUT, A. J. Yeast one-hybrid assays: A historical and technical perspective. Methods, v. 57, n. 4, p. 441-447, 2012.

RIECHMANN, J. L.; KRIZEK, B. A.; MEYEROWITZ, E. M. Dimerization specificity ofArabidopsis MADS domain homeotic proteins APETALA1, APETALA3, PISTILLATA, and AGAMOUS. PNAS, v. 93, n. May, p. 4793-4798, 1996.

RIJPKEMA, A. S. et al. Variations on a theme: Changes in the floral ABCs in angiosperms. Seminars in Cell and Developmental Biology, v. 21, n. 1, p. 100-107, 2010.

RIPOLL, J. J. et al. A novel role for the floral homeotic gene APETALA2 during Arabidopsis fruit. Development, v. 138, n. 23, p. 5167-5176, 2011.

ROBLES, P.; PELAZ, S. Flower and fruit development in Arabidopsis thaliana. The International journal of developmental biology, v. 49, n. 5-6, p. 633-43, jan. 2005.

RUIZ-GARCÍA, L. et al. Different Roles of Flowering-Time Genes in the Activation of Floral lnitiation Genes in Arabidopsis. The Plant Cell, v. 9, p. 1921-1934, 1997.

SABLOWSKI, R. Flowering and determinacy in Arabidpsis. Journal of Experimental Botany, v. 
58, n. 5, p. 899-907, 2007.

SAINSBURY, S.; BERNECKY, C.; CRAMER, P. Structural basis of transcription initiation by RNA polymerase II. Nature reviews. Molecular cell biology, v. 16, n. 3, p. 129-143, 2015.

SANCHEZ, A. M. et al. Pistil factors controlling pollination. The Plant cell, v. 16, p. S98-S106, 2004.

SANKARAN, S. et al. Aurora-A kinase regulates breast cancer-associated gene 1 inhibition of centrosome-dependent microtubule nucleation. Cancer Research, v. 67, n. 23, p. 11186-11194, 2007.

SCHWARZ-SOMMER, Z. et al. Genetic Control of Flower Development by Homeotic Genes in Antirrhinum majus. Science (New York, N.Y.), v. 250, n. 4983, p. 931-6, 1990.

SEARLE, I. et al. The transcription factor FLC confers a flowering response to vernalization by repressing meristem competence and systemic signaling in Arabidopsis. Genes and Development, v. 20, p. 898-912, 2006.

SEEWALD, M. J. et al. Biochemical characterization of the Ran-RanBP1-RanGAP system: are RanBP proteins and the acidic tail of RanGAP required for the Ran-RanGAP GTPase reaction? Molecular and cellular biology, v. 23, n. 22, p. 8124-8136, 2003.

SEYMOUR, G. B. et al. Fruit Development and Ripening. Annu. Rev. Plant Biol, v. 64, p. 219$241,2013$.

SHEAFF, R. J.; GROUDINE, M.; ROBERTS, J. M. Cyclin E-CDK2 is a regulator of p27 Kip1. p. 1464-1478, 1997.

SHELDON, C. C. et al. The molecular basis of vernalization: the central role of FLOWERING LOCUS C (FLC). PNAS, v. 97, n. 7, p. 3753-3758, 2000.

SHI, J. et al. The p34cdc2-related cyclin-dependent kinase 11 interacts with the $\mathrm{p} 47$ subunit of eukaryotic initiation factor 3 during apoptosis. Journal of Biological Chemistry, v. 278, n. 7, p. 5062-5071, 2003.

SHI, J.; HERSHEY, J. W. B.; NELSON, M. A. Phosphorylation of the eukaryotic initiation factor 3f by cyclin-dependent kinase 11 during apoptosis. FEBS Letters, v. 583, n. 6, p. 971-977, 2009. SHIMOTOHNO, A. et al. The Plant-Specific Kinase CDKF;1 Is Involved in Activating Phosphorylation of Cyclin-Dependent Kinase-Activating Kinases in Arabidopsis. v. 16, p. 2954 
2966, 2004.

SHORE, P.; SHARROCKS, A D. The MADS-box family of transcription factors. European journal of biochemistry /FEBS, v. 229, n. 1, p. 1-13, 1995.

SIERRO, N. et al. Reference genomes and transcriptomes of Nicotiana sylvestris and Nicotiana tomentosiformis. Genome biology, v. 14, n. 6, p. R60, 2013.

SIERRO, N. et al. The tobacco genome sequence and its comparison with those of tomato and potato. Nature communications, v. 5, n. May, p. 3833, 2014.

SILVER, D. P.; LIVINGSTON, D. M. Mechanisms of BRCA1 Tumor Suppression. v. 2, n. 8, p. 679-684, 2012.

SINGH, A. et al. Protein recovery from inclusion bodies of Escherichia coli using mild solubilization process. Microbial cell factories, v. 14, n. 41, p. 1-10, 2015.

SINHA, N. R.; WILLIAMS, R. E.; HAKE, S. Overexpression of the maize homeo box gene, KNOT'TED-1, causes a switch from determinate to indeterminate cell fates. Genes and Development, v. 7, p. 787-795, 1993.

SMACZNIAK, C. et al. Developmental and evolutionary diversity of plant MADS-domain factors: insights from recent studies. Development, v. 139, n. 17, p. 3081-3098, 2012.

SOMMER, H. et al. Deficiens, a homeotic gene involved in the control of flower morphogenesis in Antirrhinum majus: the protein shows homology to transcription factors. The EMBO journal, v. 9, n. 3, p. 605-613, 1990.

SPRUCK, C. et al. A CDK-independent function of mammalian Cks1: Targeting of SCFSkp2 to the CDK inhibitor p27Kip1. Molecular Cell, v. 7, n. 3, p. 639-650, 2001.

SPRUNCK, S. et al. Egg Cell-Secreted EC1 Triggers Sperm Cell Activation During Double Fertilization. Science, v. 338, n. 6110, p. 1093-1097, 2012.

STALS, H.; INZÉ, D. When plant cells decide to divide. Trends in plant science, v. 6, n. 8, p. 359-364, ago. 2001.

STRINI, E. J. SCI1 (Stigma/style Cell-cycle Inhibtor 1): análise in silico da sequência genômica de Nicotiana tabacum e estudo de parceiros de interação proteína-proteína. [s.l.] FACULDADE DE MEDICINA DE RIBEIRÃO PRETO - UNIVERSIDADE DE SÃO PAULO, 2010. 
STRINI, E. J. A análise do interactoma de SCI1 (Stigma/style Cell cycle Inhibitor 1) revela possíveis mecanismos de controle da proliferação celular. [s.l.] FACULDADE DE MEDICINA DE RIBEIRÃO PRETO - UNIVERSIDADE DE SÃO PAULO, 2014.

SUN, B. et al. A timing mechanism for stem cell maintenance and differentiation in the Arabidopsis floral meristem. Genes and Development, v. 23, n. 15, p. 1791-1804, 2009.

SUNG, S.; AMASINO, R. M. Vernalization in Arabidopsis thaliana is mediated by the PHD finger protein VIN3. Nature, v. 427, n. January, p. 159-164, 2004.

TAKAI, Y.; SASAKI, T.; MATOZAKI, T. Small GTP-binding proteins. Physiological reviews, v. 81, n. 1, p. 153-208, 2001.

TAKEUCHI, H.; HIGASHIYAMA, T. Attraction of tip-growing pollen tubes by the female gametophyte. Current Opinion in Plant Biology, v. 14, n. 5, p. 614-621, 2011.

TAKEUCHI, H.; HIGASHIYAMA, T. A Species-Specific Cluster of Defensin-Like Genes Encodes Diffusible Pollen Tube Attractants in Arabidopsis. PLoS Biology, v. 10, n. 12, 2012.

TAMARA L. WESTERN; GEORGE W. HAUGHN. BELL1 and AGAMOUS genes promote ovule identity in Arabidopsis thaliana. The Plant Journal, v. 18, n. 3, p. 329-336, 1999.

TANG, D.; GURURAJAN, R.; KIDD, V. J. Phosphorylation of PITSLRE p110 isoforms accompanies their processing by caspases during fas-mediated cell death. Journal of Biological Chemistry, v. 273, n. 26, p. 16601-16607, 1998.

TANG, W.; PERRY, S. E. Binding site selection for the plant MADS domain protein AGL15: An in vitro and in vivo study. Journal of Biological Chemistry, v. 278, n. 30, p. 28154-28159, 2003.

TANK, J. G.; THAKER, V. S. Cyclin dependent kinases and their role in regulation of plant cell cycle. Biologia Plantarum, v. 55, n. 2, p. 201-212, 2011a.

TANK, J.; THAKER, V. Cyclin dependent kinases and their role in regulation of plant cell cycle. Biologia Plantarum, v. 55, n. 2, p. 201-212, 2011b.

THEISSE, G.; KIM, J. T.; SAEDLER, H. Classification and Phylogeny of the MADS-Box Multigene Family Suggest Defined Roles of MADS-Box Gene Subfamilies in the Morphological Evolution of Eukaryotes. Journal of molecular evolution, v. 43, p. 484-516, 1996.

TILLY, J. J.; ALLEN, D. W.; JACK, T. The CArG boxes in the promoter of the Arabidopsis floral organ identity gene APETALA3 mediate diverse regulatory effects. Development (Cambridge, 
England), v. 125, n. 9, p. 1647-1657, 1998.

TOMAŠTÍKOVÁ, E. et al. TPX2 Protein of Arabidopsis Activates Aurora Kinase 1, But Not Aurora Kinase 3 In Vitro. Plant Molecular Biology Reporter, p. 1988-1995, 2015.

TREMBLEY, J. H. et al. PITSLRE p110 protein kinases associate with transcription complexes and affect their activity. Journal of Biological Chemistry, v. 277, n. 4, p. 2589-2596, 2002.

TREMBLEY, J. H. et al. Cyclin Dependent Kinase 11 in RNA Transcription and Splicing. Progress in Nucleic Acid Research and Molecular Biology, v. 77, p. 263-288, 2004.

TRIPATHI, P.; RABARA, R. C.; RUSHTON, P. J. A systems biology perspective on the role of WRKY transcription factors in drought responses in plants. p. 255-266, 2014.

TULU, U. S. et al. Molecular requirements for kinetochore-associated microtubule formation in mammalian cells. Current Biology, v. 16, n. 5, p. 536-541, 2006.

UEDA, M.; ZHANG, Z.; LAUX, T. Transcriptional Activation of Arabidopsis Axis Patterning Genes WOX8/9 Links Zygote Polarity to Embryo Development. Developmental Cell, v. 20, n. 2, p. 264-270, 2011.

UMEDA, M.; SHIMOTOHNO, A.; YAMAGUCHI, M. Control of cell division and transcription by cyclin-dependent kinase-activating kinases in plants. Plant $\boldsymbol{\&}$ cell physiology, v. 46, n. 9, p. 1437-42, set. 2005.

VADDEPALLI, P.; SCHOLZ, S.; SCHNEITZ, K. Pattern formation during early floral development. Current Opinion in Genetics \& Development, v. 32C, p. 16-23, 2015.

VAN DAMME, D. et al. Molecular dissection of plant cytokinesis and phragmoplast structure: A survey of GFP-tagged proteins. Plant Journal, v. 40, n. 3, p. 386-398, 2004.

VAN DIJK, A. D. J. et al. Sequence motifs in MADS transcription factors responsible for specificity and diversification of protein-protein interaction. PLoS Computational Biology, v. 6, n. 11, 2010.

VAN LEENE, J. et al. A tandem affinity purification-based technology platform to study the cell cycle interactome in Arabidopsis thaliana. Molecular \& cellular proteomics : MCP, v. 6, n. 7, p. $1226-38$, jul. 2007.

VAN LEENE, J. et al. Targeted interactomics reveals a complex core cell cycle machinery in Arabidopsis thaliana. Molecular Systems Biology, v. 6, n. 397, p. 1-12, 2010a. 
VAN LEENE, J. et al. Targeted interactomics reveals a complex core cell cycle machinery in Arabidopsis thaliana. Molecular systems biology, v. 6, n. 397, p. 397, 10 ago. 2010b.

VANDEPOELE, K. et al. Genome-Wide Analysis of Core Cell Cycle Genes in Arabidopsis. The Plant Cell, v. 14, p. 903-916, 2002.

VANDEPOELE, K. et al. Genome-wide identification of potential plant E2F target genes. Plant Physiology, v. 139, n. 1, p. 316-328, 2005.

VISSCHER, K. M.; KASTRITIS, P. L.; BONVIN, A. M. J. J. Non-interacting surface solvation and dynamics in protein-protein interactions. Proteins: Structure, Function and Bioinformatics, v. 83, n. 3, p. 445-458, 2015.

VOLKOV, R. A et al. Elimination and rearrangement of parental rDNA in the allotetraploid Nicotiana tabacum. Molecular biology and evolution, v. 16, n. 3, p. 311-320, 1999.

VOS, J. W. et al. The Plant TPX2 Protein Regulates Prospindle Assembly before Nuclear Envelope Breakdown. The Plant Cell, v. 20, n. 10, p. 2783-2797, 2008.

VREBALOV, J. et al. Fleshy fruit expansion and ripening are regulated by the Tomato SHATTERPROOF gene TAGL1. The Plant cell, 2009.

WANG, H.; FOWKE, L. C. A Plant Cyclin-dependent Kinase Inhibitor Gene. Nature, v. 386, n. 6624, p. 451-452, 1997.

WANG, W.; CHEN, X. HUA ENHANCER3 reveals a role for a cyclin-dependent protein kinase in the specification of floral organ identity in Arabidopsis. Development (Cambridge, England), v. 131, n. 13, p. 3147-3156, 2004.

WANG, X. et al. Duplication and DNA segmental loss in the rice genome: Implications for diploidization. New Phytologist, v. 165, n. 3, p. 937-946, 2005.

WEIGEL, D. et al. LEAFY controls floral meristem identity in Arabidopsis. Cell, v. 69, n. 5, p. 843-859, 1992.

WELCKER, M.; CLURMAN, B. E. FBW7 ubiquitin ligase: a tumour suppressor at the crossroads of cell division, growth and differentiation. Nature reviews. Cancer, v. 8, n. 2, p. 83-93, 2008.

WILKER, E. W. et al. 14-3-3 $\sum$ Controls Mitotic Translation To Facilitate Cytokinesis. Nature, v. 446, n. 7133, p. 329-332, 2007.

WILLIAMS, L. et al. Regulation of Arabidopsis shoot apical meristem and lateral organ formation 
by microRNA miR166g and its AtHD-ZIP target genes. Development (Cambridge, England), v. 132, n. 16, p. 3657-3668, 2005.

WU, J. Y.; MANIATIS, T. Specific interactions between proteins implicated in splice site selection and regulated alternative splicing. Cell, v. 75, n. 6, p. 1061-1070, 1993.

XIAO, S. H.; MANLEY, J. L. Phosphorylation of the ASF/SF2 RS domain affects both proteinprotein and protein-RNA interactions and is necessary for splicing. Genes and Development, v. 11, n. 3, p. 334-344, 1997.

YANG, Y.; FANNING, L.; JACK, T. The $\mathrm{K}$ domain mediates heterodimerization of the Arabidopsis floral organ identity proteins, APETALA3 and PISTILLATA. Plant Journal, v. 33, n. 1, p. 47-59, 2003.

YANOFSKY, M. et al. The protein encoded by the Arabidopsis homeotic gene AGAMOUS resembles transcription factors. Nature, v. 346, n. 6279, p. 35-39, 1990.

YOKOYAMA, H. et al. Cdk11 is a RanGTP-dependent microtubule stabilization factor that regulates spindle assembly rate. Journal of Cell Biology, v. 180, n. 5, p. 867-875, 2008.

YU, D.; CHEN, C.; CHEN, Z. Evidence for an Important Role of WRKY DNA Binding Proteins in the Regulation of NPR1 Gene Expression. The Plant Cell, v. 13, p. 1527-1539, 2001.

YU, Y. et al. WRKY71 accelerates flowering via the direct activation of FLOWERING LOCUS T and LEAFY in Arabidopsis thaliana. Plant Journal, v. 85, n. 1, p. 96-106, 2016.

YU, Y. M. et al. A PP1-binding motif present in BRCA1 plays a role in its DNA repair function. International Journal of Biological Sciences, v. 4, n. 6, p. 352-361, 2008.

YUKAWA, M.; TSUDZUKI, T.; SUGIURA, M. The chloroplast genome of Nicotiana sylvestris and Nicotiana tomentosiformis: Complete sequencing confirms that the Nicotiana sylvestris progenitor is the maternal genome donor of Nicotiana tabacum. Molecular Genetics and Genomics, v. 275, n. 4, p. 367-373, 2006.

ŻABICKI, P. et al. Arabidopsis cyclin-dependent kinase gene CDKG;2 is involved in organogenic responses induced in vitro. Acta Biologica Cracoviensia Series Botanica, v. 55, n. 1, p. 37-48, 2013.

ZECH, J.; DALGAARD, J. Z. Replisome components-Post-translational modifications and their effects. Seminars in Cell and Developmental Biology, v. 30, p. 144-153, 2014. 
ZHAN, L. et al. Promising roles of mammalian E2Fs in hepatocellular carcinoma. Cellular Signalling, v. 26, n. 5, p. 1075-1081, 2014.

ZHAN, L. et al. E2F1: a promising regulator in ovarian carcinoma. Tumor Biology, v. 37, n. 3, p. 2823-2831, 2016.

ZHANG, C. et al. The splicing machinery promotes RNA-directed DNA methylation and transcriptional silencing in Arabidopsis. The EMBO Journal, v. 32, n. 8, p. 1128-1140, 2013.

ZHANG, H.; DAWE, R. K. Mechanisms of plant spindle formation. Chromosome Research, v. 19, n. 3, p. 335-344, 2011.

ZHANG, J.; POWELL, S. N. The role of the BRCA1 tumor suppressor in DNA double-strand break repair. Molecular Cancer Research, v. 3, n. 10, p. 531-9, 2005.

ZHANG, X. et al. New insight into the molecular mechanisms of the biological effects of DNA minor groove binders. PLoS ONE, v. 6, n. 10, 2011.

ZHENG, N. et al. Boosted expression of the SARS-CoV nucleocapsid protein in tobacco and its immunogenicity in mice. Vaccine, v. 27, n. 36, p. 5001-5007, 2009.

ZHENG, T. et al. CDKG1 protein kinase is essential for synapsis and male meiosis at high ambient temperature in Arabidopsis thaliana. PNAS, v. 111, n. 6, p. 2182-7, 2014.

ZHONG, S. et al. Single-base resolution methylomes of tomato fruit development reveal epigenome modifications associated with ripening. Nature biotechnology, 2013. 
APÊNDICE A - ARTIGO PARA SUBMISSÃO EM REVISTA CIENTÍFICA DA ÁREA 


\section{Cyclin-Dependent Kinase Type G2 and Cyclin L1 are key proteins of the SCl1 interactome}

Greice Lubini1 ${ }^{1,2 \#}$, Vitor F. Pinoti ${ }^{1,2 \#}$, Edward J. Strini ${ }^{1,2}$, Pedro B. Ferreira ${ }^{1,2}$, Andréa C. Quiapim 1 , Gustavo H. Goldman ${ }^{3}$, Maria Helena S. Goldman ${ }^{1, \S}$

1Departamento de Biologia, Faculdade de Filosofia, Ciências e Letras de Ribeirão Preto, Universidade de São Paulo, Ribeirão Preto 14040-901, Brazil;

2PPG-Genética, Faculdade de Medicina de Ribeirão Preto, Universidade de São Paulo, Ribeirão Preto 14049-900, Brazil;

${ }^{3}$ Departamento de Ciências Farmacêuticas, Faculdade de Ciências Farmacêuticas de Ribeirão Preto, Universidade de São Paulo, Ribeirão Preto 14040-903, Brazil;

\#These authors have equally contributed to this work.

§Author for correspondence: Phone +55 16 3602-3702; Fax: +55 16 3602-4886, email: mgoldman@ffclrp.usp.br

Running title:

Key words: SCl1, Cyclin-dependent Kinase, Cyclin, Cell cycle, Protein-protein Interaction, SR-related proteins, splicing speckles; 


\section{ABSTRACT}

In general, Cyclin-dependent Kinase (CDK) and cyclin proteins are master regulators of cell division and proliferation in all eukaryotes. The cell cycle inhibitors act on CDKcyclin complexes, exerting thereby a role as one of the mechanisms that regulates this complex. In plants, it was recently described SCI1, a cell cycle inhibitor that showed specific stigmas and styles, regulating cell proliferation secretory zone of the stigma and stylus transmitter tissue. However, proteins which are regulated by this inhibitor had not yet been identified. We believe that SCI1, as well as other inhibitors, acts in order to regulate the cell cycle through the inhibition of CDK / Cyclin complexes. Here we show that SCl1 interacts with two these proteins: a CDK from G group, NtCDKG;2, and a cyclin, the NtCycL1. The literature suggests that homologous proteins from NtCDKG;2 and NtCycL1 in Arabidopsis are intrinsically involved in the RNA processing. Peculiarly, SCI1 interacts with the two proteins in the nucleolus of the cell. We believe that during this interaction, $\mathrm{SCl} 1$ is trapping proteins in this organelle, which would block the involvement of NtCDKG;2/NtCycL1 complex in RNA processing. These findings show that cell proliferation regulatory mechanisms may involve not well established processes such as the action of a tissue-specific inhibitor of the activity of proteins involved in RNA processing. 


\section{INTRODUCTION}

Sexual reproduction of plants requires the correct development of whorls involved in this process. In particular, pistil, the plant female reproductive organ, plays a crucial role in the reproductive process through many functions it exercised, as discrimination between male gametophytes of different species and selection of compatible (congruity), directing pollen tube growing, besides the production and protection of female gametophytes in ovary (SANCHEZ et al., 2004). Thus, the cell cycle is highly regulated in pistil, involving molecular mechanisms arranged in response to intracellular signals resulting from the monitoring of the cycle phases, and extracellular as a nutritional availability, hormones, developmental stage and environmental signals. Among the main regulators of the cell cycle, there are heterodimeric protein complexes highly conserved in different plant and other eukaryotes (INZÉ; DE VEYLDER, 2006). These complexes are composed by the Cyclin-Dependent Kinases-CDK (which belongs to catalytic subunit) and the cyclin (regulatory subunit) (INZÉ; DE VEYLDER, 2006). The association between CDK-cyclin subunits determines substrate specificity, besides the activity, stability and localization of the complex (INZÉ; DE VEYLDER, 2006).

The first list of putative genes coding for CDKs in plants has been published considering the amino acid sequence of the protein, similarities and features of conserved domains (JOUBÈS et al., 2000). The cyclin-binding domain served to extended the list and has classified CDKs in eight classes: CDKA the CDKG and CDKLike - CKL (MENGES et al., 2005; VANDEPOELE et al., 2002). The activity of the catalytic subunit is finely adjusted and its operation depends on the availability and interaction with different regulatory subunits and CDK-inhibitors. In Arabidopsis, all CDKs except CDKF;1 depends on the interaction with a cyclin to phosphorylate their 
target (MORGAN, 2007; INZÉ, 2007). CDKs may interact with different types of cyclin, therefore, the fundamental principle of transition through the various stages of the cell cycle is the synthesis and degradation of cyclins, generating the CDK activity peaks and directing the two crucial transitions of the cell cycle: entry into the DNA synthesis phase and entry into mitosis.

In addition to association with regulatory proteins, the activity of CDKs is also controlled by phosphorylation status. CDKs exhibit two to three sites for inhibitory phosphorylation and one activating phosphorylation site (INZÉ, 2007). The activating phosphorylation occur in a specific threonine residue conserved within the T-loop and are carried out by other kinases that activate the CDKs, such as CAKs (CDK-activating kinases). After threonine phosphorylation, T-loop allows entrance of the substrate into CDK catalytic center (INZÉ, 2007).

The CDK / cyclin complex can also be activated by inhibitory proteins. In plants were described three classes of CDKs inhibitors: 1) Inhibitor/Interactor of Cyclindependent Kinase / Kip-Related Protein (ICK/KRP) (DE VEYLDER et al., 2001; WANG; FOWKE, 1997); 2) Siamese e Siamese-related (SIM/SMR) (CHURCHMAN et al., 2006); 3) Tissue-specific inhibitors of CDK (TIC; DEPAOLI; GOLDMAN; GOLDMAN, 2012). At Arabidopsis thaliana, the first class of inhibitors, comprises a group of proteins homologous, but distantly related, to the animal CDK-inhibitor proteins family KIP (DE VEYLDER et al., 2001; WANG; FOWKE, 1997). The SIM class comprises plant-specific specific inhibitory proteins that act by regulation of endoreduplication. Classes 1 and 2 have proteins that affect the regulation of the cell cycle of all plant organs. Meanwhile, the recently described third class, comprises the tissue-specific protein SCI1 that acts exclusively regulating cell proliferation in stigmas and styles (DEPAOLI et al., 2011; DEPAOLI; DORNELAS; GOLDMAN, 2014; 
DEPAOLI; GOLDMAN; GOLDMAN, 2012). Phenotype analysis of transgenic plants overexpressing or silencing $\mathrm{SCl}$ showed that its gene product is a cell cycle inhibitor, capable of regulating proliferation and cell differentiation in the secretory zone of the stigma and the stylet tissue transmitter. However, despite SCl1 protein had functional features in cell cycle inhibition, until now, CDK/Cyclin protein complex inhibited by SCI1 had not been identified.

In this work, we identified two protein partners of SCI1 through which we believe that the inhibitor regulates cell cycle. The first protein identified is NtCDKG;2, homologous to Arabidopsis CDKG;2 (At167580). The CDKG class has two members in Arabidopsis, the CDKG;1 and CDKG;2 and is the less elucidated class from plant CDKs (MENGES et al., 2005). Initially, the information available for CDKG;2 came from large-scale studies like BiFC (Bimolecular Fluorescent complementation) in BY2 cells of N. tabacum and TAP (Tandem Affinity Purification) in Arabidopsis. These studies identified interactions between CDKG;2 and 6 cyclins (CycA3;4 / CycD4;1 / CycD4;2 / CycF1 / CycH1 / CycL1), two CDKs (CDKB;1 and CDKF;1), and one CDK inhibitor (KRP4) (BORUC et al., 2010a; VAN LEENE et al., 2007, 2010b) (Van Leene et al., 2007, Boruc et al, 2010a;. Van Leene et al, 2010).

It was recently demonstrated that the insertion mutants in CDKG;2 gene flower earlier than wild plants (MA et al., 2015). The absence of CDKG;2 also increased the resistance of these transgenics to salinity. When investigating the possible causes of these phenotypes were found changes in the expression of different genes that regulate flowering - FLC (FLOWERING LOCUS C), FT (FLOWERING LOCUS T), SOC1 (SUPPRESSOR OF Overexpression OF CO1), AP1 (APETALLA 1) and LFY (LEAFY). According to Ma and collaborators (2015), control of FLC expression and subsequently changes in flowering, may occur through CDKG;2 phosphorylating its 
interaction partner Cyclin L. This hypothesis was developed based on the fact that cyclin L belongs to the family of SR-like proteins (Serine / Arginine-Rich-like), which has members involved in splicing (FORMENT et al., 2002). The other member from CDKG family in Arabidopsis, CDKG;1 is involved in splicing regulation of pre-mRNA gene CalS5 (CALLOSE Synthase 5) during pollen wall formation (HUANG et al., 2013). Later, it was proposed its participation in the synapse processes and chromosomal recombination during male gametogenesis, complexed with Cyclin L1 (ZHENG et al., 2014). CDKG;1 also interacts with the splicing factor RS2Z33, possibly through the RS motifs in its amino terminal portion (HUANG et al., 2013).

Knowing the interaction involving CDKG;2 and CycL1 in Arabidopsis, we tested and show here the interactions involving SCl1, NtCDKG;2 and NtCyCL1 proteins from N. tabacum. We identified that both protein NtCDKG;2 and NtCycL1 interact with SCI1 in a region that resembles the nucleolar periphery. Furthermore, NtCDKG;2 NtCycL1 interact with one another into the nucleoplasm in splicing speckles-like structures. We also show that transient expression of NtCDKG;2 and NtCycL1 in N. benthamiana leaves result in their co-localization with splicing factors. Our hypothesis is that SCI1 protein could be sequestering NtCDKG;2 and NtCycL1 into the nucleolus, avoiding its performance in processing RNAs and, by the end, inhibiting the cell cycle.

\section{RESULTS}

\section{NtCDKG;2 goes to nucleolus peripheral zone during its interaction with SCl1}

SCl1 has been described as regulating cell proliferation in the upper pistil of $N$. tabacum and Arabidopsis (DEPAOLI et al., 2011; DEPAOLI; DORNELAS; GOLDMAN, 2014). However, it was no showed yet a connection involving SCl1 and the cell proliferation machinery. Protein pull-down was performed to identify SCI1 interaction 
partners, consisting the first steps to understand how SCl1 influences and modifies cell proliferation. For this, the bait protein GST-NtSCl1 was heterologously produced in $E$. coli and hold on a column. A nuclear proteins enriched extract of $N$. tabacum stigma/style was the source of prey proteins. Analyzes suggest amino acids sequence from one of the bands obtained (band 19, approximately $80 \mathrm{kDa}$ - Figure 1a) covers $29 \%$ of CDK $10 / 11$ protein from Ricinus communis. The homologous protein identified in Arabidopsis is AtCDKG;2 (At1g67580; 62\% of similarity and 50\% amino acids identity with $R$. communis CDK protein). This CDK protein carries a conserved PLTSLRE motif (MENGES et al., 2005). In mammals, its homologous (CDK11) is an important negative regulator of cell cycle progression (LIM; KALDIS, 2013). For a phylogenic relation between species, see Supplementary Figure S1.

According to the published genomes of varieties TN90, K326, and Basma Xanthi, there are 4 genes coding for CDKG;2 in N. tabacum, (Sierro et al., 2014; Supplementary Table S1). Table S1 contains the accession numbers for all mRNAs coding for CDKG;2 in the variety TN90. Of these, two pairs of genes can be distinguished, each pair coming from each of the parental genomes $-N$. sylvestris and N. tomentosiformis. In each pair, two different CDKG;2 proteins can be predicted, one larger than the other. The differences between these proteins reside in their aminoterminal domain, preceding the C-terminal kinase domain shared by both of them. The NtCDKG;2 (N. tabacum CDKG;2) described in this work was cloned based on EST sequences, prior to the publishing of the tobacco genomes in the public domain. Alignments with TN90 sequences reveal $98 \%$ similarity with the protein product of mRNA X1 (accession number XP_016508954.1). The cloned NtCDKG;2 CDS is most similar to N. tomentosiformis copy (accession number XP_009603474.1-99\% identity). 
Peer-to-peer Bimolecular Fluorescence Complementation (BiFC) assays were conducted in order to determine the in vivo subcellular distribution of NtCDKG;2 and SCl1 interaction. Co-expression of NtCDKG;2-cGFP and SCI1-nGFP resulted in green fluorescence in nuclei. Additionally, Figure 1c and 1f shows the strongest GFP signal that is observed in a particular region similar to the peripheral region of nucleoli. This strong fluorescence occurs at an intensely rich chromatin area from the peripheral zone of nucleolus. Is important highlight only interphasic cells show green fluorescence.

\section{Splicing-related cyclin NtCycL1 interacts with NtCDKG;2 and both are central members of SCl1 interactome}

CDK proteins have a key role in the regulation of plant development through cell proliferation and differentiation control (De Veylder et al., 2007). Except for CDKF;1, other CDK proteins need to complex with a cyclin protein (Jeffrey et al., 1995). Ma et al. (2015) reported CDKG;2 and Cyclin L1 from Arabidopsis interact in the nucleus (by BiFC experiment), but the subnuclear localization was not carefully analyzed. Therefore, we performed a BiFC assay to demonstrate and accurately analyze the interaction between $N$. tabacum CycL1 with both NtCDKG;2 and SCl1. NtCDKG;2nGFP and NtCycL1-cGFP co-expression demonstrate this interaction occurs dispersed on nucleoplasm. Newsworthy, our result shows a GFP strong signal in an isolate nuclear dot, most likely a splicing speckle (Figure 2a). Interestingly, when BiFC is conduced to analyze $\mathrm{SCl} 1$ and $\mathrm{NtCycL} 1$ interaction (Figure 2b) this interaction exhibits exactly the same pattern observed in BiFC assays performed with SCl1NtCDKG;2, strongly suggesting those three proteins act in a complex. 
A strong molecular tool that verifies direct interactions is the Yeast two-hybrid $(\mathrm{Y} 2 \mathrm{H})$ assay. $\mathrm{Y} 2 \mathrm{H}$ experiments were conducted to test interactions between $\mathrm{SCl}$, NtCDKG;2 and NtCycL1 (Figure 2g). As expected, the interaction between NtCDKG;2 and $\mathrm{NtCycL} 1$ is a direct interaction. The interaction between SCl1 and NtCycL1 proteins was also confirmed by $\mathrm{Y} 2 \mathrm{H}$ when the destruction-box was deleted from the cyclin (Figure 2g). However, when SCl1 and NtCDKG;2 were tested there was not yeast grow, indicating this interaction does not directly occur. To test if SCl1 and $\mathrm{NtCDKG;2} \mathrm{require} \mathrm{a} \mathrm{specifical} \mathrm{protein} \mathrm{that} \mathrm{mediates} \mathrm{the} \mathrm{interaction} \mathrm{we} \mathrm{performed} \mathrm{a}$ Yeast three-hybrid ( $\mathrm{Y} 3 \mathrm{H})$ assay with CycL1 as the tested bridge (datas not showed). Not expected, the CycL1 alone is not able to promote NtCDKG;2-NtSCI1 interaction. This negative result suggests post-translation modifications may be required for one or both proteins or another protein is also required for NtCDKG;2 and SCl1 interaction, not just NtCycL1. Literature reports the CDK status is intrinsically dependent on phosphorylation and dephosphorylation at specific sites of this molecule by the action of kinases and phosphatases enzymes (INAGAKI; UMEDA, 2011).

The green fluorescent protein (GFP) is widely used as a reporter protein when is fused to a protein of interest. This reporter protein gives a fluorescence signal which allows identification of subcellular activities including protein localization. To study NtCDKG;2 and NtCycL1 subcellular localization, $N$. benthamiana leaves were Agrotransformed with P35S::GFP-NtDKG;2 and P35S::NtCycL1-GFP. Patterns of GFPtagged NtCDKG;2 suggest it changes location in the nucleus, probably depending on the cell division stage. During interphase (Figures 3a-3f) GFP-NtCDKG;2 is found spread in the nucleoplasm and in a small dot present in nucleolar cavity (red arrow from Figure 3a). Apart from being scattered in the nucleoplasm, the protein also has an organization that resembles splicing speckles (White arrows from Figure 3d). When 
the cell seems to be entering in mitosis (Figures $3 g-3 i$ ), suggested by beginning of chromatin condensation (Figure 3h), our results show NtCDKG;2 protein is does not co-localize with the more condensed chromatin (Figure 3i). In contrast, when we analyze NtCyCL1-GFP localization, this protein was also found sprayed in nucleus but predominantly in a nucleolus-like structure. (Figures 3j-r). Subcellular GFP signal is also present in punctate subnuclear structures similar to speckles (White arrows from Figures 3j, 3m and 3p).

To study the subcellular localization of NtCDKG;2 protein during cell cycle phases, tobacco BY-2 cells were stably Agro-transformed to express the target protein with GFP fusion (Figures $4 \mathrm{a}$ to $4 \mathrm{~g}$ ). During Interphase (Figures $4 \mathrm{a}$ and 4b), NtCDKG;2 is nucleus-localized and also present in cytoplasmic traffic, although in much less amount. In middle prophase (Figure 4c), the GFP fluorescence also has nuclear signal, but the shine is absent in heterochromatic regions (were Hoechst is concentrated). The GFP-NtCDKG;2 seems to be diffuse during metaphase and completely absent in equatorial plate (Figure 4d). Interesting, during anaphase (Figure 4e), the GFPNtCDKG;2 protein appears to be organizing around chromosomes region. At the end of mitosis (Figures $4 f$ and $4 g$ ), GFP-NtCDKG;2 protein localized totally with reassembled nuclei. From these results we are convinced the subcellular localization of NtCDKG;2 is intrinsically cell cycle phase dependent.

\section{Nuclear NtCDKG;2 and NtCycL1 proteins co-localizes with cyclophlilin- containing speckles}

In an attempt to characterize in detail the nature of punctate subnuclear structures where GFP-NtCDKG;2 and NtCycL1-GFP is localized, co-localization experiments were performed with several subnuclear protein markers from 
Arabidopsis. AtFibrillarin, AtCoillin, AtCyclophilin64 (AtCyc64) and AtSRP34 proteins were used to identify nucleolus, Cajal bodies, cyclophilin-containing speckles and splicing speckles, correspondingly. GFP-NtCDKG;2 does localize in nuclei but do not either in nucleoli (Figure 5Ai - 5Al) or organized in Cajal bodies (Figure 5Am - 5Ap). Although, NtCDKG;2 shows partial co-localization with both speckles markers Cyc64 (Figure 5Aa - 5Ad) and SRP34 (Figure 5Ae - 5Ah). Intriguingly, during certain cell cycle phases, when placed together with AtCyc64 marker, NtCDKG;2 may have modified the standard known location of the marker protein. In early mitosis, NtCDKG;2 completely co-localizes with AtCyc64. When analyzed the localization of NtCDKG;2 co-expressed with AtSRP34, the target protein was observed fully co-localized with the marker protein. However, there are regions where GFP signal is displayed but the red fluorescence was not observed. In the other hand, NtCycL1-GFP co-localizes with AtFibrillarin, AtCoillin in interphasic-like cells (Figure 5B). As NtCDKG;2, CycL1 protein also co-localizes with both splicing-related markers AtCyc64 (Figures 5Ba-5Bd) and AtSRP34 (Figures 5Be-5Bh). However, co-localization of those proteins was showed only in cells with more condensed chromatin. In general, these co-localizations assays corroborate NtCyCL1 is nucleolar localized and also shows that protein is present also in Cajal bodies and in splicing speckles-like structures.

\section{NtCDKG;2 is expressed in stigmas/styles towards anthesis}

Analysis of gene expression is a widely strategy employed in the identification of organs and stages where a gene is most active and/or important. The RT-qPCR studies covers two of the four NtCDKG;2 mRNAs.

NtCDKG;2 is ubiquitously expressed in different organs of tobacco 
NtCDKG;2 expression was analyzed in different vegetative and reproductive organs, by RT-qPCR, showing a ubiquitous expression pattern. No extreme contrast was found in the expression levels across all organs (Figure 6a). The lowest expression was identified in stigmas/styles and the highest was in sepals. Thus, $\mathrm{NtCDKG;2} \mathrm{is} \mathrm{not} \mathrm{preferentially} \mathrm{or} \mathrm{exclusively} \mathrm{expressed} \mathrm{in} \mathrm{any} \mathrm{organ,} \mathrm{unlike} \mathrm{SCI1,}$ which is predominantly expressed in stigmas/styles.

NtCDKG;2 expression is regulated in S/S during tobacco floral developmental stages

An important information required in the study of genes involved in pistil development is identify their expression patterns throughout flower development stages. This information indicates in which ways a protein may act during pistil development. To fill this gap, the expression levels of NtCDKG;2 were evaluated during the twelve stages of the flower development in $N$. tabacum stigmas/styles (KOLTUNOW et al., 1990). NtCDKG;2 expression is lowest during stages 1 through 9, and it starts to increase in the last three stages, towards anthesis (Figure 6b). This pattern suggests NtCDKG;2 may have an important function in processes involved in the preparation of stigma and style for pollen-pistil interactions. The differential expression of $\mathrm{NtCDKG;2}$ in these stages might indicate a strong regulation during flower development.

\section{NtCDKG;2 protein has a putative Internal Ribosome Entry Site (IRES)}

$\mathrm{NtCDKG;2} \mathrm{coding} \mathrm{sequence} \mathrm{results} \mathrm{from} \mathrm{the} \mathrm{union} \mathrm{of} 6$ exons, spanning 2010 bp. The 669 amino acid sequence of NtCDKG;2 was analyzed to identify conserved domains (Figure 6c). Analyses indicate that the carboxi-terminal portion of NtCDKG;2 protein encompasses conserved kinase domains as STKc_CDC2L1 [Serine / Threonine Kinases and Cell Division Cycle subfamily 2-like 1 (CDC2L1)] at amino acids 
318-614 (e-value 0e+00) and PLN00009 (typical CDK domain) at amino acids 321-617 (e-value 6.33e-99). Usual sites found in kinases, such as ATP- and substrate-binding sites, the activation loop and the CDK/cyclin interface were also identified. Additionally, putative Nuclear Localization Signals (NLS) were found. The protein also has a longer amino-terminal portion, similar to its Arabidopsis homolog, with 5 RS motifs. The extended amino-terminal portion is shared by all CDKGs and contains the RS motifs, which are essential for interactions with SR splicing factors (Wu \& Maniatis, 1993; Zhu \& Krainer, 2000; Huang et al., 2013). NtCDKG;2 has 5 of these RS motifs, while AtCDKG;2 has 6 and AtCDKG;1 has 4 of them.

Analyzes were also performed on NtCDKG;2 searching for a putative IRES (Internal Ribosome Entry Site) using the context identified by Cornelis and co-workers (2000) in the homologous CDK11 from $H$. sapiens. At NtCDKG;2 mRNA sequence were found 19 AUG codons in the same reading frame as the start codon. We identified two sites with $66.7 \%$ similarity between context sequences NtCDKG;2 and CDK11. Among these sites, if the site ACUCCAUGG would be used, cap-independent translation would generate a protein of approximately $45.9 \mathrm{kDa}$. The evaluated sites and their sequences are listed in Supplementary Table S2.

\section{DISCUSSION}

The cell cycle control is highly conserved in all organisms. CDKs, cyclins and cell cycle inhibitors constitute the core proteins in this control. Although present in all organisms, plants harbor a highly larger number of these proteins compared to other eukaryotes, indicating that, in them, the cell cycle is thinly regulated. For instance, VAN LEENE and co-workers (2010) revealed there are 71 cell cycle regulator proteins in Arabidopsis, compared to 23 in H. sapiens and 15 in Saccharomyces cerevisiae. In 
previous studies, we have identified SCl1 as a inhibitor of cell cycle specific of pistil (DEPAOLI et al., 2011). Because it is the first cell cycle inhibitor presenting tissuespecificity, SCl1 opens a new class of inhibitors (DEPAOLI; GOLDMAN; GOLDMAN, 2012). In this article, we show that SCl1 interacts with NtCDKG;2 and NtCycL1 proteins and they also interact with each other. The interaction between SCl1 and NtCDKG;2 has been identified by a pull-down experiment using a protein extract enriched with protein stigmas and styles as provider of prey proteins. Interactions between SCI1 and NtCDKG;2 with CycL1 protein were confirmed by methods $\mathrm{Y} 2 \mathrm{H}$ and BiFC. We also show that, in plant cells, both interactions of SCI1 with NtCDKG;2 and CycL1 occur in a region similar to the nucleolus periphery. According to Boruc and collaborators (2010), the great majority of interactions involving cell cycle regulators occurs in the cell nucleus, however, no details were given about which nuclear sub-compartment interactions occur. The nucleolus is a structure known to be involved in the synthesis and processing of rRNAs and coupling them with ribosomal proteins (HERNANDEZVERDUN et al., 2010). However, its role in the cell goes much far beyond that. Several cell cycle regulators have been reported associated with the nucleolus in specific phases of the cell cycle, suggesting a role for this compartment to regulate specific aspects of cell cycle progression (BOISVERT et al., 2007; LAM; TRINKLE-MULCAHY, 2015).

We also report here that both NtCDKG;2 and CycL1 localize in nuclear splicing speckles structures when expressed alone and also when they interact. The literature has reported that they Arabidopsis homologous proteins, CDKG;2 and CycL1 interact in the cell nucleus, but its interaction in nuclear speckles (as shown here) had not been reported. The GFP-CDKG;1 protein also localizes in nuclear splicing speckles (DOONAN; KITSIOS, 2009 appud Kitsios, G., 2006). Similar to NtCDKG;2, its 
homologous CDK11 110 from $H$. sapiens, is located in the nucleoplasm and nuclear speckles, especially when associated with its partners CycL $\alpha$ e CycL $\beta$ (HU et al., 2003; LOYER et al., 1998; TREMBLEY et al., 2002).

Additionally, we show that amino-terminal region of NtCDKG;2 has $5 \mathrm{RS}$ motives. In A. thaliana, CDKG;1 has 4, while CDKG;2 presents 6 RS motives (HUANG et al., 2013). It is believed that the RS motives are responsible for measuring the interaction with SR splicing factor SR (HUANG et al., 2013; WU; MANIATIS, 1993). The SR splicing factors are Serine-Arginine (SR) and Arginine-Serine (RS) rich that also contains RNA binding domains and participate in constitutive and alternative splicing processes (REDDY, 2004). Similar to NtCDKG;2, the SRPKs kinases (Serine/Arginine-Rich Protein Kinases), which specifically phosphorylate SR proteins, also present RS motives (DE LA FUENTE VAN BENTEM et al., 2006). Moreover, Arabidopsis Cyclin L1 also exhibits characteristics of SR splicing factors and was already related necessary to the correct splicing of resistance genes, is involved in siRNA accumulation and DNA methylation (FORMENT et al., 2002; ZHANG et al., 2013). In H. sapiens, Cyclin $L$ has a large similarity with the splicing factor ASF/SF2 and is also involved in RNA splicing (DICKINSON et al., 2002). Thus, the interaction between NtCDKG;2 and NtCycL1 in speckles is very peculiar, since the fact it may constitute a classic CDK-cyclin interaction, NtCycL1 could also being phosphorylated by NtCDKG;2. According LORKOVIĆ and collegues (2004), when active, SR protein does not localizes into nucleolus. Therefore, we suggest that SCl1 inhibits the action of NtCDKG;2 and CycL1 while imprisoned such proteins into nucleolus.

To complete we also bring firsthand that caboxi-terminal domain of NtCDKG;2 might be translated by a cap-independent process, as well as its homologous CDK $11^{\text {p58 }}$ of $H$. sapiens. It has been proposed that cap-independent translation 
mediated by IRES, would provide to the cell a high spatial and temporal control, which is necessary to adjust stress response (GRABER; HOLCIK, 2007). In addition, IRES elements are fundamental to drive the translation in certain stages of the cell cycle where cap-dependent translation is compromised, but some proteins are still needed by the cell, as CDK11 ${ }^{\text {p58 }}$ isoform which is needed during mitosis (CORNELIS et al., 2000; FITZGERALD; SEMLER, 2009).

\section{EXPERIMENTAL PROCEDURES}

\section{Plant Material}

Wild-type Nicotiana tabacum (cv Petit Havana SR-1) plants used to RNA extraction were grown under standard greenhouse conditions. Nicotiana benthamiana plants with 70-90 days after germination were used for protein localization experiments, colocalization and BiFC. Plants were kept in a grown chamber $\left(22^{\circ} \mathrm{C}, 55 \%\right.$ of humidity and 12h:12h (light: dark photoperiod).

\section{GST Pull-down assay}

In vitro GST pull-down was used to identify interactions between SCl1 and sigma/styles nuclear proteins from $N$. tabacum. SCl1 coding region was subsequently recombined into bacterial expression vector pDEST15 (Invitrogen, Gateway Technology) via LR recombination (LR Clonase, Invitrogen) and was used to express

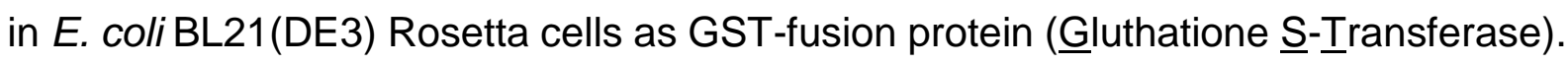
Briefly, E. coli BL21(DE3) Rosetta cells were grown overnight (16h), 100-fold diluted in fresh LB with $100 \mathrm{mg} / \mathrm{L}$ ampicillin, and incubated at $37^{\circ} \mathrm{C}$ until an $\mathrm{OD}_{600}$ of $0.4-0.6$ was reached. The expression of the recombinant proteins was induced with $0,1 \mathrm{mM}$ IPTG for $3 \mathrm{~h}$ at $37^{\circ} \mathrm{C}$. The proteins were then purified and immobilized on GSTrap (GE Healthcare) column. To obtain nuclear-enriched protein extract, $10 \mathrm{~g}$ of SR1 stigmas 
and styles were collected and the extraction performed according to the protocol described by ESCOBAR and colleagues (2001).

\section{RNA extraction and RT-qPCR}

Initially, stigmas/styles were excised from tobacco flowers at the defined developmental stages as described previously (KOLTUNOW et al., 1990), immediately frozen in liquid nitrogen and stored at $-70^{\circ} \mathrm{C}$. TRIzol $\AA^{\circ}$ Reagent (Ambion, Life Technologies) was used for RNA extraction. RNA was submitted to a specific treatment using DNA-freeTM Kit (Ambion®) and posteriorly the cDNA was done using the reverse transcriptase Superscript ${ }^{\mathrm{TM}}$ III (Invitrogen). The All the reactions were made strictly according the manufacturer's protocols. RT-qPCR was performed in 7500 Fast Real-Time PCR System (Applied Biosystems) and the SYBR Green PCR Master Mix (Applied Biosystems) was used for amplification. Amplification was carried out in $10 \mu$ reaction volume. We used RPL2 (Ribosomal protein L2) and GAPDH (Glyceraldehyde 3-phosphate dehydrogenase) as reference genes. Relative quantification estimates were made by Delta-Delta-CT method (Pfaffl, 2001).

\section{GFP-NtCDKG;2 transgenic BY-2 lines}

A suspension culture of Bright Yellow 2 (BY-2) cells expressing GFP-NtCDKG;2 was cultured in standard BY-2 medium (according NAGATA T, NEMOTO Y, 1992) and agitated on a rotary shaker at $150 \mathrm{rpm}$ at $28^{\circ} \mathrm{C}$ in the dark. The culture was maintained by transferring $1 \mathrm{ml}$ of stationary phase cells to $50 \mathrm{ml}$ of fresh medium in a $250-\mathrm{ml}$ Erlenmeyer flask at weekly intervals.

\section{Plant transformation - para localização/co-loc e BiFC}


For localization assays, we cloned the coding sequences of NtCDKG;2 and NtCycL1 in pK7WGF2 and pK7FWG2 plasmids (KARIMI; INZÉ; DEPICKER, 2002), respectively, via LR recombination (Invitrogen, Gateway System). Protein markers used for co-localization assays were described by KOROLEVA and collaborators (2009). BiFC plasmids were constructed with CaMV 35S promoter guiding the coding sequence fused with the $\mathrm{N}$ - or the $\mathrm{C}$-terminal portion of green fluorescent protein (GFP). Additionally, it has used the p19-pCB301 plasmid, which contains the coding region for p19 post-transcriptional silencing suppressor. P19 protein of tomato bushy stunt virus (TBSV) is often used to increased transient expression levels in plants (LOMBARDI et al., 2009; ZHENG et al., 2009). Agrobacterium-mediated transformation was performed for transient expression assays. Initially, Agrobacterium tumefaciens colonies were grown in $5 \mathrm{ml}$ of liquid LB medium with selective pressure of appropriate antibiotics $\left(24 \mathrm{~h}, 28^{\circ} \mathrm{C}, 200 \mathrm{rpm}\right)$. After that, $1,5 \mathrm{ml}$ of each colony was precipitated (2500 x g, $5 \mathrm{~min}$ ) and ressuspended in $1 \mathrm{ml}$ activation buffer [10 mM MES; $10 \mathrm{mM} \mathrm{MgCl} 2 ; 200 \mu \mathrm{M}$ de acetoseringone] and stayed in dark 2-4h. Optical density of each Agrobacterium solution was adjusted to 0,3. Finally, N. benthamiana leaves were totally infiltrated by syringe Agroinfiltration and analyzed 2-6 d after that procedure.

\section{DAPI and Hoechst 33342 stained}

For protein subcellular localizations and BiFC experiments, infiltrated leaves were cut in small pieces and stained with $1.25 \mu \mathrm{g} / \mathrm{mL} 4,6^{\prime}$-diamidino-2-phenylindole (DAPI) on PBS [137 mM NaCl; 2,7 mM KCl; 10 mM Na2HPO4; 2 mM KH2PO4; pH 7,2] for 15 min at vaccum $(15 \mathrm{mmHg})$ on darkness, washed in PBS and mounted on slides with PBS, just prior to analyses. To Hoechst stained, $2 \mathrm{ml}$ of a $3 \mathrm{~d}$ BY-2 culture expressing GFP-NtCDKG;2 was transferred to a $50 \mathrm{ml}$ tube and added $5 \mu \mathrm{g} / \mathrm{ml}$ Hoechst 33342. 
The culture was manteined overnight $\left(28^{\circ} \mathrm{C}, 150 \mathrm{rpm}\right)$ and analysed in confocal microscopy.

\section{Microscopy experiments}

Confocal imaging with Leica TCS SP5 (Leica Microsystems) confocal laser scanning microscope was carried out to NtCDKG;2 localization, co-localization and all BiFC experiments. Zeiss LSM780 AxioObserver (Zeiss Microsystems) was used to CycL1 co-localization assays. To DAPI and Hoechst visualization, excitation was with UV light at $405 \mathrm{\eta m}$ and the spectral detector was set between $420-480 \mathrm{\eta m}$ and $440-470 \mathrm{\eta m}$, correspondingly. To GFP visualization, excitation was with Argon laser at $488 \mathrm{~nm}$ and the detector was set between $500-530 \mathrm{~nm}$. Finally, to visualize nuclear marker protein RFP-tagged cells were excited using $543 \mathrm{~nm}$ laser and the emission was detected between 630-680 $\eta \mathrm{m}$. Image analysis was carried out with the softwares Leica LAS AF v.2.x and ImageJ.

\section{Yeast Two-hybrid assays}

Two-hybrid (Y2H) assays were carried out using yeast (Saccharomyces cerevisiae) strain PJ69-4A (James et al., 1996). SD medium and dropout solutions were made accordingly DE FOLTER and IMMINK (2011). Yeast cells were co-transformed to carry the bait and prey vectors and transformed cells were transferred to SD medium lacking Trp and Leu to select for yeasts containing prey and bait vectors. After $3 \mathrm{~d}$ on $30^{\circ} \mathrm{C}$, colonies were transferred to a liquid culture (overnight, $30^{\circ} \mathrm{C}, 250 \mathrm{rpm}$ ). Next day, the optical density of cultures was adjusted to $0,2(600 \mathrm{~nm})$ and plated on SD medium 
lacking Trp, Leu, and His. Plates were incubated for $3 \mathrm{~d}$ at $30^{\circ} \mathrm{C}$ up to $30 \mathrm{~d}$ at $20^{\circ} \mathrm{C}$. Empty prey and bait plasmids were used as negative controls with each bait and prey construct, respectively. Were considered as positives results when an indubitable growth was detected only in the yeast with bait and pray an any growth was observed on bait and pray negative controls. Three biological replicates were made with fresh transformants.

\section{LEGENDS}

Figure 1: Identification of NtCDKG;2 as an interaction partner of SCl1 by pull-down (a) and by BiFC (b-g) assays. (a) SDS-PAGE analysis of sample eluted from the pull-down test, carried out with the heterologous protein GST-SCI1, expressed in E. coli BL21 (DE3) Rosetta cells and enriched extract to nuclear stigmas/styles proteins of $\mathrm{N}$. tabacum wild type plants; M: molecular weight marker; 1, 2 and 3: eluted sample tested in biological triplicate; Black arrow indicates the localization of the bands that have been identified as NtCDKG;2; Green (b,e) indicates interaction of SCl1-nGFP and NtCDKG;2-cGFP; blue (c, d) correspond to DAPI staining; (d) overlap of images b and c; (g) overlap of images e and f; White arrows in (b, c, e, f) indicate a nucleolar region similar do periphery of nucleolus; Scale bars (b-g): $5 \mu \mathrm{m}$.

Figure 2: Identification of NtCycL1 as interaction partner of both NtCDKG;2 and SCI1 proteins by BiFC (a-f) and $\mathrm{Y} 2 \mathrm{H}(\mathrm{g})$ assays. (a) indicates interaction of NtCDKG;2-nGFP and NtCycL1-cGFP; blue (b, e) correspond to 4',6-diamidino-2-phenylindole (DAPI) staining; (c) overlapping images (a) and (b); (d) indicates interaction of SCI1-nGFP and NtCycL1-cGFP; (f) overlap of images (d) and (e); Scale bars (a-f): $5 \mu \mathrm{m}$; (g) $\mathrm{Y} 2 \mathrm{H}$ assays confirming the interactions among NtCycL1 with NtCDKG;2 and SCl1 proteins; 
Red arrow in (a) indicates a splicing speckles-like structure; White arrows in (d) and (e) indicate a nucleolar region similar do periphery of nucleolus.

Figure 3: Subcellular localization of NtCDKG;2 (left panel) and NtCycL1 (right panel). $(a, d, g)$ indicate GFP-NtCDKG;2 localization in nuclei; (j, m, p) indicate NtCycL1-GFP localization in nucleoplasm and more evident in nucleolus-like compartments; blue (b, e, h, k, n, q) correspond to 4',6-diamidino-2-phenylindole (DAPI) staining in different cells; (c, f, I, I, o, r) overlap of previous images from the same line into de same panel; Red arrow in (a) indicates a small GFP signal inside nucleolus; White arrows in (d, j, $\mathrm{m}, \mathrm{p})$ indicate splicing speckles-like structures; Scale bars: $5 \mu \mathrm{m}$.

Figure 4: Subcellular localization of NtCDKG;2 during different cell cycle phases of BY-2 cells culture. (a, d, g, j, m, p, s) indicate Hoechst 33342 staining; (b, e, h, k, n, q, t) indicate GFP-NtCDKG;2 localization in different cell cycle phases; (c, f, I, I, o, r, u) are the overlapping from previous images in the same line; White arrows indicate the corresponding cell cycle phase; I: Interphase; P: Prophase; M: Metaphase; A: Anaphase; T: Telophase; C: Cytokinesis. Scale bars: $5 \mu \mathrm{m}$;

Figure 5: Subcellular co-localization of NtCDKG;2 (Figure A) and NtCycL1 (Figure B) with the nuclear marker proteins AtCyp64, AtSRp34, AtFib1 and AtCoillin. In both Figures A and B, (a, e, I, m) indicate DAPI staining; (b), (f), (j) and (n) indicate AtCyp64RFP, AtSRp34, AtFib1 and AtCoillin localization, respectively; GFP-NtCDKG;2 localizations in nuclei are showed in (c, g, k, o) from Figure A; GFP-CycL1 localizations in nuclei are showed in $(c, g, k, 0)$ from Figure $B ;(d, h, l, p)$ overlap of previous images from the same line into de same figure; White arrow in (c) and (k) from Figure $A$ indicates small GFP dots inside nucleolus; Scale bars: $5 \mu \mathrm{m}$. 
Figure 6: NtCDKG;2 gene and protein analysis. (a) NtCDKG;2 expression level in the different tobacco organs as determined by qRT-PCR, using GAPDH and RPL2 reference genes. (b) Expression level in stigmas/styles during the 12 stages of tobacco flower development (KOLTUNOW et al., 1990). (c) Schematic diagram of the full length NtCDKG;2 protein. The NtCDKG;2 has an amino-terminal region RS-rich (green blocks) that may be involved in its interaction with splicing factors. The sequence has multiple Nuclear Location Sites (NLS - blue blocks). In addition, putative binding sites are highlighted: Blue arrows indicate sites for interaction with cyclins and CDK/cyclin complex inhibitors; brown arrow indicate substrate recongnition site; purple arrows indicate F-Box proteins binding site; pink arrow indicate binding site for 14-3-3; green and yellow arrows indicate sites for phosphorylation by CDKs (green) and dephosphorylation by phosphatase (yellow). The catalytic domain (STK_c) is grayed out and the putative site for cap-independent translation by ribosome entry (IRES) is indicated with the purple big arrow.

\section{SUPPLEMENTARY INFORMATION}

Table S1: Accession numbers for CDKG;2 proteins in N. tabacum TN90 variety.

Table S2: Identification of a putative IRES site in NtCDKG;2 mRNA sequence.

Figure S1: Molecular phylogenetic analysis inferred by ML (maximum likelihood) based on matrices model JTT (Jones-Taylor-Thornton).

\section{ACKNOWLEDGEMENTS}

We are immensely thankful for all the support gived by Elizabete Rosa Milani (FMRP/USP) during confocal procedures. pK7WGF2 and pK7FWG2 plasmids were gently provided by VIB research institute (Ghent, Belgium). RFP-tagged protein 
markers were gently provided by Dr. Peter J. Shaw (John Innes Centre, UK). We would also like to greatly thank Dr. Ruud de Maagd and Richard G. H. Immink (from Business Unit Bioscience, PRI and Laboratory of Molecular Biology, Wageningen University, NL) for all the suggestions and support for $\mathrm{Y} 2 \mathrm{H}$ experiments.

\section{REFERENCES}

BOISVERT, F.-M. et al. The multifunctional nucleolus. Nat Rev Mol Cell Biol, v. 8, n. 7, p. 574-85, 2007.

BORUC, J. et al. Functional modules in the Arabidopsis core cell cycle binary proteinprotein interaction network. The Plant cell, v. 22, n. 4, p. 1264-1280, 2010.

CHURCHMAN, M. L. et al. SIAMESE, a plant-specific cell cycle regulator, controls endoreplication onset in Arabidopsis thaliana. Plant Cell, v. 18, n. 11, p. 3145-3157, 2006.

CORNELIS, S. et al. Identification and characterization of a novel cell cycle-regulated internal ribosome entry site. Molecular Cell, v. 5, n. 4, p. 597-605, 2000.

DE FOLTER, S.; IMMINK, R. G. H. Yeast protein-protein interaction assays and screens. In: Methods in Molecular Biology. [s.I: s.n.]. v. 754p. 145-165.

DE LA FUENTE VAN BENTEM, S. et al. Phosphoproteomics reveals extensive in vivo phosphorylation of Arabidopsis proteins involved in RNA metabolism. Nucleic Acids Research, v. 34, n. 11, p. 3267-3278, 2006.

DE VEYLDER, L. et al. Functional analysis of cyclin-dependent kinase inhibitors of Arabidopsis. Plant Cell, v. 13, n. 7, p. 1653-1667., 2001.

DEPAOLI, H. C. et al. Stigma/style cell cycle inhibitor 1 (SCl1), a tissue-specific cell cycle regulator that controls upper pistil development. New Phytologist, v. 190, n. 4, p. 882-95, 2011.

DEPAOLI, H. C.; DORNELAS, M. C.; GOLDMAN, M. H. S. SCl1 is a component of the auxin-dependent control of cell proliferation in Arabidopsis upper pistil. Plant Science, v. 229 , p. 122-130, 2014.

DEPAOLI, H.; GOLDMAN, G.; GOLDMAN, M.-H. SCl1, the first member of the tissuespecific inhibitors of CDK (TIC) class, is probably connected to the auxin signaling pathway. Plant Signaling \& Behavior, v. 7, n. 1, p. 1-6, 2012.

DICKINSON, L. A. et al. Cyclin $L$ is an RS domain protein involved in pre-mRNA splicing. Journal of Biological Chemistry, v. 277, n. 28, p. 25465-25473, 2002.

DOONAN, J. H.; KITSIOS, G. Functional evolution of cyclin-dependent kinases. Molecular biotechnology, v. 42, n. 1, p. 14-29, 2009.

ESCOBAR, C. et al. Isolation of active DNA-binding nuclear proteins from tomato galls induced by root-knot nematodes. Plant Molecular Biology Reporter, v. 19, n. 4, p. 375a-375h, 2001.

FITZGERALD, K. D.; SEMLER, B. L. Bridging IRES elements in mRNAs to the eukaryotic translation apparatus. Biochim Biophys Acta, v. 1789, n. 9-10, p. 518528, jan. 2009.

FORMENT, J. et al. Expression of Arabidopsis SR-like splicing proteins confers salt tolerance to yeast and transgenic plants. The Plant journal, v. 30, n. 5, p. 511-519, jun. 2002. 
GRABER, T. E.; HOLCIK, M. Cap-independent regulation of gene expression in apoptosis. Molecular BioSystems, v. 3, n. 12, p. 825-834, 2007.

HERNANDEZ-VERDUN, D. et al. The nucleolus: Structure/function relationship in RNA metabolism. Wiley Interdisciplinary Reviews: RNA, v. 1, n. 3, p. 415-431, 2010.

$\mathrm{HU}$, D. et al. CDK11 complexes promote pre-mRNA splicing. Journal of Biological Chemistry, v. 278, n. 10, p. 8623-8629, 2003.

HUANG, X.-Y. et al. CYCLIN-DEPENDENT KINASE G1 is associated with the spliceosome to regulate CALLOSE SYNTHASE5 splicing and pollen wall formation in Arabidopsis. The Plant cell, v. 25, n. 2, p. 637-648, 2013.

INAGAKI, S.; UMEDA, M. Cell-Cycle Control and Plant Development. 1. ed. [s.I.] Elsevier Inc., 2011. v. 291

INZÉ, D. (Ed.). Cell Cycle Control and Plant Development. Annual Plant Reviews, v. 32, 2007.

INZÉ, D.; DE VEYLDER, L. Cell cycle regulation in plant development. Annual Review of Genetics, v. 40, p. 77-105, jan. 2006.

JONES, D. T.; TAYLOR, W. R.; THORNTON, J. M. The rapid generation of mutation data matrices from protein sequences. Computer Applications in the Biosciences, v. 8, n. 3, p. 275-282, 1992.

JOUBÈS, J. et al. CDK-related protein kinases in plants. Plant molecular biology, v. 43, n. 5-6, p. 607-620, 2000.

KARIMI, M.; INZÉ, D.; DEPICKER, A. GATEWAYTM vectors for Agrobacteriummediated plant transformation. Trends in Plant Science, v. 7, n. 5, p. 193-195, 2002. KOLTUNOW, A. M. et al. Different Temporal and Spatial Gene Expression Patterns Occur during Anther Development. The Plant cell, v. 2, n. 12, p. 1201-1224, 1990.

KOROLEVA, O. A et al. Dynamic behavior of Arabidopsis elF4A-III, putative core protein of exon junction complex: fast relocation to nucleolus and splicing speckles under hypoxia. The Plant cell, v. 21, n. 5, p. 1592-606, 2009.

LAM, Y. W.; TRINKLE-MULCAHY, L. New insights into nucleolar structure and function. F1000Prime Reports, v. 7, n. April, p. 48, 2015.

LIM, S.; KALDIS, P. Cdks, cyclins and CKIs: roles beyond cell cycle regulation. Development, v. 140, n. 15, p. 3079-3093, 2013.

LOMBARDI, R. et al. High-level HIV-1 Nef transient expression in Nicotiana benthamiana using the P19 gene silencing suppressor protein of Artichoke Mottled Crinckle Virus. BMC biotechnology, v. 9, p. 96, 2009.

LORKOVIĆ, Z. J.; JULIA, H.; BARTA, A. Use of fluorescent protein tags to study nuclear organization of the spliceosomal machinery in transiently transformed living plant cells. Molecular biology of the cell, v. 15, n. 7, p. 3233-3243, 2004.

LOYER, P. et al. The RNP protein, RNPS1, associates with specific isoforms of the p34cdc2-related PITSLRE protein kinase in vivo. Journal of cell science, v. 111, p. 1495-506, 1998.

MA, X. et al. CYCLIN-DEPENDENT KINASE G2 regulates salinity stress response and salt mediated flowering in Arabidopsis thaliana. Plant Molecular Biology, v. 88, n. 3, p. 287-299, 2015.

MENGES, M. et al. Global analysis of the core cell cycle regulators of Arabidopsis identifies novel genes, reveals multiple and highly specific profiles of expression and provides a coherent model for plant cell cycle control. The Plant Journal, v. 41, n. 4, p. 546-66, 2005.

MORGAN, D. O. The cell cycle - Principles of control. London: New Science Press Ltd, 2007. 
NAGATA T, NEMOTO Y, H. S. Tobacco BY-2 cell line as the "HeLa" cells in the cell biology of higher plants. In: International Review of Cytology-a Survey of Cell Biology. [s.l: s.n.]. p. 1-30.

REDDY, A. S. N. Plant serine/arginine-rich proteins and their role in pre-mRNA splicing. Trends in Plant Science, v. 9, n. 11, p. 541-547, 2004.

SANCHEZ, A. M. et al. Pistil factors controlling pollination. The Plant cell, v. 16, p. S98-S106, 2004.

TREMBLEY, J. H. et al. PITSLRE p110 protein kinases associate with transcription complexes and affect their activity. Journal of Biological Chemistry, v. 277, n. 4, p. 2589-2596, 2002.

VAN LEENE, J. et al. A tandem affinity purification-based technology platform to study the cell cycle interactome in Arabidopsis thaliana. Molecular \& cellular proteomics: MCP, v. 6, n. 7, p. 1226-38, jul. 2007.

VAN LEENE, J. et al. Targeted interactomics reveals a complex core cell cycle machinery in Arabidopsis thaliana. Molecular Systems Biology, v. 6, n. 397, p. 1-12, 2010a.

VAN LEENE, J. et al. Targeted interactomics reveals a complex core cell cycle machinery in Arabidopsis thaliana. Molecular systems biology, v. 6, n. 397, p. 397, 10 ago. 2010b.

VANDEPOELE, K. et al. Genome-Wide Analysis of Core Cell Cycle Genes in Arabidopsis. The Plant Cell, v. 14, p. 903-916, 2002.

WANG, H.; FOWKE, L. C. A Plant Cyclin-dependent Kinase Inhibitor Gene. Nature, v. 386, n. 6624, p. 451-452, 1997.

WU, J. Y.; MANIATIS, T. Specific interactions between proteins implicated in splice site selection and regulated alternative splicing. Cell, v. 75, n. 6, p. 1061-1070, 1993. ZHANG, C. et al. The splicing machinery promotes RNA-directed DNA methylation and transcriptional silencing in Arabidopsis. The EMBO Journal, v. 32, n. 8, p. 1128-1140, 2013.

ZHENG, N. et al. Boosted expression of the SARS-CoV nucleocapsid protein in tobacco and its immunogenicity in mice. Vaccine, v. 27, n. 36, p. 5001-5007, 2009.

ZHENG, T. et al. CDKG1 protein kinase is essential for synapsis and male meiosis at high ambient temperature in Arabidopsis thaliana. PNAS, v. 111, n. 6, p. 2182-7, 2014. 
FIGURES

Figure 1
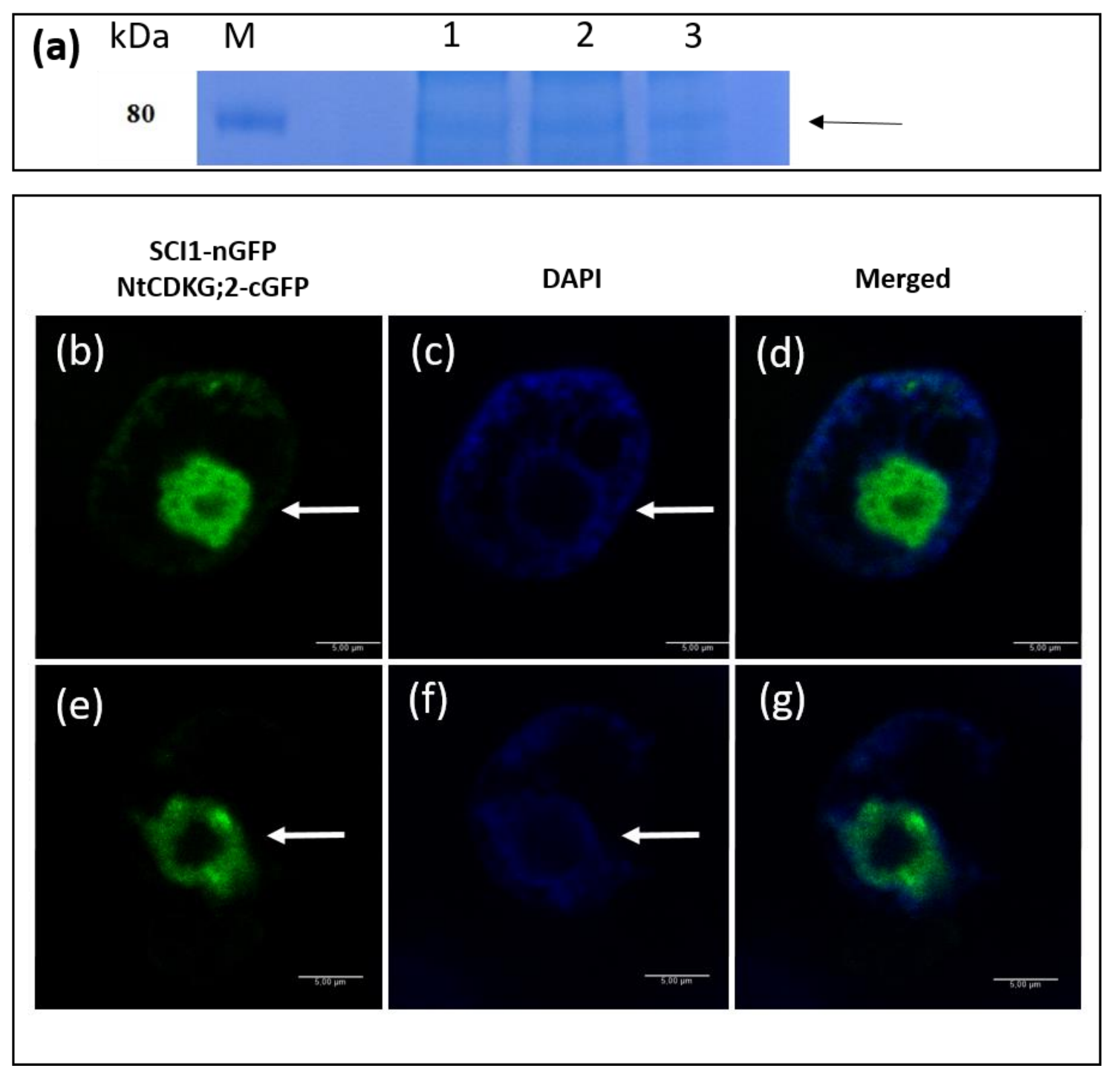
Figure 2

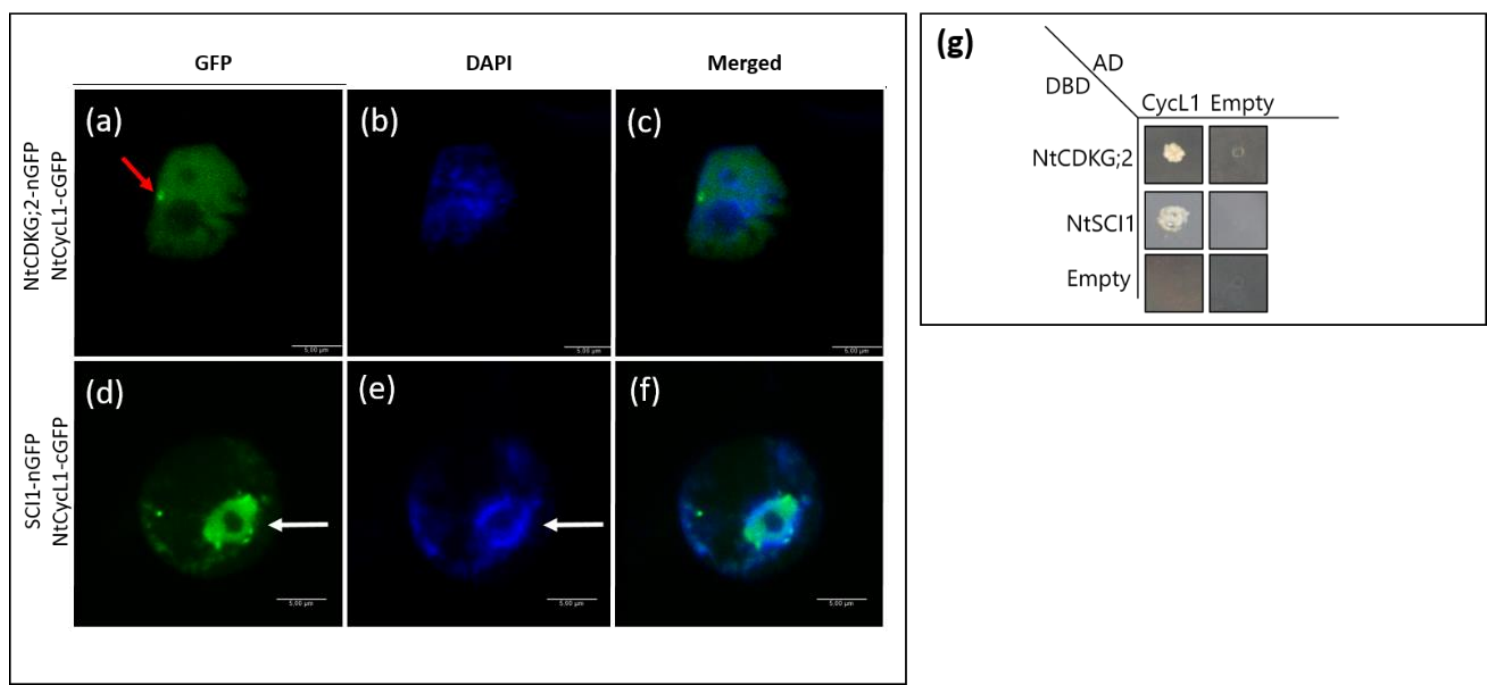

Figure 3
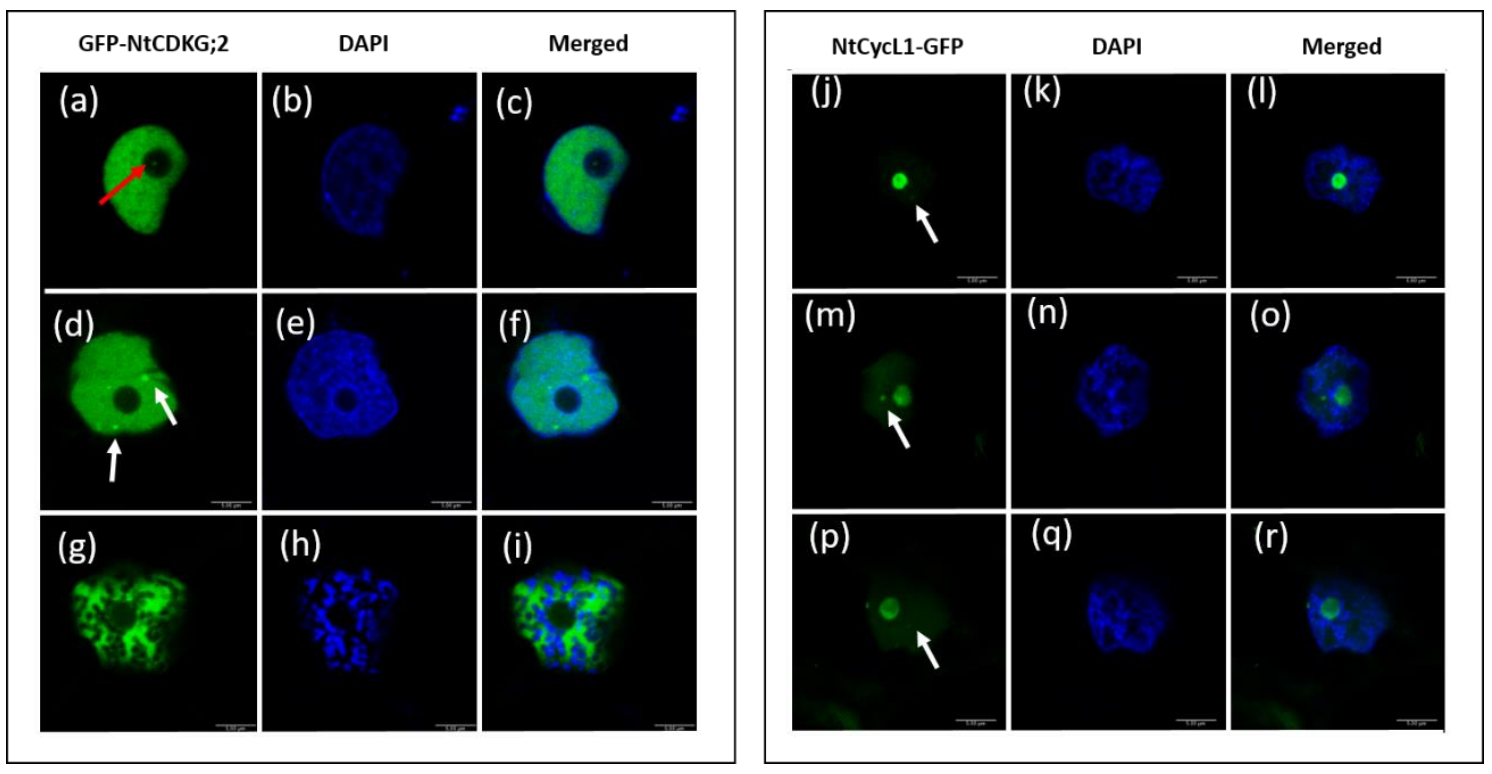
Figure 4

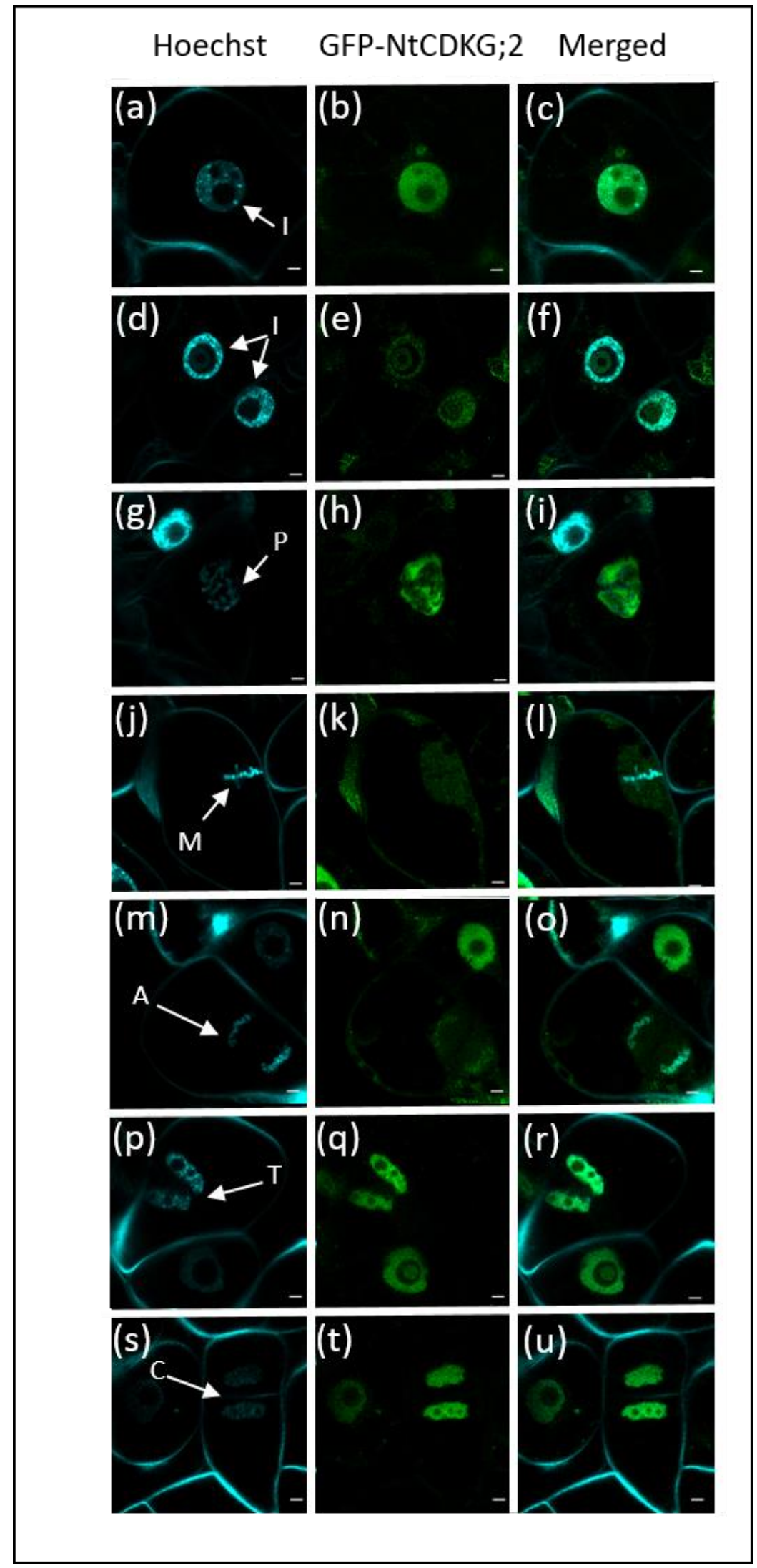


Figure 5
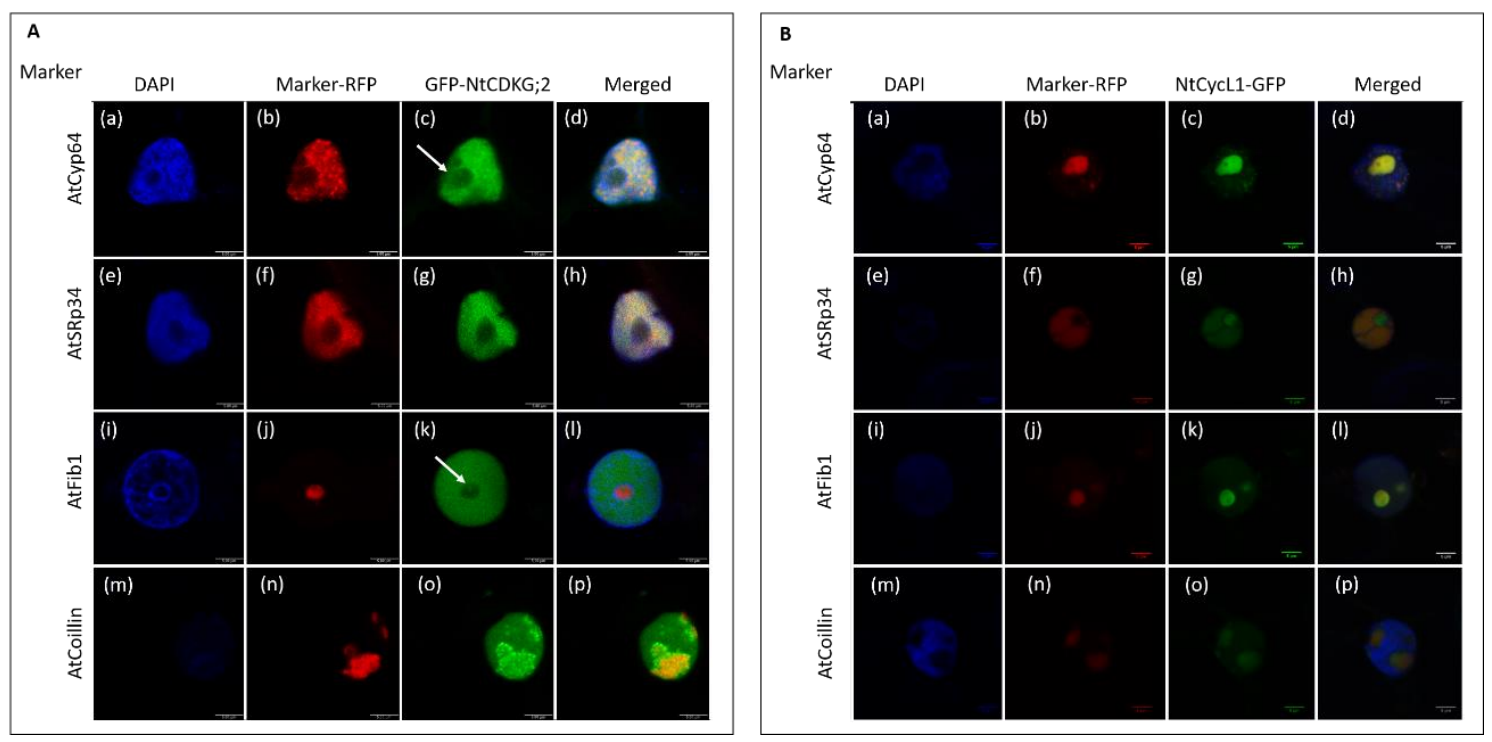

Figure 6
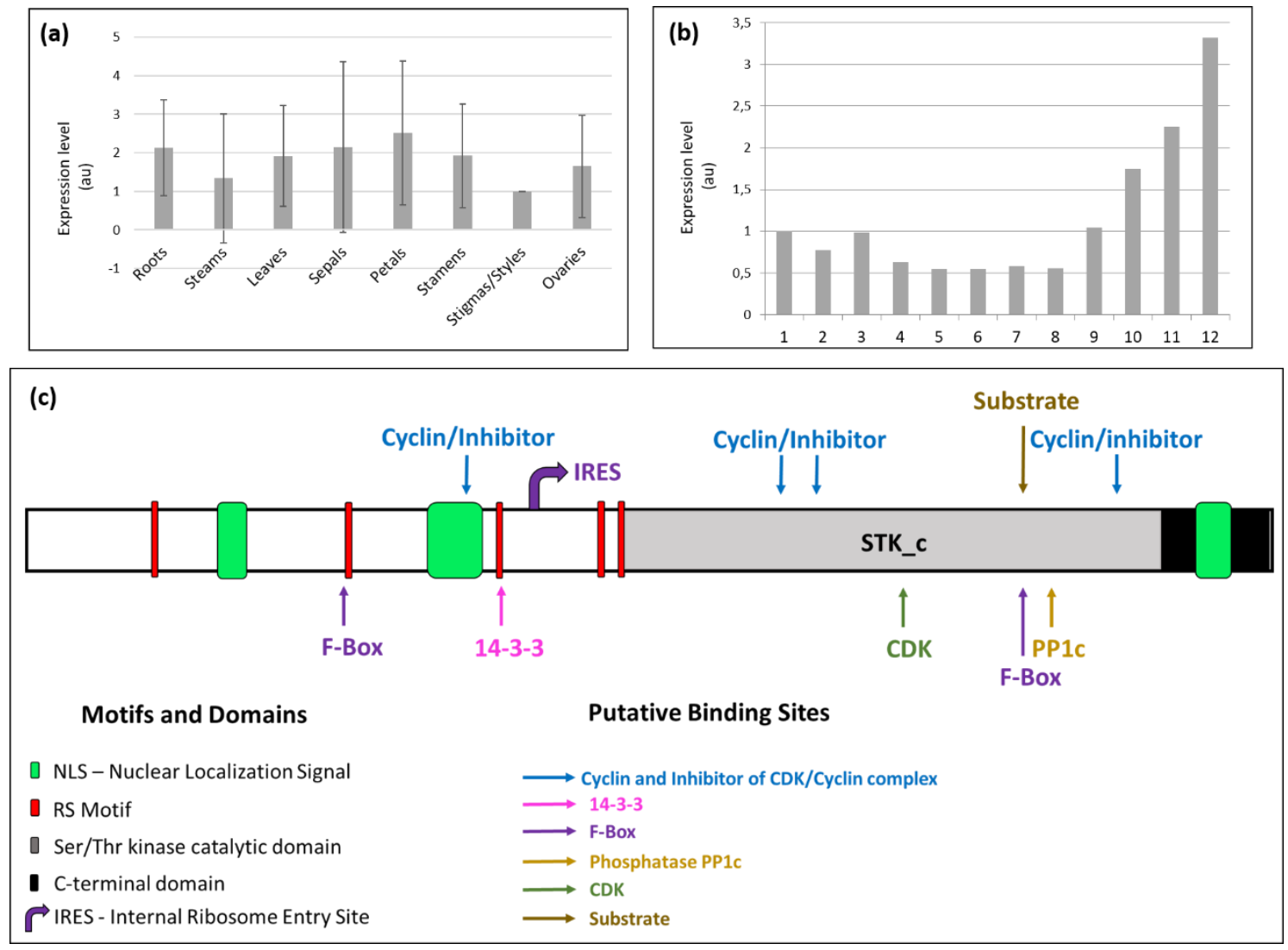


\section{SUPPLEMENTARY INFORMATION}

Table S1: Accession numbers of amino acid sequences used in the phylogenetic analysis of CDKG;2.

\begin{tabular}{|c|c|c|c|}
\hline Specie & $\begin{array}{l}\text { Cultivated } \\
\text { variety }\end{array}$ & Topology IDa & $\begin{array}{c}\text { Accession } \\
\text { number }\end{array}$ \\
\hline \multirow{6}{*}{ N. tabacum } & \multirow{3}{*}{ TN90 } & $\begin{array}{c}\text { NtaCDKG;2-like X1 } \\
(501762)\end{array}$ & XP_016501762.1 \\
\hline & & $\begin{array}{c}\text { NtaCDKG;2-like X1 } \\
(482370)\end{array}$ & XP_016482370.1 \\
\hline & & $\begin{array}{c}\text { NtaCDKG;2-like X1 } \\
\text { (498534) }\end{array}$ & XP_016498534.1 \\
\hline & \multirow{3}{*}{ SR1 } & NtaCDKG;2-like (508954) & XP_016508954.1 \\
\hline & & CL609.Contig11_All & This paper \\
\hline & & $\mathrm{NtCDKG;2}$ & This paper \\
\hline \multirow{2}{*}{ N. sylvestris } & \multirow[t]{2}{*}{-} & NsCDKG;2-like X2 & XP_009771043.1 \\
\hline & & NsCDKG;2-like X1 & XP_009798222.1 \\
\hline \multirow{2}{*}{ N. tomentosiformis } & \multirow[b]{2}{*}{ - } & NtoCDKG;2 X1 & XP_009591473.1 \\
\hline & & NtoCDKG;2-like X1 & $X P[009603474.1$ \\
\hline N. benthamiana & - & $\mathrm{NbCDK} 12$ & $\begin{array}{c}\text { Niben101Scf01073g } \\
01005.1\end{array}$ \\
\hline $\begin{array}{c}\text { Solanum } \\
\text { lycopersicum }\end{array}$ & - & SICDK10 & Solyc05g014760.2.1 \\
\hline \multirow[t]{2}{*}{$\begin{array}{l}\text { Solanum } \\
\text { tuberosum }\end{array}$} & \multirow[t]{2}{*}{ - } & StCDK10 (05g015800) & Sotub05g015800.1.1 \\
\hline & & StCDK10 (11g007830) & Sotub11g007830.1.1 \\
\hline \multirow[t]{2}{*}{ A. thaliana } & \multirow{2}{*}{ - } & AtCDKG;1 & At5g63370.1 \\
\hline & & AtCDKG;2 & At1g67580.1 \\
\hline \multirow[t]{2}{*}{ R. communis } & \multirow{2}{*}{ - } & RcCDK11B & XP_002514988.1 \\
\hline & & RcCDKG;2 & XP-015580094.1 \\
\hline \multirow[t]{2}{*}{ Oryza sativa } & \multirow{2}{*}{ - } & OsCDKG;1 & XP_015625437.1 \\
\hline & & OsCDKG;2 & XP_015635720.1 \\
\hline \multirow[t]{2}{*}{$\begin{array}{l}\text { Populus } \\
\text { tricocharpa }\end{array}$} & & PtCDKG;1 & Potri.008G178200 \\
\hline & & PtCDKG;2 & Potri.012G094600 \\
\hline Vitis vinifera & & VvCDKG;2 X1 & XP_002266306.2 \\
\hline
\end{tabular}

a Topology ID consists of abbreviations of the original annotation of each sequence.

${ }^{b}$ The accession numbers belong to NCBI banks ( $N$. tabacum, $N$. sylvestris, $N$. tomentosiformis, $R$. communis, $O$. sativa and $V$. vinifera); SOL Genomics Network ( $N$. benthamiana, $S$. lycopersicum and S. tuberosum); TAIR (A. thaliana); and Popgenie.org ( $P$. tricocharpa). 
Table S2: Identification of a putative IRES site in NtCDKG;2 mRNA sequence.

\begin{tabular}{|c|c|c|c|}
\hline & $\begin{array}{c}\text { AUG } \\
\text { (Position) }^{a}\end{array}$ & Context $^{\mathrm{b}}$ (CC[A/G]CCAUGG) & $\begin{array}{c}\text { Consensus } \\
\text { Id. }^{c}\end{array}$ \\
\hline 1 & 1 & - & \\
\hline 2 & 147 & ga c ga AUG a & 0.0 \\
\hline 3 & 168 & ga $G$ ag AUG a & 16.7 \\
\hline 4 & 171 & ag $A$ ug AUG a & 16.7 \\
\hline 5 & 348 & au $A$ ga AUG u & 16.7 \\
\hline 6 & 402 & au u Cu AUG a & 16.7 \\
\hline 7 & 813 & $\mathrm{a} C$ u CC AUG $G$ & 66.7 \\
\hline 8 & 939 & ua $A$ a $C$ AUG c & 33.3 \\
\hline 9 & 1068 & uu $A$ aa AUG $G$ & 33.3 \\
\hline 10 & 1197 & uU u uC AUG $G$ & 33.3 \\
\hline 11 & 1203 & ug $G$ ug AUG $G$ & 33.3 \\
\hline 12 & 1212 & aa $u$ aC AUG $G$ & 33.3 \\
\hline 13 & 1236 & $C g$ u ua AUG G & 33.3 \\
\hline 14 & 1245 & $\operatorname{ag} A$ Ca AUG a & 33.3 \\
\hline 15 & 1284 & $g C c$ uu AUG c & 16.7 \\
\hline 16 & 1518 & uu $G$ aC AUG u & 33.3 \\
\hline 17 & 1539 & gu $A$ u $C$ AUG $G$ & 50.0 \\
\hline 18 & 1734 & $C C \cup \cup C$ AUG $G$ & 66.7 \\
\hline 19 & 1875 & aa $u$ uC AUG c & 16.7 \\
\hline
\end{tabular}

a Position (AUG) - adenine position in the coding sequence;

${ }^{b}$ Nucleotide codons context of the 20 Met (AUG) from NtCDKG mRNA. Context - 5 nucleotides upstream and downstream nucleotide 1 of the AUG codon. Italic: nucleotides identical to the consensus sequence of IRES;

${ }^{c}$ Id. Consensus - equivalent percentage to sequence identity involving AUG codons in relation to consensus sequence of the IRES.

In gray: sequences with the highest percentage of alignment with the context (based on CORNELIS et al., 2000). 


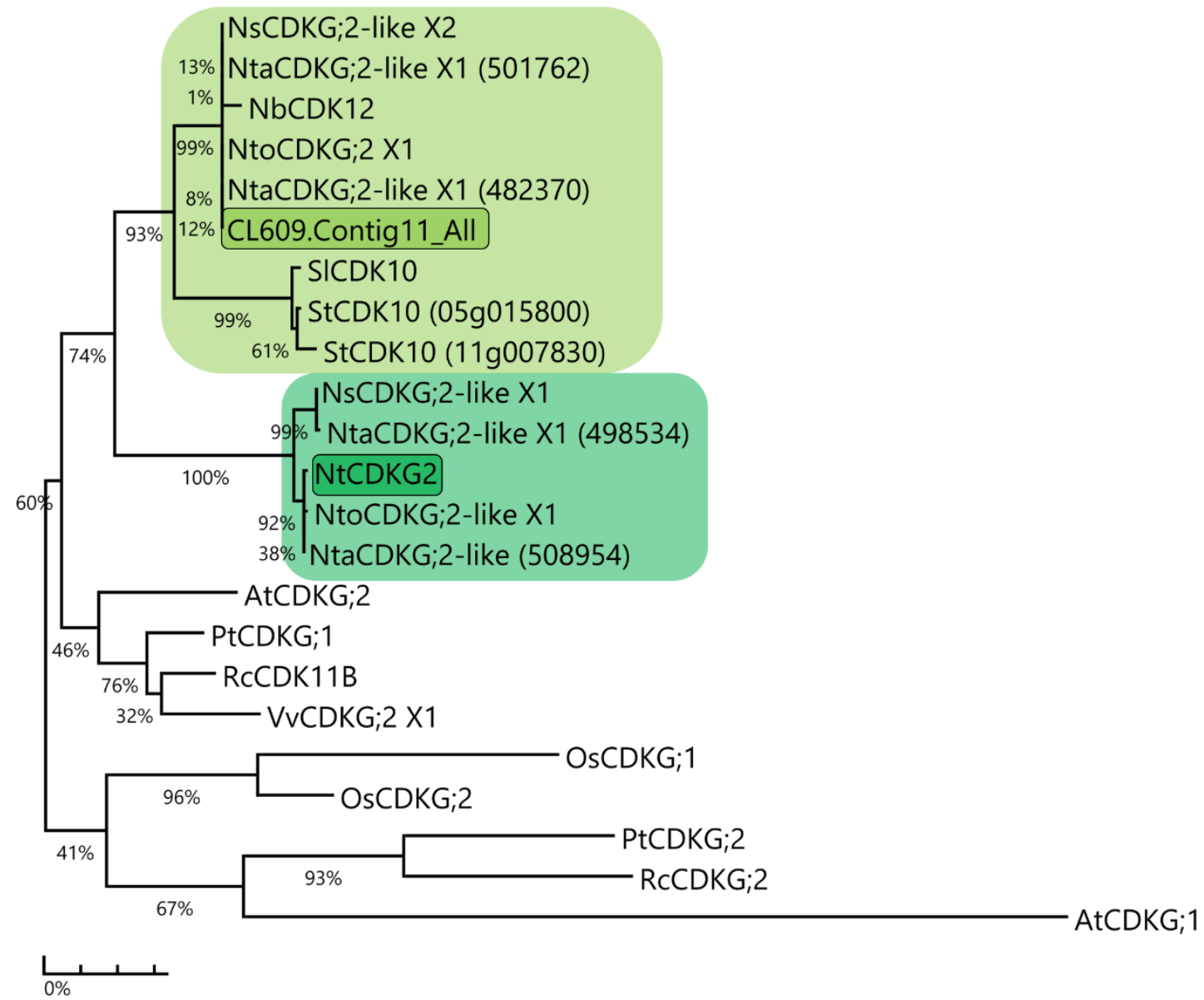

Figure S1: Molecular phylogenetic analysis inferred by ML (maximum likelihood) based on matrices model JTT (Jones-Taylor-Thornton). The figure depicts the evolutionary relationships among the CDK proteins from different species ( $N$. tabacum, $N$. benthamiana, $N$. sylvestris, $N$. tomentosiformis, S. lycopersicum, S. tuberosum, $R$. communis, $P$. tricocharpa, $O$. sativa and A. thaliana). The phylogenetic tree is represented in a scale with branch length is measured in number of amino acid substitutions. The percentage of repetitions in which the topology corresponded to the initial is next to the branches (bootstrap: 1000 replicates; Felsenstein, 1985). The initial tree was obtained with the application of algorithms Neighbour-Joining e BioNJ a distance matrix peer-to-peer estimated using JTT (JONES; TAYLOR; THORNTON, 1992) model, and selecting the topology with greater likelihood log value $(-4134.9826$ in this case). According to analysis of best substitution model, discrete gamma distribution was used to model differences in mutation rates between sites (8 categories; $G=0.58$ ). Positions containing gaps and selections were eliminated, leaving 355 positions in the final analysis. All procedures were performed in the MEGA7 software (Kumar et al., 2015). 


\section{APÊNDICE B - CLONES IDENTIFICADOS NO SCREENING DE DUPLO HÍBRIDO COM NtCDKG;2}

A Tabela 10 apresenta os resultados obtidos com as análises de sequências de todos os clones identificados, até o presente momento, no screening de duplo-híbrido entre NtCDKG;2 e a biblioteca cDNAs de estigmas e estiletes de N. tabacum. Ela inclui resultados apresentados na presente tese, além de resultados de Ferreira (2013, 2016) e Thomé (dados não publicados). As análises in silico de identificação dessas sequências foram feitas utilizando o software BLASTN no banco de dados NCBI (http://www.ncbi.nlm.nih.gov/) e o software BLASTX no banco de dados TAIR (The Arabidopsis Information Resource - http://www.arabidopsis.org/). Para cada clone, em ambas as tabelas, está apresentada apenas a sequência que demonstrou maior identidade de nucleotídeos ou aminoácidos entre as sequências e menor e-value.

Tabela 10: Identificação dos clones levantados durante o screening de Y2H utilizando NtCDKG;2 como isca e biblioteca de cDNAs de estigmas e estiletes de $\boldsymbol{N}$. tabacum como presas. Nomenclatura dos clones: e-value - probabilidade da sequência alvo (query) se alinhar com a sequência de referência (subject) ao acaso. Nta: N. tabacum; Nto: N. tomentosiformis; Nsy: N. sylvestris. Clone de levedura grifado em rosa: identificado nesta tese; Clone de levedura grifado em azul claro: identificado por Ferreira (2013); Clone de levedura grifado em azul escuro: identificado por Ferreira (2016); Clone de levedura grifado em roxo: identificado por Thomé (dados não publicados); Clone de $\boldsymbol{E}$. coli grifado em rosa: clone re-testado e positivo - apresentado nesta tese; Clone de $\boldsymbol{E}$. coli grifado em verde: clone re-testado e positivo; Clone de $\boldsymbol{E}$. coli grifado em cinza: clone re-testado e sem interação.

\begin{tabular}{|c|c|c|c|c|c|}
\hline Levedura & E. coli & NCBI - BLASTN & e-value & TAIR - BLASTX & e-value \\
\hline$\overline{\text { G1A1 }}$ & G1A2.1 & $\begin{array}{c}\text { Nsy low-temperature-induced cysteine proteinase- } \\
\text { like (LOC104220565) }\end{array}$ & 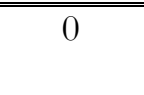 & $\begin{array}{c}\text { AT5G43060.1 - Granulin repeat cysteine protease family } \\
\text { protein }\end{array}$ & $8 \mathrm{E}-45$ \\
\hline G1A2 & G1A2.5 & Nto la-related protein 6A (LOC104096436) & 0 & AT5G46250.1 - RNA-binding protein & 0,00000005 \\
\hline G1A3 & G1A3.1 & $\begin{array}{l}\text { Nto zinc finger A20 and AN1 domain-containing } \\
\text { stress-associated protein 5-like (LOC104121001) }\end{array}$ & 0 & AT3G12630.1 - A20/AN1-like zinc finger family protein & $3 \mathrm{E}-44$ \\
\hline G1A3 & G1A3.2 & Nsy uncharacterized (LOC104221985) & 0 & AT3G52050.4 - 5'-3' exonuclease family protein & $4 \mathrm{E}-78$ \\
\hline G1A4 & G1A4.1 & Nto 40S ribosomal protein SA (LOC104121230) & 0 & AT3G04770.2 - RPSAb, 40s ribosomal protein SA B & $5 \mathrm{E}-90$ \\
\hline G1A7 & G1A7.1 & $\begin{array}{l}\text { Nsy glucan endo-1,3-beta-glucosidase } \\
\text { (LOC104243202) }\end{array}$ & 0 & AT4G16260.1 - Glycosyl hydrolase superfamily protein & $6 \mathrm{E}-57$ \\
\hline G1A7 & G1A7.2 & Nta TA20 gene & 0 & & \\
\hline G1A7 & G1A7.5 & Nto 40S ribosomal protein SA (LOC104121230) & 0 & AT3G04770.2 - RPSAb, 40s ribosomal protein SA B & $\begin{array}{l}\text { 5E-89 } \\
\text { Contint }\end{array}$ \\
\hline
\end{tabular}


Tabela 10: Continuação

\begin{tabular}{|c|c|c|c|c|c|}
\hline Levedura & E. coli & NCBI - BLASTN & e-value & TAIR - BLASTX & e-value \\
\hline "G1A8 & G1A8.2 & "Nsy circumsporozoite protein (LOC104227659) & 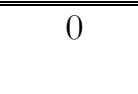 & $\begin{array}{c}\text { AT5G27690.1 - Heavy metal transport/detoxification } \\
\text { superfamily protein }\end{array}$ & $1 \mathrm{1E}-27$ \\
\hline G1A8 & G1A8.3 & $\begin{array}{c}\text { Nto 5-methyltetrahydropteroyltriglutamate-- } \\
\text { homocysteine methyltransferase-like } \\
\text { (LOC104119942) }\end{array}$ & 0 & AT3G03780.3 - ATMS2, MS2, methionine synthase 2 & $2 \mathrm{E}-134$ \\
\hline G1A8 & G1A8.4 & $\begin{array}{c}\text { Nta putative chloroplast thiazole biosynthetic } \\
\text { protein (ThiI) }\end{array}$ & 0 & $\begin{array}{l}\text { AT5G54770.1 - THI1, TZ, THI4, thiazole biosynthetic } \\
\text { enzyme, chloroplast (ARA6) (THI1) (THI4) }\end{array}$ & $3 \mathrm{E}-90$ \\
\hline G1A9 & G1A9.1 & Nto 40S ribosomal protein SA (LOC104121230) & 0 & AT3G04770.2 - RPSAb, 40s ribosomal protein SA B & 2E-109 \\
\hline G1A10 & G1A10.1 & $\begin{array}{l}\text { Nsy probable rhamnose biosynthetic enzyme } 1 \\
\text { (LOC104217794) }\end{array}$ & 0 & $\begin{array}{c}\text { AT1G63000.1 - NRS/ER, UER1, nucleotide-rhamnose } \\
\text { synthase/epimerase-reductase }\end{array}$ & $1 \mathrm{E}-103$ \\
\hline G1A11 & G1A11.1 & Nto 60S ribosomal protein L3 (LOC104098706) & 0 & AT1G61580.1 - RPL3B, ARP2, R-protein L3 B & $2 \mathrm{E}-102$ \\
\hline G1A11 & G1A11.2 & Nto 40S ribosomal protein SA (LOC104121230) & 0 & AT3G04770.2 - RPSAb, 40s ribosomal protein SA B & $5 \mathrm{E}-125$ \\
\hline G1A11 & G1A11.3 & Nto 40S ribosomal protein SA (LOC104121230) & 0 & AT3G04770.2 - RPSAb, 40s ribosomal protein SA B & 9E-97 \\
\hline G1A11 & G1A11.5 & Nsy UPF0183 protein At3g51130 (LOC104248013) & 0 & AT3G51130.1 - unknown protein & 3E-109 \\
\hline G1A12 & G1A12.1 & $\begin{array}{l}\text { Nto non-specific lipid-transfer protein } 2 \\
\text { (LOC104117473) }\end{array}$ & 0 & $\begin{array}{c}\text { AT2G38540.1 - LP1, LTP1, ATLTP1, lipid transfer } \\
\text { protein } 1\end{array}$ & $3 \mathrm{E}-21$ \\
\hline G1A12 & G1A12.2 & Nto 40S ribosomal protein SA (LOC104121230) & 0 & AT3G04770.2 - RPSAb, 40s ribosomal protein SA B & $3 \mathrm{E}-123$ \\
\hline G1A12 & G1A12.3 & Nto 40 S ribosomal protein SA (LOC104121230) & 0 & AT3G04770.2 - RPSAb, 40s ribosomal protein SA B & $6 \mathrm{E}-114$ \\
\hline G1B1 & G1B1.2 & AK324984.1 | Solanum lycopersicum cDNA & & $\begin{array}{c}\text { AT1G72370.1 - P40, AP40, RP40, RPSAA, 40s ribosomal } \\
\text { protein SA }\end{array}$ & \\
\hline G1B1 & G1B1.4 & $\begin{array}{l}\text { Vitis vinifera serine/threonine-protein kinase } \\
\text { OXI1-like }\end{array}$ & & AT1G51170.1 - Protein kinase superfamily protein & \\
\hline G1B2 & G1B2.1 & $\begin{array}{l}\text { Nsy serine carboxypeptidase 24-like } \\
\text { (LOC104239468) }\end{array}$ & 0 & $\begin{array}{c}\text { AT4G30610.1 - BRS1, SCPL24, alpha/beta-Hydrolases } \\
\text { superfamily protein }\end{array}$ & $1 \mathrm{E}-104$ \\
\hline G1B3 & G1B3.1 & N.tabacum tts-1 mRNA & 0 & $\begin{array}{c}\text { AT2G34700.1 - Pollen Ole e } 1 \text { allergen and extensin } \\
\text { family protein }\end{array}$ & $7 \mathrm{E}-31$ \\
\hline G1B4 & G1B4.1 & $\begin{array}{l}\text { Nsy pyruvate kinase, cytosolic isozyme-like } \\
\text { (LOC104236308) }\end{array}$ & 0 & AT3G52990.1 - Pyruvate kinase family protein & $2 \mathrm{E}-63$ \\
\hline G1B4 & G1B4.2 & Nsy uncharacterized (LOC104246214) & 0 & $\begin{array}{l}\text { AT2G15890.1 - CBP1, CCG-BINDING PROTEIN 1, } \\
\text { MATERNAL EFFECT EMBRYO ARREST 14, MEE14 }\end{array}$ & $9 \mathrm{E}-32$ \\
\hline G1B6 & G1B6.1 & $\begin{array}{l}\text { Nsy glucan endo-1,3-beta-glucosidase } \\
\text { (LOC104243202) }\end{array}$ & 0 & AT4G16260.1 - Glycosyl hydrolase superfamily protein & $6 \mathrm{E}-57$ \\
\hline
\end{tabular}


Tabela 10: Continuação

\begin{tabular}{|c|c|c|c|c|c|}
\hline Levedura & E. coli & NCBI - BLASTN & e-value & TAIR - BLASTX & e-value \\
\hline G1B6 & G1B6.3 & Nto switch-associated protein 70 (LOC104100654) & 0 & $\begin{array}{c}\text { AT2G30880.2 - Pleckstrin homology (PH) domain- } \\
\text { containing protein }\end{array}$ & $1 \mathrm{E}-70$ \\
\hline G1B7 & G1B7.1 & $\begin{array}{l}\text { Nsy pistil-specific extensin-like protein } \\
\text { (LOC104243206) }\end{array}$ & $8 \mathrm{E}-162$ & & \\
\hline G1B7 & G1B7.2 & $\begin{array}{l}\text { Nsy pistil-specific extensin-like protein } \\
\text { (LOC104243206) }\end{array}$ & $3 \mathrm{E}-161$ & & \\
\hline G1B7 & G1B7.3 & $\begin{array}{l}\text { Nsy UDP-glucuronate 4-epimerase } 3 \\
\text { (LOC104247730) }\end{array}$ & 0 & $\begin{array}{l}\text { AT4G00110.1 - GAE3, UDP-D-glucuronate 4-epimerase } \\
3\end{array}$ & $2 \mathrm{E}-71$ \\
\hline G1B7 & G1B7.5 & $\begin{array}{c}\text { Nsy glucose-1-phosphate adenylyltransferase small } \\
\text { subunit, chloroplastic/amyloplastic } \\
\text { (LOC104219530) }\end{array}$ & 0 & $\begin{array}{c}\text { AT5G48300.1 - ADG1, APS1, ADP glucose } \\
\text { pyrophosphorylase } 1\end{array}$ & $4 \mathrm{E}-72$ \\
\hline G1B8 & G1B8.1 & Nsy DNA topoisomerase 1 (LOC104238721) & 0 & & \\
\hline G1B9 & G1B9.1 & Nsy ADP-ribosylation factor 2 (LOC104210818) & 0 & $\begin{array}{c}\text { AT1G10630.1 - ATARFA1F, ARFA1F, ADP- } \\
\text { ribosylation factor A1F }\end{array}$ & $4 \mathrm{E}-75$ \\
\hline G1B10 & G1B10.2 & Nsy potassium transporter 4-like (LOC104243125) & 0 & $\begin{array}{c}\text { AT3G02050.1 - KUP3, ATKUP3, ATKT4, K+ uptake } \\
\text { transporter } 3\end{array}$ & $5 \mathrm{E}-74$ \\
\hline G1B12 & G1B12.1 & Nto 40S ribosomal protein SA (LOC104121230) & 0 & AT3G04770.2 - RPSAb, 40s ribosomal protein SA B & $3 \mathrm{E}-89$ \\
\hline G1C1 & G1C1.2 & $\begin{array}{l}\text { Nsy PH domain-containing protein } \\
\text { DDB_G0287875-like (LOC104210594) }\end{array}$ & & $\begin{array}{c}\text { AT3G58630.1 - sequence-specific DNA binding } \\
\text { transcription factors }\end{array}$ & \\
\hline G1C3 & G1C3.1 & Yeast two-hybrid vector pNtrp DNA & 0 & & \\
\hline G1C4 & G1C4.1 & $\begin{array}{l}\text { Nsy probable WRKY transcription factor } 32 \\
\text { (LOC104237830) }\end{array}$ & 0 & $\begin{array}{c}\text { AT4G30935.1 - WRKY32, ATWRKY32, WRKY DNA- } \\
\text { binding protein } 32\end{array}$ & $2 \mathrm{E}-44$ \\
\hline G1C4 & G1C4.2 & $\begin{array}{l}\text { Nto serine/threonine-protein phosphatase PP2A } \\
\text { catalytic subunit (LOC104105461) }\end{array}$ & 0 & AT3G58500.1 - PP2A-4, protein phosphatase 2A-4 & $6 \mathrm{E}-90$ \\
\hline G1C4 & G1C4.3 & $\begin{array}{c}\text { Nto UDP-glucuronate 4-epimerase } 3 \\
\text { (LOC104088799) }\end{array}$ & 0 & $\begin{array}{l}\text { AT1G02000.1 - GAE2, UDP-D-glucuronate 4-epimerase } \\
2\end{array}$ & $6 \mathrm{E}-70$ \\
\hline G1C5 & G1C5.1 & $\begin{array}{c}\text { Nicotiana tabacum stem-specific protein TSJT1-like } \\
\text { (LOC107777728) }\end{array}$ & & $\begin{array}{c}\text { AT4G27450.1 - Aluminium induced protein with YGL } \\
\text { and LRDR motifs }\end{array}$ & \\
\hline G1C6 & G1C6.1 & $\begin{array}{l}\text { Nsy glucan endo-1,3-beta-glucosidase } \\
\text { (LOC104243202) }\end{array}$ & 0 & AT4G16260.1 - Glycosyl hydrolase superfamily protein & $6 \mathrm{E}-57$ \\
\hline G1C7 & G1C7.4 & $\begin{array}{l}\text { Nsy glucan endo-1,3-beta-glucosidase } \\
\text { (LOC104243202) }\end{array}$ & 0 & AT4G16260.1 - Glycosyl hydrolase superfamily protein & $6 \mathrm{E}-57$ \\
\hline
\end{tabular}


Tabela 10: Continuação

\begin{tabular}{|c|c|c|c|c|c|}
\hline Levedura & E. coli & NCBI - BLASTN & e-value & TAIR - BLASTX & e-value \\
\hline G1C8 & G1C8.1 & $\begin{array}{l}\text { Nto proteasome subunit alpha type-5-like } \\
\text { (LOC104109129) }\end{array}$ & 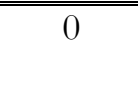 & AT1G53850.2 - PAE1, 20S proteasome alpha subunit E1 & $7 \mathrm{7E}-120$ \\
\hline G1C9 & G1C9.1 & $\begin{array}{l}\text { Nto probable BOI-related E3 ubiquitin-protein } \\
\text { ligase } 3 \text { (LOC104102401) }\end{array}$ & 0 & & \\
\hline G1C10 & G1C10.1 & $\begin{array}{l}\text { D.stramonium mRNA for S-adenosylmethionine } \\
\text { decarboxylase }\end{array}$ & $1 \mathrm{E}-153$ & $\begin{array}{c}\text { AT3G02468.1 - CPuORF9, conserved peptide upstream } \\
\text { open reading frame } 9\end{array}$ & $2 \mathrm{E}-15$ \\
\hline G1C12 & G1C12.1 & Nto 40S ribosomal protein SA (LOC104121230) & 0 & AT3G04770.2 - RPSAb, 40s ribosomal protein SA B & $2 \mathrm{E}-89$ \\
\hline G1D1 & G1D1.2 & Nsy defensin-like protein (LOC104240404) & 0 & $\begin{array}{c}\text { AT1G61070.1 - LCR66, PDF2.4, low-molecular-weight } \\
\text { cysteine-rich } 66\end{array}$ & $1 \mathrm{E}-12$ \\
\hline G1D2 & G1D2.1 & $\begin{array}{c}\text { Nsy protein transport protein Sec61 subunit beta- } \\
\text { like (LOC104222319) }\end{array}$ & 0 & $\begin{array}{c}\text { AT3G60540.2 - Preprotein translocase Sec, Sec61-beta } \\
\text { subunit protein }\end{array}$ & $1 \mathrm{E}-14$ \\
\hline G1D2 & G1D2.6 & $\begin{array}{l}\text { Nto ran-binding protein } 1 \text { homolog c-like } \\
\text { (LOC104114085) }\end{array}$ & 0 & AT5G58590.1 - RANBP1, RAN binding protein 1 & $2 \mathrm{E}-84$ \\
\hline G1D4 & G1D4.1 & $\begin{array}{l}\text { Nsy calcium-dependent protein kinase 8-like } \\
\text { (LOC104218676) }\end{array}$ & 0 & $\begin{array}{c}\text { AT2G41860.2 - CPK14, calcium-dependent protein } \\
\text { kinase } 14\end{array}$ & 0,00002 \\
\hline G1D4 & G1D4.3 & Nto 40S ribosomal protein SA (LOC104121230) & 0 & AT3G04770.2 - RPSAb, 40s ribosomal protein SA B & 4E-101 \\
\hline G1D6 & G1D6.1 & Nto $21 \mathrm{kDa}$ protein-like (LOC104102679), mRNA & 0 & $\begin{array}{c}\text { AT5G20740.1 - Plant invertase/pectin methylesterase } \\
\text { inhibitor superfamily protein }\end{array}$ & $2 \mathrm{E}-54$ \\
\hline G1D6 & G1D6.2 & $\begin{array}{l}\text { Nsy glucan endo-1,3-beta-glucosidase } \\
\text { (LOC104243202) }\end{array}$ & 0 & AT4G16260.1 - Glycosyl hydrolase superfamily protein & $6 \mathrm{E}-57$ \\
\hline G1D7 & G1D7.1 & $\begin{array}{c}\text { Tabacco Cab21 mRNA for major chlorophyll a/b } \\
\text { binding protein }\end{array}$ & 0 & $\begin{array}{l}\text { AT1G29930.1 - CAB1, AB140, CAB140, LHCB1.3, } \\
\text { chlorophyll A/B binding protein } 1\end{array}$ & $2 \mathrm{E}-114$ \\
\hline G1D7 & G1D7.3 & $\begin{array}{l}\text { Nsy probable polyamine oxidase } 2 \\
\text { (LOC104226820) }\end{array}$ & 0 & AT2G43020.1 - ATPAO2, PAO2, polyamine oxidase 2 & $2 \mathrm{E}-114$ \\
\hline G1D7 & G1D7.4 & $\begin{array}{l}\text { Nsy glucan endo-1,3-beta-glucosidase } \\
\text { (LOC104243202) }\end{array}$ & 0 & AT4G16260.1 - Glycosyl hydrolase superfamily protein & $6 \mathrm{E}-57$ \\
\hline G1D8 & G1D8.1 & Nta NtLTP1 gene for lipid transfer protein & 0 & $\begin{array}{c}\text { AT2G38540.1 - LP1, LTP1, ATLTP1, lipid transfer } \\
\text { protein } 1\end{array}$ & $4 \mathrm{E}-21$ \\
\hline G1D9 & G1D9.1 & $\begin{array}{l}\text { Nto keratinocyte proline-rich protein } \\
\text { (LOC104106673) }\end{array}$ & 0 & & \\
\hline G1D9 & G1D9.2 & $\begin{array}{c}\text { Nto uncharacterized protein OsI_027940-like } \\
\text { (LOC104099631) }\end{array}$ & 0 & $\begin{array}{c}\text { AT4G02450.2 - HSP20-like chaperones superfamily } \\
\text { protein }\end{array}$ & $4 \mathrm{E}-24$ \\
\hline
\end{tabular}


Tabela 10: Continuação

\begin{tabular}{|c|c|c|c|c|c|}
\hline Levedura & E. coli & NCBI - BLASTN & e-value & TAIR - BLASTX & e-value \\
\hline G1D11 & G1D11.2 & $\begin{array}{c}\text { Nto V-type proton ATPase subunit F } \\
\text { (LOC104118146) }\end{array}$ & 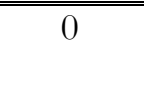 & $\begin{array}{c}\text { AT4G02620.1 - vacuolar ATPase subunit F family } \\
\text { protein }\end{array}$ & 3E-75 \\
\hline G1D12 & G1D12.1 & Nta FtsH-like protein Pftf precursor (Pftf) & 0 & $\begin{array}{c}\text { AT2G30950.1 - VAR2, FTSH2, FtsH extracellular } \\
\text { protease family }\end{array}$ & 2E-101 \\
\hline G1E1 & G1E1.1 & $\begin{array}{l}\text { Nta cyclin-dependent kinase F-1-like } \\
\text { (LOC107786402) }\end{array}$ & & $\begin{array}{c}\text { AT4G28980.2 - CDKF;1, CAK1AT, CDK-activating } \\
\text { kinase 1AT }\end{array}$ & \\
\hline G1E2 & G1E2.1 & $\begin{array}{l}\text { Nsy PH domain-containing protein } \\
\text { DDB_G0287875-like (LOC104210594) }\end{array}$ & 0 & $\begin{array}{c}\text { AT3G58630.1 - sequence-specific DNA binding } \\
\text { transcription factors }\end{array}$ & $8 \mathrm{E}-35$ \\
\hline G1E3 & G1E3.1 & $\begin{array}{c}\text { Nto thiosulfate/3-mercaptopyruvate } \\
\text { sulfurtransferase 1, mitochondrial-like } \\
\text { (LOC104085184) }\end{array}$ & 0 & $\begin{array}{c}\text { AT1G79230.1 - ST1, ATMST1, MST1, ATRDH1, STR1, } \\
\text { mercaptopyruvate sulfurtransferase } 1\end{array}$ & $1 \mathrm{E}-88$ \\
\hline G1E3 & G1E3.2 & $\begin{array}{l}\text { Nto S-adenosylmethionine synthase 2-like } \\
\text { (LOC104104053) }\end{array}$ & 0 & $\begin{array}{l}\text { AT3G17390.1 - MTO3, SAMS3, MAT4, S- } \\
\text { adenosylmethionine synthetase family protein }\end{array}$ & $4 \mathrm{E}-85$ \\
\hline G1E3 & G1E3.4 & Nto pectinesterase-like (LOC104118953) & 0 & $\begin{array}{c}\text { AT3G14310.1 - ATPME3, PME3, pectin methylesterase } \\
3\end{array}$ & 0,0000004 \\
\hline G1E4 & G1E4.1 & $\begin{array}{l}\text { Nsy glucan endo-1,3-beta-glucosidase } \\
\text { (LOC104243202) }\end{array}$ & 0 & AT4G16260.1 - Glycosyl hydrolase superfamily protein & $9 \mathrm{E}-57$ \\
\hline G1E5 & G1E5.1 & $\begin{array}{l}\text { Nta mitochondrial adenine nucleotide transporter } \\
\text { ADNT1-like (LOC107767971) }\end{array}$ & & $\begin{array}{l}\text { AT4G01100.2 - ADNT1, adenine nucleotide transporter } \\
1\end{array}$ & \\
\hline G1E5 & G1E5.2 & $\begin{array}{l}\text { Nta metallothionein-like protein type } 2 \\
\text { (LOC107809985) }\end{array}$ & & AT5G02380.1 - Symbols: MT2B, metallothionein 2B & \\
\hline G1E5 & G1E5.3 & Nta NtLTP1 gene for lipid transfer protein & & AT5G59320.1 - LTP3, lipid transfer protein 3 & \\
\hline G1E5 & G1E5.4 & Nta mRNA for cytosolic ascorbate peroxidase & & $\begin{array}{l}\text { AT1G07890.8 - APX1, MEE6, CS1, ATAPX1, } \\
\text { ATAPX01, ascorbate peroxidase } 1\end{array}$ & \\
\hline G1E6 & G1E6.1 & $\begin{array}{l}\text { Nsy glucan endo-1,3-beta-glucosidase } \\
\text { (LOC104243202) }\end{array}$ & 0 & AT4G16260.1 - Glycosyl hydrolase superfamily protein & $6 \mathrm{E}-57$ \\
\hline G1E6 & G1E6.4 & $\begin{array}{l}\text { Nsy pistil-specific extensin-like protein } \\
\text { (LOC104211461) }\end{array}$ & 0 & $\begin{array}{l}\text { AT2G34700.1 - Pollen Ole e } 1 \text { allergen and extensin } \\
\text { family protein }\end{array}$ & $5 \mathrm{E}-31$ \\
\hline G1E6 & G1E6.6 & Nto 40S ribosomal protein SA (LOC104121230) & 0 & AT3G04770.2 - RPSAb, 40s ribosomal protein SA B & $9 \mathrm{E}-129$ \\
\hline G1E7 & G1E7.4 & Nto phytanoyl-CoA dioxygenase (LOC104094447) & 0 & $\begin{array}{c}\text { AT2G01490.1 - phytanoyl-CoA dioxygenase }(\mathrm{PhyH}) \\
\text { family protein }\end{array}$ & $1 \mathrm{E}-71$ \\
\hline G1E8 & G1E8.1 & Nto uncharacterized (LOC104096722) & 0 & AT1G04340.1 - HR-like lesion-inducing protein-related & $\begin{array}{l}7 \mathrm{E}-46 \\
\text { Contin }\end{array}$ \\
\hline
\end{tabular}


Tabela 10: Continuação

\begin{tabular}{|c|c|c|c|c|c|}
\hline Levedura & E. coli & NCBI - BLASTN & e-value & TAIR - BLASTX & e-value \\
\hline G1E10 & G1E10.2 & Yeast two-hybrid vector pNtrp DNA & 1E-154 & & \\
\hline G1E11 & G1E11.2 & $\begin{array}{l}\text { Nto zinc-finger homeodomain protein 2-like } \\
\text { (LOC104111235) }\end{array}$ & 0 & $\begin{array}{c}\text { AT4G24660.1 - ATHB22, MEE68, HB22, ZHD2, } \\
\text { homeobox protein } 22\end{array}$ & $1 \mathrm{E}-27$ \\
\hline G1E12 & G1E12.1 & Nsy uncharacterized (LOC104225393) & 0 & AT1G33780.1 - Protein of unknown function (DUF179) & $5 \mathrm{E}-20$ \\
\hline G1F3 & G1F3.1 & $\begin{array}{l}\text { Nsy pistil-specific extensin-like protein } \\
\text { (LOC104211461) }\end{array}$ & 0 & $\begin{array}{c}\text { AT2G34700.1 - Pollen Ole e } 1 \text { allergen and extensin } \\
\text { family protein }\end{array}$ & $4 \mathrm{E}-27$ \\
\hline G1F3 & G1F3.2 & Nsy uncharacterized (LOC104210248) & 0 & AT3G03150.1 - unknown protein & $8 \mathrm{E}-26$ \\
\hline G1F4 & G1F4.1 & Nta histone H2B1 & & AT5G59910.1 - HTB4, Histone superfamily protein & \\
\hline G1F5 & G1F5.5 & Sequenciamento ruim & & Sequenciamento ruim & \\
\hline G1F5 & G1F5.6 & Nta NtLTP1 gene for lipid transfer protein & & AT5G59320.1 - LTP3, lipid transfer protein 3 & \\
\hline G1F6 & G1F6.1 & $\begin{array}{l}\text { Nsy pistil-specific extensin-like protein } \\
\text { (LOC104211461) }\end{array}$ & 0 & $\begin{array}{c}\text { AT2G34700.1 - Pollen Ole e } 1 \text { allergen and extensin } \\
\text { family protein }\end{array}$ & $2 \mathrm{E}-27$ \\
\hline G1F6 & G1F6.2 & $\begin{array}{c}\text { Nsy glucan endo-1,3-beta-glucosidase } \\
\text { (LOC104243202) }\end{array}$ & 0 & AT4G16260.1 - Glycosyl hydrolase superfamily protein & $6 \mathrm{E}-57$ \\
\hline G1F7 & G1F7.1 & $\begin{array}{c}\text { Nsy F-box/LRR-repeat protein 17-like } \\
\text { (LOC104230052) }\end{array}$ & 0 & AT3G54650.1 - FBL17, RNI-like superfamily protein & $9 \mathrm{E}-42$ \\
\hline G1F7 & G1F7.2 & $\begin{array}{l}\text { Nsy glucan endo-1,3-beta-glucosidase } \\
\text { (LOC104243202) }\end{array}$ & 0 & AT4G16260.1 - Glycosyl hydrolase superfamily protein & $6 \mathrm{E}-57$ \\
\hline G1F8 & G1F8.1 & $\begin{array}{l}\text { Nto serine/threonine-protein phosphatase PP2A } \\
\text { catalytic subunit (LOC104105461) }\end{array}$ & 0 & AT3G58500.1 - PP2A-4, protein phosphatase 2A-4 & $2 \mathrm{E}-126$ \\
\hline G1F8 & G1F8.4 & & & AT2G06950.1 - transposable element gene & \\
\hline G1F8 & G1F8.5 & $\begin{array}{l}\text { Nto stem-specific protein TSJT1-like } \\
\text { (LOC104102628) }\end{array}$ & 0 & $\begin{array}{c}\text { AT4G27450.1 - Aluminium induced protein with YGL } \\
\text { and LRDR motifs }\end{array}$ & $6 \mathrm{E}-72$ \\
\hline G1F9 & G1F9.1 & $\begin{array}{c}\text { Nsy B3 domain-containing transcription factor } \\
\text { NGA1-like (LOC104211226) }\end{array}$ & 0 & & \\
\hline G1F9 & G1F9.4 & Nto 40 S ribosomal protein SA (LOC104121230) & 0 & AT3G04770.2 - RPSAb, 40s ribosomal protein SA B & $1 \mathrm{E}-100$ \\
\hline G1F10 & G1F10.2 & $\begin{array}{l}\text { Nto peroxisomal membrane protein 11D } \\
\text { (LOC104094270) }\end{array}$ & 0 & AT2G45740.3 - PEX11D, peroxin 11D & $3 \mathrm{E}-95$ \\
\hline G1F11 & G1F11.2 & $\begin{array}{c}\text { Nsy putative } \\
\text { phosphatidylglycerol/phosphatidylinositol transfer } \\
\text { protein DDB_G0282179 (LOC104210839) }\end{array}$ & 0 & $\begin{array}{l}\text { AT3G11780.1 - MD-2-related lipid recognition domain- } \\
\text { containing protein / ML domain-containing protein }\end{array}$ & $1 \mathrm{E}-48$ \\
\hline G1F12 & G1F12.1 & Nto protein SPIRAL1-like 1 (LOC104092384) & 0 & AT1G26355.1 - SP1L1, SPIRAL1-like1 & $\begin{array}{r}1 \mathrm{E}-29 \\
\text { Contin }\end{array}$ \\
\hline
\end{tabular}


Tabela 10: Continuação

\begin{tabular}{|c|c|c|c|c|c|}
\hline Levedura & E. coli & NCBI - BLASTN & e-value & TAIR - BLASTX & e-value \\
\hline G1G1 & G1G1.1 & $\begin{array}{l}\text { Nsy glyceraldehyde-3-phosphate dehydrogenase, } \\
\text { cytosolic (LOC104229411) }\end{array}$ & 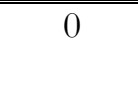 & $\begin{array}{c}\text { AT1G13440.1 - GAPC-2, GAPC2, glyceraldehyde-3- } \\
\text { phosphate dehydrogenase C2 }\end{array}$ & $7 \mathrm{E}-110$ \\
\hline G1G2 & G1G2.1 & $\begin{array}{c}\text { Saccharomyces cerevisiae strain ySR127 } \\
\text { chromosome XV }\end{array}$ & 0 & & \\
\hline G1G3 & G1G3.1 & $\begin{array}{l}\text { Nsy DNA-directed RNA polymerase II subunit } \\
\text { RPB7 (LOC104232520) }\end{array}$ & 0 & $\begin{array}{c}\text { AT5G59180.1 - NRPB7, DNA-directed RNA } \\
\text { polymerase II }\end{array}$ & $6 \mathrm{E}-72$ \\
\hline G1G6 & G1G6.5 & $\begin{array}{l}\text { Nsy pistil-specific extensin-like protein } \\
\text { (LOC104211461) }\end{array}$ & 0 & $\begin{array}{c}\text { AT2G34700.1 - Pollen Ole e } 1 \text { allergen and extensin } \\
\text { family protein }\end{array}$ & $4 \mathrm{E}-31$ \\
\hline G1G6 & G1G6.6 & $\begin{array}{l}\text { Nsy pyruvate dehydrogenase E1 component } \\
\text { subunit beta-3 (LOC104234378) }\end{array}$ & 0 & AT2G34590.1 - Transketolase family protein & $1 \mathrm{E}-63$ \\
\hline G1G7 & G1G7.4 & $\begin{array}{c}\text { Nsy glucan endo-1,3-beta-glucosidase } \\
\text { (LOC104243202) }\end{array}$ & 0 & AT4G16260.1 - Glycosyl hydrolase superfamily protein & $7 \mathrm{E}-57$ \\
\hline G1G7 & G1G7.5 & $\begin{array}{c}\text { Nsy V-type proton ATPase } 16 \mathrm{kDa} \text { proteolipid } \\
\text { subunit (LOC104250106) }\end{array}$ & 0 & $\begin{array}{l}\text { AT1G19910.1 - AVA-P2, AVA-2PE, ATVHA-C2, } \\
\text { ATPase, F0/V0 complex, subunit C protein }\end{array}$ & $2 \mathrm{E}-73$ \\
\hline G1G8 & G1G8.4 & $\begin{array}{l}\text { Nsy uncharacterized LOC104230829 } \\
\text { (LOC104230829) }\end{array}$ & 0 & AT5G13100.1 - unknown protein & $3 \mathrm{E}-61$ \\
\hline G1G9 & G1G9.2 & Nto cysteine proteinase 15A-like (LOC104104816) & 0 & $\begin{array}{c}\text { AT4G39090.1 - RD19, RD19A, Papain family cysteine } \\
\text { protease }\end{array}$ & $8 \mathrm{E}-77$ \\
\hline G1G9 & G1G9.4 & $\begin{array}{l}\text { Nto phosphoglucan phosphatase LSF1, } \\
\text { chloroplastic (LOC104103074) }\end{array}$ & 0 & AT3G01510.1 - LSF1, like SEX4 1 & $2 \mathrm{E}-130$ \\
\hline G1G10 & G1G10.2 & $\begin{array}{c}\text { Nsy serine/threonine-protein phosphatase } 2 \text { A } 65 \\
\mathrm{kDa} \text { regulatory subunit A beta isoform-like } \\
\text { (LOC104226350) }\end{array}$ & 0 & $\begin{array}{c}\text { AT3G25800.2 - PDF1, PR 65, PP2AA2, protein } \\
\text { phosphatase } 2 \text { A subunit A2 }\end{array}$ & $6 \mathrm{E}-88$ \\
\hline G1G11 & G1G11.1 & Nto 40S ribosomal protein SA (LOC104121230) & 0 & AT3G04770.2 - RPSAb, 40s ribosomal protein SA B & $2 \mathrm{E}-119$ \\
\hline G1G11 & G1G11.2 & Nto 40S ribosomal protein SA (LOC104121230) & 0 & AT3G04770.2 - RPSAb, 40s ribosomal protein SA B & $1 \mathrm{E}-122$ \\
\hline G1G12 & G1G12.1 & $\begin{array}{l}\text { Nto uncharacterized LOC104100927 } \\
\text { (LOC104100927) }\end{array}$ & 0 & $\begin{array}{l}\text { AT2G46220.1 - Uncharacterized conserved protein } \\
\text { (DUF2358) }\end{array}$ & $7 \mathrm{E}-52$ \\
\hline G1H1 & G1H1.1 & Nsy FRIGIDA-like protein 3 (LOC104247802) & 0 & AT5G48385.1 - FRIGIDA-like protein & $7 \mathrm{E}-43$ \\
\hline G1H3 & G1H3.1 & $\begin{array}{l}\text { Nsy pistil-specific extensin-like protein } \\
\text { (LOC104211461) }\end{array}$ & 0 & $\begin{array}{c}\text { AT2G34700.1 - Pollen Ole e } 1 \text { allergen and extensin } \\
\text { family protein }\end{array}$ & $3 \mathrm{E}-30$ \\
\hline G1H4 & G1H4.1 & $\begin{array}{l}\text { Nta 40S ribosomal protein SA-like } \\
\text { (LOC107816512) }\end{array}$ & & AT3G04770.2 - RPSAb, 40s ribosomal protein SA B & \\
\hline
\end{tabular}


Tabela 10: Continuação

\begin{tabular}{|c|c|c|c|c|c|}
\hline Levedura & E. coli & NCBI - BLASTN & e-value & TAIR - BLASTX & e-value \\
\hline G1H6 & G1H6.1 & $\begin{array}{l}\text { Nsy 60S ribosomal protein L21-1-like } \\
\text { (LOC104235115) }\end{array}$ & 0 & $\begin{array}{c}\text { AT1G57860.1 - Translation protein SH3-like family } \\
\text { protein }\end{array}$ & $7 \mathrm{E}-83$ \\
\hline G1H6 & G1H6.2 & $\begin{array}{l}\text { Nsy glucan endo-1,3-beta-glucosidase } \\
\text { (LOC104243202) }\end{array}$ & 0 & AT4G16260.1 - Glycosyl hydrolase superfamily protein & $7 \mathrm{E}-57$ \\
\hline G1H7 & G1H7.2 & Nto apyrase-like (LOC104116308) & 0 & AT5G18280.1 - ATAPY2, APY2, apyrase 2 & $5 \mathrm{E}-40$ \\
\hline G1H7 & G1H7.3 & $\begin{array}{l}\text { Nsy glucan endo-1,3-beta-glucosidase } \\
\text { (LOC104243202) }\end{array}$ & 0 & AT4G16260.1 - Glycosyl hydrolase superfamily protein & $5 \mathrm{E}-57$ \\
\hline G1H8 & G1H8.1 & $\begin{array}{l}\text { Nto soluble inorganic pyrophosphatase } 1, \\
\text { chloroplastic-like (LOC104103165) }\end{array}$ & 0 & AT5G09650.1 - AtPPa6, PPa6, pyrophosphorylase 6 & 4E-64 \\
\hline G1H8 & G1H8.5 & $\begin{array}{l}\text { Nsy UDP-glucuronate 4-epimerase } 3 \\
\text { (LOC104247730) }\end{array}$ & 0 & $\begin{array}{c}\text { AT4G00110.1 - GAE3, UDP-D-glucuronate 4-epimerase } \\
3\end{array}$ & $2 \mathrm{E}-100$ \\
\hline G1H9 & G1H9.3 & $\begin{array}{l}\text { Nsy uncharacterized LOC104233075 } \\
\text { (LOC104233075) }\end{array}$ & 0 & $\begin{array}{c}\text { AT1G64430.2 - Pentatricopeptide repeat (PPR) } \\
\text { superfamily protein }\end{array}$ & $2 \mathrm{E}-67$ \\
\hline G1H9 & G1H9.4 & $\begin{array}{l}\text { Solanum lycopersicum uncharacterized } \\
\text { (LOC101247896) }\end{array}$ & & $\begin{array}{c}\text { AT1G64430 - Pentatricopeptide repeat (PPR) superfamily } \\
\text { protein }\end{array}$ & \\
\hline G1H10 & G1H10.1 & N.tabacum STIG1 gene & 0 & AT1G53130.1 - GRI, Stigma-specific Stig1 family protein & $1 \mathrm{E}-11$ \\
\hline G1H12 & G1H12.1 & Nto 40S ribosomal protein SA (LOC104121230) & 0 & AT3G04770.2 - RPSAb, 40s ribosomal protein SA B & $6 \mathrm{E}-121$ \\
\hline G2A1 & G2A1.1 & $\begin{array}{l}\text { Nto transcription factor TCP7-like } \\
\text { (LOC104091236) }\end{array}$ & 0 & AT5G23280.1 - TCP family transcription factor & $3 \mathrm{E}-42$ \\
\hline G2A2 & G2A2.1 & & & $\begin{array}{c}\text { AT5G52920.1 - PKP1, PKP-BETA1, PKP2, plastidic } \\
\text { pyruvate kinase beta subunit } 1\end{array}$ & \\
\hline G2A2 & G2A2.2 & Nto zinc-finger homeodomain protein 2-like & 0 & $\begin{array}{c}\text { AT4G24660.1 - ATHB22, MEE68, HB22, ZHD2, } \\
\text { homeobox protein } 22\end{array}$ & \\
\hline G2A3 & G2A3.1 & (LOC104111235) & & AT1G31330.1 - PSAF, photosystem I subunit F & \\
\hline G2A3 & G2A3.2 & Nta uncharacterized (LOC107804685) & & AT5G64510.1 - TIN1, unknown protein & \\
\hline G2A3 & G2A3.4 & Nta annexin D2-like (LOC107815719) & & AT1G35720.1 - ANNAT1, OXY5, ATOXY5, annexin 1 & \\
\hline G2A4 & G2A4.1 & $\begin{array}{l}\text { Nta protein disulfide-isomerase 5-3-like } \\
\text { (LOC107784201) }\end{array}$ & & $\begin{array}{l}\text { AT4G27080.1 - ATPDIL5-4, ATPDI7, PDI7, PDIL5-4, } \\
\text { PDI-like 5-4 }\end{array}$ & \\
\hline G2A4 & G2A4.2 & Nta uncharacterized (LOC107792131) & & $\begin{array}{c}\text { AT2G06025.1 - Acyl-CoA N-acyltransferases (NAT) } \\
\text { superfamily protein }\end{array}$ & \\
\hline
\end{tabular}


Tabela 10: Continuacão

\begin{tabular}{|c|c|c|c|c|c|}
\hline Levedura & E. coli & NCBI - BLASTN & e-value & TAIR - BLASTX & e-value \\
\hline G2A5 & G2A5.2 & $\begin{array}{c}\text { Nto peptide-N4-(N-acetyl-beta- } \\
\text { glucosaminyl)asparagine amidase A-like } \\
\text { (LOC104108298) }\end{array}$ & 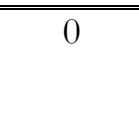 & $\begin{array}{l}\text { AT3G14920.1 - Peptide-N4-(N-acetyl-beta- } \\
\text { glucosaminyl)asparagine amidase A protein }\end{array}$ & 1E-60 \\
\hline G2A5 & G2A5.3 & Nto GILT-like protein F37H8.5 (LOC104087376) & 0 & AT1G07080.1 - Thioredoxin superfamily protein & $4 \mathrm{E}-73$ \\
\hline G2A5 & G2A5.4 & $\begin{array}{l}\text { Nsy transmembrane protein } 205 \\
\text { (LOC104236282) }\end{array}$ & 0 & $\begin{array}{l}\text { AT3G62580.1 - Late embryogenesis abundant protein } \\
\text { (LEA) family protein }\end{array}$ & $2 \mathrm{E}-35$ \\
\hline G2A5 & G2A5.5 & $\begin{array}{l}\text { Nto uncharacterized LOC104115460 } \\
\text { (LOC104115460) }\end{array}$ & 0 & $\begin{array}{c}\text { AT3G44510.2 - alpha/beta-Hydrolases superfamily } \\
\text { protein }\end{array}$ & $7 \mathrm{E}-64$ \\
\hline G2A5 & G2A5.6 & $\begin{array}{l}\text { Nto geranylgeranyl pyrophosphate synthase } \\
\text { (LOC104091068) }\end{array}$ & 0 & $\begin{array}{c}\text { AT4G36810.1 - GGPS1, geranylgeranyl pyrophosphate } \\
\text { synthase } 1\end{array}$ & $4 \mathrm{E}-58$ \\
\hline G2A7 & G2A7.1 & Nta uncharacterized (LOC107801520) & & $\begin{array}{c}\text { AT3G02470.1 - SAMDC, S-adenosylmethionine } \\
\text { decarboxylase }\end{array}$ & \\
\hline G2A7 & G2A7.3 & Nsy riboflavin synthase (LOC104221024) & & AT2G20690.1 - lumazine-binding family protein & \\
\hline G2A7 & G2A7.5 & $\begin{array}{l}\text { Nsys uncharacterized LOC104246078 } \\
\text { (LOC104246078) }\end{array}$ & & AT4G17670.1 - Protein of unknown function (DUF581) & \\
\hline G2A8 & G2A8.1 & Nta syntaxin-71-like (LOC107799493) & & AT3G09740.1 - SYP71, ATSYP71, syntaxin of plants 71 & \\
\hline G2A9 & G2A9.3 & $\begin{array}{l}\text { Nta nucleoside diphosphate kinase 1-like } \\
\text { (LOC107771678) }\end{array}$ & & $\begin{array}{l}\text { AT4G09320.1 - NDPK1 Nucleoside diphosphate kinase } \\
\text { family protein }\end{array}$ & \\
\hline G2A10 & G2A10.1 & $\begin{array}{l}\text { Nta UDP-glucose 6-dehydrogenase 3-like } \\
\text { (LOC107764147) }\end{array}$ & & $\begin{array}{l}\text { AT3G29360.2 - UDP-glucose 6-dehydrogenase family } \\
\text { protein }\end{array}$ & \\
\hline G2A12 & G2A12.1 & $\begin{array}{l}\text { Nta transmembrane protein 205-like } \\
\text { (LOC107788056) }\end{array}$ & & $\begin{array}{l}\text { AT3G62580.1 - Late embryogenesis abundant protein } \\
\text { (LEA) family protein }\end{array}$ & \\
\hline G2B1 & G2B1.3 & Nta mannose-binding lectin (MBL3) & 0 & $\begin{array}{l}\text { AT1G78830.1 - Curculin-like (mannose-binding) lectin } \\
\text { family protein }\end{array}$ & $2 \mathrm{E}-49$ \\
\hline G2B1 & G2B1.4 & $\begin{array}{l}\text { Nsy oxygen-dependent coproporphyrinogen-III } \\
\text { oxidase (LOC104240653) }\end{array}$ & 0 & $\begin{array}{l}\text { AT1G03475.1 - LIN2, HEMF1, ATCPO-I, } \\
\text { Coproporphyrinogen III oxidase }\end{array}$ & $4 \mathrm{E}-89$ \\
\hline G2B2 & G2B2.1 & & & $\begin{array}{l}\text { AT1G29930.1 - CAB1, AB140, CAB140, LHCB1.3, } \\
\text { chlorophyll A/B binding protein } 1\end{array}$ & \\
\hline G2B2 & G2B2.2 & & & AT1G72370.2 - P40, AP40, RP40, RPSAA, 40s ribosomal & \\
\hline G2B2 & G2B2.5 & & & AT1G03130.1 - PSAD-2, photosystem I subunit D-2 & \\
\hline G2B3 & G2B3.1 & Nta protein YLS3-like (LOC107781098) & & AT5G12250.1 - TUB6, beta-6 tubulin & \\
\hline G2B4 & G2B4.1 & $\begin{array}{l}\text { Nta } 40 \text { S ribosomal protein SA-like } \\
\text { (LOC107813555) }\end{array}$ & & AT3G04770.2 - RPSAb, 40s ribosomal protein SA B & \\
\hline
\end{tabular}


Tabela 10: Continuação

\begin{tabular}{|c|c|c|c|c|c|}
\hline Levedura & E. coli & NCBI - BLASTN & e-value & TAIR - BLASTX & e-value \\
\hline G2B5 & G2B5.1 & Nto polyphenol oxidase E (LOC104085920) & 0 & & \\
\hline G2B6 & G2B6.1 & Nta acidic endochitinase P (LOC107771200) & & $\begin{array}{c}\text { AT3G12500.1 - ATHCHIB, PR3, PR-3, CHI-B, B-CHI, } \\
\text { HCHIB, basic chitinase }\end{array}$ & \\
\hline G2B7 & G2B7.1 & $\begin{array}{l}\text { Nta proline-rich protein DC2.15-like } \\
\text { (LOC107817575) }\end{array}$ & & AT1G12090.1 - ELP, extensin-like protein & \\
\hline G2B7 & G2B7.4 & $\begin{array}{c}\text { Nta probable methyltransferase PMT3 } \\
\text { (LOC107759039) }\end{array}$ & & $\begin{array}{l}\text { AT4G14360.2 - S-adenosyl-L-methionine-dependent } \\
\text { methyltransferases superfamily protein }\end{array}$ & \\
\hline G2B9 & G2B9.1 & $\begin{array}{l}\text { Nta non-specific lipid-transfer protein } 2 \\
\text { (LOC107814800) }\end{array}$ & & AT3G51590.1 - LTP12, lipid transfer protein 12 & \\
\hline G2B9 & G2B9.3 & Nta uncharacterized (LOC107802204) & & AT5G44890.1 - transposable element gene & \\
\hline G2B10 & G2B10.1 & $\begin{array}{l}\text { Nta chlorophyll a-b binding protein } 40 \\
\text { (LOC107773465) }\end{array}$ & & $\begin{array}{c}\text { AT1G29910.1 - CAB3, AB180, LHCB1.2, chlorophyll } \\
\text { A/B binding protein } 3\end{array}$ & \\
\hline G2B11 & G2B11.4 & $\begin{array}{l}\text { Nta ACCUMULATION AND REPLICATION } \\
\text { OF CHLOROPLASTS } 6 \text { (LOC107788198) }\end{array}$ & & $\begin{array}{c}\text { AT5G42480.1 - ARC6, Chaperone DnaJ-domain } \\
\text { superfamily protein }\end{array}$ & \\
\hline G2B12 & G2B12.1 & $\begin{array}{c}\text { Nta 40S ribosomal protein SA-like } \\
\text { (LOC107816512) }\end{array}$ & & AT3G04770.1 - RPSAb, 40s ribosomal protein SA B & \\
\hline G2C1 & G2C1.1 & Nto polyphenol oxidase E (LOC104085920) & 0 & & \\
\hline $\mathrm{G} 2 \mathrm{C} 2$ & G2C2.3 & & & $\begin{array}{l}\text { AT2G38630.1 - Transducin/WD40 repeat-like } \\
\text { superfamily }\end{array}$ & \\
\hline G2C2 & G2C2.4 & & & $\begin{array}{c}\text { AT2G34420.1 - LHB1B2, LHCB1.5, photosystem II light } \\
\text { harvesting complex gene B1B2 }\end{array}$ & \\
\hline G2C2 & G2C2.5 & & & $\begin{array}{c}\text { AT1G07890.8 - APX1, MEE6, CS1, ATAPX1, } \\
\text { ATAPX01, ascorbate peroxidase } 1\end{array}$ & \\
\hline G2C2 & G2C2.6 & $\begin{array}{c}\text { Nsy DNA-directed RNA polymerases II, IV and } \\
\text { V subunit 11-like (LOC104213168) }\end{array}$ & & $\begin{array}{l}\text { AT3G52090.1 - ATRPB13.6, NRPB11, NRPD11, } \\
\text { NRPE11, DNA-directed RNA polymerase, RBP11-like }\end{array}$ & \\
\hline G2C4 & G2C4.1 & $\begin{array}{l}\text { Nsy small glutamine-rich tetratricopeptide repeat- } \\
\text { containing protein (LOC104227878) }\end{array}$ & 0 & $\begin{array}{c}\text { AT4G08320.1 - TPR8, Tetratricopeptide repeat (TPR)- } \\
\text { like superfamily protein }\end{array}$ & $3 \mathrm{E}-55$ \\
\hline G2C5 & G2C5.1 & $\begin{array}{l}\text { Nta L-ascorbate peroxidase 1, cytosolic-like } \\
\text { (LOC107776943) }\end{array}$ & & $\begin{array}{l}\text { AT1G07890.6 - APX1, MEE6, CS1, ATAPX1, } \\
\text { ATAPX01, ascorbate peroxidase }\end{array}$ & \\
\hline G2C5 & G2C5.3 & $\begin{array}{c}\text { Nta non-specific lipid-transfer protein 2-like } \\
\text { (LOC107760448) }\end{array}$ & & AT5G59320.1 - LTP3, lipid transfer protein 3 & \\
\hline G2C5 & G2C5.6 & $\begin{array}{l}\text { Nta GDP-mannose 3,5-epimerase 1-like } \\
\text { (LOC107797479) }\end{array}$ & & AT5G28840.1 - GME, GDP-D-mannose 3',5'-epimerase & \\
\hline
\end{tabular}


Tabela 10: Continuação

\begin{tabular}{|c|c|c|c|c|c|}
\hline Levedura & E. coli & NCBI - BLASTN & e-value & TAIR - BLASTX & e-value \\
\hline G2C6 & G2C6.1 & $\begin{array}{l}\text { Nto uncharacterized LOC104111497 } \\
\text { (LOC104111497) }\end{array}$ & $3 \mathrm{E}-116$ & $\begin{array}{c}\text { AT4G34588.1 - CPuORF2, conserved peptide upstream } \\
\text { open reading frame } 2\end{array}$ & $3 \mathrm{E}-09$ \\
\hline G2C7 & G2C7.3 & $\begin{array}{l}\text { Nta nucleoside diphosphate kinase 1-like } \\
\text { (LOC107771678) }\end{array}$ & & $\begin{array}{l}\text { AT4G09320.1 - NDPK1, Nucleoside diphosphate kinase } \\
\text { family protein }\end{array}$ & \\
\hline G2C8 & G2C8.1 & $\begin{array}{l}\text { Nta polyphenol oxidase E, chloroplastic-like } \\
\text { (LOC107789348) }\end{array}$ & & AT3G44160.1 - Outer membrane OMP85 family protein & \\
\hline G2C10 & G2C10.1 & Nsy riboflavin synthase (LOC104221024) & & AT2G20690.1 - lumazine-binding family protein & \\
\hline G2C10 & G2C10.2 & $\begin{array}{l}\text { Nta 40S ribosomal protein SA-like } \\
\text { (LOC107816512) }\end{array}$ & & $\begin{array}{c}\text { AT1G72370.1 - P40, AP40, RP40, RPSAA, 40s ribosomal } \\
\text { protein SA }\end{array}$ & \\
\hline $\mathrm{G} 2 \mathrm{C} 11$ & G2C11.1 & $\begin{array}{l}\text { Nta ABC transporter I family member } 1 \\
\text { (LOC107776986) }\end{array}$ & & $\begin{array}{l}\text { AT1G63270.1 - ATNAP10, NAP10, non-intrinsic ABC } \\
\text { protein } 10\end{array}$ & \\
\hline G2D1 & G2D1.1 & $\begin{array}{l}\text { Nsy uncharacterized LOC104210248 } \\
\text { (LOC104210248) }\end{array}$ & 0 & AT3G03150.1 - unknown protein & $4 \mathrm{E}-26$ \\
\hline G2D2 & G2D2.1 & & & AT1G59218.2 - Disease resistance protein & \\
\hline G2D3 & G2D3.3 & $\begin{array}{l}\text { Nta autophagy-related protein 8f-like } \\
\text { (LOC107815935) }\end{array}$ & & $\begin{array}{c}\text { AT4G16520.2 - ATG8F, Ubiquitin-like superfamily } \\
\text { protein }\end{array}$ & \\
\hline G2D4 & G2D4.1 & $\begin{array}{l}\text { Nsy thiol-disulfide oxidoreductase LTO1 } \\
\text { (LOC104228526) }\end{array}$ & 0 & AT4G35760.1 - NAD(P)H dehydrogenase (quinone)s & $4 \mathrm{E}-43$ \\
\hline G2D4 & G2D4.2 & $\begin{array}{l}\text { Nto uncharacterized LOC104111497 } \\
\text { (LOC104111497) }\end{array}$ & $4 \mathrm{E}-115$ & $\begin{array}{c}\text { AT4G34588.1 - CPuORF2, conserved peptide upstream } \\
\text { open reading frame } 2\end{array}$ & 4E-09 \\
\hline G2D5 & G2D5.6 & Nto polyphenol oxidase E (LOC104085920) & 0 & & \\
\hline G2D6 & G2D6.1 & $\begin{array}{l}\text { Nsy pistil-specific extensin-like protein } \\
\text { (LOC104211461) }\end{array}$ & 0 & $\begin{array}{c}\text { AT2G34700.1 - Pollen Ole e } 1 \text { allergen and extensin } \\
\text { family protein }\end{array}$ & $3 \mathrm{E}-23$ \\
\hline G2D6 & G2D6.3 & $\begin{array}{l}\text { Nto methyl-CpG-binding domain-containing } \\
\text { protein 11-like (LOC104115877) }\end{array}$ & 0 & $\begin{array}{l}\text { AT1G15340.1 - MBD10, methyl-CPG-binding domain } \\
10\end{array}$ & $4 \mathrm{E}-34$ \\
\hline G2D7 & G2D7.1 & $\begin{array}{l}\text { Nta 40S ribosomal protein SA-like } \\
\text { (LOC107816512) }\end{array}$ & & AT3G04770.2 - RPSAb, 40s ribosomal protein SA B & \\
\hline G2D9 & G2D9.1 & $\begin{array}{l}\text { Nta uncharacterized LOC107794225 } \\
\text { (LOC107794225) }\end{array}$ & & AT4G09480.1 - transposable element gene & \\
\hline G2D10 & G2D10.3 & $\begin{array}{l}\text { Nta transcription factor TCP7-like } \\
\text { (LOC107830175) }\end{array}$ & & AT5G23280.1 - TCP family transcription factor & \\
\hline G2D11 & G2D11.2 & $\begin{array}{l}\text { Nta non-classical arabinogalactan protein 31-like } \\
\text { (LOC107813352) }\end{array}$ & & $\begin{array}{c}\text { AT2G34700.1 - Pollen Ole e } 1 \text { allergen and extensin } \\
\text { family protein }\end{array}$ & \\
\hline
\end{tabular}


Tabela 10: Continuação

\begin{tabular}{|c|c|c|}
\hline Levedura & E. coli & NCBI - BLASTN \\
\hline G2D11 & G2D11.3 & $\begin{array}{l}\text { Nta transmembrane protein 205-like } \\
\text { (LOC107788056) }\end{array}$ \\
\hline G2D11 & G2D11.4 & $\begin{array}{l}\text { Nta ubiquitin-fold modifier-conjugating enzyme } 1 \\
\text { (LOC107805705) }\end{array}$ \\
\hline G2D12 & G2D12.1 & Nta 40S ribosomal protein S5 (LOC107815336) \\
\hline G2D12 & G2D12.2 & $\begin{array}{l}\text { Nta L-ascorbate peroxidase 2, cytosolic-like } \\
\text { (LOC107759703) }\end{array}$ \\
\hline G2E1 & G2E1.1 & Nto 40S ribosomal protein SA (LOC104121230) \\
\hline G2E1 & G2E1.4 & $\begin{array}{l}\text { Nto transcription factor TCP7-like } \\
\text { (LOC104091236) }\end{array}$ \\
\hline G2E3 & G2E3.3 & Nto ADP, ATP carrier protein (LOC104090015) \\
\hline G2E3 & G2E3.4 & $\begin{array}{l}\text { Nsy photosystem I reaction center subunit III } \\
\text { (LOC104229855) }\end{array}$ \\
\hline G2E3 & G2E3.6 & Nsy acetolactate synthase 1 (LOC104220509) \\
\hline G2E4 & G2E4.1 & $\begin{array}{l}\text { Nsy calmodulin-binding transcription activator 4- } \\
\text { like (LOC104248500) }\end{array}$ \\
\hline G2E5 & G2E5.1 & $\begin{array}{l}\text { Nta 40S ribosomal protein SA-like } \\
\text { (LOC107816512) }\end{array}$ \\
\hline G2E6 & G2E6.4 & Nto dnaJ protein homolog (LOC104096272) \\
\hline G2E7 & G2E7.1 & Nta riboflavin synthase-like (LOC107825203) \\
\hline G2E7 & G2E7.3 & $\begin{array}{l}\text { Nta ribulose bisphosphate carboxylase small chain } \\
\text { (LOC107766567) }\end{array}$ \\
\hline G2E8 & G2E8.1 & $\begin{array}{c}\text { Nsy serine/threonine-protein phosphatase 2A } 65 \\
\text { kDa regulatory subunit A beta isoform-like } \\
\text { (LOC104226350) }\end{array}$ \\
\hline G2E8 & G2E8.4 & $\begin{array}{l}\text { Nta nucleoside diphosphate kinase 1-like } \\
\text { (LOC107771678) }\end{array}$ \\
\hline G2E12 & G2E12.1 & $\begin{array}{c}\text { Nta serine hydroxymethyltransferase } 3 \\
\text { (LOC107759094) }\end{array}$ \\
\hline G2E12 & G2E12.2 & Nta DEAD-box ATP-dependent RNA helicase 5-like \\
\hline
\end{tabular}

e-value

TAIR - BLASTX

e-value

AT3G62580.1 - Late embryogenesis abundant protein (LEA) family protein

AT1G27530.1 - CONTAINS InterPro DOMAIN/s:

Ubiquitin-conjugating enzyme/RWD-like

AT3G11940.1 - ATRPS5A, AML1, RPS5A, ribosomal protein $5 \mathrm{~A}$

AT1G07890.8 - APX1, MEE6, CS1, ATAPX1, ATAPX01

AT3G04770.2 - RPSAb, 40s ribosomal protein SA B

6E-86

AT5G23280.1 - TCP family transcription factor

$1 \mathrm{E}-43$

AT5G13490.2 - AAC2, ADP/ATP carrier 2

AT1G31330.1 - PSAF, photosystem I subunit F

$3 \mathrm{E}-74$

AT3G48560.1 - CSR1, ALS, AHAS, TZP5, IMR1,

$1 \mathrm{E}-114$ chlorsulfuron/imidazolinone resistant 1

AT1G67310.1 - Calmodulin-binding transcription activator protein with CG-1 and Ankyrin domains

AT3G04770.2 - RPSAb, 40s ribosomal protein SA B

AT3G44110.2 - ATJ3, ATJ DNAJ homologue 3

AT2G20690.1 - lumazine-binding family protein

AT5G38410.1 - Ribulose bisphosphate carboxylase (small chain)

AT3G25800.2 - PDF1, PR 65, PP2AA2, protein phosphatase $2 \mathrm{~A}$ subunit A2

AT4G09320.1 - NDPK1, Nucleoside diphosphate kinase family protein

AT3G46450.2 - SEC14 cytosolic factor family protein / phosphoglyceride transfer family protein

AT1G31970.1 - STRS1, DEA(D/H)-box RNA helicase family protein 
Tabela 10: Continuação

\begin{tabular}{|c|c|c|c|c|c|}
\hline Levedura & E. coli & NCBI - BLASTN & e-value & TAIR - BLASTX & e-value \\
\hline G2F1 & G2F1.1 & $\begin{array}{l}\text { Nto transcription factor TCP7-like } \\
\text { (LOC104091236) }\end{array}$ & 0 & AT5G23280.1 - TCP family transcription factor & $5 \mathrm{E}-55$ \\
\hline G2F2 & G2F2.1 & $\begin{array}{c}\text { Nsy U2 small nuclear ribonucleoprotein A' } \\
\text { (LOC104239324) }\end{array}$ & & $\begin{array}{l}\text { AT1G09760.1 - U2A', U2 small nuclear ribonucleoprotein } \\
\text { A }\end{array}$ & \\
\hline G2F2 & G2F2.2 & & & AT1G72370.2 - P40, AP40, RP40, RPSAA, 40s ribosomal & \\
\hline G2F2 & G2F2.3 & & & AT3G06150.1 - unknown protein & \\
\hline G2F3 & G2F3.3 & $\begin{array}{c}\text { Nto chlorophyll a-b binding protein CP29.2 } \\
\text { (LOC104086099) }\end{array}$ & 0 & $\begin{array}{c}\text { AT3G08940.2 - LHCB4.2, light harvesting complex } \\
\text { photosystem II }\end{array}$ & $6 \mathrm{E}-103$ \\
\hline G2F3 & G2F3.4 & $\begin{array}{c}\text { Nto autophagy-related protein 8f } \\
\text { (LOC104117639) }\end{array}$ & 0 & $\begin{array}{c}\text { AT4G16520.2 - ATG8F, Ubiquitin-like superfamily } \\
\text { protein }\end{array}$ & $4 \mathrm{E}-76$ \\
\hline $\mathrm{G} 2 \mathrm{~F} 4$ & G2F4.1 & $\begin{array}{l}\text { Nto polygalacturonase inhibitor-like } \\
\text { (LOC104101441) }\end{array}$ & 0 & $\begin{array}{c}\text { AT5G06860.1 - PGIP1, ATPGIP1, polygalacturonase } \\
\text { inhibiting protein } 1\end{array}$ & $5 \mathrm{E}-60$ \\
\hline G2F5 & G2F5.1 & $\begin{array}{c}\text { Nsy nitrogen regulatory protein P-II homolog } \\
\text { (LOC104237003) }\end{array}$ & $4 \mathrm{E}-180$ & AT4G01900.1 - PII, GLB1, GLNB1 homolog & $3 \mathrm{E}-51$ \\
\hline G2F6 & G2F6.2 & $\begin{array}{l}\text { Nto serine/arginine-rich splicing factor RSZ21A- } \\
\text { like (LOC104101004) }\end{array}$ & 0 & $\begin{array}{c}\text { AT1G23860.3 - SRZ-21, SRZ21, RSZ21, At-RSZ21,RS- } \\
\text { containing zinc finger protein } 21\end{array}$ & $1 \mathrm{E}-25$ \\
\hline G2F6 & G2F6.6 & $\begin{array}{l}\text { Nsy protein TRANSPORT INHIBITOR } \\
\text { RESPONSE 1-like (LOC104215201) }\end{array}$ & 0 & $\begin{array}{c}\text { AT3G62980.1 - TIR1, F-box/RNI-like superfamily } \\
\text { protein }\end{array}$ & $6 \mathrm{E}-54$ \\
\hline G2F7 & G2F7.1 & $\begin{array}{l}\text { Nta 60S ribosomal protein L13-1 } \\
\text { (LOC107766512) }\end{array}$ & & $\begin{array}{c}\text { AT3G49010.3 - ATBBC1, BBC1, RSU2, breast basic } \\
\text { conserved } 1\end{array}$ & \\
\hline G2F8 & G2F8.1 & Nta uncharacterized (LOC107765337) & & $\begin{array}{l}\text { AT3G53980.2 - Bifunctional inhibitor/lipid-transfer } \\
\text { protein/seed storage } 2 S \text { albumin superfamily protein }\end{array}$ & \\
\hline G2F10 & G2F10.1 & Nta riboflavin synthase-like (LOC107825203) & & AT2G20690.1 - lumazine-binding family protein & \\
\hline G2G1 & G2G1.1 & $\begin{array}{c}\text { Nto transcription factor TCP7-like } \\
\text { (LOC104091236) }\end{array}$ & 0 & AT5G23280.1 - TCP family transcription factor & $5 \mathrm{E}-55$ \\
\hline G2G3 & G2G3.2 & $\begin{array}{l}\text { Nta 40S ribosomal protein SA-like } \\
\text { (LOC107816512) }\end{array}$ & & AT3G04770.2 - RPSAb, 40s ribosomal protein SA B & \\
\hline G2G4 & G2G4.1 & $\begin{array}{l}\text { Nta transmembrane protein 205-like } \\
\text { (LOC107788056) }\end{array}$ & & $\begin{array}{c}\text { AT3G62580.1 - Late embryogenesis abundant protein } \\
\text { (LEA) family protein }\end{array}$ & \\
\hline G2G4 & G2G4.2 & $\begin{array}{l}\text { Nta gamma-interferon-inducible lysosomal thiol } \\
\text { reductase-like (LOC107793859) }\end{array}$ & & AT1G07080.1 - Thioredoxin superfamily protein & \\
\hline G2G4 & G2G4.5 & $\begin{array}{l}\text { Nta geranylgeranyl pyrophosphate synthase } \\
\text { (LOC107774226) }\end{array}$ & & $\begin{array}{c}\text { AT4G36810.1 - GGPS1, geranylgeranyl pyrophosphate } \\
\text { synthase } 1\end{array}$ & \\
\hline
\end{tabular}


Tabela 10: Continuação

\begin{tabular}{|c|c|c|c|c|c|}
\hline Levedura & E. coli & NCBI - BLASTN & e-value & TAIR - BLASTX & e-value \\
\hline G2G5 & G2G5.1 & Nto transcription factor TCP7-like (LOC104091236) & 0 & AT5G23280.1 - TCP family transcription factor & $2 \mathrm{E}-42$ \\
\hline G2G5 & G2G5.3 & $\begin{array}{l}\text { Nsy uncharacterized LOC104227417 } \\
\text { (LOC104227417) }\end{array}$ & 0 & AT3G49960.1 - Peroxidase superfamily protein & 0,002 \\
\hline G2G6 & G2G6.1 & $\begin{array}{l}\text { Nto pistil-specific extensin-like protein } \\
\text { (LOC104109755) }\end{array}$ & 0 & & \\
\hline G2G8 & G2G8.1 & $\begin{array}{l}\text { Nta nucleoside diphosphate kinase 1-like } \\
\text { (LOC107771678) }\end{array}$ & & $\begin{array}{c}\text { AT4G09320.1 - NDPK1, Nucleoside diphosphate kinase family } \\
\text { protein }\end{array}$ & \\
\hline G2G10 & G2G10.1 & $\begin{array}{c}\text { Nta probable plastid-lipid-associated protein } 13 \\
\text { (LOC107760813) }\end{array}$ & & AT3G58010.1 - PGL34, plastoglobulin 34kD & \\
\hline G2G10 & G2G10.2 & $\begin{array}{c}\text { Nto RNA polymerase II subunit 5-mediating protein } \\
\text { homolog (LOC104101100) }\end{array}$ & & & \\
\hline G2G10 & G2G10.5 & $\begin{array}{c}\text { Nto RNA polymerase II subunit 5-mediating protein } \\
\text { homolog (LOC104101100) }\end{array}$ & & & \\
\hline G2G10 & G2G10.6 & Nsy uncharacterized (LOC104242493) & & $\begin{array}{l}\text { AT1G58250.2 - SAB, Golgi-body localisation protein domain; } \\
\text { RNA pol II promoter Fmp27 protein domain }\end{array}$ & \\
\hline G2G12 & G2G12.3 & Nta uncharacterized (LOC107792131) & & AT5G56780.1 - ATET2, ET2, effector of transcription2 & \\
\hline G2H3 & G2H3.3 & Nta patellin-3-like (LOC107806665) & & $\begin{array}{l}\text { AT4G09160.1 - SEC14 cytosolic factor family protein } \\
\text { / phosphoglyceride transfer family protein }\end{array}$ & \\
\hline $\mathrm{G} 2 \mathrm{H} 3$ & G2H3.4 & $\begin{array}{l}\text { Nta zinc-finger homeodomain protein 2-like } \\
\text { (LOC107790230) }\end{array}$ & & $\begin{array}{c}\text { AT4G24660.1 - ATHB22, MEE68, HB22, ZHD2, homeobox } \\
\text { protein } 22\end{array}$ & \\
\hline $\mathrm{G} 2 \mathrm{H} 4$ & G2H4.2 & $\begin{array}{l}\text { Nto peptide-N4-(N-acetyl-beta- } \\
\text { glucosaminyl)asparagine amidase A-like } \\
\text { (LOC104108298) }\end{array}$ & 0 & $\begin{array}{l}\text { AT3G14920.1 - Peptide-N4-(N-acetyl-beta- } \\
\text { glucosaminyl)asparagine amidase A protein }\end{array}$ & $2 \mathrm{E}-60$ \\
\hline G2H4 & G2H4.6 & $\begin{array}{l}\text { Nto auxin-responsive protein IAA17-like } \\
\text { (LOC104104598) }\end{array}$ & 0 & $\begin{array}{c}\text { AT1G04250.1 - AXR3, IAA17, AUX/IAA transcriptional } \\
\text { regulator family protein }\end{array}$ & $7 \mathrm{E}-34$ \\
\hline G2H5 & G2H5.1 & $\begin{array}{l}\text { Nto uncharacterized LOC104091634 } \\
\text { (LOC104091634) }\end{array}$ & 0 & & \\
\hline G2H5 & G2H5.2 & $\begin{array}{l}\text { Nto uroporphyrinogen-III synthase, chloroplastic } \\
\text { (LOC104101896) }\end{array}$ & 0 & $\begin{array}{l}\text { AT2G26540.1 - HEMD, UROS, ATUROS, ATDUF3, DUF3, } \\
\text { uroporphyrinogen-III synthase family protein }\end{array}$ & $7 \mathrm{E}-54$ \\
\hline G2H5 & G2H5.4 & $\begin{array}{l}\text { Nsy induced stolen tip protein TUB8-like } \\
\text { (LOC104242855) }\end{array}$ & 0 & & \\
\hline G2H9 & G2H9.1 & Nta 40S ribosomal protein SA-like (LOC107816512) & & AT3G04770.2 - RPSAb, 40s ribosomal protein SA B & \\
\hline
\end{tabular}


Tabela 10: Conclusão

\begin{tabular}{|c|c|c|c|c|c|}
\hline Levedura & E. coli & NCBI - BLASTN & e-value & TAIR - BLASTX & e-value \\
\hline $\mathrm{G} 2 \mathrm{H} 10$ & G2H10.1 & $\begin{array}{c}\text { Sesamum indicum chlorophyll a-b binding } \\
\text { protein } 21 \text { (LOC105167309) }\end{array}$ & & $\begin{array}{l}\text { AT1G29930.1 - CAB1, AB140, CAB140, LHCB1.3, } \\
\text { chlorophyll A/B binding protein } 1\end{array}$ & \\
\hline G2H10 & G2H10.3 & $\begin{array}{l}\text { Nto cysteine-rich and transmembrane domain- } \\
\text { containing protein A (LOC104097420) }\end{array}$ & & AT2G33520.1 - unknown protein & \\
\hline G2H11 & G2H11.1 & $\begin{array}{c}\text { Nta 40S ribosomal protein SA-like } \\
\text { (LOC107816512) }\end{array}$ & & $\begin{array}{c}\text { AT1G72370.1 - P40, AP40, RP40, RPSAA, 40s ribosomal } \\
\text { protein SA }\end{array}$ & \\
\hline G2H12 & G2H11.2 & $\begin{array}{l}\text { Nta } 40 \text { S ribosomal protein SA-like } \\
\text { (LOC107813555) }\end{array}$ & & AT3G04770.2 - RPSAb, 40s ribosomal protein SA B & \\
\hline G2H12 & G2H12.1 & Nta TCP1 protein-like gene & & AT1G58100.1 - TCP family transcription factor & \\
\hline G2H10 & G2H10.1 & $\begin{array}{l}\text { Sesamum indicum chlorophyll a-b binding } \\
\text { protein } 21 \text { (LOC105167309) }\end{array}$ & & $\begin{array}{c}\text { AT1G29930.1 - CAB1, AB140, CAB140, LHCB1.3, } \\
\text { chlorophyll A/B binding protein } 1\end{array}$ & \\
\hline
\end{tabular}




\section{APÊNDICE C - ALINHAMENTO DAS SEQUÊNCIAS GENÔMICAS DE SCI1 DE $N$.}

\section{tabacum, N. tomentosiformis E N. sylvestris}

O alinhamento foi feito com fragmentos de sequências genômicas retiradas do repositório Gene Bank. A Tabela 11 mostra a sequência, seu número de acesso no Gene Bank e a referida identificação no alinhamento.

Tabela 11: Sequências genômicas utilizadas para o alinhamento de SCI1 de N. tabacum, N. tomentosiformis e $\mathbf{N}$. sylvestris.

\begin{tabular}{|l|l|l|}
\hline \multicolumn{1}{|c|}{ Sequência Genômico } & \multicolumn{1}{|c|}{ Acesso no Gene Bank } & \multicolumn{1}{c|}{$\begin{array}{c}\text { Identificação no } \\
\text { alinhamento }\end{array}$} \\
\hline $\begin{array}{l}\text { NtSCI1 de N. tabacum } \\
\text { correspondente à cópia de } N . \\
\text { tomentosiformis }\end{array}$ & Ntab-TN90_scaffold2941 & Ntabacum_Ntomentosiformis \\
\hline $\begin{array}{l}\text { NtSCI1 de N. tabacum } \\
\text { correspondente à cópia de N. } \\
\text { sylvestris }\end{array}$ & Ntab-TN90_scaffold75632 & Ntabacum_Nsylvestris \\
\hline $\begin{array}{l}\text { SCI1 de N. tomentosiformis } \\
\text { SCI1 DE N. sylvestris }\end{array}$ & $\begin{array}{l}\text { Ntom_v01 Nsyl_scaffold21378 } \\
\text { Ntom_scaffold12288 }\end{array}$ & Ntomentosiformis \\
\hline
\end{tabular}

O alinhamento foi feito com o software MUSCLE (3.8). Os primers Fw utilizados para amplificar as cópias de SCI1 correspondentes à N. tomentosiformis e N. sylvestris estão destacados em preto. Os 4 éxons estão destacados em amarelo, azul, rosa e verde, respectivamente.

Ntabacum_Nsylvestris Nsylvestris

Ntabacum Ntomentosiformis Ntomentosiformis

Ntabacum Nsylvestris Nsylvestris

Ntabacum Ntomentosiformis Ntomentosiformis

Ntabacum Nsylvestris Nsylvestris Ntabacum Ntomentosiformis Ntomentosiformis

Ntabacum_Nsylvestris Nsylvestris

Ntabacum Ntomentosiformis Ntomentosiformis
TATTTTGAAGGTT----TTGGGAATAGCGTGTGGAGCCGTT-TCCTCGTTGTACGGTTGT TATTTTGAAGGTT----TTGGGAATAGCGTGTGGAGCCGTT-TCCTCGTTGTACGGTTGT ---TTTATAAGTTAAAATCGGCCATAAGCTATAAGTTGGTCACCCCCAACTTATGATTTT ---TTTATAAGTTAAAATCGGCCATAAGCTATAAGTTGGTCACCCCCAACTTATGATTTT

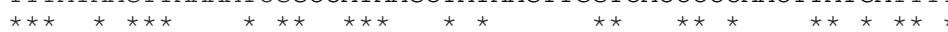

TCGACGAATCGACCAATGTCTCGTTTTGGTAGTAACTTTGGGGCGAATTTATCGACCCTT TCGACGAATCGACCAATGTCTCGTTTTGGTAGTAACTTTGGGGCGAATTTATCGACCCTT TCAGCTTATAAGC--ACTTTTAGTTTGACCAAGACTTTT---ACTAATTTAT-----CCT TCAGCTTATAAGC--ACTTTTAGTTTGACCAAGACTTTT---ACTAATTTAT-----CCT

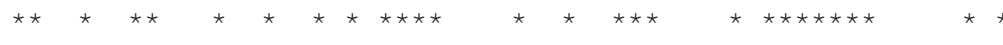

TCTTGATGCTCCCTCATCTGGTCACGGAGCACCTT----------GTTTTT--GTTTTC TCTTGATGCTCCCTCATCTGGTCACGGAGCACCTT----------GTTTTT--GTTTTC TAATAATATTTTTAAT----TTACAAAATATTTTTTCAAAATAAATTTTTAAATTTTC

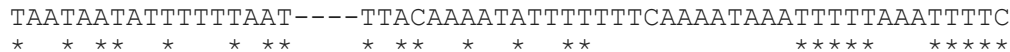

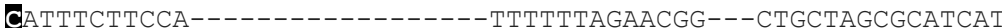
CATTTCTTCCA-----------------TTTTTTAGAACGG---CTGCTAGCGCATCAT TCTTCATTCCATATTCGTTGTTTATCATTTTCTCTACAAAGAAACTTTTTAATTCATAAT TCTTCATTCCATATTCGTTGTTTATCATTTTCTCTACAAAGAAACTTTTTAATTCATAAT 
Ntabacum Nsylvestris Nsylvestris Ntabacum Ntomentosiformis Ntomentosiformis

Ntabacum Nsylvestris Nsylvestr̄is Ntabacum Ntomentosiformis Ntomentosiformis

Ntabacum_Nsylvestris Nsylvestris

Ntabacum Ntomentosiformis Ntomentosiformis

Ntabacum_Nsylvestris Nsylvestris

Ntabacum Ntomentosiformis Ntomentos̄iformis

Ntabacum_Nsylvestris Nsylvestris

Ntabacum_Ntomentosiformis Ntomentosiformis

Ntabacum Nsylvestris

Nsylvestris

Ntabacum_Ntomentosiformis Ntomentosiformis

Ntabacum Nsylvestris Nsylvestris Ntabacum Ntomentosiformis Ntomentosiformis

Ntabacum Nsylvestris Nsylvestris

Ntabacum Ntomentosiformis Ntomentosiformis

Ntabacum Nsylvestris Nsylvestris

Ntabacum Ntomentosiformis Ntomentosiformis

Ntabacum Nsylvestris Nsylvestr̄is

Ntabacum Ntomentosiformis Ntomentosiformis

Ntabacum Nsylvestris Nsylvestris

Ntabacum Ntomentosiformis Ntomentosiformis

Ntabacum_Nsylvestris Nsylvestris

Ntabacum Ntomentosiformis Ntomentosiformis
TACCTGCATCAACAGTGGGGTAAGTGTTTCATGTTTGAGGAATGGGCTGCTTGCCGGTGG TACCTGCATCAACAGTGGGGTAAGTGTTTCATGTTTGAGGAATGGGCTGCTTGCCGGTGG СтTTTATAAAAAATTTAAGGGTATTTTTATCTTTTTAACAAGAGAACAGTTTATCAGCAC CTTTTATAAAAAATTTAAGGGTATTTTTATCTTTTTAACAAGAGAACAGTTTATCAGCAC

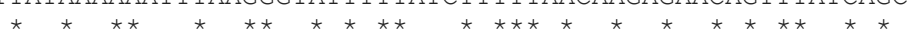

TTGTT-----ATGATATCTGCTTGCGCGGTATTTTTGTTCTCCCTTTGAGCAGGTCTGTC TTGTT-----ATGATATCTGCTTGCGCGGTATTTTTGTTCTCCCTTTGAGCAGGTCTGTC TTTTCTACCAAACATATCAG---------GTGCTTATTATCAGTTTCAGCACGTCTATC TTTTCTACCAAACATATCAG---------GTGCTTATTATCAGTTTCAGCACGTCTATC

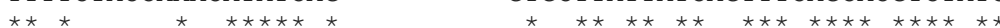

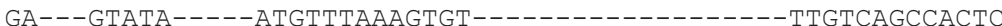
GA---GTATA-----ATGTTTAAAGTGT----------------TTGTCAGCCACTC CAAACACATAAATAGATATTTAAAAAATTAATTCCAGCACTTCAAGATTATCAGTTA- - T CAAACACATAAATAGATATTAAAAAATTAATTCCAGCACTTCAAGATTATCAGTTA--T

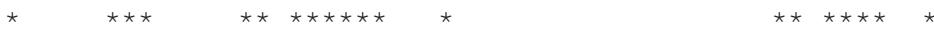

TTCTAGTAATTTTTTCACTACTGGT------------GGTGCTTCTTCA------TTCTAGTAATTTTTTCACTACTGGT-------------GGTGCTTCTTCA--------TTACAATAAGCTAATCCAAACGGGTTAAGTTTAATTAAGGTTGCTCCTTAATTAAATTAT TTACAATAAGCTAATCCAAACGGGTTAAGTTTAATTAAGGTTGCTCCTTAATTAAATTAT

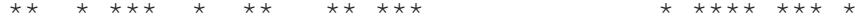

GCTGTAGATGTGGAGGCTCCCCTTTCGCGTGAAGGTGTCACGCTTTCGTGAGG-GGAGGT GCTGTAGATGTGGAGGCTCCCCTTTCGCGTGAAGGTGTCACGCTTTCGTGAGG-GGAGGT TTTGTAAGGGAAGGAGTACTCAC------TGCAATTACAACGTTATTACATGGTTGCGGC TTTGTAAGGGAAGGAGTACTCAC------TGCAATTACAACGTTATTACATGGTTGCGGC

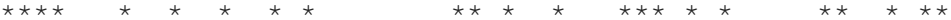

GAAGCACTTCGCCTCGGCATAGTGTTTGGTGTCACATTT---------TCATTG----TC GAAGCACTTCGCCTCGGCATAGTGTTTGGTGTCACATTT---------TCATTG----TC GAA----TACGTGCCAGCATCGATGTGGGCAAGATATATAAGACTTAATCATTGAGCTAT GAA----TACGTGCCAGCATCGATGTGGGCAAGATATATAAGACTTAATCATTGAGCTAT

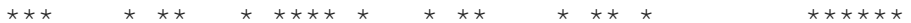

TTCCCTGCCATCTTCGTTAATGGTGTTCAAAATGTTGGTGGTGACGCCTGCTAT----TTCCCTGCCATCTTCGTTAATGGTGTTCAAAATGTTGGTGGTGACGCCTGCTAT-----TTTATTGGAAAATTTGAGAATAAAAAAGAAAATATACAAAACAACTTATACTATTAAGAA TTTATTGGAAAATTTGAGAATAAAAAAGAAAATATACAAAACAACTTATACTATTAAGAA

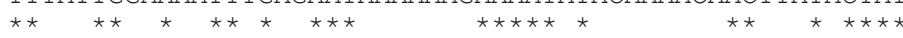

---TGCTTTCAGTCTTGC-------ATCGCCTTTTCCT--GCCATTGTTAGTTCGTGCA ---TGCTTTCAGTCTTGC--------ATCGCCTTTTCCT--GCCATTGTTAGTTCGTGCA TCATAATTTGAGTTATACTACAAGTTAGAGTCTCTCACTTAATCACTATTATTCTACTCG TCATAATTTGAGTTATACTACAAGTTAGAGTCTCTCACTTAATCACTATTATTCTACTCG

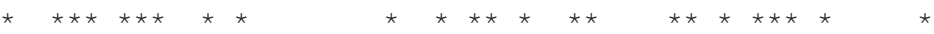

AACGAAG-AAGAGATGACTGTTTTTTT----------------------------TA

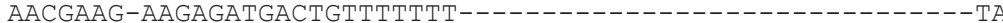
ATTAAAACCAGTGAGG--TGTTTTTTTGAAAATAGTGTTAGATAATTTGATAACAAAGTA ATTAAAACCAGTGAGG--TGTTTTTTTGAAAATAGTGTTAGATAATTTGATAACAAAGTA

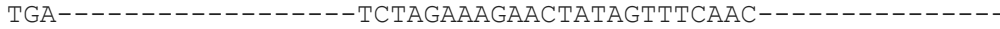

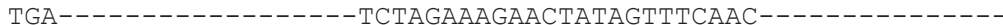
TGAAATTGAGAAAACAGCCCTTCTGGAGGAAACTA-ATCATCAATAAGATAGAGGTAAAA TGAAATTGAGAAAACAGCCCTTCTGGAGGAAACTA-ATCATCAATAAGATAGAGGTAAAA

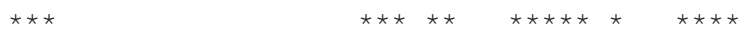

----TAAAAACCTCCCCACAGACGGCGCCAAAT----TGTTTGAG---CAAAT--AATT -----TAAAAACCTCCCCACAGACGGCGCCAAAT----TGTTTGAG---CAAAT--AATT ATTTATAAAATCTTCTTTATAATCAATGCCATGTCCCATGTTTCTATCTCAAGTGGAATT ATTTATAAAATCTTCTTTATAATCAATGCCATGTCCCATGTTTCTATCTCAAGTGGAATT

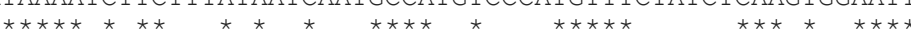

GCTAAAC-------CAATTAATAATAAATTAGAAGGGACGAATCCTTGAACTTAATAA-GCTAAAC------CAATTAATAATAAATTAGAAGGGACGAATCCTTGAACTTAATAA-GAAAAACATAGGTAATATACATAATAAACCAACATATATATGTGCATGTA--TAATAAGC GAAAAACATAGGTAATATACATAATAAACCAACATATATATGTGCATGTA--TAATAAGC

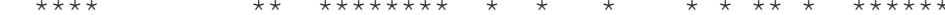


Ntabacum Nsylvestris Nsylvestris Ntabacum Ntomentosiformis Ntomentosiformis

Ntabacum Nsylvestris Nsylvestris

Ntabacum Ntomentosiformis Ntomentosiformis

Ntabacum Nsylvestris Nsylvestris

Ntabacum_Ntomentosiformis Ntomentosiformis

Ntabacum Nsylvestris Nsylvestris

Ntabacum Ntomentosiformis Ntomentosiformis

Ntabacum Nsylvestris Nsylvestris

Ntabacum Ntomentosiformis Ntomentosiformis

Ntabacum_Nsylvestris Nsylvestris

Ntabacum Ntomentosiformis Ntomentosiformis

Ntabacum Nsylvestris Nsylvestris

Ntabacum Ntomentosiformis Ntomentosiformis

Ntabacum Nsylvestris Nsylvestris

Ntabacum_Ntomentosiformis Ntomentosiformis

Ntabacum Nsylvestris Nsylvestris

Ntabacum Ntomentosiformis Ntomentosiformis

Ntabacum Nsylvestris Nsylvestris

Ntabacum Ntomentosiformis Ntomentosiformis

Ntabacum_Nsylvestris Nsylvestr̄is

Ntabacum Ntomentosiformis Ntomentosiformis

Ntabacum Nsylvestris Nsylvestris

Ntabacum Ntomentosiformis Ntomentosiformis
ATTCTAG- -ATCGAATA

-------- ATTCTAG--ATCGAATA---------------------------AAA

CCTCCGTCCCATTTTAAGTATCGGATATAGTTTTTCAATTGTATTTATGTTCTTATTGAT CCTCCGTCCCATTTTAAGTATCGGATATAGTTTTTCAATTGTATTTATGTTCTTATTGAT $\star \star \star * \star * * \star \star * \star * * *$

TAAAGCTCTTGTATAGCGATTAGAGTTTAGGA--GCATT--------AAACAAT-----TAAAGCTCTTGTATAGCGATTAGAGTTTAGGA--GCATT--------AAACAAT-----TAAATTTTTTATCTACCGTTGATTTCTTAGGGCCTCATTTTAGTTGGAAATAATTTTTTA TAAATTTTTATCTACCGTTGATTCTTAGGGCCTCATTTTAGTTGGAAATAATTTTTTA

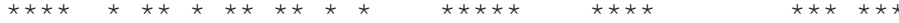

GAACTTAATGTGCTATGAT--TGATAATACA------TGCTATAG--CATAAATGTATAA GAACTTAATGTGCTATGAT--TGATAATACA------TGCTATAG--CATAAATGTATAA TACATTAATATGTTCAGCTAATGAGATTTCAGAAGTTCACTACAGCTCAAAAATCTATAA TACATTAATATGTTCAGCTAATGAGATTTCAGAAGTTCACTACAGCTCAAAAATCTATAA

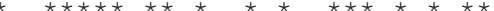

TAAATGTGA-------------------GTAATGAC-------------AAGGATT

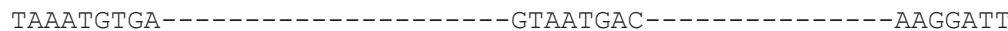
TATATATGCTAATTAAAAGCTCGAAAAAGTGCAAAAACATAGATAAACCAAAAAAGAAAA TATATATGCTAATTAAAAGCTCGAAAAAGTGCAAAAACATAGATAAACCAAAAAAGAAAA

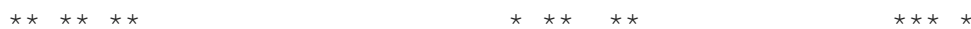

ATAACGGGAAAGGAACTATCACCT---------AATGATTATATGATTGGAATGTTCC ATAACGGGAAAGGAACTATCACCT----------AATGATTATATGATTGGAATGTTCC ATGAAAAATAAAAAAATAGCAACTTTAGTTGAAAGAATAATAGTATGA-CAAAATATTTT ATGAAAAATAAAAAATAGCAACTTTAGTTGAAAGAATAATAGTATGA-CAAAATATTTT

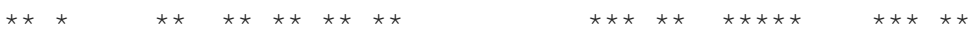

-------------------TTTTCTCTGACGACGACATG---GAAAAGCGAGAGGTC -TTTTCTCTGACGACGACATG---GAAAAGCGAGAGGTC ACATGTGAAGTAGAACATCGTACTTACAGTGAGGACTACAAACATTAAATGTTAATTGTA ACATGTGAAGTAGAACATCGTACTTACAGTGAGGACTACAAACATTAAATGTTAATTGTA

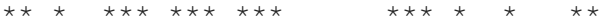

AAAATGTGTATGGGATCTTGA--GATTTATGGATCAAGGT----TGAACAACATGTGCTT AAAATGTGTATGGGATCTTGA--GATTTATGGATCAAGGT----TGAACAACATGTGCTT ACCATTTTCATAGTTGTTTGAATGATTAGCTTATCAAAATAATGAGAAAAAGAAAACTTT ACCATTTTCATAGTTGTTGAATGATtAGCTTATCAAAATAATGAGAAAAAGAAAACTTT

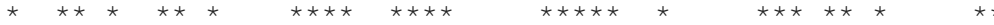

GAATAAATGAAT------------------AAGACAACT---CTTTCATATATTCTTC

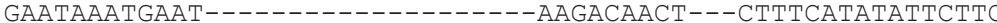
ATCTCTATGAGTTGCAAGATTTTATTGTGCGGAAAATACCTTGATTTTCGGGTATCGCTC ATCTCTATGAGTTGCAAGATTTTATTGTGCGGAAAATACCTTGATTTTCGGGTATCGCTC

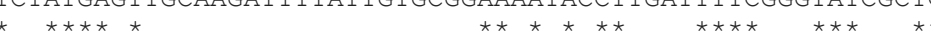

-----CTTTCAACTTTTACAATATGTTCCCAGTTCAGAAAAAAAAA---GGCAG----------CTTTCAACTTTTACAATATGTTCCCAGTTCAGAAAAAAAAA---GGCAACCCCCC GATCATTTTCATTTTCTG------GTACGGAATTGAGAATAACTAATTGAGTAG-----GATCATTTTCATTTTCTG-----GTACGGAATTGAGAATAACTAATTGAGTAG------

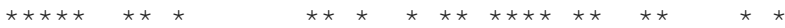

----ANNNCGTCCCCTATCTCTTCCTATTTATAAGACACATTCCCCAАAАATCCT---CCCCCCCCCGTCCCCTATCTCTTCCTATTTATAAGACACATTCCCCAAAAATCCT---- -------CATACGATGCGGTTTCACTTTAATACGAGAC--TTCATAAAATTAGTTGGAT -------CATACGATGCGGTTTCACTTTAATACGAGAC--TTCATAAAATTAGTTGGAT

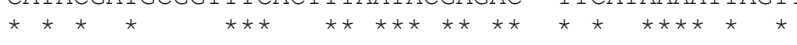

-AAAAGGTACAGCATAAAGAATATCCGATCTTAGCTGCC------CGCTTCTGGCAT---AAAAGGTACAGCATAAAGAATATCCGATCTTAGCTGCC------CGCTTCTGGCAT--AАATAAATCTAACATAATAATAATAATTTATAAGTTTGCACAAAGTGACTCTAGGATTCA AAATAAATCTAACATAATAATAATAATTATAAGTTTGCACAAAgTGACTCTAGgATTCA

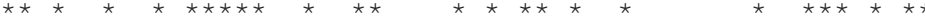

--------CAACCTT----TATGAGGACGACCT-----GCAGTCGTTGT--ATCGTGGT --------CAACCTT----TATGAGGACGACCT-----GCAGTCGTTGT--ATCGTGGT AATTTCACACAACGTTAGTATACAACAATTAGCTTTTAGGTAATGGTTGTGAGTTGTGAC AATTTCACACAACGTTAGTATACAACAATTAGCTTTTAGGTAATGGTTGTGAGTTGTGAC

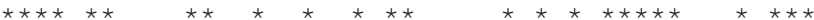


Ntabacum Nsylvestris Nsylvestris Ntabacum_Ntomentosiformis Ntomentosiformis

Ntabacum_Nsylvestris Nsylvestris

Ntabacum Ntomentosiformis Ntomentosiformis

Ntabacum_Nsylvestris Nsylvestris

Ntabacum_Ntomentosiformis Ntomentosiformis

Ntabacum Nsylvestris Nsylvestris

Ntabacum_Ntomentosiformis Ntomentosiformis

Ntabacum Nsylvestris Nsylvestris

Ntabacum Ntomentosiformis Ntomentosiformis

Ntabacum_Nsylvestris Nsylvestris

Ntabacum Ntomentosiformis Ntomentosiformis

Ntabacum_Nsylvestris Nsylvestris

Ntabacum_Ntomentosiformis Ntomentosiformis

Ntabacum_Nsylvestris Nsylvestr̄is

Ntabacum Ntomentosiformis Ntomentosiformis

Ntabacum_Nsylvestris Nsylvestris

Ntabacum_Ntomentosiformis Ntomentosiformis

Ntabacum Nsylvestris Nsylvestris Ntabacum_Ntomentosiformis Ntomentosiformis

Ntabacum Nsylvestris Nsylvestris

Ntabacum Ntomentosiformis Ntomentosiformis

Ntabacum_Nsylvestris Nsylvestris

Ntabacum Ntomentosiformis Ntomentosiformis

Ntabacum Nsylvestris Nsylvestris

Ntabacum Ntomentosiformis Ntomentosiformis
CGACC-----CTGTCCTTTGTCTTGCTTA-------------TCCGTTACTGTGGTTA

CGACC-----CTGTCCTTTGTCTTGCTTA--------------TCCGTTACTGTGGTTA TAACAAATTGTTATACGTTTTCTCATTTACTGATCTTAAGTGGCTTCGTAATATCTTTTA TAACAAATTGTTATACGTTTTCTCATTTACTGATCTTAAGTGGCTTCGTAATATCTTTTA

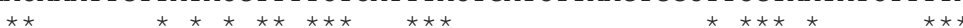

CCAAАTTTGGACCTATACAGTCACTATATTCTTTTTCCGCTCATTTTTGTTCTTTGAGTC CCAAATTTGACCTATACAGTCACTATATTCTTTTTCCGCTCATTTTTTTCTTTGAGTC

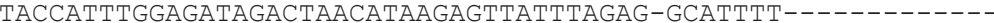
TACCATTTGGAGATAGACTAACATAAGAGTTATTTAGAG-GCATTTT------------

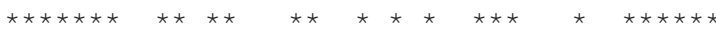

CAAAAGAACCA-------CATTTTGGTT--CCGGACTCGCTCCTCTATAATATAGTAAA CAAAAGAACCA-------CATTTTGGTT--CCGGACTCGCTCCTCTATAATATAGTAAA CAAAGAGACAAATTTAGACCATTTGGATTGATAGGATCAGAACTTAAATAATGGCTAAAA CAAAGAGACAAATTTAGACCATTTGGATTGATAGGATCAGAACTTAAATAATGGCTAAAA

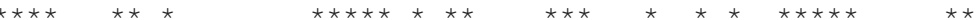

GTAAAATATATA----AAATTAATTATATATGCATATGCAAGAAATATTCAATATATAT GTAAAATATATA----AAATTAATTATTATATGCATATGCAAGAAATATTCAATATATAT G---AATATACAGTGCAAATAATCTAATTTTTTTATAACTAAAAAAAAC------TACAC G---AATATACAGTGCAAATAATCTAATTTTTTTATAACTAAAAAAAAC------TACAC

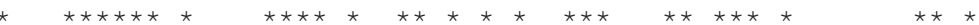

TCTATCTCATTTAAGCTTATCAATA-_-_-_-_-GTAGTTAGTATAAATATAAATTTAC TCTATCTCATTTAAGCTTATCAATA---------GTAGTTAGTATAAATATAAATTTAC TCAAACTTTTAGAACGGTATTATTGGGCCCGTGCTGCGGCTATCATAA--------CTAG TCAAACTTTTAGAACGGTATTATTGGGCCCGTGCTGCGGCTATCATAA-------CTAG

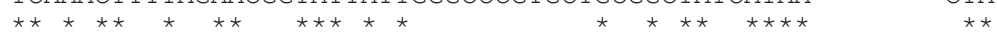

TAAAATAAATAAAAGGAAGACAACAATCTCAAGATTTGTTCTTCTGC-AAATAGAATCAG TAAAATAAATAAAAGGAAGACAACAATCTCAAGATTTGTTCTTCTGC-AAATAGAATCAG TAAAATAAATAAAAGGAAGACAACAATTTCAAGAATATTTTTTCTGCGAAATAGAATCAG TAAAATAAATAAAAGGAAGACAACAATTTCAAGAATATTTTTTCTGCGAAATAGAATCAG

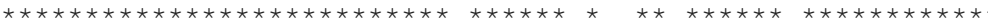

AGGTGCGAGTAAATGGGGAGCGATAAGAAGACGCCGGAGGAGAAGAGGAAGCATAAGAGA AGGTGCGAGTAAATGGGGAGCGATAAGAAGACGCCGGAGGAGAAGAGGAAGCATAAGAGA AGGTGCGAGTAAATGGGGAGCGATAAGAAGACGACGGAGGAGAAGAGGAAGCATAAGAGA AGGTGCGAGTAAATGGGGAGCGATAAGAAGACGACGGAGGAGAAGAGGAAGCATAAGAGA

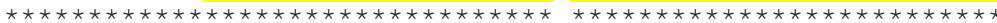
AGTTCGCCTTCTTCTCN------------------TATATATATATATATATATATATA AGTTCGCCTTCTTCTCCACGAGGTTTTTTCTTTCTTGTGTCTTCCAAAAGCTGCAAAGA AATTCGCCTTCTTCTCCACGAGGTTTTTTCCTTTCTTGTGTCTTCCAAAATCTGCAAAGA AATTCGCCTTCTTCTCCACGAGGTTTTTCCTTTCTTGTGTCTTCCAAAATCTGCAAAGA

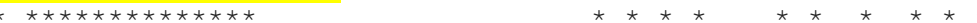

TAтAтAтAтAтAтAтAтAтAтAтAтAт-----------ATATATATGGGCTTATACGTG GATA-ATTTTTGAATATATATATATATANNNNNNNNNATATATATATGGGCTTATACGTG GATA-ATTTTTGA--------------------ATATATATGGGCTTATACGTC GATA-ATTTTTGA-----------------------ATATATATGGGCTTATACGTC

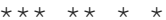

TTTGTGTCT-------AGATGAAGTGAAAAGCAAACGCCAGAATATCAAAGGGGATGAД TTTGTGTCT-------AGATGAAGTGAAAAGCAAACGCCAGAATATCAAAGGGGATGAA TTTGTGTCTGCTTAAACAGATGAAGTGAAAAGCAAACGCCAGAATATCAAAGGGGATGAA TTTGTGTCTGCTTAAACAGATGAAGTGAAAAGCAAACGCCAGAATATCAAAGGGGATGAA $* * * * * * * * *$.

GAGCGAAGGAAAGAAAAGAAGGACAAATCCAAGAAGGAGAAGCACAAATCC-..-...-. GAGCGAAGGAAAGAAAAGAAGGACAAATCCAAGAAGGAGAAGCACAAATCC------GAGCGAAGGAAAGAA---AAGGACAAATCCAAGAAGGAGAAGCACAAATCCCATAAATCC GAGCGAAGGAAAGAA---AAGGACAAATCCAAGAAGGAGAAGCACAAATCCCATAAATCC

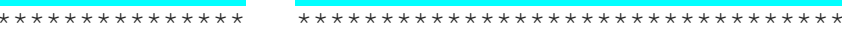

------CATTCTAGTGAAGGTACTTGCACAATTTTATTTTTATTTTAAATTTTGTATAT -----CATTCTAGTGAAGGTACTTGCACAATTTTTATTTTTATTTTAAATTTTGTATAT AAATGTCATTCTAGTGAAGGTACTTGCACAATTTTTGTTTTTGTTTTAAATTTTGTATAT AAATGTCATTCTAGTGAAGGTACTTGCACAATTTTTGTTTTTGTTTTAAATTTTGTATAT

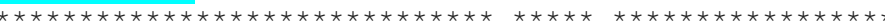
GAGTTCTGTTCAGTATTATTACAAAATAAGCTGAGAATTACTGATTTTATTATGAAAAT GAGTTCTGTTCAGTATTATTACAAAATAAGCTGAGAATTTACTGATTTTATTATGAAAAT GAGTTCTGTTCAGTAT---------TAAGCTGAGAATTTACTGATTTTATTATGAAAAT GAGTTCTGTTCAGTAT--------- TAAGCTGAGAATTTACTGATTTTATTATGAAAAT

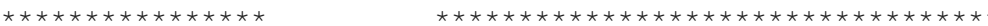


Ntabacum Nsylvestris Nsylvestris Ntabacum_Ntomentosiformis Ntomentosiformis

Ntabacum_Nsylvestris Nsylvestris

Ntabacum Ntomentosiformis Ntomentosiformis

Ntabacum Nsylvestris Nsylvestris

Ntabacum Ntomentosiformis Ntomentosiformis

Ntabacum Nsylvestris Nsylvestris

Ntabacum Ntomentosiformis Ntomentosiformis

Ntabacum Nsylvestris

Nsylvestris

Ntabacum_Ntomentosiformis Ntomentosiformis

Ntabacum Nsylvestris Nsylvestris Ntabacum Ntomentosiformis Ntomentosiformis

Ntabacum_Nsylvestris Nsylvestris

Ntabacum Ntomentosiformis Ntomentosiformis

Ntabacum_Nsylvestris Nsylvestris

Ntabacum Ntomentosiformis Ntomentosiformis

Ntabacum Nsylvestris

Nsylvestris

Ntabacum Ntomentosiformis

Ntomentosiformis

Ntabacum Nsylvestris Nsylvestris

Ntabacum Ntomentosiformis Ntomentosiformis

Ntabacum_Nsylvestris Nsylvestris

Ntabacum Ntomentosiformis Ntomentosiformis

Ntabacum Nsylvestris Nsylvestris

Ntabacum Ntomentosiformis Ntomentosiformis

TTAGGGATTTTGTTCTTTAATTGGGCCTCAGAAGGGTTCGTTTAGTTCCGTAAAACGTTT TTAGGGATTTTGTTCTTTAATTGGGCCTCAGAAGGGTTCGTTTAGTTCCGTAAAACGTTT TTAGGGATTTTGTTCTTTACTTGGGCCTCAGAAGGGTTCGTTTAGTTCCGTAAAACGTTT TTAGGGATTTTGTTCTTTACTTGGGCCTCAGAAGGGTTCGTTTAGTTCCGTAAAACGTTT

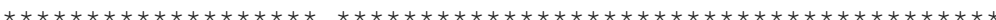

GCTATTTAGTATTTGATGTTGTTGCTGTTAGGGTTTGCTGCACTGATTAGTATAATGAGT GCTATTTAGTATTTGATGTTGTTGCTGTTAGGGTTTGCTGCACTGATTAGTATAATGAGT GCGATTTAGAATTTGATGTTGTTGCTGTTAGGGTTTGCTGCACTGATTAGTATAATGAGT GCGATTTAGAATTTGATGTTGTTGCTGTTAGGGTTTGCTGCACTGATTAGTATAATGAGT

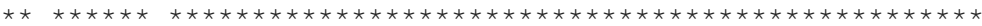

TTGAAAAGGGAAAGCAAGTATTATGCCGCTCAGCAATCCTTTTGCTTTGGTTTCCAATTC TTGAAAAGGGAAAGCAAGTATTATGCCGCTCAGCAATCCTTTTGCTTTGGTTTCCAATTC TTGAAAAGGGAAAGCAAGTATTATGCCGCTCAGCAATCCTTTTGCTTTGTTTTCCAATTC TTGAAAAGGGAAAGCAAGTATTATGCCGCTCAGCAATCCTTTTGCTTTGTTTTCCAATTC

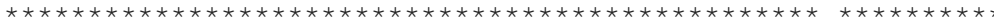

AATTGATAGTTACGTGTAGGTTATGTGATCTGCCATTTATTAAGCAACTAAACAATAAAT AATTGATAGTTACGTGTAGGTTATGTGATCTGCCATTTATTAAGCAACTAAACAATAAAT AATTGATAGTTATGTGTAGGTTATGTGATCTGCCATTTATTAAGCAACTAAACTATAAAT AATTGATAGTTATGTGTAGGTTATGTGATCTGCCATTTATTAAGCAACTAAACTATAAAT

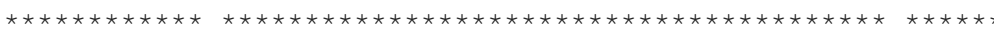

TAGGTCTGCACACAAACACATATAAAAAAGAAAAAGAAGAAAAATGATGGGTACGTATGT TAGGTCTGCACACAAACACATATAAAAAAGAAAAAGAAGAAAAATGATGGGTACGTATGT TAGGGCTGCACACAAACACATATAAAAAAGAAAAAGAAGAAAAATGATGGGTACGTATGT TAGGGCTGCACACAAACACATATAAAAAAGAAAAAGAAGAAAAATGATGGGTACGTATGT

GGAAATAGTTAGAACACCATTTACAACAACAACAACCCACTATAATCCCACTAGTGGGGT GGAAATAGTTAGAACACCATTTACAACAACAACAACCCACTATAATCCCACTAGTGGGGT

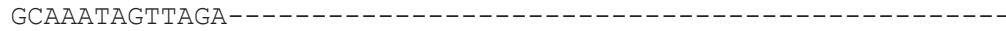
GCAAATAGTTAGA $\star \star \star * * \star \star * \star * * * *$

CTGGGGAGCGAAGTGTGTACGCAGACCTTACCCCTATTCTGGAGGTTGTTTCCGATAGAC CTGGGGAGCGAAGTGTGTACGCAGACCTTACCCCTATTCTGGAGGTTGTTTCCGATAGAC

CCTCGGCACAAGAAGATGACATGCGACAATAGAATGGTAACAACAACATAACCATAAAAA CCTCGGCACAAGAAGATGACATGCGACAATAGAATGGTAACAACAACATAACCATAAAAA

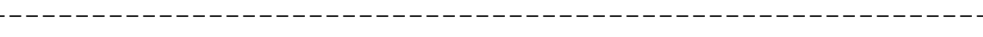

TAGTACCAGCGAGCCAAGTGTCAGAAAATATACCTGGAAAAGCAATATCAATAATGATGG TAGTACCAGCGAGCCAAGTGTCAGAAAATATACCTGGAAAAGCAATATCAATAATGATGG

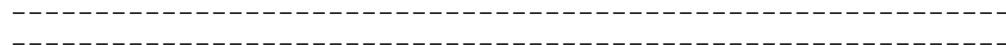

GTTAGTACACCATTTGCCTTTGGAAATGATGGGTGCTTGCTAGTGACTAAGCCTTCTTCT GTTAGTACACCATTTGCCTTTGGAAATGATGGGTGCTTGCTAGTGACTAAGCCTTCTTCT -----ACACCATTTGCCTTTGGAAATGATGGGTGCTTGCTAGTGGCTAAGCCTTCTTCT - - - - - ACACCATTTGCCTTTGGAAATGATGGGTGCTTGCTAGTGGCTAAGCCTTCTTCT

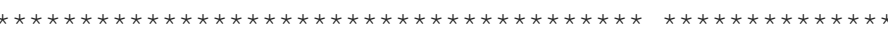

TTGAAATGGAGTTCTCTGTTCAGATCTTCCATTTACAATGGTGTTATTTACTGAACTCCA TTGAAATGGAGTTCTCTGTTCAGATCTTCCATTTACAATGGTGTTATTTACTGAACTCCA TTGAAATGGAGTTCTTTGTTCAGATCTTCCATTTACAATGGTGTTATTTACTGAACTCCA TTGAAATGGAGTTCTTTGTTCAGATCTTCCATTTACAATGGTGTTATTTACTGAACTCCA

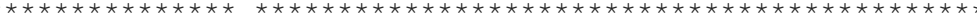

AGATCTTAGAGTGCAATCCATGTACGGATGCGAGTCAAAGCTAGGATATCTTATTCTAAT AGATCTTAGAGTGCAATCCATGTACGGATGCGAGTCAAAGCTAGGATATCTTATTCTAAT AGATCTTAGAGTGTAATCCATGTACAGATGTGAGTCAAAGCTAGGATATCTTATTCTAAT AGATCTTAGAGTGTAATCCATGTACAGATGTGAGTCAAAGCTAGGATATCTTATTCTAAT 
Ntabacum Nsylvestris Nsylvestris Ntabacum_Ntomentosiformis Ntomentosiformis

Ntabacum_Nsylvestris Nsylvestris

Ntabacum Ntomentosiformis Ntomentosiformis

Ntabacum_Nsylvestris Nsylvestris

Ntabacum_Ntomentosiformis Ntomentosiformis

Ntabacum Nsylvestris Nsylvestris

Ntabacum_Ntomentosiformis Ntomentosiformis

Ntabacum Nsylvestris Nsylvestris

Ntabacum Ntomentosiformis Ntomentosiformis

Ntabacum Nsylvestris Nsylvestris

Ntabacum Ntomentosiformis Ntomentosiformis

Ntabacum_Nsylvestris Nsylvestris

Ntabacum_Ntomentosiformis Ntomentosiformis

Ntabacum Nsylvestris Nsylvestris

Ntabacum_Ntomentosiformis Ntomentosiformis

Ntabacum Nsylvestris Nsylvestris Ntabacum Ntomentosiformis Ntomentosiformis

Ntabacum_Nsylvestris Nsylvestris

Ntabacum Ntomentosiformis Ntomentosiformis

Ntabacum Nsylvestris Nsylvestris

Ntabacum Ntomentosiformis Ntomentos̄iformis

Ntabacum Nsylvestris Nsylvestris

Ntabacum Ntomentosiformis Ntomentosiformis

Ntabacum Nsylvestris Nsylvestris Ntabacum Ntomentosiformis Ntomentosiformis
AАTTGAAAAGGTCTTCG-----------ATTTTGTTCAAATAGAATTAGGGTTCCCTTG AATTGAAAAGGTCTTCG-----------ATTTTGTTCAAATAGAATTAGGGTTCCCTTG AACTGAAAAGGTCTTCGATTGCTGTGCACATTTTGTTCAAATAGAATTAGGGTTCCCTTG AACTGAAAAGGTCTTCGATTGCTGTGCACATTTTGTTCAAATAGAATTAGGGTTCCCTTG $* * * * * * * * * * * * *+20$

GGTTCTTTCAACTCTTTATATAGTGATGGAGTAACTAATAGTCTTAGAGATAGACTTGTG GGTTCTTTCAACTCTTTATATAGTGATGGAGTAACTAATAGTCTTAGAGATAGACTTGTG GGTTCTTTCAACTCTTTATATAGTGATGGAGTAACTAATAGTCTTAGAGATAGAGTTGTG GGTTCTTTCAACTCTTTATATAGTGATGGAGTAACTAATAGTCTTAGAGATAGAGTTGTG

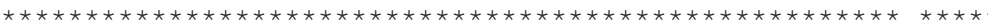

ACTTGTCAGTGATGATCTGTTAGATTTTAGGCAATCTTTTACAATCTAAACAAAGGATCA ACTTGTCAGTGATGATCTGTTAGATTTTAGGCAATCTTTTACAATCTAAACAAAGGATCA ACTTGTCAGTGATGATCTGTTAGATTT--GGCAATCTTTTACAATGAAAACAAAGGATCA ACTTGTCAGTGATGATCTGTTAGATTT--GGCAATCTTTTACAATGAAAACAAAGGATCA

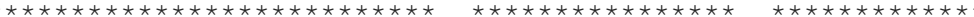

AAGGCTGGATTGCTGGTTCTACTTCATGTTACTAACCTTTGTTCTTGGTATTATTAGGTT AAGGCTGGATTGCTGGTTCTACTTCATGTTACTAACCTTTGTTCTTGGTATTATTAGGTT AAGACTGGATCGCTGGTTCTACTTCATGTTACTAACCTTTGTTCTTGATATTATTAGGTT AAGACTGGATCGCTGGTTCTACTTCATGTTACTAACCTTTGTTCTTGATATTATTAGGTT

TCACTCCATTATTTTGTGCGACTCATGGTGACATCTTGTTTGTAGCTTTATAGATT--_TCACTCCATTATTTTGTGCGACTCATGGTGACATCTTGTTTGTAGCTTTATAGATT--TCACTCCATTATTTTGTGTGACTCATGGTGACATCTTGTTGGTAGCTTTATAGATTTATA TCACTCCATTATTTTGTGTGACTCATGGTGACATCTTGTTGGTAGCTTTATAGATTTATA

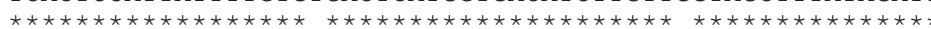

CCACTATTGTTTTTTTTTTTTGATGAACTGGGAATTTATTCATTAGAAATTACTCACTAC CCACTATTGTTTTTTTTTTTGATGAACTGGGAATTTATTCATTAGAAATTACTCACTAC

----------------------TAAACCACTATAGTTATGTTGTATGATTATTA ------------------------TAAACCACTATAGTTATGTTGTATGATTATTA TACAGTTTTGATCCTGTGGATCATTACATATACCACTATAGTTATTTTGTATGATTATTA TACAGTTTTGATCCTGTGATCATTACATATACCACTATAGTTATTTTGTATGATTATTA

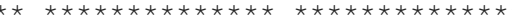

TAGCAAATGGTCGTTCTGATATTTTAAATAATGTATGTTTATACATAGGGAGATGTGTG TAGCAAATGGTCGTTTCTGATATTTTAAATAATGTATGTTTATACATAGGGAGATGTGTG TAGCAAGTGGTCGTTTCTGATATTTTAAATATTGTATGTTTATACATAGGGAGATGTGTG TAGCAAGTGGTCGTTTCTGATATTTTAAATATTGTATG-TTATACATAGGGAGATGTGTG

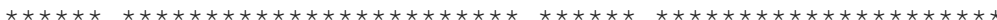

CACTTAGATTAAATGGTTTCCATGTATGTTACTGGTTTGGTGCTAGAAGATATGTTAGA CACTTAGATTAAATGGTTTCCATGTATGTTACTGGTTTGGTGCTAGAAGATATGTTAGAC CACTTAAATTAAATGGTTCCCCTGTATGTTACTGGTTTGGTGCTAGAAGTTATGTTAGAC CACTTAAATTAAATGGTTCCCTGTATGTTACTGGTTTGGTGCTAGAAGTTATGTTAGAC

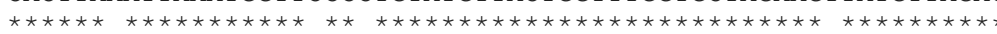
ACACTGACTCACTGATATTGCTTCA ACACTGACTCACTGATATTGCTTCA ACGCTGACTCACTGATATTGCTTCA ACGCTGACTCACTGATATTGCTTC

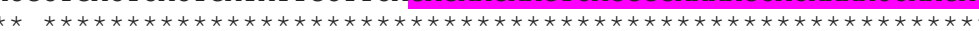

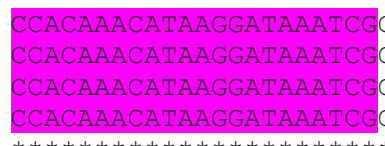

GTGAGTGCTTCTTGTTTAATACCTACATTTCTTTTGCT TTGATGCTTCTTGTTTAATACCTACATTTCTTTTGCT GTGAGTGCTTCTTGTTTAATACCTACATTTCTTTTGCT GTGAGTGCTTCTTGTTTAATACCTACATTTCTTTTGCT

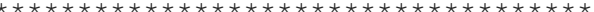

TCAAАATAACATTCTCAAGCTTACCATTTTACTCTGTATCATATCTCGTGGAAGG-AAAT TCAAAATAACATTCTCAAGCTTACCATTTTACTCTGTATCATATCTCGTGGAAGG-AAAT TCAAAATAACATTCTCAAGCTTATCATTTTACTCTGTATCATATCTCGTGGAAGGAAAAT TCAAAATAACATTCTCAAGCTTATCATTTTACTCTGTATCATATCTCGTGGAAGGAAAAT

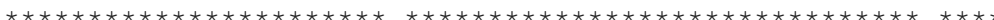

TGTTATCTGCTCGCATAGTTATTATCCTCCGCACTAATTTGTTGCTGTATGTAGGTAGCA TGTTATCTGCTCGCATAGTTATTATCCTCCGCACTAATTTGTTGCTGTATGTAGGTAGCA TGTTATCTGCTCGCGTAGTTATTATCCTTCGCACTAATTTGTTGCTGTATGTAGGTAGCA TGTTATCTGCTCGCGTAGTTATTATCCTTCGCACTAATTTGTTGCTGTATGTAGGTAGCA

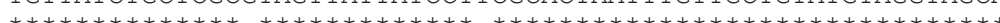


Ntabacum Nsylvestris Nsylvestris Ntabacum_Ntomentosiformis Ntomentosiformis

Ntabacum_Nsylvestris Nsylvestris

Ntabacum Ntomentosiformis Ntomentosiformis

Ntabacum_Nsylvestris Nsylvestris

Ntabacum Ntomentosiformis Ntomentosiformis

Ntabacum Nsylvestris Nsylvestris

Ntabacum_Ntomentosiformis Ntomentosiformis

Ntabacum Nsylvestris Nsylvestris

Ntabacum Ntomentosiformis Ntomentosiformis

Ntabacum Nsylvestris Nsylvestris

Ntabacum Ntomentosiformis Ntomentosiformis

Ntabacum_Nsylvestris Nsylvestris

Ntabacum_Ntomentosiformis Ntomentosiformis

Ntabacum Nsylvestris

Nsylvestris

Ntabacum Ntomentosiformis

Ntomentosiformis

Ntabacum Nsylvestris Nsylvestris

Ntabacum Ntomentosiformis Ntomentosiformis

Ntabacum_Nsylvestris Nsylvestris

Ntabacum Ntomentosiformis Ntomentosiformis

Ntabacum Nsylvestris Nsylvestris

Ntabacum Ntomentosiformis Ntomentosiformis

Ntabacum Nsylvestris Nsylvestris

Ntabacum Ntomentosiformis Ntomentosiformis

Ntabacum Nsylvestris Nsylvestris

Ntabacum Ntomentosiformis Ntomentosiformis
TTGGTTTAAGTTGGTGTTGAATCTGTTGAATATAATAGGTTGCTCGTCTTTTTCTGTTTT TTGGTTTAAGTTGGTGTTGAATCTGTTGAATATAATAGGTTGCTCGTCTTTTTCTGTTTT TTGGTTTAAGTTGGTGTTGAATCTGTTGAATATAATAGGTTGCTCGTCTTTTTCTGTTTT TTGGTTTAAGTTGGTGTTGAATCTGTTGAATATAATAGGTTGCTCGTCTTTTTCTGTTTT

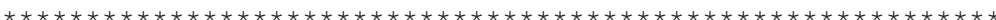

GGCTGGAACTGATAGTTAGATATAGCTTTCTTGTGGTATGACGTTTCAGTTATCTATGTT GGCTGGAACTGATAGTTAGATATAGCTTTCTTGTGGTATGACGTTTCAGTTATCTATGTT GGCTGGAACTGATAGTTAGATATAGCTTTCTTGTGGTATGACCTTTCAGCTATCTATGTT GGCTGGAACTGATAGTTAGATATAGCTTTCTTGTGGTATGACCTTTCAGCTATCTATGTT

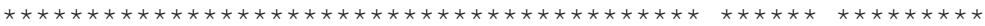

AATTCTTGTAGAGAGTCTTCATTACATATGTGGCTGGCTGATGCTTAGAAATAAGTCTGT AATTCTTGTAGAGAGTCTTCATTACATATGTGGCTGGCTGATGCTTAGAAATAAGTCTGT AATTCTTGTAGAGAGTCTTCATTACATATGTGGCTGGCTGATGCTTAGAAATAAGTCTGT AATTCTTGTAGAGAGTCTTCATTACATATGTGGCTGGCTGATGCTTAGAAATAAGTCTGT

AAACTTGGAAAAATACTGGAGTTCCATTTTCTTCAGTTGTGATATCTGAAATCTTGGTTG AAACTTGGAAAAATACTGGAGTTCCATTTTCTTCAGTTGTGATATCTGAAATCTTGGTTG AAACTTGGAAAAATACTGGAGTTCCATTTTCTTCAGTTGTGATATCTGAAATCTTGGTTG AAACTTGGAAAAATACTGGAGTTCCATTTTCTTCAGTTGTGATATCTGAAATCTTGGTTG

GACTATTGTCGTCTTGATTGCAGATATAAAATAGTATTTGTGAAGTAAACCAAGGTATTC GACTATTGTCGTCTTGATTGCAGATATAAAATAGTATTTGTGAAGTAAACCAAGGTATTC GACTATTGCTGTCTTGATTGCTGATATAAAA---TATTTGTGAAATAAACCAAGGTATTC GACTATTGCTGTCTTGATTGCTGATATAAAA---TATTTGTGAAATAAACCAAGGTATTC

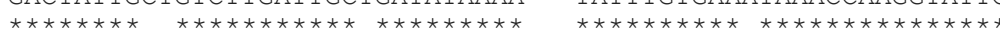

ATATATGGAGGAATCATTCTTTTGAAGAGAACCTGTCAGATTCAAGAAGGGCAATAATTT ATATATGGAGGAATCATTCTTTTGAAGAGAACCTGTCAGATTCAAGAAGGGCAATAATTT ATATATGGAGGAATCATTCTTTTGAAGAGAACCTGTCAGATTCAAAAAGGGCAATAATTT ATATATGGAGGAATCATTCTTTTGAAGAGAACCTGTCAGATTCAAAAAGGGCAATAATTT

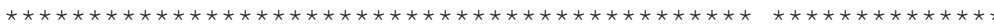

CTGTGTGGTGAATTGTTAATGGCGTCCACACTTTCAG

CTGTGTGGTGAATTGTTAATGGCGTCCACACTTTCAGTGTGTGGTGAATTGTTAATGGCGTCCACACTATCAGAGCTCTTTAATACTTGAAAAATT

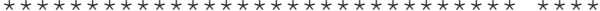

GTTAGACTGTAGCAGTAGCAGTAACTGTTTTCGCCTCTGTTCTTTCTCATGACTTCCTTT GTTAGACTGTAGCAGTAGCAGTAACTGTTTTCGCCTCTGTTCTTTCTCATGACTTCCTTT

------AGCTCTTTAATACTTGAAAAGTTGTTAGATTGTAGCAGTAGCAGTAACTGTT -------AGCTCTTTAATACTTGAAAAGTTGTTAGATTGTAGCAGTAGCAGTAACTGTT ATGAAAATAGCTCTTTAATACTTGAAAAATTGTTAGACTGTAGCAGTAGCAGTAACTGTT ATGAAAATAGCTCTTTAATACTTGAAAAATTGTTAGACTGTAGCAGTAGCAGTAACTGTT

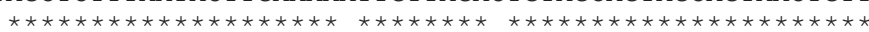

TTCTCCTCTGTTCTTTCTCACGACTTCCTTTATGAAAATAATTAGGACATCCATTTTCAC TTCTCCTCTGTTCTTTCTCACGACTTCCTTTATGAAAATAATTAGGACATCCATTTTCAC TTCGCCTCTGTTCTTTCTCATGACTTCCTTTATGAAAATAAGTAGGACATCCATTTTGAC TTCGCCTCTGTTCTTTCTCATGACTTCCTTTATGAAAATAAGTAGGACATCCATTTTGAC

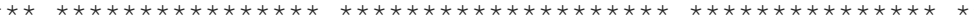

TCAGGCTTTATTCCTCCATCTTTGATTTTTAATTATATTGCTTTACCTTCTTTCTCAGA TCAGGCTTTATTCCTCCATCTTTGATTTTAATATATTGCTTTACCTTCTTTCTCAGA TCAGGCTTTATTCCTCCATCTTTGATTTTAATTATTTTCTTTACCTTCTTTCTCAGA TCAGGCTTTATTCCTCCATCTTTGATTTTAATTATTTGCTTTACCTTCTTTCTCAGA

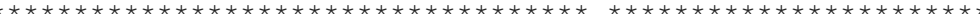

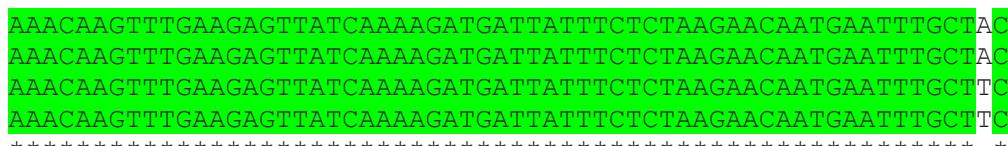
A 
Ntabacum Nsylvestris

Nsylvestris

Ntabacum Ntomentosiformis

Ntomentosiformis

Ntabacum Nsylvestris

Nsylvestris

Ntabacum Ntomentosiformis

Ntomentosiformis
TTTATTCTCTGACTTTGTCATACAATGGAACAAAGGAAAGCTTGACAGCCAATACTATGA

TTTATTCTCTGACTTTGTCATACAATGGAACAAAGGAAAGCTTGACAGCCAATACTATG

TTTATTCTCTGACTTTGTCATACAATGGAACAAGGGAAAGCTTGACAGCCAATACTATGA

TTTATTCTCTGACTTTGTCATACAATGGAACAAGGGAAAGCTTGACAGCCAATACTATGA

GGGAATTGCAACCGGGCCTCGGTCATCCCACGCTTGGAATATCAAAAAGTAATAGAATTC

GGGAATTGCAACCGGGCCTCGGTCATCCCACGCTTGGAATATCAAAAAGTAATAGAATTC

GGGAATTGCAACCGGGCCTCGGTCATCCCACGCTTGGAATATCAAAAAGTAATAGAATTC

GGGAATTGCAACCGGGCCTCGGTCATCCCACGCTTGGAATATCAAAAAGTAATAGAATTC 


\section{APÊNDICE D - ELEMENTOS CIS REGULATÓRIOS IDENTIFICADOS NO PROMOTOR DE NtSCI1 CÓPIA DE $N$. tomentosiformis}

A Tabela 12 apresenta os elementos cis regulatórios encontrados na putativa sequência promotora de NtSCI1 correspondente à cópia de N. tomentosiformis. Foram feitas buscas nos bancos de dados Place, Transfac, Jasper e Agris e nos modelos N. tabacum, Arabidopsis, soja, arroz, tomate, ervilha e aveia.

Tabela 12: Identificação dos elementos cis regulatórios encontrados na sequência promotora de $\boldsymbol{N} \boldsymbol{S} \boldsymbol{S C I 1}$ correspondente à cópia de $\boldsymbol{N}$. tomentosiformis. A tabela informa os elementos encontrados, a sua posição (lembrando que eles podem estar na fita + ou na - de DNA), sequência, o organismo no qual foi identificado, além do banco de dados que gerou esse resultado. A cor dos boxes dos respectivos elementos corresponde à cor utilizada para identificá-los na Figura 26. Em dois casos os boxes não foram preenchidos: 1) o elemento foi encontrado em mais de um banco de dados e já foi destacado; 2) elementos que não foram considerados relevantes para o estudo de $\mathrm{Y} 1 \mathrm{H}$. Box referente à posição de um elemento preenchido com amarelo: Esse elemento também foi encontrado no promotor de NtSCI1 cópia de N. sylvestris; Box referente à posição de um elemento preenchido com verde: Esse elemento não foi encontrado no promotor de NtSCI1 cópia de N. sylvestris.

\begin{tabular}{|c|c|c|c|c|}
\hline Elemento & Posição & Sequência & Organismo & Banco de dados \\
\hline ABRELATERD1 & 71 & ACGTG & Arabidopsis & PLACE \\
\hline$\underline{\text { ACGTATERD1 }}$ & 1126 & ACGT & Arabidopsis & PLACE \\
\hline$\overline{\text { ACGTATERD1 }}$ & 1189 & ACGT & Arabidopsis & PLACE \\
\hline$\overline{\text { ACGTATERD1 }}$ & 46 & ACGT & Arabidopsis & PLACE \\
\hline$\overline{\text { ACGTATERD1 }}$ & 46 & ACGT & Arabidopsis & PLACE \\
\hline$\overline{\text { ACGTATERD1 }}$ & 71 & ACGT & Arabidopsis & PLACE \\
\hline$\underline{\mathrm{AG}}$ & 689 & taaaCCAAAaaagaaaaa & Arabidopsis & TRANSFAC \\
\hline$\overline{\mathrm{AG}}$ & 1219 & tttataccaTTTGGagat & Arabidopsis & TRANSFAC \\
\hline$\overline{\mathrm{AG}}$ & 1281 & tttagaccaTTTGGattg & Arabidopsis & TRANSFAC \\
\hline Agamous & 1237 & CCATTTGGAGA & Arabidopsis & JASPER \\
\hline Agamous & 486 & CCATTTTAAGT & Arabidopsis & JASPER \\
\hline ANT & 930 & ttTCGGGtatcgct & Arabidopsis & TRANSFAC \\
\hline$\overline{\mathrm{AP1}}$ & 1376 & CTAAAAA & Arabidopsis & AGRIS \\
\hline$\overline{\mathrm{AP1}}$ & 705 & CCAAAAA & Arabidopsis & AGRIS \\
\hline$\overline{\mathrm{ARF}}$ & 1285 & GAGACA & Arabidopsis & AGRIS \\
\hline ARFAT & 1285 & GAGACA & Arabidopsis/Soybean/rice & PLACE \\
\hline$\overline{\text { ARR10 }}$ & 1203 & ACTGATCT & Arabidopsis & JASPER \\
\hline ARR10 & 1223 & TAATATCT & Arabidopsis & JASPER \\
\hline ARR10 & 1355 & AATAATCT & Arabidopsis & JASPER \\
\hline ARR10 & 280 & AGATAATT & Arabidopsis & JASPER \\
\hline ARR10 & 365 & TAAAATCT & Arabidopsis & JASPER \\
\hline ARR10 & 646 & AAAAATCT & Arabidopsis & JASPER \\
\hline ARR10 & 913 & AGATTTTTA & Arabidopsis & JASPER \\
\hline ARR1AT & 1060 & AATCT & Arabidopsis & PLACE \\
\hline ARR1AT & 109 & AATCA & Arabidopsis & PLACE \\
\hline$\overline{\text { ARR1AT }}$ & 1108 & GGATT & Arabidopsis & PLACE \\
\hline ARR1AT & 1305 & GGATT & Arabidopsis & PLACE \\
\hline ARR1AT & 1358 & AATCT & Arabidopsis & PLACE \\
\hline ARR1AT & 1498 & AATCA & Arabidopsis & PLACE \\
\hline ARR1AT & 181 & AATCA & Arabidopsis & PLACE \\
\hline ARR1AT & 223 & AATCA & Arabidopsis & PLACE \\
\hline ARR1AT & 241 & CGATT & Arabidopsis & PLACE \\
\hline ARR1AT & 335 & AATCA & Arabidopsis & PLACE \\
\hline ARR1AT & 368 & AATCT & Arabidopsis & PLACE \\
\hline ARR1AT & 380 & AATCA & Arabidopsis & PLACE \\
\hline ARR1AT & 534 & TGATT & Arabidopsis & PLACE \\
\hline
\end{tabular}


Tabela 12: Continuação

\begin{tabular}{|c|c|c|c|c|}
\hline Elemento & Posição & Sequência & Organismo & Banco de dados \\
\hline ARR1AT & 557 & TGATT & Arabidopsis & PLACE \\
\hline ARR1AT & 621 & AGATT & Arabidopsis & PLACE \\
\hline$\overline{\text { ARR1AT }}$ & 649 & АATCT & Arabidopsis & PLACE \\
\hline$\overline{\text { ARR1AT }}$ & 859 & TGATT & Arabidopsis & PLACE \\
\hline$\overline{\text { ARR1AT }}$ & 913 & AGATT & Arabidopsis & PLACE \\
\hline ARR1AT & 938 & TGATT & Arabidopsis & PLACE \\
\hline Athb-1 & 169 & aatcATAATttgag & Arabidopsis & TRANSFAC \\
\hline$\overline{\text { Athb-1 }}$ & 213 & tcactATTATtcta & Arabidopsis & TRANSFAC \\
\hline$\overline{\text { Athb-1 }}$ & 266 & ttagATAATttgat & Arabidopsis & TRANSFAC \\
\hline Athb-1 & 362 & ctttATAATcaatg & Arabidopsis & TRANSFAC \\
\hline Athb-1 & 424 & atacATAATaaacc & Arabidopsis & TRANSFAC \\
\hline Athb-1 & 453 & atgtATAATaagcc & Arabidopsis & TRANSFAC \\
\hline Athb-1 & 571 & ggaaATAATttttt & Arabidopsis & TRANSFAC \\
\hline Athb-1 & 638 & atctATAATatata & Arabidopsis & TRANSFAC \\
\hline$\overline{\text { Athb-1 }}$ & 738 & aagaATAATagtat & Arabidopsis & TRANSFAC \\
\hline Athb-1 & 859 & caaAATAATgagaa & Arabidopsis & TRANSFAC \\
\hline$\overline{\text { Athb-1 }}$ & 1052 & taacATAATaataa & Arabidopsis & TRANSFAC \\
\hline Athb-1 & 1055 & cataATAATaataa & Arabidopsis & TRANSFAC \\
\hline Athb-1 & 1058 & aataATAATaattt & Arabidopsis & TRANSFAC \\
\hline Athb-1 & 1061 & aataATAATttata & Arabidopsis & TRANSFAC \\
\hline Athb-1 & 1312 & ttaaATAATggcta & Arabidopsis & TRANSFAC \\
\hline Athb-1 & 1340 & gcaaATAATctaat & Arabidopsis & TRANSFAC \\
\hline$\overline{\text { Athb-1 }}$ & 1393 & acggtATTATtggg & Arabidopsis & TRANSFAC \\
\hline ATHB5 & 1327 & AATAATGGC & Arabidopsis & JASPER \\
\hline$\overline{\mathrm{ATHB}-5}$ & 34 & acgTTATTа & Arabidopsis & TRANSFAC \\
\hline ATHB-5 & 109 & attTTATTg & Arabidopsis & TRANSFAC \\
\hline$\overline{\mathrm{ATHB}-5}$ & 128 & gAATAAaaa & Arabidopsis & TRANSFAC \\
\hline ATHB-5 & 216 & ctaTTATTc & Arabidopsis & TRANSFAC \\
\hline$\overline{\overline{\text { ATHB-5}}}$ & 329 & cAATAAgat & Arabidopsis & TRANSFAC \\
\hline ATHB-5 & 429 & tAATAAacc & Arabidopsis & TRANSFAC \\
\hline$\overline{\text { ATHB-5 }}$ & 458 & tAATAAgcc & Arabidopsis & TRANSFAC \\
\hline ATHB-5 & 515 & ttcTTATTg & Arabidopsis & TRANSFAC \\
\hline ATHB-5 & 573 & aAATAAttt & Arabidopsis & TRANSFAC \\
\hline ATHB-5 & 711 & aAATAAaaa & Arabidopsis & TRANSFAC \\
\hline ATHB-5 & 740 & gAATAAtag & Arabidopsis & TRANSFAC \\
\hline ATHB-5 & 861 & aAATAAtga & Arabidopsis & TRANSFAC \\
\hline$\overline{\text { ATHB-5 }}$ & 903 & attTTATTg & Arabidopsis & TRANSFAC \\
\hline$\overline{\text { ATHB-5 }}$ & 975 & gAATAActa & Arabidopsis & TRANSFAC \\
\hline$\overline{\mathrm{ATHB}-5}$ & 1043 & aAATAAatc & Arabidopsis & TRANSFAC \\
\hline$\overline{\text { ATHB-5 }}$ & 1057 & tAATAAtaa & Arabidopsis & TRANSFAC \\
\hline ATHB-5 & 1060 & tAATAAtaa & Arabidopsis & TRANSFAC \\
\hline ATHB-5 & 1063 & tAATAAttt & Arabidopsis & TRANSFAC \\
\hline$\overline{\text { ATHB-5 }}$ & 1249 & gagTTATTt & Arabidopsis & TRANSFAC \\
\hline ATHB-5 & 1314 & aAATAAtgg & Arabidopsis & TRANSFAC \\
\hline$\overline{\text { ATHB-5 }}$ & 1342 & aAATAAtct & Arabidopsis & TRANSFAC \\
\hline$\overline{\text { ATHB-5 }}$ & 1396 & gtaTTATTg & Arabidopsis & TRANSFAC \\
\hline$\overline{\text { ATHB-5 }}$ & 1434 & aAATAAata & Arabidopsis & TRANSFAC \\
\hline$\overline{\text { ATHB-5 }}$ & 1438 & aAATAAaag & Arabidopsis & TRANSFAC \\
\hline ATHB-9 & 91 & agacttaATCATtgagcta & Arabidopsis & TRANSFAC \\
\hline$\overline{\text { ATHB-9 }}$ & 163 & attaagaATCATaatttga & Arabidopsis & TRANSFAC \\
\hline ATHB-9 & 317 & gaaactaATCATcaataag & Arabidopsis & TRANSFAC \\
\hline$\overline{\text { ATHB-9 }}$ & 839 & tgtttgaATGATtagctta & Arabidopsis & TRANSFAC \\
\hline ATHB-9 & 939 & tcgctcgATCATtttcatt & Arabidopsis & TRANSFAC \\
\hline$\overline{\text { ATHB-9 }}$ & 1414 & tgcggctATCATaactagt & Arabidopsis & TRANSFAC \\
\hline AtMYC2 & 778 & CATGTG & Arabidopsis & AGRIS \\
\hline Bellringer & 1042 & AAATTAGT & Arabidopsis & AGRIS \\
\hline Bellringer & 1360 & TCTAATTT & Arabidopsis & AGRIS \\
\hline BOXIINTPATPB & 1494 & ATAGAA & tobacco & PLACE \\
\hline BOXIINTPATPB & 401 & TTCTAT & tobacco & PLACE \\
\hline C8GCARGAT & 452 & CATATATATG & Arabidopsis & PLACE \\
\hline$\overline{\text { C8GCARGAT }}$ & 600 & CATTAATATG & Arabidopsis & PLACE \\
\hline$\overline{\text { C8GCARGAT }}$ & 871 & CAAAATAATG & Arabidopsis & PLACE \\
\hline CARGCW8GAT & 452 & CATATATATG & Arabidopsis & PLACE \\
\hline CARGCW8GAT & 600 & CATTAATATG & Arabidopsis & PLACE \\
\hline$\overline{\text { CARGCW8GAT }}$ & 871 & CAAAATAATG & Arabidopsis & PLACE \\
\hline CCA1 & 646 & AAAAATCT & Arabidopsis & AGRIS \\
\hline CCA1ATLHCB1 & 646 & AAAAATCT & Arabidopsis & PLACE \\
\hline
\end{tabular}


Tabela 12: Continuação

\begin{tabular}{|c|c|c|c|c|}
\hline Elemento & Posição & Sequência & Organismo & Banco de dados \\
\hline $\mathrm{CDC5}$ & 596 & tgtTCAGCtaa & Arabidopsis & TRANSFAC \\
\hline CIACADIANLELHC & 914 & GATTTTATTG & tomato & PLACE \\
\hline Core & 1025 & TAAT & Arabidopsis & AGRIS \\
\hline$\overline{\text { Core }}$ & 1044 & ATTA & Arabidopsis & AGRIS \\
\hline$\overline{\text { Core }}$ & 1069 & TAAT & Arabidopsis & AGRIS \\
\hline Core & 1072 & TAAT & Arabidopsis & AGRIS \\
\hline$\overline{\text { Core }}$ & 1075 & TAAT & Arabidopsis & AGRIS \\
\hline$\overline{\text { Core }}$ & 1078 & TAAT & Arabidopsis & AGRIS \\
\hline Core & 108 & TAAT & Arabidopsis & AGRIS \\
\hline Core & 1142 & ATTA & Arabidopsis & AGRIS \\
\hline Core & 1155 & TAAT & Arabidopsis & AGRIS \\
\hline Core & 1223 & TAAT & Arabidopsis & AGRIS \\
\hline Core & 1329 & TAAT & Arabidopsis & AGRIS \\
\hline Core & 1357 & TAAT & Arabidopsis & AGRIS \\
\hline$\overline{\text { Core }}$ & 1362 & TAAT & Arabidopsis & AGRIS \\
\hline Core & 1410 & ATTA & Arabidopsis & AGRIS \\
\hline Core & 175 & ATTA & Arabidopsis & AGRIS \\
\hline$\overline{\text { Core }}$ & 186 & TAAT & Arabidopsis & AGRIS \\
\hline Core & 222 & TAAT & Arabidopsis & AGRIS \\
\hline Core & 230 & ATTA & Arabidopsis & AGRIS \\
\hline Core & 243 & ATTA & Arabidopsis & AGRIS \\
\hline Core & 283 & TAAT & Arabidopsis & AGRIS \\
\hline$\overline{\text { Core }}$ & 334 & TAAT & Arabidopsis & AGRIS \\
\hline Core & 379 & TAAT & Arabidopsis & AGRIS \\
\hline Core & 40 & ATTA & Arabidopsis & AGRIS \\
\hline Core & 432 & TAAT & Arabidopsis & AGRIS \\
\hline Core & 441 & TAAT & Arabidopsis & AGRIS \\
\hline Core & 470 & TAAT & Arabidopsis & AGRIS \\
\hline Core & 51 & ATTA & Arabidopsis & AGRIS \\
\hline Core & 536 & ATTA & Arabidopsis & AGRIS \\
\hline$\overline{\text { Core }}$ & 588 & TAAT & Arabidopsis & AGRIS \\
\hline Core & 601 & ATTA & Arabidopsis & AGRIS \\
\hline Core & 603 & TAAT & Arabidopsis & AGRIS \\
\hline Core & 616 & TAAT & Arabidopsis & AGRIS \\
\hline Core & 655 & TAAT & Arabidopsis & AGRIS \\
\hline Core & 667 & TAAT & Arabidopsis & AGRIS \\
\hline Core & 669 & ATTA & Arabidopsis & AGRIS \\
\hline$\overline{\text { Core }}$ & 755 & TAAT & Arabidopsis & AGRIS \\
\hline$\overline{\text { Core }}$ & 820 & ATTA & Arabidopsis & AGRIS \\
\hline Core & 829 & TAAT & Arabidopsis & AGRIS \\
\hline Core & 861 & ATTA & Arabidopsis & AGRIS \\
\hline Core & 876 & TAAT & Arabidopsis & AGRIS \\
\hline Core & 994 & TAAT & Arabidopsis & AGRIS \\
\hline E2FCONSENSUS & 63 & CGGCGAAT & Arabidopsis/tobacco/rice & PLACE \\
\hline GAREAT & 1175 & TAACAAA & Arabidopsis & PLACE \\
\hline$\overline{\text { GAREAT }}$ & 291 & TAACAAA & Arabidopsis & PLACE \\
\hline GATABOX & 1052 & GATA & petunia/Arabidopsis/rice & PLACE \\
\hline GATABOX & 1226 & TATC & petunia/Arabidopsis/rice & PLACE \\
\hline GATABOX & 1246 & GATA & petunia/Arabidopsis/rice & PLACE \\
\hline GATABOX & 1310 & GATA & petunia/Arabidopsis/rice & PLACE \\
\hline GATABOX & 1432 & TATC & petunia/Arabidopsis/rice & PLACE \\
\hline GATABOX & 281 & GATA & petunia/Arabidopsis/rice & PLACE \\
\hline GATABOX & 289 & GATA & petunia/Arabidopsis/rice & PLACE \\
\hline$\overline{\text { GATABOX }}$ & 347 & GATA & petunia/Arabidopsis/rice & PLACE \\
\hline GATABOX & 404 & TATC & petunia/Arabidopsis/rice & PLACE \\
\hline GATABOX & 496 & TATC & petunia/Arabidopsis/rice & PLACE \\
\hline GATABOX & 501 & GATA & petunia/Arabidopsis/rice & PLACE \\
\hline GATABOX & 547 & TATC & petunia/Arabidopsis/rice & PLACE \\
\hline GATABOX & 699 & GATA & petunia/Arabidopsis/rice & PLACE \\
\hline GATABOX & 868 & TATC & petunia/Arabidopsis/rice & PLACE \\
\hline$\overline{\text { GATABOX }}$ & 896 & TATC & petunia/Arabidopsis/rice & PLACE \\
\hline GATABOX & 949 & TATC & petunia/Arabidopsis/rice & PLACE \\
\hline GATABOX & 95 & GATA & petunia/Arabidopsis/rice & PLACE \\
\hline GBF5 & 903 & ATGAGT & Arabidopsis & AGRIS \\
\hline GT1CONSENSUS & 1052 & GATAAA & pea/oat/rice/tobacco/Arabidopsis & PLACE \\
\hline GT1CONSENSUS & 1153 & GGTAAT & pea/oat/rice/tobacco/Arabidopsis & PLACE \\
\hline GT1CONSENSUS & 1276 & ATTTTC & pea/oat/rice/tobacco/Arabidopsis & PLACE \\
\hline
\end{tabular}


Tabela 12: Continuação

\begin{tabular}{|c|c|c|c|c|}
\hline Elemento & Posição & Sequência & Organismo & Banco de dados \\
\hline GT1CONSENSUS & 129 & GGAAAA & pea/oat/rice/tobacco/Arabidopsis & PLACE \\
\hline$\overline{\text { GT1CONSENSUS }}$ & 130 & GAAAAT & pea/oat/rice/tobacco/Arabidopsis & PLACE \\
\hline GT1CONSENSUS & 1482 & TTTTTC & pea/oat/rice/tobacco/Arabidopsis & PLACE \\
\hline$\overline{\text { GT1CONSENSUS }}$ & 150 & GAAAAT & pea/oat/rice/tobacco/Arabidopsis & PLACE \\
\hline GT1CONSENSUS & 268 & GAAAAT & pea/oat/rice/tobacco/Arabidopsis & PLACE \\
\hline$\overline{\text { GT1CONSENSUS }}$ & 281 & GATAAT & pea/oat/rice/tobacco/Arabidopsis & PLACE \\
\hline GT1CONSENSUS & 353 & GGTAAA & pea/oat/rice/tobacco/Arabidopsis & PLACE \\
\hline$\overline{\text { GT1CONSENSUS }}$ & 420 & GAAAAA & pea/oat/rice/tobacco/Arabidopsis & PLACE \\
\hline GT1CONSENSUS & 430 & GGTAAT & pea/oat/rice/tobacco/Arabidopsis & PLACE \\
\hline$\overline{\text { GT1CONSENSUS }}$ & 508 & TTTTTC & pea/oat/rice/tobacco/Arabidopsis & PLACE \\
\hline GT1CONSENSUS & 545 & TTTATC & pea/oat/rice/tobacco/Arabidopsis & PLACE \\
\hline$\overline{\text { GT1CONSENSUS }}$ & 583 & GGAAAT & pea/oat/rice/tobacco/Arabidopsis & PLACE \\
\hline GT1CONSENSUS & 680 & GAAAAA & pea/oat/rice/tobacco/Arabidopsis & PLACE \\
\hline GT1CONSENSUS & 699 & GATAAA & pea/oat/rice/tobacco/Arabidopsis & PLACE \\
\hline GT1CONSENSUS & 713 & GAAAAA & pea/oat/rice/tobacco/Arabidopsis & PLACE \\
\hline GT1CONSENSUS & 720 & GAAAAA & pea/oat/rice/tobacco/Arabidopsis & PLACE \\
\hline$\overline{\text { GT1CONSENSUS }}$ & 840 & ATTTTC & pea/oat/rice/tobacco/Arabidopsis & PLACE \\
\hline GT1CONSENSUS & 882 & GAAAAA & pea/oat/rice/tobacco/Arabidopsis & PLACE \\
\hline GT1CONSENSUS & 894 & TTTATC & pea/oat/rice/tobacco/Arabidopsis & PLACE \\
\hline GT1CONSENSUS & 927 & GGAAAA & pea/oat/rice/tobacco/Arabidopsis & PLACE \\
\hline GT1CONSENSUS & 928 & GAAAAT & pea/oat/rice/tobacco/Arabidopsis & PLACE \\
\hline GT1CONSENSUS & 940 & ATTTTC & pea/oat/rice/tobacco/Arabidopsis & PLACE \\
\hline GT1CONSENSUS & 961 & ATTTTC & pea/oat/rice/tobacco/Arabidopsis & PLACE \\
\hline GT1CONSENSUS & 967 & ATTTTC & pea/oat/rice/tobacco/Arabidopsis & PLACE \\
\hline IBOX & 866 & CTTATC & tomato/Arabidopsis & PLACE \\
\hline INRNTPSADB & 1018 & TTСАСТTT & tobacco & PLACE \\
\hline INRNTPSADB & 303 & AAATTGAG & tobacco & PLACE \\
\hline INRNTPSADB & 415 & GAATTGAA & tobacco & PLACE \\
\hline INRNTPSADB & 571 & СТСАТTTT & tobacco & PLACE \\
\hline INRNTPSADB & 715 & AAAATGAA & tobacco & PLACE \\
\hline$\overline{\text { INRNTPSADB }}$ & 964 & TTCATTTT & tobacco & PLACE \\
\hline INRNTPSADB & 980 & GAATTGAG & tobacco & PLACE \\
\hline LECPLEACS2 & 770 & ATATTTTA & tomato & PLACE \\
\hline MYB1AT & 247 & AAACCA & Arabidopsis & PLACE \\
\hline MYB1AT & 445 & AAACCA & Arabidopsis & PLACE \\
\hline MYB1AT & 702 & AAACCA & Arabidopsis & PLACE \\
\hline$\overline{\mathrm{MYB} 1 \mathrm{AT}}$ & 835 & TAACCA & Arabidopsis & PLACE \\
\hline MYB2CONSENSUSAT & 553 & CCGTTG & Arabidopsis & PLACE \\
\hline MYBCORE & 553 & CCGTTG & Arabidopsis/petunia & PLACE \\
\hline MYBCOREATCYCB1 & 1404 & AACGG & Arabidopsis & PLACE \\
\hline MYBCOREATCYCB1 & 553 & CCGTT & Arabidopsis & PLACE \\
\hline MYBST1 & 1051 & GGATA & potato & PLACE \\
\hline$\overline{\text { MYBST1 }}$ & 500 & GGATA & potato & PLACE \\
\hline MYCATERD1 & 778 & CATGTG & Arabidopsis & PLACE \\
\hline MYCCONSENSUSAT & 1238 & CATTTG & Arabidopsis & PLACE \\
\hline MYCCONSENSUSAT & 1238 & CATTTG & Arabidopsis & PLACE \\
\hline MYCCONSENSUSAT & 1300 & CATTTG & Arabidopsis & PLACE \\
\hline MYCCONSENSUSAT & 409 & CAAGTG & Arabidopsis & PLACE \\
\hline MYCCONSENSUSAT & 513 & CAATTG & Arabidopsis & PLACE \\
\hline MYCCONSENSUSAT & 778 & CATGTG & Arabidopsis & PLACE \\
\hline P1BS & 1341 & GAATATAC & Arabidopsis/tomato/Medicago/barley & PLACE \\
\hline$\overline{\mathrm{PIF3}}$ & 52 & ggcgaatACGTGccagca & Arabidopsis & TRANSFAC \\
\hline POLASIG1 & 1056 & AATAAA & pea/rice/Arabidopsis & PLACE \\
\hline POLASIG1 & 123 & TTTATT & pea/rice/Arabidopsis & PLACE \\
\hline POLASIG1 & 141 & AATAAA & pea/rice/Arabidopsis & PLACE \\
\hline POLASIG1 & 1447 & AATAAA & pea/rice/Arabidopsis & PLACE \\
\hline POLASIG1 & 1451 & AATAAA & pea/rice/Arabidopsis & PLACE \\
\hline POLASIG1 & 442 & AATAAA & pea/rice/Arabidopsis & PLACE \\
\hline POLASIG1 & 724 & AATAAA & pea/rice/Arabidopsis & PLACE \\
\hline POLASIG1 & 917 & TTTATT & pea/rice/Arabidopsis & PLACE \\
\hline POLLEN1LELAT52 & 1193 & TTTCT & tomato & PLACE \\
\hline $\begin{array}{l}\text { POLLEN1LELAT52 } \\
\end{array}$ & 1484 & TTTCT & tomato & PLACE \\
\hline POLLEN1LELAT52 & 149 & AGAAA & tomato & PLACE \\
\hline POLLEN1LELAT52 & 309 & AGAAA & tomato & PLACE \\
\hline$\overline{\text { POLLEN1LELAT52 }}$ & 400 & TTTCT & tomato & PLACE \\
\hline$\overline{\text { POLLEN1LELAT52 }}$ & 560 & TTTCT & tomato & PLACE \\
\hline
\end{tabular}


Tabela 12: Conclusão

\begin{tabular}{|c|c|c|c|c|}
\hline Elemento & Posição & Sequência & Organismo & Banco de dados \\
\hline POLLEN1LELAT52 & 712 & AGAAA & tomato & PLACE \\
\hline POLLEN1LELAT52 & 881 & AGAAA & tomato & PLACE \\
\hline POLLEN1LELAT52 & 887 & AGAAA & tomato & PLACE \\
\hline POLLEN1LELAT52 & 969 & TTTCT & tomato & PLACE \\
\hline PREATPRODH & 903 & ATGAGT & Arabidopsis & PLACE \\
\hline RAV1 & 434 & aacCAACAtata & Arabidopsis & TRANSFAC \\
\hline RAV1 & 1122 & ataCAACAatta & Arabidopsis & TRANSFAC \\
\hline RAV1 & 1449 & agaCAACAattt & Arabidopsis & TRANSFAC \\
\hline RAV1-A & 1137 & CAACA & Arabidopsis & AGRIS \\
\hline RAV1-A & 1464 & CAACA & Arabidopsis & AGRIS \\
\hline RAV1-A & 449 & CAACA & Arabidopsis & AGRIS \\
\hline RAV1AAT & 1137 & CAACA & Arabidopsis & PLACE \\
\hline RAV1AAT & 1464 & CAACA & Arabidopsis & PLACE \\
\hline RAV1AAT & 449 & CAACA & Arabidopsis & PLACE \\
\hline$\overline{\mathrm{RBCSCONSENSUS}}$ & 1303 & TTGGATT & tomato/petunia/tobacco/pea & PLACE \\
\hline RHERPATEXPA7 & 71 & ACGTGC & Arabidopsis & PLACE \\
\hline SEBFCONSSTPR10A & 1285 & GAGACAA & potato & PLACE \\
\hline SITEIIATCYTC & 1415 & TGGGCC & Arabidopsis/rice & PLACE \\
\hline SORLIP1AT & 1214 & GTGGC & Arabidopsis & PLACE \\
\hline SORLIP2AT & 1416 & GGGCC & Arabidopsis & PLACE \\
\hline SORLIP2AT & 1417 & GGCCC & Arabidopsis & PLACE \\
\hline SORLIP2AT & 567 & GGGCC & Arabidopsis & PLACE \\
\hline SREATMSD & 1051 & GGATAA & Arabidopsis & PLACE \\
\hline SURECOREATSULTR11 & 1031 & GAGAC & Arabidopsis & PLACE \\
\hline SURECOREATSULTR11 & 1285 & GAGAC & Arabidopsis & PLACE \\
\hline SURECOREATSULTR11 & 212 & GTCTC & Arabidopsis & PLACE \\
\hline TAAAGSTKST1 & 1022 & CTTTA & potato & PLACE \\
\hline TAAAGSTKST1 & 374 & CTTTA & potato & PLACE \\
\hline$\overline{\text { TAAAGSTKST1 }}$ & 740 & CTTTA & potato & PLACE \\
\hline$\overline{\text { TAAAGSTKST1 }}$ & 893 & CTTTA & potato & PLACE \\
\hline TATABOX2 & 1080 & ATTTATA & pea/tobacco/bean & PLACE \\
\hline$\overline{\text { TATABOX2 }}$ & 360 & ATTTATA & pea/tobacco/bean & PLACE \\
\hline TBOXATGAPB & 1095 & CAAAGT & Arabidopsis & PLACE \\
\hline$\overline{\text { TBOXATGAPB }}$ & 294 & CAAAGT & Arabidopsis & PLACE \\
\hline TEIL & 38 & tatTACAT & Tobacco & TRANSFAC \\
\hline$\overline{\text { TEIL }}$ & 422 & ataTACAT & Tobacco & TRANSFAC \\
\hline TEIL & 453 & ATGTAtaa & Tobacco & TRANSFAC \\
\hline TEIL & 583 & ttaTACAT & Tobacco & TRANSFAC \\
\hline UP1ATMSD & 1412 & TATTGGGCC & Arabidopsis & PLACE \\
\hline WBOXNTERF3 & 1100 & TGACT & tobacco & PLACE \\
\hline WBOXNTERF3 & 1171 & TGACT & tobacco & PLACE \\
\hline
\end{tabular}




\section{APÊNDICE E - ELEMENTOS CIS REGULATÓRIOS IDENTIFICADOS NO PROMOTOR DE NtSCI1 CÓPIA DE N. sylvestris}

A Tabela 13 apresenta os elementos cis regulatórios encontrados na putativa sequência promotora de NtSCI1 correspondente à cópia de N. sylvestris. Foram feitas buscas nos bancos de dados Place, Transfac, Jasper e Agris e nos modelos N. tabacum, Arabidopsis, soja, arroz, tomate, ervilha e aveia.

Tabela 13: Identificação dos elementos cis regulatórios encontrados na sequência promotora de $\boldsymbol{N} \boldsymbol{t} \boldsymbol{S C I} 1$ correspondente à cópia de $\boldsymbol{N}$. sylvestris. A tabela informa os elementos encontrados, a sua posição (lembrando que eles podem estar na fita + ou na - de DNA), sequência, o organismo no qual foi identificado, além do banco de dados que gerou esse resultado. A cor dos boxes dos respectivos elementos corresponde à cor utilizada para identificá-los na Figura 26. Em dois casos os boxes não foram preenchidos: 1) o elemento foi encontrado em mais de um banco de dados e já foi destacado; 2) elementos que não foram considerados relevantes para o estudo de $\mathrm{Y} 1 \mathrm{H}$. Box referente à posição de um elemento preenchido com amarelo: Esse elemento também foi encontrado no promotor de NtSCI1 cópia de N. tomentosiformis; Box referente à posição de um elemento preenchido com verde: Esse elemento não foi encontrado no promotor de NtSCI1 cópia de N. tomentosiformis.

\begin{tabular}{|c|c|c|c|c|}
\hline Elemento & Posição & Sequência & Organismo & Banco de dados \\
\hline AGL3 & 885 & caaaatgtgTATGGgatc & Arabidopsis & TRANSFAC \\
\hline$\underline{A G L 3}$ & 902 & cttgagattTATGGatca & Arabidopsis & TRANSFAC \\
\hline$\underline{\mathrm{AG}}$ & 3 & ggtagtaacTTTGGggcg & Arabidopsis & TRANSFAC \\
\hline$\underline{A G}$ & 381 & ggcatagtgTTTGGtgtc & Arabidopsis & TRANSFAC \\
\hline$\underline{\mathrm{AG}}$ & 588 & ggcgCCAAAttgtttgag & Arabidopsis & TRANSFAC \\
\hline$\underline{\mathrm{AG}}$ & 1069 & ttccCCAAAaatcctaaa & Arabidopsis & TRANSFAC \\
\hline$\underline{\mathrm{AG}}$ & 1210 & gttaCCAAAtttggacct & Arabidopsis & TRANSFAC \\
\hline$\underline{\mathrm{AG}}$ & 1269 & gagtCCAAAagaaccaca & Arabidopsis & TRANSFAC \\
\hline$\underline{\mathrm{AG}}$ & 1211 & TTACCAAATTTGGA & Arabidopsis & AGRIS \\
\hline Agamous & 1213 & ACCAAATTTGG & Arabidopsis & JASPER \\
\hline Agamous & 1214 & CCAAATTTGGA & Arabidopsis & JASPER \\
\hline ANAERO1CONSENSUS & 74 & TTTGTTT & maize/Arabidopsis/pea/barley/rice & PLACE \\
\hline ANAERO2CONSENSUS & 106 & GCTGCT & maize/Arabidopsis/pea/barley/rice & PLACE \\
\hline ANAERO2CONSENSUS & 167 & GCTGCT & maize/Arabidopsis/pea/barley/rice & PLACE \\
\hline ANAERO4CONSENSUS & 613 & TTGCTAAAC & maize/Arabidopsis/pea/barley/rice & PLACE \\
\hline AP1 & 1073 & CCAAAAA & Arabidopsis & AGRIS \\
\hline AP1 & 568 & CTAAAAA & Arabidopsis & AGRIS \\
\hline $\mathrm{AP1}$ & 95 & TTTTTAG & Arabidopsis & AGRIS \\
\hline ARR10 & 1461 & AGATTTGT & Arabidopsis & JASPER \\
\hline$\underline{\mathrm{ARR} 10}$ & 540 & TATGATCT & Arabidopsis & JASPER \\
\hline ARR1AT & 1078 & AATCC & Arabidopsis & PLACE \\
\hline$\overline{\text { ARR1AT }}$ & 1454 & AATCT & Arabidopsis & PLACE \\
\hline ARR1AT & 1461 & AGATT & Arabidopsis & PLACE \\
\hline ARR1AT & 1483 & AATCA & Arabidopsis & PLACE \\
\hline ARR1AT & 648 & AATCC & Arabidopsis & PLACE \\
\hline$\overline{\text { ARR1AT }}$ & 700 & CGATT & Arabidopsis & PLACE \\
\hline$\underline{\text { ARR1AT }}$ & 743 & TGATT & Arabidopsis & PLACE \\
\hline ARR1AT & 797 & GGATT & Arabidopsis & PLACE \\
\hline$\overline{\mathrm{ARR} 1 \mathrm{AT}}$ & 828 & TGATT & Arabidopsis & PLACE \\
\hline$\underline{\text { ARR1AT }}$ & 836 & TGATT & Arabidopsis & PLACE \\
\hline ARR1AT & 906 & AGATT & Arabidopsis & PLACE \\
\hline ASF1MOTIFCAMV & 454 & TGACG & tobacco/Arabidopsis & PLACE \\
\hline ASF1MOTIFCAMV & 858 & TGACG & tobacco/Arabidopsis & PLACE \\
\hline Athb-1 & 237 & gagtATAATgttta & Arabidopsis & TRANSFAC \\
\hline$\overline{\text { Athb-1 }}$ & 605 & gcaaATAATtgcta & Arabidopsis & TRANSFAC \\
\hline Athb-1 & 624 & attaATAATaaatt & Arabidopsis & TRANSFAC \\
\hline Athb-1 & 745 & attgATAATacatg & Arabidopsis & TRANSFAC \\
\hline Athb-1 & 770 & atgtATAATaaatg & Arabidopsis & TRANSFAC \\
\hline
\end{tabular}


Tabela 13: Continuação

\begin{tabular}{|c|c|c|c|c|}
\hline Elemento & Posição & Sequência & Organismo & Banco de dados \\
\hline Athb-1 & 794 & caaggATTATaacg & Arabidopsis & TRANSFAC \\
\hline$\overline{\text { Athb-1 }}$ & 825 & taatgATTATatga & Arabidopsis & TRANSFAC \\
\hline Athb-1 & 1307 & ctctATAATatagt & Arabidopsis & TRANSFAC \\
\hline$\overline{\text { Athb-1 }}$ & 1337 & aattaATTATtata & Arabidopsis & TRANSFAC \\
\hline Athb-1 & 1340 & taattATTATatgc & Arabidopsis & TRANSFAC \\
\hline$\overline{\text { Athb-1 }}$ & 608 & AATAATTG & Arabidopsis & JASPER \\
\hline ATHB5 & 608 & AATAATTGC & Arabidopsis & JASPER \\
\hline$\overline{\mathrm{ATHB}-5}$ & 607 & aAATAAttg & Arabidopsis & TRANSFAC \\
\hline ATHB-5 & 626 & tAATAAtaa & Arabidopsis & TRANSFAC \\
\hline ATHB-5 & 629 & tAATAAatt & Arabidopsis & TRANSFAC \\
\hline ATHB-5 & 660 & tAATAAatt & Arabidopsis & TRANSFAC \\
\hline$\overline{\text { ATHB-5 }}$ & 676 & gAATAAaat & Arabidopsis & TRANSFAC \\
\hline ATHB-5 & 681 & aAATAAagc & Arabidopsis & TRANSFAC \\
\hline ATHB-5 & 775 & tAATAAatg & Arabidopsis & TRANSFAC \\
\hline$\overline{\mathrm{ATHB}-5}$ & 940 & gAATAAatg & Arabidopsis & TRANSFAC \\
\hline$\overline{\text { ATHB-5 }}$ & 948 & gAATAAgac & Arabidopsis & TRANSFAC \\
\hline$\overline{\mathrm{ATHB}-5}$ & 1340 & taaTTATTa & Arabidopsis & TRANSFAC \\
\hline ATHB-5 & 1432 & aAATAAata & Arabidopsis & TRANSFAC \\
\hline ATHB-5 & 1436 & aAATAAaag & Arabidopsis & TRANSFAC \\
\hline$\overline{\text { ATHB-9 }}$ & 110 & ctagcgcATCATtacctgc & Arabidopsis & TRANSFAC \\
\hline ATHB-9 & 180 & ggttgttATGATatctgct & Arabidopsis & TRANSFAC \\
\hline ATHB-9 & 534 & tttttttATGATctagaaa & Arabidopsis & TRANSFAC \\
\hline$\overline{\text { ATHB-9 }}$ & 735 & atgtgctATGATtgataat & Arabidopsis & TRANSFAC \\
\hline ATHB-9 & 820 & tcacctaATGATtatatga & Arabidopsis & TRANSFAC \\
\hline ATHB-9 & 828 & tgattatATGATtggaatg & Arabidopsis & TRANSFAC \\
\hline AtMYC2 & 931 & CATGTG & Arabidopsis & AGRIS \\
\hline Bellringer & 1336 & AAATTAAT & Arabidopsis & AGRIS \\
\hline Bellringer & 633 & AAATTAGA & Arabidopsis & AGRIS \\
\hline$\overline{\text { BOXIINTPATPB }}$ & 1379 & TTCTAT & tobacco & PLACE \\
\hline BOXIINTPATPB & 1479 & ATAGAA & tobacco & PLACE \\
\hline C8GCARGAT & 606 & CAAATAATTG & Arabidopsis & PLACE \\
\hline C8GCARGAT & 92 & CATTTTTTAG & Arabidopsis & PLACE \\
\hline CARGATCONSENSUS & 1214 & CCAAATTTGG & Arabidopsis & PLACE \\
\hline CARGCW8GAT & 606 & CAAATAATTG & Arabidopsis & PLACE \\
\hline CARGCW8GAT & 92 & CATTTTTTAG & Arabidopsis & PLACE \\
\hline CCA1 & 1451 & AACAATCT & Arabidopsis & AGRIS \\
\hline$\overline{\mathrm{CDC5}}$ & 257 & $\operatorname{ttgTCAGCcac}$ & Arabidopsis & TRANSFAC \\
\hline$\overline{\mathrm{CDC5}}$ & 301 & tctTCAGCtgt & Arabidopsis & TRANSFAC \\
\hline CGCGBOXAT & 200 & GCGCGG & Arabidopsis & PLACE \\
\hline Core & 120 & ATTA & Arabidopsis & AGRIS \\
\hline Core & 1312 & TAAT & Arabidopsis & AGRIS \\
\hline Core & 1338 & ATTA & Arabidopsis & AGRIS \\
\hline Core & 1340 & TAAT & Arabidopsis & AGRIS \\
\hline Core & 1342 & ATTA & Arabidopsis & AGRIS \\
\hline Core & 1345 & ATTA & Arabidopsis & AGRIS \\
\hline$\overline{\text { Core }}$ & 242 & TAAT & Arabidopsis & AGRIS \\
\hline Core & 276 & TAAT & Arabidopsis & AGRIS \\
\hline Core & 430 & TAAT & Arabidopsis & AGRIS \\
\hline Core & 610 & TAAT & Arabidopsis & AGRIS \\
\hline Core & 624 & ATTA & Arabidopsis & AGRIS \\
\hline Core & 626 & TAAT & Arabidopsis & AGRIS \\
\hline Core & 629 & TAAT & Arabidopsis & AGRIS \\
\hline Core & 635 & ATTA & Arabidopsis & AGRIS \\
\hline$\overline{\text { Core }}$ & 660 & TAAT & Arabidopsis & AGRIS \\
\hline Core & 702 & ATTA & Arabidopsis & AGRIS \\
\hline$\overline{\text { Core }}$ & 718 & ATTA & Arabidopsis & AGRIS \\
\hline Core & 733 & TAAT & Arabidopsis & AGRIS \\
\hline Core & 750 & TAAT & Arabidopsis & AGRIS \\
\hline Core & 775 & TAAT & Arabidopsis & AGRIS \\
\hline Core & 788 & TAAT & Arabidopsis & AGRIS \\
\hline$\overline{\text { Core }}$ & 799 & ATTA & Arabidopsis & AGRIS \\
\hline$\overline{\text { Core }}$ & 825 & TAAT & Arabidopsis & AGRIS \\
\hline Core & 830 & ATTA & Arabidopsis & AGRIS \\
\hline E2FCONSENSUS & 16 & GGGCGAAT & Arabidopsis/tobacco/rice & PLACE \\
\hline E2FCONSENSUS & 589 & GCGCCAAA & Arabidopsis/tobacco/rice & PLACE \\
\hline ELRECOREPCRP1 & 882 & GGTCAA & parsley/tobacco & PLACE \\
\hline GATABOX & 1044 & TATC & petunia/Arabidopsis/rice & PLACE \\
\hline
\end{tabular}


Tabela 13: Continuação

\begin{tabular}{|c|c|c|c|c|}
\hline Elemento & Posição & Sequência & Organismo & Banco de dados \\
\hline GATABOX & 1104 & TATC & petunia/Arabidopsis/rice & PLACE \\
\hline GATABOX & 1165 & TATC & petunia/Arabidopsis/rice & PLACE \\
\hline GATABOX & 1196 & TATC & petunia/Arabidopsis/rice & PLACE \\
\hline$\overline{\text { GATABOX }}$ & 1382 & TATC & petunia/Arabidopsis/rice & PLACE \\
\hline GATABOX & 1397 & TATC & petunia/Arabidopsis/rice & PLACE \\
\hline GATABOX & 189 & GATA & petunia/Arabidopsis/rice & PLACE \\
\hline$\overline{\text { GATABOX }}$ & 191 & TATC & petunia/Arabidopsis/rice & PLACE \\
\hline$\overline{\text { GATABOX }}$ & 25 & TATC & petunia/Arabidopsis/rice & PLACE \\
\hline GATABOX & 748 & GATA & petunia/Arabidopsis/rice & PLACE \\
\hline GATABOX & 818 & TATC & petunia/Arabidopsis/rice & PLACE \\
\hline$\overline{\text { GT1CONSENSUS }}$ & 1008 & GAAAAA & pea/oat/rice/tobacco/Arabidopsis & PLACE \\
\hline GT1CONSENSUS & 120 & ATTACC & pea/oat/rice/tobacco/Arabidopsis & PLACE \\
\hline GT1CONSENSUS & 1245 & TTTTTC & pea/oat/rice/tobacco/Arabidopsis & PLACE \\
\hline$\overline{\text { GT1CONSENSUS }}$ & 1246 & TTTTCC & pea/oat/rice/tobacco/Arabidopsis & PLACE \\
\hline$\overline{\text { GT1CONSENSUS }}$ & 23 & TTTATC & pea/oat/rice/tobacco/Arabidopsis & PLACE \\
\hline GT1CONSENSUS & 280 & TTTTTC & pea/oat/rice/tobacco/Arabidopsis & PLACE \\
\hline GT1CONSENSUS & 401 & ATTTTC & pea/oat/rice/tobacco/Arabidopsis & PLACE \\
\hline GT1CONSENSUS & 488 & TTTTCC & pea/oat/rice/tobacco/Arabidopsis & PLACE \\
\hline$\overline{\text { GT1CONSENSUS }}$ & 748 & GATAAT & pea/oat/rice/tobacco/Arabidopsis & PLACE \\
\hline GT1CONSENSUS & 78 & TTTTCC & pea/oat/rice/tobacco/Arabidopsis & PLACE \\
\hline GT1CONSENSUS & 870 & GGAAAA & pea/oat/rice/tobacco/Arabidopsis & PLACE \\
\hline HDZIP2ATATHB2 & 1340 & TAATTATTA & Arabidopsis & PLACE \\
\hline HDZIP2ATATHB2 & 825 & TAATGATTA & Arabidopsis & PLACE \\
\hline IBOX & 1194 & CTTATC & tomato/Arabidopsis & PLACE \\
\hline $\mathrm{IBOX}$ & 1395 & CTTATC & tomato/Arabidopsis & PLACE \\
\hline INRNTPSADB & 1253 & СТСАТTTT & tobacco & PLACE \\
\hline INRNTPSADB & 471 & TTCAGTCT & tobacco & PLACE \\
\hline L1BOXATPDF1 & 767 & TAAATGTA & Arabidopsis/cotton & PLACE \\
\hline LECPLEACS2 & 1325 & TAAAATAT & tomato & PLACE \\
\hline LIM1 & 170 & gcttgccGGTGG & Tobacco & TRANSFAC \\
\hline$\overline{\mathrm{LIM} 1}$ & 285 & cactactGGTGG & Tobacco & TRANSFAC \\
\hline LIM1 & 442 & aaatgttGGTGG & Tobacco & TRANSFAC \\
\hline MYB1AT & 1208 & TGGTTA & Arabidopsis & PLACE \\
\hline$\overline{\text { MYB1AT }}$ & 618 & AAACCA & Arabidopsis & PLACE \\
\hline MYB1LEPR & 501 & GTTAGTT & Arabidopsis/tomato & PLACE \\
\hline$\overline{\text { MYB2CONSENSUSAT }}$ & 1199 & CCGTTA & Arabidopsis & PLACE \\
\hline MYB2CONSENSUSAT & 803 & TAACGG & Arabidopsis & PLACE \\
\hline MYB4 & 180 & GGTTGTT & Arabidopsis & AGRIS \\
\hline$\overline{\text { MYB4 }}$ & 389 & GTTTGGT & Arabidopsis & AGRIS \\
\hline MYB4 & 501 & GTTAGTT & Arabidopsis & AGRIS \\
\hline MYBCORE & 1199 & CCGTTA & Arabidopsis/petunia & PLACE \\
\hline$\overline{\text { MYBCORE }}$ & 131 & CAACAG & Arabidopsis/petunia & PLACE \\
\hline MYBCORE & 803 & TAACGG & Arabidopsis/petunia & PLACE \\
\hline MYBCOREATCYCB1 & 102 & AACGG & Arabidopsis & PLACE \\
\hline MYBCOREATCYCB1 & 1199 & CCGTT & Arabidopsis & PLACE \\
\hline$\overline{\text { MYBCOREATCYCB1 }}$ & 804 & AACGG & Arabidopsis & PLACE \\
\hline MYBPLANT & 389 & GTTTGGTG & snapdragon/bean/petunia/Arabidopsis & PLACE \\
\hline MYBST1 & 1104 & TATCC & potato & PLACE \\
\hline MYBST1 & 1196 & TATCC & potato & PLACE \\
\hline MYCATERD1 & 931 & CATGTG & Arabidopsis & PLACE \\
\hline MYCCONSENSUSAT & 1353 & CATATG & Arabidopsis & PLACE \\
\hline MYCCONSENSUSAT & 305 & CAGCTG & Arabidopsis & PLACE \\
\hline$\overline{\text { MYCCONSENSUSAT }}$ & 50 & CATCTG & Arabidopsis & PLACE \\
\hline$\overline{\text { MYCCONSENSUSAT }}$ & 931 & CATGTG & Arabidopsis & PLACE \\
\hline P1BS & 1101 & GAATATCC & Arabidopsis/tomato/Medicago/barley & PLACE \\
\hline P1BS & 1352 & GCATATGC & Arabidopsis/tomato/Medicago/barley & PLACE \\
\hline POLASIG1 & 1433 & AATAAA & pea/rice/Arabidopsis & PLACE \\
\hline$\overline{\text { POLASIG1 }}$ & 630 & AATAAA & pea/rice/Arabidopsis & PLACE \\
\hline$\overline{\text { POLASIG1 }}$ & 661 & AATAAA & pea/rice/Arabidopsis & PLACE \\
\hline$\overline{\text { POLASIG1 }}$ & 677 & AATAAA & pea/rice/Arabidopsis & PLACE \\
\hline$\overline{\text { POLASIG1 }}$ & 682 & AATAAA & pea/rice/Arabidopsis & PLACE \\
\hline POLASIG1 & 776 & AATAAA & pea/rice/Arabidopsis & PLACE \\
\hline POLASIG1 & 941 & AATAAA & pea/rice/Arabidopsis & PLACE \\
\hline POLLEN1LELAT52 & 1007 & AGAAA & tomato & PLACE \\
\hline POLLEN1LELAT52 & 1361 & AGAAA & tomato & PLACE \\
\hline$\overline{\text { POLLEN1LELAT52 }}$ & 34 & TTTCT & tomato & PLACE \\
\hline POLLEN1LELAT52 & 548 & AGAAA & tomato & PLACE \\
\hline
\end{tabular}


Tabela 13: Conclusão

\begin{tabular}{|c|c|c|c|c|}
\hline Elemento & Posição & Sequência & Organismo & Banco de dados \\
\hline POLLEN1LELAT52 & 85 & 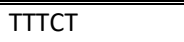 & tomato & PLACE \\
\hline POLLEN1LELAT52 & 852 & TTTCT & tomato & PLACE \\
\hline RAV1 & 128 & catCAACAgtgg & Arabidopsis & TRANSFAC \\
\hline RAV1 & 441 & aaaaTGTTGgtg & Arabidopsis & TRANSFAC \\
\hline RAV1 & 925 & gaaCAACAtgtg & Arabidopsis & TRANSFAC \\
\hline RAV1 & 1447 & agaCAACAatct & Arabidopsis & TRANSFAC \\
\hline RAV1-A & 131 & CAACA & Arabidopsis & AGRIS \\
\hline$\overline{\text { RAV1-A }}$ & 1450 & CAACA & Arabidopsis & AGRIS \\
\hline RAV1-A & 445 & TGTTG & Arabidopsis & AGRIS \\
\hline RAV1-A & 928 & CAACA & Arabidopsis & AGRIS \\
\hline RHERPATEXPA7 & 352 & TCGTGA & Arabidopsis & PLACE \\
\hline RHERPATEXPA7 & 507 & TCGTGC & Arabidopsis & PLACE \\
\hline SITEIIATCYTC & 164 & TGGGCT & Arabidopsis/rice & PLACE \\
\hline SORLIP1AT & 263 & GCCAC & Arabidopsis & PLACE \\
\hline$\overline{\text { SREATMSD }}$ & 1195 & TTATCC & Arabidopsis & PLACE \\
\hline TAAAGSTKST1 & 1097 & TAAAG & potato & PLACE \\
\hline$\overline{\text { TAAAGSTKST1 }}$ & 1138 & CTTTA & potato & PLACE \\
\hline TAAAGSTKST1 & 1320 & TAAAG & potato & PLACE \\
\hline TAAAGSTKST1 & 249 & TAAAG & potato & PLACE \\
\hline TAAAGSTKST1 & 684 & TAAAG & potato & PLACE \\
\hline TATABOX2 & 1055 & ATTTATA & pea/tobacco/bean & PLACE \\
\hline TATABOX 2 & 1413 & TATAAAT & pea/tobacco/bean & PLACE \\
\hline TATABOX2 & 1419 & TATAAAT & pea/tobacco/bean & PLACE \\
\hline TBOXATGAPB & 10 & ACTTTG & Arabidopsis & PLACE \\
\hline$\overline{\text { TEIL }}$ & 750 & taaTACAT & Tobacco & TRANSFAC \\
\hline TEIL & 770 & ATGTAtaa & Tobacco & TRANSFAC \\
\hline WBOXATNPR1 & 883 & GTCAA & Arabidopsis & PLACE \\
\hline WBOXNTERF3 & 1232 & AGTCA & tobacco & PLACE \\
\hline WBOXNTERF3 & 527 & TGACT & tobacco & PLACE \\
\hline WBOXNTERF3 & 55 & GGTCA & tobacco & PLACE \\
\hline WBOXNTERF3 & 882 & GGTCA & tobacco & PLACE \\
\hline
\end{tabular}


APÊNDICE F - RESULTADOS OBTIDOS DURANTE O PERÍODO DE DOUTORADO REALIZADO NA UNIVERSIDADE DE WAGNENINGEN, REINO DOS PAÍSES BAIXOS 


\section{INTRODUÇÃO GERAL}

Durante o meu doutorado, tive a oportunidade de executar um projeto relacionado ao estudo do desenvolvimento e amadurecimento do fruto de outra espécie membro da família Solanaceae, o tomateiro (Solanum lycopersicum), como planta experimental. Esse projeto foi desenvolvido durante meu doutorado-sanduíche na Universidade de Wageningen (WUR; Wageningen University and Research), Países Baixos, sob orientação de Ruud A. de Maagd. O período de doutorado sanduíche foi de excelente contribuição para minha formação profissional e pessoal. Tive contato com muitas metodologias novas, algumas das quais apliquei no desenvolvimento da pesquisa aqui no Brasil. Além disso, um artigo científico será organizado para publicação. Abaixo, seguem uma breve introdução e os resultados das atividades desenvolvidas.

\subsection{DESENVOLVIMENTO E AMADURECIMENTO DE FRUTOS EM TOMATE}

Os frutos evoluíram tomando diferentes características que permitem a proteção das sementes até que elas estejam em ambientes favoráveis para a sua dispersão. Apesar das diferenças morfológicas, há fortes similaridades nas redes regulatórias que desencadeiam o desenvolvimento e amadurecimento de frutos secos e carnosos (SEYMOUR et al., 2013). Nos últimos anos, diversas pesquisas têm aprofundado os conhecimentos acerca do desenvolvimento e amadurecimento de frutos secos, principalmente utilizando a planta modelo A. thaliana (ROBLES; PELAZ, 2005). Entretanto, pouco se sabe a respeito do desenvolvimento dos frutos carnosos, os quais se tornaram indispensáveis na dieta humana.

Como mencionado, o tomateiro (S. lycopersicum) também é um membro da família Solanaceae muito utilizado como modelo experimental. Entretanto, diferente de N. tabacum que possui um fruto seco, o fruto do tomateiro, o tomate, é um fruto carnoso do tipo baga. O tomate é utilizado como o principal modelo de frutos carnosos devido a uma combinação de razões científicas, como vasta gama de pesquisas disponíveis (BEMER et al., 2012; GIOVANNONI, 2007; KARLOVA et al., 2011, 2013, 2014), além de razões agronômicas, como ciclo de vida curto e facilidade de cultivo.

O desenvolvimento do fruto de tomate pode ser dividido em uma série de estádios. Primeiramente, os frutos são menos atrativos, pequenos, duros e com um elevado acúmulo de ácidos orgânicos. Durante o processo de amadurecimento do tomate, a expressão de 
vários genes leva a importantes alterações bioquímicas e fisiológicas, como o acúmulo de açúcares, pigmentos e compostos voláteis o que caracterizará modificações perceptíveis na textura, aroma e sabor dos frutos (GIOVANNONI, 2007; KLEE; GIOVANNONI, 2011; LUNN et al., 2013). Ao final do processo, o fruto pode apresentar deterioramento de estruturas celulares, apodrecer e se tornar mais susceptível a patógenos (LUNN et al., 2013).

O processo de fertilização inicia o desenvolvimento do fruto e é designado como estádio 0 (PESARESI et al., 2014). O primeiro estádio do desenvolvimento do fruto tem início logo após a fertilização e é caracterizado pela divisão celular acentuada (GIOVANNONI, 2004; PESARESI et al., 2014). No segundo estádio, com início aproximado após duas semanas de fertilização, há expansão celular com pronunciado aumento de massa, processos observados devido à expansão celular (BERGERVOET et al., 1996). Após o segundo estádio, o fruto entra em um estádio conhecido como mature green (MG) (GIOVANNONI, 2004; HO; HEWITT, 1986) no qual atinge seu tamanho final, porém ainda não está convencionalmente maduro (CHEVALIER, 2007). Após esse estádio, o fruto reorganiza a maquinaria metabólica e inicia no processo de amadurecimento, no qual, três novas fases podem ser facilmente distinguidas: Breaking (BR), Turning ( $\mathrm{T}$ ) e Red Ripening (RR) (GILLASPY; BEN-DAVID; GRUISSEM, 1993). O BR é o exato momento onde o fruto ainda está verde, porém com um início de amadurecimento evidente na parte basal. $\mathrm{O}$ fruto passa então de verde para amarelo/laranja graças ao processo de degradação da clorofila concomitante com a produção de carotenoides, como licopeno. Na fase $\mathrm{T}$, o fruto passa de amarelo/laranja para vermelho. O processo de amadurecimento do fruto termina no estádio RR com a formação da zona de abscisão. A Figura 1 identifica os estádios de amadurecimento em frutos de tomateiro.

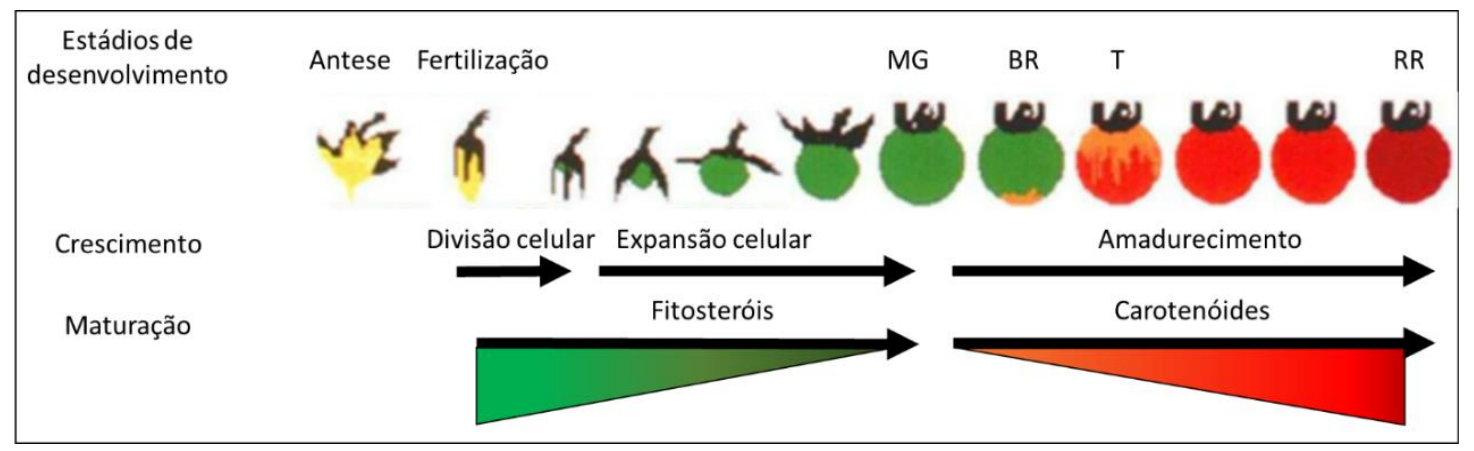

Figura 1: Estádios de desenvolvimento do fruto do tomateiro (S. 1ycopersicum). F: Flor fertilizada; 1: Primeiro estádio de desenvolvimento; 2: Segundo estádio de desenvolvimento; MG: Mature Green; BR:Breaking; T: Turning; RR: Red Ripe. Extraído e modificado de GILLASPY; BENDAVID; GRUISSEM (1993). 
Até os fatores de transcrição envolvidos na regulação do amadurecimento de tomate serem caracterizados, acreditava-se que o processo de amadurecimento poderia ser algo linear. No entanto, com os avanços nessa área, hoje sabemos que a rede de interações é muito vasta e complexa, envolvendo respostas de feedback a fatores de transcrição, como, por exemplo, os MADS-Box.

\subsection{FATORES DE TRANSCRIÇÃO DA FAMÍIA MADS-BOX}

Os fatores de transcrição da família MADS-box estão presentes em eucariotos como fungos, animais e em maior número, plantas (HEIJMANS; MOREL; VANDENBUSSCHE, 2012). Em plantas, os genes MADS-box regulam transição da fase vegetativa para reprodutiva além de desenvolvimento de flores e frutos (NG; YANOFSKY, 2001). O nome da família é um acrônimo que foi dado em referência a quatro membros (SCHWARZSOMMER et al., 1990; SHORE; SHARROCKS, 1995): MCM1 de Saccharomyces cerevisiae (AMMERER, 1990), AGAMOUS de A. thaliana (YANOFSKY et al., 1990), DEFICIENS de Antirrbinum majus (SOMMER et al., 1990) e $\underline{\mathrm{S}} \mathrm{F}$ de H. sapiens (NORMAN et al., 1988). As proteínas MADS-box possuem quatro domínios com diferentes papéis (KAUFMANN; MELZER; THEISSE, 2005; THEISSE; KIM; SAEDLER, 1996): o domínio MADS (M) é responsável pelo reconhecimento e ligação ao DNA (MASIERO et al., 2002). Ele é seguido pelos domínios Intervening (I) o qual participa nas interações com outras proteínas (KRIZEK; MEYEROWITZ, 1996; RIECHMANN; KRIZEK; MEYEROWITZ, 1996) e Keratin-like (K), que promove além de interações proteína-proteína a formação de complexos de ordem superior (EGEA-CORTINES; SAEDLER; SOMMER, 1999; YANG; FANNING; JACK, 2003). E, por fim, encontra-se a porção C-terminal, a qual participa da formação de complexos de ordem superior e da ativação transcricional (VAN DIJK et al., 2010).

As proteínas MADS formam dímeros (homo ou heterodímeros) os quais se ligam a regiões específicas dos promotores, denominadas CArG-boxes (RIECHMANN; KRIZEK; MEYEROWITZ, 1996). Quando dois dímeros se ligam a CArG-boxes adjacentes eles levam à formação de um loop no DNA e permitem a interação entre os dímeros e a transcrição do gene sob controle do promotor (Figura 2). De acordo com o modelo descrito por Smaczniak et al. (2012), a determinação da identidade do órgão floral em $A$. thaliana ocorre através da formação de um tetrâmero funcional com proteínas MADS-Box e consequente indução da expressão do gene que é regulado pelo promotor ao qual o tetrâmero se liga. Há quatro subfamílias de genes MADS-Box que, mediante interações coordenadas, determinam a identidade floral. São elas: APETALA, PISTILLATA, AGAMOUS e SEPALLATA. 


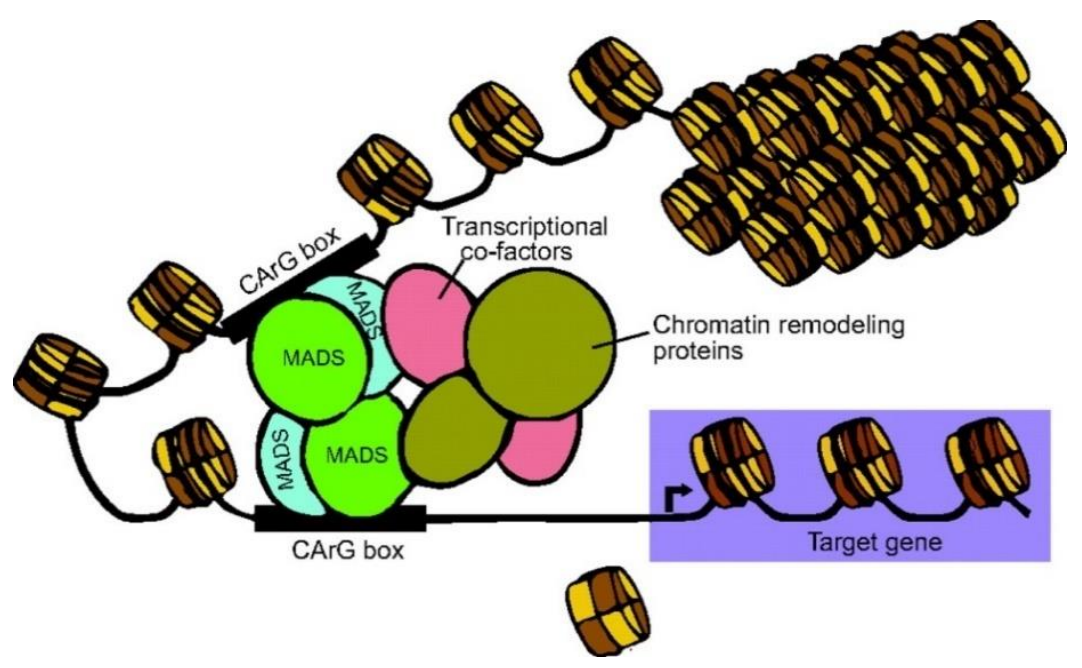

Figura 2: Modelo de atuação de complexos proteicos MADS-Box. Extraído de Smaczniak et al. (2012).

\subsection{CONTROLE MOLECULAR NO DESENVOLVIMENTO E}

\section{AMADURECIMENTO DO FRUTO EM $A$. thaliana E $S$. lycopersicum}

Além de funções claras na promoção da identidade dos verticilos florais, os fatores de transcrição da família MADS-box também apresentam papéis na regulação da identidade dos tecidos em vários estágios do fruto da planta modelo $A$. thaliana (IRISH, 2010). Como exemplo, temos o gene $A G$, cujo produto proteico determina a identidade do carpelo no desenvolvimento da flor (BOWMAN; SMYTH; MEYEROWITZ, 1989). Os genes SHATTERPROOF 1 e 2 (SHP1, SHP2) residem no mesmo clado filogenético de $A G$. As proteínas SHP1 e SHP2 são expressas nas margens da valva e ambas são requisitadas para a identidade da zona de deiscência, além de serem funcionalmente redundantes a AG na determinação do carpelo (LILJEGREN et al., 2000; PINYOPICH et al., 2003). A proteína codificada pelo gene FRUITFULL (FUL), por sua vez, é requerida para a identidade das células da valva e expansão da síliqua durante o desenvolvimento do fruto (GU et al., 1998). As proteínas FUL e SHP1/2 reprimem mutuamente a expressão de seus transcritos (FERRÁNDIZ et al., 2000). Em mutantes onde o gene de uma delas não é expresso, a expressão do outro se estende a domínios nos quais o gene não se expressaria em frutos selvagens. Mais recentemente descobriu-se que as proteínas da família SEPALLATA atuam 
como adesivos, mediando a interação entre as proteínas das outras famílias na formação dos tetrâmeros ativos (GOTO; KYOZUKA; BOWMAN, 2001; IMMINK et al., 2009).

Recentemente, foi mostrado que alguns genes não pertencentes à família MADS-box também apresentam funções importantes no desenvolvimento do fruto. O gene AP2 codifica uma proteína que era conhecida por estar envolvida na identidade de órgãos florais (BOWMAN; SMYTH; MEYEROWITZ, 1991). Hoje, sabe-se que ela funciona também como repressora da identidade da margem da valva (reprimindo SHP1/2), bem como repressora da identidade do replum (RIPOLL et al., 2011).

Proteínas ortólogas e, em muitos casos, co-ortólogas, de $A$. thaliana já tiveram suas funções bem caracterizadas em tomate. Por exemplo, existem dois ortólogos de FUL: FUL1/TDR4 e FUL2/ MBP27, além de outros dois genes no mesmo clado, MBP10 e MBP20, os quais não possuem ortólogos óbvios em $A$. thaliana (HILEMAN et al., 2006). Há também em tomate um ortólogo de SHP, o gene TAGL1 (VREBALOV et al., 2009) e três co-ortólogos de AP2, que são AP2a, AP2b e AP2c (KARLOVA et al., 2011). A função de alguns desses ortólogos já foi avaliada através de caracterização de plantas com os genes silenciados por RNAi. Plantas com expressão diminuída de TAGL1 mostraram defeitos no amadurecimento e inibição da expansão do pericarpo (ITKIN et al., 2009; VREBALOV et al., 2009). Plantas transgênicas com menor expressão dos ortólogos de FUL1/2 também mostraram defeitos no amadurecimento, porém, sem grandes alterações na identidade dos tecidos (BEMER et al., 2012).

Em tomate, os fatores de transcrição pertencentes à família SEPALLATA estão envolvidos nos processos de amadurecimento do fruto (KLEE; GIOVANNONI, 2011). Os mutantes com expressão diminuída do fator de transcrição RIN (Ripening inbibitor) apresentam menor produção de etileno, não respondem a aplicações externas de etileno, permanecem firmes e com menos produção de licopeno ao decorrer do amadurecimento. A proteína LeMADS1 afeta a produção de etileno e atua como um regulador negativo do amadurecimento através da interação com RIN (DONG et al., 2013). Plantas com expressão diminuída de SIAP2a, um dos co-ortólogos de AP2, mostraram defeitos no amadurecimento dos frutos, aumento na produção de etileno e deterioração, indicando que SlAP2a é um inibidor do amadurecimento (CHUNG et al., 2010; KARLOVA et al., 2011). O gene Colorless non-ripening (CNR) atua upstream ao gene SLAP2. Assim, a proteína CNR regula SLAP2 positivamente ao se ligar em seu promotor. Em contrapartida, o gene CNR é direta ou indiretamente regulado negativamente pela proteína SIAP2 (KARLOVA et al., 2011). 
Através dos levantamentos na literatura, constata-se a evidência entre as diferenças no desenvolvimento e na arquitetura dos frutos de $A$. thaliana e tomate. Além disso, percebese que há diferentes fatores que interferem na função gênica dos ortólogos. Apesar de muito já ter sido desvendado nas redes regulatórias e quais suas semelhanças/diferenças entre essas espécies modelos, ainda há lacunas que precisam ser preenchidas. O presente trabalho satisfaz algumas dessas lacunas através da análise de interações possíveis entre fatores MADS-Box além de indicar alguns complexos proteicos que eles podem formar durante as fases de desenvolvimento do tomate.

\subsection{INTERAÇÃO ENTRE PROTEÍNA-PROTEÍNA E DNA-PROTEÍNA}

Para realizar suas funções, muitas proteínas regulatórias atuam em complexos. A exemplo disso temos os processos que envolvem a replicação e transcrição de DNA (DUDERSTADT et al., 2014; SAINSBURY; BERNECKY; CRAMER, 2015), a tradução do RNA mensageiro em proteínas (GRAIFER; KARPOVA, 2015), as modificações póstraducionais que as proteínas sofrem (ZECH; DALGAARD, 2014), a transdução de sinal dentro das células (VISSCHER; KASTRITIS; BONVIN, 2015) e o próprio ciclo celular (INAGAKI; UMEDA, 2011). Para compreender os processos celulares é crucial desvendar as redes regulatórios envolvidas nos mesmos. Ou seja, é necessário identificar as interações proteína-proteína e DNA-proteína. Há diversos métodos utilizados para detecção de proteínas-proteínas e DNAs-proteínas que interagem fisicamente. Os métodos in vitro incluem técnicas imunológicas, como co-imunoprecipitação de proteínas, imunoprecipitação de cromatina (ChIP) e Far-western blot, métodos físicos de afinidade, como EMSA

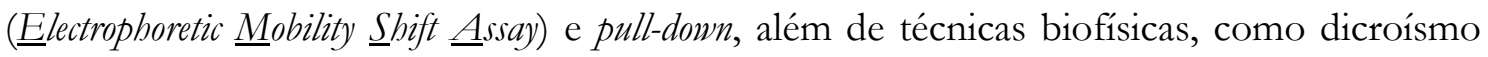
circular e RMN de proteínas (espectroscopia mediante ressonância magnética nuclear de proteínas). Dentre métodos in vivo podemos citar métodos genéticos, como o sistema de duplo-híbrido e métodos de fluorescência como BiFC (Bimolecular Fluorescence Complementation). 
Lubini, G. 2016

\subsubsection{OS SISTEMAS DE YEAST TWO-HYBRID, YEAST THREE-HYBRID E YEAST ONE-HYBRID}

Em 1989, Fields e Song desenvolveram um método ainda muito utilizado para avaliação de interação proteína-proteína. Certas proteínas possuem múltiplos domínios que agem independentemente e que, quando aproximados por meio de ligações não covalentes, reconstituem a atividade da proteína intacta. Baseados nessa característica de algumas

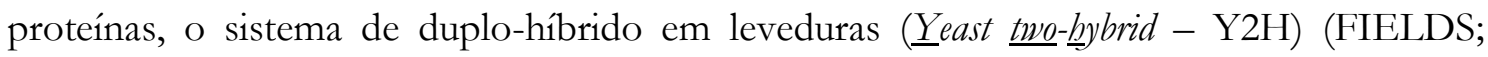
SONG, 1989) é um método in vivo para detecção de interações entre proteínas. Essa técnica utiliza os domínios do fator de transcrição GAL4: Domínio de Ligação ao DNA (DNA Binding Domain, BD) e Domínio de Ativação da transcrição (杰tivation Domain, AD). Cada um dos domínios é expresso em forma de proteínas de fusão com uma das proteínas candidatas à interação. Somente se as proteínas candidatas interagirem ocorre reaproximação dos domínios e expressão de genes repórteres que promoverão auxotrofia a aminoácidos. Para a detecção das interações, são utilizadas linhagens de leveduras que possuem genes repórteres, como o HIS3, ADE2 e lacZ, cujas cópias ativas foram introduzidas no genoma das leveduras e sua regulação está sob controle de um promotor GAL4-indutível. Em nosso laboratório, foi construída uma biblioteca de cDNAs para uso no sistema ProQuest Two-Hybrid com a tecnologia Gateway (STRINI, 2014). Nessa biblioteca, o RNA de estigmas/estiletes foi convertido em cDNAs que foram clonados, através do sistema Gateway de recombinação, em vetores contendo o domínio $\mathrm{AD}$, constituindo as presas utilizadas no estudo.

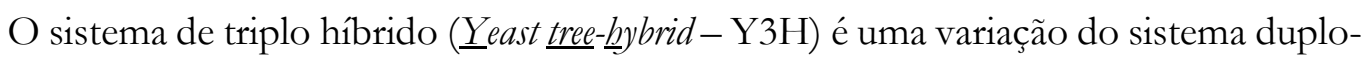
híbrido. Porém, nesse caso, verifica-se a interação de duas proteínas híbridas (que estão sendo produzidas em fusão com os domínios $\mathrm{AD}$ e $\mathrm{BD}$ ) que somente pode ocorrer com o auxílio de uma terceira proteína, a qual servirá de ponte/auxílio para uma interação que antes não ocorria. Esse método também foi utilizado para testar a interação entre inibidores de ciclo celular e quinases (BECKER et al., 2004) e entre proteínas MADS-box em tomate (LESEBERG et al., 2008).

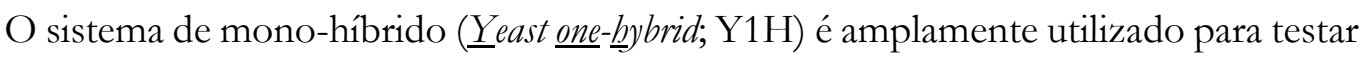
a interação de proteínas (normalmente fatores de transcrição) e um fragmento de DNA de interesse (REECE-HOYES; MARIAN WALHOUT, 2012). Fatores de transcrição podem ativar ou reprimir um gene através de sua ligação com elementos cis regulatórios. Esses elementos podem estar presentes na região promotora do gene alvo, dentro de íntrons, éxons 
ou mesmo a distâncias maiores. Portanto, foi necessário desenvolver um método que possa ser utilizado para detecção dessas interações. No sistema de Y1H, uma única proteína é fusionada ao domínio de ativação AD do GAL4 e ela mesma serve como ligante ao DNA (BD). Assim, se a proteína se ligar ao DNA alvo, a transcrição do gene repórter é ativada. Finalmente, a interação é testada através do crescimento das leveduras em antibiótico.

\section{OBJETIVOS}

O presente trabalho teve como objetivos elucidar as semelhanças e diferenças entre as interações de proteínas necessárias para o desenvolvimento e amadurecimento do fruto de S. bycopersicum quando comparadas com as interações identificadas em A. thaliana. Assim, especificamente, o trabalho visava atender aos seguintes objetivos:

1. Determinar putativos complexos MADS-box que possam ativar promotores de genes responsáveis pelo amadurecimento do fruto de S. lycopersicum;

2. Determinar se as formas de splicing alternativos em genes MADS-box são expressas e se elas interagem de forma diferente com relevância no amadurecimento do fruto de S. lycopersicum;

3. Determinar se os diferentes alelos de SIFUL1 interagem de forma diferenciada com outras proteínas;

4. Determinar os possíveis parceiros de interação da proteína AP2 no fruto de $S$. lycopersicum;

5. Determinar possíveis reguladores da expressão do gene $C N R$ e seus possíveis parceiros de interação no fruto de $S$. lycopersicum. 


\section{RESULTADOS E DISCUSSÕES}

\section{VARIANTES DE SPLICING DE DOIS GENES SEPALLATA SÃO EXPRESSOS DURANTE O DESENVOLVIMENTO DE TOMATE}

Em estudos prévios realizados pelo doutorando José Hernandes Lopes Filho durante seu doutorado sanduíche na Universidade de Wageningen (Projeto CAPES/Nuffic processo 0256/13-7), foram descobertas variantes de splicing para dois genes MADS-box da família SEPALLATA: LeMADS1 e RIN. O sequenciamento dos clones LeMADS1 indicou a presença de dois RNAs mensageiros que diferem quanto à presença/ausência de uma sequência de 42 nucleotídeos (14 aminoácidos). Verificando-se a sequência correspondente no genoma de tomate, foi observado que este evento de splicing se trata de um caso de "perda" do sexto éxon que ocorre na short splice form (Figura3).

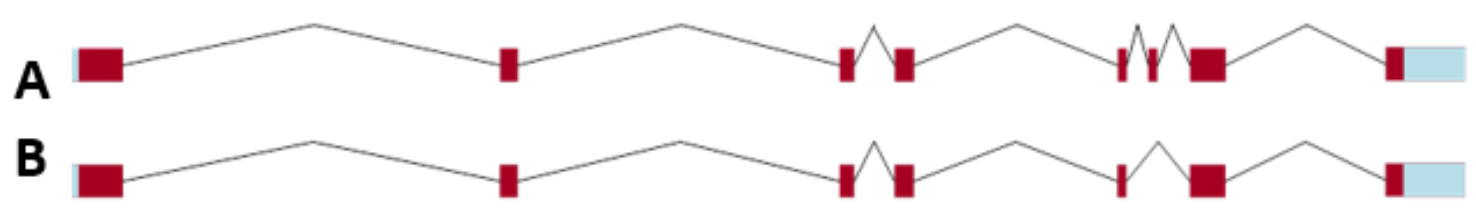

Figura 3: Formas alternativas de splicing do gene LeMADS1. Blocos vermelhos correspondem a éxons, linhas cinzas correspondem a íntrons e blocos azuis correspondem às regiões não traduzidas do gene. A: Forma long, possui 8 éxons e 7 íntrons. B: Forma short, possui 7 éxons e 6 íntrons.

A fim de verificar o efeito dos diferentes eventos de splicing, as proteínas resultantes destes RNA mensageiros foram avaliadas. Suas sequências indicam que a presença/ausência dos 14 aminoácidos ocorre na porção terminal do domínio $K$, responsável por interações entre proteínas. Mais especificamente, a sequência é parte integrante da última alfa-hélice presente neste domínio, reconhecidamente responsável pela especificidade em interações com outras proteínas MADS.

Outra forma de splicing alternativo encontrada na família SEPALLATA foi o mRNA do gene RIN. Este é um caso em que há presença/ausência de uma sequência de 35 nucleotídeos que faz parte do oitavo éxon do gene. Neste caso, o éxon pertence à porção Cterminal da proteína, a qual é responsável por ativação transcricional e formação de complexos proteicos de ordem superior. A ausência dos nucleotídeos na versão short splicing gera um encurtamento natural da porção C-terminal do gene (Figura 4). 


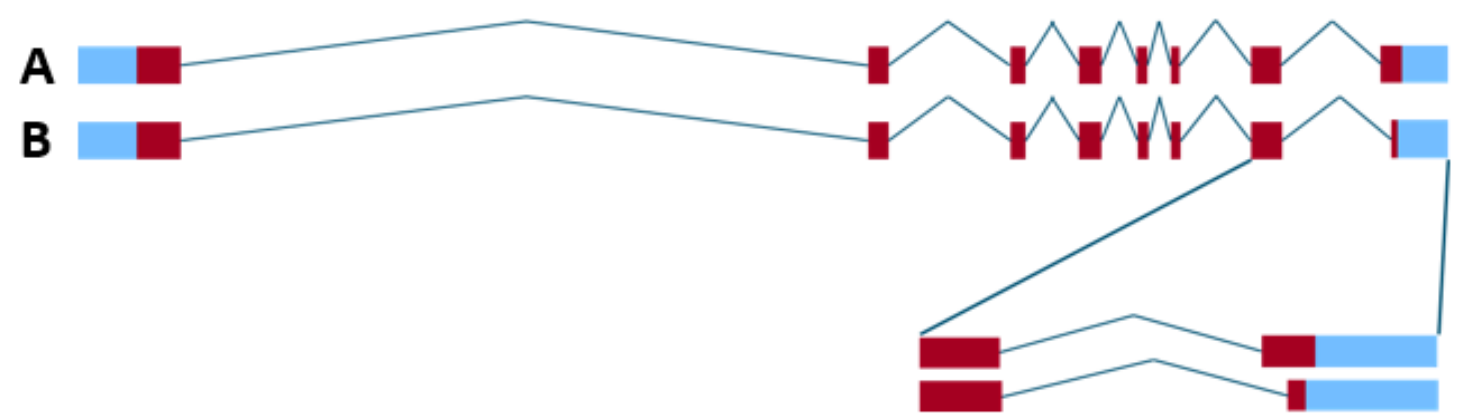

Figura 4: Formas alternativas de splicing do gene RIN. Blocos vermelhos correspondem a éxons, linhas cinzas correspondem a íntrons e blocos azuis correspondem às regiões não traduzidas do gene. A: Forma long, possui 8 éxons e 7 íntrons. B: Forma short, também possui 8 éxons e 7 íntrons, no entanto, difere da forma long quanto ao tamanho do último éxon.

Foram feitas análises de expressão do gene LeMADS1 por qRT-PCR em flores e em cinco estádios diferentes de frutos de tomate da variedade Ailsa Craig. As reações de qRTPCR foram feitas pelo método relativo com base no gene de referência actina. Os gráficos de expressão relativa foram gerados após análises pelo método delta-delta Ct (Pfaffl, 2001), comparando-se as médias dos valores obtidos para splicing alternativos dos genes LeMADS1 e RIN com o desvio padrão e barra de erro das médias dos genes de referência. Os gráficos abaixo (Figuras 5 e 6) apresentam os dados de expressão para os variantes de splicing dos genes LeMADS1 e RIN.

\section{LeMADS1}
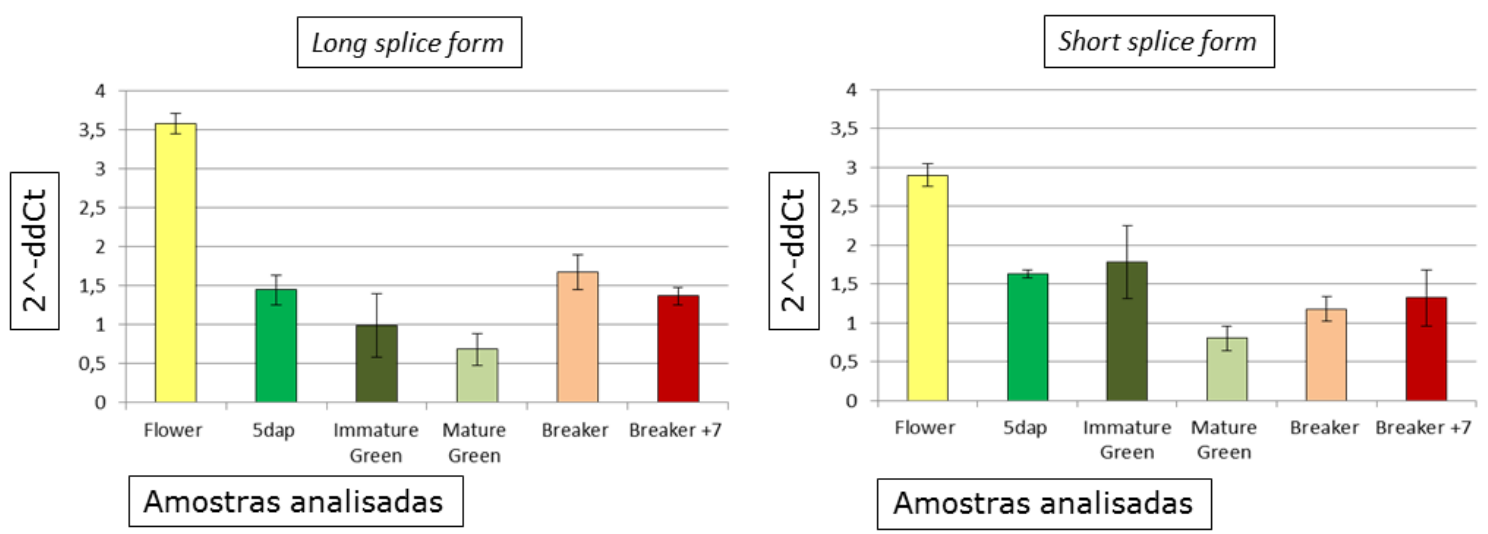

Figura 5: Análise da expressão relativa de LeMADS1 longe short variantes de splicing nos órgãos de S.lycopersicum. A expressão foi analisada em relação ao resultado obtido para short splice form, amostra biológica 1 de Breaker, utilizando o gene de referência actina. As barras indicam os valores médios da expressão de LeMADS1 long e short com o desvio padrão e barra de erros apresentados para as triplicatas biológicas de órgãos analisados. 
Analisando os gráficos acima, podemos observar que ambas as formas de splicing LeMADS1 são expressas em todos órgãos analisados em uma taxa aproximada de 50\%. Este é um indicativo de que a forma short também deva ter função no desenvolvimento/amadurecimento do fruto de tomate.

\section{RIN}
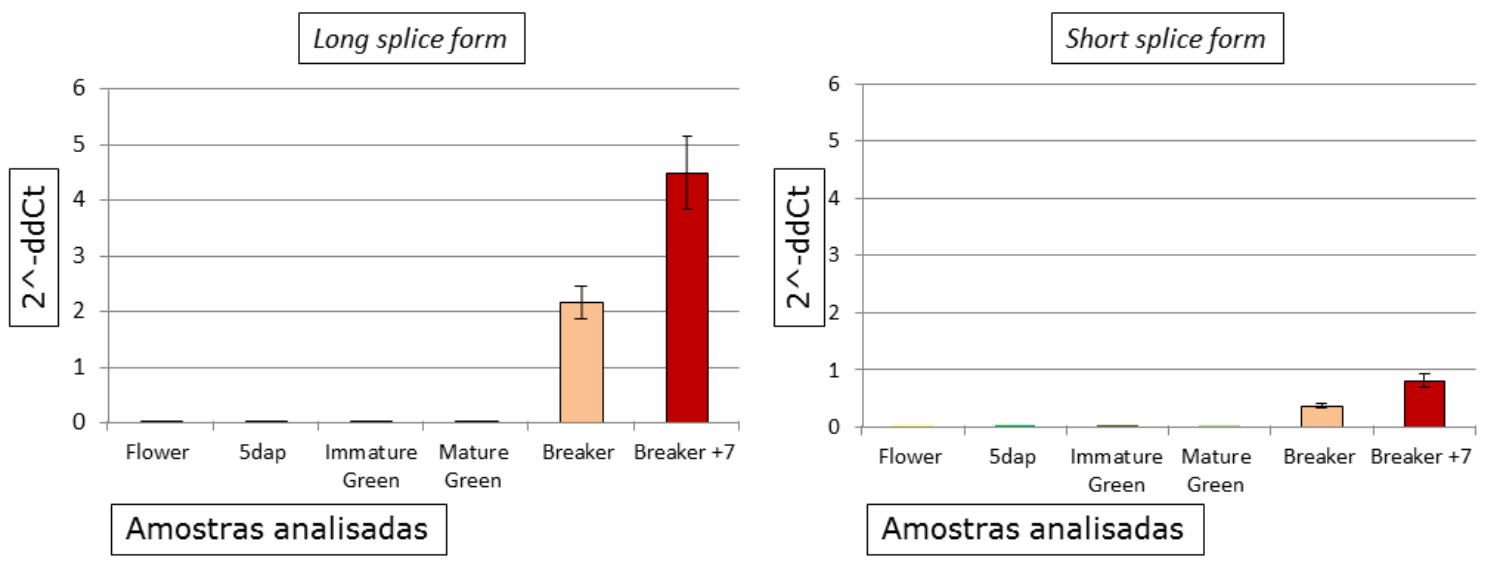

Figura 6: Análise da expressão relativa de RIN long e short variantes de splicing nos órgãos de S.lycopersicum. A expressão foi analisada em relação ao resultado obtido para short splice form, amostra biológica 1 de Breaker, utilizando o gene de referência actina. As barras indicam os valores médios da expressão de RIN long e short com o desvio padrão e barra de erros apresentados para as triplicatas biológicas de órgãos analisados.

De acordo com os gráficos acima, vemos que ambas as formas de splicing alternativo de RIN se expressam apenas durante estádios tardios de amadurecimento do fruto (Breaker e Breaker +7). A forma long é 80\% mais expressa que a forma short nestes estádios. Entretanto, convém lembrar que aqui neste trabalho somente foram analisadas as expressões em frutos de tomate da variedade Ailsa Craig. Não podemos afirmar que em outras variedades ou até mesmo em outras condições ambientais, como estresse térmico ou hídrico, as expressões se comportem da mesma forma.

\subsection{BUSCA POR PARCEIROS DE INTERAÇÃO ENTRE PROTEÍNAS MADS- BOX DE TOMATE ATRAVÉS DE ENSAIOS DE DUPLO -HÍBRIDO}

Conforme previamente mencionado, as proteínas MADS interagem entre si formando dímeros e tetrâmeros e ativando a transcrição de genes envolvidos nos processos de desenvolvimento e amadurecimento de tomate. Para analisar a interação de proteínas 
envolvidas nos processos de desenvolvimento e amadurecimento de tomate, foi utilizada a técnica de Yeast two-bybrid (Y2H) de acordo com de Folter e Immink (2011).

Os genes de interesse foram previamente clonados pelo grupo de pesquisa de Wageningen. Lembrando que o gene FUL de $A$. thaliana, pertencente à família APETALA1/FRUITFULL/ SQUAMOSA possui dois ortólogos em tomate: SIFUL1 e SIFUL2. O ortólogo FUL1 possui dois alelos, round e cherry. A principal diferença entre os dois alelos é uma deleção de 15 nucleotídeos no início da porção C-terminal do alelo round, resultando em uma proteína com 5 aminoácidos a menos. Ainda em relação ao alelo round, foram encontradas diferenças importantes de acordo com a variedade. A principal diferença entre as variedades é encontrada em Ailsa Craig e Money Berg, nas quais a deleção de uma citosina gera uma mudança no quadro de leitura da transcrição e um códon de terminação precoce. As Figuras 7 e 8 apresentam a disposição de nucleotídeos e aminoácidos, respectivamente, para os alelos FUL1 analisados nas diferentes variedades de tomate.

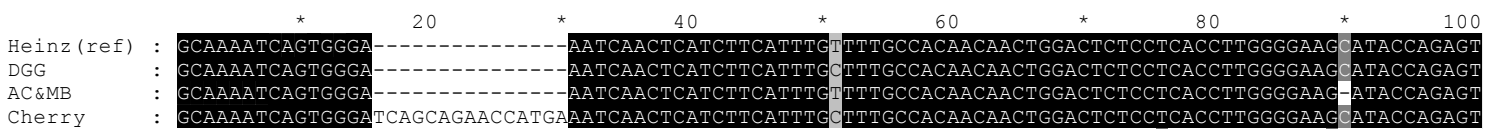

Figura 7: Sequência nucleotídica (correspondente à porção C-terminal da proteína) do gene FRUITFULL1 (FUL1) de $S$. lycopersicum. As três primeiras sequências correspondem ao alelo round encontrado nas variedades Heinz, Dixy Golden Giant (DGG), Ailsa Craig (AC) e Money Berg (MB). Observe que as variedades AC e MB possuem a deleção nucleotídica. A quarta sequência, contendo $15 \mathrm{pb}$ a mais que round, corresponde ao alelo encontrado na variedade cherry.

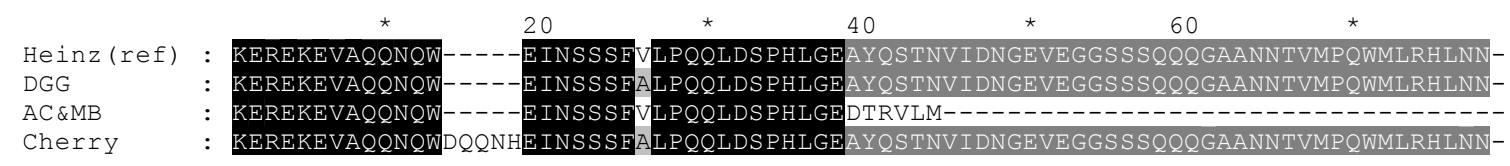

Figura 8: Sequência de aminoácidos correspondente à porção C-terminal da proteína FRUITFULL1 (FUL1) de $\boldsymbol{S}$. lycopersicum. As três primeiras sequências correspondem ao alelo round encontrado nas variedades Heinz, Dixy Golden Giant (DGG), Ailsa Craig (AC) e Money Berg (MB). Observe que, graças deleção de um nucleotídeo nas variedades AC e $\mathrm{MB}$, ouve mudança no quadro de leitura durante a tradução e consequente formação de um códon de terminação precoce. A quarta sequência, contendo 5 aminoácidos a mais que round, corresponde à proteína codificada pelo alelo FUL1 encontrado na variedade cherry.

Assim, para a família APETALA1 temos 5 alelos distintos para os quais foram analisadas as interações: SIFUL1 alelos round das variedades Heinz, Dixy Golden Giant, Money Berg, SIFUL1 alelo cherry e SIFUL2. 
Em relação à família AGAMOUS foram analisadas interações envolvendo as proteínas codificadas pelos genes TAG e TAGL1. Já da família SEPALLATA temos as duas formas variantes de splicing de LeMADS1 e RIN, além de TM5, SEP1 e SIMBP21. Em estudos prévios foi constatado que a porção C-terminal de proteínas da família SEPALLATA pode funcionar como ativador da transcrição e, quando as proteínas estão fusionadas ao domínio BD do GAL4 podem autoativar o sistema, gerando falsos-positivos. Para evitar autoativação, a porção C-terminal das proteínas SEPALLATAS é deletada. No entanto, os estudos publicados até o momento assumiram que todas as SEPALLATAS autoativam o sistema e não testaram a autoativação efetivamente. Lembrando que a porção C-terminal é importante em interações de ordem superior entre proteínas, é possível que a omissão desta porção pode acarretar diferenças significativas nos resultados. Dessa forma, foram feitos testes de autoativação com as proteínas LeMADS1 (formas long e short de splicing) e SEP1 e as mesmas não autoativam o sistema. Já as proteínas RIN (long splicing form e com deleção C-terminal), TM5 e SIMBP21 autoativam o sistema. Para evitar a autoativação, foram feitos ensaios utilizando diferentes concentração e 3-AT (.3-Amino-1,2,4-triazole) O experimento foi realizado em triplicata biológica, utilizando uma matriz de combinações entre os referidos genes. A Tabela abaixo (Tabela 1) sumariza os resultados de interação entre as proteínas utilizadas e o domínio com o qual foram fusionadas. 
Tabela 1: Matriz de resultados obtidos após cruzamento das leveduras contendo plasmídeos com expressão de proteínas em fusão com o domínio AD de GAL4 (horizontal) com leveduras contendo plasmídeos com expressão de proteínas em fusão com o domínio BD de GAL4 (vertical). Em azul, proteínas pertencentes à família FRUITFULL/APETALA1; em laranja, proteínas da família SEPALLATA; em vermelho, proteínas da família AGAMOUS. Os resultados foram obtidos após 3 réplicas biológicas. As leveduras diploides foram selecionadas com base no crescimento em meio seletivo para auxotrofia de aminoácidos. Blocos pretos representam interações que ocorreram nas duas direções (independente da fusão, as duas proteínas interagem); blocos cinza-escuros representam interações que ocorreram unidirecionalmente; blocos cinza-claros indicam interações que só puderam ser testas nessa direção; Blocos brancos indicam que não houve interação. * indica que esta interação já havia sido reportada pela literatura (Leseberg et al., 2008).

Proteínas fusionadas ao domínio AD

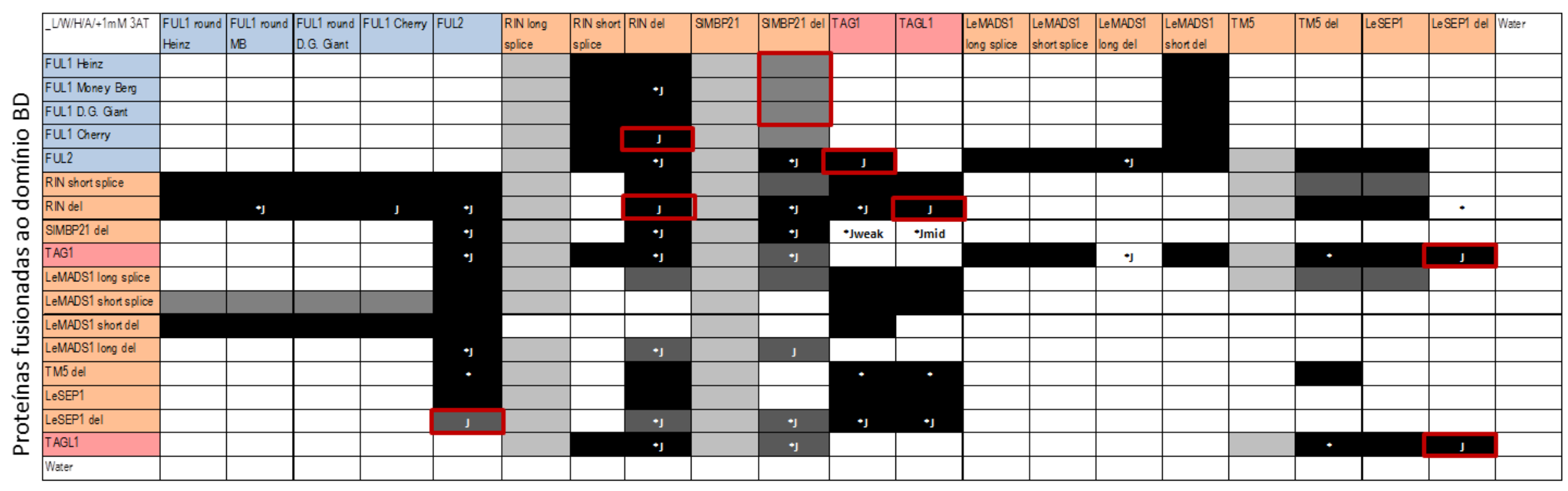


Como resultado do ensaio de $\mathrm{Y} 2 \mathrm{H}$, foram confirmadas diversas interações já conhecidas na literatura, bem como identificadas novas interações. A Tabela 2 mostra as novas interações encontradas, indicando também o domínio do GAL4 ao qual a respectiva proteína estava fusionada.

Tabela 2: Novas interações encontradas através do ensaio de Y2H. Em azul, proteínas pertencentes à família FRUITFULL/APETALA1; em laranja, proteínas da família SEPALLATA; em vermelho, proteínas da família AGAMOUS. A indicação laranjada aponta para uma interação que não havia sido verificada neste sentido (TAGL1 fusionada ao AD e RIN del ao BD).

\begin{tabular}{ll}
\multicolumn{1}{c}{ AD } & \multicolumn{1}{c}{ BD } \\
RIN del & FUL1 all alleles \\
FUL1 all alleles & RIN del \\
FUL2 & LeSEP1 del \\
\hline TAGL1 & RIN del \\
\hline TAG1 & FUL2 \\
SLMBP21 del & FUL1 all alleles \\
LeSEP1 del & TAG1 \\
LeSEP1 del & TAGL1 \\
RIN del & RIN del \\
SLBMP21 del & LeMADS1 long del
\end{tabular}

Em relação às análises de interação das proteínas dos diferentes alelos de FUL, não foram encontradas diferenças entre as proteínas FUL1 e a proteína FUL2 apresentou maior número de interações em relação a FUL1. A proteína correspondente à forma de splicing variante long LeMADS1 (com ou sem a deleção C-terminal) interagiu com quatro proteínas que a proteína da forma short não interagiu. São elas: RIN, SIMBP21, TM5 e LeSEP1, as três primeiras são proteínas truncadas, com a deleção na porção C-terminal. Todas estas proteínas pertencem à família SEPALLATA. Já a proteína da forma short de splicing variante LeMADS1 interagiu com as proteínas de todos alelos de FUL1 e com a proteína TAGL1, pertencentes às famílias APETALA1 e AGAMOUS, respectivamente. A interação entre LeMADS1 long com a deleção já havia sido reportada por Dong et al., (2013) em estudo que indicou que LeMADS1 é um regulador negativo do amadurecimento através da interação com RIN. No entanto, nenhum estudo havia sido feito até o momento com as proteínas LeMADS1 short. Assim, as interações descobertas neste estudo podem indicar outro mecanismo através do qual LeMADS1 pode regular o amadurecimento do tomate. Quanto aos estudos realizados para avaliar diferenças nas interações entre RIN, foram encontradas proteínas que interagem com RIN long ou RIN com a deleção, mas não interagem com 
RIN short. São elas: RIN short, SIMBP21 com a deleção, LeMADS1 long, LeMADS1 com a deleção e LeMADS1 short. Estes resultados indicam que a proteína RIN short apresenta dobramento diferente da proteína RIN long, expondo ou obstruindo sítios de ligação a algumas proteínas.

\subsection{IDENTIFICAÇÃO DE COMPLEXOS DE ORDEM SUPERIOR EM PROTEÍNAS MADS-BOX POR TRIPLO-HÍBRIDO}

Com os dados de interação gerados pelo ensaio de yeast two-bybrid foram delineados experimentos de yeast tree-hybrid. É importante salientar o princípio de que as proteínas MADS-Box se tornam funcionais e ativam a transcrição quando organizadas em complexos de ordem superior(SMACZNIAK et al., 2012). Assim sendo, algumas interações que não ocorreram par-apar (proteínas fusionadas aos domínios AD e BD) poderiam vir a ocorrer caso esteja disponível no sistema uma terceira proteína (a qual interage com uma das proteínas em questão) como mediadora da interação. Assim, o gene codificante das proteínas foi também clonado no vetor de expressão pTFT1 (CIANNAMEA et al., 2006) e o plasmídeo gerado foi transformado em leveduras que já continham as proteínas fusionadas no AD. Foram feitas 103 combinações AD-TFT1, correspondendo às 103 interações encontradas no ensaio de $\mathrm{Y} 2 \mathrm{H}$ onde o gene que estava fusionado ao BD foi transferido ao vetor TFT1. Todas as 103 combinações foram testadas para interação com todas proteínas fusionadas ao BD (exceto SIMBP21 e o alelo FUL1 da variedade Dixy Golden Giant), totalizando um screening de 1545 possibilidades de interações, das quais, 602 interações seriam entre proteínas que não interagiram pelo Y2H. Esperava-se que as proteínas que apresentaram interação no $\mathrm{Y} 2 \mathrm{H}$ continuassem a interagir, gerando muitos controles positivos para o ensaio. $\mathrm{O}$ ensaio de $\mathrm{Y} 3 \mathrm{H}$ foi realizado em duplicata biológica. A primeira réplica biológica mostrou 35 novas interações e a segunda apresentou 123 novas interações. Comparando as duplicatas, 22 interações ocorreram nos dois cruzamentos (Tabela 3). 
Tabela 3: Complexos de ordem superior formados através do ensaio de Y3H. Em azul, proteínas pertencentes à família FRUITFULL/APETALA1; em laranja, proteínas da família SEPALLATA; em vermelho, proteínas da família AGAMOUS.

\begin{tabular}{lll}
\hline FUL2 & LeMADS1 long splice & FUL2 \\
FUL2 & LeMADS1 short splice & FUL2 \\
LeMADS1 long splice & FUL2 & RIN short splice \\
\hline TM5 & TAG1 & RIN short splice \\
TM5 & LeMADS1 long splice & RIN short splice \\
TM5 & TM5 del & RIN short splice \\
TM5 & TAGL1 & RIN short splice \\
TM5 del & TAG1 & RIN short splice \\
\hline TM5 del & TAGL1 & RIN short splice \\
MADS1 long splice & FUL2 & LeMADS1 long splice \\
LeMADS1 short splice & FUL2 & LeMADS1 long splice \\
LeMADS1 long del & FUL2 & LeMADS1 long splice \\
LeMADS1 short del & FUL2 & LeMADS1 long splice \\
\hline TM5 del & TAG1 & LeMADS1 long splice del \\
RIN del & FUL2 & LeMADS1 short splice \\
RIN del & TAGL1 & LeMADS1 short splice \\
\hline TAGL1 & TM5 del & LeMADS1 long splice del \\
MADS1 long splice & FUL2 & LeMADS1 long splice del \\
MADS1 short del & FUL2 & TAG1 \\
TM5 & TAGL1 & LeSEP1 \\
LeSEP1 del & RIN del & LeSEP1 \\
LeSEP1 & & LeSEP1 \\
\hline
\end{tabular}

Dentre as 22 interações, se não considerarmos diferença entre variantes de splicing e não fizermos distinção entre as proteínas truncadas e as completas, foram identificados 14 possíveis complexos de ordem superior (Tabela 4). 
Tabela 4: Diferentes complexos de ordem superior formados através do ensaio de Y3H. Em azul, proteínas pertencentes à família FRUITFULL/APETALA1; em laranja, proteínas da família SEPALLATA; em vermelho, proteínas da família AGAMOUS.

$\begin{array}{lll}\text { LeSEP1 } & \text { RIN del } & \text { TM5 del } \\ \text { TM5 } & \text { LeMADS1 } & \text { RIN } \\ \text { TM5 } & \text { TM5 } & \text { RIN } \\ \text { FUL2 } & \text { LeMADS1 } & \text { FUL2 } \\ \text { LeMADS1 } & \text { FUL2 } & \text { RIN } \\ \text { LeMADS1 } & \text { FUL2 } & \text { LeMADS1 } \\ \text { LeMADS1 } & \text { FUL2 } & \text { LeSEP1 } \\ \text { TM5 } & \text { TAG1 } & \text { RIN } \\ \text { TM5 } & \text { TAGL1 } & \text { RIN } \\ \text { TM5 } & \text { TAG1 } & \text { LeMADS1 } \\ \text { RIN } & \text { TAGL1 } & \text { LeMADS1 } \\ \text { TM5 } & \text { TAG1 } & \text { LeSEP1 } \\ \text { LeSEP1 } & \text { TAGL1 } & \text { LeSEP1 } \\ \text { TAGL1 } & \text { TM5 } & \text { LeMADS1 }\end{array}$

Em relação às diferenças de interações entre as proteínas splicing variantes de RIN, foi verificado que a forma RIN short forma complexo de ordem superior com TM5 (del) e TAGL1, o qual não é formado com RIN long. Analisando os resultados de interações para as variantes de splicing de LeMADS1 (long e short), verificam-se maiores diferenças. A proteína LeMADS1 long utiliza somente FUL2 como ponte para as interações em complexos de ordem superior com outras proteínas LeMADS1 long ou short, enquanto a proteína LeMADS1 short também utiliza TAGL1 e FUL1 Heinz para formar complexos com RIN e LeMADS1 short. De acordo com a literatura, FUL e TAGL1 interagem ambos com RIN (LESEBERG et al., 2008). Devido a isso, questionou-se se as três proteínas poderiam formar um complexo. De acordo com os resultados de $\mathrm{Y} 3 \mathrm{H}$, as três proteínas em questão não formam juntas um complexo de ordem superior. A partir disso, sugerese que elas atuem em vias separadas na regulação do desenvolvimento e amadurecimento do fruto. 


\subsection{IDENTIFICAÇÃO DE PUTATIVOS PARCEIROS DE INTERAÇÃO DA PROTEÍNA AP2}

Foi demonstrado no grupo de pesquisa da WUR que AP2 é um fator de transcrição que regula o amadurecimento de frutos através da regulação da biossíntese e sinalização do hormônio etileno (KARLOVA et al., 2011). No entanto, pouco se sabe sobre os possíveis parceiros com os quais AP2 interage e desencadeia os processos regulatórios. Assim, foi realizado um screening na tentativa de descobrir os parceiros de interação de AP2 em tomate. O ensaio de Y2H foi feito com uma biblioteca de cDNAs de frutos (em estágios iniciais e finais de desenvolvimento) de tomate. O screening produziu 134 colônias, das quais 35 tiveram seu DNA plasmidial sequenciado. Os resultados dos sequenciamentos foram analisados por similaridade em bancos de dados como SOL e NCBI e estão dispostos no Apêndice E.1. Dentre os resultados mais promissores, foram encontrados dois clones correspondentes a quinases, três clones correspondentes a proteínas não caracterizadas, dois clones do fator de transcrição NF-X1, um clone de uma proteína ligante ao DNA e o clone AT-book motif nuclear localized protein 17. Estes clones terão suas interações confirmadas e serão estudados em maior detalhamento pelo grupo de pesquisas de Wageningen para posterior submissão em artigo científico da área.

\subsection{IDENTIFICAÇÃO DE POSSÍVEIS PROTEÍNAS REGULADORAS DO GENE CNR}

\subsubsection{EPIMUTAÇÃO NO PROMOTOR DO GENE CNR}

Tem sido hipotetizado que a metilação no DNA contribui para a regulação do amadurecimento do fruto. Um dos maiores reguladores de amadurecimento em tomate pode ser o gene CNR (Colorless non-ripening). Parte de seu promotor sofre uma mutação epigenética espontânea (Manning et al., 2006), a qual, se for removida por inibidores de metiltransferases, possibilita o amadurecimento do fruto (ZHONG et al., 2013). Em duas regiões do promotor CNR foram encontrados sítios de ligação para o fator de transcrição RIN, ligação que é atenuada em mutantes hipermetilados (ZHONG et al., 2013). Levando em consideração todos esses fatores é importante saber quais outros fatores de transcrição ou proteínas reguladoras podem atuar na regulação do promotor $C N R$. Para tanto, foram selecionados três fragmentos do promotor $C N R(\sim 500$ pb cada 
um). O primeiro e o segundo fragmentos continham os sítios de ligação para o fator de transcrição RIN e o terceiro, por sua vez, correspondia à região hipermetilada nos mutantes naturais. Cada um dos fragmentos de CNR no genoma de leveduras e foram realizados três screenings yeast one bybrid $(\mathrm{Y} 1 \mathrm{H})$ com uma biblioteca de cDNAs de frutos em estágios iniciais e tardios de amadurecimento que foi clonada no vetor pDEST22 (com domínio AD do GAL4). Além disso, também foram utilizadas as 103 combinações AD-TFT1 citadas no item anterior para fazer análises de interação. O teste, similar ao Y2H e Y3H baseia-se no crescimento de colônias em meio seletivo (neste caso, o antibiótico aureobasidina) quando há interação entre proteína e região promotora.

\subsubsection{IDENTIFICAÇÃO DE PROTEÍNAS REGULADORAS DO GENE CNR COM SCREENING EM BIBLIOTECA DE cDNAS DE FRUTO}

As colônias foram isoladas e sequenciadas para descobrir quais as proteínas que poderiam ter interagido com o promotor CNR. Os screenings dos fragmentos 1, 2 e 3 produziram 49, 150 e mais de 1000 colônias, respectivamente, as quais continham proteínas candidatas à interação. O DNA plasmidial das leveduras foi extraído e amplificado por PCR. O produto das amplificações foi colocado em gel de agarose e submetido à eletroforese. Ao total, foram extraídos DNAs plasmidiais de 52, 96 e 108 colônias de leveduras contendo os fragmentos 1, 2 e 3, respectivamente. Após corrida eletroforética, foram sequenciadas colônias onde somente um clone do pDEST22 havia sido transformado. Ao total, foram sequenciados e analisados os DNAs de 31 clones do screening do fragmento 1, 54 clones do fragmento 2 e 62 clones do fragmento 3. As sequências obtidas foram analisadas por tBLASTx nos bancos de dados SOL e NCBI. Os resultados foram promissores e indicaram proteínas importantes que podem regular o promotor $C N R$. Nos ensaios de $\mathrm{Y} 1 \mathrm{H}$ é comum o aparecimento de muitos falsos-positivos, como proteínas ribossomais e diversas enzimas. A lista completa das putativas proteínas reguladoras da expressão do gene $C N R$ está disposta no Apêndice E.2. As proteínas mais promissoras encontradas estão listadas na tabela abaixo (Tabela 5). 
Tabela 5: Interações de proteínas com o os fragmentos 1, 2 e 3 do promotor de $\boldsymbol{C N R}$.

\begin{tabular}{|l|l|l|}
\hline Fragmento & $\begin{array}{l}\text { BLAST em tomate } \\
\text { (SOL) }\end{array}$ & Descrição e comentários \\
\hline 1 & NAC4 & $\begin{array}{l}\text { Proteínas NAC estão envolvidas em diversos } \\
\text { processos de desenvolvimento. }\end{array}$ \\
\hline 2 & LHP1 & Metil-transferase. \\
\hline 2 & CRF1/Pti6 & Fator de transcrição responsivo a etileno. \\
\hline 3 & JERF1 & Fator de transcrição responsivo a etileno. \\
\hline 3 & ASR1 & $\begin{array}{l}\text { Proteína responsiva ao estresse hídrico. Esta } \\
\text { proteína foi encontrada duas vezes no screening. }\end{array}$ \\
\hline 3 & HSFA9a/HSFA2a/HSF30 & $\begin{array}{l}\text { Proteínas de beat shock. Foram encontrados 5 } \\
\text { vezes no screening. }\end{array}$ \\
\hline 3 & Proteínas desconhecidas & $\begin{array}{l}\text { Foram encontradas algumas proteínas ainda não } \\
\text { caracterizadas que podem estar envolvidas no } \\
\text { amadurecimento. }\end{array}$ \\
\hline
\end{tabular}

\subsubsection{IDENTIFICAÇÃO DE PROTEÍNAS REGULADORAS DO GENE CNR COM DÍMEROS DE MADS-BOX}

Os dímeros de MADS-Box já haviam sido produzidos para os ensaios de Y3H. As 103 combinações AD-TFT1 foram utilizadas para busca de interações com os fragmentos 1, 2 e 3 do promotor do gene $C N R$. Em relação às buscas por interações com os dímeros de MADS-box não foram encontradas diferenças em interações para os fragmentos do promotor CNR. Os 3 fragmentos selecionados mostraram interação com as proteínas FUL, RIN, TAG, TAGL1, LeMADS1, TM5 e LeSEP1 (quando as proteínas estão fusionadas ao domínio AD).

O grupo de pesquisas da universidade de Wageningen se dedicará a validar as interações encontradas através de outras técnicas. Assim, se forem confirmadas as interações entre as proteínas e os fragmentos do promotor do gene $C N R$, o próximo passo será verificar o possível papel dessas proteínas na regulação do promotor $C N R$ quando não-metilado e o consequente amadurecimento do fruto de tomate. 


\section{Apêndice E.2}

Proteínas putativas parceiras de interação da proteína AP2 identificadas por sequenciamento e análise de similaridade das sequênicas por BLAST (NCBI ou SOL). Frag: Fragmento correspondente do gene CNR; Col: Colônia sequenciada.

\begin{tabular}{|c|c|c|}
\hline Col & BLAST SOL & Descrição encontrada no SOL \\
\hline 3 & Solyc01g008230 & TCP family transcription factor (AHRD V1 *_** A6MCZ2_9ORYZ) \\
\hline 29 & Solyc01g057310 & $\begin{array}{l}\text { Kinesin (Centromeric protein)-like protein (AHRD V1 *_*- } \\
\text { Q9LJ60_ARATH) }\end{array}$ \\
\hline 17 & Solyc01g080330 & $\begin{array}{l}\text { Transmembrane BAX inhibitor motif-containing protein } 4 \text { (AHRD V1 } \\
\text { **_-_B6TGH7_MAIZE) }\end{array}$ \\
\hline 34 & Solyc01g081430 & Expressed protein (Fragment) (AHRD V1 ***_ Q108V0_ORYSJ) \\
\hline 7 & Solyc01g096490 & Kinase family protein (AHRD V1 *_-- D7MA69_ARALY) \\
\hline 24 & Solyc01g096490 & Kinase family protein (AHRD V1 *--- D7MA69_ARALY) \\
\hline 46 & Solyc01g099810 & $\begin{array}{l}\text { Arginine/serine-rich splicing factor (AHRD V1 ***_ } \\
\text { Q176A9_AEDAE) }\end{array}$ \\
\hline 37 & Solyc01g108670 & Kinesin-like protein (AHRD V1 *-*_ Q75LL2_ORYSJ) \\
\hline 19 & Solyc01g110540 & Unknown Protein (AHRD V1) \\
\hline 36 & Solyc02g082100 & Neuralized (AHRD V1 *_-- B4M452_DROVI) \\
\hline 18 & Solyc03g078080 & Uridylate kinase (AHRD V1 **** B6TC37_MAIZE) \\
\hline 32 & Solyc $03 \mathrm{~g} 078080$ & Uridylate kinase (AHRD V1 **** B6TC37_MAIZE) \\
\hline 38 & Solyc03g116230 & Agglutinin isolectin I (Fragment) (AHRD V1 *--- Q9S7K1_URTDI) \\
\hline 12 & Solyc03g118420 & NF-X1 finger transcription factor (AHRD V1 **_-_ C5GCI1_AJEDR) \\
\hline 48 & Solyc03g118420 & NF-X1 finger transcription factor (AHRD V1 **_- C5GCI1_AJEDR) \\
\hline 16 & Solyc04g025040 & Unknown Protein (AHRD V1) \\
\hline 21 & Solyc04g025040 & Unknown Protein (AHRD V1) \\
\hline 22 & Solyc04g025040 & Unknown Protein (AHRD V1) \\
\hline 9 & Solyc05g009290 & Myosin-like protein (AHRD V1 **_- Q9C717_ARATH) \\
\hline 11 & Solyc $05 \mathrm{~g} 013850$ & $\begin{array}{l}\text { Sieve element-occluding protein } 3 \text { (AHRD V1 } * *_{--} \\
\text {B5THF7_MEDTR) }\end{array}$ \\
\hline 13 & Solyc06g053400 & 2-isopropylmalate synthase 1 (AHRD V1 **** Q30DX9_9BRAS) \\
\hline 35 & Solyc06g053400 & 2-isopropylmalate synthase 1 (AHRD V1 **** Q30DX9_9BRAS) \\
\hline 15 & Solyc06g059740 & Alcohol dehydrogenase 2 (AHRD V1 **** Q84UY3_PETHY) \\
\hline 6 & Solyc06g074530 & Prephenate dehydratase (AHRD V1 **** Q6JJ29_IPOTF) \\
\hline 20 & Solyc06g082710 & Nucleic acid binding protein (AHRD V1 **_* B4FN92_MAIZE) \\
\hline 44 & Solyc $08 \mathrm{~g} 029190$ & At1g62390-like protein (Fragment) (AHRD V1 *--- C0JCT9_9BRAS) \\
\hline 10 & Solyc09g007490 & Cell number regulator 8 (AHRD V1 **_- B4FUS3_MAIZE) \\
\hline 33 & Solyc09g007490 & Cell number regulator 8 (AHRD V1 **-- B4FUS3_MAIZE) \\
\hline 23 & Solyc09g013120 & E3 ubiquitin-protein ligase Hakai (AHRD V1 *_-- C0H8T4_SALSA) \\
\hline 42 & Solyc09g055760 & T-snare (AHRD V1 ***_ Q2HS23_MEDTR) \\
\hline 41 & Solyc11g012470 & $\begin{array}{l}\text { Heterogeneous nuclear ribonucleoprotein A3 (AHRD V1 *--- } \\
\text { B6TGB9_MAIZE) }\end{array}$ \\
\hline 25 & Solyc11g066890 & Prephenate dehydratase (AHRD V1 ***_ Q6JJ29_IPOTF) \\
\hline 27 & Solyc11g066890 & Prephenate dehydratase (AHRD V1 ***_ Q6JJ29_IPOTF) \\
\hline 31 & Solyc11g072940 & $\begin{array}{l}\text { CCR4-NOT transcription complex subunit } 2 \text { (AHRD V1 ** } \\
\text { B6SVB8_MAIZE) }\end{array}$ \\
\hline 28 & Solyc12g087950 & $\begin{array}{l}\text { AT-hook motif nuclear localized protein } 17 \text { (AHRD V1 **-- } \\
\text { Q9LTA2_ARATH) }\end{array}$ \\
\hline
\end{tabular}




\section{Apêndice E.1}

Putativos reguladores do gene CNR identificados após sequenciamento e BLAST (NCBI ou SOL). Frag: Fragmento correspondente do gene CNR; Col: Colônia sequenciada.

\begin{tabular}{|c|c|c|c|}
\hline Frag & Col & $\begin{array}{l}\text { Correspondente no } \\
\text { SOL ou NCBI }\end{array}$ & Descrição \\
\hline 1 & 52 & $\begin{array}{l}\text { NCBI: } \\
\text { ref|XM_004243346.1 } \\
\text { /SL2.40sc03685 }\end{array}$ & $\begin{array}{l}\text { Heat-induced chilling tolreance protein HCT6, transcript variant } 2 \\
\text { (HCT6) }\end{array}$ \\
\hline 1 & 33 & NCBI: gb | KF281605.1 & Pepino mosaic virus, complete genome \\
\hline 1 & 3 & Solyc01g073640 & $\begin{array}{l}\text { Uncharacterized oxidoreductase Mb1385 (AHRD V1 ***_ } \\
\text { Y1385_MYCBO) }\end{array}$ \\
\hline 1 & 47 & Solyc02g062620 & $\begin{array}{l}\text { Nuclear cap-binding protein subunit } 2 \text { (AHRD V1 **** } \\
\text { B6SNB6_MAIZE) }\end{array}$ \\
\hline 1 & 22 & Solyc02g065570 & DVL1 (AHRD V1 **-- Q6X5V0_ARATH) \\
\hline 1 & 39 & Solyc02g088690 & $\begin{array}{l}\text { UDP-glucose 6-dehydrogenase (AHRD V1 **** } \\
\text { B6TBY8_MAIZE) }\end{array}$ \\
\hline 1 & 20 & Solyc02g094390 & $\begin{array}{l}\text { Palmitoyltransferase-like protein (AHRD V1 *_** } \\
\text { C6YXK4_ORYSJ) }\end{array}$ \\
\hline 1 & 42 & Solyc03g005760 & $\begin{array}{l}\text { Chlorophyll a-b binding protein 3C-like (AHRD V1 **** } \\
\text { Q2XTE0_SOLTU) }\end{array}$ \\
\hline 1 & 30 & Solyc03g019940 & $\begin{array}{l}\text { Asparaginyl-tRNA synthetase (AHRD V1 **** } \\
\text { D6YS69_WADCW) }\end{array}$ \\
\hline 1 & 21 & Solyc03g093360 & Wound/stress protein (AHRD V1 **_- Q672Q3_SOLLC) \\
\hline 1 & 12 & Solyc04g008740 & Pyruvate kinase (AHRD V1 **** Q3S1N4_SOLTU) \\
\hline 1 & 45 & Solyc04g009030 & $\begin{array}{l}\text { Glyceraldehyde-3-phosphate dehydrogenase (AHRD V1 **** } \\
\text { D7UNZ5_BRARC) }\end{array}$ \\
\hline 1 & 16 & Solyc04g011400 & UDP-glucose 4-epimerase (AHRD V1 **_* D5RML8_9PROT) \\
\hline 1 & 38 & Solyc04g054810 & Pollen allergen Phl p 11 (AHRD V1 ***_B6T2Z8_MAIZE) \\
\hline 1 & 19 & Solyc04g-080300 & $\begin{array}{l}\text { 2-hydroxyacid dehydrongenase (Fragment) (AHRD V1 *_*_ } \\
\text { C6F725_PSEMZ) }\end{array}$ \\
\hline 1 & 46 & Solyc06g059740 & Alcohol dehydrogenase 2 (AHRD V1 **** Q84UY3_PETHY) \\
\hline 1 & 23 & Solyc06g065970 & $\begin{array}{l}\text { Cortical cell-delineating protein (AHRD V1 **_-- } \\
\text { B6UGA2_MAIZE) }\end{array}$ \\
\hline 1 & 14 & Solyc06g073190 & Fructokinase-like (AHRD V1 **_* Q307Z3_SOLTU) \\
\hline 1 & 2 & Solyc06g076040 & $\begin{array}{l}\text { U-box domain-containing protein (AHRD V1 }{ }^{* *} *_{--} \\
\text {D7KBV1_ARALY) }\end{array}$ \\
\hline 1 & 9 & Solyc06g076640 & Tubulin beta chain (AHRD V1 ***-B9GKJ5_POPTR) \\
\hline 1 & 41 & Solyc07g061790 & Heme-binding protein 2 (AHRD V1 **** B6T0C0_MAIZE) \\
\hline 1 & 8 & Solyc07g063550 & Arf-GAP with GTPase \\
\hline 1 & 17 & Solyc07g064130 & Ubiquitin (AHRD V1 ***_ Q39257_PEA) \\
\hline 1 & 49 & Solyc08g079630 & $\begin{array}{l}\text { AT-hook motif nuclear localized protein } 1 \text { (AHRD V1 ***_ } \\
\text { Q8VYJ2_ARATH) }\end{array}$ \\
\hline 1 & 40 & Solyc09g091480 & Ring finger protein 12 (AHRD V1 *_*- Q4V889_RAT) \\
\hline 1 & 44 & Solyc10g006950 & Unknown Protein (AHRD V1) \\
\hline 1 & 13 & Solyc10g083570 & $\begin{array}{l}\text { Fructose-bisphosphate aldolase (AHRD V1 ***_ } \\
\text { Q308A5_SOLTU) }\end{array}$ \\
\hline 1 & 5 & Solyc10g084310 & 30S ribosomal protein S12 (AHRD V1 ***_ RS12_MYCPU) \\
\hline 1 & 48 & Solyc10g086760 & Tubulin beta chain (AHRD V1 ***- B9HP96_POPTR) \\
\hline 1 & 31 & Solyc11g017470 & $\begin{array}{l}\text { NAC domain protein IPR003441 (AHRD V1 ***_ } \\
\text { B9GU14_POPTR) }\end{array}$ \\
\hline
\end{tabular}




\begin{tabular}{|c|c|c|c|}
\hline 1 & $\mid 1$ & Solyc12g095820 & $\begin{array}{l}\text { Thioredoxin-related transmembrane protein } 2 \text { (AHRD V1 ***_ } \\
\text { TMX2_XENTR) }\end{array}$ \\
\hline 2 & 23 & Solyc01g009630 & $\begin{array}{l}\text { Cleavage and polyadenylation specificity factor subunit } 5 \text { (AHRD } \\
\text { V1 ***_C1BVK1_9MAXI) }\end{array}$ \\
\hline 2 & 54 & Solyc01g081500 & $\begin{array}{l}\text { Histone-lysine N-methyltransferase SUV39H2 (AHRD V1 *_* } \\
\text { SUV92_CHICK) }\end{array}$ \\
\hline 2 & 24 & Solyc01g089970 & $\begin{array}{l}\text { Nucleoside diphosphate kinase (AHRD V1 ***_ } \\
\text { Q3Y5A4_SOLCH) }\end{array}$ \\
\hline 2 & 18 & Solyc01g091620 & Glycogen synthase kinase (AHRD V1 **** C7AE95_SOYBN) \\
\hline 2 & 9 & Solyc01g098990 & $\begin{array}{l}\text { Os06g0146300 protein (Fragment) (AHRD V1 ***_ } \\
\text { Q0DEL6_ORYSJ) }\end{array}$ \\
\hline 2 & 29 & Solyc01g100100 & RING finger protein (AHRD V1 *_*- B8M8P5_TALSN) \\
\hline 2 & 30 & Solyc01g101060 & S-adenosylmethionine synthase (AHRD V1 ***- B8LFH4_IPOBA) \\
\hline 2 & 12 & Solyc02g063250 & $\begin{array}{l}\text { Peptide methionine sulfoxide reductase msrA (AHRD V1 *_** } \\
\text { D7E9W5_METEZ) }\end{array}$ \\
\hline 2 & 1 & Solyc02g068430 & $\begin{array}{l}\text { Choline-phosphate cytidylyltransferase B (AHRD V1 **** } \\
\text { B4F7T8_MAIZE) }\end{array}$ \\
\hline 2 & 49 & Solyc02g-084360 & $\begin{array}{l}\text { V-type proton ATPase } 16 \mathrm{kDa} \text { proteolipid subunit c2 (AHRD V1 } \\
* * * * \text { VATL2_ARATH) }\end{array}$ \\
\hline 2 & 10 & Solyc03g-007870 & $\begin{array}{l}\text { Heavy metal-associated domain containing protein expressed } \\
\text { (AHRD V1 *_*_ Q8S5W0_ORYSJ) }\end{array}$ \\
\hline 2 & 6 & Solyc03g123630 & Pectinesterase (AHRD V1 ***_ Q564D7_SOLLC) \\
\hline 2 & 36 & Solyc04g015020 & Proline-rich protein (AHRD V1 *_*_ A1YL94_GOSHI) \\
\hline 2 & 11 & Solyc04g-055170 & Annexin 2 (AHRD V1 ***_ A9X4R2_BRAJU) \\
\hline 2 & 40 & Solyc05g-014470 & $\begin{array}{l}\text { Glyceraldehyde 3-phosphate dehydrogenase (AHRD V1 **** } \\
\text { Q8LK04_SOLTU) }\end{array}$ \\
\hline 2 & 43 & Solyc06g035720 & BCL-2 binding anthanogene-1 (AHRD V1 **** B4FV61_MAIZE) \\
\hline 2 & 15 & Solyc06g065590 & 60S ribosomal protein L18a (AHRD V1 ***_ D2D962_9ROSI) \\
\hline 2 & 47 & Solyc06g073430 & 40S ribosomal protein S29 (AHRD V1 ***_ A2ZG71_ORYSI) \\
\hline 2 & 25 & Solyc06g075180 & Ribosomal protein L12 (AHRD V1 ***_ A8J597_CHLRE) \\
\hline 2 & 13 & Solyc06g076020 & heat shock protein (AHRD V1 ***_B2D2G5_CAPSN) \\
\hline 2 & 17 & Solyc07g042550 & Sucrose synthase (AHRD V1 **** O82691_SOLLC) \\
\hline 2 & 17 & Solyc07g042550 & Sucrose synthase (AHRD V1 **** O82691_SOLLC) \\
\hline 2 & 39 & Solyc07g049140 & $\begin{array}{l}\text { Metallocarboxypeptidase inhibitor (AHRD V1 ***_ } \\
\text { O24639_SOLTU) }\end{array}$ \\
\hline 2 & 26 & Solyc07g-065790 & $\begin{array}{l}\text { Genomic DNA chromosome } 5 \text { P1 clone MYN21 (AHRD V1 ** } \\
\text { Q9FG69_ARATH) }\end{array}$ \\
\hline 2 & 22 & Solyc08g077420 & ATP dependent helicase (AHRD V1 **_* A8NEE6_COPC7) \\
\hline 2 & 38 & Solyc09g009890 & Polyadenylate-binding protein (AHRD V1 *--- B8N3I8_ASPFN) \\
\hline 2 & 8 & Solyc09g010390 & Unknown Protein (AHRD V1) \\
\hline 2 & 4 & Solyc09g010440 & Actin-depolymerizing factor 1 (AHRD V1 **** B2CM17_SOLCH) \\
\hline 2 & 20 & Solyc09g059620 & SAM domain family protein (AHRD V1 **_- B6TMA1_MAIZE) \\
\hline 2 & 19 & Solyc09g090980 & Major allergen Mal d 1 (AHRD V1 ***_ Q84LA7_MALDO) \\
\hline 2 & 32 & Solyc09g098540 & Chitinase-like protein (AHRD V1 ***_ Q6JX03_GOSHI) \\
\hline 2 & 28 & Solyc10g006130 & $\begin{array}{l}\text { Ethylene responsive transcription factor 3a (AHRD V1 **** } \\
\text { C0J9I5_9ROSA) }\end{array}$ \\
\hline 2 & 45 & Solyc10g078520 & Inhibitor of growth protein 4 (AHRD V1 ***_ C3KHB0_ANOFI) \\
\hline 2 & 2 & Solyc12g015880 & Heat shock protein 90 (AHRD V1 ***_ Q14TB1_TOBAC) \\
\hline 2 & 21 & Solyc12g049220 & $\begin{array}{l}\text { Mitochondrial import inner membrane translocase subunit tim23 } \\
\text { (AHRD V1 ***_ B6T238_MAIZE) }\end{array}$ \\
\hline 2 & 37 & Solyc12g055720 & Receptor like kinase \\
\hline
\end{tabular}




\begin{tabular}{|c|c|c|c|}
\hline 2 & 57 & Solyc09g092320 & $\begin{array}{l}\text { RNA binding protein-like protein (AHRD V1 **** } \\
\text { Q3HVL3_SOLTU) }\end{array}$ \\
\hline 2 & 58 & Solyc06g-082590 & $\begin{array}{l}\text { Ethylene responsive transcription factor 1b (AHRD V1 } *_{-} *_{-} \\
\text {C0J9I8_9ROSA) }\end{array}$ \\
\hline 2 & 61 & Solyc06g068090 & Phospholipase D (AHRD V1 **** D2E4A5_9ROSI) \\
\hline 2 & 62 & Solyc01g096870 & Prolyl-tRNA synthetase (AHRD V1 **** Q7XZD2_RAPSA) \\
\hline 2 & 64 & Solyc01g099770 & $\begin{array}{l}\text { Translationally-controlled tumor protein homolog (AHRD V1 *** } \\
\text { B5XDL0_SALSA) }\end{array}$ \\
\hline 2 & 74 & Solyc06g076040 & $\begin{array}{l}\text { U-box domain-containing protein (AHRD V1 } *_{--} \\
\text {D7KBV1_ARALY) }\end{array}$ \\
\hline 2 & 76 & Solyc10g007850 & Gpi-anchor transamidase (AHRD V1 **_* Q16SV5_AEDAE) \\
\hline 2 & 85 & Solyc07g049140 & $\begin{array}{l}\text { Metallocarboxypeptidase inhibitor (AHRD V1 ***_ } \\
\text { O24639_SOLTU) }\end{array}$ \\
\hline 2 & 87 & Solyc02g089630 & Proline dehydrogenase (AHRD V1 **** A1E289_ACTDE) \\
\hline 2 & 88 & Solyc10g081170 & Calmodulin-2 (AHRD V1 ***_ D7LFI7_ARALY) \\
\hline 2 & 89 & Solyc02g-089870 & RING finger protein 5 (AHRD V1 **-- B6TLS1_MAIZE) \\
\hline 2 & 90 & Solyc05g041800 & Unknown Protein (AHRD V1) \\
\hline 2 & 91 & Solyc10g085410 & Cactin (AHRD V1 ***_ A1L014_RAT) \\
\hline 2 & 92 & Solyc03g121860 & $\begin{array}{l}\text { Mitochondrial import inner membrane translocase subunit tim23 } \\
\text { (AHRD V1 ***_B6T238_MAIZE) }\end{array}$ \\
\hline 2 & 93 & Solyc01g067660 & Beta-amylase (AHRD V1 **** Q5F304_SOYBN) \\
\hline 2 & 94 & Solyc04g074440 & $\begin{array}{l}\text { Os06g0220000 protein (Fragment) (AHRD V1 *** } \\
\text { Q0DDJ2_ORYSJ) }\end{array}$ \\
\hline 2 & 95 & Solyc06g060400 & Ribosomal protein L15 (AHRD V1 ***_ B9GPA1_POPTR) \\
\hline 2 & 96 & Solyc06g061050 & TOM2B (AHRD V1 ***_ B6TGV7_MAIZE) \\
\hline 3 & 21 & Solyc00g006800 & Transaldolase (AHRD V1 ***_ Q9FVH1_SOLLC) \\
\hline 3 & 39 & Solyc01g008370 & $\begin{array}{l}\text { 26S proteasome regulatory subunit (AHRD V1 ***_ } \\
\text { A8J8V5_CHLRE) }\end{array}$ \\
\hline 3 & 44 & Solyc01g-010810 & $\begin{array}{l}\text { RAN guanine nucleotide release factor (AHRD V1 **_* } \\
\text { B6TPU9_MAIZE) }\end{array}$ \\
\hline 3 & 45 & Solyc01g010810 & $\begin{array}{l}\text { RAN guanine nucleotide release factor (AHRD V1 **_* } \\
\text { B6TPU9_MAIZE) }\end{array}$ \\
\hline 3 & 10 & Solyc01g067680 & Tubby-like F-box protein 6 (AHRD V1 ***_ TLP6_ORYSJ) \\
\hline 3 & 7 & Solyc01g095200 & Reticulon family protein (AHRD V1 ***_ B2WS91_9BRAS) \\
\hline 3 & 26 & Solyc01g103410 & Nucleic acid binding protein (AHRD V1 **_* B6T8Q7_MAIZE) \\
\hline 3 & 8 & Solyc02g014090 & $\begin{array}{l}\text { LysM domain containing protein expressed (AHRD V1 ***_ } \\
\text { Q7XD97_ORYSJ) }\end{array}$ \\
\hline 3 & 36 & Solyc02g086880 & Formate dehydrogenase (AHRD V1 **** Q5NE18_SOLLC) \\
\hline 3 & 18 & Solyc02g092880 & Unknown Protein (AHRD V1) \\
\hline 3 & 30 & Solyc03g062890 & Superoxide dismutase (AHRD V1 **** B6ZBR0_POPTN) \\
\hline 3 & 50 & Solyc03g114640 & $\begin{array}{l}\text { Signal peptide peptidase SppA type (AHRD V1 ***_ } \\
\text { Q01NK5_SOLUE) }\end{array}$ \\
\hline 3 & 16 & Solyc04g005680 & Ribosomal protein (AHRD V1 ***_ B3TM27_ELAGV) \\
\hline 3 & 11 & Solyc04g063290 & 30S ribosomal protein S5 (AHRD V1 ***_C5K1T7_AJEDS) \\
\hline 3 & 24 & Solyc04g-071610 & $\begin{array}{l}\text { Water-stress inducible protein } 3 \text { (Fragment) (AHRD V1 ---- } \\
\text { Q5G112_PINTA) }\end{array}$ \\
\hline 3 & 27 & Solyc04g-071610 & $\begin{array}{l}\text { Water-stress inducible protein } 3 \text { (Fragment) (AHRD V1 ---- } \\
\text { Q5G112_PINTA) }\end{array}$ \\
\hline 3 & 1 & Solyc04g076230 & AP-2 complex subunit mu (AHRD V1 ***_ D0N5Q6_PHYIN) \\
\hline 3 & 3 & Solyc05g018520 & $\begin{array}{l}\text { NADH-cytochrome b5 reductase-like protein (AHRD V1 **** } \\
\text { B6TCK3_MAIZE) }\end{array}$ \\
\hline 3 & 20 & Solyc05g-052260 & $\begin{array}{l}\text { Appr-1-p processing domain protein (AHRD V1 ** } *_{--} \\
\text {B8FDL2_DESAA) }\end{array}$ \\
\hline
\end{tabular}




\begin{tabular}{|c|c|c|c|}
\hline 3 & 28 & Solyc06g059740 & Alcohol dehydrogenase 2 (AHRD V1 **** Q84UY3_PETHY) \\
\hline 3 & 2 & Solyc06g074430 & $\begin{array}{l}\text { 60s acidic ribosomal protein-like protein (AHRD V1 ***_ } \\
\text { Q3HVP0_SOLTU) }\end{array}$ \\
\hline 3 & 42 & Solyc07g040680 & $\begin{array}{l}\text { Heat stress transcription factor A3 (AHRD V1 **** } \\
\text { D1M7W9_SOLLC) }\end{array}$ \\
\hline 3 & 38 & Solyc08g062960 & $\begin{array}{l}\text { Heat stress transcription factor A3 (AHRD V1 *_** } \\
\text { D1M7W9_SOLLC) }\end{array}$ \\
\hline 3 & 49 & Solyc08g062960 & $\begin{array}{l}\text { Heat stress transcription factor A3 (AHRD V1 *_** } \\
\text { D1M7W9_SOLLC) }\end{array}$ \\
\hline 3 & 51 & Solyc08g062960 & $\begin{array}{l}\text { Heat stress transcription factor A3 (AHRD V1 *-** } \\
\text { D1M7W9_SOLLC) }\end{array}$ \\
\hline 3 & 37 & Solyc09g059970 & $\begin{array}{l}\text { Small ubiquitin-related modifier } 2 \text { (AHRD V1 ***_ } \\
\text { C3KI25_ANOFI) }\end{array}$ \\
\hline 3 & 54 & Solyc09g090580 & $\begin{array}{l}\text { Eukaryotic translation initiation factor 4E-2 (AHRD V1 *** } \\
\text { B6UD29_MAIZE) }\end{array}$ \\
\hline 3 & 31 & Solyc10g007690 & Chlorophyll a-b binding protein 8 \\
\hline 3 & 13 & Solyc10g061940 & $\begin{array}{l}\text { Casein kinase II subunit beta-4 (AHRD V1 ***_ } \\
\text { B6TGH2_MAIZE) }\end{array}$ \\
\hline 3 & 5 & Solyc10g075090 & $\begin{array}{l}\text { Non-specific lipid-transfer protein (AHRD V1 **** } \\
\text { Q4A1N0_SOLLC) }\end{array}$ \\
\hline 3 & 15 & Solyc10g084400 & Glutathione S-transferase (AHRD V1 ***_ Q76KW1_PEA) \\
\hline 3 & 43 & Solyc11g010600 & $\begin{array}{l}\text { Os01g0841200 protein (Fragment) (AHRD V1 ** } \\
\text { Q0JHU9_ORYSJ) }\end{array}$ \\
\hline 3 & 40 & Solyc11g012320 & Unknown Protein (AHRD V1) \\
\hline 3 & 41 & Solyc11g039840 & $\begin{array}{l}\text { Ubiquinol-cytochrome c reductase iron-sulfur subunit (AHRD V1 } \\
\text { **** Q38M54_SOLTU) }\end{array}$ \\
\hline 3 & 29 & Solyc11g042930 & SKP1 (AHRD V1 ***_ Q68GS0_TOBAC) \\
\hline 3 & 14 & Solyc11g065180 & $\begin{array}{l}\text { THUMP domain-containing protein (AHRD V1 ***_ } \\
\text { D7M518_ARALY) }\end{array}$ \\
\hline 3 & 34 & Solyc11g072490 & $\begin{array}{l}\text { Interactor of constitutive active ROPs } 3 \text { (AHRD V1 *** } \\
\text { ICR3_ARATH) }\end{array}$ \\
\hline 3 & 35 & Solyc11g072490 & $\begin{array}{l}\text { Interactor of constitutive active ROPs } 3 \text { (AHRD V1 ***_ } \\
\text { ICR3_ARATH) }\end{array}$ \\
\hline 3 & 4 & Solyc12g009980 & $\begin{array}{l}\text { Complex interacting protein } 9 \text { (AHRD V1 } * * *- \\
\text { Q8LDX3_ARATH) }\end{array}$ \\
\hline 3 & 6 & Solyc12g014630 & Cortical cell-delineating protein (AHRD V1 *--- B6U436_MAIZE) \\
\hline 3 & 19 & Solyc12g055720 & Receptor like kinase \\
\hline 3 & 61 & Solyc04g008740 & Pyruvate kinase (AHRD V1 **** Q3S1N4_SOLTU) \\
\hline 3 & 62 & Solyc12g007280 & Casein kinase 1-like protein 4 (AHRD V1 ***_ Q8LPI7_ARATH) \\
\hline 3 & 63 & Solyc02g062020 & $\begin{array}{l}\text { Ras-like GTP-binding protein RHO (AHRD V1 **_- } \\
\text { RHO_APLCA) }\end{array}$ \\
\hline 3 & 76 & Solyc08g062960 & $\begin{array}{l}\text { Heat stress transcription factor A3 (AHRD V1 *_** } \\
\text { D1M7W9_SOLLC) }\end{array}$ \\
\hline 3 & 84 & Solyc02g094390 & $\begin{array}{l}\text { Palmitoyltransferase-like protein (AHRD V1 *_** } \\
\text { C6YXK4_ORYSJ) }\end{array}$ \\
\hline 3 & 87 & Solyc06g073840 & $\begin{array}{l}\text { Peptidyl-prolyl cis-trans isomerase D (AHRD V1 *--- } \\
\text { PPID_HUMAN) }\end{array}$ \\
\hline 3 & 89 & Solyc04g080540 & ST225 (AHRD V1 ***_ B4YYB7_THEHA) \\
\hline 3 & 90 & Solyc04g009800 & $\begin{array}{l}\text { Calcium-dependent protein kinase } 2 \text { (AHRD V1 **** } \\
\text { Q93YF4_TOBAC) }\end{array}$ \\
\hline 3 & 91 & Solyc04g082200 & Dehydrin (AHRD V1 *_*-Q1A4H3_COFCA) \\
\hline 3 & 92 & Solyc02g083810 & $\begin{array}{l}\text { Ferredoxin--NADP reductase (AHRD V1 }{ }^{* * *} *_{-} \\
\text {D7MN04_ARALY) }\end{array}$ \\
\hline 3 & 96 & Solyc08g069030 & $\begin{array}{l}\text { Delta-aminolevulinic acid dehydratase (AHRD V1 ***_ } \\
\text { B9RJ27_RICCO) }\end{array}$ \\
\hline 3 & 98 & Solyc02g085730 & Allene oxide cyclase (AHRD V1 **** Q9LEG5_SOLLC) \\
\hline
\end{tabular}




\begin{tabular}{|l|l|l|l|}
3 & 99 & Solyc01g005820 & $\begin{array}{l}\text { Splicing factor arginine/serine-rich 4 (AHRD V1 *--- } \\
\text { B6U7F9_MAIZE) }\end{array}$ \\
\hline 3 & 101 & Solyc09g010800 & Type 2 metallothionein (AHRD V1 ***_ B3VKV4_SOLNI) \\
\hline 3 & 102 & Solyc08g068180 & Ribosomal protein L37 (AHRD V1 ***_ B9RS60_RICCO) \\
\hline 3 & 103 & Solyc11g011960 & $\begin{array}{l}\text { UTP-glucose 1 phosphate uridylyltransferase (AHRD V1 ***_ } \\
\text { B3VDY8_EUCGR) }\end{array}$ \\
\hline 3 & 104 & Solyc06g063070 & $\begin{array}{l}\text { Ethylene responsive transcription factor 2a (AHRD V1 ***_ } \\
\text { C0J9I7_9ROSA) }\end{array}$ \\
\hline 3 & 105 & Solyc04g049670 & Pseudo response regulator (AHRD V1 ***_ B9HM08_POPTR \\
\hline 3 & 106 & Solyc05g050980 & $\begin{array}{l}\text { 3-phosphoshikimate 1-carboxyvinyltransferase (AHRD V1 **** } \\
\text { Q30CZ8_FAGSY) }\end{array}$ \\
\hline 3 & 107 & Solyc10g081570 & KED (AHRD V1 *_*_ Q9LW95_TOBAC) \\
\hline
\end{tabular}




\section{ANEXO A - PLASMÍDEOS UTILIZADOS PARA AS CLONAGENS}

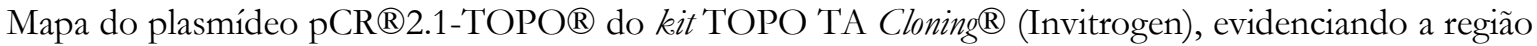
do sítio múltiplo de clonagem. Plac: promotor do gene lacZa; lacZa: gene codificador da $\beta$-galactosidase; o plasmídeo confere resistência aos antibióticos canamicina e ampicilina. O gene de interesse é inserido no gene lacZa, impossibilitando a tradução da enzima ativa.

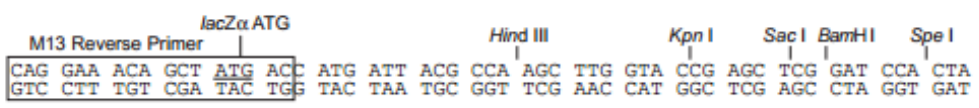
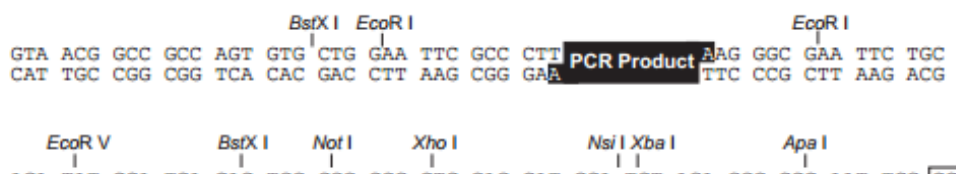

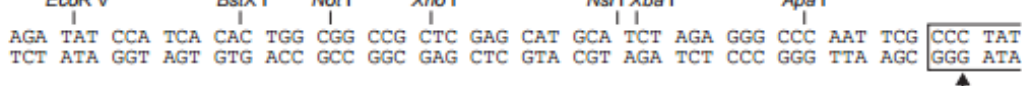

T7 Promoter M13 Forward (-20) Primer

\begin{tabular}{l} 
AGT GAG TCG TAT TAF AAT TCA CTG GCC GTC GTT TTA GAA CGT CGT GAC TGG GAA AAC \\
TCA CTC AGC ATA ATG TTA AGT GAC CGG CAG CAA AAT GTT GCA GCA CTG ACC CTT TTG \\
\hline
\end{tabular}

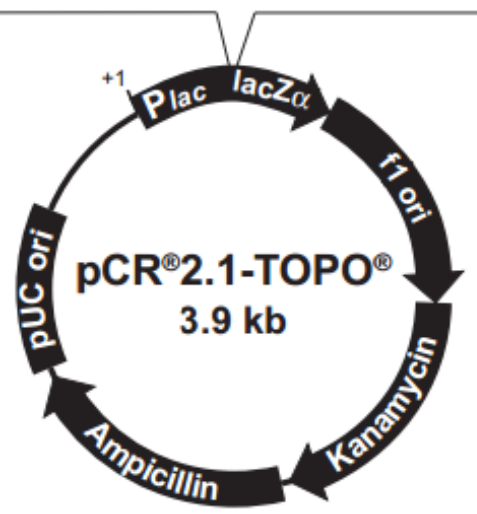

Mapa do vetor pDONR201 (vetor de entrada no sistema Gateway; Invitrogen); attP1 e attP2: sítios de recombinação; CmR: resistência a cloranfenicol; ccdB: sequência codificadora da proteína ccdB, a qual é responsável por se ligar à DNA girase, impedindo o crescimento da maioria das linhagens de E. coli. Os sítios M13-Forward e M13-Reverse são utilizados para sequenciamento. O vetor pDONR201 possui marcador de resistência à canamicina. Após reação $\mathrm{BP}$, os genes $\mathrm{ccdB}$ e $\mathrm{CmR}$ são substituídos pelo fragmento de interesse.

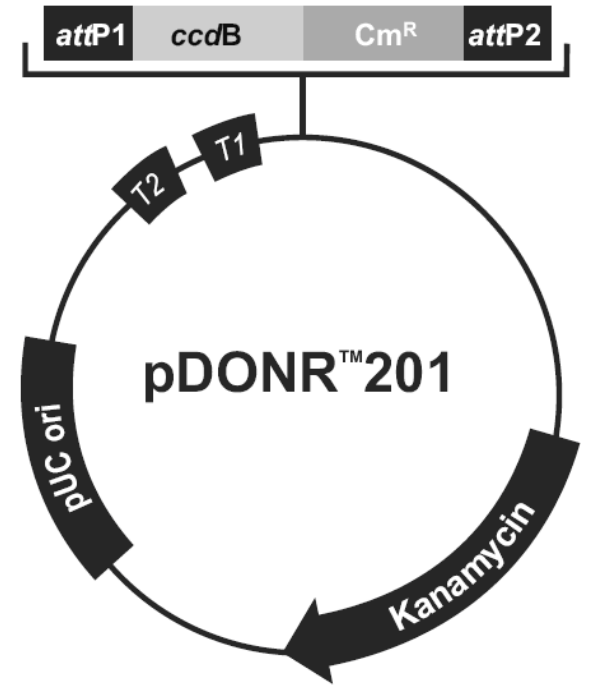


Mapa dos vetores pDONR221 e pDONR/Zeo (vetores de entrada no sistema Gateway; Invitrogen) de entrada no sistema Gateway; attP1 e attP2: sítios de recombinação; $\mathbf{C m R}$ : resistência a cloranfenicol; ccdB: sequência codificadora da proteína $\mathrm{ccdB}$, a qual é responsável por se ligar à DNA girase, impedindo o crescimento da maioria das linhagens de E. coli. Os sítios M13-Forward e M13-Reverse são utilizados para sequenciamento. $\mathrm{O}$ vetor $\mathrm{pDONR} 221$ possui marcador de resistência à canamicina. Após reação $\mathrm{BP}$, os genes ccdB e $\mathrm{CmR}$ são substituídos pelo fragmento de interesse.

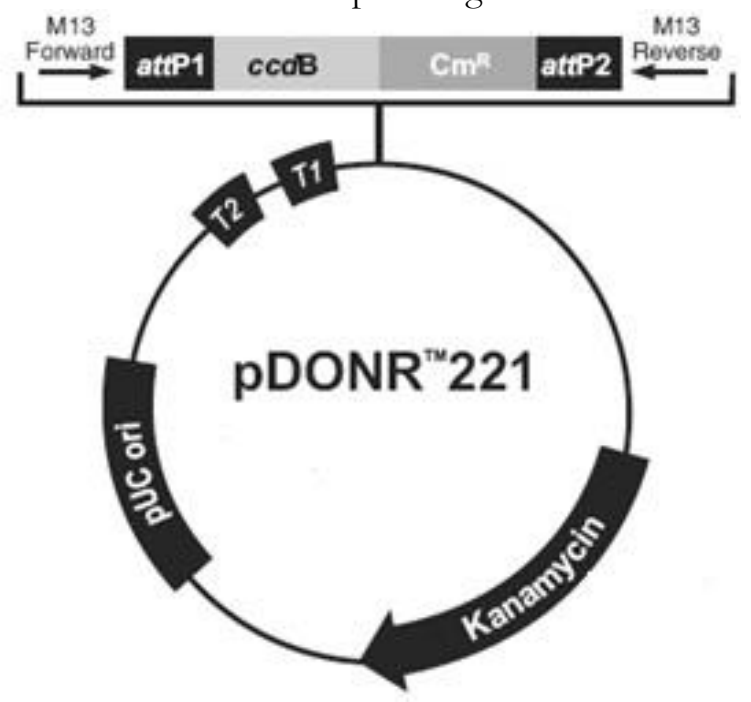

Mapa do vetor de integração no genoma de pABAi-GW (vetor de destino no sistema Gateway; modificado de Clontech). AurR: gene de resistência ao antibiótico Aureobasidina A; URA3: CDS do gene URA3. Essa porção é utilizada para recombinação homóloga com o genoma de leveduras; Ori: Origem de replicaçõa em E. coli; GW: Sítios attR1 e attR2 para recombinação pelo sistema Gateway.

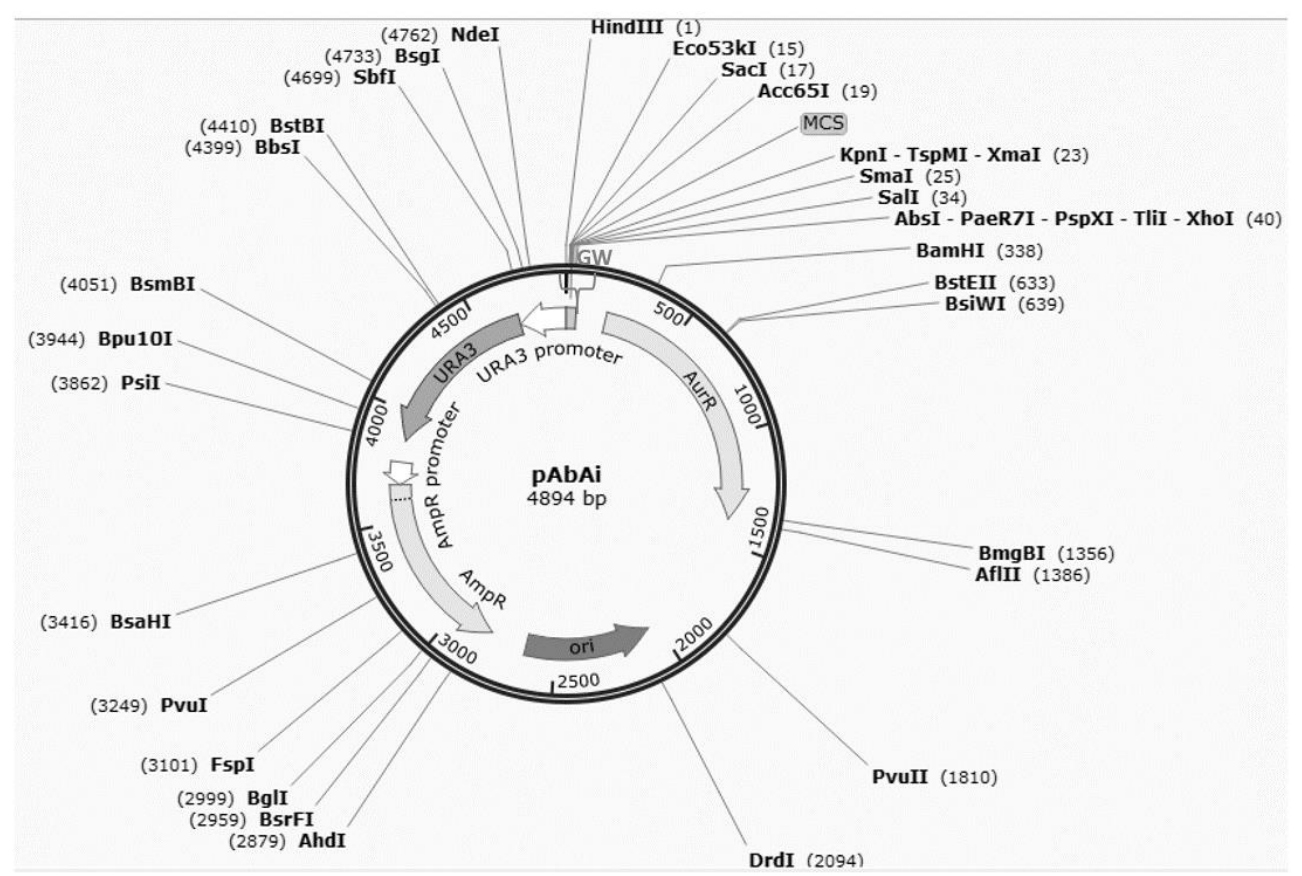


Mapa do vetor de expressão em leveduras pDEST22 (vetor de destino no sistema Gateway; Invitrogen), para clonagem das presas, via recombinação pela reação LR. O vetor apresenta o gene que confere resistência à ampicilina em bactérias e o gene TRP1, que codifica uma enzima da via de biossíntese do triptofano, para seleção em leveduras. Os cDNAs da biblioteca foram clonados neste vetor, produzindose as presas. A sequência dos $\mathrm{cDNAs}$ fusionam-se à sequência do domínio de ativação ( $\mathrm{AD}$ ) do fator de transcrição GAL4, na porção carboxi-terminal de AD. Um sinal de localização nuclear (NLS) está fusionado à sequência $\mathrm{AD}$. As presas são clonadas por recombinação entre os sítios attL, presentes nas presas, com os sítios attR, presentes no vetor.

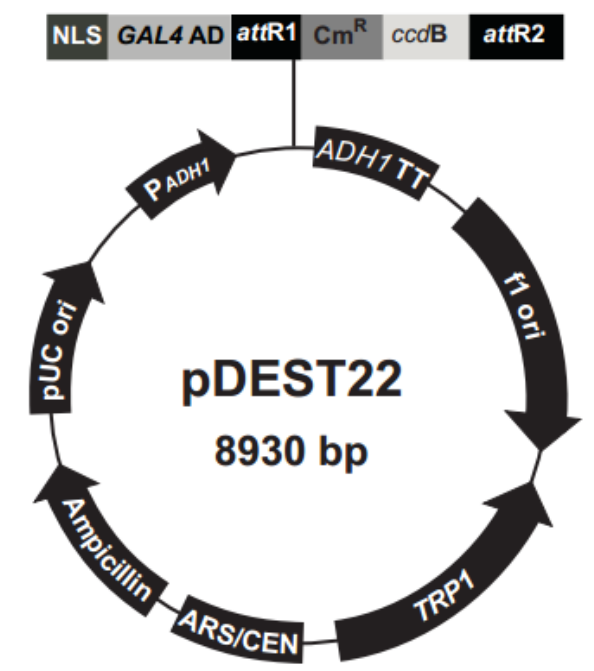

Mapa do vetor de expressão em leveduras pDEST32 (vetor de destino no sistema Gateway; Invitrogen), para clonagem da isca, via recombinação pela reação LR. O vetor apresenta o gene que confere resistência à gentamicina em bactérias e o gene Leu2, que codifica uma proteína da via de biossíntese do aminoácido leucina, para seleção em leveduras. A sequência da isca fusiona-se à sequência do domínio de ligação ao DNA (BD) do fator de transcrição GAL4, na porção carboxi-terminal de BD.

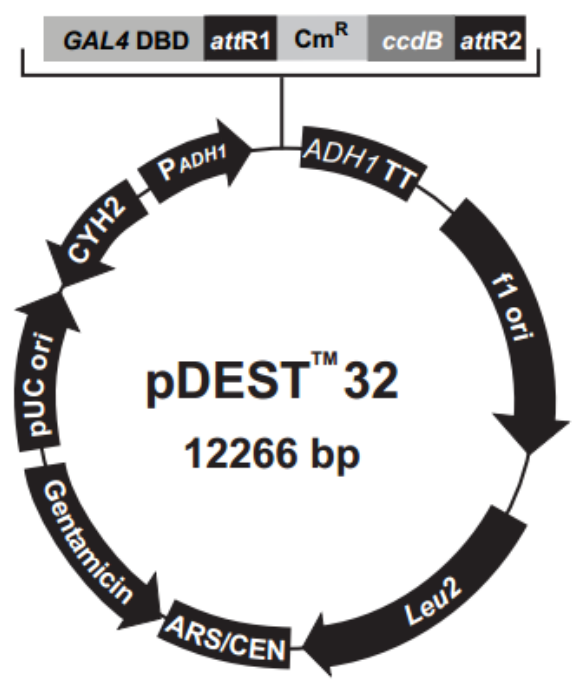

